


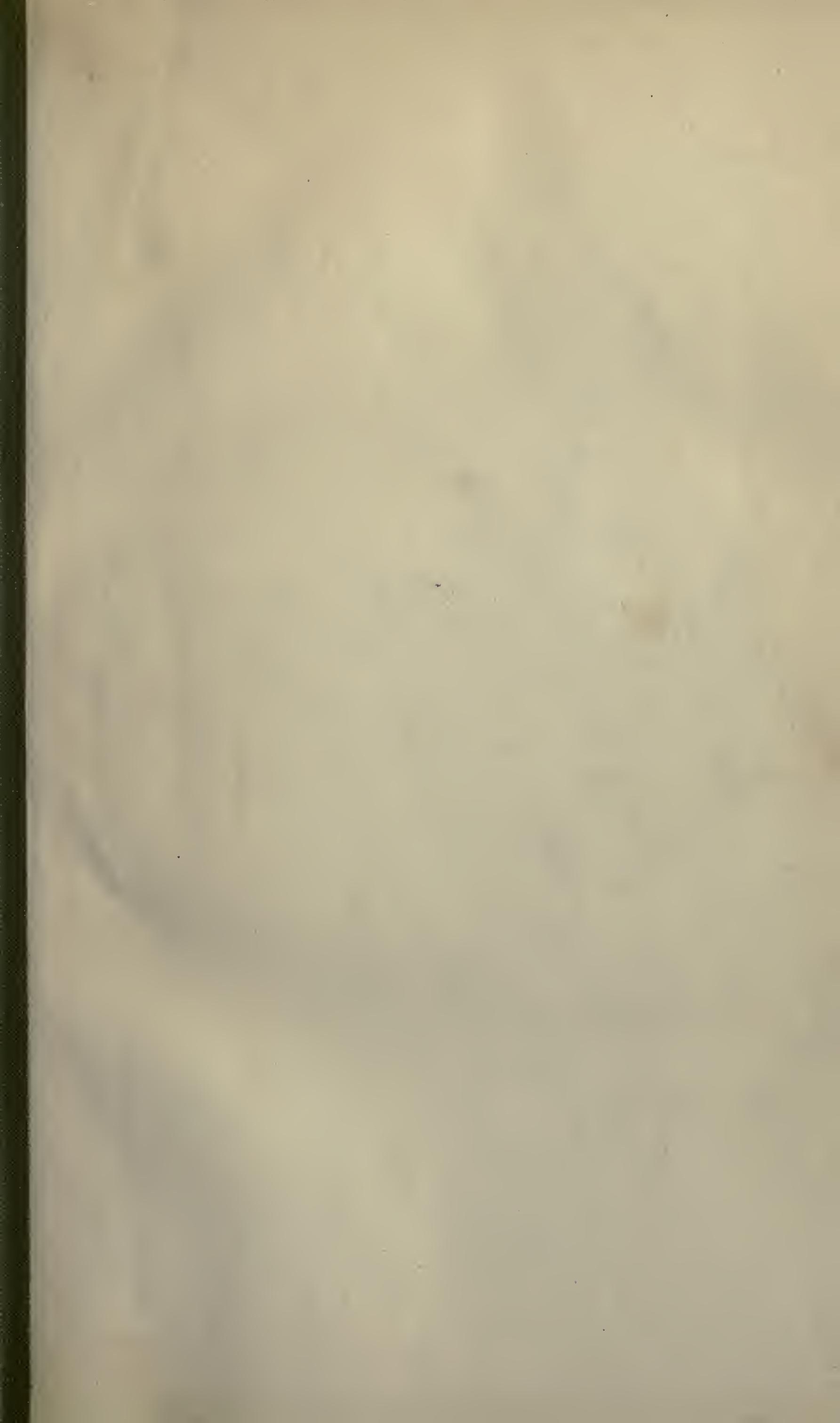



Digitized by the Internet Archive in 2007 with funding from Microsoft Corporation 

THELEPHORACEAE

$$
\text { OF }
$$

NORTHAMERCA

$$
\text { NOS. } 1 \text { - } 10
$$

\section{by}

\section{EDWARD A. BURT}

$$
\frac{2+35 / 140}{25 \mid}
$$


QK 629

14387 1984

v. 1

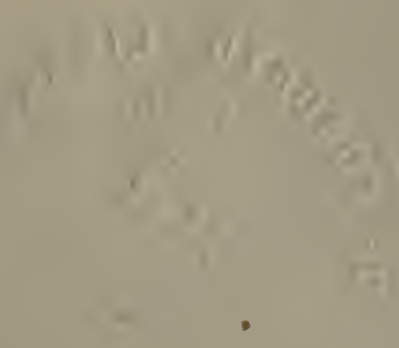

Ix y

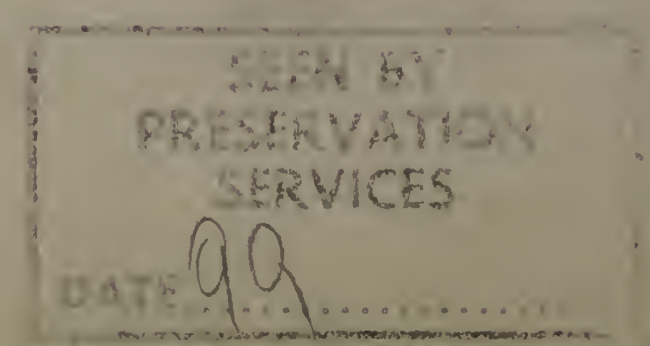




\title{
THE THELEPHORACEÆ OF NORTH AMERICA. I
}

\author{
EDWARD ANGUS BURT \\ Mycologist and Librarian to the Missouri Botanical Garden \\ Associate Professor in the Henry Shaw School of Botany of \\ Washington University
}

\section{INTRODUCTION}

This monographic study of the North American Thelephoracece was begun in 1894 as the author's contribution towards a greatly needed manual of the Basidiomycetes of the United States,- - a need that still confronts us. It has been necessary to carry on these investigations in connection with college and other work which required most of my time, but the long period covered has been an advantage; for during these two decades there has been such widespread interest in the Thelephoracece on the part of American students of fungi that it has been possible to study this family and its distribution from extensive series of freshly collected specimens from all the important regions of North America with the exception of Alaska, Mexico, and the ColoradoNew Mexico region of the United States, from which but small collections have been received. These specimens have been preserved unpoisoned in my herbarium in insect-proof tin boxes which receive herbarium sheets, and each will be cited by the number or other designation adopted by my correspondents in order that their specimens may be as useful for future reference as my own. The quantity of material always awaiting examination has confined my work to a systematic treatment of this family.

Except in the case of types of species, specimens of published exsiccati, and the specimens of Schweinitz's herbarium, I cite but few specimens from the large herbaria. This is done on account of the difficulty and large amount of time involved in making a study of the material contained in them. Serious changes in the condition of the specimens in these herbaria have been occasioned partly by time but more largely by the poisonous solutions with which the specimens were soaked for preservation under old-fashioned methods of herbarium procedure,-

${ }^{1}$ Issued July 1, 1914.

ANN. Mo. Bot. GARD., Vou. 1, 1914 
methods well enough adapted for flowering plants but not for fungi.

Early in the work it became apparent that the diagnoses of known species of resupinate Thelephoracece had failed utterly to enable the leading working mycologists of any country to recognize with certainty in the species about them those described in other countries, or those described for their own country by earlier students. The truth of this statement is shown by the errors and confusion in names of the common species which have been distributed in exsiccati, by the fact that in the large herbaria several different species are likely to bear the same specific name on the same or successive sheets, and by the vastly more important fact that the masters of mycology of each age, when relying wholly on the diagnoses published by their contemporaries or predecessors, have described as new species common and conspicuous resupinate fungi which had been accurately described by immediate contemporaries or predecessors, and in very many cases just as accurately by still earlier students. All the mycologists concerned in these redescriptions have been earnest strivers after truth, I am convinced, and would have preferred to employ the earlier names for their plants, could they have known that those earlier names referred with certainty to their specimens. All these people were relying, as was the usage of their time, on a few words of published description in some other than their mother tongue.

It is time to recognize generally that the resupinate Hymenomycetes, and especially the Thelephoracece, are extremely difficult taxonomic problems. Descriptions must include more than a rather vague and generalized characterization of the mere superficial appearance and habit of the specimen with possibly a reference to spores which some one recorded for what was perhaps this species. The fungus itself is an individual of the species; the description in words and by illustration has merit in proportion to the success it has in producing in the mind of any educated stranger exactly the ideas which he could derive from the study in detail of the specimen itself. From the specimen, exact ideas may be had of coloration, of form, of dimensions, of texture, of consistency, of internal structure, of organs of minute size, of place of growth, and of host and 
substratum. If the description fails to give the color as exactly as if it had been noted by comparison with such a standard work as Ridgway's 'Color Standards' or Saccardo's 'Chromotaxia,' then it is inferior to the specimen; if the description contains no information as to whether the basidia are simple or cruciate, making up the whole hymenium or arranged side by side with other organs of characteristic form, standing directly on the substratum or separated from it by densely or loosely interwoven hyphæ or other form of subhymenial layer;-if it does not contain all this information in exact terms and as much in addition as the specimen itself could afford, then it is an imperfect description of the species. It may be so imperfect that a dozen different species of fungi could be assembled, to any one of which it would apply as well as to any other, as is the case with the supposedly common and cosmopolitan Corticium lacteum and C. calceum. Published exsiccati probably contain the full dozen under each of these names.

In the case of resupinate Hymenomycetes, types and authentic specimens of the species are of the highest importance to supplement the prevailingly imperfect descriptions with full and exact data. Hence, the types of fungi on which the descriptions are based and the authentic specimens from the authors of the species are of importance in proportion to the degree in which these plants may yield data not afforded by the descriptions and existing illustrations of the species. In the case of the resupinate Hymenomycetes, the early descriptions are of slight practical value except as they are backed up by types and specimens from their authors. For this reason, if there had been no other, the International Botanical Congress, at Brussels, acted for the best interests of mycology in fixing the beginning of the naming of Hymenomycetes with the publication of Fries' 'Systema Mycologicum,'-the time when the preservation of types and authentic specimens of such fungi in herbaria became so prevalent that it was possible for later mycologists to distinguish the resupinate species by taking the trouble to study the types, if authentic specimens could not be obtained.

My method of becoming acquainted with our described species of Thelephoracece has been to study and arrange by species in my herbarium the specimens as they have accumu- 
lated. In this arrangement due regard has been given to original descriptions of species and to all details of internal structure. Spore collections on glass slides have been made for each species whenever possible, and about five thousand mounts of sectional preparations in glycerin have been made from collections and preserved for reference in connection with internal structure of the specimens. From time to time I have taken my Thelephoracece to herbaria where the types of our American species are stored and have there painstakingly matched them with the types. I have made sectional preparations from a fragment of each of these types in order to make sure that my specimens match the types not only in external characters but also in all details of internal structure. The sectional preparations of type specimens have been preserved in glycerin. Specimens from my herbarium which have been so matched with type specimens have been used by me later for the determinations of subsequent collections. Such methods of investigation are probably too laborious and require too much time to become popular and they afford little opportunity for the inspirational flights attributed to genius, but they do afford a means of determining within very narrow limits the species of North American Thelephoracece.

I am under especial obligation to Dr. W. G. Farlow for suggesting this work, for interest in its progress, and for frequent access to the Curtis Herbarium for comparisons with types. I am indebted also to Dr. C. H. Peck for opportunity to study his types in the New York State Herbarium, to the late Dr. L. M. Underwood for similar opportunity with the Ellis types in the Herbarium of the New York Botanical Garden, to Dr. S. W. Dixon and Professor S. Brown, of the Philadelphia Academy of Natural Sciences, for the privilege of studying in the Schweinitz Herbarium, to Sir W. T. Thistleton-Dyer and Mr. G. Massee for access to types and authentic specimens in Kew Herbarium, to the late Dr. T. M. Fries for the privilege of studying in the Herbarium of Elias Fries, at Upsala, and to Mr. Lars Romell, of Stockholm, Dr. P. A. Karsten, of Mustiala, and Abate G. Bresadola, of Trient, for many authentic specimens of their own species and for specimens which they had compared with types of early authors of Thelephoracece of 
Europe. In the later pages names of the many botanists who have participated in this work by the contribution of specjmens from their respective regions are given in connection with the specimens. I feel my obligation to each of these correspondents.

Having become thoroughly familiar with the species of a family of fungi, one then faces the task of deciding under what genera they shall be grouped in order that others may more easily recognize them. Our studies in systematic botany and the accumulations of plants in herbaria are primarily for the purpose of enabling those who wish to obtain information about any particular plant, however obscure, to determine its name accurately and so be in a position to get at the world's literature and knowledge concerning that species; and also to enable botanists so to entitle and index their researches that the results will be more available to the world at large. Stability in the nomenclature of plants is therefore important, and revolutionary changes in generic conceptions should not be lightly and frequently made. Whenever one proposes new genera to supersede a well-established genus which has satisfactorily embraced the related species of the world, the burden of proof should be on the one who makes the change to demonstrate that the advantages from the innovation will more than compensate for the confusion which would result as well as for the loss of knowledge indexed under the superseded name.

Many new genera of fungi have been proposed during recent years. These have frequently come from students with a limited knowledge of the species of the world. It is not surprising that a botanist working on the few species of a limited region should be led to the establishment of new genera on the basis of what seem to be sharp differences in his species or groups of species. When, however, his knowledge encompasses just as definitely the structure of the many species of some large portion of the world, his perspective changes, and he may now find that the species which he formerly regarded as generically distinct are so closely connected by intermediate species that the contemplated generic separation would be unnatural and a hindrance to botanical progress. It is fundamental that genera be so sharply defined that any accurate observer who will make 
the study necessary for the application of the generic definition may be sure ninety-nine times out of a hundred that the fungus on which he is working is a Stereum, for example, and not a Thelephora, nor a Craterellus, nor a Cladoderris, nor a Corticium, nor a Peniophora, nor a Sebacina. It is an obligation on authors to group their species so accurately under genera that Stereum, for example, shall comprise all the species of this genus known to science, and no others. The synonomy of species in later pages will show how vaguely the genera of Thelephoracece have been comprehended.

It is desirable that a genus should consist of but few species in those cases where the group is sharply and naturally set off from others, that is, where no intermediate species connect the genus with other groups. While such small genera are desirable, if wholly natural, it is in the highest degree objectionable to create small artificial genera by arbitrarily segregating the species of a natural genus and so establishing indefinite lines of demarkation between genera. Under such a procedure the generic location of certain species becomes wholly arbitrary and always continues as a stumbling block for new students and this leads to the loading of our literature with so-called new species. A case in point is Saccardo's scheme in the 'Sylloge Fungorum' in which he separates Hypochnus from Corticium and Peniophora without any natural generic planes of cleavage. In practical work one needs to know exactly what the generic limits of Corticium, Peniophora, and Hypochnus are. The question naturally arises as to just how loose and open the structure of the fructification must be to be included in the genus Hypochnus rather than in Corticium or Peniophora. Henning's violation of the principle involved is still more flagrant, for he separated the Hypochnacece as a new family from the Thelephoracea 1 and placed Hypochnus of Saccardo in the Hypochnacea, and Corticium and Peniophora in the Thelephoracece. As all students of the Thelephoracece have found Hypochnus, as understood by Saccardo, wholly unworkable, it would increase the usefulness of the 'Sylloge Fungorum' if Saccardo were to distribute among Corticium and Peniophora, the species which he now includes under Hypochnus.

${ }^{1}$ Engler und Prantl, Nat. Pflanzenfam. (I. $1^{* *}$ ): 114. 1898. 
Probably all species of Corticium, as originally understood, have an hymenium composed of basidia arranged side by side between non-sporebearing organs termed paraphyses. In many species, it is difficult to distinguish between the basidia and the paraphyses except by prolonged study of special preparations or by observations made at the time the basidia bear spores. In other species the sterile organs are conspicuous and distinct from the basidia either by their larger size, different form, or thicker or incrusted walls. Such conspicuous bodies are called cystidia, but if the paraphyses are merely finely but characteristically branched near their tips, they are not called cystidia. Such branched paraphyses occur in the hymenium of occasional species of several genera of the Thelephoracece and are valuable characters for specific diagnosis.

In 1880, Cooke proposed, from Kew Herbarium, to divide the old genus Corticium into two genera,- the name Corticium to be retained for those species having the non-sporebearing organs of the hymenium not distinguishable from the basidia, and the generic name Peniophora to be given to those species having cystidia. As the species of Corticium were very numerous and extremely difficult taxonomically, this proposal was hopefully received, and for more than thirty years the transfer of species from Corticium to Peniophora has been going on and the end has not been reached yet. During this long period there has been confusion as to which species of the old genus Corticium belong in the emended Corticium and which in the genus Peniophora.

Peniophora is an artificial rather than a natural genus, however, and its adoption has given to many species a position intermediate between this genus and Corticium. These intermediate species have to be classed with the one genus or the other according to personal judgment, for no one can state just how conspicuous the sterile organs must be, nor of how constant occurrence, to merit the name cystidia. In Corticium Sambuci Fr., for example, cystidia are readily found in preparations from some collections, but several preparations may have to be made to demonstrate them in other collections. In the same species and in different parts of the same section, cystidia may sometimes be sparingly and sometimes not at all incrusted. Some 
species which I have placed in the genus Peniophora because of the presence of cystidia students may look for under Corticium when, by a more hasty study of their collections, they fail to detect these organs. On the other hand, students using more discriminating methods than mine may detect cystidia in species in which I have overlooked them, and such students will search in Peniophora for species which I have placed under Corticium. Species intermediate between genera always cause such trouble. There are many intermediates between Peniophora and Corticium, yet in this particular case the advantage from the separation undoubtedly more than compensates for the disadvantages occasioned by the intermediate species.

The case of Peniophora has been considered at length, because this genus is being regarded as a precedent for subdividing Stereum and grouping under Lloydella all those species which have conspicuous non-sporebearing organs between the basidia. Such a separation, however, would be artificial and give rise to a troublesome series of intermediate species, without the compensating advantage which accrued in the case of Peniophora and Corticium. Stereum is not a genus of difficult species nor does it comprise an immense number of species. It is just a fine, natural group of species capable of being more sharply defined than it was by Fries, so as to receive some species from Thelephora of Fries and to part with some to Corticium. So defined, even beginners will have no trouble in recognizing species of Stereum. Systematic work in mycology should strive to establish and maintain just such natural, clean-cut genera as Stereum.

It seems to me best to work along constructive rather than destructive lines. Fries had a wonderful ability for the perception of the natural grouping of fungi on the basis of gross morphology and habit. Since his time, research has greatly enlarged the knowledge of the internal structure of fungi and of the organs of propagation. The value of such organs in the classification of seed plants is well known. It is feasible to modify somewhat the genera of Thelephoracece as defined by Fries, in accordance with the true relationships and differences shown by the present knowledge of internal structure, basidia, and spores, and a system results which is the natural evolution of taxonomic and morphologic study of Thelephoracee. This 
system has been communicated to my correspondents in connection with specimens. Its principal features are:

1. To restrict Thelephora to pileate species with simple basidia and colored spores.

2. To follow Karsten and Bresadola in placing under Hypochnus only resupinate species with colored echinulate spores.

3. To restrict Stereum to pileate species which have simple basidia and colorless spores and lack setæ in the hymenium.

4. To include in Hymenochoete all species having setæ.

5. To include in Corticium species always resupinate, which have colorless spores and lack cystidia, excepting those species which for other reasons are placed in Exobasidium. Include in Corticium hypochnoid as well as compact species.

6. To include in Peniophora all species which differ from Corticium merely by the presence of cystidia.

I find this system workable and very satisfactory for the accurate location of species in genera, except in the case of the species intermediate between Peniophora and Corticium. The proposals to subdivide Peniophora into Gloocystidium, Peniophorella, Glocopeniophora, etc., would create large numbers of species intermediate between the new genera, without compensating advantages.

I have studied the species of my predecessors and co-workers sympathetically and have endeavored to find real differences between their species and those previously known so that the validity of theirs might be confirmed. The great area of land covered by the present work, the differences in climate and substratum, and the keen search by my correspondents have brought to hand a very large number of specimens. I have earnestly striven to place them under species already known, but it has been necessary to describe many as new. I regret that there are so many of these. Should any one have reason to believe that in any case I have described as new a species already known, I shall esteem it a favor to receive an authentic specimen of the older species or to be informed where such a specimen can be consulted. 
Colors of specimens were noted and recorded during the first years of my work by comparison with Saccardo's 'Chromotaxia' in accordance with his descriptive terms. Recently I have been using Ridgway's 'Color Standards and Nomenclature,' 1912, which has a greater variety of colors useful in the characterization of the species of Thelephoracece.

In my own work with collections of living fungi I am endeavoring to gather for each species a spore collection on a glass slip. The spores adhere well so that they may be covered by paper and preserved in the envelope with the dried specimens from which the spores were obtained. Such collections give the exact color and dimensions of mature spores. These dimensions are generally rather larger than those obtained from spores of sectional preparations of dried herbarium specimens. The spores of dried specimens, i. e., those remaining attached to the specimens, are probably too immature to be of normal size, and sometimes there are so few of them that one must exercise caution to avoid errors due to the study of spores foreign to the fungus.

Latex exists in many species of several of the genera and is more abundant and conspicuous in some species than in others, and its containing elements often extend to the hymenial surface. When specimens are in the vegetative condition, injury to the hymenium may liberate the fluid contents of the latex bodies so that this fluid exudes in colored drops at the edges of the wound, or discolors the bruised surface. For many of our species there is a lack of data concerning the color of this fluid or the discoloration. The latex bodies are pale brown in microscopic preparations made by my methods and must not be confused with setæ or cystidia. Latex is well shown in Stereum spadiceum, S. sanguinolentum, and Corticium lactescens.

There has been a disposition on the part of some authors to regard the Thelephoracece as not sharply separated from the Hyphomycetes. The specimens which I have collected, in striving to find all the Thelephoracece of my collecting region, and the specimens received from my correspondents afford no embarrassment in recognizing the most hypochnoid species of Thelephoracece by the basidia which characterize the families of Hymenomycetes in general. 
The microscopical technique has been simplified as much as possible. Usually dried herbarium material had to be used for study and proved very satisfactory except in the case of specimens which had been subjected to poisoning processes for preservation in herbaria. A small bit of the fructification having a promising hymenial surface 2 or $3 \mathrm{~mm}$. square-but smaller if the specimen is a valuable type-is first moistened with alcohol, then wet with water and cut out from the rest of the specimen and from the substratum. This bit is then placed in a holder of elder pith and oriented so that the sections may be cut perpendicular to the surface of the hymenium and also contain as long hyphæ as possible. The sections are cut as thin as possible, free hand, with a very keen section razor flooded with alcohol. The thinnest sections are placed on a slide in a drop of water and then a drop of seven per cent aqueous solution of potassium hydrate is added.

Close observation of the sections should be made when the potassium hydrate solution comes in contact with them. For most species, the sections are merely cleared and the hyphæ swelled to the normal size of vegetative hyphæ. In a few species, the alkaline solution may dissolve out the color of the section on coming in contact with it, or it may change this color to a violet, which finally disappears, or it may cause disorganization changes in certain structures leading to their disappearance or destruction. Such changes should be observed and noted, for they are of help in the determination of the species. In the cases in which potassium hydrate solution exerts a destructive action, lactic acid should be employed with other sections in the manner described for potassium hydrate. Lactic acid clears and swells sections well, but so much more slowly than potassium hydrate that I have used it only where the latter is not satisfactory. After the sections have been cleared, the potassium hydrate should be drained off, the sections lightly stained on the slide with alcoholic solution of eosin (but not overstained), mounted in water, and studied at once.

For a thorough study of the species of the family at least one permanent preparation of each species should be retained for future comparisons. Permanent preparations may be made from the temporary water mounts by adding dilute glycerin- 
two-thirds glycerin and one-third water-at the edge of the cover glass and allowing the glycerin to run under the latter as the water evaporates. When concentration of the glycerin is adequate, the excess should be wiped away with moist filter paper and the resulting smear removed to the very edge of the cover glass with a soft cloth moistened with 95 per cent alcohol. The preparations may then be sealed from the atmosphere by painting a ring of microscopical cement about the edge of the cover glass. At least two coats should be used for this ring, a light and very narrow one, and, after this dries, a very heavy, broad one. I have used Bell's Microscopical Cement, made in London, and Brunswick Black Cement. A variable percentage of the rings crack in the course of a few years and allow the glycerin to escape from under the cover glass, but the sections in such preparations can be remounted. Dr. Thaxter has very recently informed me that he has been using King's Transparent White Cement and King's Amber Cement for fifteen years and that none of the rings made with these cements have cracked. By the use of circular cover glasses rather than square ones, a microscopist's turn table may be used, thereby materially lessening the labor of preparing the rings.

\section{Systematic Account}

\section{THELEPHORACEAE}

Thelephorece Persoon, Myc. Eur. I: 109. 1822; Fries, Hym. Eur. 629. 1872; Saccardo, Syll. Fung. 6:513. 1888.

Hymenomycetes with the hymenium inferior or amphigenous (on the lower surface or surrounding the fructification), coriaceous or waxy, even, rarely ribbed or papillate.

Through several of the genera the Thelephoracece connect closely with all the other families of the Hymenomycetes. Hypochnus approaches Grandinia of the Hydnacece in the granular hymenial surface of many of the species, but can be separated from this hydnaceous genus by the spore characters. Lachnocladium, with coriaceous structure, hairy stem, and colorless spores, is an intermediate genus between Clavaria, of the Clavariacece, and Thelephora but can be separated from the latter by the spore characters. Craterellus connects with 
Cantharellus, of the Agaricacece. Some species of Corticium must be cautiously separated from Merulius, of the Polyporacex. The species of Tremellodendron, Hirneolina, and Sebacina were formerly distributed among Thelephora, Stereum, and Corticium respectively, but are now separated from these genera by the cruciate character of the basidia, - such basidia as are present in many Tremellacece. All these connecting genera will be included in the present monograph.

Michenera and Heterobasidium are excluded genera. Lyman has shown ${ }^{1}$ that Michenera artocreas B. \& C. is only a stage in the life history of Corticium subgiganteum B. \& C., and that the genus Michenera has ceased to be a genus of the Basidiomycetes. My own study of the type of Heterobasidium chlorascens Massee, which is the type species of the genus, failed to locate any basidia whatever.

Very many Thelephoracece are of great economic importance on account of the dry rot induced by the growth of the mycelium in sills, floors, mine, bridge, and dock timbers, and other wooden structures located in moist, poorly ventilated places. Coniophora puteana is a common species which rots coniferous wood. Only a very few Thelephoracece are classed as serious plant parasites. Of these the rhizoctonial stage of Corticium vagum is the most important.

\section{Key to the Genera}

\section{EU-THELEPHORE无:}

Fructification not containing green lichen gonidia.

Fructification fleshy or membranaceous, often infundibuliform, with the hymenium distinct, continuous, even, ribbed or at length rugose; ba-

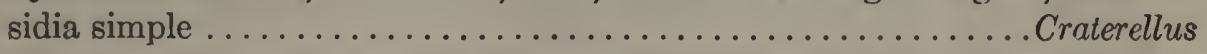
Fructification submembranaceous, cup-shaped, often pendulous; hymenium typically concave, discoid; basidia simple............... Cyphella Fructification consisting of only a fleshy hymenium on the surface of living leaves and shoots; basidia simple.................. Exobasidium Fructification coriaceous or hard . ...................... 1

1. Basidia globose or pyriform, longitudinally cruciately 4 -septate or divided when mature; fructification erect, clavariform, more or less branched .......

Tremellodendron ${ }^{1}$ Cultural studies on the polymorphism of Hymenomycetes. Proc. Boston Soc. Nat. Hist. 33: 151-60. 1907. 
1. Basidia cruciate as in Tremellodendron; fructification effuso-reflexed or cupshaped with the margin free .......................... Heolina

1. Basidia cruciate as in Tremellodendron; fructification always resupinate. Sebacina

1. Basidia simple but with such large sterigmata as to resemble longitudinally

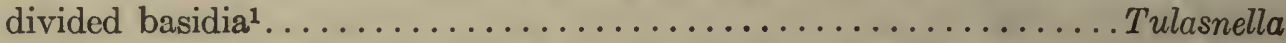

1. Basidia at first globose and simple, at length elongated and transversely septate, straight or curved, bearing sterigmata on the convex side; fructification

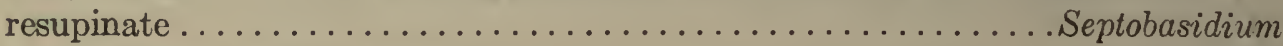

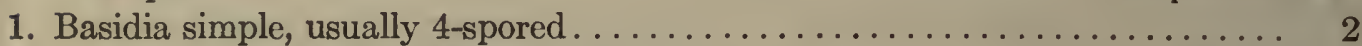

2. Spores colored; fructification pileate................. Thelephora

2. Spores colored, rough-walled to echinulate; fructification resupinate......

Hypochnus

2. Spores ochraceous, ferruginous or fuscous, even; fructification resupinate..

Coniophora

2. Spores white or rarely bright colored, even or rarely uneven....... 3

3. Setæ (brown, cylindric, rigid, even-walled bodies) present in the hymenium;

fructifications range from pileate to resupinate............ Hymenochœete

3. Cylindric teeth composed of many consolidated hyphæ protrude from the hymenium but are not covered by it. Our southern species was originally

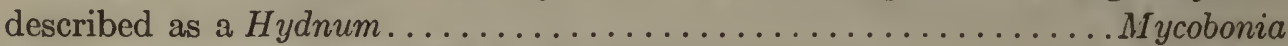

3. Neither setæ nor teeth present in the hymenium ............... 4

4. Fructification coriaceous, erect, clavariform; stem often hairy . Lachnocladium

4. Fructification cup-shaped, resupinate with free margin or simply resupinate; hymenium pulverulent; with some two or three of the following characters: (1) large white spores ranging from 14-34 x 12-20 $\mu$; (2)much granular matter in the fructification; (3) prominent moniliform or branched paraphyses; (4) racemose organs in the hymenium which produce a crop of conidia before basidiospores develop..........Aleurodiscus

4. Fructification pileate ranging from infundibuliform and flabelliform to very narrowly reflexed forms; hymenium even. Some reflexed species may occur resupinate............................ Ster

4. Fructification like that of an urn-shaped Stereum but hard and stuffed. One tropical species $\ldots \ldots \ldots \ldots \ldots \ldots \ldots \ldots \ldots \ldots \ldots \ldots \ldots \ldots \ldots$ Hypolyssus

4. Fructification like that of Stereum but with the hymenium hardened and with radiating branched ribs. Species tropical........... Cladoderris

4. Fructification always resupinate; structure not as in Aleurodiscus..... 5 5. Subhymenial tissue contains conspicuous brown stellate organs composed of

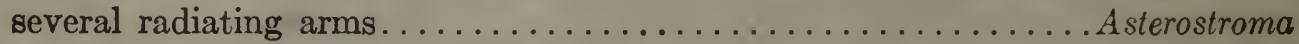

5. Such brown stellate organs not present. ................... 6

6. Cystidia present in hymenium, or in subhymenial tissue, or in both; structure may be compact or hypochnoid .............. Peniophora

6. Cystidia not present; structure compact or hypochnoid.......... Corticium

1 With regard to the nature of these bodies see H. O. Juel, Bihang till K. Sv. Vet.-Akad. Handl. 23 ${ }^{12}$ : Afd. III. 3-27. 1897. 


\section{HYMENO-LICHENS:}

Fructification regularly containing green lichen gonidia. Species tropical.

Fructification pileate, coriaceous-membranaceous, with hymenium on the lower surface and somewhat waxy; gonidial layer composed of somewhat cubical masses of algal cells....................... Cora

Fructification like Cora in most respects but with the hymenium somewhat gelatinous and the gonidial layer composed of algal cells arranged in rows (cateniform)

Rhipidonema

\section{THELEPHORA}

Thelephora Ehrhart [Crypt. Exsic. No. 178. 1785] Fries, Syst. Myc. I: 428. 1821 (in part).-Persoon, Myc. Eur. I: 110. 1822 (in part).-Saccardo, Syll. Fung. 6: 521. 1888 (in part).-Hennings, in Engl. \&. Prantl, Nat. Pflanzenfam. (I. $\left.1^{* *}\right)$ : 125. 1898 (in part).

The type species of the genus is Thelephora terrestris Ehrh. ex .Fries.

Fructifications pileate or clavate, coriaceous; hymenium continuous with the hymenophore and similar to it, inferior, or amphigenous in a few species, even or faintly ribbed or papillose; basidia simple, 4-spored; spores colored, typically muricate but even, or rough-walled in a few species.

As more broadly defined by Fries and the other authors cited, Thelephora has been heterogeneous, consisting chiefly of the natural and homogeneous group of species defined above but also of some pileate species with simple basidia and lyaline spores, transferred to Stereum; also of some species with globose, longitudinally septate basidia, transferred to Tremellodendron, if with erect fructifications, or to Sebacina, if resupinate; and also of some resupinate species having simple basidia, of which those with muricate and colored spores may be found in Hypochnus, those with colored and even spores, in Coniophora, and those with hyaline spores, in Corticium and Peniophora. It is probable that the species of Patouillard's section Dendrocladium of the genus Lachnocladium as understood by Patouillard ${ }^{1}$ might be transferred to Thelephora with advantage both to Thelephora and Lachnocladium, but these species are not within the geographical limits of my work.

${ }^{1}$ Fragments Mycologiques (suite). Jour. de Bot. 3:33-37. 1889. 


\section{Key to THE SPECIES}

Erect species, usually with central stem and pileus divided into very narrow, branching, flattened or cylindric divisions; hymenium inferior or am-

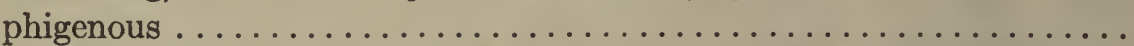
Erect species, usually with central stem and more or less infundibuliform, cup-shaped or flabelliform pileus, which may be radially split into

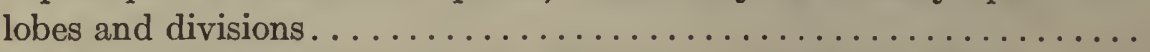
Species of incrusting, effuso-reflexed, dimidiate, or applanate habit......

1. 2-6 cm. high, much branched, glabrous, with fetid odor when growing, perhaps rarely odorless......................... palmata

1. 3-5 cm. high, much branched, minutely pubescent; stem villose, without fetid odor. Compare T. multipartita.................... T. anthocephala

1. Less than $2 \frac{1}{2} \mathrm{~cm}$. high, branching at or below surface of ground, dusky drab except at base.............................. T. coespitulans

1. Less than $2 \mathrm{~cm}$. high, very slender and fragile, cinereous. Known only from

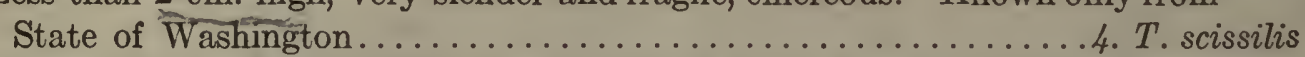

1. Large species, highly branched, with body of spore of regular obovoid form. Known only from Central America.................. T. angustata 2. Hymenium dark colored, i. e., brown to fuscous............... 3

2. Hymenium light colored, i. e., pallid to gray................ 4

3. Small species, $1 \frac{1}{2}-3 \mathrm{~cm}$. high, upper surface usually drying pallid, usually deeply cleft or many-parted into narrow divisions; stem villose.6. T. multipartita

3. Small species, $6 \mathrm{~mm} .-2 \frac{1}{2} \mathrm{~cm}$. high, infundibuliform or deeply divided into two or three triangular divisions, or flabelliform; stem villose. Closely related

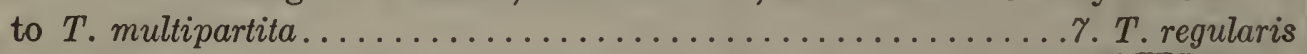

3. Fructification $1 \mathrm{~cm}$. high, white; stem white, glabrous. Known only from Guadaloupe .......................... pusiola

3. $1 \frac{1}{2}-5 \mathrm{~cm}$. high, larger species than the three preceding but with thinner pileus, fuscous purple (Rood's brown) throughout, often with the thin lobes imbricate like the petals of a carnation; stem villose........9. T. caryophyllea

3. 2-4 $\mathrm{cm}$. high, somewhat tubular, hymenium vinaceous brown to drab; stem sulce te and pitted but not villose; spores $10-14 \mu$ in diameter. Known only r.um Jamaica............................. T. T. magnispora

3. Large species, $2 \frac{1}{2}-7 \mathrm{~cm}$. in diameter, with upper surface pallid except at the center and with the hymenium dark .................. 13. T. vialis

4. Small species, less than $2 \mathrm{~cm}$. in height and in diameter, somewhat pallid to brick-red.......................... T. regularis

4. Pileus with outer lobes forming a cup and with inner lobes distinct, crowded, erect, cinereo-fuscous. Known from Costa Rica and Brazil.

11. T. corbiformis

4. Large species, 5-7 cm. broad, deeply infundibuliform, habit and color of Craterellus cornucopioides. Costa Rica and Jamaica...12. T. cornucopioides

5. Growing in applanate clusters, effuso-reflexed, or dimidiate........... 6

5. Always incrusting ( $T$. albido-brunnea is sometimes incrusting) ......... 8

6. Hymenium pale and colored like the pileus, cinnamon-buff; pileus spongy, more than $2 \mathrm{~mm}$. thick; spores $8-10 \times 6-8 \mu \ldots 14 . T$. albido-brunnea

6. Hymenium and pileus yellowish, less than $2 \mathrm{~mm}$. thick; spores $5-6 \times 4 \mu$

15. T. lutosa 
6. Hymenium drab, becoming sage-green when crushed in 7 per cent potassium hydrate solution; pileus pinkish buff to cinnamon-brown with a broad pale margin....................... T. cuticularis

6. Hymenium ferruginous brown (Rood's brown) to fuscous ......... 7

7. Pileus, when squamulose, with the fibers matted and agglutinated into appressed and wholly adnate squamules, margin dilated and whitish fimbriate becoming entire and concolorous...................17. T. intybacea 7. Pileus not zonate, fibrous-squamulose and usually strigose, margin fibrousfimbriate ............................. Terrestris

7. Pileus zonate, in other respects resembling the preceding species.........

19. T. griseozonata

8. Incrusting and ascending small plants, free branches somewhat terete but flattened towards the tips; spores umbrinous............20.T. fimbriata

8. Resupinate on leaves and twigs on the ground and sending up free, simple or branching trunks; spores fuscous. Known from Cuba only 21.T. perplexa

8. Incrusting leaves, etc., on the ground and ascending as sessile flabelliform pilei which are dentate at the upper end or deeply divided, honeyyellow to tawny olivaceous throughout. Known from Cuba only....

22. $T$. dentosa

8. Typically effused, rising obliquely upward from the support as a cluster of small trunks which branch and terminate in spiculous tips.23. T. spiculosa

I. Thelephora palmata Scop. ex Fries, Syst. Myc. I: 432. 1821.

Plate 4. fig. 4.

Clavaria palmata Scop. Fl. Carn. 2: 483. 1760.-Ramaria palmata Holmsk. Fun. Dan. I: 106. pl.-1799. -Merisma foetidum Pers. Syn. Fung. 584. 1801.-M. palmata Pers. Myc. Eur. I:113. 1822.-Thelephora palmata americana Peck, Rep. N. Y. State Mus. 53: 857. 1900.

Illustrations: Greville, Crypt. Fl. I: pl. 46.-Holmskiold, Fun. Dan. I: pl. of Ramaria palmata.-Krombholz, Abbild. und Beschr. pl. 54.f. 24, 25.-Nees, System pl. 16. f. 151 B.-Baillon, Dictionn. de Botan. I: 737. f. \%.-Loudon, Encyc. of Plants f. 16131.-Winter, Crypt. Flora I : 321 .

Fructification coriaceous-soft, fuscous purple, drying cinnabar-brown or chestnut-brown, erect, very much branched, with very fetid odor; pileus with numerous somewhat fastigiate, palmate divisions which are even, flattened, dilated above, and with fimbriate and whitish tips; stem simple or soon branched; hymenium amphigenous; spores pale umbrinous under the microscope, sparingly echinulate, $10 \times 7-8 \mu$.

Fructification of American specimens 2-6 cm. high, 1-3 cm. broad; stem 1-1 $\frac{1}{2} \mathrm{~cm}$. long, 1-2 mm. thick. 
On moist ground in coniferous woods and also in grassy fields. Prince Edward Island to North Carolina and west to Illinois. June to October.

In the American collections of this species the divisions of the pileus are narrow and a short stem is present. The habit is so similar to that of Thelephora anthocephala that record of the fetid odor should always be made if observed. The ultimate branches may be more or less terete, leading to the variety americana $\mathrm{Pk}$.

Specimens examined:

Exsiccati: Ell. \& Ev., N. Am. Fungi, 1937.

Austria: G. Bresadola. ${ }^{1}$

Sweden: L. Romell, 53.

Canada: Rustico Bay, Prince Edward Island, J. Macoun, 324. New Hampshire: Chocorua, W. G. Farlow.

? Vermont: no locality data for specimen in Frost Herb., Univ. of Vermont.

Connecticut: Manchester, C. C. Hanmer, 1898.

New York: Fischer's Island, C. C. Hanmer, 196.

New Jersey: C. G. Lloyd, 4612.

Pennsylvania: Bethlehem, Schweinitz, Syn. N. Am. Fungi, 612 (in Herb. Schw.); Trexlertown, Dr. W. Herbst; Kitanning, D. R. Sumstine, 2; West Chester, B. M. Everhart, Ell. \& Ev., N. Am. Fungi, 1937.

Delaware: Newark, H. S. Jackson.

Dist. of Columbia: Washington, O.F. Cook, comm. by P. L. Ricker, 1, 3.

N. Carolina: Asheville, H. C. Beardslee, 924.

Ohio: Connecticut, C. G. Lloyd, 4493.

Illinois: Glencoe, E. T. and S. A. Harper, 664, 665.

Missouri: St. Louis, N. M. Glatfelter (in Mo. Bot. Gard. Herb., 42560).

${ }^{1}$ With regard to the citation of specimens all except those of "Exsiccati" are in Burt Herb. which are cited without explicit reference to place in other herbaria. For example, the specimen cited, "Connecticut: Manchester, C. C. Hanmer, 196," is in Burt Herb. The data given is that received with the specimen and may identify a duplicate in another herbarium. The location of all specimens in herbaria other than my own is designated by the name of the herbarium in parenthesis with the prefix "in." For example, the specimen cited, "Louisiana: St. Martinville, A.B. Langlois (in Lloyd Herb., 3000)," is in Lloyd Herb., but not in Burt Herb. 
2. T. anthocephala Bull. ex Fries, Syst. Myc. I: 433. 1821. Plate 4. fig. 1.

Clavaria anthocephala Bull. Herb. de la France 2: 197. pl. 452. f. 1.1789 .

Illustrations: Bulliard, Ibid. pl. 452. f. 1.-Sowerby, Col. Figs. Eng. Fun. pl. 156.-Berkeley, Outlines Brit. Fung. $p l$. 17. f. 4.-Dufour, Atlas des Champ. pl. 70.

Fructification coriaceous-soft, somewhat ferruginous, drying fawn-color or cinnamon-brown, inodorous; pileus pubescent, divided to the stem into flaps which are dilated upwards and fimbriate and whitish at the apex or divided into irregular, branched, erect branches; stem simple, equal, villose; hymenium even; spores pale umbrinous under the microscope, ranging from angular-tuberculate to tuberculate-echinulate, $8-10 \times 7-8 \mu$.

Fructifications $3-5 \mathrm{~cm}$. high, $1-3 \mathrm{~cm}$. broad; stem $1-1 \frac{1}{2} \mathrm{~cm}$. long, 1-2 mm. thick.

On the ground in woods. Massachusetts and Ohio to Louisiana. June to August. Rare.

Our specimens of $T$. anthocephala and T. palmata have the same habit but may be separated, even when dried, by the fine pubescence of the pileus visible with a lens, and by the villosetomentose stem of the former. The spores of $T$. anthocephala are further slightly paler and have shorter spines with broader bases than those of $T$. palmata.

Specimens examined:

Austria: G. Bresadola.

Massachusetts: Newton, W. G. Farlow (in Farlow Herb.).

New York: Van Cortlandt Park, N. Y. City, L. O. Overholts (in Overholts Herb., 688).

Pennsylvania: Kitanning, D. R. Sumstine, 10; Bethlehem, Schweinitz (in Herb. Schw.), the 614 of Syn. N. A. Fungi under the name T. flabellaris.

North Carolina: Asheville, H. C. Beardslee, 0268.

Louisiana: St. Martinville, A.B. Langlois, unnumbered specimen, and 1971, and by the same collector (in Lloyd Herb., 3000). Ohio: Norwood and Linwood, C. G. Lloyd, 1472 and 02164 respectively.

Kentucky: C. G. Lloyd, 1395. 
Missouri: St. Louis, N. M. Glatfelter (in Mo. Bot. Gard. Herb., 42559).

3. T. caespitulans Schw. Trans. Am. Phil. Soc. N. S. 4: 166. $1831 .{ }^{1}$

Type: in Herb. Schweinitz.

Fructification erect, coriaceous, dusky drab to olive-brown below, paler above, very much branched, forming clusters $2 \frac{1}{2}$ $\mathrm{cm}$. high by $2 \frac{1}{2} \mathrm{~cm}$. broad; pileus with numerous divisions joined together into a solid base but assurgent above and pressed together closely, compressed, subcanaliculate, frequently obtuse and whitish at the apex; hymenium amphigenous; spores umbrinous under the microscope, sparingly tuberculate, 7-8 $\mathrm{x}$ $5-6 \mu$.

On the ground in mixed woods, Vermont to South Carolina, and in dense coniferous woods, Washington. September. Rare.

This species is related to T. palmata but is more olivaceous, and it is probably inodorous, - at least no odor has been noted. The dimensions for the clusters given above, as stated by Schweinitz, are probably maximum dimensions, for the specimens recently collected have been rather smaller. My Vermont specimens were growing with the thick, solid base buried in sandy ground in a wood road; they have dried pallid except at the base and are slightly pubescent. The general habit of this species is somewhat suggested by a small cluster of Tremellodendron pallidum (Schw.) Atk.

Specimens examined:

Vermont: Lake Dunmore, E. A. Burt.

Pennsylvania: Bethlehem, Schweinitz, type (in Herb. Schw., Acad. Nat. Sci., Phila.).

South Carolina: Santee Canal, Ravenel, 1660 (in Curtis Herb. under name $T$. vialis).

Washington: Chebalis, C. J. Humphrey, 1287; Bingen, W. N. Suksdorf, 689.

4. T. scissilis Burt, n. sp. Plate 4. fig. 8. Type: in Burt Herb.

Fructifications gregarious, coriaceous, erect, clavariform, branched, longitudinally ridged by the bases of numerous,

1 A figure will be given in Part II. 
small, appressed, acicular branches, the larger of which are at the apex of the fructification and spread slightly outward in fan-shaped manner; stem glabrous, castaneous; hymenium amphigenous, on upper half of the fructification, avellaneo-cinereous; basidia simple, hyaline, 4-spored; spores pale umbrinous

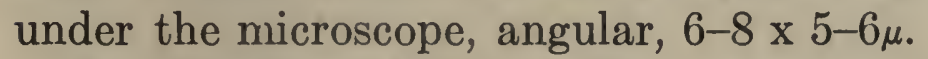

Fructifications $1 \frac{1}{2}-2 \mathrm{~cm}$. high; spread of branches at the top 2-6 mm.; stem 7-10 mm. long, $1 \mathrm{~mm}$. thick.

On the ground. Washington. January.

This species is very distinct by its slender erect habit, cinereous color, and only slightly spreading branches.

Specimens examined:

Washington: Bingen, Klickitat Co., W. N. Suksdorf, 716, type.

5. T. angustata Fries, (Nov. Symb. Myc. 92.) Actis R. Soc. Sc. Upsal. III. I : 108.1851.

Type: in Herb. Fries.

Fructification erect, cinereo-fuscous, pliant, becoming rigid and somewhat woody; stem elongated, radicated, rugose, glabrous, compressed, irregularly divided at the upper end into unequal, fastigiate, compressed branches, which are clothed on the whole outer surface with the hymenium; hymenium amphigenous, subrugose, gray; basidia simple; spores umbrinous under the microscope, obovoid, apiculate at base, flattened on one side, echinulate, $14 \times 7-9 \mu$.

On decaying wood. Central America.

Substance, color, and hymenium exactly as in T. cornucopioides, but of the very different form of Clavaria rugosa and having highly branched forms; stem $5 \mathrm{~cm}$. long; color fuliginous. The fructification is fleshy-pliant when fresh, but on drying hardens much more than species of Stereum.

Specimens examined:

Costa Rica: Oersted (in Herb. Fries), type.

6. T. multipartita Schw. in Fries, Elenchus Fung. I: 166. 1828.

Plate 4. fig. $7 \mathrm{a}$.

Type: in Herb. Schweinitz.

Fructifications gregarious, erect, coriaceous, fusco-cinereous, usually drying pallid; pileus infundibuliform, sometimes cleft 
more or less deeply and unequally into a few lobes, sometimes divided to the stem and spreading so as to appear dimidiate, very often deeply divided and subdivided into many narrow and spreading divisions more or less dilated and whitish at the apex; stem erect or incurved, equal or tapering upward, sometimes branched above, drying walnut-brown or pallid, villose; hymenium inferior, glabrous, even, fawn-color or vinaceous drab; spores unbrinous under the microscope, tuberculate, 7-9 x $5-6 \mu$.

Fructification $1 \frac{1}{2}-3 \frac{1}{2} \mathrm{~cm}$. high, 1-3 cm. broad; stem $1-2 \mathrm{~cm}$. long, $1-3 \mathrm{~mm}$. thick.

On ground in groves of broad-leaved trees, especially under oak. New York and Pennsylvania to Illinois. July to September.

The upper surface of the pileus was originally described as glabrous, but it is minutely pubescent under a lens, or sometimes fibrillose. This species is very perplexing by its close relationship to $T$. regularis. The multipartite pileus is the only character which seems available to separate collections of the former from the latter species. If a given collection consists wholly of specimens with pileus many-parted and subdivided into narrow divisions, or if it contains some such specimens in addition to others with more regular infundibuliform pileus, I refer the collection to T. multipartita, as in the cases of the collections. cited below from C. O. Smith and Dr. C. H. Peck respectively. As yet, I know of no characters by which to assort and separate into their respective species specimens mixed together of typical $T$. regularis and those specimens of $T$. multipartita which have the pileus infundibuliform or merely cleft more or less deeply and unequally into a few lobes. Therefore it is my opinion that $T$. multipartita is a variety of $T$. regularis, but the collections which have so far been submitted to me, have been composed of too few fructifications to assure me that this opinion is correct.

Specimens examined:

Exsiccati: Ell. \& Ev., N. Am. Fungi, 2806, under the name $T$. caryophyllea. 
New York: Bolton, C. H. Peck, 3, 4, 5; Ithaca, C. O. Smith, Cornell Univ. Herb., 13359, and C. O. Smith and W. H. Long, Cornell Univ. Herb., 7743.

New Jersey: Newfield, J. B. Ellis, Ell. \& Ev., N. Am. Fungi, 2806.

Pennsylvania: on island in Lehigh River, Schweinitz, type (in Herb. Schw.); Bethlehem, Schweinitz (in Herb. Schw.), the T. tuberosa of Syn. N. Am. Fungi, 613; Trexlertown, W. Herbst, 22, 36.

Ohio: A. P. Morgan, Lloyd Herb., 2581, 2647; Oxford, L. O. Overholts (in Overholts Herb., 1685). Illinois: River Forest, E. T. and S. A. Harper, 666.

7. T. regularis Schw. Schrift. d. Naturforsch. Gesell., Leipzig, I: 105.1822 .

Plate 4. figs. $6,7 \mathrm{~b}$.

Thelephora Ravenelii Berk. Grevillea I: 148. 1873.-T. hiscens Berk. \& Rav. Grevillea I: 148. 1873.

Type: in Herb. Schweinitz, Acad. Nat. Sci., Phila.

Pileus coriaceous, solitary, infundibuliform or divided to the stem into triangular divisions or flabelliform, fibrillose, drying pallid or tawny-olive, darker at center of the cup or at base of the divisions, margin lacerate; hymenium usually hair-brown, sometimes pallid; spores melleus to umbrinous under the microscope, angular-tuberculate, 6-7 × $4 \frac{1}{2}-5 \mu$.

Fructification $6 \mathrm{~mm} .-2 \frac{1}{2} \mathrm{~cm}$. high; pileus $5 \mathrm{~mm} .-2 \frac{1}{2} \mathrm{~cm}$. broad; stem $3-15 \mathrm{~mm}$. long, $1-1 \frac{1}{2} \mathrm{~mm}$. thick.

In moss in wet places and on humus. Ontario to Alabama and westward to Kansas.

The differences in form of the pileus of $T$.regularis are well shown by the type in Herb. Schweinitz; this type consists of three fructifications, two of which are infundibuliform, the third and largest, flabelliform. The hymenium is sometimes merely pallid, as in the case of the specimen which is the $T$. pannosa of Schweinitz, Syn. N. Am. Fungi, No. 606, but is not $T$. pannosa Fr. The cotypes of $T$. Ravenelii and T. hiscens agree in all respects with the authentic specimen of $T$. regularis in Curtis Herb. Specimens of $T$. regularis which have the pileus infundibuliform and little cleft are suggestive of small specimens of $T$. caryophyllea but differ from the latter by the thicker pileus 
and paler coloration of $T$. multipartita which is wholly lacking in the rufescent coloration of $T$. caryophyllea. There is a difference of form between specimens of these two species which is brought out well by the figures in pl. 4 .

Specimens examined:

Canada: Shannonville, Ontario, J. Macoun, 330.

Maine: Portage, L. W. Riddle, 4 .

New Hampshire: Chocorua, W. G. Farlow (in Farlow Herb.).

Massachusetts: near Boston, Sprague, 246 (in Curtis Herb. under the name T. anthocephala); Newton, W. G. Farlow (in Farlow Herb.).

Pennsylvania: Bethlehem, Schweinitz, station cited by Schweinitz; also the specimen (in Herb. Schw.) under the name T. pannosa of Syn. N. Am. Fungi, No. 606; Trexlertown, C. G. Lloyd; Kitanning, D. R. Sumstine.

Delaware: Clayton, H. S. Jackson.

North Carolina: Salem, Schweinitz, type (in Herb. Schw.); G. F. Atkinson, Cornell Univ. Herb., 23254.

South Carolina: Greenville, Ravenel, 1498, type and cotype (in Kew Herb. and in Curtis Herb. respectively) of T. Ravenelii Berk.; Santee Canal, Ravenel, type and cotype (in Kew Herb. and in Curtis Herb. respectively) of T. hiscens Berk. \& Rav.

Alabama: Peters, 576 bis (in Curtis Herb. under the name T. anthocephala).

Wisconsin: Madison, W. Trelease (in Farlow Herb.); Lake Geneva, E. T. and S. A. Harper, 882, and (in Harper Herb., 883).

Illinois: East St. Louis, N. M. Glatfelter (in Mo. Bot. Gard. Herb., 42563).

Iowa: Johnson County, T. J. Fitzpatrick, 39.

Missouri: St. Louis, N. M. Glatfelter (in Mo. Bot. Gard. Herb., 42564).

Kansas: Bourbon County, A. O. Garrett, 80.

8. T. pusiola Pat. in Duss, Champ. Guad. \& Martinique 12. 1903.

Pileus with divisions triangular, white, hard, thin, entire or cut-lobed, glabrous, even or rugose, sometimes zonate, atten- 
uated into a slender stem; stem colored like the pileus, glabrous, cylindric, woody; hymenium inferior, even, brown; basidia clavate, $25 \times 10 \mu$, four-spored; spores globose-angular, colorless or somewhat fuliginous, $6 \mu$ in diameter; no cystidia.

Fructification $1 \mathrm{~cm}$. high, divisions $5 \mathrm{~mm}$. broad.

Solitary or in clusters on dead wood. Guadaloupe. Forest of Bains-Jaune, Duss, 589.

Var. terrestris Pat. Ibid, has the divisions of the pileus narrower, laciniate, divergent, rigid.

On the ground, Matouba, Guadaloupe, Duss.

I have seen no specimens of either this species or its variety, neither of which have been reported since their original discovery. 1821.

9. T. caryophyllea Schaeffer ex Fries, Syst. Myc. I: 430. Elvella caryophyllea Schaeffer, Icon. Fung. 3: 115. pl. 325. 1762-1774.-Craterella ambigua Pers. Obs. Myc. I: 36. pl. 6. f. 8-10. 1796.-Thelephora caryophyllea $\gamma$ ambigua Pers. Myc. Eur. I: 112. 1822.

Illustrations: Schaeffer, Icon. Fung. $p l$. 325.-Persoon, Obs. Myc. I: pl. 6.f. 8-10.-Schnizlein, in Sturm, Deutsch. Flora 3: fasc. 31. $p l$. 6.-Lanzi, Fungi di Roma $p l$. 11. f. 4.-Saunders and Smith, Myc. Ill. pl. 41.f. 7-12.-Smith, W. G. Brit. Basid. 399. f. $96 a, b$.

Fructifications solitary or cespitose, coriaceous, fuscous purple but drying wood-brown; pileus infundibuliform, simple, or doubled by proliferous growth of smaller pilei from the disk of the principal pileus or of wedge-shaped lobes rising from its upper surface, upper surface radiately ridged or striate with masses of agglutinated fibers which are often dark colored, obscurely zonate when moist, margin incised; stem usually central, cylindric, villose, simple or branched; hymenium inferior, even, grayish olive to light yellowish olive; spores pale umbrinous, tuberculate, $7-8 \times 6 \mu$.

Fructification $1 \frac{1}{2}-5 \mathrm{~cm}$. high, $1 \frac{1}{2}-5 \mathrm{~cm}$. broad; stem $1 \mathrm{~cm}$. long, 2-3 mm. thick.

On the ground under pines. Canada to South Carolina and west to Ohio, also in the Pacific states. August to November. Abundant locally. 
T. caryophyllea may be distinguished from our other northern species which have a central stem and dark hymenium, by the thin lobes of the pileus which dry paler than the hymenium, and by the frequent occurrence of specimens with the pileus consisting of many lobes and pilei imbricately arranged in a manner suggestive of a double pink or carnation, as shown by Schaeffer's fig. 5, and Persoon's fig. 10 of the illustrations cited. Our specimens agree well with the figures of Schaeffer and Persoon-those of Persoon are especially good but unfortunately occur in a work which is very rare.

We find occasionally specimens which agree well with $T$. radiata (Holmsk.) Fr., but these specimens are connected so closely by intermediate forms-often in the same collectionwith others which are undoubtedly $T$. caryophyllea that I refer them to the latter species.

Specimens examined:

Sweden: K. Starback, in Romell, Fun. Scand., 121.

Canada: J. Macoun, 54 and 75 of 1903.

Quebec: Hull, J. Macoun, 190.

Ontario: London, J. Dearness (in Lloyd Herb.).

New Brunswick: Restigouche River, T. F. Allen, comm. by Dr. Farlow.

Maine: Orono, L. W. Riddle, 9.

New Hampshire: Shelburne, W. G. Farlow.

Vermont: Newfane, C. D. Howe; Middlebury, E. A. Burt, four collections.

Massachusetts: Sprague, 47, Russell, 131, and D. Murray, 545 (all in Curtis Herb.); Worcester, G. E. Francis, 105.

Connecticut: East Hartford, C. C. Hanmer, 1449; Central Village, J. L. Sheldon, 68, comm. by New York Bot. Gard.

New York: Bolton, C. H. Peck; Ithaca, G. F. Atkinson, 9993, 9994; Saranac Lake, E. A. Burt; East Galway, E. A. Burt.

Pennsylvania: Bethlehem, Schweinitz (in Herb. Schw.), the 608 of Syn. N. Am. Fungi.

Dist. of Columbia: Zoölogical Park, Coville and Cook, No. A, comm. by P. L. Ricker.

North Carolina: Schweinitz (in Herb. Schw.). 
Michigan: C. G. Lloyd, 4547; Sailor's Encampment, E. T. and S. A. Harper, 439, and Univ. of Wis. Herb., 2.

Ohio: C. G. Lloyd, 1422, 2720; Cincinnati, A. P. Morgan, Lloyd Herb., 2641, and (in Lloyd Herb., 1152); Loveland, D. L.

James (in Herb. U. S. Dept. Ag.).

Kentucky: C. G. Lloyd, 1152.

Washington: Bingen, W. N. Suksdorf, 717, 690.

California: Jackson, J. H. Barber, comm. by W. A. Setchell;

Stanford University, C. F. Baker, 255, distributed by Baker,

Pacific Slope Fungi, 3743, under the name $T$. radiata (Holmsk.) Fr.

ro. T. magnispora Burt, n. sp.

Plate 4. fig. 5.

Type: in Burt Herb.

Fructifications solitary or gregarious, coriaceous, stipitate; pileus irregularly infundibuliform, somewhat tubular, with ascending recurved lobes, drying avellaneous, becoming fuscous at the center with age, fibrous torn becoming radiately striate, margin incised; stem equal, solid, drying hard, irregularly angled, sulcate and pitted, vinaceous brown to drab; hymenium inferior, even, vinaceous brown; basidia simple; spores pale cinnamon, subglobose, echinulate, $10-14 \mu$ in diameter.

Fructification 2-4 cm. high; pileus $1-2 \mathrm{~cm}$. in diameter; stem 7-12 $\mathrm{mm}$. long, 2-5 $\mathrm{mm}$. thick.

On mossy ground. Chester Vale, Jamaica. December.

In some of the specimens the pileus is decidedly eccentric through greater growth on one side than on the other, and it is not always lobed. The offensive odor of the dried specimens and the color of the hymenium are suggestive of $T$. cuticularis.

Specimens examined:

Jamaica: Chester Vale, W. A. and Edna L. Murrill, type, New York Bot. Gard., Fungi of Jamaica, 295.

II. T. corbiformis Fries, (Nov. Symb. Myc. 92.) Actis. R. Soc. Sc. Upsal. III. I: 108. 1851.-Romell, Hymenomycetes Austro-Americani. Bihang till K. Sv. Vet.-Akad. Handl. 266 Afd. III. 44. 1901.

Type: in Herb. Fries.

Fructification sessile, rigid, cinereo-fuscous, with cespitose lobes of which the outer ascend and coalesce into a rounded 
cupulate pileus here and there lacunose-pervious, and the inner are distinct, crowded, erect, narrow; hymenium inferior, uneven, whitish; basidia simple; spores slightly colored, becoming uneven, ovoid, 5-6 x 4-5 $\mu$.

On the ground. Costa Rica and Brazil. January.

"In substance, texture, color, etc., this species agrees exactly with Thel. cornucopioides and Thel. angustata but in form it exhibits a type unique in the Hymenomycetes. The clusters are regularly rounded, very dense, divided all the way to the base into innumerable lobes, of which the interior are free and erect, the exterior regularly ascendant, broader, compressed, clothed underneath by the hymenium and grown together into a cup here and there lacunose-pervious, undulate-crisped at the apex and fimbriate."-Translation of the original comment on this species.

In 1899, I found the type in Herb. Fries to be cinereo-pallid with a slight fuscous tinge and with basidia and spores as stated above but many of the spores even. Romell describes the spores of his specimens from Brazil as "hyalinæ, laeves, ellips., 5-7 x 3-4 mmm.," and as agreeing with the type. I have reëxamined my sections from the type; the spores are certainly colored and many of them rough-walled.

Specimens examined:

Costa Rica: San José, Oersted (in Herb. Fries, Univ. Upsal.), type.

I2. T. cornucopioides Fries, (Nov. Symb. Myc. 91.) Actis R. Soc. Sc. Upsal. III. I : $107.1851 .{ }^{1}$

Type: not known to be in existence; not in Herb. Fries, at Upsala, nor in Kew Herb.

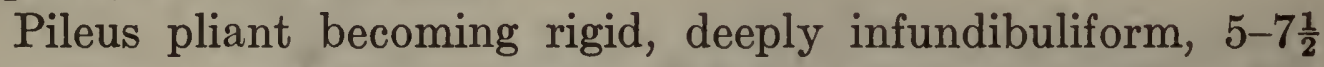
$\mathrm{cm}$. broad, radiately rugose, glabrous, fuscous; stem solid, rather glabrous, pallid; hymenium inferior, somewhat rugose, gray.

On the ground. Near San José, Costa Rica.

This species bears so singular a resemblance to Craterellus cornucopioides that from pictures they are scarcely to be distinguished. The present species has the stem truly solid and the substance fleshy pliant when living, nearly stony-woody

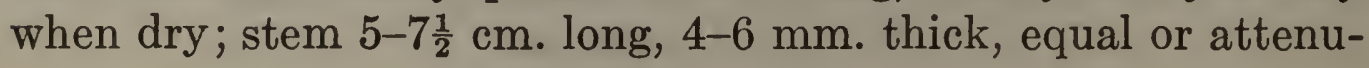

${ }^{1}$ A figure will be given in Part II. 
ated at the base, compressed, rather glabrous, very tough, pallid; pileus membranaceous-cartilaginous, when dry quite rigid, radiately rugose, with the ridges elevated towards the undulate and at first fimbriate margin, not zonate after the manner of species of Stereum; hymenium inferior, hardened. Related to Cladoderris.

I refer to T. cornucopioides a collection made in Jamaica by Prof. F. S. Earle, in 1902, the specimens of which agree well with the original description, as translated above, except in size. They are $3-3 \frac{1}{2} \mathrm{~cm}$. high and $2 \mathrm{~cm}$. broad with stem about $1 \mathrm{~cm}$. long by $2-4 \mathrm{~mm}$. thick. The dried fructification is very hard and stony and softens so little with water that the edge of the razor is turned in sectioning. The spores are colorless and even at first and become slightly colored and angular, 9-10 x $6 \mu$.

Specimens examined:

Jamaica: Castleton Gardens, F. S. Earle, New York Bot. Gard., Plants of Jamaica, 238.

I3. T. vialis Schw. (Syn. N. Am. Fungi) Trans. Am. Phil. Soc. N. S. 4:165. 1834.

Plate 5. fig. 15.

T. tephroleuca B. \& C. Grevillea I:149. 1873.

Type: in Herb. Schweinitz.

Fructification coriaceous, dirty whitish or pallid, sometimes wood-brown at the center, upper surface usually radiately plicate or rough with masses of agglutinated fibers; pileus polymorphic, sometimes composed of ascending lobes or small pilei which arise from a common base and grow together above to form a broad cup, or sometimes with the whole interior of the cup filled with small pilei and lobes many of which arise proliferously from the upper surface of the outer lobes; stem central when present; hymenium inferior, rugose, somewhat papillose, yellowish pallid becoming avellaneous or somewhat fuscous; spores olive-buff under the microscope, bluntly angular (i. e., tips of the angles obtuse), $4 \frac{1}{2}-7 \times 4 \frac{1}{2}-5 \mu$.

Fructification $2 \frac{1}{2}-5$ or $6 \mathrm{~cm}$. high, $2 \frac{1}{2}-7 \mathrm{~cm}$. broad.

On ground in frondose woods. Vermont to South Carolina and west to Illinois. September.

This is a fine, large species well marked by the dirty whitish or yellowish, fibrillose upper surface of the pileus, thick substance of the same color unless the specimen is old, and the brown, 
slightly wrinkled hymenium. As in the otherwise very different $T$. caryophyllea, large specimens sometimes resemble a double flower from the great number of small pileoli and lobes present in the center. Schweinitz described the species as sometimes having dimidiate pilei, but I have seen no such specimens. My collection assumed a disagreeable odor in drying but no such odor has been noted by others.

Specimens examined:

Exsiccati: Ell. \& Ev., N. Am. Fungi, 1110, and Fun. Col., 1593, in both under the name $T$. caespitulans.

Vermont: Lake Dunmore, E. A. Burt.

New Jersey: Newfield, J. B. Ellis (in Mo. Bot. Gard. Herb., 5155), also in the exsiccati cited.

Pennsylvania: Bethlehem, Schweinitz, type (in Herb. Schw.); Michener, 1504 (in Curtis Herb. and in Kew Herb.), the cotype and type respectively of $T$. tephroleuca; Trexlertown, W. Herbst, 43, C. G. Lloyd and W. Herbst, 2866, 3088 (both in Lloyd Herb.); N. M. Glatfelter (in Mo. Bot. Gard. Herb., 42561).

Dist. of Columbia: Washington, F. J. Braendle, comm. by C. H. Peck.

North Carolina: G. F. Atkinson (in Cornell Univ. Herb., 23253); Asheville, H. C. Beardslee; Schweinitz cited North Carolina as a station.

South Carolina: Caesar's Head, Ravenel, one of the types (in Curtis Herb. and Kew Herb.) of T. tephroleuca. Ohio: C. G. Lloyd, 4000.

Illinois: Glen Ellen, E. T. and S. A. Harper, 669.

14. T. albido-brunnea Schw. Trans. Am. Phil. Soc. N. S. 4: 166.1834.

Plate 5. fig. 13.

Stereum Micheneri B. \& C. Grevillea I : 162.1873 (in part).Stereum spongiosum Massee, Jour. Linn. Soc. Bot. 27: 172. 1889.-Thelephora odorifera Peck, Rep. N. Y. State Mus. 44: 132 (22). 1891.

Type: in Herb. Schweinitz.

Pileus sessile or with very short stem, coriaceous, spongy when dry, uniformly cinnamon-buff or with the older portions chestnut-brown, sometimes assuming mesopod form when encircling small twigs or shrubs, sometimes effuso-reflexed, usually dimidi- 
ate and somewhat imbricated, fibrous-tomentose, margin thick and entire; substance concolorous with the upper surface, spongy, more than $2 \mathrm{~mm}$. thick, with hyphae $4 \frac{1}{2}-5 \mu$ in diameter; hymenium inferior, even, not polished, cinnamon-buff; basidia simple; spores deep olive-buff under the microscope, echinulate, $8-10 \times 6-8 \mu$.

Pileus $2-4 \mathrm{~cm}$. in diameter when circular, or $1-2 \frac{1}{2} \mathrm{~cm}$. long, 2-4 cm. broad, often $1 \mathrm{~cm}$. thick at base when dimidiate.

Running up and encircling twigs on the ground and against the base of shrubs. Canada to Louisiana and west to Wisconsin. August.

Peck describes the odor as quite fragrant at first but states that it is lost after a few weeks; I did not notice any especial odor for my collection. T. albido-brunnea may be distinguished from our other dimidiate and reflexed species of Thelephora by its even and pale hymenium and thick spongy pileus. Schweinitz confused one collection of this species with $T$. biennis Fr., from the specimen of which in the Fries Herbarium, at Upsala, it is clearly distinct. The types of Stereum spongiosum Massee, viz., Curtis, 3582, and Ravenel, 1732, in Kew Herbarium, have colored echinulate spores $8-10 \times 6-7 \mu$, although described by

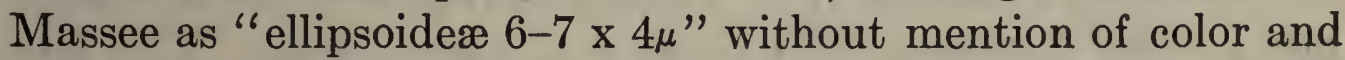
projections of the wall. The type of Thelephora odorifera Peck, in Coll. N. Y. State, is somewhat bleached or faded but quite typical.

Specimens examined:

Exsiccati: Ravenel, Fun. Car. IV, 12, the type distribution of $T$. Micheneri B. \& C.; Ell. \& Ev., N. Am. Fungi, 1599, and

Fun. Col., 1209, under the name $T$. Micheneri in both.

Canada: Toronto, J. Dearness (in Lloyd Herb.).

Vermont: Lake Dunmore, E. A. Burt.

New York: Selkirk, C. H. Peck (in Coll. N. Y. State), the type of T. odorifera Pk.; Alcove, C. L. Shear, 1010, 1163, 1184; Jamesville, L. M. Underwood.

Pennsylvania: Bethlehem, Schweinitz (in Herb. Schw.), the type, and also the Nos. 627 and 625 of Syn. N. Am. Fungi under the names respectively of $T$. biennis and T. laciniata; Michener (in Curtis Herb., 3582, and also in Kew Herb., same number), type of Stereum spongiosum Massee; Trexlertown, W. Herbst, 18, and (in Lloyd Herb., 3052). 
North Carolina: Blowing Rock, G. F. Atkinson, 4322.

South Carolina: Ravenel, 790 (in Curtis Herb. and in Kew Herb.), under the name Thelephora biennis; Santee Canal, Ravenel, 1732 (in Curtis Herb. and in Kew Herb.), type of Stereum spongiosum Massee.

Louisiana: Bogalusa, C. J. Humphrey, 466.

Ohio: Cincinnati, A. P. Morgan, Lloyd Herb., 2627.

Michigan: Saugatuck, E. A. and S. A. Harper, 654.

Wisconsin: Milwaukee Co., comm. by Mrs. F. W. Patterson.

15. T. lutosa Schw. Trans. Am. Phil. Soc. N.S.4:166. 1834. ${ }^{1}$

Type: in Herb. Schweinitz.

Pilei cespitose, densely imbricated, at first somewhat fleshy but at length hard, undulate-plicate, yellowish, almost subtomentose with pulverulence, somewhat horizontally attenuated behind, margin sublobate, at length inflexed; pileus less than $2 \mathrm{~mm}$. thick, with hyphae $3 \mu$ in diameter; hymenium becoming yellowish, even; spores olive-buff under the microscope, angular, $5-6 \times 3 \frac{1}{2}-4 \mu$.

Cluster about $1 \frac{1}{2} \mathrm{~cm}$. high and broad.

On the ground in roads and in woods. North Carolina.

The type is distinct from $T$. albido-brunnea, having thinner pileus, finer hyphae, and smaller and paler spores. The pilei were crowded together into a small buff-colored cluster about $1 \frac{1}{2} \mathrm{~cm}$. high and broad, somewhat as in Tremellodendron pallidum (Schw.); I failed to find stems at their bases.

Specimens examined:

North Carolina: Salem, Schweinitz (in Herb. Schw.), type.

I6. T. cuticularis Berk. Hooker's Lond. Jour. Bot. 6: 324. 1847. Republished in Lea, Catalogue of Plants in Vicinity of Cincinnati 66. d. 1849.

Plate 5. fig. 14.

Type: in Kew Herb., and a portion of it from Berkeley in Curtis Herb.

Pilei coriaceous-soft, effuso-reflexed or dimidiate, imbricate, sometimes laterally confluent, drying pinkish buff to cinnamonbrown, with a broad, pale margin, surface radiately rugose, soft, silky fibrillose; substance of the same color as pileus; hymenium inferior, concave, even, drab to brownish drab; spores umbrinous under the microscope, flattened on one side or some-

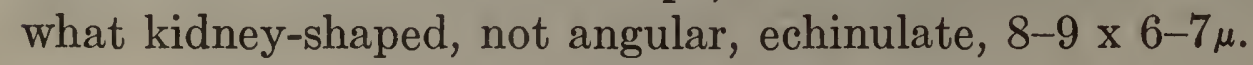

${ }^{1}$ A figure will be given in Part II. 
Pileus $1-1 \frac{1}{2} \mathrm{~cm}$. long, $2-4 \mathrm{~cm}$. broad, $1 \mathrm{~mm}$. thick.

On mossy bark at the base of trees and on fallen twigs in groves. Vermont to Texas and west to Missouri. June to August.

In his description Berkeley noted that the odor of this species is strong and unpleasant; my specimens retained such an odor for several years but I did not notice it before they were dried. T. cuticularis may be distinguished from our other species by its drab hymenium, portions of which become sage-green when crushed under a cover glass in a 7 per cent solution of potassium hydrate, and by its spores, which are not at all angular or irregular as regards the main body of the spore, but ovoid and flattened on one side or slightly kidney-shaped and sparingly studded with slender spines.

Specimens examined:

Vermont: Middlebury, E. A. Burt.

Rhode Island: Olney, 1851 (in Kew Herb. and in Curtis Herb.). Pennsylvania: Bethlehem, Schweinitz (in Herb. Schw.), the Nos. 628 and 629 of Syn. N. Am. Fungi, under the names respectively of T. fuscocinerea, and T. gausapata; Kitanning, D. R. Sumstine, 1.

Delaware: Newark, H. S. Jackson.

North Carolina: Asheville, H. C. Beardslee, 03195.

Florida: Mrs. Sams, comm. by C. G. Lloyd.

Texas: W. H. Long, Jr., 351, 387 (in Cornell Univ. Herb.).

Ohio: Waynesville, T. G. Lea (in Kew Herb.), type; Preston, A.P. and L. V. Morgan, comm. by C. G. Lloyd, also C. G. Lloyd, specimen dated July 26, 1896; Cincinnati, C. G. Lloyd, 4492. Wisconsin: Blue Mounds, E. T. and S. A. Harper, 861. Missouri: Columbia, B. M. Duggar, 289.

I7. T. intybacea Pers. ex Fries, Syst. Myc. I : 431. 1821.

Plate 5. fig. 11.

T. intybacea Pers. Syn. Fung. 567. 1801-1807; Myc. Eur. I: 110.1822.

Illustrations: Bulliard, Champ. de la France pl. 278.-Bigeard et Guillemin, Champ. Super. France 436. pl. 44. f. 1 .

Fructifications cespitose, soft, whitish, then rufous-ferruginous, drying chestnut-brown to Rood's brown, with stems 
somewhat lateral and growing into one another; pilei imbricated, fibrous, usually with the fibers matted and agglutinated into appressed and wholly adnate squamules, margin dilated and whitish-fimbriate at first, at length becoming entire and colored like the rest of the pileus; hymenium inferior, concolorous with the upper surface, papillose; spores concolorous with hymenium, snuff-brown under the microscope, angular-tuberculate, $7-9 \times 6-8 \mu$.

Clusters often $5-8 \mathrm{~cm}$. in diameter; individual pileus $2-3 \mathrm{~cm}$. long, 2-4 $\mathrm{cm}$. broad, $1 \mathrm{~mm}$. thick.

On the ground in pine woods, growing up from the layer of fallen leaves. Ontario to North Carolina and westward to Ohio and Michigan. August to October.

The clusters are sometimes central but more often with the pilei lateral and triangular; sometimes the mass ascends small sticks and then extends out from this support in reflexed forms; the upper surface is usually uneven and dries somewhat depressed between the adnate squamules. This species is distinguished from ferruginous specimens of $T$. terrestris by the thicker and entire margin of the pileus and by the absence of free squamules.

Specimens examined:

Exsiccati: Ell. \& Ev., Fun. Col., 1410.

Austria: G. Bresadola.

Ontario: Toronto, J. Dearness, comm. by C. G. Lloyd; Harraby, Lake Rosseau, E. T. and S. A. Harper, 682.

Maine: Portage, L. W. Riddle, 3.

New Hampshire: Shelburne, W. G. Farlow.

Vermont: Middlebury, Sudbury, Grand View Mt., E. A. Burt. Massachusetts: A. P. D. Piguet, comm. by Dr. Farlow; Natick, G. E. Morris, No. E.

Connecticut: East Hartford, C. C. Hanmer, 1434.

New York: Alcove, C. L. Shear, 1009; East Galway, E. A. Burt;

Ithaca, G. F. Atkinson, Cornell Univ. Herb., 3050, 19652.

Dist. of Columbia: Takoma Park, C. L. Shear, 799, 796; Washington, $O . F$. Cook, 4, comm. by P. L. Ricker.

North Carolina: Asheville, H. C. Beardslee, 0341.

Ohio: A. P. Morgan (in Lloyd Herb.).

Michigan: C. G. Lloyd, 4546; Lawton, L. A. Hawkins; Sailor's

Encampment, Allen and Stuntz, 1, Univ. of Wis. Herb. 
18. T. terrestris Ehrh. ex Fries, Syst. Myc. I : 431. 1822.

Plate 5. fig. 10.

T. terrestris Ehrh. Crypt. Exsicc. No. 178. 1785.-Persoon, Syn. Fung. 566. 1801; Myc. Eur. I: 113. 1822.-Stereum laciniatum Pers. Obs. Myc. I: 36. 1796.-Thelephora laciniata Pers. Syn. Fung. 567. 1801.-T. caryophyllea $\beta$ laciniata Pers. Myc. Eur. I: 112. 1822.-T. laciniata Fries, Syst. Myc. I : 431. 1821.

Illustrations: Batsch, Elenchus Fung. pl. 24. f. 121.-Nees, System der Pilze pl. 34. f. 251.-Bolton, Hist. Fung. pl. 173.Sowerby, Col. Fig. of Eng. Fungi pl. 213.-Cooke, Handbook I: 310.-Stevenson, Brit. Hym. 2: 261.-Smith, Brit. Basid. 399. f. 96 C-E.

Fructifications dark fuscous to fawn-color, coriaceous-soft, cespitose, obconic, with a short stem-like base, or dimidiate and sessile, or incrusting and effuso-reflexed; pileoli more or less imbricated, sometimes laterally confluent, fibrous-squamulose and usually strigose, thin, margin fibrous-fimbriate and laciniate; hymenium inferior, papillose, fuscous to fawn-color; spores pale fuscous, irregular, angular, sometimes slightly tuberculate, $6-9 \times 6 \mu$.

Clusters $5-8 \mathrm{~cm}$. in diameter, with single pileolus about $3 \mathrm{~cm}$. long and broad; obconic pileus $2-3 \mathrm{~cm}$. in diameter; dimidiate pileolus $1 \frac{1}{2}-2 \mathrm{~cm}$. long, $2-3 \mathrm{~cm}$. broad, about $1 \mathrm{~mm}$. thick.

On sandy ground in bare fields and at base of trunks and from fallen twigs and leaves in pine woods. Canada to South Carolina, and in Michigan, Jamaica, and Alaska. July to December.

My observations of this species acquired from specimens received and from seeing it growing abundantly near Middle Grove, N. Y., seem to show that the medium from which this fungus derives its food produces an interesting effect on the fructification. Growing from bare, sandy ground the fructifications are dark fuscous in color, and may be flattened clusters of imbricated pileoli, or of the obconic-pileus type composed of ascending pileoli confluent laterally, or dimidiate, sessile pileoli. When growing on abundant woody matter, as is the case in the specimen in Sowerby's illustration already cited, the fructification assumes a redder color and replaces its dimidiate, sessile pileus on earth by a reflexed one on the wood. With regard to 
other forms of the clusters and pileoli, the covering of the upper surface, and the spore characters there is no difference between those fructifications produced without woody food and those having it. There is no sharp color separation between these color extremes.

Specimens growing on the ground usually have a short stemlike base, while those growing on wood are reflexed; the same collection may show both these conditions, as, for example, that from Skagway, Alaska, if some of the fructifications start from sticks and others directly from the ground. Persoon regarded the stem in $T$. terrestris as the chief character separating that species from his T. laciniata, as may be seen from his own descriptions contrasting the two in his 'Synopsis Fungorum,' pp. 566 and 567, as follows:

"3. TheL. TERRESTRIS: subimbricata obscure fusca, pileo applanato fibroso-strigoso."

"Hab. in arenosis ad terram. Stipes breuis, lateralis omnino adest. Substantia submollis, non ita coriacea sicca, vti in ceteris speciebus."

"4. Thel. Laciniata: imbricata obscure fusca, pileo tenui laciniato crispo subtus papillis congestis scabro."

"Hab. ad radices truncorum. Cespitem difformem efformat, 2 vnc. lata, tenuis. Stip. vix adest distinctus."

These descriptions supplement each other as a description for one species; each has special application to fructifications growing side by side under such conditions as to show that they are from a common mycelium. Persoon never claimed that his species differed from T. terrestris in color. Fries gave a different description of $T$. laciniata in his works cited-to the injury of T. intybacea-, but the characters he gives are not satisfactory. European mycologists with a wide knowledge of the Thelephoracece as they grow are unable to distinguish these two species. In letters to me, Bresadola regards $T$. laciniata as a synonym of $T$. terrestris; and Romell does not know $T$. terrestris if it is distinct from T. laciniata.

Specimens examined:

Exsiccati: Ellis, N. Am. Fungi, 511; Ell. \& Ev., N. Am. Fungi, 2732 , under the name $T$. intybacea.

Austria: G. Bresadola.

Sweden: G. Romell, 52, 55, 56, 5\%.

Newfoundland: A. C. Waghorne, 276 (in Mo. Bot. Gard. Herb.). 
Quebec: Gaspe, J. Macoun, 229.

Ontario: Ottawa and Belleville, J. Macoun.

Maine: Wells, J. Blake, comm. by P. L. Ricker.

New Hampshire: Chocorua, W. G. Farlow.

Massachusetts: Magnolia and Woods Hole, W. G. Farlow; Ipswich, G. E. Morris, No. F.

Connecticut: South Windsor, East Hartford, and Rockville, C. C. Hanmer, 1227-29, 944, $105 \%$.

New York: East Galway and Middle Grove, E. A. Burt, three collections from the latter station; Ithaca, G. F. Atkinson, Cornell Univ. Herb., 22976.

New Jersey: Belleplain, C. L. Shear, 1246; Newfield, J. B. Ellis, Ellis, N. Am. Fungi, 511.

Pennsylvania: Schweinitz (in Herb. Schw.), the 624 of Syn. N. Am. Fungi.

North Carolina: Asheville, H. C. Beardslee, 02280; Salem, Schweinitz (in Herb. Schw.), the 624 of Syn. N. Am. Fungi.

Alabama: Tuskegee, Beaumont, 199 (in Curtis Herb.).

South Carolina: Society Hill, M. A. Curtis, 2693 (in Curtis Herb.).

Michigan: Agricultural College, G. H. Hicks, Ell. \& Ev., Fun. Col., 2732.

Alaska: Skagway, J. Macoun, 47; Evans, 410 (in Mo. Bot. Gard. Herb.).

Jamaica: Cinchona, W. A. and E. L. Murrill, New York Bot. Gard., Fun. of Jamaica, 451.

19. T. griseozonata Cooke, Grevillea I9: 104. 1891.

Type: in Ravenel, Fun. Amer., 444.

Plate 5. fig. 12.

Fructifications cespitose, coriaceous-soft; pileoli extended into a short sublateral stem, imbricate, applanate, silky-strigose, zonate with alternating cervine (Rood's brown) and light buff zones, margin subfimbriate; hymenium inferior, castaneous when fresh, drying Rood's brown, rugose, somewhat papillose; spores pale fuscous, angular, $6-9 \times 6-7 \mu$.

Cluster $3-6 \mathrm{~cm}$. in diameter; obconic pileus and single pileolus each $2-3 \mathrm{~cm}$. in diameter. 
On sandy ground in pine woods. New Jersey to Louisiana. August to November.

This species is closely related to $T$. terrestris and has the same habitat, habit of growth, and spore characters, but is distinguished from that species by its zonate pileus. The fructifications usually occur in flattened clusters with spreading pileoli; sometimes the individual pileoli acquire an infundibuliform appearance by the growing together for part of their length of opposite edges of individual pileoli; sometimes a small obconic pileus occurs composed of two or more pileoli with adjacent edges confluent. In the collection cited below from Mississippi, small lobes are present in the cavity of the cup, as in $T$. vialis and T. caryophyllea.

Specimens examined:

Exsiccati: Ravenel, Fungi Am., 444, type distribution; Ravenel,

Fun. Car. II, 28, under the name T. caryophyllea; Ellis, N.

Am. Fungi, 714; Ell. \& Ev., Fun. Col., 1305.

New Jersey: Newfield, J. B. Ellis, in his exsiccati cited.

South Carolina: Aiken, H. W. Ravenel, Fungi Am., 444, type collection.

Alabama: Auburn, C. F. Baker, Lloyd Herb., 3462.

Mississippi: Biloxi, Mrs. E. S. Earle, 32.

Louisiana: St. Martinville, A. B. Langlois, by.

20. T. fimbriata Schw. ex Schweinitz, Trans. Am. Phil. Soc. N. S. $4: 166.1834$.

Plate 4. fig. 3.

Merisma fimbriatum Schw. (Syn. Fung. Car., No. 1067) Schrift. d. Naturforsch. Gesell., Leipzig, I: 110. 1822.-Thelephora scoparia Peck, Rep. N. Y. State Mus. 42: 123 (27). pl. 2. f. 20, 21. 1889.

Illustrations: Peck, Rep. N. Y. State Mus. 42: pl. 2. f. 20, 21.

- Type: in Herb. Schweinitz.

Fructification coriaceous-soft, incrusting and ascending small plants (mosses, etc.), here and there emitting fascicles of branches united below, subterete, acuminate or fimbriately incised, at first pale or whitish, soon ferruginous brown, drying Rood's brown; hymenium even, pruinose-pubescent; spores umbrinous, tuberculate, $7-11 \times 6-9 \mu$. 
Incrusting and ascending upward 1-3 cm.; free branches 5-10 $\mathrm{mm}$. long, $1 \mathrm{~mm}$. thick, sweep of fascicle about 5-10 $\mathrm{mm}$.

In moist places. New York to South Carolina, and west to Illinois. July and August.

The type is an incrusting specimen, covering as its main axis a small twig in one specimen and a moss in the other, and sending out a few lateral branches which are flattened towards the free ends and subfimbriate; main trunk is cylindric, latericius (of 'Chromotaxia'), ends of branches paler; spores umbrinous under the microscope, tuberculate, 7-8 x $6 \mu$. Schweinitz described the species as becoming hard and cartilaginous, but this is an error probably due to the foreign matter surrounded by the main trunk. Several other specimens are present in his herbarium under various names.

Specimens examined:

Exsiccati: Ellis, N. Am. Fungi, 512, under the name T. cristata. Massachusetts: Weston, A. B. Seymour; T 1 (in Mo. Bot. Gard. Herb., 45573).

New York: Bethlehem and Selkirk, C. H. Peck (in Coll. N. Y. State), type of T. scoparia; Syracuse, from Herb. Cornell Univ., 19474.

New Jersey: Newfield, J. B. Ellis, N. Am. Fungi, 512.

Pennsylvania: Bethlehem, Schweinitz (in Herb. Schw.), the 615 of Syn. N. Am. Fungi, under the name T. stabularis.

North Carolina: Salem, Schweinitz (in Herb. Schw.), type, and also the 1063 of Syn. Fung. Car., under the name Merisma fuscescens.

Indiana: Millers, E. T. and S. A. Harper, 670.

Illinois: Havana, H. C. Beardslee; Riverside, E. T. and S. A. Harper, 668.

2I. T. perplexa Burt, n. sp. ${ }^{1}$

Type: in Curtis Herb.

Fructification incrusting, coriaceous, consisting of a resupinate membrane from the central portion of which arise cylindric trunks either simple or digitately branched; resupinate portion spongy, firm, separable, fuscous at the center, margin thin, determinate, pinkish buff; ascending portions spongy, firm,

${ }_{1}$ A figure will be given in Part II. 
fuscous, simple and tapering upward or soon branching and terminating in paler either subulate tips or somewhat flattened ends; spores fuscous, subglobose, echinulate, $8-10 \times 8-9 \mu$.

The resupinate membrane may be $3 \mathrm{~cm}$. in diameter; ascending portion of fructification $2-3 \mathrm{~cm}$. high, $1 \frac{1}{2}-2 \mathrm{~mm}$. thick.

On decaying leaves and sticks on the ground. Cuba.

Berkeley \& Curtis based their description of Thelephora dentosa on two collections made in Cuba by C. Wright in different years; these collections are different specifically. The original description applies chiefly to the earlier collection, made in 1857, which is unnumbered. I take my type of $T$. perplexa from the later collection, C. Wright, 238.

Specimens examined:

Exsiccati: Fungi Cubenses Wrightiani, C. Wright, 238, under the name Thelephora dentosa B. \& C.

Cuba: C. Wright, 238, type (in Curtis Herb.).

22. T. dentosa Berk. \& Curtis emend Burt. ${ }^{1}$

T. dentosa B. \& C. (Fungi Cubenses) Jour. Linn. Soc. Bot. I0: 329.1867.

Type: type and cotype in Kew Herb. and Curtis Herb. respectively.

Fructification coriaceous-soft, incrusting leaves and small twigs on the ground and ascending as free, sessile, dilated, triangular, flabelliform pilei which are dentate at the upper end or deeply divided into a few finger-shaped divisions, honeyyellow to tawny olivaceous throughout, minutely hairy under a lens; spores honey-yellow, globose to ovoid, weakly echinulate, 6-10 × 6-8 .

Pileus $1 \mathrm{~cm}$. high, $5 \mathrm{~mm} .-1 \mathrm{~cm}$. broad.

On rotten vegetation. Cuba. June.

As already stated in connection with $T$. perplexa, Berkeley $\&$ Curtis cited for types of their $T$. dentosa specimens from two collections made in Cuba by C. Wright. These collections were made with an interval of several years between the collections, which differ specifically. As noted by Berkeley \& Curtis, their description applies better to the earlier collection, to which I now

${ }^{1}$ A figure will be given in Part II. 
restrict their species. This earlier collection was distributed by C. Wright, unnumbered, under the name Thelephora dentosa B. \& C. before the publication of the description of this species, and the cotype in Curtis Herb. is unnumbered also. By what was apparently a slip of the pen, Berkeley cited this type as C. Wright, 50\%. By the kindness of Dr. Farlow I have been permitted to examine the manuscript records which show that Wright collected only one No. 507, which was determined by Berkeley as Xylaria obovata Berk. and is cited under this species by Berk. \& Curtis, Jour. Linn. Soc. Bot. Io: 380. 1867. I find in Curtis Herb. such a specimen labelled Xylaria obovata Berk., Cuba, C. Wright, 50\%. I conclude that the type and cotype of $T$. dentosa B. \& C., first cited in their description, are from the collection distributed by $\mathrm{C}$. Wright, unnumbered, under the name Thelephora dentosa B. \& C.

Specimens examined:

Exsiccati: Plantae Cubenses Wrightianae, unnumbered, under the name Thelephora dentosa B. \& C.

Cuba: C. Wright, cotype (in Curtis Herb.).

23. T. spiculosa Fries, Syst. Myc. I : 434. 1821; Epicr. Syst. Myc. 539. 1836-38.

Plate 4. fig. 2.

Illustrations: Persoon, Syn. Fung. pl. 3. f. 16.

Type: an authentic specimen from Fries, in Kew Herb.

Fructifications cespitose, from byssoid becoming fleshy, variable by incrusting habit, pale buff at first, main portions becoming purplish-fuscous (Rood's brown) with age, ramosespiculous, tips penicillate and whitish; spores umbrinous under the microscope, irregular, echinulate, 8-9 × 6-7 $\mu$.

Clusters $1-2 \mathrm{~cm}$. high, $2-4 \mathrm{~cm}$. in diameter, single fructification 1-2 $\mathrm{cm}$. high, about $1 \mathrm{~mm}$. in diameter, with branches spreading 4-6 $\mathrm{mm}$.

On leaves on ground in moist groves. Ohio to Wisconsin. July. Rare.

The best specimens which I have seen have main trunks of the fructifications running side by side over partially decayed beech leaves and confluent into an effused mass. These trunks ascend obliquely from the leaves to a height of 1-2 cm., branch sparingly, and terminate in spiculous tips. The fructification 
must be inconspicuous in the woods since the general color of the mass is the same as that of the leaves on which it is effused, although the main trunks may be darker.

Specimens examined:

Exsiccati: Kunze, Fun. Sel. Exsic., 560.

Sweden: specimen from Fries (in Kew Herb.).

Austria: G. Bresadola.

Ohio: Preston, C. G. Lloyd.

Michigan: Glen Lake, C. G. Lloyd, 02471.

Wisconsin: Lake Geneva, E. T. and S. A. Harper, 883.

\section{(To be continued.)}

\section{Explanation of Plate}

PLATE 4

All figures of plates 4 and 5 have been reproduced natural size from photographs of dried herbarium specimens of species of Thelephora.

Fig. 1. Thelephora anthocephala. From specimen collected at Linwood, Ohio, by C. G. Lloyd, No. 02164.

Fig. 2. T. spiculosa. a, from specimen on leaves of Fagus collected in Europe by Bresadola, which I compared with the specimen from Fries in Kew Herbarium; $b$, from specimen collected at Glen Lake, Mich., by C. G. Lloyd, No. 02471.

Fig. 3. T. fimbriata. From specimen incrusting living strawberry (Fragaria) plant, collected at Riverside, Ill., by E. T. and S. A. Harper, No. 668.

Fig. 4. T. palmata. From specimen from New Jersey, from C. G. Lloyd, No. 4612 .

Fig. 5. T. magnispora. From type specimens collected at Chester Vale, Jamaica, by W. A. and Edna L. Murrill, No. 295. a shows upper surface and side of pileus, and $b$, the hymenium.

Fig. 6. T. regularis. From a sketch of the type in Herb. Schweinitz.

Fig. 7 a. T. multipartita. From specimens collected at Trexlertown, Pa., by Dr. W. Herbst.

Fig. 7 b. T. regularis. From specimens collected at Clayton, Del., by H. S. Jackson.

Fig. 8. T. scissilis. From type specimens collected at Bingen, Wash., by W. N. Suksdorf, No. 716 .

Fig. 9. T. caryophyllea. From specimens collected in Michigan, by C. G. Lloyd, No. 4547. 

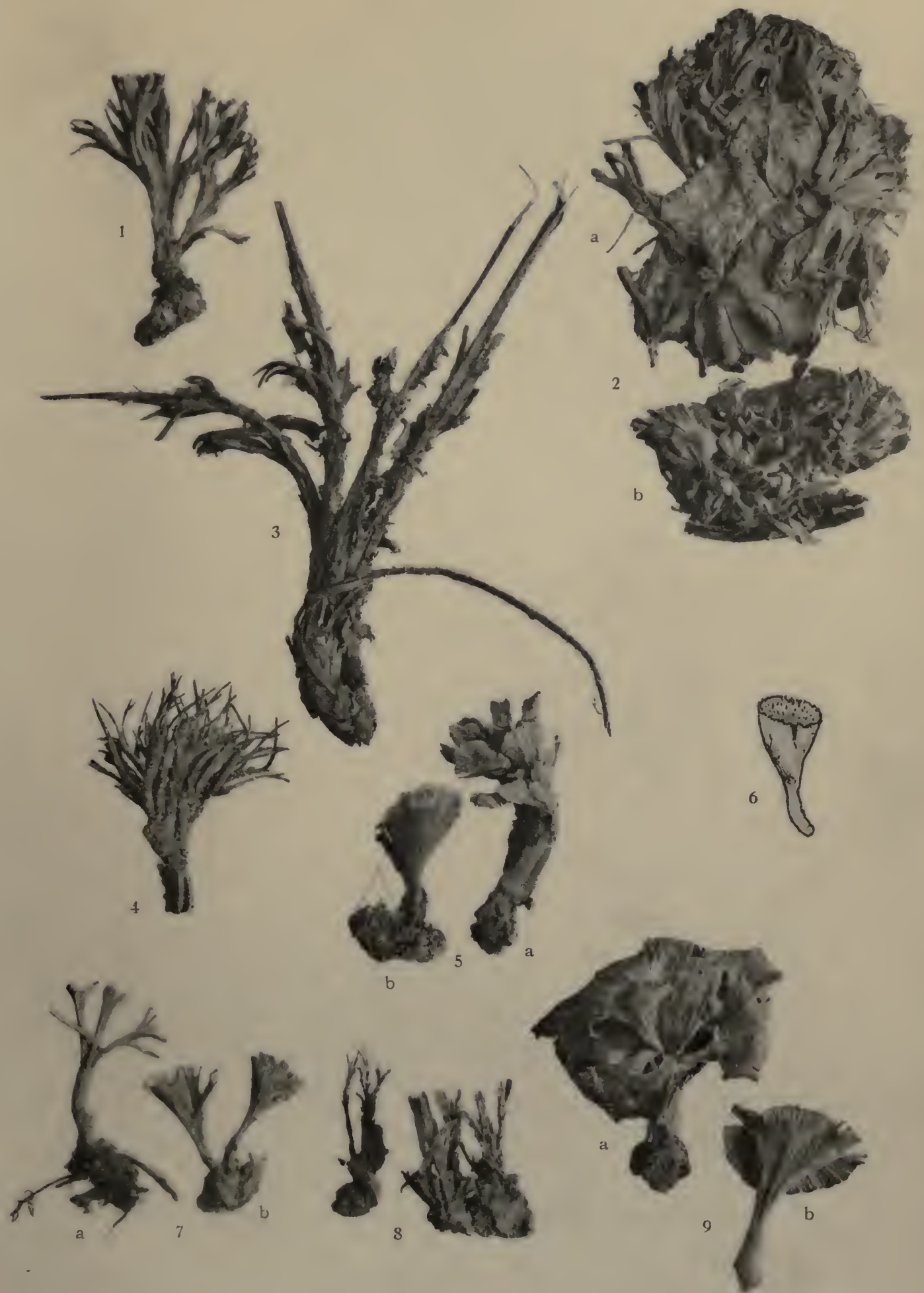

BURT-THELEPHORACEAE OF NORTH AMERICA

1. THELEPHORA ANTHOCEPHALA.-2. T. SPICULOSA. - 3. T. FIMBRIATA. 4. T. PALMATA. - 5. T. MAGNISPORA.-6 AND 7 b. T. REGULARIS. -7 a. T. MULTIPARTITA. -8. T. SCISSILIS.--9. T. CARYOPHYLLEA. 




\section{Explanation of Plate}

PLATE 5.

Fig. 10. T. terrestris. From specimens collected on ground in open fields at Middle Grove, N. Y. $a$ shows the fibrose-strigose upper surface and fimbriate margin of the pileus, and $b$, the hymenium of lower surface.

Fig. 11. T. intybacea. From specimens collected in pine woods incrusting fallen pine leaves and twigs at Middlebury, Vt. a shows upper surface with matted, adnate squamules and whitish, thick, entire margin; $b$, the hymenium of lower surface.

Fig. 12. T. griseozonata. From specimen of type collection, distributed in Ravenel, Fun. Amer., No. 444.

Fig. 13. T. albido-brunnea. a, upper side of specimen collected at Saugatuck, Mich., by E. T. and S. A. Harper, No. 654 . The specimen is about $2 \mathrm{~cm}$. thick; $b$, hymenium of specimen collected at Lake Dunmore, Vt.

Fig. 14. T. cuticularis. From specimens collected at Blue Mounds, Wis., by E. T. and S. A. Harper, No. 861. $a$, viewed obliquely from above; $b$, viewed from under side to show hymenium.

Fig. 15. T. vialis. From specimen collected at Lake Dunmore, Vt. 

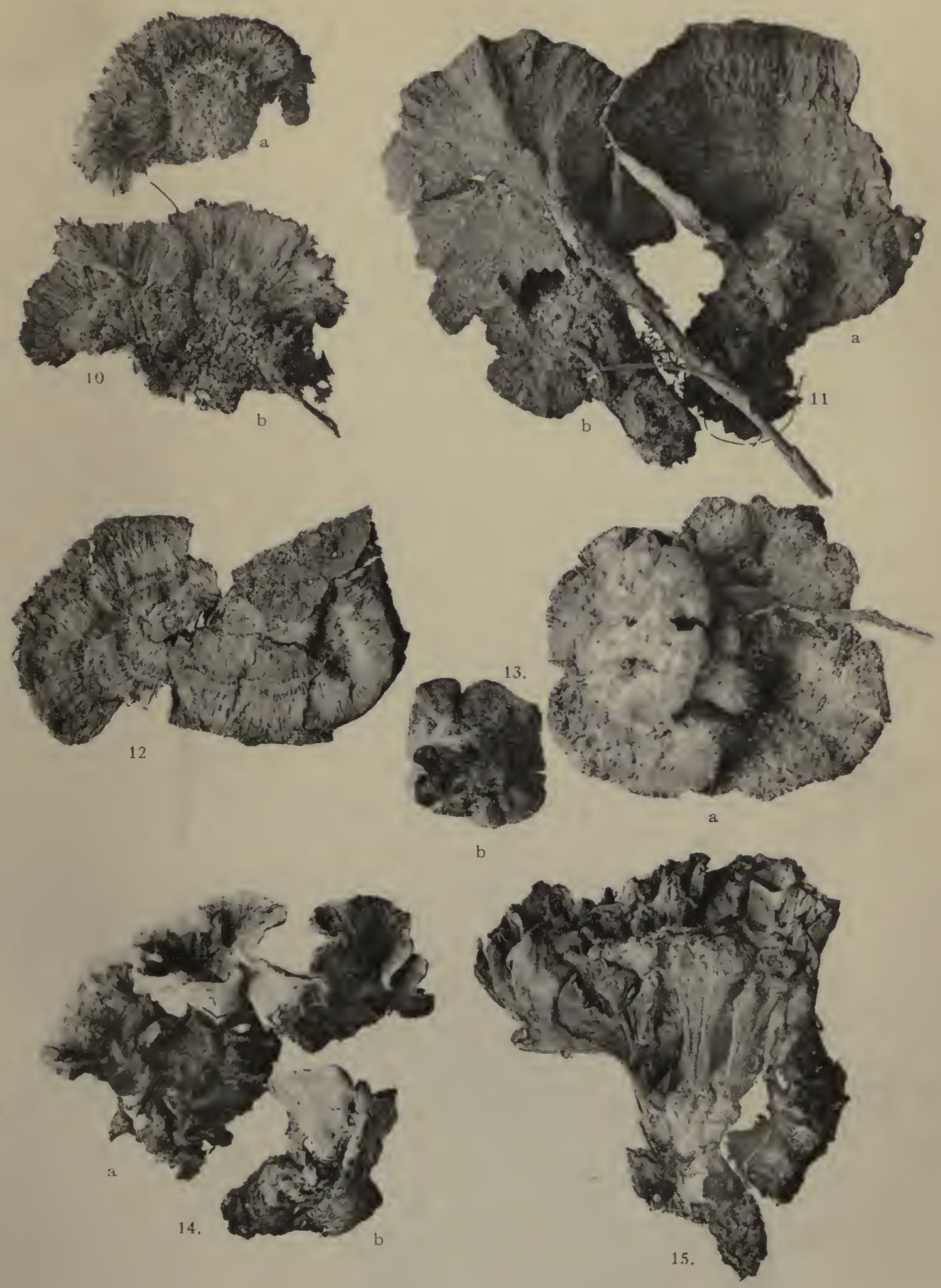

BURT - THELEPHORACEAE OF NORTH AMERICA

10. THELEPHORA TERRESTRIS. - 11. T. INTYBACEA. - 12. T. GRISEO-ZONATA. 13. T. ALBIDO $-B R U N N E A .-14$. T. CUTICULARIS. - 15. T. VIALIS. 

The Thelephoraceae of North America. II

\section{Craterellus}

\section{EDWARD ANGUY BURT}

Reprinted fiom innals of the Missouri Botanicai. G.1RDen 1: 327-350. September, 1914 


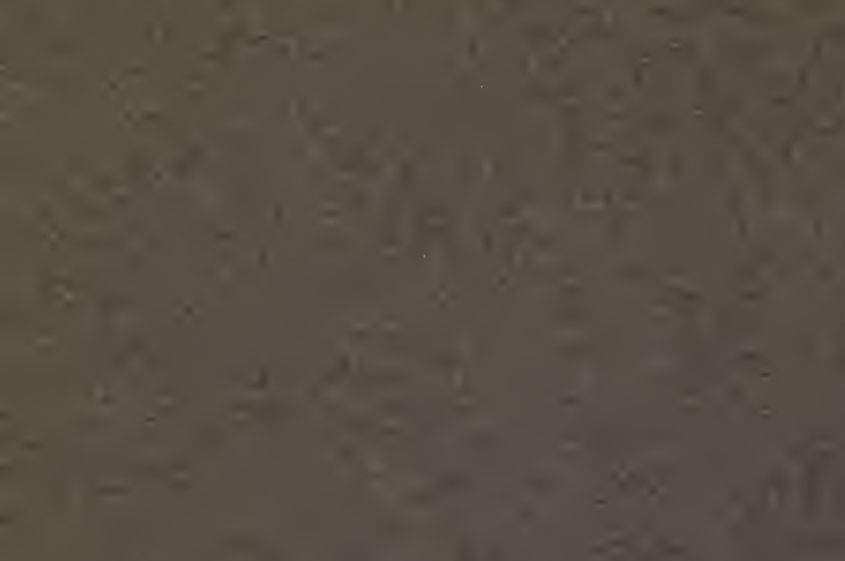

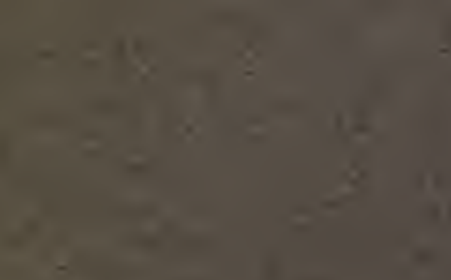

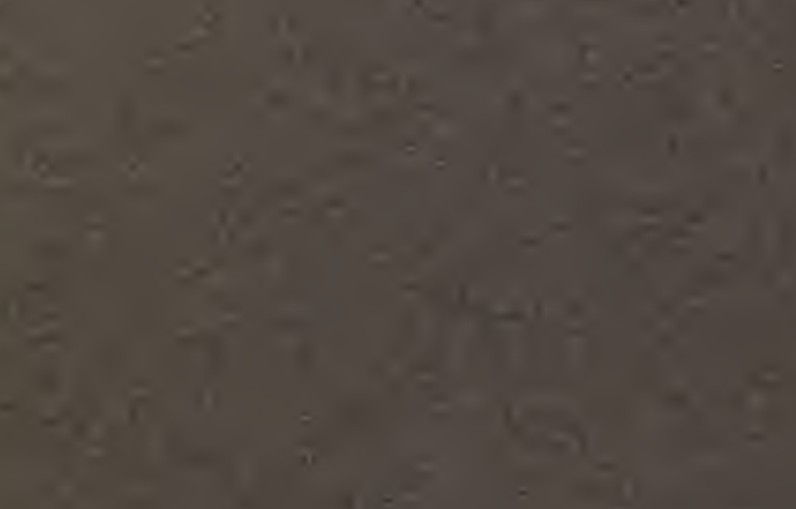




\title{
THE THELEPHORACEÆ OF NORTH AMERICA. II ${ }^{2}$
}

\section{Craterellus}

\section{EDWARD ANGUS BURT}

\begin{abstract}
Mycologist and Librarian to the Missouri Botanical Garden Associate Professor in the Henry Shaw School of Botany of

Washington University
\end{abstract}

\section{CRATERELLUS}

Craterellus Pers. Myc. Eur. 2:4. 1825.-Fries, Epicr. 531. 1838; Hym. Eur. 630. 1874. - Saccardo, Syll. Fung. 6:514. 1888.-Hennings, in Engl. \& Prantl, Nat. Pflanzenfam. (ז. 1**): 127. 1898.

The type species of the genus is Craterellus cornucopioides L. ex Pers.

Fructifications fleshy or membranaceous, pileate, often tubiform, infundibuliform, or flabelliform, sometimes clavate; hymenium waxy-membranous, distinct, continuous, adnate to the hymenophore, even or rugose; basidia simple; spores usually white.

Craterellus is closely related by its fleshy C. Cantharellus, C. odoratus, C. lutescens, etc., with the genus Cantharellus. These species resemble so closely in coloration and habit species of the latter genus that careful examination of the hymenium should be made for generic determination. Craterellus has its hymenium even or slightly rugose. In exceptional connecting species, such as $C$. clavatus, it is somewhat lamelliform for a part of the distance from margin of the pileus to the stem. The clavate $C$. pistillaris and $C$. unicolor connect Craterellus closely with Clavaria.

Craterellus cornucopioides, C. ochrosporus, C. clavatus, C. Cantharellus, and $C$.odoratus are edible species, which are often abundant locally.

${ }^{1}$ Issued September 30, 1914.

Nоте.-Explanation in regard to the citation of specimens studied is given in Part I, Ann. Mo. Bot. Gard. I: 202, footnote. The technical color terms used in this work are those of Ridgway, Color Standards and Nomenclature. Washington, D. C., 1912.

ANN. MO. BOT. GARD., Vor. 1, 1914 


\section{Key to THe Species}

Hymenium somewhat radiately lamelliform-at least near the margin;

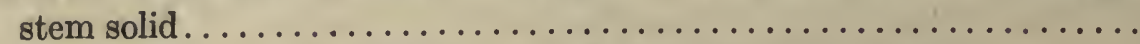
Hymenium plane, rugose-wrinkled, or ribbed and rugose-wrinkled. . . . . . .

1. Fructification large, $4-10 \mathrm{~cm}$. high; stem about $1 \mathrm{~cm}$. thick; spores $10-13 \mathrm{x}$

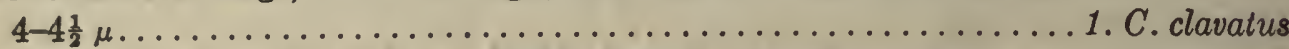

1. Fructification small, $1-1 \frac{1}{2} \mathrm{~cm}$. high; stem $1 \mathrm{~mm}$. thick; pileus umbilicate;

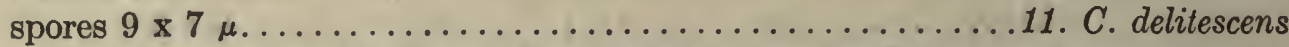
2. Fructification with pileus infundibuliform and pallid rose; hymenium and stem white. In N. Carolina in moss near Kalmia bushes. . . 4. C. roseus 2. Fructification entirely egg-yellow, about $3-9 \mathrm{~cm}$. high, $2 \frac{1}{2}-9 \mathrm{~cm}$. broad... 3

2. Fructification neither entirely egg-yellow nor with pileus pallid rose and hymenium and stem white...................... 4

3. Pileus convex, then depressed or infundibuliform; stem solid...2. C. Cantharellus

3. Pileus convex, then depressed or cyathiform; stem hollow or cavernous; fructification sometimes branched ................... . odoratus 4. Pileus tubiform with cavity extending nearly or quite to the base of

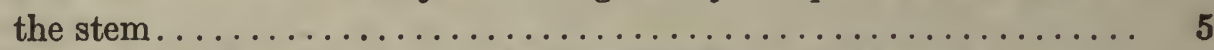

4. Pileus not tubiform, but instead infundibuliform, depressed, truncate, convex, or flabelliform . . . . . . . . . . . . . . . . . .

5. Pileus and stem smoky brown to blackish; hymenium cinereous drab; spores

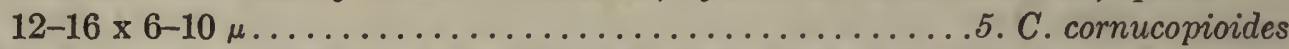

5. Pileus drying avellaneous to snuff-brown; stem black with chamois-colored pubescence at its base; hymenium chamois-colored or colored like the pileus; spores $12-15 \times 7-8 \mu \ldots \ldots \ldots \ldots \ldots \ldots \ldots \ldots \ldots \ldots \ldots \ldots \ldots \ldots \ldots$. ochrosporus

5. Pileus somewhat tubiform; hymenium dark cinereous; spores $6-7 \frac{1}{2} \times 4 \frac{1}{2}-5 \mu$

7. C. dubius

5. Pileus somewhat tubiform or umbilicate, yellowish brown to fuscous; hymenium and stem yellow; spores $10-12 \times 6-8 \mu \ldots \ldots \ldots \ldots . .6$. lutescens 6. Pileus infundibuliform, $2-3 \mathrm{~cm}$. broad; hymenium pallid cinereous; spores $10-12 \times 6-7 \mu \ldots \ldots \ldots \ldots \ldots \ldots \ldots . \ldots . .$. . . sinuosus

6. Pileus deeply cup-shaped, 4-8 $\mathrm{mm}$. broad; hymenium cream-buff; spores $8 \times 6 \mu \ldots \ldots \ldots \ldots \ldots \ldots \ldots \ldots \ldots \ldots \ldots \ldots \ldots \ldots \ldots \ldots$ C. calyculus

6. Pileus convex, then umbilicate, $5 \mathrm{~mm}$. broad; hymenium sometimes obscurely lamelliform, chamois-colored; stem chamois-colored; spores

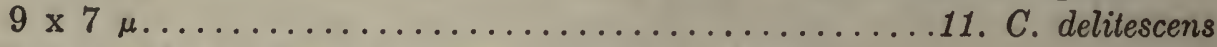

6. Pileus merely depressed, truncate, convex, or clavate.......... 7

6. Pileus flabelliform ............................ 8

7. Fructification small, 1-3 cm. high, 4-9 $\mathrm{mm}$. broad, narrowly obconic, white; spores $3-4 \mu$ in diameter...................... taxophilus

7. Fructification $2-5 \mathrm{~cm}$. high, from obconic often becoming abruptly enlarged and somewhat cerebriform at the upper end but with the stem remaining comparatively slender......................... Unicolor

7. Fructification large, 6-15 cm. high, clavate or obconic and truncate, tapering downward; stem often bulbous at the base. Fructification dries sorghumbrown to fuscous...................... pistillaris

8. Pileus ligulate at first, then spreading laterally and becoming somewhat palmately cleft into a few branches, fawn-color shading into bonebrown. Known from Ohio.................... palmatus 
8. Pileus somewhat triangular, drying a dirty pinkish buff; hymenium drying Isabella-color to clay-color. Known only from Florida. .16. C. dilatus

8. Fructification entirely white; pileus reniform, dimidiate, attached laterally to a slender erect stem. Known only from Washington

17. C. Humphreyi

I. Craterellus clavatus Pers. ex Fries, Epicr. 533. 18361838. Plate 15. fig. 6.

Merulius clavatus Pers. Obs. Myc. I: 21. 1896.-Cantharellus clavatus Fries, Syst. Myc. I : 322. 1821.-Nevrophyllum clavatum Fries ex Patouillard, Tab. Anal. Fung. I: 193. f. 434. 18831886. - Cantharellus brevipes Peck, Rep. N. Y. State Mus. 33: 21. pl. 1.f. 18-20. 1879.

Illustrations: Schæffer, Icon. Fung. pl. 164, 276.-Krombholz, Abbild. und Beschr. pl. 45. f. 13-17.-Fries, Sverig. Ätl. Svamp. pl. 91.-Richon et Roze, Atlas Champ. pl.50.f. 10-14.Bresadola, Funghi Manger. $p l$. 82.-Peck, Rep. N. Y. State Mus. 33: pl. 1.f. 18-20.-Harper, Mycologia 5: pl. 93, 94.

Fructifications solitary or cespitose, fleshy, flesh whitish; pileus narrowly obconic, turbinate, truncate or depressed, glabrous, ochraceous buff, attenuated into the stem, the margin thin and erect; stem short, solid, tomentose at the base; hymenium lamelliform near the margin, rugose-wrinkled elsewhere, becoming pruinose with the spores, light vinaceous drab, drying

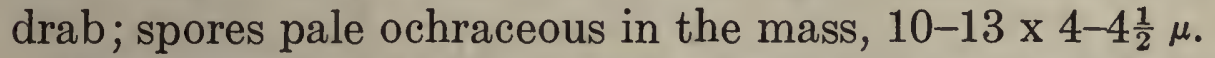

Fructifications $4-10 \mathrm{~cm}$. high; pileus $3-8 \mathrm{~cm}$. broad; stem 1-2 cm. long, 8-15 mm. thick.

On the ground in coniferous woods. Maine to Connecticut and west to Minnesota, and in Montana. July to September.

This species is intermediate between Craterellus and Cantharellus. The marginal portion of the hymenium is like that of a Cantharellus, and the remainder of the hymenium, like that of a Craterellus. There is good authority for including this species in ?antharellus and there is the authority of Fries and herbarium usage for classing it in Craterellus. C. clavatus is edible but too rare, at least in the east, to be common in herbaria.

Specimens examined:

Exsiccati: De Thuemen, Myc. Univ., 1807.

Austria: G. Bresadola.

Maine: Sprague (in Curtis Herb., 5786). 
New Hampshire: Shelburne, W. G. Farlow (in Mo. Bot. Gard. Herb., 4868).

Vermont: Lake Dunmore, E. A. Burt.

Connecticut: Rainbow, C. C. Hanmer, 1454 (in Hanmer Herb.). New York: Ballston, C. H. Peck, the type of Cantharellus brevipes (in Coll. N. Y. State).

2. C. Cantharellus Schw. ex Fries, Epicr. 534. 1836-1838. Plate 15 . fig. 7. Thelephora Cantharella Schw. Schrift. d. Naturforsch. Gesell., Leipzig, I: 105. 1822.-Craterellus lateritius Berk. Grevillea I : 147.1873 .

Illustrations: Peck, Rep. N. Y. State Mus. 49: pl. 44. f. 1-5; Mem. N. Y. State Mus. $3^{4}:$ pl. 56. f. 17-21.-Hard, Mushrooms f. 378.-Marshall, Mushroom Book 73. $f$.

Type: in Herb. Schweinitz.

Fructifications single or cespitose, fleshy, firm, egg-yellow; pileus convex, becoming depressed or infundibuliform, glabrous, yellow, the margin often lobed or irregular; stem solid, cylindric or tapering downward, glabrous, yellow; hymenium nearly even or rugose wrinkled, yellow, or with a reddish salmon tinge and drying ochre-red; spores $7-10 \times 3 \frac{1}{2}-5 \frac{1}{2} \mu$.

Fructifications $4-9 \mathrm{~cm}$. high; pileus $2 \frac{1}{2}-8 \mathrm{~cm}$. broad; stem $2 \frac{1}{2}-5 \mathrm{~cm}$. long, 5-10 mm. thick.

On the ground in open woods. Massachusetts to Alabama and westward to Ohio; also in Mexico. June to September. Abundant locally.

This species is so similar to Cantharellus cibarius in habit, coloration, size and form-differing from the latter only in the more even hymenium, that figures of $C$. cibarius will serve very well for Craterellus Cantharellus, if allowance is made for the different hymenium. The firm and solid stem of $C$. Cantharellus distinguishes this species from $C$. odoratus easily. The latter species sometimes has its pileus greatly branched. My illustration of this species is photographed from the dried herbarium specimen of the cotype of $C$. lateritius Berk. In this specimen the lobes of the pileus were pressed together above before drying. The hymenium of this specimen is now ochre-red and agrees in color with that of the authentic specimen of $C$. Cantharellus in Curtis Herb.; both these specimens have been poisoned. I 
found the spores of the type in Herb. Schw. 8-9 $\times 3 \frac{1}{2}-4 \mu$, or a little slenderer than in northern specimens. Hard states that the spores are yellowish or salmon colored in the mass when collected. This species is edible.

Specimens examined:

Exsiccati: Ell. \& Ev., N. Am. Fungi, 1921.

Massachusetts: Sprague (in Curtis Herb.); Milton, H.Webster. Connecticut: East Hartford, C. C. Hanmer, 2391, 2468 (both in Hanmer Herb.).

Pennsylvania: West Chester, B. M. Everhart, Ell. \& Ev., N. Am. Fungi, 1921.

West Virginia: Eglon, C. G. Lloyd, 02292.

North Carolina: Schweinitz, type (in Herb. Schweinitz); Blowing Rock, G. F. Atkinson, 4313.

South Carolina: Clemson College, P. H. Rolfs, 1830.

Alabama: Peters (in Curtis Herb., 4539, and in Kew Herb.), the cotype and type respectively of $C$. lateritius; Auburn, F. S. Earle (in Mo. Bot. Gard. Herb., 4928).

Ohio: A. P. Morgan (in Lloyd Herb.).

Kentucky: C. G. Lloyd (in Lloyd Herb.).

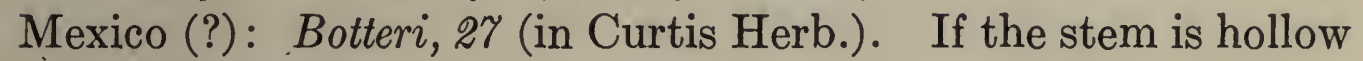
this specimen is $C$. odoratus.

3. C. odoratus Schw. ex Fries, Epicr. 532. 1836-1838.

Plates 15, 16. figs. 8-10.

Merulius odoratus Schw. Schrift. d. Naturforsch. Gesell., Leipzig, I: 91. 1822.-Cantharellus odoratus Fries, Elenchus Fung. I : 51. 1828.-C. confluens Berk. \& Curtis, Jour. Linn. Soc. Bot. 9: 423. 1867.

Type: in Herb. Schweinitz.

Fructifications gregarious, sometimes cespitose, simple or branched, egg-yellow; pileus thin, convex, then depressed and somewhat cyathiform, sometimes pervious, yellow, the margin deflexed, often lobed or irregular; stem cylindric or somewhat tapering towards the base, concolorous with the pileus, hollow or cavernous; hymenium even or somewhat rugose-wrinkled, ochraceous orange or with a reddish tinge approaching Sanford's brown; spores even, 7-9 x 4-5 $\mu$.

Fructifications $3-7 \mathrm{~cm}$. high; pileus $2-9 \mathrm{~cm}$. broad; stem $2-4$ cm. long, 3-8 mm. thick. 
In moist places in woods. North Carolina and Georgia to Ohio and Missouri. June to October.

Specimens of this species have sometimes been confused in recent years with the better known $C$. Cantharellus, which ranges farther north. The color and general habit of these species is the same; both have the egg-yellow color and the characteristic fragrance of Cantharellus cibarius when moistened after drying, and all three are edible. Craterellus odoratus is more membranaceous than C. Cantharellus and it differs from both this species and Cantharellus cibarius in having a hollow or cavernous stem whose pliant walls may be pinched together, like those of a rubber tube, before the specimens are dried. Highly branched forms may occur as shown in pl. 16 fig. 10a; this character was unduly emphasized in the original description. The ample collections in the Glatfelter Herbarium seem to show that Craterellus odoratus is the most frequent Craterellus in the vicinity of St. Louis. Dr. Glatfelter notes on his collection that he has eaten this species and found it quite good. In pl. 15 fig. 8, I give a figure, natural size, from a photograph of the dried herbarium cotype of $C$. confluens B. \& C., to show how close the resemblance is to the specimens of $C$. odoratus, collected at St. Louis and figured in the following plate. The type of $C$. confluens has the hymenium rugose-wrinkled, as is often the case in specimens of $C$. odoratus; its habit, dimensions, structure, coloration, and spores are quite those of $C$.odoratus.

Specimens examined:

North Carolina: Salem, Schweinitz, type (in Herb. Schweinitz). South Carolina: Society Hill, Ravenel, 192 (in Curtis Herb.). Georgia: Station cited by Schweinitz. Alabama: Auburn, L. M. Underwood.

Ohio: Oxford, L. O. Overholts, 1721 (in Overholts Herb.).

Missouri: near St. Louis, N. M. Glatfelter, 348 (in Mo. Bot. Gard. Herb., 42590), and J. B. S. Norton (in Mo. Bot. Gard. Herb., 4926).

Mexico: near Orizaba, Botteri, 6 (type and cotype in Kew Herb. and Curtis Herb., respectively, of C. confluens).

4. C. roseus Schw. ex Fries, Epicr. 533. 1836-1838. Merulius roseus Schw. Schrift. d. Naturforsch. Gesell., Leip- 
zig, I: 91. 1822.-Cantharellus roseus Fries, Elenchus Fung. 53. 1828.

Fructifications solitary, somewhat fleshy; pileus infundibuliform, somewhat strigose, pallid rose, the margin lobed and inflexed; stem apparently stuffed, attenuated downward, white; hymenium somewhat rugose, white.

In mosses, especially in proximity to Kalmia. North Carolina.

Specimens of this species have the habit of Cantharellus cibarius but are thinner. Fries received a specimen of Craterellus roseus from Schweinitz and expressed the opinion in 'Elenchus' that the species is good. I have seen no specimens of $C$. roseus and base the above on the original description and the comments by Schweinitz and Fries.

\section{C. cornucopioides L. ex Pers. Myc. Eur. 2: 5. 1825.}

Plate 17. fig. 17.

Peziza cornucopioides L. Sp. Pl. 1181. 1753. [1st ed.]Elvella cornucopioides Scop. Fl. Carn. 2: 476. 1760.-Merulius cornucopioides Pers. Syn. Fung. 491. 1801.-Cantharellus cornucopioides Fries, Syst. Myc. I : 321. 1821.

Illustrations: Vaillant, Botan. Paris. pl. 13. f. 2, 3.-Bolton, Hist. Fung. pl. 103.-Flor. Dan. pl. 384, 1260.-Holmskiold, Fung. Dan. 2. pl. 5.-Sowerby, Brit. Fung. pl. 74.--Schæffer, Icon. Fung. pl. 165.-Bulliard, Herb. de la France pl. 150.Schnizlein, in Sturm, Deutsch. Flora 3: fasc. 31. pl. 5.-Bresadola, Funghi Manger. 75. pl. 83.-Cooke, Brit. Edible Fung. pl. 11. f. 39.-Dufour, Atlas Champ. pl. 70. f. 15\%.-Hard, Mushrooms 451. f. 379.-Peck, Rep. N. Y. State Mus. 48: pl. 24.f. 7-10.-cf. Saccardo, Syll. Fung. 19: 478, for other references to illustrations.

Fructifications gregarious or somewhat cespitose; pileus thin, - somewhat membranaceous, tubæform, pervious, sometimes granular or minutely squamulose, smoky brown to blackish, usually drying Prout's brown, with the erect, spreading, or decurved margin generally lobed, wavy, or irregular; stem short, hollow, even, blackish brown; hymenium even or rugosewrinkled, cinereous drab; spores hyaline, even, $12-16 \times 6-10 \mu$.

Fructification $5-8 \mathrm{~cm}$. high; pileus $2 \frac{1}{2}-5 \mathrm{~cm}$. broad; stem 1-3 cm. long, 3-5 mm. thick. 
On earth in mixed woods. Canada to South Carolina and westward to Missouri. June to September.

The cornucopia craterellus is well characterized by its cornucopia-shaped or narrowly trumpet-shaped pileus ashy to sooty brown in color, by thin flesh which is somewhat tough and flexile, cinereous drab hymenium which sometimes has a brownish tinge, and black stem. This species is too infrequent to afford more than a few herbarium specimens in the regions where I have collected fungi, but it is reported so plentiful in some states as to be highly regarded as an edible species.

Specimens examined:

Exsiccati: Ravenel, Fung. Car. II. 27; Ellis, N. Am. Fungi, 321; Ell. \& Ev., Fung. Col., 1723; Shear, N. Y. Fungi, 49; Rabenhorst-Winter, Fung. Eur., 3640.

Sweden: L. Romell, 48.

Canada: J. Macoun, 72, 73.

Ontario: Casselman, J. Macoun, 34\%.

Vermont: Grand View Mt., E. A. Burt.

Massachusetts: Sprague, 211 (in Curtis Herb.).

Connecticut: W. A. Setchell.

New York: Sand Lake, C. H. Peck (in Coll. N. Y. State);

Alcove, C. L. Shear, Shear's N. Y. Fungi, 49; Ithaca, H. von Schrenk (in Mo. Bot. Gard. Herb., 4763, 42584), W. $H$. Long, Jr., Ell. \& Ev., Fung. Col., 1723.

New Jersey: Newfield, H. Leahy, Ellis, N. Am. Fungi, 321.

Pennsylvania: locality cited by Schweinitz, Syn. N. Am.

Fungi; W. Herbst (in Lloyd Herb.).

North Carolina: (in Curtis Herb., 502); locality cited by Schweinitz, Syn. Fung. Car. Sup.

South Carolina: M. A. Curtis (in Curtis Herb.).

Ohio: Loveland, D. L. James, comm. by U. S. Dept. Agr.

Kentucky: Mammoth Cave, C. G. Lloyd.

Missouri: Perryville, C. H. Demetrio, Rabenhorst-Winter, Fung. Eur., 3640; Meramec Highlands, P. Spaulding (in Mo. Bot. Gard. Herb., 4869).

6. C. ochrosporus Burt, n. sp. Plate 17. fig. 15 . An C. ocreatus Pers. Myc. Eur. 2: 5. pl. 13. f. 2. 1825?

Type: in Mo. Bot. Gard. Herb., 42585.

Fructifications gregarious or cespitose; pileus thin, somewhat 
membranaceous, tubæform, pervious, minutely floccose-squamulose, drying avellaneous to snuff-brown, the margin erect or decurved; stem short, hollow, black, with chamois-colored pubescence at the base; hymenium even or somewhat rugose, sometimes colored like the pileus but in the type chamoiscolored; spores straw-yellow in the mass, even, obtuse, 12-15 $\mathrm{x} 7-8 \mu$.

Fructifications $4-7 \mathrm{~cm}$. high; pileus $1-3 \frac{1}{2} \mathrm{~cm}$. broad, $1-2 \frac{1}{2}$ cm. long, 2-4 mm. thick.

On the ground among mosses in woods. New York and Missouri. June to September. Probably abundant in Missouri.

Dr. Glatfelter noted a pleasant minty odor for the specimens. This species closely resembles $C$. cornucopioides in form, but differs from that species in having hymenium, spores, and base of stem yellow. A collection from the same spot from which the type collection came, but made in June two years later, has the hymenium snuff-brown and approaches $C$. cornucopioides in this respect. I am not aware of any data on $C$. ocreatus Pers. except that based on the original description which is cited above. That species has presumably not been collected by European mycologists since the original collection from the environs of Paris a century ago. Our specimens differ from that description in having the stem yellow pubescent at the base and the hymenium somewhat rugose, and they may differ in other characters, e. g., spore colors, etc., not given in the brief description of $C$. ocreatus. Hence I give to our American specimens a distinct name.

Specimens examined:

New York: East Galway, E. A. Burt.

Missouri: Meramec Highlands, N. M. Glatfelter (in Mo. Bot. Gard. Herb., 42585, type, and 42586-87); Columbia, B. $M$. Duggar, 134.

7. C. dubius Peck, Rep. N. Y. State Mus. 3r: 38. 1879.

Illustrations: Hard, Mushrooms f. 380.

Type: in Coll. New York State.

Fructifications solitary or cespitose; pileus thin, infundibuliform or subtubiform, subfibrillose, dark brown or lurid brown, pervious, the margin generally wavy and lobed; stem short, hollow, colored like the hymenium; hymenium dark 
cinereous and rugose when moist, the obscure crowded irregular wrinkles abundantly anastomosing, nearly even and paler when dry; spores broadly elliptical or subglobose, $6-7 \frac{1}{2} \times 4 \frac{1}{2}-5 \mu$.

Fructification $5-7 \frac{1}{2} \mathrm{~cm}$. high; pileus $2 \frac{1}{2}-5 \mathrm{~cm}$. broad, $4 \mathrm{~mm}$. thick.

On ground in woods. Ontario and New York to Illinois. August to October. Rare.

The specimens of this species have the same coloration as those of $C$. cornucopioides but differ from the latter in having a shorter and more funnel-shaped pileus, and smaller spores. Moffatt reported $C$. dubius as abundant at Glencoe, Illinois.

Specimens examined:

Ontario: Belleville, J. Macoun, 228 (in Coll. N. Y. State). New York: Adirondack Mts., C. H. Peck, type (in Coll. N. Y. State).

Michigan: Sailor's Encampment, Univ. of Wis. Herb., 46.

8. C. lutescens Pers. ex Fries, Epicr. 532. 1838.

Plate 17. fig. 20.

Merulius lutescens Pers. Syn. Fung. 489. 1801; Albertini \& Schweinitz, Consp. Fung. 234. 1805.-Cantharellus lutescens Fries, Syst. Myc. I: 320. 1821.-Merulius xanthopus Pers. Myc. Eur. 2 : 19. pl. 13.f. 1. 1825.

Illustrations: Vaillant, Botan. Paris. pl. 11. f. 9, 10.Schæffer, Icon. Fung. pl. 15\%.-Bolton, Hist. Fung. pl. 105. f. 2.. -Persoon, Myc. Eur. 2: pl. 13. f. 1.-Hennings, in Engl. \& Prantl, Nat. Pflanzenfam. (I.1**): 129. f. 70 H.-Stevenson, Brit. Hym. 2 : 259.

Fructifications solitary to cespitose; pileus thin, somewhat membranaceous, varying from convex and umbilicate to tubiform or funnel-shaped, often pervious, yellowish brown to fuscous, with margin often lobed or irregular; stem flexuous, cylindric, hollow, yellow, drying ochraceous buff, often hairy at the base; hymenium remotely ribbed, even or rugose-wrinkled, yellow, drying cadmium-yellow to ochraceous buff; spores even, $10-12 \times 6-8 \mu$.

Fructifications $2 \frac{1}{2}-5 \mathrm{~cm}$. high; pileus $1 \frac{1}{2}-3 \mathrm{~cm}$. broad, stem $1 \frac{1}{2}-4 \mathrm{~cm}$. long, 2-4 mm. thick.

On moist ground in woods and swamps. Newfoundland to North Carolina and westward to Michigan. August to October. 
This species probably ranks next to $C$. cornucopioides in frequency in the United States. The long and yellow stem readily distinguishes this species from $C$. ochrosporus. Specimens of Cantharellus infundibuliformis resemble those of Craterellus lutescens in form, size, and color, but those of the former species have true lamellæ.

Specimens examined:

Exsiccati: Ellis, N. Am. Fungi, 1302; De Thuemen, Myc. Univ., 404.

Sweden: Stockholm, L. Romell, 49; Femsjö, L. Romell.

Newfoundland: Bay of Islands, A. C. Waghorne, 34 (in Mo. Bot. Gard. Herb.).

New Hampshire: Shelburne, W. G. Farlow, Ellis, N. Am. Fungi, 1302, and (in Mo. Bot. Gard. Herb., 4932).

Vermont: Lake Dunmore, E. A. Burt. Massachusetts: Worcester, G. E. Francis, 100.

New England: Sprague, 1689 (in Curtis Herb.).

New York: Sand Lake and Helderberg Mts., C. H. Peck (in

Coll. N. Y. State); East Galway, E. A. Burt.

Pennsylvania: locality cited by Schweinitz, Syn. N. Am. Fungi. North Carolina: locality cited by Schweinitz, Syn. Fung. Car. Sup.

Michigan: Glen Lake, C. G. Lloyd, 02462.

9. C. sinuosus Fries ex Fries, Epicr. 533. 1836-1838.

Cantharellus sinuosus Fries, Syst. Myc. I : 319. 1821.

Illustrations: Vaillant, Botan. Paris. pl. 11.f. 11-23.-Fries, Icon. Hym. 2 : pl. 196. f. 2.-Dangeard, Le Botaniste 4 : 147.f.Gillet, Champ. France Hym. $p l$.

Fructifications cespitose, slightly fleshy; pileus infundibuliform, undulate and floccose, light drab; stem cylindric, stuffed, pallid cinereous; hymenium at length with interwoven wrinkles, pallid cinereous; spores $10-12 \times 6-7 \mu$.

Fructifications $2-3 \mathrm{~cm}$. high; pileus $2-3 \mathrm{~cm}$. broad; stem $1 \frac{1}{2}-2$ cm. long, 2-4 mm. thick.

On ground in mixed woods. South Carolina. Rare.

I have seen only dried herbarium specimens of Craterellus sinuosus. The spore measurements are those of a specimen from Sweden received from Romell. In this specimen the hymenium has dried somewhat chamois-colored. 
Specimens examined:

Exsiccati: Rabenhorst, Fung. Eur., 208 (in Kew Herb.).

Sweden: L. Romell, 50.

South Carolina: Ravenel (in Curtis Herb., 2982).

C. crispus Fr., sometimes regarded as a variety of C. sinuosus, was reported from New England, Sprague, by Berkeley \& Curtis, Grevillea I: 147, but the specimen is not satisfactory for study. I do not, therefore, like to include C. crispus as one of our species.

I0. C. calyculus (B. \& C.) Burt, n. comb.

Stereum calyculus Berk. \& Curtis, Hooker's Jour. Bot. and Kew Gard. Misc. I : 238. 1849; Grevillea I : 161. 1873.

Type: type and cotype in Kew Herb. and Curtis Herb. respectively.

Fructifications somewhat fleshy-membranaceous; pileus thin, deeply cup-shaped, minutely tomentose, drying Saccardo's umber, opaque; stem apparently hollow, cream buff, attenuated below, tomentose at the base; hymenium even or slightly venose, cream buff; spores slightly yellowish under the microscope, even, $8 \times 6 \mu$.

Fructifications $2-3 \mathrm{~cm}$. high; pileus $4-8 \mathrm{~mm}$. broad; stem $1 \mathrm{~cm}$. long, 1-2 mm. thick.

On ground in damp shady woods. North and South Carolina. August and September.

Upon moistening, the type in Kew Herbarium proved too soft and fleshy and the hymenium too waxy for a Stereum. The sections have the structure of Craterellus. The species is near C. sinuosus and may prove to be a small form of this when ample material gives more complete knowledge of the species, but, for the present, I regard $C$. calyculus as a distinct species. I refer to $C$. calyculus a collection made by Professor Atkinson at Blowing Rock, North Carolina, the rough-dried and cespitose specimens of which show a somewhat tubiform pileus and spores $7-8 \times 4 \frac{1}{2} \mu$.

Specimens examined:

North Carolina: Blowing Rock, G. F. Atkinson, 4200.

South Carolina: Santee River, Ravenel, Curtis Herb., 1716 (the type and cotype in Kew Herb. and Curtis Herb. respectively). 
I I. C. delitescens Burt, n. sp.

Plate 17. fig. 18.

Type: in Burt Herb.

Fructifications gregarious, cespitose, somewhat fleshy; pileus thin, convex, then umbilicate, dry, fibrillose, sepia-colored, the margin inrolled; stem equal, solid, glabrous, chamois-colored; hymenium even or sometimes obscurely lamelliform, chamoiscolored; spores white, even, broadly ovoid, $9 \times 7 \mu$, borne four to a basidium.

Fructification 10-15 mm. high; pileus $5 \mathrm{~mm}$. broad; stem 10-15 mm. long, $1 \mathrm{~mm}$. thick.

Growing among mosses on very thin soil on rocks by waterfall. Vermont. August.

This species is intermediate between Cantharellus and Craterellus in its hymenial structure, but, as some of the specimens have the hymenium even and bearing mature spores, I include the species in Craterellus. The specimens are much smaller than those of $C$. calyculus and have the pileus becoming merely umbilicate. The little fructifications were well concealed among the mosses; I have found them but once.

Specimens examined:

Vermont: Falls of Lana, Lake Dunmore, E. A. Burt, type.

12. C. taxophilus Thom, Bot. Gaz. 37: 215-19. f. 1-8. 1904. Plate 17. fig. 21.

Illustrations: Thom, ibid. f. 1-8.

Type: in Cornell Univ. Herb., 15445.

Fructifications single, rarely gregarious, fleshy-membranaceous, entirely white when young, becoming pallid to ochraceous buff with age, drying cinnamon buff; pileus narrowly obconic, slightly viscid, the apex truncate, plane, or depressed and with a thin margin which is erect or expanded; stem solid, equal or tapering downward, flexuous, pruinose, with scattered white hairs at the base; hymenium even, becoming longitudinally rugose-wrinkled with age or upon drying; spores white, even, subglobose, 3-4 $\mu$ in diameter, borne four to a basidium.

Fructifications $1-3 \mathrm{~cm}$. high; pileus $4-9 \mathrm{~mm}$. broad; stem $\frac{1}{2}-2$ $\mathrm{cm}$. long, $\frac{1}{2}-1 \mathrm{~mm}$. thick.

On rotten twigs and leaves under prostrate branches of Taxus canadensis. New York. October and November.

This delicate fungus was under observation by Dr. Thom 
for a month and is described in detail and beautifully illustrated in connection with his original description in the work cited above. I reproduce merely some simple outline sketches of C. taxophilus; this is a very distinct species. The specimens were found in Fall Creek Gorge and nowhere except under prostrate branches of Taxus, yet they grew on rotting twigs and leaves of other species as well as on pieces of Taxus.

Specimens examined:

New York: Ithaca, C. Thom, Cornell Univ. Herb., 15445.

I3. C. unicolor Rav. Grevillea I : 148. 1873.

Plate 16. fig. 11, 12.

C. corrugis Peck, Bull. Torr. Bot. Club 26: 69. 1899.

Type: in Ravenel, Fung. Car. II. 26.

Fructifications solitary or cespitose, fleshy, with the flesh white, soft, soon shrinking and leaving the pileus hollow; pileus at first clavate, obtuse, flesh-colored tinted with violet, soon obconic or turbinate, broadly convex or truncate, and often abruptly cerebriform at the upper end, glabrous, ochraceous buff, drying Rood's brown to Natal-brown, the margin obtuse, corrugated by the hymenial wrinkles; stem short, equal or tapering downwards, colored like or a little paler than the pileus; hymenium wrinkled or corrugated, colored like the pileus; spores white, $8-12 \times 4-6 \mu$.

Fructifications $2-5 \mathrm{~cm}$. high; pileus $1 \frac{1}{2}-5 \mathrm{~cm}$. broad; stem $1-2 \frac{1}{2}$ cm. long, 5-8 $\mathrm{mm}$. thick.

On ground in thin woods. Massachusetts, Pennsylvania, and South Carolina. October to January.

This fungus presents strikingly the vagaries in the distribution of fungi. It was originally collected at Black Oak, South Carolina, in 1850 , by Ravenel, in sufficient quantity so that he distributed the type collection in his exsiccati. Apparently, this fungus, whenever collected, was referred to other species until 1898, when members of the Boston Mycological Club found it in several localities in Massachusetts and it was adequately described by Peck, as $C$. corrugis, from specimens received from Dl. Francis. I have received no specimens of this species since that season; I searched for it in vain for several years in the adjoining state, Vermont. I have compared the specimens of C.corrugis, received from Dr. Francis, with Peck's 
type and with the specimens of $C$. unicolor in five different copies of Ravenel's 'Fungi Caroliniani.' C. corrugis is certainly the same species as $C$. unicolor. It is very strange that in the interval of nearly half a century from the time of the original collection, $C$. unicolor did not attract attention from an intermediate station.

Specimens examined:

Exsiccati: Ravenel, Fung. Car. II. 26; Ell. \& Ev., N. Am. Fungi, 1922a under the name C. pistillaris.

Massachusetts: Worcester, G. E. Francis, 61, 84, and collection dated Nov. 2, also the type (in Coll. N. Y. State) of C. corrugis; Lynn, H. Webster; Medford, Mrs. Page and Mrs. De Long, ex Herb. Boston Mycological Club, 420; Arlington Heights, E. A. Burt.

Pennsylvania: Trexlertown, $W$. Herbst, the $C$. clavatus of his 'Fungal Flora'; West Chester, B. M. Everhart, Ell. \& Ev., N. Am. Fungi, 1922a.

South Carolina: Black Oak, Ravenel, 1406 (in Curtis Herb. and in Kew Herb.), and type, Ravenel, Fung, Car. II. 26.

I4. C. pistillaris Fries, Epicr. 534. 1836-1838.

Plates 16, 17. figs. 13, 14.

Illustrations: Schæffer, Icon. Fung. pl. 169.-Harper, Mycologia 5 : 263. pl. 95 .

Fructifications gregarious, fleshy-spongy, drying sorghumbrown to fuscous; pileus somewhat clavate to turbinate or narrowly obconic, truncate, or somewhat convex, at first yellowish cinnamon, then becoming tinged with fuscous, the edge obtuse; stem solid, paler than the pileus, often bulbous at the base; hymenium corrugated and rugose-wrinkled, colored like the pileus, drying sorghum-brown to fuscous; spores even, 10-12 x $6-8 \mu$.

Fructifications $6-12 \mathrm{~cm}$. high; pileus $2-3 \frac{1}{2} \mathrm{~cm}$. broad; stem 3-6 $\mathrm{cm}$. long, 4-12 mm. thick.

On ground in woods under coniferous trees. New Hampshire, Vermont, and Michigan. August to October.

Specimens of this species have so nearly the coloration of $C$. unicolor that those, small and undeveloped, in a collection of C. pistillaris cannot readily be distinguished from partially developed specimens of $C$. unicolor; but with age, those of $C$. 
unicolor-or at least some of them-have the pileus enlarge abruptly in diameter near the upper end and become abruptly globose-cerebriform on a slender stem, as shown in figs. 11 and 12 , while $C$. pistillaris increases in length as well as in diameter, tapers downward more uniformly from the truncate upper end, and may have the stem bulbous at the base.

It is a vexed question with mycologists whether Craterellus pistillaris Fr. is Clavaria pistillaris L. The specimens which I refer to Craterellus pistillaris agree well with specimens of this species in Curtis Herbarium, collected at Upsala, Sweden, in 1853, and communicated by E. P. Fries. Pl. 16 fig. 13 is from a photograph, natural size, of these specimens. Their spores are $9 \times 6 \mu$. The Friesian specimens have the same dark color as our American specimens. Only one of the former shows a bulbous tendency at the base of the stem; in this respect our specimens are more like the illustration of Schæffer, cited above. I believe, therefore, that we have Craterellus pistillaris Fr. in our flora. I have collected in mixed frondose woods in Missouri what I refer to Clavaria pistillaris as understood by European mycologists. As compared with the former species it is of softer structure, much paler in color, more regularly clavate in form, sometimes splitting at the apex. The illustrations of most European authors agree well in regard to Clavaria pistillaris. The colored figures of this species in Batsch, Bulliard, Sturm, Dufour, Flora Danica, Hussey, Krombholz, Quelet, and Sowerby present fructifications of the same habit and bright coloration which we have by Peck, Bull. N. Y. State Mus. 94: pl. 93. f. 1-4. and Mem. N. Y. State Mus. 4:pl. 66. f. $15-1 \%$.

Specimens examined:

Sweden: Upsala, E: P. Fries (in Curtis Herb.).

Austria: G. Bresadola.

New Hampshire: Shelburne, W. G. Farlow (in Mo. Bot. Gard. Herb., 4933).

Vermont: Middlebury, E. A. Burt.

I5. C. palmatus Burt \& Overholts, n. sp. Plate 17. fig. 19. Type: in Mo. Bot. Gard. Herb. and in Overholts Herb.

Fructifications gregarious or perhaps cespitose, fleshy-soft; pileus fawn-color shading into bone-brown towards the stem, 
glabrous, flattened and ligulate at first, then spreading out laterally at the apex; and at length somewhat palmately cleft into 2-12 unequal, obtuse, finger-shaped branches; stem curved, solid, equal or somewhat tapering towards the base, bonebrown, sometimes swollen where attached to the substratum; hymenium even or but slightly venose, inferior, colored like the pileus; spores white, even, pyriform, tapering to the base, 6-8 × 3-4 $\mu$.

Fructifications $1-2 \frac{1}{2} \mathrm{~cm}$. high; pileus $3-15 \mathrm{~mm}$. broad, 1

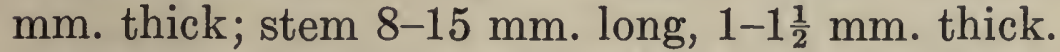

On rotten chunks of wood in frondose woods. Ohio. June.

All specimens of the collection except one have the pileus flabelliform; in this exceptional specimen, the pileus is narrowly turbinate, depressed, and with the finger-shaped branches arranged in a circle on the margin, pl. 17 fig. 19b. This species makes for Craterellus the same connection between the centralstemmed, cup-shaped type of pileus and the flabelliform type that Thelephora multipartita shows in Thelephora, and that is common in Stereum. The hymenium of the flabelliform specimens of Craterellus palmatus is so similar to the upper surface of the pileus in color and consistency that one cannot readily distinguish between these surfaces in the dried specimens. For these reasons, the present species cannot be referred to either Skepperia or Friesula, and it is of especial interest in showing that Craterellus has a natural section of species with flabelliform pileus. The spores of $C$. palmatus are noteworthy.

Specimens examined:

Ohio: Oxford, L. O. Overholts, 1649, type (in Mo. Bot. Gard. Herb. and in Overholts Herb.).

I6. C. dilatus Burt, n. sp.

Plate 17. fig. 16.

Type: in Farlow Herb.

Fructifications single, fleshy; pileus flabelliform, somewhat triangular, glabrous, drying a dirty pinkish buff, the margin somewhat irregularly lobed, crisped, and curving upward; stem solid, equal, flexuous, drying Natal-brown, with white mycelium at the base; hymenium even, drying Isabella-color to claycolor; spores white, even, broadly ovoid, obtuse, 8-10 x 6-7 $\mu$.

Dried fructification $4 \mathrm{~cm}$. long; pileus $15 \mathrm{~mm}$. long, $15 \mathrm{~mm}$. broad, $\frac{1}{2} \mathrm{~mm}$. thick; stem $2 \frac{1}{2} \mathrm{~cm}$. long, hardly $1 \mathrm{~mm}$. thick. 
On sandy ground in swamp. Florida. September.

Only a single fructification was collected; the description is based upon this dried specimen. The species is distinguished by its fan-shaped, triangular pileus and the comparatively long and slender stem. Its characters are those of a true Craterellus and yet such that we cannot regard it as a flabellate form of any other species.

Specimens examined:

Florida: Sorrento Swamp, R. Thaxter, type (in Farlow Herb.).

I7. C. Humphreyi Burt, n. sp.

Plate 17. fig. 22.

Type: in Burt Herb. and in Humphrey Herb.

Fructifications gregarious, fleshy, moderately tough and flexible, entirely white, usually with the pileus standing out horizontally at the apex of the erect stem; pileus reniform, dimidiate, sometimes clasping behind, convex, becoming plane or somewhat depressed, usually even, dry, minutely pubescent, the margin entire, even or slightly crisped; stem lateral, erect, often bent at right angles just before joining the pileus, cylindric below, equal, solid, pubescent; hymenium nearly even, sometimes radiately venose near the stem, brittle when fresh; spores white, even, subglobose, $3 \frac{1}{2}-4 \frac{1}{2} \times 3 \frac{1}{2} \mu$.

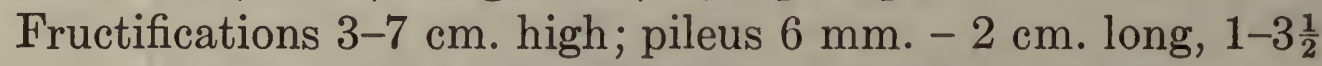
$\mathrm{cm}$. broad, $\frac{3}{4} \mathrm{~mm}$. thick; stem $2 \frac{1}{2}-6 \mathrm{~cm}$. long, $2 \mathrm{~mm}$. thick.

On humus and among mosses in low swampy thicket. Washington. October.

The habit of this curious species is very suggestive of Hydnum auriscalpium; many of the specimens have the erect stem bent at right angles near the apex so that the pileus extends out in a horizontal plane. Sometimes the stem branches at its upper end and bears two pilei. The pubescence on the stem is rather coarse and is most abundant towards the base. All parts of the fructification were rather brittle in vegetative condition, and broke when bent too far. It is a connecting species between Craterellus and Arrhenia, but with the hymenium rather too even for Arrhenia, in my opinion.

Specimens examined:

Washington: Hoquiam, C. J. Humphrey, 1386, type. 
Berkeley \& Curtis, Jour. Linn. Soc. Bot. Io: 328, described three species of Craterellus from Cuba, which have been transferred to other genera by Patouillard, Bull. Soc. Myc. France I5: 193-94. pl. 9, as follows: C. spathularius to Skepperia and C. marasmioides and C. pulverulentus to Cymatella. I have received no collections referable to these genera and defer their consideration to the final part of my monograph in the hope that some specimens may be received in the meantime.

Craterellus canadensis Kl. ex Saccardo, Syll. Fung. 6: 519. 1888, was published by Berkeley, Ann. Nat. Hist. 3 : 380. 1839, under the name Cantharellus canadensis $\mathrm{Kl}$. from a specimen in Hooker Herb. bearing manuscript notes by Klotzsch. The specimen was collected in Canada by Richardson. In connection with the original description, Berkeley noted that the nearest affinities of $C$. canadensis are with C. clavatus. In 1856, after studying the specimens in Herb. Schweinitz, Berkeley \& Curtis, Jour. Acad. Nat. Sci., Phila. N. S. 3: 206. 1856, note that Cantharellus canadensis Kl. is apparently the same species as Cantharellus floccosus Schw. I have seen no specimens of C. canadensis and follow Berkeley's final disposition of the species.

(To be continued.) 


\section{Explanation of Plate PLATE 15}

All figures of this plate have been reproduced natural size from photographs of dried herbarium specimens.

Fig. 1. Thelephora coespitulans. From authentic specimen in Curtis Herb., collected by Schweinitz in North Carolina.

Fig. 2. T. Lutosa. From authentic specimen in Curtis Herb., collected by Schweinitz in North Carolina.

Fig. 3. T. dentosa. From cotype in Curtis Herb., collected in Cuba by C. Wright.

Fig. 4. T. perplexa. From type in Curtis Herb., collected in Cuba by C. Wright, 238. $a$ shows a resupinate portion, and $b$, an ascending portion of the specimen.

Fig. 5. T. cornucopioides. From specimen collected in Castleton Gardens, Jamaica, by F. S. Earle, 238.

Fig. 6. Craterellus clavatus. From specimen collected at Lake Dunmore, Vt.

Fig. 7. C. Cantharellus. From the cotype in Curtis Herb., 4539, of C. lateritius, collected in Alabama, by Peters.

Fig. 8. C. odoratus. From the cotype in Curtis Herb. of $C$. confluens, collected near Orizaba, Mexico, by Botteri, 6.

Fig. 9. C. odoratus. From the specimens in Curtis Herb., collected at Society Hill, S. Carolina, by Ravenel, 192. 

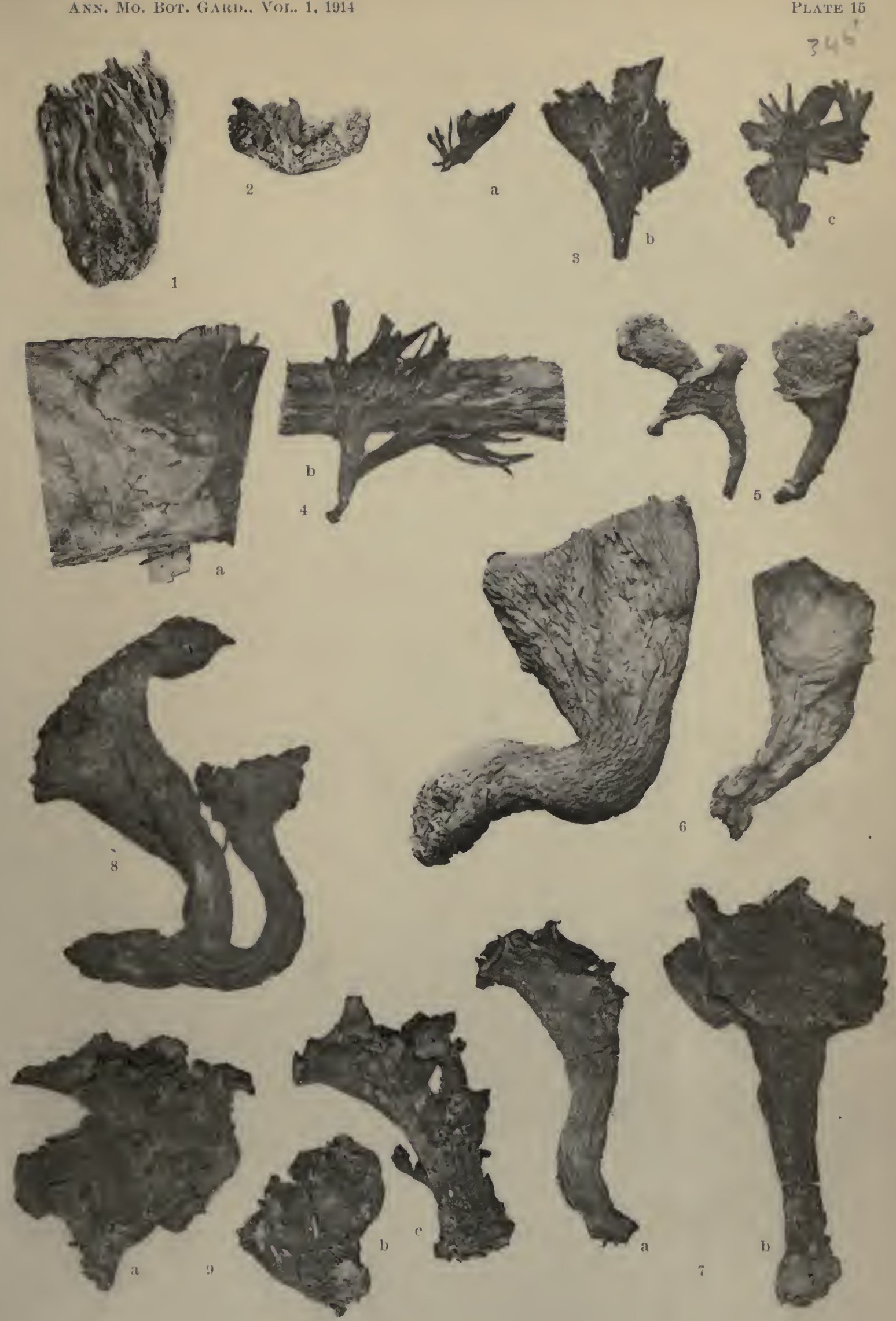

BURT - THELEPHORACEAE OF NORTH AMERICA

1. THELEPHORA CAESPITULANS. - 2. T. LUTOSA. - 3. T. DENTOSA.-4. T. PLRPLEXA - 5. T. CORNUCOPIOLDES. - 6. Cratereldus Clavatus. - 7. C. Cantharellus. 8 AND 9. C. ODORATUS. 



\section{Explanation of Plate PLATE 16}

All figures of this plate have been reproduced natural size from photographs of dried herbarium specimens, but in the case of fig. 10 the specimens were moistened.

Fig. 10. C. odoratus. From specimens collected near St. Louis, Mo., by N. M. Glatfelter, 348. The rough dried specimens were moistened before being photographed. $a$ shows a branched specimen; $b$, a fructification split longitudinally to show extent of depression of the pileus and the hollow stem; $c$, view of hymenium.

Fig. 11. C. unicolor. From authentic specimen in Curtis Herb., collected at Black Oak, S. Carolina, by Ravenel, 1406.

Fig. 12. C. unicolor. From specimen of $C$. corrugis collected at Medford, Mass., by Mrs. Page and Mrs. DeLong.

Fig. 13. C. pistillaris. From specimen in Curtis Herb., collected at Upsala, Sweden, by E. P. Fries. 


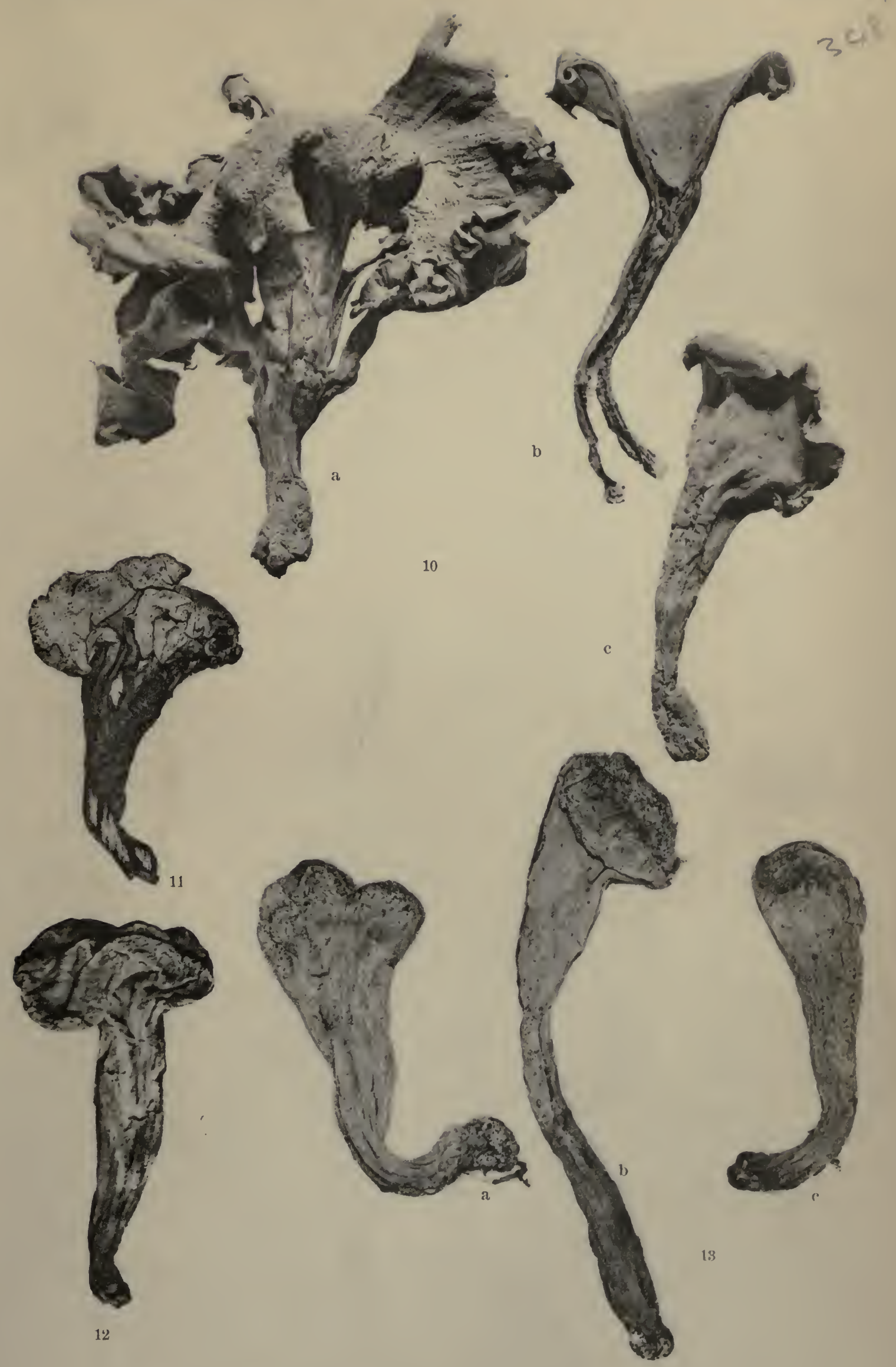

BURT - THELEPHORACEAE OF NORTH AMERICA

10. Craterellus odoratus. - 11 and 12. C. UNicolor.-13. C. pistlllaris. 


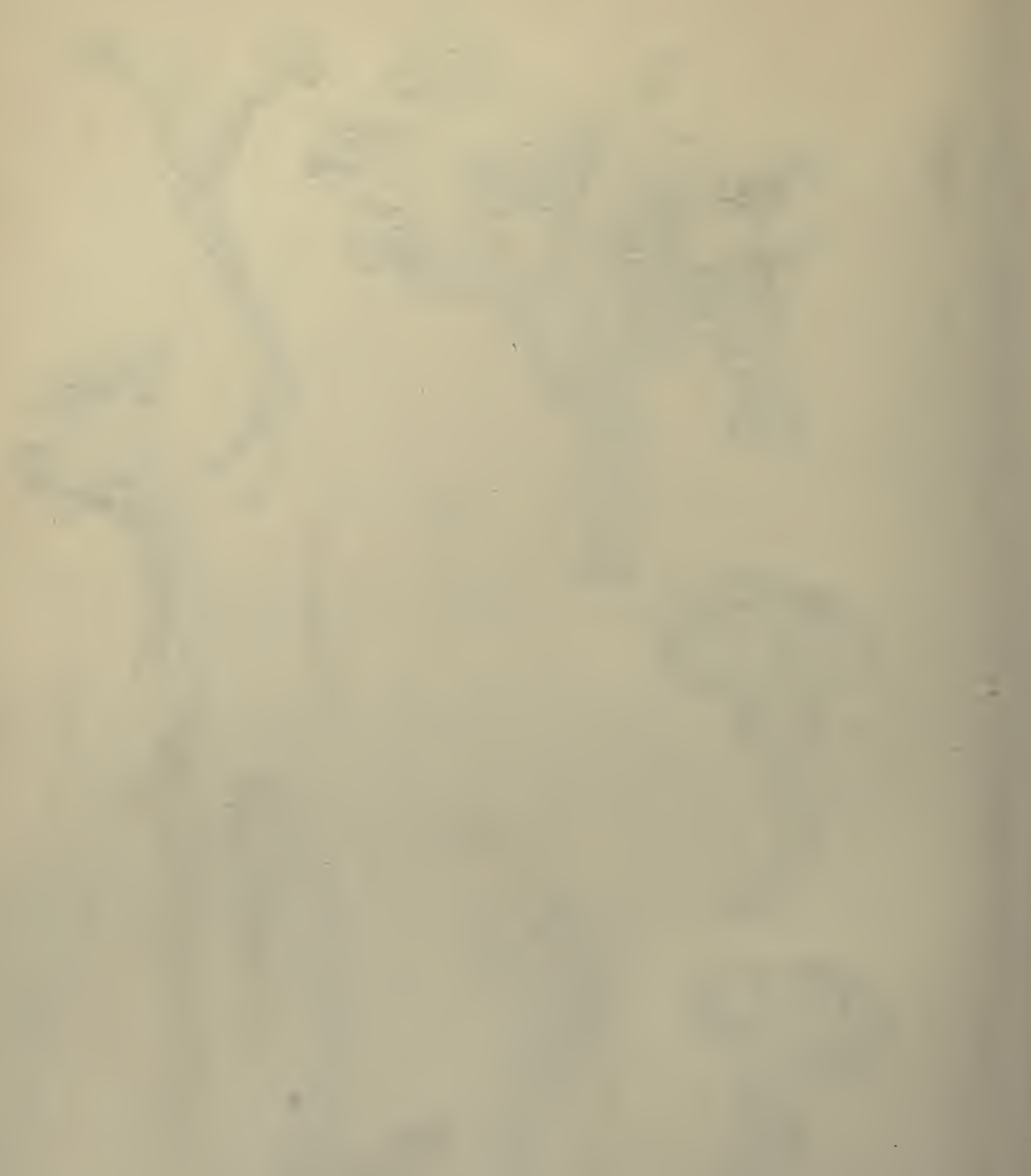




\section{Explanation of Plate}

\section{PLATE 17}

All figures are natural size. Figures 14-20 are from photographs of dried herbarium specimens, but which were moistened before being photographed in case of specimens used for figs. 15 and 17.

Fig. 14. C. pistillaris. From specimen collected under hemlock (Tsuga) tree, at Middlebury, Vt.

Fig. 15. C. ochrosporus. From type specimens in Mo. Bot. Gard. Herb., collected near St. Louis, Mo., by N. M. Glatfelter, 1253. $a$ is split longitudinally to show the depth of depression of the pileus; $b$, side view.

Fig. 16. C. dilatus. From type in Farlow Herb., collected at Sorrento Swamp, Florida, by R. Thaxter. $a$ shows upper surface of pileus, and $b$, the hymenium. 72.

Fig. 17. C. cornucopioides. From specimen collected in Canada, by J. Macoun,

Fig. 18. C. delitescens. From type specimens collected at Lake Dunmore, Vt.

Fig. 19. C. palmatus. From type specimens in Mo. Bot. Gard. Herb. and Overholts Herb., collected at Oxford, Ohio, by L. O. Overholts, 1649. $a$ shows specimens having flabelliform pileus, and $b$, a specimen with turbinate pileus.

Fig. 20. C. lutescens. $a$ shows hymenium of specimen collected at Shelburne, New Hampshire, by W. G. Farlow, and $b$, upper surface of specimen collected at Lake Dunmore, Vt.

Fig. 21. C. taxophilus. From sketches of photographs of type specimens when in vegetative condition, collected at Ithaca, New York, by C. Thom.

Fig. 22. C. Humphreyi. From sketches of the type specimens when in vegetative condition, collected at Hoquiam, Wash., by C. J. Humphrey, 1386. 

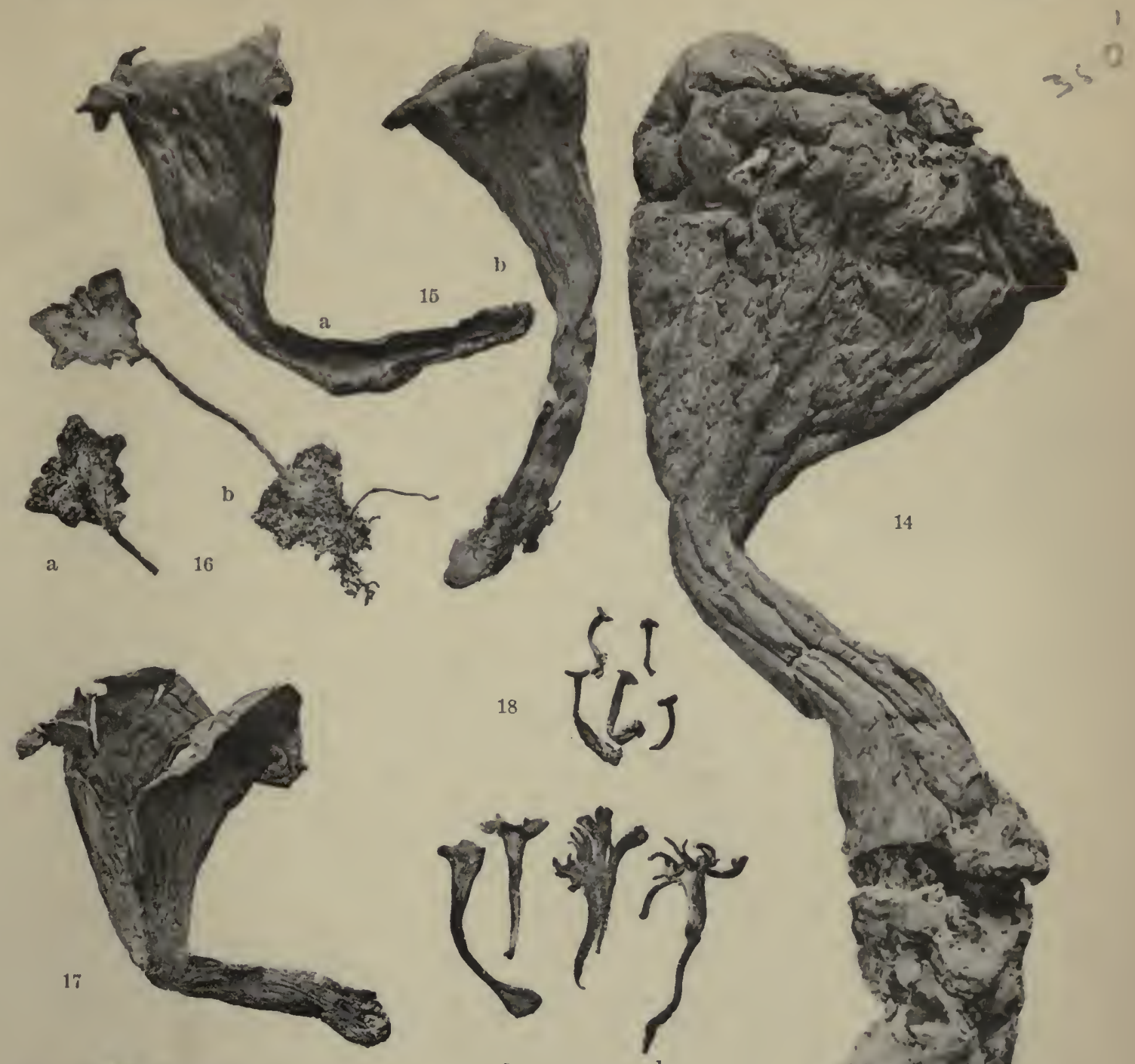

a 19
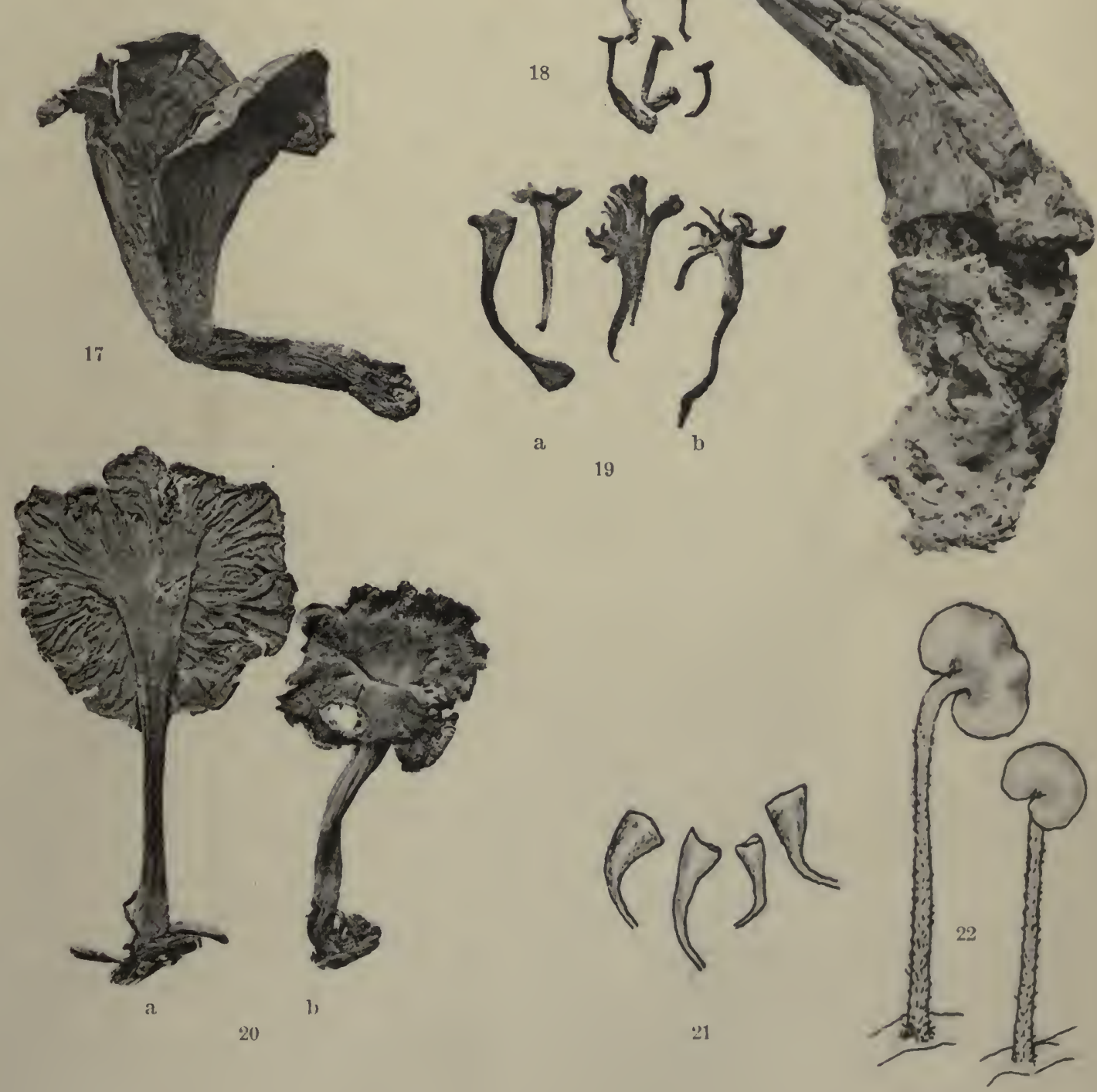

BURT - THELEPHORACEAE OF NORTH AMERICA

14. CRATERELLUS PISTILLARIS. - 15. C. OCHROSPORUS. - 16. C. IILATUS. 17. C. CORNUCOPIOIDES. - 18. C. DELITESCENS. - 19. C. PALILATUS. - 20. C. LUTESCENS. -21. C. TAXOPHILUS. - 22. C. HUMPHIREY. 

The Thelephoracex of North America. III.

Craterellus borealis and Cyphella

Reprinted frous Axwals of THE Mrssouri Botanical

Gablơ 1: 357-382. November, 1914 


\title{
THE THELEPHORACE $\approx$ OF NORTH AMERICA III ${ }^{1}$
}

\author{
Craterellus borealis and Cyphella \\ EDWARD ANGUS BURT \\ Mycologist and Librarian to the Missouri Botanical Garden \\ Associate Professor in the Henry Shaw School of Botany of \\ Washington University
}

Since the publication of Part II, on Craterellus, Dr. Farlow has very kindly called my attention to, and permitted me to study, a specimen of a rare species from Labrador which was not included in my account of our North American species. This species is now described here so as to bring its description and illustration continuous with those of our other species of Craterellus.

The following is suggested for insertion in "Key to the Species," on page 328 (Ann. Mo. Bot. Gard. r: 328. 1914).

6. Pileus membranaceous, infundibuliform, pale buff; hymenium pale buff; spores

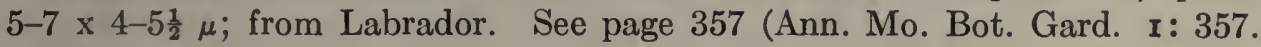

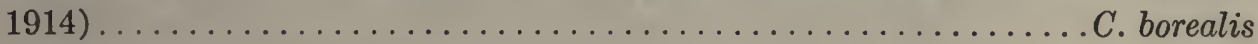

Craterellus borealis Burt, $\mathrm{n}$. sp.

Plate 19. fig. 1.

Type: in Farlow Herb.

Fructifications solitary, small; pileus infundibuliform, tapering uniformly to the stem, glabrous, drying between cartridge buff and cream-buff, the margin entire; stem nearly equal,

Noте.-Explanation in regard to the citation of specimens studied is given in Part I, Ann. Mo. Bot. Gard. I: 202. 1914, footnote. The technical color terms used in this work are those of Ridgway, Color Standards and Nomenclature. Washington, D. C., 1912.

${ }^{1}$ Issued January 30, 1915.

ANn. MO. BOT. GARD., VoL. 1, 1914 
slender, minutely downy, pale mouse-gray; hymenium colored like the pileus, remotely ribbed, with the ribs radiating from

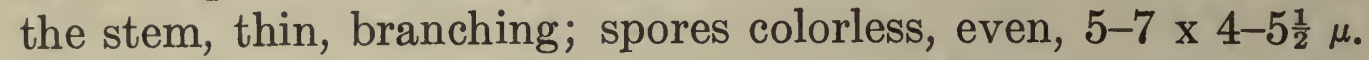

Fructification $2 \mathrm{~cm}$. high; pileus $1 \mathrm{~cm}$. broad, $13 \mathrm{~mm}$. long; stem $7 \mathrm{~mm}$. long, $\frac{1}{2} \mathrm{~mm}$. thick, enlarging to $1 \mathrm{~mm}$. where joining the pileus.

In moss. Labrador. August 8, 1908.

The above description is based on the single dried specimen collected by the Bryant Labrador Expedition. The small size, regular obconic form, and very pale color of the membranaceous pileus and the slender stem are characters making $C$. borealis clearly distinct from other species of Craterellus.

Specimens examined:

Labrador: Gready Harbor, Gready Island, Owen Bryant, type (in Farlow Herb.)

\section{CYPHELLA}

Cyphella Fries, Syst. Myc. 2: 201. 1823.

Fructifications somewhat membranaceous, cup-shaped, rarely plane, adnate behind, commonly extended in stem-like form, pendulous; hymenium typically concave or disk-shaped, definitely inferior in the pendulous species, even or at length rugulose; basidia typically four-spored; spores subovate or globose, hyaline, rarely colored.

C. digitalis Fries is the type species of this genus.

The fructifications of all our North American species are comparatively small, ranging in diameter from a fraction of a millimeter for some species to five to fifteen millimeters for those of the largest species. The fructifications are produced on the bark of small rotting twigs on the ground and on dead herbage, and can only be distinguished from small Pezizce by demonstrating basidia rather than asci in the hymenium. This demonstration is simply made by crushing under a cover glass a portion of a fructification in water containing a little seven per cent solution of potassium hydrate, and then examining the preparation with the compound microscope. The basidia are usually four-spored; in a few species I have as yet been able to detect only two-spored basidia.

Cyphella is closely related to Solenia by such species as $C$. fasciculata and C. mellea, but is separated from it in such cases 
by the absence of a hyphal subiculum over the area on which the fructifications are distributed, and by the less cylindric form of fructifications of Cyphella. Cyphella is allied to Merulius by C. muscigena and also to Craterellus by this species, specimens of which were described as a Craterellus.

A few species of Cyphella are common and widely distributed, but most of our North American species are apparently extremely local and are known only from their respective type collections. The lack of specimens available for carrying about to compare with types has been a serious disadvantage in my study of this genus. Basidia and basidiospores have not as yet been found for some species which, although originally referred to Cyphella, have to be regarded as even doubtful Basidiomycetes. I have supplemented the original descriptions with measurements of dried fructifications and with such data in regard to basidia and spores as the specimens afford. In the case of very scanty types, the few fructifications are too precious for gross comparison to be used for microscopic study. For such species, it seems to me that the descriptions should stand on the original data, without prejudice, until new collections become available. Such imperfectly known and partially described species are grouped together under the heading "Species Imperfectly Known." Cyphella convoluta Cke., C. Cupressi (Schw.) Fries and C. subcyanea Ell. \& Ev. are excluded species.

\section{Key to the Species}

Fructifications sulphur-colored; hymenium even; spores $4 \frac{1}{2} \times 2 \frac{1}{2}-3 \mu$ 1.C. sulphurea Fructifications sulphur-colored; hymenium minutely pitted; spores $6-8 \mathrm{x}$

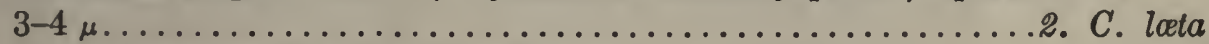

Fructifications white or whitish; on mosses................. 1

Fructifications white; not on mosses..................... 2

Fructifications neither white nor sulphur-colored ............... 3

1. Fructifications helmet-shaped; hymenium slightly wrinkled; spores $10 \mathrm{x}$

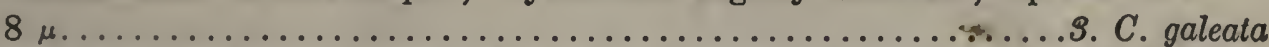

1. Fructifications flattened, irregular in form, sometimes stipitate; spores $3-5$

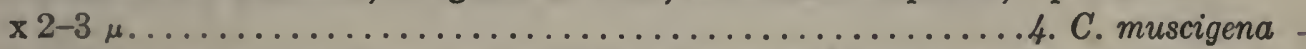

1. Fructifications seated upon or developing from webby strings of mycelium

5. C. arachnoidea

2. Fructifications villose, not easily crushed, with a firm base or a short stem; spores $12-18 \times 6-6 \frac{1}{2} \mu \ldots \ldots \ldots \ldots \ldots \ldots \ldots \ldots$. C. Tilia

2. Fructifications villose, easily crushed, sessile; spores $10-12 \times 5-7 \mu$

7. C. villosa

2. Fructifications whitish, minutely webby-hairy, easily crushed, sessile;

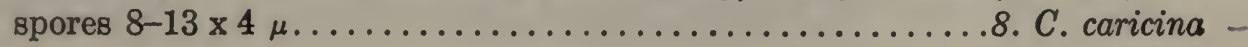


2. Fructifications glabrous, with an oblique stem; spores $4 \frac{1}{2}-6 \times 3-3 \frac{1}{2} \mu$ 9. C. capula

2. Fructifications villose, snow-white, sessile, very minute and delicate; spores $5-6 \times 4-4 \frac{1}{2} \mu$; from New England.........10. C. minutissima

2. Compare with C. cinereo-fusca, C. Palmarum, C. Peckii, C. perexigua, C. pezizoides and C. trachychoeta of "Species Imperfectly Known."

3. Fructifications wholly pale ivory-yellow, downy-pubescent, cup-shaped, sessile; spores $4-7 \times 3-4 \mu \ldots \ldots \ldots \ldots \ldots \ldots \ldots \ldots$. C. Langloisii

3. Fructifications wholly cream-color, not hairy, helmet-shaped, sessile, resupinate-reflexed; hymenium wrinkled; spores $7 \frac{1}{2} \times 4 \frac{1}{2} \mu$; on prickle-bearing stems, Jamaica ............................. porrigens

3. Fructifications mineral-gray, tomentose, cup-shaped, sessile; hymenium fuscous; spores angular, $4 \frac{1}{2}-6 \times 4 \frac{1}{2} \mu$; on Juniperus.......13. C. cupulceformis

3. Fructifications wholly gray-pallid, flocculose, sessile; spores $4 \times 3 \mu \ldots \ldots$.

14. C. griseo-pallida

3. Fructifications externally cinereous, farinaceous, flattened, sessile; hymenium convex, brown; spores $8 \times 3 \frac{1}{2} \mu$; on Alnus.........15. C. subgelatinosa

3. Fructifications darker colored than the above................ 4

4. Fructifications vinaceous-buff, hairy, sessile, $\frac{4}{5} \mathrm{~mm}$. broad; spores 10-12 x 6-8 $\mu$; on bark of Carya.................... 16. Ravenelii

4. Fructifications drying Isabella-color, hairy, sessile, 1-1 $\frac{1}{2} \mathrm{~mm}$. broad; spores $13 \times 8 \mu$; on Quercus................... texensis

4. Fructifications Isabella-color, hairy, sessile, $\frac{1}{5}-\frac{1}{2} \mathrm{~mm}$. broad; some spores colored, $5-6 \times 4-4 \frac{1}{2} \mu$; on Salix.................

4. Fructifications tawny-olive, tomentose, stipitate; often cespitose; spores $7-9 \times 2-2 \frac{1}{2} \mu$; usually on Alnus................ 19. fasciculata .

4. Fructifications fuscous when moist, drying mouse-gray, cespitose and sessile on a common short trunk, glabrous, structure gelatinous 20. C. conglobata

4. Fructifications sepia or olive-brown, cup-shaped, probably glabrous, sessile or with a very short stem; spores $6-8 \times 3 \frac{1}{2}-4 \mu$; on rotting leaves of Gladiolus...............................21. C. fumosa

4. Compare C. Banance, C. filicicola and C. musccola in "Species Imperfectly Known."

I. C. sulphurea Batsch ex Fries, Hym. Eur. 665. 1874.

Peziza sulphurea Batsch, Elenchus Fung. Contin. I: 209. pl. 27. f. 146. 1786. - P. campanula Nees, System d. Pilze 268. f. 295. 1816. - Cyphella sulphurea Batsch, in Patouillard, Tab. Anal. Fung. 114. f. 256. 1883; Peck, Rep. N. Y. State Mus. 3I: 38.1879.

Illustrations: Batsch, Elenchus Fung. Contin. pl. 27. f. 146. -Nees, System d. Pilze f. 295.-Patouillard, Tab. Anal. Fung. f. 256.-Oudemans, Ned. Kruidk. Archief III. 2: pl. 3. f. 1-5. Fructifications scattered or gregarious, membranaceous, broadly campanulate, somewhat irregular, extended into a short stem, even, glabrous, sulphur-yellow, the margin somewhat repand; hymenium even; basidia cylindric, $16 \times 4 \frac{1}{2} \mu$, 4-spored; 
spores colorless, even, broadly ovoid, somewhat flattened on one side, $4 \frac{1}{2} \times 2 \frac{1}{2}-3 \mu$.

Fructifications about 2-3 mm. high; pileus $1-2 \mathrm{~mm}$. broad; stem $1 \mathrm{~mm}$. long, $\frac{1}{4} \mathrm{~mm}$. thick.

On living stems of herbs in damp places. New York. September. Rare.

The minimum dimensions given above for the fructifications are about those of European specimens of this species as figured; the American specimens run rather larger in Peck's collection. Peck noted that some of his specimens were white when collected, but that they dried yellow like the others of the collection. In other respects our American specimens agree closely with the figures and description of European specimens. Oudemans gives the spore dimensions as 10-12 x 4-5 $\mu$, but Patouillard gives them as they are in American specimens.

Specimens examined:

New York: Griffins, Delaware Co., C. H. Peck (in Coll. N. Y. State).

2. C. 1æta Fries, Epicr. 568. 1836-1838.

Illustrations: Patouillard, Tab. Anal. Fung. f. 362.

Fructifications membranaceous, obliquely cup-shaped, extended at the vertex into a stem, pendulous, entire, everywhere glabrous and sulphur-colored; stem straight or somewhat flexuous, hymenium minutely pitted; spores colorless, even, $6-8 \mathrm{x}$ 3-4 $\mu$, borne four to a basidium.

Fructifications 3-5 mm. high, 2-4 mm. broad; stem 1-2 mm. long, about $\frac{1}{2} \mathrm{~mm}$. thick.

On dead stems of large herbs lying on the ground. New York. August.

Fries described the fructifications as $6-8 \mathrm{~mm}$. broad; the dimensions given above are those of Patouillard's figures and of the specimens collected by Peck. Patouillard notes that the specimens blacken when old; Peck states, "The beautiful sulphur-color is lost in drying." The pitted surface of the hymenium is a noteworthy character of C. locta and this and the larger spores of $C$. loeta distinguish it from $C$. sulphurea.

Specimens examined:

New York: East Berne, C. H. Peck (in Coll. N. Y. State). 
3. C. galeata Schum. ex Fries, Epicr. 567. 1836-1838.

Plate 19. fig. 2.

Merulius galeatus Schum. Plant. Sællandiæ 2: 371. 1803.Cantharellus galeatus Fries, Syst. Myc. I : 524. 1821; Flor. Dan. I2: fasc. 34. 11. pl. 2027. f. 1. 1830.

Illustrations: Flor. Dan. pl. 202\%. f. 1.

Fructifications membranaceous-soft, somewhat sessile, obversely cup-shaped and then dimidiate, helmet-shaped, even, whitish, the margin entire; hymenium at length rufescent, slightly wrinkled; spores ovate or obovate, $10 \times 8 \mu$.

Fructifications $4-15 \mathrm{~mm}$. in diameter.

On mosses. Ohio.

When young entire, cup-shaped; gray when moist, snowwhite when dry, then rufescent. The above description is that given in European works. The species has been reported from Ohio by Morgan but I have not studied his specimens nor any European specimens of this species. The form and coloration of the pileus and the large spores should distinguish $C$. galeata from the other species which occur on mosses in North America.

4. C. muscigena Pers. ex Fries, Epicr. 567. 1836-1838.

Plate 19. fig. 3.

Thelephora muscigena Pers. Syn. Fung. 572. 1801; Fries, Syst. Myc. I:524.1821. - T. vulgaris $\alpha$ candida Pers. Myc. Eur. I:115. pl.7.f. 6.1822.-Cantharellus loevis Fries, Syst. Myc. I :524.1821; Elenchus Fung. 55. 1828.-Craterellus Pogonati Peck, Bull. Torr. Bot. Club 33: 218. 1906.

Illustrations: Persoon, Myc. Eur. I: pl. 7.f. 6.-Patouillard, Tab. Anal. Fung. f. 465.-Oudemans, Ned. Kruidk. Archief III. $2: p l .11 . f .2$.

Pileus membranaceous-soft, sessile, stipitate or attached by upper surface, irregular, flattened, white, externally minutely tomentulose or silky under a lens; stem when present lateral or eccentric, slender, white; hymenium even or sometimes rugulose, drying pinkish buff; spores white in collection on slide, even, apiculate at base, flattened on one side, $4 \frac{1}{2}-5 \times 2 \frac{1}{2}-3 \mu$ but only $3-4 \frac{1}{2} \times 2-3 \mu$ in preparations of the hymenium, borne four to a basidium.

Pileus 2-6 mm. in diameter; stem when present $3-5 \mathrm{~mm}$. long, $\frac{1}{2} \mathrm{~mm}$. thick. 
On Polytrichum and other mosses. New England and New York. August and September.

The fructifications are very variable in form and they are attached in various ways to the moss plants; they may be somewhat incrusting but at some distance above the ground. The substance of the pileus is very soft and its upper surface is somewhat bibulous and shows its interwoven fibers under a lens. The spores of this species are given in Saccardo's 'Sylloge' as $8-10 \times 5 \mu$, but the European specimens of exsiccati cited below have small spores of the dimensions which I give for American specimens, and Bresadola, Ann. Myc. I: 111. 1903, gives the spore dimensions as $3-4 \times 3 \mu$. The specimens of $C$. Pogonati were described as sterile by Peck; I find them to be rather immature but bearing spores $3 \times 2 \mu$.

Specimens examined:

Exsiccati: Karsten, Fung. Fenn., 441; Krieger, Fung. Sax., 1564. Finland: Karsten (in Herb. Fries), and Fung. Fenn., 441.

Germany: Saxony, W. Krieger, Krieger, Fung. Sax., 1564.

Vermont: near Falls of Lana, Salisbury, E. A. Burt.

Connecticut: South Windsor, C. C. Hanmer, 1956, the type collection of Craterellus Pogonati Pk.

New York: Floodwood, E. A. Burt.

5. C. arachnoidea Peck, Rep. N. Y. State Mus. 44: 134 (22). 1891.

Type: in Collection New York State.

Fructifications membranaceous, very thin, tender, white, externally downy, irregularly cup-shaped; hymenium somewhat uneven in large specimens; spores colorless, even, somewhat flattened on one side, $4-5 \times 3 \frac{1}{2}-4 \mu$, borne at least two to a basidium.

Fructifications 2-4 $\mathrm{mm}$. in diameter.

On bark and mosses. Vermont and New York. September. The cups are seated upon or developing from fine, white, loosely branching, webby strings of mycelium. This is a marked character in the type and is the chief character for separating this species from C. muscigena. The spores are slightly more globose than in the latter and it may be that the hymenium of C. arachnoidea is superior; in C. muscigena it is inferior. The hyphæ are about $2 \mu$ in diameter in each species. 
Specimens examined:

Vermont: South Lincoln Notch, near Middlebury, E. A. Burt. New York: Carrollton, C. H. Peck, type (in Coll. N. Y. State).

6. C. Tiliæ Peck ex Cooke, Grevillea 20: 9. 1891.

Plate 19. fig. 16.

Peziza Tilice Peck, Rep. N. Y. State Mus. 24: 96. 1872.Trichopeziza Tilice (Peck) Sacc. Syll. Fung. 8: 428. 1889; Seaver, Proc. Iowa Acad. Sci. I2: 116. 1905; Mycologia I: 110. 1909.

Type: in Collection New York State and a portion from it in Kew Herbarium.

Fructifications gregarious, rather fleshy, minute, sessile or nearly so but with firm base, white, globose, then expanded and concave, drying cup-shaped, densely white villose; hairs straight, cylindric, granular incrusted, $200 \times 6 \mu$; hymenium concave, even, ivory-yellow to vinaceous buff; spores white in a collection on a slide, simple, even, ovate, somewhat curved, $12-18 \mathrm{x}$ 6-6 $\frac{1}{2} \mu$, borne four to a basidium.

Fructifications $\frac{1}{2}-1 \mathrm{~mm}$. high, $\frac{1}{3}-1 \mathrm{~mm}$. broad; stem, when present, about one-half the height of the whole fructification.

On bark of dead branches of Tilia Americana and Ulmus on the ground. Canada and Vermont westward to Missouri. March to October. Probably common.

C. Tilice has somewhat the habit of $C$. albo-violascens but differs from the latter in having no violaceous tints, in being more hairy, in having slenderer spores, and in having at the base a very firm tubercle which offers considerable resistance when the fructification is crushed under a cover glass or sectioned. While not cespitose the fructifications of $C$. Tilice are often so near together that seven or eight have been counted on an area a centimeter square. I refer to C. Tilice many American specimens which have been distributed under the name $C$. pezizoides Zopf. The European specimens which Sydow has distributed under the latter name seem to me from the studies and comparisons which I made in Kew Herbarium to be C. Curreyi B. \& Br. rather than C. Tilice.

Specimens examined:

Exsiccati: Shear, N. Y. Fungi, 55; Ell. \& Ev., N. Am. Fungi, 2316a, under the name C. pezizoides; Ell. \& Ev., Fung. 
Col., 5, under the name C. pezizoides; Rabenhorst, Fung. Eur., 3942, under the name $C$. pezizoides.

Quebec: Hull, J. Macoun, 672.

Ontario: Ottawa, J. Macoun, 318, 430; London, J. Dearness,

Ell. \& Ev., N. Am. Fungi, 2316a, and Fung. Col., 5.

Vermont: Middlebury, C. O. Smith, and also E. A. Burt.

New York: Knowersville (Altamont), C. H. Peck, type (portion

in Kew Herb.); Alcove, C. L. Shear, Shear, N. Y. Fungi, 55.

Ohio: Oberlin, F. D. Kelsey (in Mo. Bot. Gard. Herb., 4942). Michigan: Agricultural College, G. H. Hicks, comm. by W. G.

Farlow, 6 (in Mo. Bot. Gard. Herb., 43807).

Wisconsin: Blue Mounds, I. E. Melhus, comm. by C. J. Humphrey, 2410 (in Mo. Bot. Gard. Herb.).

Missouri: C. H. Demetrio, Rabenhorst, Fung. Eur., 3942.

7. C. villosa Pers. ex Karsten, (Mycol. Fenn. 3) Bidrag Finska Vet.-Soc. 25: 325. 1876. Plate 19. fig. 13.

Peziza villosa Pers. Syn. Fung. 655. 1801; Fries, Syst. Myc. 2: 104, pr. p. 1823.-An Cyphella pezizoides Zopf, in Morgan, (Myc. Fl. Miami Val.) Jour. Cincinnati Soc. Nat. Hist. Io: 202. 1888 ?

Illustrations: Patouillard, Tab. Anal. Fung. f. 25\%.

Fructifications gregarious, membranaceous, sessile, drying globose or obconic and with the pore nearly closed by the hairs, white, externally white-villose; the hairs granular incrusted, cylindric, $200 \times 5-6 \mu$; hymenium even, concave; spores hyaline, even, ovoid, flattened on one side, broadest near the base, $10-12 \times 5-7 \mu$.

Fructifications about $\frac{1}{5} \mathrm{~mm}$. high, $\frac{1}{5}-\frac{1}{4} \mathrm{~mm}$. broad.

On dead stems of Artemisia, Helianthus, and Solidago. South Carolina, Missouri and California. June and July.

The fructifications of $C$. villosa resemble those of $C$. Tilice in form, color, and hairiness but are much smaller than those of C. Tilice, more membranaceous and easily crushed under a cover glass, and have smaller spores. The hymenium is very pale with not more than a very slight yellowish tint.

Specimens examined:

Exsiccati: Krieger, Fung. Sax., 1457; Ravenel, Fung. Am., 459; Ell. \& Ev., N. Am. Fungi, 2316b, under the name Cyphella pezizoides Zopf. 
South Carolina: Aiken, Ravenel, Ravenel, Fung. Am., 459.

Missouri: Emma, C. H. Demetrio, Ell. \& Ev., N. Am. Fungi, 2316b.

California: Half-moon Bay, San Mateo Co., E. B. Copeland, Baker, Pacific Coast Fungi, 3611 (in Mo. Bot. Gard. Herb., 4944).

8. C. caricina Peck, Rep. N. Y. State Mus. 33:22. 1880.

Plate 19. fig. 8.

Type: in Collection New York State.

Fructifications scattered, membranaceous, sessile, wholly white, externally minutely webby-hairy; hymenium glabrous, uneven in large specimens; basidia cylindric, $20 \times 5 \mu$, 4-spored; spores colorless, even, lanceolate or subclavate, pointed at base, $8-13 \times 4 \mu$.

Fructifications 1-2 mm. broad.

On culms and leaves of carices. New York. August.

The spores of the type are noteworthy by their tapering base.

Specimens examined:

New York: Verona, C. H. Peck, type (in Coll. N. Y. State).

9. C. capula Holmsk. ex Fries, Epicr. 568. 1836-1838.

Plate 19. fig. 4.

Peziza Capula Holmsk. Nov. Act. Havn. I: 286. f. 7; Fung. Dan. 2: 41. pl. 22. 1899.

Illustrations: Holmskiold, Nov. Act. Havn. I : 286. f. 7; Fung. Dan. 2: pl. 22.-Flor. Dan. 33: pl. 1970. f. 3.-Patouillard, Tab. Anal. Fung. $\mathbf{I}: f .35$.

Fructifications membranaceous, obliquely campanulate, extended into an oblique stem, glabrous, whitish, the margin sinuate, irregularly shaped; hymenium even. . . . On dead stems of herbaceous plants.

-Translation of description in Fries' 'Epicrisis.'

Fructifications in the figures of Holmskiold 4-9 mm. high; pileus 2-7 $\mathrm{mm}$. long, 2-4 $\mathrm{mm}$. broad; stem 1-2 $\mathrm{mm}$. long.

On dead stems of Foniculum and other herbs. New York and South Carolina.

I have not been able to study any European specimens of this species. In the copy of Cooke's 'Fungi Britannici' in the herbarium of the Missouri Botanical Garden the packet labeled C. capula, 112, contains only some pieces of stubble. The Amer- 
ican specimens distributed in Ravenel's 'Fungi Americani,' 458 , were determined by Cooke. In their present dried condition these specimens agree well with Holmskiold's illustrations in form; the stem of these specimens is now hair-brown and the pileus pale olive-buff; their dimensions are: fructifications 1-3 $\mathrm{mm}$. long, pileus $\frac{1}{2}-2 \mathrm{~mm}$. long and broad; stem $\frac{1}{3}-1 \mathrm{~mm}$. long x $100 \mu$ thick. The basidia are 16-20 x $3 \frac{1}{2}-4 \frac{1}{2} \mu$; spores colorless, even, flattened on one side, $4 \frac{1}{2}-6 \times 3-3 \frac{1}{2} \mu$.

Specimens examined:

Exsiccati: Ravenel, Fung. Am., 458.

South Carolina: Aiken, Ravenel, Ravenel, Fung. Am., 458.

ro. C. minutissima Burt, n. sp. Plate 19. fig. 5.

Type: in Mo. Bot. Gard. Herb. and in Farlow Herb.

Fructifications gregarious, very minute, membranaceous and very delicate, sessile, globose, snow-white, externally villose, often with mouth oblique, margin inrolled; hairs white, incrusted, $75-90 \times 4 \mu$; hymenium concave, white; basidia clavate, $16 \times 4 \mu$; spores colorless, even, $5-6 \times 4-4 \frac{1}{2} \mu$.

Fructifications $200-500 \mu$ broad, about 200-500 $\mu$ high.

On inner bark of Populus. New Hampshire. August.

The characters of this species agree in some details with those in the incomplete description of $C$. globosa Pat., the specimens of which were collected on the under side of leaves of ferns in Ecuador by von Lagerheim, but as no mention is made of spore characters for $C$. globosa and as other species of Cyphella have not been found to vary widely with regard to kind of substratum, it seems best to regard our New England species as probably distinct. C. punctiformis (Fries) Karst. is a small white Cyphella, described by Karsten as having spores $5-8 \times 2-4 \mu$; I have not been able to study authentic specimens of $C$. punctiformis, but comparison of C. minutissima with this species of northern Europe should be made.

I refer to C. minutissima a collection made by myself in Vermont on bark of rotting locust limbs. The fructifications of this collection lack spores but agree in all other respects with the type.

Specimens examined:

New Hampshire: Chocorua, W. G. Farlow, 3, type (in Mo. Bot. Gard. Herb., 43803, and in Farlow Herb.).

Vermont: Middlebury, E. A. Burt. 
II. C. Langloisii Burt, n. sp. Plate 19. fig. 6.

Type: in Farlow Herb. and Burt Herb.

Fructifications gregarious, membranaceous, cup-shaped, sessile, drying pale ivory-yellow, externally downy pubescent, the margin inrolled; hairs colorless, somewhat crinkled together,

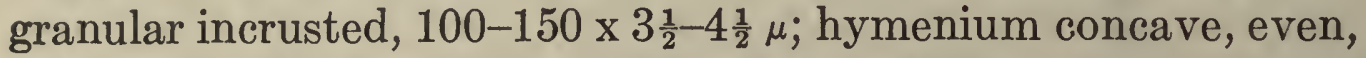
pale ivory-yellow to cream color; spores colorless, even, pointed at the base, 4-7 × 3-4 $\mu$; basidia clavate, $20 \times 5 \mu$, 2-spored.

Fructifications about $\frac{1}{4} \mathrm{~mm}$. high; $\frac{1}{4}-\frac{1}{2} \mathrm{~mm}$. broad.

On dead stems of Arundinaria and on decaying pieces of wood lying on the ground. Louisiana. September and April.

The fructifications of $C$. Langloisii are about as small as those of $C$. minutissima but differ from them in being somewhat extended laterally and occasionally somewhat laterally confluent rather than always globose, in having an ivory-yellow rather than snow-white color, and in having the hymenium colored and the hairs longer than in C.minutissima. Comparison should be made with $C$. fraxinicola B. \& Br., of which I have studied no specimens but which seems distinct by some characters of the incomplete published description.

Specimens examined:

Louisiana: St. Martinville, A. B. Langlois, 1802, type (in Farlow Herb.), and $c z$, type, in Burt Herb., and $c y$, and from the same collector but comm. by W. G. Farlow, 5 (in Mo. Bot. Gard. Herb., 43791).

12. C. porrigens Burt, n. sp. Plate 19. fig. 7.

Type: in Burt Herb. and New York Bot. Gard. Herb.

Fructifications scattered, membranaceous, thin, wholly creamcolor, sessile, obversely cup-shaped or helmet-shaped, resupinate by the upper surface of one side but with the greater portion of the pileus extended and reflexed; hymenium inferior, somewhat wrinkled when moistened, concave, basidia clavate, $20-25 \mathrm{x}$ $4-4 \frac{1}{2} \mu$, with four sterigmata; spores colorless, even, flattened on one side, obovate, $7 \frac{1}{2} \times 4 \frac{1}{2} \mu$.

Fructifications $\frac{1}{2}-1 \mathrm{~mm}$. broad.

On dead prickle-bearing stems, possibly Rubus $s p$. Wet mountainous region at altitude 4500-5200 feet. Cinchona, Jamaica. About January 1.

This species does not appear closely related to any other 
species; it is marked by the resupinate-reflexed habit of most fructifications; only rarely is a fructification attached by its vertex. The dried specimens are externally minutely fibrillose under a lens but do not show hairs in microscopic preparations. When the fructifications are moistened the hymenium shows two or three minute wrinkles radiating from an eccentric point.

Specimens examined:

Jamaica: Cinchona, W. A. and Edna L. Murrill, N. Y. Bot. Gard., Fungi of Jamaica, 607, type.

I3. C. cupulæformis Berk. \& Rav. Grevillea 2: 5. 1873.

Plate 19. fig. 9.

Type: type and cotype in Kew Herb. and in Curtis Herb. respectively.

Fructifications scattered, rarely in clusters of two or three, sessile, cup-shaped, somewhat globose, externally mineral gray and obscurely tomentose, the margin incurved; hymenium concave, even, fuscous; basidia clavate, 20-25 x 4-6 $\mu$, having 2-4 sterigmata which become finely attenuated; spores colorless, angular, $4 \frac{1}{2}-6 \times 4 \frac{1}{2} \mu$.

Fructifications $\frac{1}{2} \mathrm{~mm}$. high, $\frac{1}{2}-1 \mathrm{~mm}$. broad.

On bark of Juniperus virginiana. South Carolina and Georgia.

The hairiness of the exterior of the pileus is due to the irregularly curved and interwoven hyphæ which form the surface layer of the pileus; these hyphæ are colorless and about $3 \mu$ in diameter, and they bear scattered but large incrusting granules. The angular spores of this species are often octahedral in form and are noteworthy for Cyphella; at maturity, they are attached to the basidium by sterigmata becoming $6 \mu$ long and so finely attenuated that the attachment of the spores to the basidia is made out with difficulty. This species may be readily known by its occurrence on bark of Juniperus virginiann and by its angular spores.

Specimens examined:

Exsiccati: Ravenel, Fung. Am., 224.

South Carolina: Ravenel, 1403, type (in Kew. Herb.).

Georgia: Darien, Ravenel, Ravenel, Fung. Am., 224.

I4. C. griseo-pallida Weinm. Hymeno- et Gastero-mycetes in Rossico. 522. 1836.

Illustrations: Patouillard, Tab. Anal. Fung. f. 255. 
Fructifications gregarious, adnate-sessile, membranaceous, wholly gray-pallid, externally flocculose; hymenium glabrous, even.

At first having the form of globose, closed granules, soon open, campanulate or crateriform, often dimidiate in old stages.

Fructifications $\frac{1}{2} \mathrm{~mm}$. high, $\frac{1}{2}-2 \mathrm{~mm}$. broad.

On moist ground and on pine wood thinly covered with earth and on old cracked trunks of Lonicera tartarica (in Europe). -Translation of original description.

On bark, twigs and leaves lying on the ground. New York and Ohio. November.

I have not seen the type of $C$. griseo-pallida nor any European specimens which have been compared with it, but Peck, Rep. N. Y. State Mus. 30: 48. 1879, has referred to this species a collection which he made at Sand Lake, New York. Peck notes that his specimens sometimes have a very short stem. I found the spores of these specimens hyaline, even, somewhat flattened on one side, $4 \times 3 \mu$; basidia $12 \times 4 \mu$.

Specimens examined:

New York: Sand Lake, C. H. Peck (in Coll. N. Y. State).

I5. C. subgelatinosa Berk. \& Rav. Grevillea 2: 5. 1873.

Type: in Kew Herb.

Fructifications scattered, somewhat gelatinous, sessile, flattened, externally cinereous and farinaceous, the thin margin inflexed; hymenium slightly convex, even, brown; basidia clavate, about $25 \times 5-6 \mu$, probably 2 -spored; spores colorless, even, ellipsoidal, $8 \times 3 \frac{1}{2} \mu$.

Fructifications about $1 \frac{1}{2} \mathrm{~mm}$. broad.

On Alnus serrulata. South Carolina.

The fructifications of the type have dried with the slightly convex hymenium so prominently visible that they resemble brown apothecia of lichens with a pale margin (exciple). The most of the basidia are immature; I found one showing two sterigmata distinctly. No spores were found attached to basidia; the spore characters, which are given above, are those of loose spores in the preparation. C. subgelatinosa is so very distinct from our other species of Cyphella that it will probably be overlooked by botanists collecting Basidiomycetes only, unless especially kept in mind. 
Specimens examined:

South Carolina: Aiken, Ravenel, 1714, type (in Kew Herb.).

r6. C. Ravenelii Berk. Grevillea 2: 5. 1873. Plate 19. fig. 14.

Type: type and cotype in Kew Herb. and in Curtis Herb. respectively.

Fructifications single or gregarious, sessile, subglobose, somewhat flattened, depressed at the pore, minutely hairy under a lens, vinaceous buff; hairs minutely rough, about $300 \mu$ long, $4 \mu$ thick, tapering towards the free end, olive-yellow under the microscope; spores hyaline, or perhaps very slightly colored, even, broadly ellipsoidal, 10-12 x 6-8 $\mu$.

Fructifications $0.6 \mathrm{~mm}$. high, $0.8 \mathrm{~mm}$. broad; pore $0.15 \mathrm{~mm}$. in diameter.

On bark of Carya. South Carolina.

The specimens of this species which I have seen have been on thick and cracked portions of bark apparently from large branches or the main trunk of the tree. Sometimes only one fructification occurs on a piece of bark a centimeter square; sometimes such a piece bears from 3 to 6 fructifications with some of them barely in contact with one another. The type specimen contains so few fructifications that I made a microscopic preparation at Kew Herbarium from the specimen distributed by Ravenel in Ellis, N. Am. Fungi, 721, which seems to me to be certainly the same species as the type. Berkeley described the spores in his original description as "elliptic, .00025 (in.) long"; I found them about twice this length in my preparation referred to and also in a preparation recently made from the specimen in Ravenel, Fung. Am., 130, in the Mo. Bot. Gard. Herb.

Specimens examined:

Exsiccati: Ravenel, Fung. Am., 130; Ellis, N. Am. Fungi, 721. South Carolina: Aiken, Ravenel, 1755, the type and cotype (in

Kew Herb. and in Curtis Herb. respectively); and also Aiken, Ravenel, Ravenel, Fung. Am., 130, and Ellis, N. Am. Fungi, 721.

17. C. texensis Berk. \& Curtis, Grevillea 20: 9. 1891.

Type: in Kew Herb.

Plate 19. fig. 10.

Fructifications scattered, sessile, pallid but at present time 
Isabella-color (melleus of 'Chromotaxia'), cup-shaped, at length flattened and disk-shaped, externally hairy; hairs olive-ocher under the microscope, granular incrusted, cylindric, 300-400

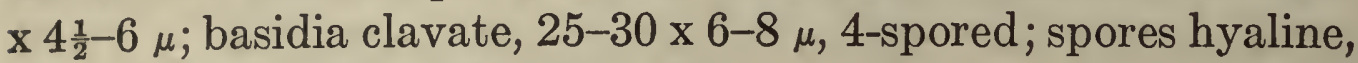
even, broadly ellipsoidal, $13 \times 8 \mu$.

Fructifications $1-1 \frac{1}{2} \mathrm{~mm}$. broad.

On Quercus. Texas.

The type is scanty, consisting of three fructifications, but these fructifications are in fine condition and present well the. characters of the species. C. texensis now impresses me as more closely related to $C$. Ravenelii than I observed when studying the specimens of both in Kew Herbarium. The fructifications of C. texensis are the melleus of Saccardo's 'Chromotaxia' and the hairs are of a little greater diameter and have larger incrusting granules than those of $C$. Ravenelii, but the spores and basidia are very similar in form and dimensions in both species.

Specimens examined:

Texas: Wright, 3779, type (in Kew Herb.).

I8. C. mellea Burt, n. sp. Plate 19. fig. 12.

Type: in Burt Herb. and in U. S. Dept. Ag. Herb.

Fructifications closely gregarious, sessile, Isabella-color, spherical and with margin inrolled in the dried state, sometimes obconic, externally hairy; hairs granular incrusted, baryta-

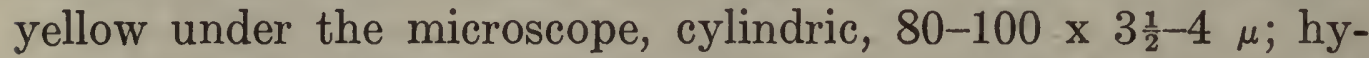
menium even, whitish or pale olive-buff; basidia clavate, 12-16 x $6 \mu$; spores mostly colorless but some pale baryta-yellow, even, broadly ellipsoidal, $5-6 \times 4-4 \frac{1}{2} \mu$.

Fructifications about $\frac{1}{5}-\frac{1}{2} \mathrm{~mm}$. high and broad.

On rotten wood of Salix nigra. Louisiana. December.

In the specimen upon which the description is based, the most of the fructifications are about $\frac{1}{5} \mathrm{~mm}$. high and broad and are distributed on the rotten wood at the rate of about 200 per square centimeter. Rarely a short stem-like base is visible when the fructifications emerge from the bottom of small crevices between the fibers of the wood, but the fructifications are generally sessile. The species is intermediate between Cyphella and Solenia but is included in the former genus because the fructifications do not arise from a common subiculum and are more globose than in Solenia. The description of $C$. mellea suggests 
those of $C$. Ravenelii and $C$. texensis in many respects, but the fructifications are much smaller and more numerous than in either of these species, and their various parts are also much smaller and some of the spores are colored.

Specimens examined:

Louisiana: Bohemia, Plaquemines Co., A. B. Langlois, 864a, type, in Burt Herb. and also (in U. S. Dept. Ag. Herb.); A. B. Langlois, 864 (in U. S. Dept. Ag. Herb.).

19. C. fasciculata (Schw. ex Berk. \& Curtis, Jour. Acad. Nat. Sci. Phila. 3 : 207. 1856. Plate 19. fig. 17.

Cantharellus fasciculatus Schw. Trans. Am. Phil. Soc. N. S. 4: 153. 1831.-C. fasciculatus Schw. in Saccardo, Syll. Fung. 5: 495. 1887.-Cyphella fasciculata Berk. \& Curtis, Grevillea 2: 6. 1873.-Solenia anomala Pers. var. orbicularis Peck, Rep. N.Y. State Mus. 47: 168 (42). 1894.-Cyphella fulva Berk. \& Rav. Grevillea 2: 5. 1873.-C. Ravenelii Saccardo, Syll. Fung. 6: 672 . 1888.-C. Saccardoi Sydow, in Saccardo, Syll. Fung. I4: 233. 1900.-C. furcata Berk. \& Curtis, Grevillea 2: 5. 1873.

Type: in Herb. Schweinitz.

Fructifications gregarious, sometimes fascicled, pezizoid, tawny olive; pileus stipitate, cup-shaped, extended vertically or pendulous, tomentose with tawny-olive, even-walled hairs which are flexuous or somewhat spirally curved towards the tips, the margin strongly inrolled; stem short, variable in length, cylindric, tomentose, colored like the pileus; hymenium concave, even, drying olive-buff; spores hyaline, even, cylindric, slightly curved, $7-9 \times 2-2 \frac{1}{2} \mu$, borne four to a basidium.

Fasciculate clusters about $2 \mathrm{~mm}$. in diameter, $1 \mathrm{~mm}$. high; fructifications $\frac{1}{3}-1 \mathrm{~mm}$. in diameter, 1-2 mm. high; stem $\frac{1}{2}-1$ $\mathrm{mm}$. long, $\frac{1}{5}-\frac{1}{2} \mathrm{~mm}$. thick.

On bark of twigs of Alnus in swamps and rarely on Prunus virginiana and Pyrus Malus. Canada and Newfoundland to South Carolina and westward to Wisconsin. Throughout the year, more highly fasciculate from autumn to spring. Common.

This fungus is very common on dead twigs of Alnus in swamps. The color is similar to that of Solenia anomala but the fructifications are rather larger and more cup-shaped than those of the latter and have the hymenium merely concave rather than lining a tube. The fructifications burst out through the outer bark 
either singly or in clusters of from two to twenty individuals more or less connected together at the base. The differences in habit between the extremes of highly fascicled forms and those with fructifications gregarious and largely single, impress one as of specific weight at first and I should like to recognize these extremes as two species but they intergrade too completely. The dated collections which I have seen, indicate that the specimens become highly fasciculate in autumn and winter.

I do not understand why Berkeley attempted authorship for this species. The C. fasciculata B. \& C. is certainly that of Schweinitz both in description and in fascicled form of types; and as for C. fulva B. \& Rav., it is noted in the original description that it is the same as Cantharellus fasciculatus Schw.

Specimens examined:

Exsiccati: Ellis, N. Am. Fungi, 936, fascicled form; Ell. \& Ev., Fung. Col., 1818, fascicled form under the name C. Ravenelii Berk.; Shear, N. Y. Fungi, 308, fascicled form under the name Solenia anomala (Pers.) Fr. var. orbicularis. Pk. Peck det.; Ravenel, Fung. Car. IV., 16, the type distribution of C. fulva B. \& Rav.; Ravenel, Fung. Am., 129 (bearing spores in abundance); Shear, N. Y. Fungi, 56.

Newfoundland: Headquarters, B. L. Robinson \& H. von Schrenk (in Mo. Bot. Gard. Herb., 4764 and 43789, the latter communicated by W. G. Farlow); Bay of Islands, A. C. Waghorne, 127 (in Mo. Bot. Gard. Herb., 42593).

Quebec: Hull, J. Macoun, 355.

Ontario: Ottawa, J. Macoun, 23.

Maine: J. Blake (in Curtis Herb., 6926, and in Kew Herb.).

New Hampshire: Conway, W. G. Farlow; North Conway, W.

G. Farlow (in Mo. Bot. Gard. Herb., 43786); Shelburne, H. von Schrenk (in Mo. Bot. Gard. Herb., 4765), W. G. Farlow (in Mo. Bot. Gard. Herb., 43787); Franklin Falls, Mrs. J. B. Harrison, Ellis, N. Am. Fungi, 936.

Vermont: Middlebury, on Alnus and on Prunus virginiana, E. A. Burt.

Massachusetts: Newton, W. G. Farlow (in Mo. Bot. Gard. Herb., 42591, 42592 and 43788).

New York: Torrey, type (in Herb. Schw.); Sartwell, cotype and type of C.fasciculata B. \& C. (in Curtis Herb., 2659, and in 
Kew Herb. respectively) and specimen (in Mo. Bot. Gard. Herb., 4937); Ithaca, G. F. Atkinson; East Galway, E. A. Burt; Keeseville, C. O. Smith, Ell. \& Ev., Fung. Col., 1818; Alcove, C. L. Shear, Shear, N. Y. Fungi, 56 and 308; Albany, C. H. Peck, comm. by H. D. House (in Mo. Bot. Gard. Herb., 43821); Karner, C. H. Peck, comm. by H. D. House (in Mo. Bot. Gard. Herb., 43820).

South Carolina: Ravenel, 1683 (in Curtis Herb. and in Kew Herb.), and in Ravenel, Fung. Car. IV., 16; Aiken, Ravenel, Ravenel, Fung. Am., 129.

Alabama: Beaumont, the cotype and type of $C$. furcata (in Curtis Herb., 4022, and in Kew Herb. respectively).

Wisconsin: Madison, W. Trelease (in Mo. Bot. Gard. Herb., 42594).

20. C. conglobata Burt, n. sp.

Plate 19. fig. 15.

Type: in Mo. Bot. Gard. Herb. and in Farlow Herb.

Fructifications cespitose, 10-30 together, sessile on a common short trunk which is erumpent through the bark; individual fructifications subglobose, fuscous and glabrous when moist, drying mouse-gray and with the margin inrolled; hymenium concave, black or nearly black; basidia simple, with four sterigmata; spores colorless, even, cylindric, slightly curved, 8-10 x $2 \frac{1}{2}-3 \mu$.

Cluster 1-2 $\mathrm{mm}$. in diameter, emerging about $\frac{1}{2} \mathrm{~mm}$. from the bark; cups $400-500 \mu$ broad, nearly as high.

Clusters scattered on small limbs of Alnus. New Hampshire and New York. July and September.

The clusters of this curious fungus are distributed at the rate of about 5 or 6 clusters to the square centimeter on what I conclude to have been the under side of a horizontal limb-perhaps a limb prostrate on the ground; for cups in clusters exactly on this presumably under side have the pore central while in the clusters which emerged more obliquely from the limb the cups are somewhat auriform with oblique pore and are arranged in imbricated manner. The outer surface of the cups is composed of irregularly branched and interwoven pale brownish hyphæ about $2 \mu$ in diameter. The substance of the fructifications and common trunk-like base is composed of colorless hyphæ with walls gelatinously modified. 
One might regard this fungus as the type species of a new genus distinct from Cyphella or Solenia by the common central mass on which the individual cups are borne, but in Cyphella fasciculata the cups sometimes occur singly and sometimes branching from a common central or basal mass. For this reason it seems best to include the present species in Cyphella through its relationship in plan of structure to C. fasciculata, from which it is specifically distinct in other respects, however. Both these species are excluded from Solenia by their short and globose fructifications and by the absence of a subiculum on the general area over which the clustered fructifications are distributed.

Specimens examined:

New Hampshire: Lower Bartlett, $R$. Thaxter, comm. by W. G. Farlow, 4, type (in Mo. Bot. Gard. Herb., 43806, and in Farlow Herb.).

New York: Adirondack Mts., C. H. Peck, comm. by H. D. House (in Coll. N. Y. State and in Mo. Bot. Gard. Herb., 43818); North Elba, C. H. Peck, comm. by H. D. House (in Mo. Bot. Gard. Herb., 43819).

21. C. fumosa Cooke, Grevillea 20:9. 1891. Plate 19. fig. 11. Type: in Kew Herb.

Fructifications gregarious, membranaceous, cup-shaped, flexuous, sepia or olive-brown and blackening, even, attenuated below into a very short stipe, or sessile; hymenium even; basidia cylindric-clavate, $20 \times 4-5 \mu$; spores colorless, even, somewhat flattened on one side, $6-8 \times 3 \frac{1}{2}-4 \mu$.

Fructifications 1-2 mm. broad.

On rotting leaves of Gladiolus. South Carolina.

Cooke described the spores of this species as globose, $4 \mu$ in diameter, but I found no such spores in my preparation from the type. Spores $6-8 \times 3 \frac{1}{2}-4 \mu$ are abundant and are probably the spores of this species, although I could not find any spores still attached to the basidja. I conclude from my microscopical preparations that the fructifications are glabrous.

Specimens examined:

South Carolina: Aiken, Ravenel, 30\%1, type (in Kew Herb.). 


\section{SPECIES IMPERFECTLY KNOWN}

C. cinereo-fusca Schw. ex Saccardo, Michelia 2: 303. 1881.

Peziza cinereo-fusca Schw. Schrift. d. Naturforsch. Gesell., Leipzig, I: 119. 1822; Fries, Syst. Myc. 2: 97. 1823.-Cyphella cinereo-fusca (Schw.) Sacc. Syll. Fung. 5: 674. 1888. -Lachnella cinereo-fusca (Schw.) Sacc. Syll. Fung. 8: 399. 1889.

Fructifications minute, gregarious, sessile, externally farinaceous-hirsute and ash-green, the margin incurved; hymenium fuscous-bay.

On decorticated branches of Cercis. [North Carolina.] $3 \mathrm{~mm}$. broad. Cups often closed.

-Translation of original description.

I have not seen an authentic specimen of this species nor anything on Cercis which seems referable to it. The species is given here on the authority of Saccardo, $l$. $c$., who refers to this species a Cyphella collected on Vitis vinifera near Toulouse, France, by Roumeguere. Saccardo does not state that he made comparison with an authentic specimen from Schweinitz, and he has entered the species in the 'Sylloge Fungorum' in both the Basidiomycetes and the Discomycetes.

C. Palmarum Berk. \& Curtis, (Fung. Cub.) Jour. Linn. Soc. Bot. 10: 337. 1867.

Type: type and cotype probably in Kew Herb. and Curtis Herb. respectively.

White, pileus cyathiform, externally obscurely pruinose; stem short, tomentose, rather thick.

Scarcely $2 \mathrm{~mm}$. high; stem rather thick for the size of the pileus, often oblique.

On petioles of palms. Cuba. June. C. Wright, 758 .

-Arranged from original description.

C. Peckii Sacc. Syll. Fung. 6: 684. 1888.

C. candida Peck, Rep. N. Y. State Mus. 27: 99. 1875.

Type: in Coll. N. Y. State.

Fructifications scattered or gregarious, membranaceous, soft, obconic, nearly or quite sessile, sometimes deflexed, wholly white, externally tomentose; hairs tapering to a sharp point, rough-walled, $60-70 \times 3 \frac{1}{2} \mu$. 
Fructifications about $1 \mathrm{~mm}$. broad.

On dead stems of ferns, Osmunda cinnamomea. New York. September.

The type specimens of this species are immature. I could make out neither distinct asci nor basidia in the hymenium. In a crushed preparation I found one spore, colorless, even, pointed at one end, $6 \times 2 \frac{1}{2} \mu$. It may have been a basidiospore of this species or it may have been a foreign spore.

Specimens examined:

New York: Forestburgh, C. H. Peck, type (in Coll. N. Y. State).

C. perexigua Sacc. Michelia 2: 136. 1880.

Cups bell-shaped, very short and obliquely stipitate, small, $\frac{1}{2}-\frac{3}{4} \mathrm{~mm}$. long, thin-membranaceous, internally and externally whitish cinereous, externally minutely puberulent; spores not seen. Appears related to C. erucceformis and cupuliformis but is one-third as large. . . . On decorticated branches. South Carolina. Ravenel.-Translation of original description.

I have not seen the type of $C$. perexigua, which is probably in Saccardo Herb. As basidia and basidiospores have not been found for American specimens, it is uncertain whether this species is a Cyphella. Patouillard, Tab. Anal. Fung. 19. f. 34. 1883, referred to $C$. perexigua a species of Cyphella which he collected at Poligny, France, but that reference is doubtful in the absence of knowledge in regard to basidia and basidiospores for American specimens.

C. pezizoides Zopf, in Morgan, (Myc. Fl. Miami Val.) Jour. Cincinnati Soc. Nat. Hist. Io: 202. 1888.

Type: probably in the State Univ. of Iowa Herb.

"Fructifications membranaceous, nearly sessile, globose then cup-shaped, clothed externally with long erect white hairs. Hymenium even, brownish; spores obovate, .012-.013 mm. in length.

"On old herbaceous stems; not common, cupule pezizoid, scarcely pedicillate, about half a line in diameter. The long hairs are erect and connivent over the hymenium; they are hyaline and incrusted with crystals of calcium oxalate."

The type is not accessible at present.

-Original description. 
C. trachychæta Ell. \& Ev. Jour. Myc. 4:73. 1888.

Type: in New York Bot. Gard. Herb.

Fructifications gregarious, sessile by a narrow base, white, cup-shaped, clothed outside with appressed hairs; hairs subhyaline, very rough, with a smooth tapering tip 12-15 $\mu$ long; hairs paler around the base of the fructification and coarsely roughened by irregularly shaped tubercles, some of which are prolonged into short spines; hymenium nearly white with a slight tinge of slate color; basidia and spores could not be well made out, but the latter are apparently very minute.

Fructifications $300-400 \mu$ high and broad, occasionally $1 \mathrm{~mm}$. broad and with the margin distinctly lobed.

On fallen leaves of Quercus. Louisiana. July.

The above description is arranged from that originally published. I am under obligation to Dr. Murrill for recently sending to me a portion of the type for study, but the specimen proves too immature to show whether this species is a basidiomycete. The hymenium of this specimen is now pale olivebuff; the hairs are 50-75 × $6 \mu$, heavily encrusted except near the tips, but I failed to find any hairs roughened by tubercles or bearing spines.

Specimens examined:

Louisiana: A. B. Langlois, 1424 , type (in N.Y. Bot. Gard. Herb.).

C. Bananæ Cooke, Grevillea 6: 132. 1878.

Type: probably in Kew Herb.

Fructifications fuliginous or wood-brown, finger-shaped, pendulous-extended behind, glabrous, the margin entire; hymenium white, rugose; spores linear, obtuse, curved, 10-12 x $2 \frac{1}{2} \mu$.

- Translation of original description.

On dead leaves of Musa. Gainesville, Florida. Ravenel.

C. filicicola Berk. \& Curtis, Grevillea 2: 5. 1873.

Type: type and cotype probably in Kew Herb. and Curtis Herb. respectively.

Stem very short; cups irregular, sometimes oblique, externally very obscurely tomentose, umber.

On dead fern. North Carolina. Curtis Herb., 4934, type. The above contains all the items of the original description; I overlooked this species when studying in Curtis Herb. and in Kew Herb. 
C. musæcola Berk. \& Curtis, Jour. Linn. Soc. Bot. Io: 337. 1867.

Type: type and cotype in Kew Herb. and Curtis Herb. respectively.

Pileus crucible-form, pallid purple, with very short stem or sessile, externally tomentose; hymenium luteus (cadmiumyellow).

-Translation of original description.

About $2 \mathrm{~mm}$. across.

On sheaths of plantain leaves. Cuba. C. Wright, 751 .

By the kindness of Dr. Farlow I have been permitted to examine a specimen from the type collection. I fail to find any fructifications of a Cyphella present. A leaf-spot fungus has caused some dark purple discolorations 1-2 $\mathrm{mm}$. in diameter at various points in the surface of the leaf.

Specimens examined:

Cuba: C. Wright, 751, comm. by W. G. Farlow (in Mo. Bot. Gard. Herb., 43790).

\section{EXCLUDED SPECIES}

C. convoluta Cooke, (Fungi of Texas) Ann. N. Y. Acad. Sci. I : 179.1878.

Type: In Kew Herb.

"Scattered, cup-shaped, then flattened, 1 to $2 \mathrm{~mm}$. wide, margin membranaceous, involute, externally white, internally fleshy-red; spores oblong (.007 mm. long).

"On trunks. Ravenel (295)."-The original description.

I examined the type of this fungus, which was collected at Houston, Texas, and do not regard it as a Cyphella. The "basidia" are filiform and only 1-spored; spores are abundant, hyaline, even, $4-5 \times 2-2 \frac{1}{2} \mu$.

C. Cupressi Schw. ex Fries, Epicr. 567. 1836-1838.

Merulius Cupressi Schweinitz, Schrift d. Naturforsch. Gesell., Leipzig, I: 92.1822.

This species is an insect gall, not a Basidiomycete. Its true nature seems to have been first pointed out by Berkeley \& Curtis, Jour. Acad. Nat. Sci. Phila. 3: 207. 1856.

C. subcyanea Ell. \& Ev. Jour. Myc. 2: 37. 1885.

As this species is not mentioned in Saccardo's 'Sylloge Fungorum' and as the early numbers of the Journal of Mycology are rare, I quote the original description as follows: 
"On living leaves of Sabal Palmetto, Louisiana, Nov. 1885. Rev. A. B. Langlois, No. 57. Shallow cup-shaped, thin, substipitate, oblique, less than $1 \mathrm{~mm}$. across, whitish and nearly smooth outside, hymenium bluish or lead colored. Spores filiform multinucleate, upper end thickened, curved into a semicircle, $40-60 \mu$ long by $1 \frac{1}{2} \mu$ thick, on short (11-12 x $1 \frac{1}{2}-2 \mu$ ) subcylindrical sporophores, which are a little thickened below."

This species was distributed in 1891 in Ell. \& Ev., N. Am. Fungi, 2602, the specimens having been collected on living stems of Smilax in Louisiana by Mr. Langlois. Mr. Langlois communicated to me still better specimens on dead canes of Arundinaria. The fructifications occur scattered here and there in grayish areas $2-4 \mathrm{~mm}$. long by $\frac{1}{2}-1 \mathrm{~mm}$. broad on the surface of the stems. Dr. Farlow informs me in a letter as the proofs are at hand that the above species is the lichen Heterothecium Augustinii Tuckm.

(To be continued.) 


\section{Explanation of Plate}

\section{PLATE 19}

The figures of this plate have been reproduced natural size from photographs of dried herbarium specimens except in the cases noted otherwise.

Fig. 1. Craterellus borealis. From the type specimen collected at Gready Island, Labrador, by Owen Bryant.

Fig. 2. Cyphella galeata. From photograph, natural size, of the figure in Flor. Dan. pl. 2027.f. 1.

Fig. 3. C. muscigena. The two figures on the left are from specimens collected at Floodwood, New York, by E. A. Burt; the two on the right are from the type collection of Craterellus Pogonati collected at South Windsor, Connecticut, by C. C. Hanmer, 1956.

Fig. 4. C. capula. From photograph, natural size, of the figure in Fung. Dan. 2: $p l .22$.

Fig. 5. C. minutissima. From the type specimens collected at Chocorua, New Hampshire, by W. G. Farlow, 3 . Drawings of, $a$, two fructifications, $\mathrm{x} 14 ; b$, spores, $\mathrm{x} 510$; $c$, a hair from outer wall of fructification, $\mathrm{x} 510$.

Fig. 6. C. Langloisii. From the type specimens collected at St. Martinville, Louisiana, by A. B. Langlois, cz. Drawings of, $a$, two fructifications, $\mathrm{x} 17 ; b$, spores, $\mathrm{x} 510$; $c$, a hair from outer wall of fructification, $\mathrm{x} 510$.

Fig. 7. C. porrigens. From the type specimens collected at Cinchona, Jamaica, by W. A. and Edna L. Murrill, 607. Drawings greatly enlarged of, $a$, a fructification showing attachment to a piece of woody stem; $b$, diagrammatic section of the same fructification; $c$, two spores, $\mathrm{x} 510$.

Fig. 8. C. caricina. Three spores, $\mathrm{x} 510$, from the type specimen collected at Verona, New York, by C. H. Peck.

Fig. 9. C. cupuloeformis. From the specimens in Ravenel, Fung. Am., 224, collected at Darien, Georgia, by Ravenel. Drawings of, $a$, two fructifications, $\mathrm{x} 6 ; b$, a basidium, $\mathrm{x} 510$; $c$, four spores, $\mathrm{x} 510$.

Fig. 10. C. texensis. Three spores, $\mathrm{x} 510$, from the type specimens collected in Texas, by C. Wright, 3779 .

Fig. 11. C. fumosa. Three spores, $\mathrm{x} 510$, from the type specimens collected at Aiken, South Carolina, by Ravenel, 3071.

Fig. 12. C. mellea. From the type specimens collected at Bohemia, Louisiana, by A. B. Langlois, 864a. Photograph, $a$, of a piece of wood bearing many fructifications, and drawings of, $b$, median longitudinal section of a fructification, $\mathrm{x} 60 ; c$, three spores, $\mathrm{x} 510 ; d$, a hair from outer wall of fructification, $\mathrm{x} 510$.

Fig. 13. C. villosa. Three spores, $\mathrm{x} 510$, from the specimens in Krieger, Fung. Sax., 1457, collected at Königstein, Germany, by W. Krieger.

Fig. 14. C. Ravenelii. From the specimens in Ravenel, Fung. Am., 130, collected at Aiken, South Carolina, by Ravenel. Drawings of, $a$, a fructification on a piece of bark, $\mathrm{x} 6$; $b$, two spores, $\mathrm{x} 510$.

Fig. 15. C. conglobata. From the type specimens collected at Lower Bartlett, New Hampshire, by R. Thaxter. Photograph, $a$, of a portion of a branch bearing many clusters of fructifications, and drawings of, $b$, a median vertical section through one cluster of fructifications, $\mathrm{x} 6$; $c$, two spores, $\mathrm{x} 510$.

Fig. 16. C. Tilice. From specimens collected at Middlebury, Vermont, by E. A. Burt. Photograph of, $a$, a piece of limb bearing many fructifications, and drawing of, $b$, three spores, $\mathrm{x} 510$.

Fig. 17. C. fasciculata. From specimens collected at Ottawa, Canada, by J. Macoun, 23. Photograph of, $a$, a piece of bark bearing many fructifications, and drawings of, $b$, a cluster of fructifications, $\mathrm{x} 6 ; c$, three fructifications, $\mathrm{x} 10 ; d$, two spores, $\mathrm{x} 510$. 


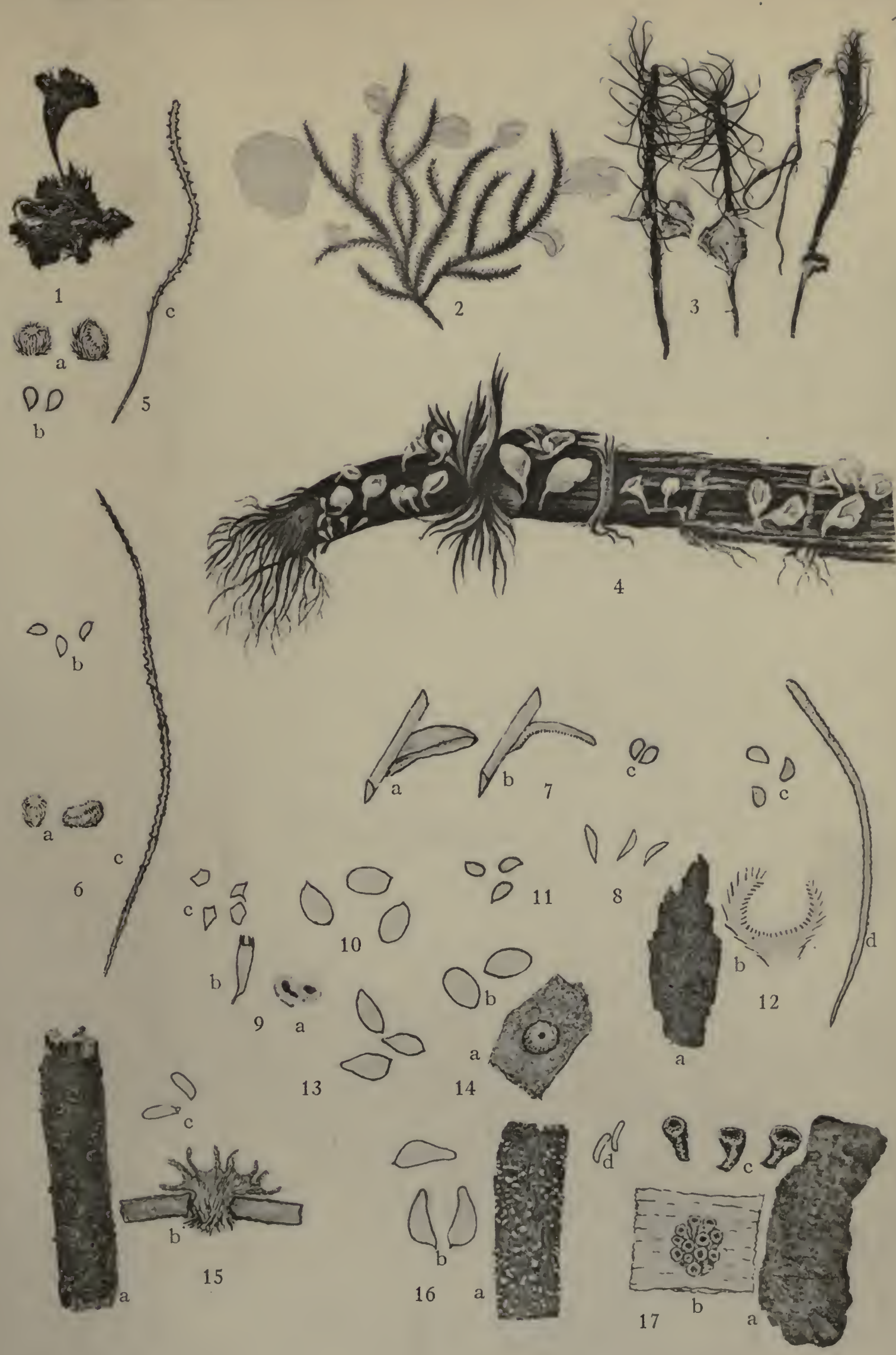

BURT - THELEPHORACEAE OF NORTH AMERICA

1. CRATERELLUS BOREALIS.-2. CYPHELLA GALEATA.-3. C. MUSCIGENA.-4. C. CAPULA.5. C. MINUTISSIMA.-6. C. LANGLOISII.-7. C. PORRIGENS -8. C. C.ARICINA.--9. C. CUPULAEFORMIS 10 C. TEXENSIS,-11. C. FUMOSA.-12. C. MELLEA.-13. C. VILLOSA.-14. C. RAVENELII.15. C. CONGLOBATA.-16. C. TILIAE.-17. C. FASCICULATA. 


\section{.}
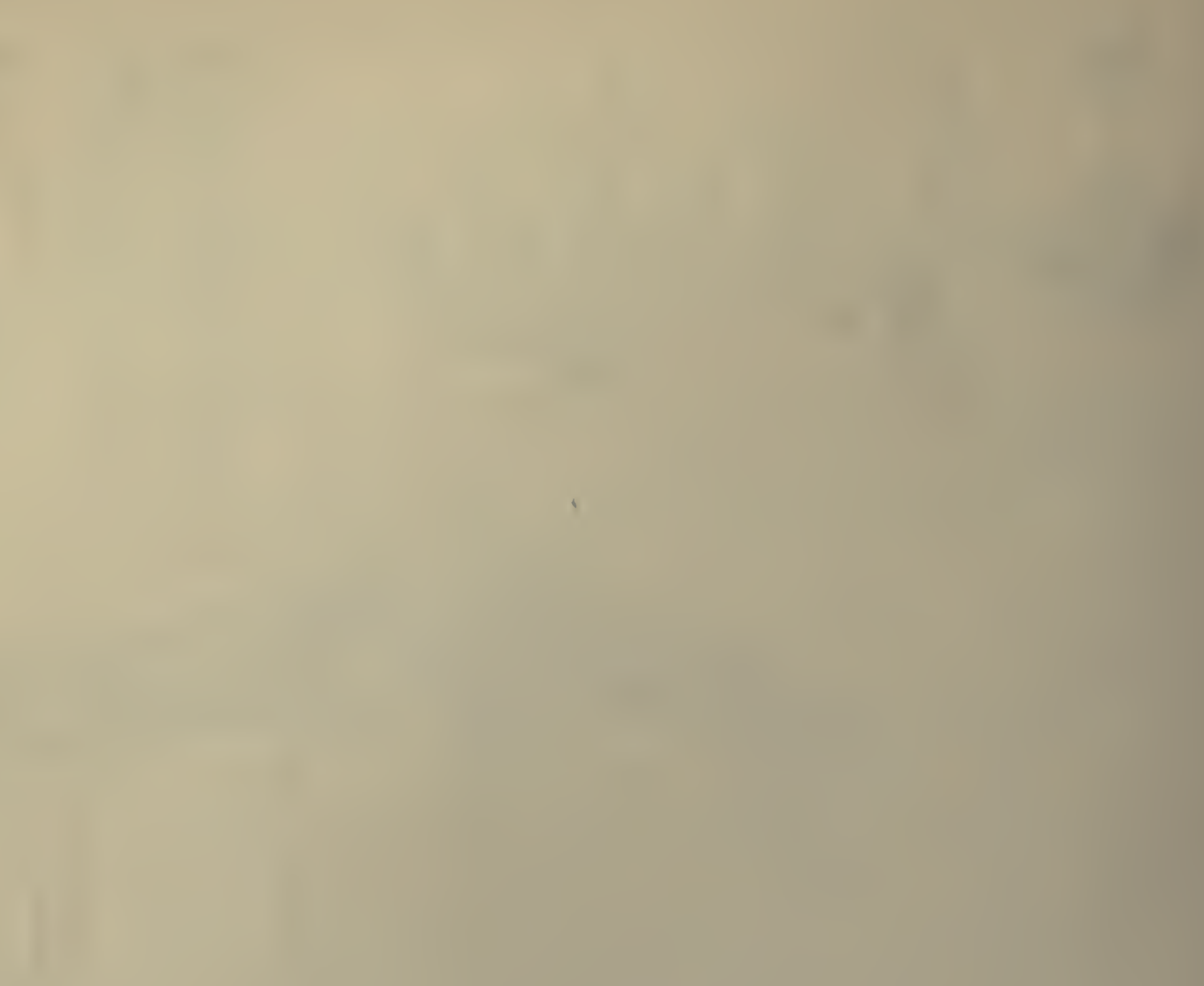
The Thelephoraceae of North America. IV

\section{Exobasidium}

(.DW ARI) A.vaUs BHR'

Reprinted fom ANNals of TuK Missouri BuTANiCA. Fabnen 2:627-654. Si ptember, 1915 

THE THELEPHORACEAE OF NORTH AMERICA. IV ${ }^{1}$

\author{
Exobasidium \\ EDWARD ANGUS BURT \\ Mycologist and Librarian to the Missouri Botanioal Garden \\ Associate Professor in the Henry Shaw School of Botany of \\ Washington University
}

EXOBASIDIUM

Exobasidium Woronin, Naturforsch. Ges. Freiburg Verhandl. 4: 397-416. pl. 1-3. 1867.-Saccardo, Syll. Fung. 6: 664. 1888. - Hennings, in Engl. \& Prantl, Nat. Pflanzenfam. (I.1**) : 103. 1897.

The type species of the genus is Exobasidium Vaccinii Fuck. ex Wor.

Fungi parasitic in leaves, shoots, and flowers, which they deform more or less, producing on the surface of these organs an effused hymenium, rarely composed of basidia alone and more usually felt-like and composed chiefly of interwoven hyphae bearing basidia and conidiophores; basidia simple; spores white, simple or septate.

Exobasidium resembles so closely in the thinness of its fructifications such species of Corticium and Peniophora as Corticium byssinum, Peniophora asperipilata, P. pilosa, and $P$. subalutacea that I follow Saccardo and include it with the above genera in the Thelephoraceae. Hennings in Engler \& Prantl's 'Die Natürlichen Pflanzenfamilien,' has raised $E x$ obasidium to ordinal rank but this is not justified by the structure of the many fructifications of Exobasidium which I have sectioned; the illustrations in text-books of the structure in section of the fructification are decidedly diagrammatic and simplified.

In his work already cited, Woronin gives a detailed account of the morphology and life history of Exobasidium Vaccinii and illustrates this account with three double plates. The interest in this fungus which Woronin's work aroused has

${ }^{1}$ Issued October 8, 1915.

NoтE.-Explanation in regard to the citation of specimens studied is given in Part I, Ann. Mo. Bot. Gard. 1: 202, footnote.

ANN. Mo. Bot. Gard., Vol. 2, 1915 
resulted in the publication of other species by various authors, whose descriptions contrast sharply with that of Woronin in giving little weight to the morphological characters of the fungus under consideration, but extended description of the form and color of the gall of a particular collection, with passing reference to the occurrence of the fungus upon a hitherto unpublished host. In case of the galls, the descriptions usually fail to state what other forms besides the one mentioned the galls may have on other organs of the new host and likewise omit mention of the different forms they may have at other times in the year than the particular time at which the type collection was made. Woronin's description of $E$. Vaccinii was based upon field observations extended through two seasons, during which more than a thousand specimens were collected. He gives one double page colored plate to show the various types of galls produced by the different organs of Vaccinium vitis-idaea.

Plate 21 is a photographic reproduction, reduced one-fifth, of Woronin's colored plate; it shows the forms of galls as determined by the particular organ of the host, Vaccinium vitis-idaea, which makes hypertrophic response to local stimulation by the parasitic fungus. A local change of color from green to some shade of red is common in plant portions infested with Exobasidium. In the photographic reproduction of Woronin's plate the reddened areas of the original appear light colored. In fig. 1, the left side of the uppermost leaf was attacked by the fungus, producing what I term a leaf spot gall. The affected region of the leaf is reddened on the upper side and bears the fructification which may be felty or scurfy on the under side; this leaf is not distorted much in form and thickness.

Figures 2-9 present leaf galls, reddened on the upper side of the leaf and distorted and thickened by hypertrophic growth so as to become more or less concave with respect to the upper surface. I designate this form of gall as leaf concavity.

Figures 10-17 illustrate shoot galls, in the production of which, stems of the current season's growth have been greatly 
enlarged and have turned pale and slightly pink under the stimulus of the infecting fungus. In figs. 10-15 the lateral axillary buds along the infected stem have abnormally enlarged by the stimulation of the fungus and have developed in several instances short, delicate, wax-like or coralloid branchlets of carmine color. Such branchlet shoot galls are beautiful objects in their vegetative condition; they constitute a noteworthy type of gall which is quite different in appearance from the more common leaf galls, produced in response to local infection of leaves. Nevertheless, the common cause of these different gall forms is well brought out by Woronin's illustrations, especially by figs. 11, 12, 13, and 15. Upon shoot galls similar to the above, there have been published Exobasidium Andromedae Karst. non Peck for the shoot galls of Andromeda polifolia, E. cassiopes Peck for the shoot gall of Cassiope Mertensiana, and E. Oxycocci Rostrup for that of Oxycoccus palustris.

Figures 16-18 show the flower type of gall of Vaccinium vitis-idaea, that is, the abnormal growth form made by individual flowers in response to the stimulation of their tissues by the fungus. That both the flower gall and the leaf gall have a common cause has been brought out well by the selection of the specimens used for figs. 16 and 17. In fig. 18 there is presented local infection of a single flower. This is important because isolated flower galls upon a new host have in some cases been regarded as prima facie evidence that they have been caused by a new species of Exobasidium.

Other host plants produce some types of galls, when infected with Exobasidium, which were not figured by Woronin for Vaccinium vitis-idaea but which are more or less common. Such gall types are:

(a) Leaf type in which scattered whole leaves of the host are infected. These leaves redden more or less on the upper side and bear on the whole under side the scurfy or felty fructification but are not notably thickened or deformed. This gall differs from the leaf spot gall of Woronin's fig. 1 merely in having the whole of the leaf infected.

(b) Shoot gall with all the leaves toward the tip of the 
shoot infected but not deformed. These leaves may be almost normally green on the upper side or they may be more or less reddened, sometimes to carmine red; on the under side they become clothed with the felty fructification of the fungus but the leaves are not deformed. This is merely a more general infection than the leaf type $a$, described above, and is often associated with it on the same plant as well as with the leaf spot and leaf concavity forms.

(c) Bag gall of Andromeda ligustrina. This is the extreme in gall production. This gall finally becomes a hollow bag which attains a maximum size of $10-15 \mathrm{~cm}$. in length by $5-10 \mathrm{~cm}$. in diameter. These bag galls are either terminal or lateral on leafy shoots of the current season's growth. When lateral, such a gall has the morphological position of a leaf.

(d) Bud gall of Symplocos tinctoria. The expanding leaf buds are deformed into a subglobose mass which may be $3-3 \frac{1}{2}$ $\mathrm{cm}$. in diameter. In this gall, the undeveloped stem of the bud is greatly enlarged and the individual leaves of the bud are greatly thickened and deformed.

In North America, we have a large number of species of Ericaceae which produce galls when infected by Exobasidium. The specimens which have accumulated under Exobasidium in herbaria show that none of the gall forms which I have designated under distinctive names in the preceding paragraph are isolated forms. Favorable hosts show a connection and gradation between the various gall forms as intimate as that presented by Woronin for Vaccinium vitis-idaea. However, the terms which I employ are useful for contrasting and comparing the data presented by the specimens which I have studied. These data are later given in tabular form.

The microscopic examination of an Exobasidium gall shows that it is composed principally of the tissues of the host plant. Hyphae of the fungus ramify about between the cells of the host and, in the galls in which deformation has taken place, the presence of the fungous hyphae has caused the host both to multiply and enlarge its cells in the infected region. The gall is, therefore, a direct product of the host plant, which 
is stimulated to growth by the presence of the parasitic vegetative hyphae, by absorption of organic products from the host, and, undoubtedly, by excreta from the hyphae. We may see from Woronin's figures that the various organs of a given host produce different galls when infected by the same fungus; from which we may conclude that the several organs of the host make different growth responses to the same stimulating cause. We have in the host itself, in its several organs, and also in the age of tissues of these organs, as I shall point out later, factors not only able to produce, but actually producing, diversity in gall form even though but a single species of Exobasidium is the parasitic stimulant. Of what value, then, is the form of the gall as a taxonomic character for species of Exobasidium?

The different organs of the host differ in the resistance which they offer to infection by Exobasidium. Woronin notes in his work cited that out of more than a thousand specimens of Exobasidium Vaccinii, only twelve showed flower galls. Hence the flowers of Vaccinium vitis-idaea are much less subject to infection than the leaves. In only the one case, which he illustrates by fig. 18, did he observe local infection of a flower. In figs. 16 and 17, the infected flowers are borne on infected shoots and may have become infected through these shoots. We may therefore conclude that in a given host a high resistance of certain organs to infection by Exobasidium restricts the galls for that host to fewer organs and to a smaller number of forms than in some other host with a lesser resistance.

That the age of the organs, or their cells, of a host is an important factor in the determination of gall form is apparent if one observes throughout a season the succession of galls produced by a favorable host. In this connection Richards ${ }^{1}$ has stated, "and also on Gaylussacia resinosa in the earliest formed distortions, whole shoots are transformed. Later in the season the Exobasidium forms only slight local distortions on the leaves, and still later one finds forms which do not distort the tissues of the host plant at all, but simply form a

1Bot. Gaz. 21 : 107. 1896. 
scurf on the lower side of the leaves. The same succession is found in the forms on Andromeda down to the last mentioned." Richards determined by culture experiments that the remarkable bag galls of Andromeda ligustrina are merely early (June in Massachusetts) productions under the same specific fungous stimulus which later in the season induces leaf concavities on this host. The account of his experiments ${ }^{1}$ may be summarized as follows: During July, Exobasidium spores were removed with suitable precautions from fresh mature bag galls of Andromeda ligustrina and were immediately transferred to buds and young leaves of experimental plants of the same species, which were isolated in a moist chamber. In about ten days faint discolorations of the leaves were noticed, at first yellowish and then pink. About five days later, the spots which had considerably enlarged, began to show unmistakable signs of thickening, forming the peculiar concavities in the leaves seen in other Exobasidia. In external form, and also in the matter of basidia and spores, this distortion resembled precisely the leaf form on Andromeda ligustrina, and indicates that the Exobasidium which produces the bag galls of the young buds is identical with the fungus which produces the leaf form found later in the season.

The foregoing presentation of the Exobasidium gall as a growth response of the host under stimulation by the fungus shows that very different forms of galls and differences in regard to abundance of each form on a host may result-

(a) From the different organs making the response.

(b) From differences in resistance of the several organs, which, in many cases, may undoubtedly be so great as to give complete immunity for certain organs.

(c) From the age of the organ attacked.

Since the host produces a great variety of gall forms as growth responses to attack by a single species of Exobasidium, how are we to decide whether a given gall form is ever sufficiently distinct to entitle its causative organism to separate specific rank? Gall forms are host products to so large an

${ }^{1}$ loc. cit., p. 105. 
extent that they can have little, if any, value for discriminating between species of Exobasidium. Into the formation of such galls so many other factors besides the Exobasidium hyphae enter that it is impossible to consider galls as homologous with the fructification of an ascomycete or that of a toadstool, and they should not be used therefore in the way these true fungous fructifications are used for affording in their form specific characters. As a matter of fact, the layer of basidia and conidia-bearing hyphae at the outside of the gall comprise the whole fructification of the parasitic fungus; this layer alone is morphologous with a toadstool. The mere form of the foreign substratum covered by the resupinate fructification of Exobasidium should have no greater taxonomic weight than it has in the closely related genus Corticium.

We should now consider the distribution of Exobasidium Vaccinii as a parasite upon various genera and species of the Ericaceae. Woronin limited his investigation of $E$. Vaccinii to what he observed on Vaccinium vitis-idaea and left the matter there for other investigators to go on with, if they were so disposed. As the collections which are made on this host nearly always show the fungus occurring in leaf spot galls and leaf concavity galls, and since these forms of galls are the only ones on this host common enough for distribution in published exsiccati, the species Exobasidium Vaccinii seems to have become altogether too closely associated with, and limited in mycological practice to, merely the very commonest gall forms which are produced under stimulation by E. Vaccinii. For example, Shear ${ }^{1}$ states, "The typical form of Exobasidium Vaccinii occurs on Vaccinium vitisidaea, producing hypertrophied spots on the leaves. No record has been found of the occurrence of hypertrophied shoots on this host similar to those found on cranberry plants. Rostrup ${ }^{51}$ seems to have been the first to describe this form. In 1883 he reported it as occurring on Oxycoccus palustris in Denmark."'

${ }^{1}$ Cranberry Diseases. U. S. Dept. Agr., Bur. Pl. Ind., Bul. 110: 36. 1907. 
Without doubt, this misapprehension of the galls produced by Vaccinium vitis-idaea is due to the scarcity of copies of Woronin's original account of Exobasidium Vaccinii, for Woronin is at great pains to show that to $E$. Vaccinii are due both shoot galls and flower galls.

That the erroneous tendency of limiting to $E$. Vaccinii the production of only the commonest leaf galls is potent, is apparent from inspection of the table towards the close of this paper where under the heading, "Exobasidium Vaccinii (Fuck.) Wor. The following have been referred here invariably" there are grouped all Exobasidium galls produced by Vaccinium vitis-idaea, $\nabla$. vacillans, $V$. arboreum, $V$. pennsylvanicum, V. stamineum, Gaylussacia frondosa, G. resinosa, Arctostaphylos uva-ursi, A. nevadensis, Arbutus Menziesii, Rhododendron canadense, $R$. maximum, and Lyonia jamaicensis.

Our Gaylussacia frondosa and G. resinosa of this list merit some detailed consideration for they compare very favorably with Vaccinium vitis-idaea as hosts for Exobasidium Vaccinii. The galls of these two species of Gaylussacia include during the season two shoot forms, leaf concavity type, leaf spot type, and the flower type. The flower type of gall is probably very rare; I have seen a dried herbarium specimen of it collected by Dr. Farlow, at Brewster, Massachusetts, and two others, preserved in alcohol in Seymour Herbarium, one of which was collected by A. B. Seymour, at Woods Hole, Massachusetts, and the other by Mrs. Pier, at Biddeford, Maine. These flower galls have a diameter of 10-12 mm.; all the floral organs are enlarged as in case of the flower galls illustrated by Woronin. Bartholomew collected and distributed in his 'Fungi Columbiani,' 3429, the shoot gall of the wax-like or coralloid type such as is produced by Vaccinium vitis-idaea. Gaylussacia resinosa very frequently produces as its earliest galls the other form of shoot gall with all the leaves felty on the whole under surface, more or less reddened above, and not deformed. Such a shoot gall is produced by Vaccinium Myrtillus in Europe; it has usually been regarded by European mycologists as due to Exobasidium Vaccinii. Its regular 
1915]

occurrence in North America in a series of E. Vaccinii forms confirms the correctness of the reference.

As we take up the consideration of North American species of Exobasidium which have been published since 1867, we find that in nearly all cases peculiarities of galls have furnished the distinctive portion of the description. These odd or striking forms of galls have been discovered upon new hosts, as was to be expected, for a new host species would witheut doubt have composition and properties at least slightly different from those of Vaccinium vitis-idaea-so different that the growth response, i. e., the gall of this new host, might differ somewhat, perhaps differ notably, from that of $V$. vitis-idaea, even though the stimulus should be given by the same fungus. Two of the specific names to be considered are based entirely upon the occurrence of Exobasidium on a new host, and the other eight are founded upon more or less noteworthy galls. Reference to the second division of my table shows that gall form rather than host has caused the publication of specific names in Exobasidium.

Exobasidium Peckii, for example, was published as the cause of flower galls produced by Andromeda Mariana. Its flower galls are produced so frequently that they attracted attention; leaf concavity galls are common here also. The morphological characters of the fungous cause of these galls agree closely with those of Exobasidium Vaccinii, and the galls themselves are of types that $V$ accinium vitis-idaea produces under stimulation by Exobasidium Vaccinii. No evidence of any nature has been offered tending to show that $E$. Peckii is not E. Vaccinii in all respects. The frequent production of flower galls by Andromeda Mariana can be simply accounted for as due to the susceptibility of the young flower to infection by the fungus, that is, to a special property of this host. I regard Exobasidium Peckii as a synonym of $E$. Vaccinii.

In connection with the discussion of $E$. Peckii, attention should be called to occasional flower galls produced by Lyonia (Andromeda) ferruginea. I have seen only four specimens of these galls, two from Georgia and two from Florida. All 
resemble monstrous flowers-up to $5 \mathrm{~cm}$. long in the dried state-with all floral organs enlarged proportionally, as in the flower galls of Andromeda Mariana, Gaylussacia resinosa, and Vaccinium vitis-idaea. Only flower galls are as yet known to me for Lyonia ferruginea, but as the morphological characters of the fungus found on the galls are those of Exobasidium Vaccinii, I regard these galls as similar to those of Andromeda Mariana but much larger and due to Exobasidium Vaccinii. The large size of these Lyonia galls is the expression of the growth response of the flower tissue of this host. It will be interesting if further collections of this host show that only the flowers are susceptible to infection by Exobasidium.

Exobasidium Oxycocci was proposed as a name for the fungus causing the shoot galls of wax-like or coralloid habit which are produced by Oxycoccus palustris. Similar galls are produced in the United States by Vaccinium macrocarpon and $\nabla$. intermedium. Shoot galls of $V$. macrocarpon are illustrated in color by Shear ${ }^{1}$ and also the leaf spot and leaf concavity galls which this host produces. The morphological characters of the fungus producing the shoot galls on the cranberry species of Vaccinium are the same as those of Exobasidium Vaccinii; the galls produced by cranberry plants are such as $E$. Vaccinii produces. As there is no evidence of any kind that $E$. Vaccinii, common throughout the same region, does not cause the cranberry galls, the name $E$. Oxycocci seems quite unnecessary.

Exobasidium Cassiopes and E. Karstenii have been published as causes of the shoot galls produced by Cassiope Mertensiana and Andromeda polifolia respectively. These shoot galls are of the wax-like or coralloid type such as Vaccinium vitis-idaea produces under stimulation by Exobasidium $V$ accinii. As the morphological characters of the so-called $E$. Cassiopes and E. Karstenii are those of E. Vaccinii, and as no evidence has ever been presented that $E$. Vaccinii does not cause the galls referred to, E. Cassiopes and $E$. Karstenii should also be regarded as synonyms of $E$. Vaccinii.

1 loc. cit., pl. 8. 
Exobasidium Andromedae Peck is based on the bag gall produced by Andromeda ligustrina. This gall described in detail on a preceding page, is so very large and remarkable in structure that it did seem that here, if anywhere, must be the anomaly for higher fungi of a fungous cause, specifically different from Exobasidium Vaccinii, yet having the same morphological characters. From this point of view, Richards' experiment, ${ }^{1}$ already described, of growing on the leaves of Andromeda ligustrina a July crop of leaf concavity galls from spores produced by a bag gall which had matured at the beginning of July, was very illuminating. It showed that such a bag gall is noteworthy only because it shows peculiar properties inherent early in the season in shoots and leaves of Andromeda ligustrina, that this bag gall belongs in the series with, and is caused by, the same fungus as the leaf concavity galls such as Exobasidium Vaccinii produces.

Richards made other experiments tending to show that $E$. Vaccinii produces the bag galls on Andromeda ligustrina. He demonstrated that the latter species is not immune to undoubted Exobasidium Vaccinii, that it is as susceptible to such spores as to those produced by its own bag galls. In July, spores of $E$. Vaccinii gathered from leaf concavity galls of Gaylussacia resinosa were transferred to buds and young leaves of Andromeda ligustrina. After about the same lapse of time as when spores from the bag galls were used, there appeared on the Andromeda leaves infected with Exobasidium Vaccinii distortions very similar to those produced by spores from the bag galls. As the large bag gall was the only occasion for the name $E$. Andromedae Peck, I agree with Richards that this name is a synomym of $E$. Vaccinii.

In confirmation from the herbarium side of the correctness of the above conclusion, I have a specimen collected in Idaho by Professor Piper, 772, on Menziesia glabella, which has a small terminal bag gall such as is produced by Andromeda ligustrina, and also a leaf concavity gall.

In the light of what we now know about bag galls the names Exobasidium Azaleae, E. discoideum, and E. Rhododendri

${ }^{1}$ loc. cit. 
appear superfluous, for their galls pass through the concavity stage and the morphological characters of the fungi concerned differ in no respect from those of $E$. Vaccinii.

Exobasidium Cassandrae was based on a leaf concavity of Cassandra calyculata. The new host was the sole basis for this new name and its author closed his description with the comment, "perhaps this is only a form of E. Vaccinii." Since we now regard $E$. Vaccinii as able to infect many species of the Ericaceae, the host alone in this case (with the morphological characters of the fungus agreeing with those of $E$. Vaccinii) does not afford sufficient justification for regarding E. Cassandrae as distinct from $E$. Vaccinii.

Exobasidium Arctostaphyli was founded on a leaf spot on Arctostaphylos pungens. As in the case of Exobasidium Cassandrae, there is no evidence whatever that the fungus concerned is not $E$. Vaccinii, the characters of the fungus and its work being quite those of the latter species.

The usual errors in connection with the preceding series of synonyms which are grouped together in the second division of my table are due, it seems to me, to attaching to a strange gall form-a host product-the same weight which one would give to a toadstool, and to ignoring the true fructifications of the Exobasidium concerned. In the taxonomy of the $\mathrm{Hy}$ menomycetes, species are based upon differences in morphological characters. It is so remarkable an innovation in our taxonomic usage in this group of plants to propose a new species which has precisely the same morphological characters as a well-known and established one that it makes it incumbent upon, and an unusual opportunity for, an author so establishing a species to show conclusively the truth of the paradox that actually good and distinct species of Hymenomycetes have the same morphological characters. In all the cases which have been considered, no evidence tending toward such proof has been offered. In the above, I but express the views of many of the best mycologists, who have consistently regarded the above-mentioned Exobasidium names as synonyms of $E$. Vaccinii. 
Winter ${ }^{1}$ wrote of Exobasidium Vaccinii in Europe where there is a similar confusion as to species, "der Pilz erzeugt ausnahmslos Formänderungen der verschiedensten Art an den von ihm bewohnten Pflanzentheilen . . . . . Ich finde zwischen den einzelnen verschiedene Nährpflanzen bewohnenden Formen keine wesentlichen Unterschiede."

The specimens which I have studied show that we have in North America perhaps three species of Exobasidium, two of which are rare and are present in herbaria in so few specimens that present conclusions concerning them are somewhat tentative. These species are as follows:

\section{E. Vaccinii (Fuck.) Wor.}

This species is common and wide-spread and is parasitic on many ericaceous host plants. There is as yet no evidence of which I am aware tending to show that so-called physiological races or forms with parasitism limited to a particular host exist in this species. This fungus attacks leaves developing leafy shoots, and flowers of susceptible plants, making its most successful infections when these organs are very young. The vegetative hyphae live in the infected organs between the cells, which are stimulated by the presence and activities of the parasitic hyphae to make a more or less marked hypertrophic growth response, termed a gall. The galls are of varied and sometimes strange form according to the host, the organ, and its age. The distribution of the galls upon the host is dependent upon the susceptibility of its various organs to infection.

In fruiting, the hyphae push through the epidermis to the surface and produce there a resupinate fructification which is amphigenous in the case of galls from tissues so young that they form galls of wax-like or coralloid structure, and hypophyllous on the more common leaf galls. The fructification is variable in thickness, consisting sometimes of scattered clusters of basidia but usually with hyphae present in variable quantity between the basidia so that the fructification may attain a maximum thickness of $60-70 \mu$, as in the case of col-

${ }^{1}$ In Rabenhorst, Krypt. Flora $1^{1}: 322.1884$. 
lections on Vaccinium vitis-idaea. As shown by Richards, ${ }^{1}$ these hyphae bear simple, acicular, conidia about $6-9 \times 1-1 \frac{1}{2} \mu$. Conidia are nearly always present in the preparations but have been entered only occasionally in my table. The basidia are generally 4-spored. The basidiospores from herbarium specimens are colorless, simple or with some uniseptate, $10-20 \times 2 \frac{1}{2}-5 \mu$, but are usually about $12-18 \times 3-3 \frac{1}{2} \mu$. They are sometimes a little shorter, or a little longer, or a little thinner, or a little thicker, but are so variable within the extremes stated for different collections on the same host within the same regions or distant regions-as will be seen by reference to my table-that a moderate latitude in spore dimensions seems evident.

2. E. Vaccinii uliginosi Boud.

The European specimen of this species distributed from Norway in Briosi and Cavara, 'Funghi Paras.,' 261, has a resupinate, hypophyllous felty fructification, 30-45 $\mu$ thick, which is composed almost wholly of large basidia, standing close together and presenting in sections the appearance of a distinct palisade layer. This fructification begins below the epidermis and tears the cells of the latter loose and apart from each other and carries them outward between the basidia. The hymenium is abundantly fruited with basidiospores, borne two to a basidium. The spores are simple, colorless, even, curved towards the base, 18-20×6-7 $\mu$. No conidial hyphae could be found between the basidia in this specimen.

The specimen distributed in Eriksson, 'Fungi Par. Scand.,' $286 \mathrm{a}$, has similar spores $16-20 \times 8 \mu$. This specimen is in poorer condition and does not show basidia clearly. In some places the fructification is composed of very fine, short-celled hyphae, which are not bearing conidia. Both the above specimens are shoot galls with leaves felty below and reddened above.

Professor Piper, 443, collected on Vaccinium membranaceum, at Mt. Ranier, Washington, in August, a shoot gall similar to the European specimens and having a well fruited

1 loc. cit. 
Exobasidium with 2 -spored basidia and spores $16-20 \times 8 \mu$. The fungus agrees in all respects with the specimen in Briosi and Cavara, 261. Several other collections on Vaccinium membranaceum of buff colored leaf concavity and leaf spot galls appear to bear Exobasidium Vaccinii. The very thick spores, borne two to a basidium, distinguish $E$. Vaccinii uliginosi from $E$. Vaccinii.

3. E. Symploci Ell. \& Mart.

This fungus attacks the developing leaf buds of Symplocos tinctoria and deforms them into a lobed mass. In fruiting, the hyphae protrude on the surface of the mass and bear acicular, simple, colorless, slightly curved conidia, ranging from about $7 \times 1 \mu$ upward. The largest spores are $24 \times 2 \mu$, acicular, curved, and of the same form as those of intermediate size and so on down to attached conidia. I have not found any of the largest spores attached, nor have I found basidia. In the original description the reference to spore characters is "conidia hyaline, cylindric, nearly straight, $15-21 \times 2 \mu . "$

I conclude that basidia have yet to be demonstrated for this fungus.

As I have had an opportunity to examine a large number of Exobasidium specimens, collected in widely separated localities, on many hosts and at various times in the growing season, it has seemed that a concise summary of the data obtained in regard to each specimen might prove useful for comparison purposes to others who study our specimens of this genus in the future. Pains have been taken to give the hosts accurately. I am indebted to Dr. J. M. Greenman for aid in host determinations in several cases.

In the matter of spores the stated dimensions are those of the preparations. which were studied. No effort was made to study preparation after preparation from the same collection in order to find spores possibly larger or smaller than those of the first preparation which showed the spores well. The dimensions stated are those obtained by treating all specimens in exactly the same way and give such results as herbarium specimens afford. 
[VoL. 2

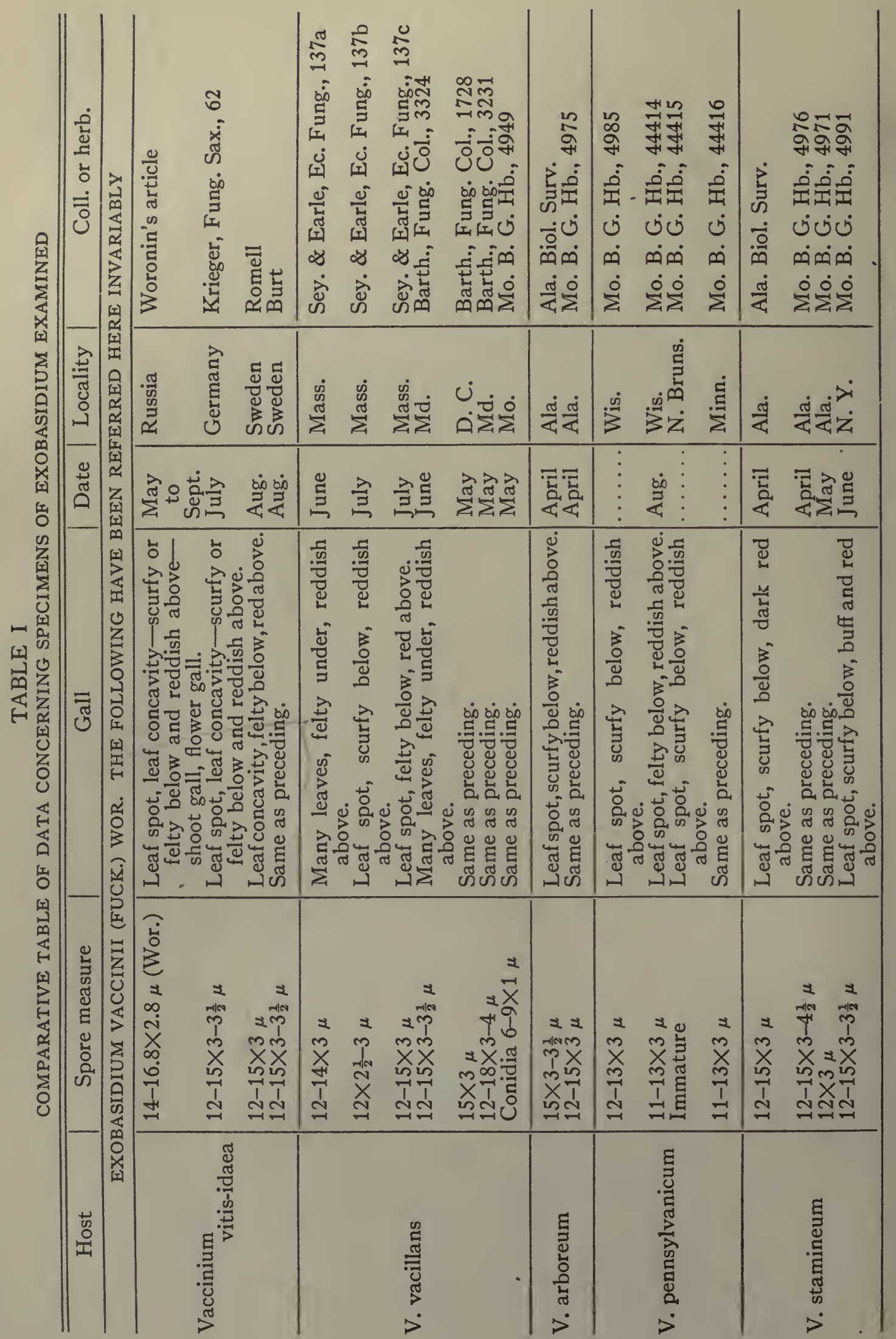




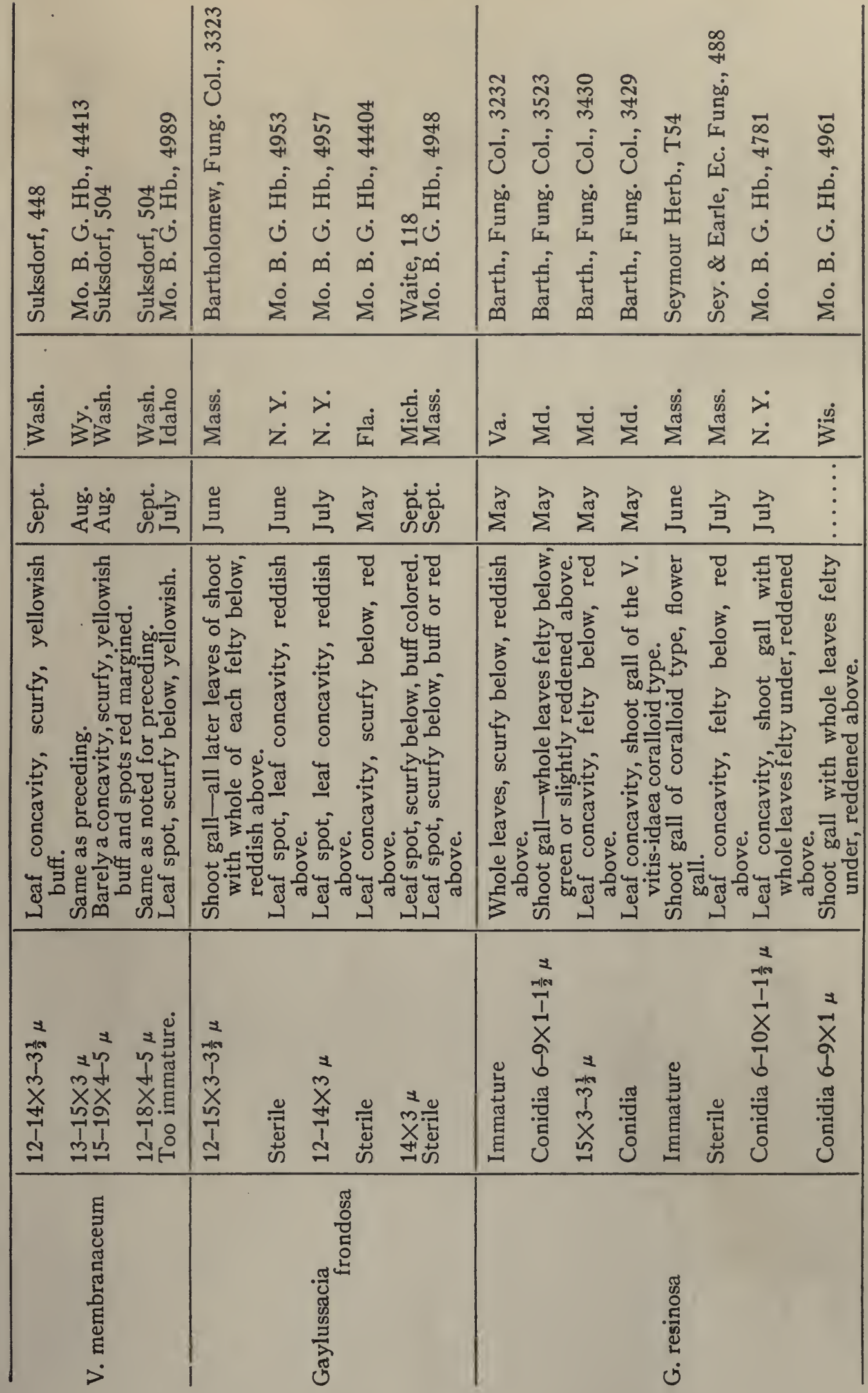


[VoL. 2

\begin{tabular}{|c|c|c|c|c|c|c|c|c|c|}
\hline 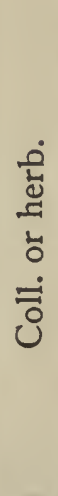 & 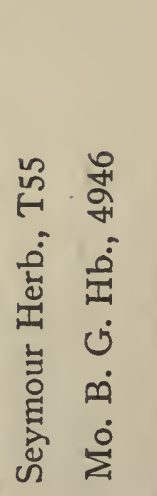 & 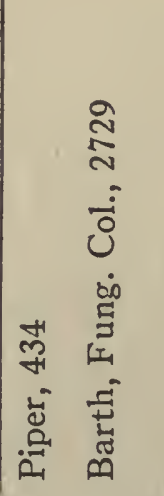 & 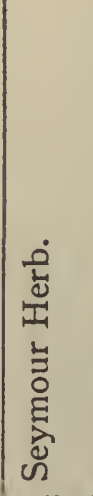 & 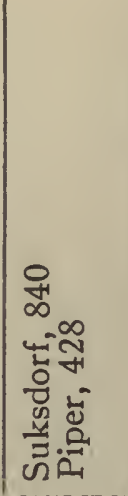 & 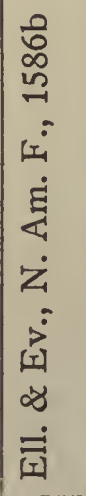 & 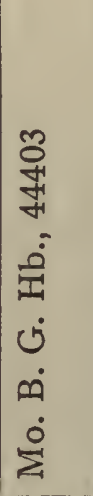 & 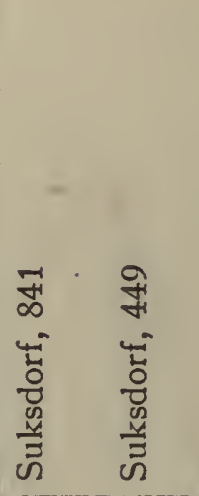 & 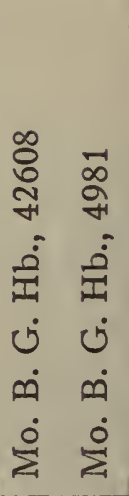 & 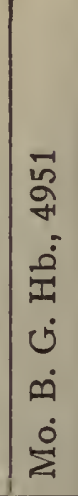 \\
\hline 鴶 & 党 & $\vec{j}^{\frac{\dot{j}}{n}}$ & తే & 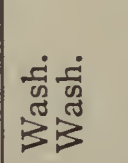 & نं & 胥 & $\sum^{\frac{1}{10}}$ & 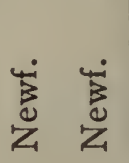 & $\begin{array}{l}\dot{\vec{J}} \\
\dot{\tilde{z}}\end{array}$ \\
\hline 营 & $\stackrel{2}{\Xi} \vdots$ & $\stackrel{\partial}{\Xi} \stackrel{0}{\Xi}$ & $\stackrel{2}{\Xi}$ & 冬完 & ? & 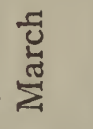 & 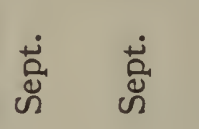 & $\begin{array}{l}\dot{\overrightarrow{0}} \\
\stackrel{0}{\ddot{~}}\end{array}$ & 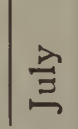 \\
\hline స్ & 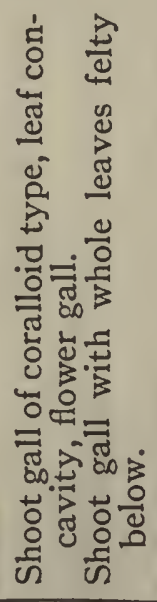 & 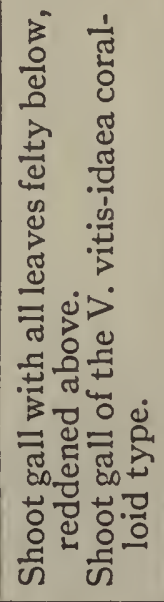 & 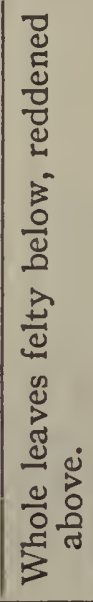 & 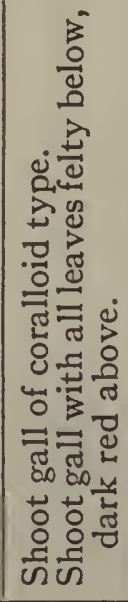 & 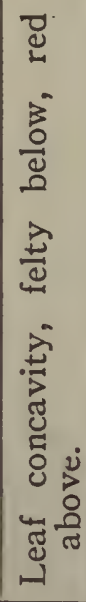 & 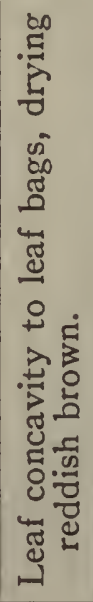 & 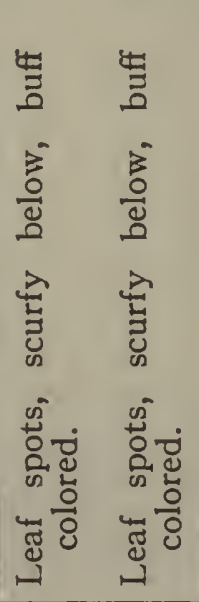 & 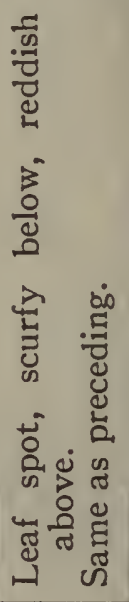 & 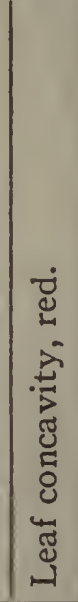 \\
\hline 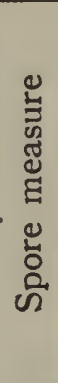 & 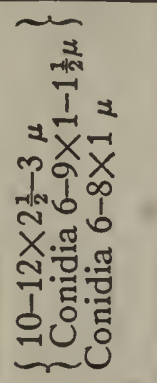 & 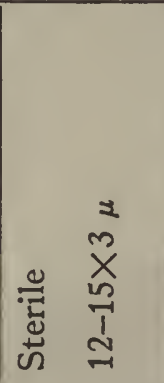 & $\underset{\sim}{z}$ & 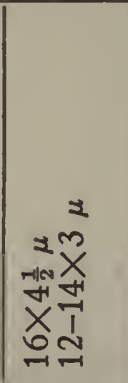 & 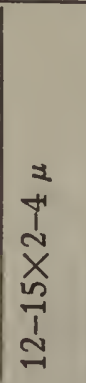 & 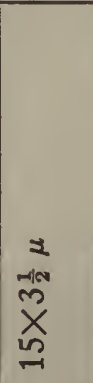 & 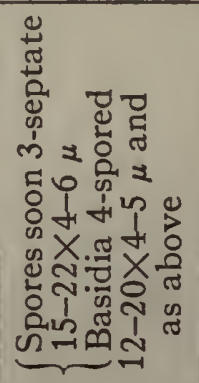 & ن & $\begin{array}{l}y \\
y \\
x \\
\stackrel{4}{x} \\
\stackrel{1}{1} \\
\stackrel{-}{a}\end{array}$ \\
\hline 葆 & 兽 & 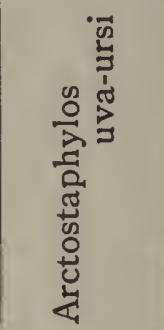 & 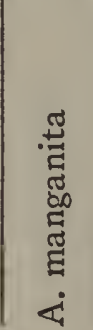 & 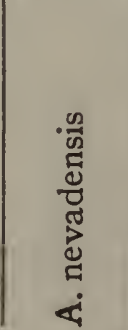 & 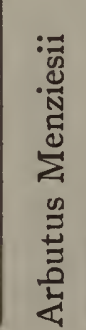 & 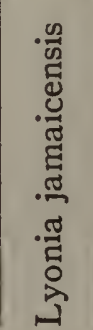 & 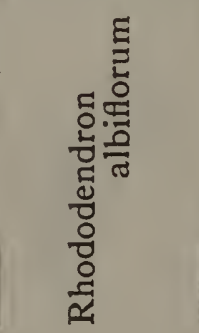 & 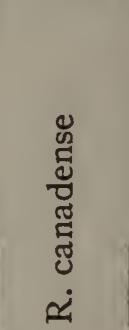 & 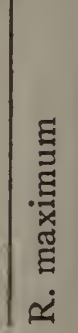 \\
\hline
\end{tabular}




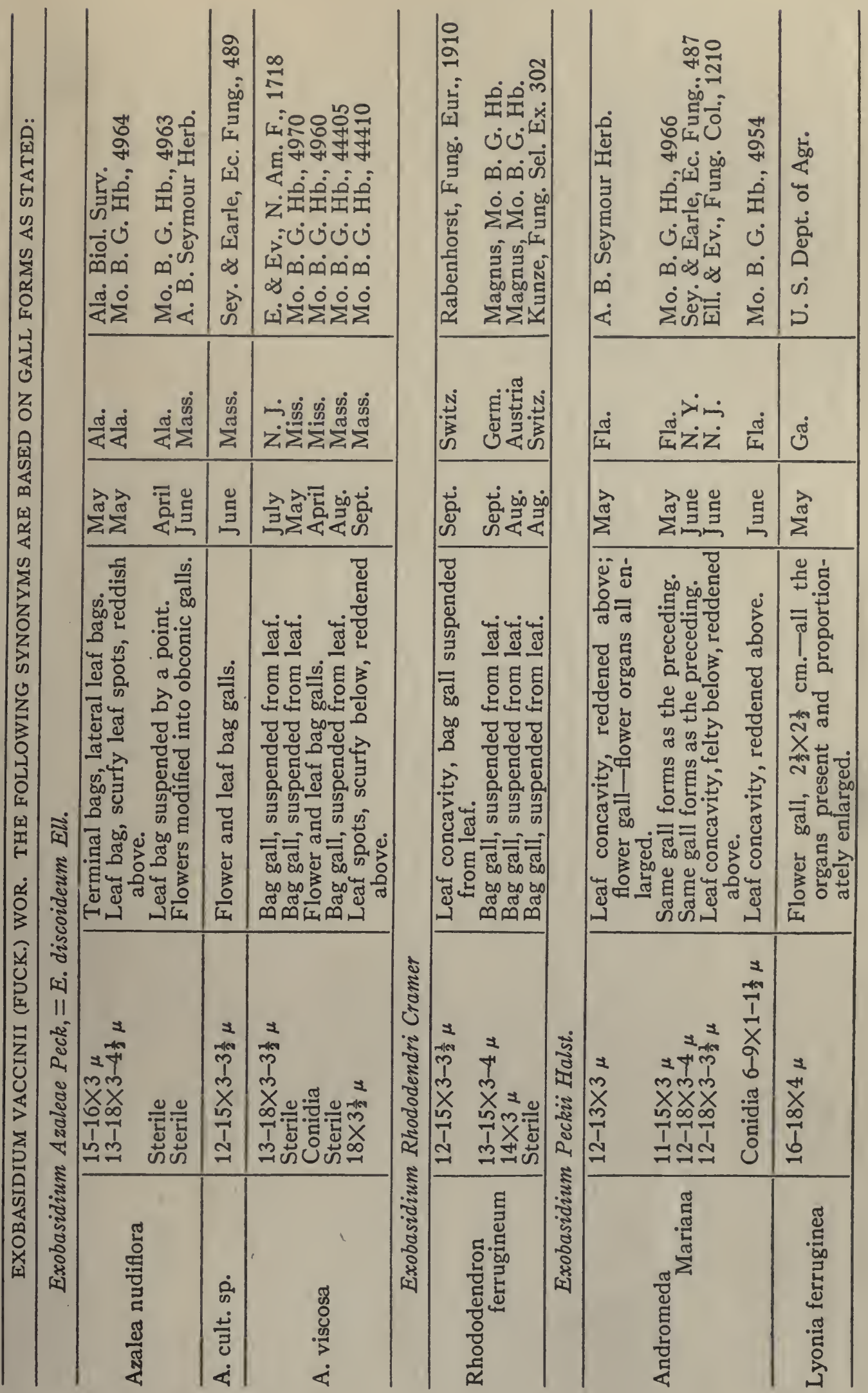




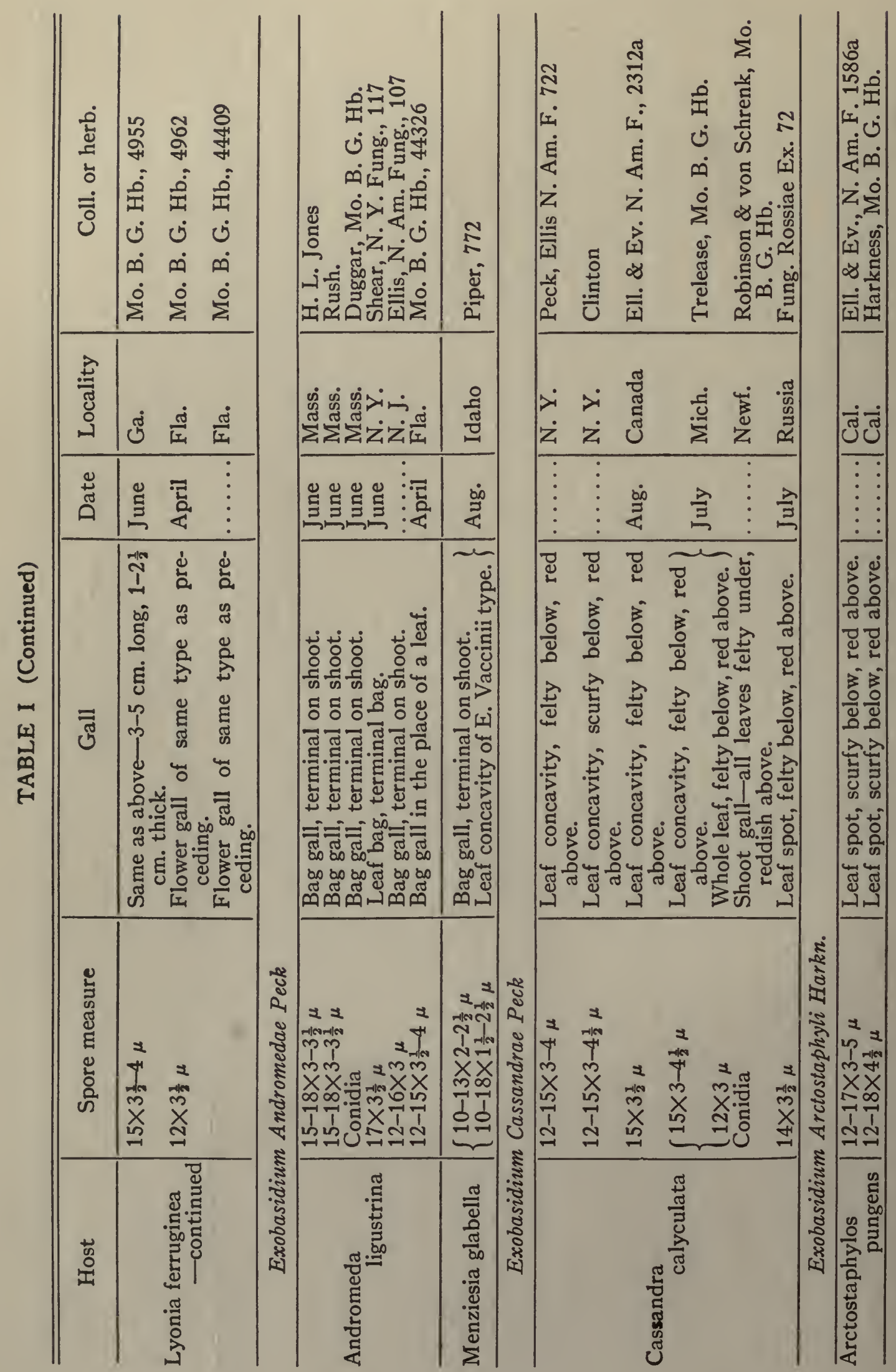




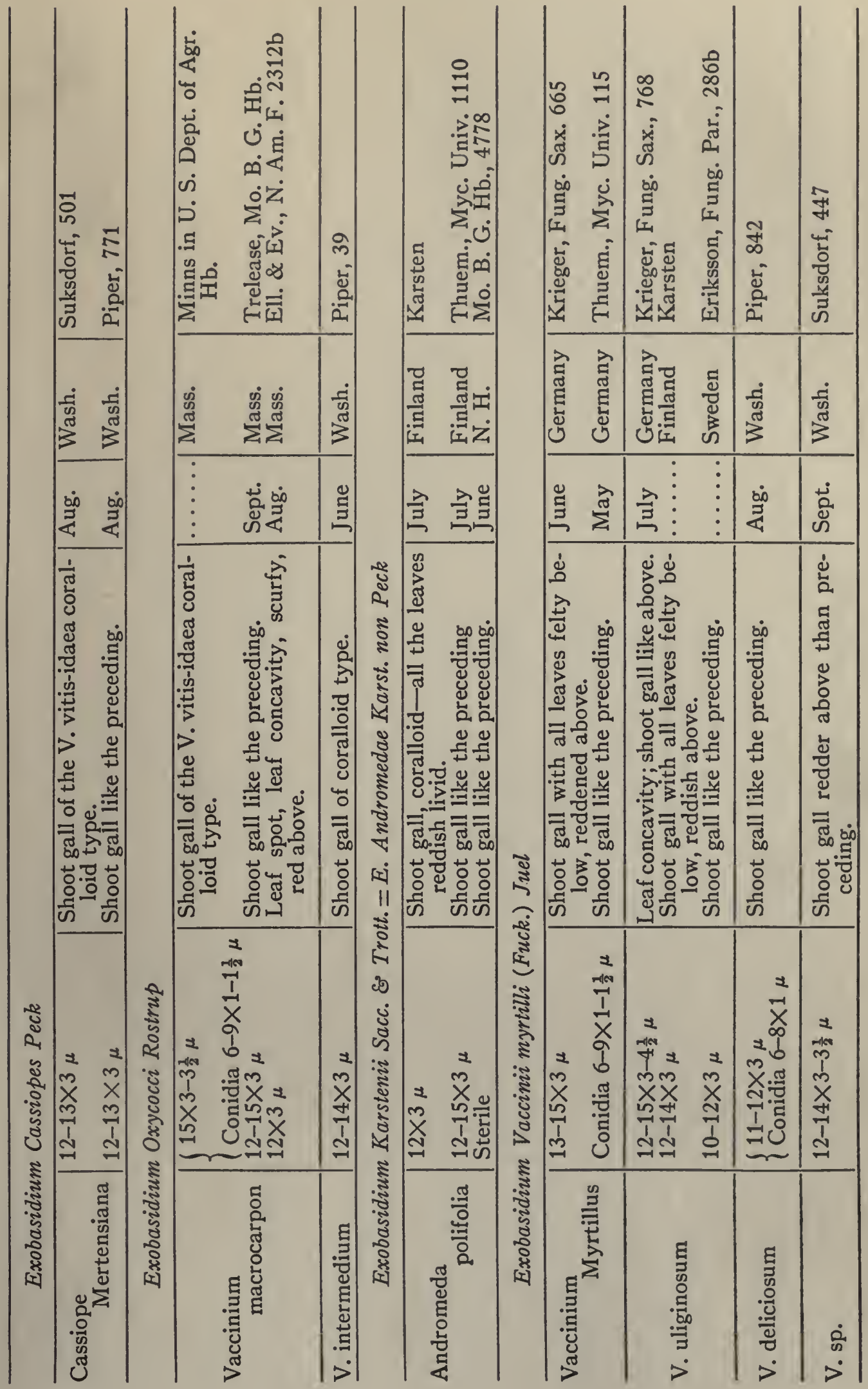




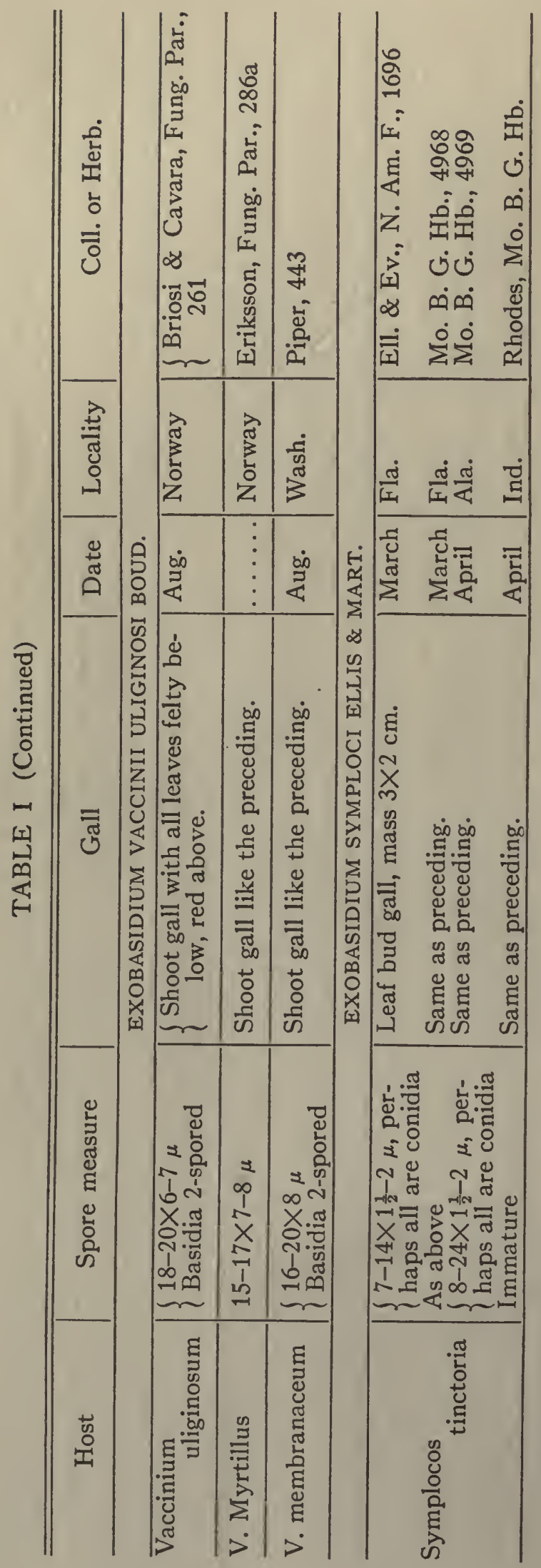




\section{Systematic Summary}

1. Exobasidium Vaccinii Fuck. ex. Wor. Naturforsch. Ges. Freiburg Verhandl. 4: 397-416. pl. 1-3. 1867.

Plate 21.

Fusidium Vaccinii Fuck. Bot. Zeit. 19:251. 1861.-Exobasidium Andromedae Peck, Buffalo Soc. Nat. Hist. Bul. 1: 63. 1873; N. Y. State Mus. Rept. 26: 73. 1874.-E. Azaleae Peck, Buffalo Soc. Nat. Hist. Bul. 1: 63. 1873; N. Y. State Mus. Bul. 26: 72. 1874.-E. discoideum Ellis, Torr. Bot. Club Bul. 5: 46. 1874.-E. Rhododendri Cramer in Rabenh. Fung. Eur. 1910. 1875.-E. Andromedae Karst. in De Thuemen, Myc. Univ. 1110. 1878; Finland Natur och Folk Bidrag 37: 153. 1882.-E. Karstenii Sacc. \& Trott. in Sacc. Syll. Fung. 21: 420. 1912.-E. Cassandrae Peck, N. Y. State Mus. Bul. 29: 46. 1874.-E. Arctostaphyli Harkn. Calif. Acad. Sci. Bul. 1: 30. 1884.-E. Myrtilli (Thuem.) Karst. Finlands Natur och Folk Bidrag 37: 152. 1882.-E. Vaccinii Myrtilli (Fuck.) Juel, Svensk. Bot. Tids. 6: 364. 1912.-E. Oxycocci Rostr. Bot. Tidsskr. 14: 243. 1885.-E. Cassiopes Peck, N. Y. State Mus. Rept. 45: 24. 1893.-E. Peckii Halst. Torr. Bot. Club Bul. 20: 437. 1893.

Illustrations: Woronin. loc. cit.-Richards, Bot. Gaz. 21: pl. 6. f. 1-20.-Petri, Ann. Myc. 5: 342-346.-Brefeld, Untersuch. Myk. 8: pl. 1. f. 17-22.-Duggar, Fung. Dis. f. 215, 216.Shear, U. S. Dept. Agr., Bur. Pl. Ind. Bul. 110 : pl. \%. f. A-D.Juel, Svensk. Bot. Tids. 6: 353-372. f. A-C.—Engl. \& Prantl, Nat. Pflanzenfam. (I. $1^{* *}$ ) : 104. f. 65.-Other illustrations in many text-books. References to other illustrations in Sacc. Syll. Fung. 19: 694 .

Fructifications hypophyllous or amphigenous, resupinate, effused, scurfy or felty and compact, grayish, consisting of somewhat scattered clusters of basidia or of basidia and fine, suberect, more or less interwoven and branched hyphae which bear conidia and give to the fructification a maximum thickness ranging up to $60-70 \mu$; basidia with 4 sterigmata usually; basidiospores colorless, simple or with some 1-septate, 10-20 $\times 2 \frac{1}{2}-5 \mu$, but usually about $12-18 \times 3-3 \frac{1}{2} \mu$, becoming 3 -septate in germinating; conidia simple, $6-9 \times 1-1 \frac{1}{2} \mu$. 
Parasitic in leaves, young shoots, and flowers of various ericaceous hosts, and stimulating the infected parts to the production of leaf, shoot, or flower galls which bear the fructifications on their surface. Leaf galls are usually somewhat reddish on the upper side and bear the fructification on the lower side.

From Newfoundland to Florida and westward to California and Washington, also in Jamaica.

I have referred here, with some doubt, the Exobasidium causing yellow-buff leaf spot galls on Rhododendron albiflorum, collected on mountains in Washington by W. N. Suksdorf. The basidia are $20-30 \times 6 \mu$, with 4 prominent sterigmata; the basidiospores are mostly $18-21 \times 4 \frac{1}{2}-6 \mu$, and are nearly all 3 -septate. Some of these spores are germinating, hence the septation of the spores may possibly be due to their over maturity when collected, combined with weather conditions at that time favorable to germination. Other collections which show the full series of gall forms on this host are desirable and should give the needed information in regard to septation of the spores.

Specimens examined:

Exsiccati : Ellis, N. Am. Fung., 107, 722; Ell. \& Ev., N. Am. Fung., 1586a, 1586b, 1718, 2312a, 2312b; Ell. \& Ev., Fung. Col., 220, 1210; Bartholomew, Fung. Col., 1728, 2729, 3231, 3232, 3323, 3324, 3429, 3430, 3523 ; Seymour \& Earle, Econ. Fung., 137a, 137b, 137c, 487, 488, 489 ; Shear, N. Y. Fung., 117; De Thuemen, Myc. Univ., 115, 210, 1110, 1808; Eriksson, Fung. Par., 286b ; Jaczewski, Komarov \& Tranzschel, Fung. Rossiae Ex., 72; Kunze, Fung. Sel. Ex., 302; Krieger, Fung. Sax., 62, 665, 768; Rabenhorst, Fung. Eur., 1910; Romell, Fung. Scand., 38.

Austria: On Rhododendron ferrugineum, Tyrol, P. Magnus (in Mo. Bot. Gard. Herb., 4988).

Germany: On Vaccinium vitis-idaea, Königstein, Krieger, Krieger, Fung. Sax., 62; Bavaria, De Thuemen, Myc. Univ., 910; on Rhododendron ferrugineum, P. Magnus; on Vaccinium Myrtillus, Leipzig, G. Winter, De Thuemen, Myc. 
Univ., 115; Königstein, Krieger, Fung. Sax., 665; on V. uliginosum, Altenberg, Krieger, Fung. Sax., 768.

Russia: On Cassandra calyculata, Novgorod, Jaczewski, Fung. Rossiae Ex., 72.

Finland: On Vaccinium uliginosum, Mustiala, $P$. A. Karsten; on Andromeda polifolia, Mustiala, P. A. Karsten; and also in De Thuemen, Myc. Univ., 1110.

Sweden: On Vaccinium vitis-idaea, Femsjö, L. Romell; Upsala, E. A. Burt; on Andromeda polifolia, L. Romell, Romell, Fung. Scand., 38; on Vaccinium uliginosum, Eriksson, Fung. Par. Scand, 286b.

Switzerland: On Rhododendron ferrugineum, Luzern, $G$. Winter in Kunze, Fung. Sel. Ex., 302 ; same host, Maderaner Thal, Cramer, Rabenhorst, Fung. Eur., 1910.

Canada: on Cassandra calyculata, London, J. Dearness, Ell. \& Ev., N. Am. Fung., 2312a.

Newfoundland: on Cassandra calyculata, Pennie's River, $B$. L. Robinson \& H. von Schrenk (in Mo. Bot. Gard. Herb., 4779); on Rhododendron canadense, Bluff Head, A. C. Waghorne, 940 (in Mo. Bot. Gard. Herb., 42608) ; Virginia Water, B. L. Robinson \& H. von Schrenk (in Mo. Bot. Gard. Herb., 4981).

New Brunswick: on Vaccinium pennsylvanicum, Hays, 16 (in Mo. Bot. Gard. Herb., 44415).

Maine: on Gaylussacia baccata, Biddeford, Mrs. A. M. Pier (in Seymour Herb., T55).

New Hampshire: on Andromeda polifolia, Shelburne, H. von Schrenk (in Mo. Bot. Gard. Herb., 4778).

Massachusetts: on Vaccinium vacillans, Arlington, Magnolia, and Medford, A. B. Seymour, Sey. \& Earle, Econ. Fung., 137a, 137b, 137c respectively; Plymouth, E. Bartholomew, Fung. Col., 3324; Weston, A. B. Seymour, T56 (in Seymour Herb.); Rafes Chasm, A. B. Seymour, T58 (in Seymour Herb.) ; Middlesex Falls, J. G. Jack (in Seymour Herb.); on $V$. macrocarpon, Woods Hole, W. Trelease (in Mo. Bot. Gard. Herb., 4982); Chatham, Miss Minns, and also (in U. S. Dept. Agr. Herb.) ; Harwich, B.D.Halsted, Ell.\& Ev.,N.Am. Fung., 2312b; Waverly, A. B. Seymour, T60 (in Seymour 
Herb.) ; on $V$. pennsylvanicum, Rafes Chasm, A. B. Seymour T59 (in Seymour Herb.); on Gaylussacia frondosa, Woods Hole, W. Trelease (in Mo. Bot. Gard. Herb., 4948); Plymouth, E. Bartholomew, Fung. Col., 3323; on G. resinosa, Manchester, W. C. Sturgis, Sey. \& Earle, Econ. Fung., 488; Falmouth, A. B. Seymour, T53 (in Seymour Herb.); Woods Hole, A. B. Seymour, T54 (in Seymour Herb.); Dartmouth, W. G. Farlow (in Seymour Herb.) ; Brewster, W. G. Farlow (in Seymour Herb.); on Andromeda ligustrina, Cambridge, $M r$. Rush; Dedham, H. L. Jones, and also B. M. Duggar (in Mo. Bot. Gard. Herb., 44411) ; Woods Hole, W. Trelease (in Mo. Bot. Gard. Herb., 44410) ; Hampden, A. B. Seymour, T51 (in Seymour Herb.); Granville, A. B. Seymour (in Seymour Herb.); on Rhododendron cult. sp., Brookline, A. B. Seymour, Sey. \& Earle, Econ. Fung., 489 ; on $R$. nudiflorum, Granville, A. B. Seymour (in Seymour Herb.) ; on $R$. viscosum, Woods Hole, W. Trelease (in Mo. Bot. Gard. Herb., 44405, 44408).

New York: on Vaccinium stamineum, Ithaca, W. Trelease (in Mo. Bot. Gard. Herb., 4991); on Gaylussacia frondosa, Eastport, J. Schrenk (in Mo. Bot. Gard. Herb., 4953) ; Eastport, H. von Schrenk (in Mo. Bot. Gard. Herb. 4957); on G. resinosa, Deer Park, H. von Schrenk (in Mo. Bot. Gard. Herb., 4781); on Andromeda ligustrina, Alcove, C. $L$. Shear, N. Y. Fung., 117; on A. Mariana, Westbury, F. C. Stewart, Sey. \& Earle, Econ. Fung., 487; on Cassandra calyculata, Adirondack Mts., C. H. Peck, Ellis, N. Am. Fung., 722; Buffalo, G. W. Clinton.

New Jersey: on Andromeda ligustrina, Ellis, N. Am. Fung., 107 ; on A. Mariana, Newfield, Ellis, Ell. \& Ev., Fung. Col., 1210; on Rhododendron viscosum, Newfield, Ellis, Ell. \& Ev., N. Am. Fung., 1718; and (in Mo. Bot. Gard. Herb., 4959).

Maryland: on Vaccinium vacillans, Rosecraft, Bartholomew, Fung. Col., 3231; on Gaylussacia resinosa, Lanham, $E$. Bartholomew, Fung. Col., 3429, 3430; Bartholomew \& Swingle, Fung. Col., 3523. 
District of Columbia: on Vaccinium vacillans, Takoma Park, C. L. Shear, Fung. Col., 1728.

Virginia: on Gaylussacia resinosa, Vienna, E. Bartholomew, Fung. Col., 3232.

North Carolina: on Rhododendron maximum, H. von Schrenk (in Mo. Bot. Gard. Herb., 4951) ; on R. nudiflorum, H. von Schrent (in Mo. Bot. Gard. Herb., 4950).

Georgia: on Lyonia ferruginea, Brunswick, comm. by U. S. Dept. Agr. Herb.; W. Trelease (in Mo. Bot. Gard. Herb., 4955).

Florida: on Gaylussacia frondosa, Dunedin, S. M. Tracy, 6649 (in Mo. Bot. Gard. Herb., 44404); on Andromeda ligustrina, St. Leo, Rev. Jerome (in Mo. Bot. Gard. Herb., $44326)$; on A. Mariana, White Springs, H. H. Hume, 88 (in Mo. Bot. Gard. Herb., 4966), and also (in Seymour Herb.); Chapman (in Mo. Bot. Gard. Herb., 4954); on Lyonia ferruginea, Chapman (in Mo. Bot. Gard. Herb., 44409).

Alabama: on Vaccinium arboreum, Auburn, Ala. Biol. Surv., and also (in Mo. Bot. Gard Herb., 4975) ; on V. stamineum, Auburn, Ala. Biol. Surv., and also (in Mo. Bot. Gard. Herb., 4976) ; Auburn, F. S. Earle \& L. M. Underwood (in Mo. Bot. Gard. Herb., 4971); on Rhododendron nudiflorum, Auburn, Ala. Biol. Surv., and also (in Mo. Bot. Gard. Herb., 4964, 4963).

Mississippi: on Rhododendron viscosum, Ocean Springs, $F$. S. Earle (in Mo. Bot. Gard. Herb., 4970) ; and S. M. Tracy (in Mo. Bot. Gard. Herb., 4960).

Michigan: on Galylussacia frondosa, Lansing, M. B. Waite, 118 (in U. S. Dept. Agr. Herb.) ; on G. resinosa, Agricultural College, G. H. Hicks (in Seymour Herb.); on Cassandra calyculata, Republic, W. Trelease (in Mo. Bot. Gard. Herb., 4983) ; Agricultural College, G. H. Hicks (in Seymour Herb.).

Minnesota: on Vaccinium pennsylvanicum, Hokal, $L$. $H$. Pammel (in Mo. Bot. Gard. Herb., 44416).

Wisconsin: on V. pennsylvanicum, La Crosse, L. H. Pammel (in Mo. Bot. Gard. Herb., 44414); Kirtland, (in Mo. Bot. 
Gard. Herb., 4985) ; on Gaylussacia resinosa, Kirkland (in Mo. Bot. Gard. Herb., 4961).

Missouri: on Vaccinium vacillans, Crystal City, (in Mo. Bot. Gard. Herb., 4949).

Wyoming: on $V$. membranaceum, Teton Mts., A. Nelson, E. Nelson, 6525 (in Mo. Bot. Gard. Herb., 44413).

Idaho: on $V$. membranaceum, Forest, Nez Perces Co., $A$. $A$. \& E. G. Heller, 3465 (in Mo. Bot. Gard. Herb., 4989); on Menziesia glabella, Bitter Root Mt., C.V. Piper, rr2.

Colorado: on Arctostaphylous uva ursi, Glacier Lake, Bartholomew \& Bethel, Fung. Col., 2729.

Washington: on Vaccinium deliciosum, Mt. Rainier, C. V. Piper, 842; on V. membranaceum, Mt. Paddo, W. N. Suksdorf, 448; Chiquash Mts., W. N. Sutisdorf, 504; on Vaccinium sp., probably $V$. membranaceum, Mt. Paddo, W. N. Suksdorf, 447; on V. intermedium, Seattle, C.V.Piper, 39; on Arctostaphylos uva ursi, Orchard Point, C. V. Piper, 434; on A. nevadensis, Mt. Paddo, W. N. Suksdorf, 840; Longwire Springs, C. V. Piper, 428; on Cassiope Mertensiana, Chiquash Mts., Skamania Co., W. N. Suksdorf, 501; Olympic Mts., C. V. Piper, ry1; on Rhododendron albiflorum, Chiquash Mts., Skamania Co., W. N. Suksdorf, 841; Mt. Paddo, W. N. Suksdorf, 449.

California: on Arctostaphylos pungens, H.W. Harkness (in Mo. Bot. Gard. Herb., 4972); and also Ell. \& Ev., N. Am. Fung., 1586a; on $A$. manganita, Sisson's, Siskiyou Co., $W$. C. Blasdale (in Seymour Herb.) ; on Arbutus Menziesii, $H$. W. Harkness, Ell. \& Ev., N. Am. Fung., 1586b.

Jamaica: on Lyonia jamaicensis, Cinchona, H. von Schrenk (in Mo. Bot. Gard. Herb., 44403).

2. E. Vaccinii uliginosi Boud. Soc. Bot. Fr. Bul. 41: CCXLIV. 1894.

Illustrations: Juel, Svensk. Bot. Tids. 6: 353-372. pl. \%.f. 5. text.f. $D$.

Fructification hypophyllous, resupinate on the whole lower surface of the leaves, felty, 30-45 $\mu$ thick, composed of large basidia arranged side by side in a compact hymenium; basidia 
with 2 sterigmata; spores colorless, even, curved towards the base, $16-20 \times 7-8 \mu$.

Parasitic on Vaccinium membranaceum, which produces shoot galls with all the later leaves of the gall red on the upper side, felty below, and but slightly, if at all, deformed.

Mt. Rainier, Washington. August.

In the original description of this species, the spore dimensions are stated as $25-32 \times 8-12 \mu$. The European specimens in the exsiccati cited below, which European authors refer here, have spores of the dimensions of the American collection. Shoot galls of the type stated are the only form known to be caused by this species, but other forms may yet be found.

Specimens examined:

Exsiccati : Briosi \& Cavara, Fung. Par., 261; Eriksson, Fung.

Par. Scand., 286a under the name Exobasidium Vaccinii.

Norway: on Vaccinium Myrtillus, Eriksson, Fung. Par. Scand., 286a; on V. uliginosum, G. von. Lagerheim, Briosi \& Cavara, Fung. Par., 261.

Washington: on Vaccinium membranaceum, Mt. Rainier, $C$. V. Piper, 443.

3. E. Symploci Ell. \& Mart. Am. Nat. 18: 1147. 1884.

Fructification amphigenous, resupinate, effused, consisting of lax, slender, colorless hyphae which bear solitary conidia at the tips of very short, lateral, ascending branches; conidia colorless, even slightly curved, acicular, $7-24 \times 1-2 \mu$; basidia and basidiospores unknown.

Parasitic on Symplocos tinctoria which produces bud galls $3-3 \frac{1}{2} \mathrm{~cm}$. in diameter, lemon yellow, subglobose and sublobate.

Florida, Alabama, and Indiana. March and April.

In the original description it is stated that the galls are distorted flower buds. In a specimen collected in Indiana, the gall is a partially developed leaf bud.

Specimens examined:

Exsiccati : Ell. \& Ev., N. Am. Fung., 1696.

Florida: on Symplocos tinctoria, Green Cove Springs, $G$. Martin (in Mo. Bot. Gard. Herb., 4968); and in Ell. \& Ev., N. Am. Fung., 1696. 
Alabama: on Symplocos tinctoria, Auburn, Ala. Biol. Surv. (in. Mo. Bot. Gard. Herb., 4969).

Indiana: on Symplocos tinctoria, Robertsdale, A. M. Rhodes (in Mo. Bot. Gard. Herb., 741178).

\section{SPECIES IMPERFECTLY KNOWN}

Æ. decolorans Harkness, Cal. Acad. Sci. Bul. 1: 31. 1884.

"Receptaculum effused, producing conspicuous yellowishwhite, orbicular spots, 1-2 cm. in diameter, not at all distorting the leaf; spores appearing upon the under surface, hyaline, straight, $\mu$ 7-8 $\times 4-5$.

"On living leaves of Rhododendron occidentale. Tamalpais [Cal.]. Autumn. 2887."

The above is the original description. I have seen no specimens referable here nor on the host stated.

\section{EXCLUDED SPECIES}

E. mycetophilum Peck ex Burt, Torr. Bot. Club Bul. 28: 285-287. pl. 23. 1901.

Tremella mycetophila Peck, N. Y. State Mus., Bul. 28: 53. pl.1. f. 4. 1879.

This curious structure on Collybia dryophila, I no longer regard as parasitic but, rather, as a teratological production of C. dryophila, induced by protracted wet weather during development of the fructification.

(To be continued.) 


\section{Explanation of Plate}

\section{PLATE 21.}

This plate is a photographic reproduction, $\times 4 \%$, of Plate 1 by Woronin 1 of the various galls produced by Vaccinium vitis-idaea when parasitized by Exobasidium Vaccinii. The original plate is colored and with all figures natural size; red colors of the original have photographed light colored.

Fig. 1. Leaf spot gall, on left side of uppermost leaf; the leaf is reddish on the upper side in the infested area, not deformed, and was felty or scurfy on the lower side.

Figs. 2-9. Leaf concavity galls. More or less deformation of the infected region is present here.

Figs. 10-15. Shoot galls of the wax-like or coralloid type. Extended portions of leafy shoots are infected. Figure 11 shows whole branchlets completely hypertrophied.

Figs. 16-17. Flower galls borne on, and a part of, shoot galls.

Fig. 18. Flower gall. Local infection of a single flower, noted as the only such instance observed.

${ }^{1}$ loc. cit. 


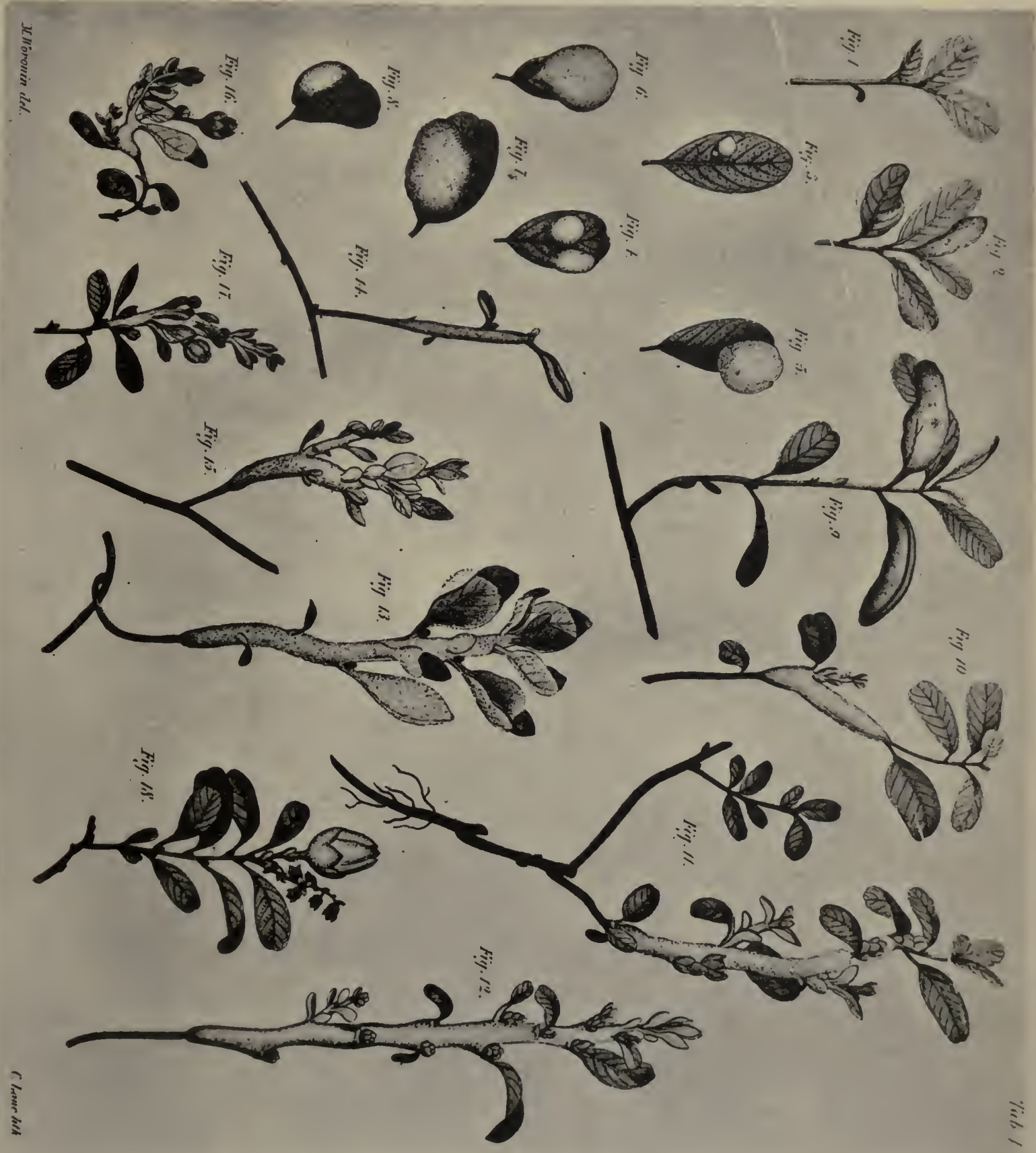





\section{ne fand conte}

\section{THE THELEPHORACEAE OF NORTH AMERICA V1}

\section{Tremellodendron, Eiohleriella, and Sebacina EDWARD ANGUS BURT \\ Mycologist and Librarian to the Missouri Botanical Garden Associate Professor in the Henry Shavo School of Botany of Washington University}

The group of fungi comprising the present part probably attains its greatest development both in form and numbers in the western continent where it culminates in the erect Tremellodendron, apparently confined to North America. This continent has five of the seven species of Eichleriella; it has twenty-six species of Sebacina against fifteen for the Old World.

The better-known species of these genera were originally described in Thelephora, Stereum, and Corticium, with which they conform so closely in general habit of growth and consistency of the fructification that it is impossible to separate them from the latter except by microscopic examination of preparations which show the mature basidia to be longitudinally cruciately septate. Collectors invariably roughly grade their findings of Sebacina as Corticium. The recognition of longitudinally septate basidia is not always easy with the aid of the microscope; for example, the fungus originally described as Stereum Leveillianum B. \& C. has been studied critically at several times by experts without their observing the true structure of the basidia.

I regret that the present account of our species and their range in North America does not include all the material at hand. The Missouri Botanical Garden herbarium contains several hundred undetermined specimens of possible Corticiums which have been received during the last two years.

NoTE.-Explanation in regard to the citation of specimens studied is given in Part I, Ann. Mo. Bot. Gard. 1 : 202. 1914, footnote. The technical color terms used in this work are those of Ridgway, Color Standards and Nomenclature. Washington, D. C., 1912.

${ }^{1}$ Issued December 20, 1915 
I have looked through these collections very carefully to sort out, without examination now of everything by microscopic methods, just those specimens which ought to be studied at once for citation in this part, but some of the specimens most desirable for citation have undoubtedly been deferred for the present as probable Corticiums.

As it is really a nice microscopical task to recognize longitudinally septate basidia when they are not at their best, some notes, based on my experience, may be helpful. Species of Tremellodendron are the most easily recognized, for a little of the moistened and softened hymenium may be picked out with a scalpel, placed in a drop of water, stained with aqueous solution of eosin, 7 per cent potassium hydrate solution added, and then crushed down by pressure on the cover glass. In the detection of species of Eichleriella and Sebacina, thin vertical sections of the fructification are necessary. After the sections have been made turgid and clear by potassium hydrate solution, the latter should be drained off and the sections stained by merely a sufficient amount of solution of Gruebler's eosin soluble in alcohol, and mounted in water for temporary examination. It may be necessary to spread apart the tissues of the preparation somewhat by pressure upon the cover glass. If the preparation is to be preserved permanently in glycerin, a drop of dilute solution of sodium chloride should be run under the cover glass before the glycerin is added to insure a permanent stain by the Gruebler eosin.

Longitudinally cruciately septate basidia are simple and pyriform or subglobose when young, but so are the probasidia of Septobasidium, the possible storage organs of Corticium polygonium, and the basidia of some species of Corticium. The basidia of the latter are likely to form a layer at the surface of the fructification and are certainly simple if any can be detected bearing sterigmata and perhaps spores while still non-septate. In a fructification having longitudinally septate basidia, the hymenial surface is usually composed of paraphyses and of long, slender sterigmata arranged side by side; in this surface layer-but sometimes at a con- 
siderable distance from the surface, as in Thelephora Helvelloides Schw.-is situated the layer of basidia. Only very rarely do the basidia of Sebacina or Eichleriella constitute the surface of the fructification.

If a fructification contains a palisade layer of deeply staining, pyriform bodies among or underneath the paraphyses and with no simple basidia in the surface layer, more or less prolonged examination of the pyriform bodies is likely to show longitudinal septa in some of them.

The three genera which comprise the present part of this monograph, are treated here by the writer, because their general habit and consistency conform so closely with Thelephoraceae having simple basidia, that they may be regarded as a connecting group, although belonging with the Tremellaceae by the structure of their basidia. Such of the species as were described in the past were described as Thelephoraceae or by authors with special knowledge of the Thelephoraceae; the taxonomic recognition of fungi of these genera seems likely to continue to fall in the future to students of the Thelephoraceae, for other mycologists will hardly care to glean for material of so few species among the many Thelephoraceae of similar aspect.

\section{TREMELLODENDRON}

Tremellodendron Atkinson, Jour. Myc. 8: 106. 1902; Saccardo, Syll. Fung. 17: 208. 1905.

The type species is Merisma candidum Schw.

Fructifications coriaceous, erect, pileate, branched or rarely simple; hymenium amphigenous or inferior; basidia longitudinally cruciately septate; spores white, even.

The species of Tremellodendron are indigenous to North America; none have been reported for other regions, so far as I am aware. The fructifications spring up on the ground in deep woods during wet weather in summer and early autumn, and have the general habit of Thelephora vialis, of branched Clavarias, or, very rarely, of simple clubs. In active vegetative condition the fructifications may be distinguished from species of Clavaria of similar habit by coriaceous and 
tough consistency and by lack of brittleness. The longitudinally septate basidia afford a decisive character in all doubtful cases.

The specific distinctions between the more common species of this genus are based largely upon the form of mature and well-developed fructifications; very young, deformed, or fragmentary specimens can not be referred very confidently to their species.

\section{Key to the Species}

Fructifications branched when well developed. Simple forms may be present when very young or in the same colony with normal branched

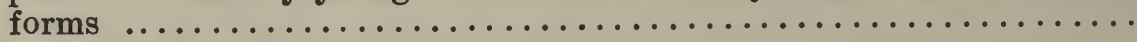

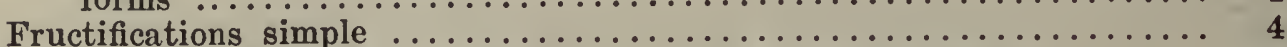

1. Fructifications normally cespitose, more or less grown together....... 2

1. Fructifications solitary or scattered........................ 3

2. With pileate divisions flattened, grown together at many points of contact, forming rosette-like masses $2-15 \mathrm{~cm}$. in diameter. 1. T. pallidum

2. With the stems grown together into a main stem 2-10 $\mathrm{mm}$. thick; pileate divisions cylindric, spreading, grown together at only few points of contact; the smaller divisions about $11 / 2 \mathrm{~mm}$. thick..... ......................................... T. candidum

2. Sometimes with both stems and pileate divisions grown together into compact bundles, usually merely closely cespitose and with the branches intricately intertangled; much slenderer than preceding species and with the habit of Pterula............. T. merismatoides

3. Stem about $11 \frac{2}{2} \mathrm{~mm}$. thick, palmately few-branched; branches once or twice similarly branched, cylindric or subcylindric, often channelled on the upper side; basidia $15 \times 9 \mu$; spores $9-15 \times 4 \frac{1}{2}-6 \mu$, pointed at the base only ............................................... T.

3. Stem about $1 / 2-1 \mathrm{~mm}$. thick, sometimes with occasional, scattered, divergent branches from its side, dilated at the upper end, divided into a few, short, finger-shaped branches; basidia 20-24×12-14 $\mu$; spores $14-16 \times 6-7 \mu$, pointed at both ends, Known from Jamaica only............ 4. T. tenue 4. Fructification dark orange, probably with medullary tissue pale as in all the preceding species; basidia subglobose, $10-12 \mu$ in diameter ..................................... T. aurantium

4. Fructification black with the exception of the hymenium; hymenium olive-ocher, amphigenous on the lower third of the fructification; basidia $11 \times 7 \mu$. Known from Porto Rico only.......... T. T. simplex

1. Tremellodendron pallidum (Schw.) Burt, n. comb.

Plate 26, fig. 6.

Thelephora (Merisma) pallida Schw. Am. Phil. Soc. Trans. N. S. 4: 166. 1834.-T. Schweinitzii Peck, N. Y. State Mus. Rept. 29: 67. 1878; Saccardo, Syll. Fung. 6: 534. 1888.Tremellodendron Schweinitzii (Peck) Atk. Jour. Myc. 8: 106. 1902.

Illustrations: Hard, Mushrooms f. 381.-Moffatt, Chicago Acad. Sci. Bul. 7 : pl. 22. f. 1. 1909. 
Type: in Herb. Schweinitz and a portion in Curtis Herb.

Fructification cespitose, erect, white or pallid, drying warm buff, stipitate by one to several or many stems which may be distinct below or arise from a common, swollen, basal mass; above, the stems branch into flattened, more or less furrowed, pileate divisions which grow together at surfaces of contact to form a somewhat cup-shaped or rosette-like mass; divisions in center of mass somewhat subulate at the apex, those at margin dilated and sometimes fimbriate, splitting when dry into sharp fibers or spicules; hymenium inferior, warm buff, best developed towards the base of the pileate divisions; basidia pyriform, longitudinally cruciately septate, 12-15 $\times 9$ $\mu$; spores from a spore collection, white, simple, 10-12 $\times 4 \frac{1}{2}$ $5 \frac{1}{2} \mu$, and 9-12 $\times 4 \frac{1}{2} \mu$ from an herbarium specimen.

Fructifications $2-10 \mathrm{~cm}$. high, 2-15 cm. broad.

On the ground in deep woods. Canada to South Carolina and westward to Missouri. June to October. Common.

Full-grown and well-developed specimens are rosette-like and resemble Thelephora vialis when viewed from above but may have the pileate mass supported by many stems; small specimens with only a single stem do occur. The large specimens are apparently due to the concrescence of many small fructifications. In the large specimens the pileate divisions on the outside of the mass become broader and more flattened than those in the interior. The flattened form of the divisions of the pileus and their growing together at numerous points of contact are characters separating Tremellodendron pallidum from $T$. candidum. The small specimens, distributed as T. pallidum in published exsiccati, are often so immature and fragmentary that they cannot be distinguished from $T$. candidum.

Forms of $T$. pallidum which have the tips of pileate divisions split into sharp fibers or spicules are the Thelephora cristata and T. serrata of Schweinitz, 'Syn. N. Am. Fungi,' Nos. 621 and 623.

Specimens examined:

Exsiccati : Ravenel, Fungi Car. II, 29; Ellis, N. Am. Fungi, 510; Ell. \& Ev., Fungi Col., 1208; Shear, N. Y. Fungi, 50. 
Canada, Ontario: London, J.Dearness, and also in Ell. \& Ev., Fungi Col., 1208; Belleville, J. Macoun, 174, 230 (both in Can. Geol. Surv. Herb.).

Maine: N. Parsonfield, R. G. Leavitt.

Vermont: near Burlington, $L$. R. Jones, two collections; Middlebury, E. A. Burt, two collections.

Massachusetts: Sprague, r73 (in Curtis Herb: under the name Thelephora vialis); Brookline, S. Davis.

Connecticut: East Hartford, C. C. Hanmer; and also No. 1567 (in Hanmer Herb.).

New York: Alcove, C. L. Shear, N. Y. Fungi, 50; Floodwood, E. A. Burt; Taughannock, H. H. Whetzel, Cornell Univ. Herb., 13600; Buffalo, G. W. Clinton (in U. S. Dept. Agr. Herb.); Tarrytown, H. von Schrenk (in Mo. Bot. Gard. Herb., 42800).

New Jersey: Laning (in Mo. Bot. Gard. Herb., 701330, 701331, 701333); Newfield, J. B. Ellis (in Mo. Bot. Gard. Herb., 5162), and also N. Am. Fungi, 510.

Pennsylvania: Bethlehem, Schweinitz, type (in Herb. Schweinitz, and a portion in Curtis Herb. and also the Nos. 621 and 623 of Schweinitz, 'Syn. N. Am. Fungi,' under the names Thelephora cristata and T. serrata, respectively); Trexlertown, W. Herbst (in Lloyd Herb.) ; Kittanning, D. R. Sumstine.

Delaware: Newark, H. S. Jackson, B10.

District of Columbia: Washington, O. F. Cook, 2, comm. by P. L. Ricker.

Virginia: Great Falls, C. L. Shear, 1044.

North Carolina: Blowing Rock, G. F. Atkinson, Cornell Univ. Herb., 10666, 10667, 10669, 10664 (of which the first two numbers and part of the third are in Cornell Univ. Herb. and part of the third and the last in Mo. Bot. Gard. Herb.). South Carolina: Ravenel, Fungi Car. II, 29.

Ohio: C. G. Lloyd, 2346 (in Lloyd Herb.); Loveland, D. L. James (in U. S. Dept. Agr. Herb.).

West Virginia: Eglon, C. G. Lloyd, 02601.

Kentucky: S. M. Price (in Mo. Bot. Gard. Herb., 5141, 5144, 701332, 712372) ; Mammoth Cave, C. G. Lloyd, 1071. 
Illinois: H. C. Beardslee (in Lloyd Herb., 2175); Newton's Ferry, E.T.\& S. A. Harper, 441; Riverside, E. T. \& S. A. Harper, 696.

Wisconsin: Blanchardville, Univ. of Wis. Herb., 52 ; Madison, E. T. \& S. A. Harper, 881; C. J. Humphrey, 948 (in Mo. Bot. Gard. Herb., 44783).

Iowa: T. J. Fitzpatrick (in Lloyd Herb.).

Missouri: St. Louis, N. M. Glatfelter (in Mo. Bot. Gard. Herb., 701335, 701370, 701371) ; Cliff Cave, J. B. S. Norton (in Mo. Bot. Gard. Herb., 5126) ; Columbia, B. M. Duggar, 140; Creve Coeur, Miss E. M. Briggs (in Mo. Bot. Gard. Herb., 44756).

2. T. candidum Schw. ex Atkinson, Jour. Myc. 8: 106. 1902. Plate 26, fig. 3.

Merisma candidum Schweinitz, Naturforsch. Ges. Leipzig Schrift. 1:110. 1822.-Thelephora candida Fries, Elenchus Fung. 168. 1828; Schweinitz, Am. Phil. Soc. Trans. N. S. 4 : 166. 1834.

Type: in Herb. Schweinitz, Acad. Nat. Sci. Phila.

Fructifications cespitose, erect, coriaceous-soft, white, drying warm buff, stipitate; stem thick, palmately branched, with branches spreading, branching, cylindric or subcylindric; hymenium inferior on the main branches, often amphigenous on secondary branches; basidia longitudinally septate, 10 $12 \times 7 \frac{1}{2}-9 \mu$; spores colorless, simple, even, $7 \frac{1}{2}-10 \times 4 \frac{1}{2}-5 \frac{1}{2} \mu$.

Fructifications $2 \frac{1}{2}-5 \mathrm{~cm}$. high, $2-5 \mathrm{~cm}$. broad; stem $2-10 \mathrm{~mm}$. thick; smaller pileate branches about $1 \frac{1}{2} \mathrm{~mm}$. thick.

On ground in open woods. Vermont to North Carolina and westward to Missouri. July to September. Infrequent.

The type of $T$. candidum has the dimensions given above for recent collections. In the original description Schweinitz noted that fructifications may attain a breadth of $15 \mathrm{~cm}$.; at that time he had not given specific recognition to the large and common $T$. pallidum and it may be that the large specimens to which he referred were of the latter species. T. candidum is closely related to $T$. pallidum but contrasts with the latter in having consolidation between adjacent fructifications 
confined to the main stems from the base upward to about the region of branching; from here the branches spread so that they grow together only rarely; furthermore, the branches are distinctly cylindric or subcylindric. The spores average a little shorter than those of related species.

Specimens examined:

Vermont: Lake Dunmore, E. A. Burt; Newfane, C. D. Howe. Massachusetts: Woods Hole, G. T. Moore.

New York: Alcove, C. L. Shear, 1218; Fishers Island, C. C. Hanmer, 192, 193, 194 (all in Hanmer Herb.).

North Carolina: Schweinitz, type (in Herb. Schweinitz); Blowing Rock, G. F. Atkinson, Cornell Univ. Herb., 10662, 10668 (in Mo. Bot. Gard. Herb., 44775, 44776) and (in Cornell Univ. Herb., 10663).

Ohio: Granville, H. L. Jones.

Missouri: near St. Louis, N. M. Glatfelter (in Mo. Bot. Gard. Herb., 701336).

3. T. Cladonia (Schw.) Burt, n. comb. Plate 26, figs. 1, 2. Merisma Cladonia Schweinitz, Naturforsch. Ges. Leipzig Schrift. 1:110. 1822.-Thelephora Cladonia Fries, Elenchus Fung. 168. 1828; Epicr. 537. 1836-1838; Schweinitz, Am. Phil. Soc. Trans. N. S. 4:166. 1834; Saccardo, Syll. Fung. 6:535. 1888.-Thelephora gracilis Peck, Torr. Bot. Club Bul. 25 : 371. 1898.

Type: in Herb. Schweinitz.

Fructifications solitary or gregarious, erect, coriaceous-soft, pallid, drying warm buff, sometimes with the older portions pale olive-gray, stipitate; stem cylindric, palmately branched into a few-often three-cylindric branches, each or some of which occasionally branch again in similar manner; branches arranged in a plane from flattened end of stem or branch or in a circle about the cylindric end of the stem which is then sometimes perforate and the branches often channelled; hymenium amphigenous, or inferior when the branch is channelled; basidia longitudinally septate, pyriform, $15 \times 9 \mu$; spores colorless, simple, even, curved, $9-15 \times 4 \frac{1}{2}-6 \mu$. 
Fructifications $2 \frac{1}{2}-5 \mathrm{~cm}$. high, $7 \mathrm{~mm} .-2 \mathrm{~cm}$. broad; stem about $1 \frac{1}{2} \mathrm{~mm}$. thick.

On ground in woods. Canada to Mississippi and westward to Missouri. August and September.

The fructification of this species is smaller than that of $T$. candidum and has but few branches, which are often arranged in a circle about the end of the stem so as to appear somewhat proliferous on the margin of an imperfect cup as in some species of the lichen, Cladonia-hence the specific name-or with the branches standing up side by side from the compressed apex of the main stem. Both forms of branching have been found so associated in the same collection as to preclude the possibility of regarding this difference as a basis for two species. The branches are so frequently in threes that "trifaria" was contemplated as a name for the species by one author.

Specimens examined:

Canada: J. Macoun, 78.

Vermont: Smugglers Notch, L. R. Jones; Middlebury, $E$. A. Burt; Brattleboro, C. C. Frost (in Univ. Vermont Herb.). Massachusetts: Sprague, 871 (in Curtis Herb., 5762).

New York: Hague, C. H. Peck, 7; Ithaca, G. F. Atkinson, Cornell Univ. Herb., 7708.

Pennsylvania: Trexlertown, W. Herbst (in Lloyd Herb.).

District of Columbia: Takoma Park, P. L. Ricker, 822 (in Ricker Herb.).

North Carolina: Schweinitz, type (Herb. Schweinitz and a portion in Curtis Herb.) ; Blowing Rock, G. F. Atkinson (in Cornell Univ. Herb., 10665, 10008. A part of the latter number is in Mo. Bot. Gard. Herb., 44774).

Georgia: Tallulah Falls, A. B. Seymour, Farlow Herb., O, P, Q, R, U, W (in Mo. Bot. Gard. Herb., 44619, 44623-44625, 44628, 44630).

Alabama: F. S. Earle, 13, type of Thelephora gracilis (in Coll. N. Y. State).

Mississippi: Biloxi, Mrs. F. S. Earle, 32A.

Ohio: Cincinnati, A. P. Morgan (in Lloyd Herb., 32) ; Loveland, D. L. James. 
West Virginia: Eglon, C. G. Lloyd, 02634.

Missouri: Creve Coeur, E. A. Burt (in Mo. Bot. Gard. Herb., 44755).

4. T. tenue Burt, n. sp.

Plate 26, fig. 7.

Type: in Burt Herb. and in N. Y. Bot. Gard. Herb.

Fructifications scattered, erect, very slender, coriaceoussoft, drying warm buff, stipitate; stem equal, flexuous, drying somewhat twisted and flattened, becoming fibrillose, sometimes giving off two or three scattered, divergent, small branches, dilated above and divided in a few palmately arranged, finger-shaped branches; hymenium inferior on the dilated portion and branches; basidia longitudinally septate, 20-24 $\times 12-14 \mu$; spores colorless, simple, even, curved, pointed at both ends, $14-16 \times 6-7 \mu$.

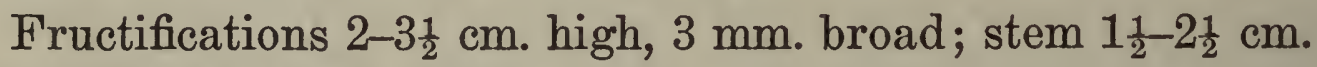
long, about $\frac{1}{2}-1 \mathrm{~mm}$. thick.

On the ground in wet mountainous region, altitude 3000$5200 \mathrm{ft}$. Jamaica. December and January.

This species is characterized by its long and slender stem, few branches, and the largest basidia and spores of any species of the genus. The spores differ from those of the other species in being pointed at the apex.

Specimens examined:

Jamaica: Chester Vale, W. A. \& E. L. Murrill, N. Y. Bot. Gard., Fungi of Jamaica, 400, type; Cinchona, W. A. \& E. L. Murrill, N. Y. Bot. Gard., Fungi of Jamaica, 614.

5. T. merismatoides (Schw.) Burt, n. comb. Plate 26, fig. 4. Clavaria merismatoides Schweinitz, Am. Phil. Soc. Trans. N. S. 4:182. 1834.-Merisma Schweinitzii Leveille, Ann. Sci. Nat. Bot. IV. 5:157. 1846._Lachnocladium merismatoides (Schw.) Morgan, Cincinnati Soc. Nat. Hist. Jour. 10:193. 1888.-Pterula merismatoides (Schw.) Saccardo, Syll. Fung. 6: 742. 1888.-Thelephora merismatoides Lloyd, Letter No. 26 : 2. 1909. Nomen nudum.-Tremellodendron merismatoides Lloyd, Letter No. 40:2. 1912. Nomen nudum.-Thelephora pteruloides Berk. \& Curt., Hooker's Jour. Bot. 1: 238. 1849; Grevillea 1:148. 1873. 
Type: In Herb. Schweinitz, Acad. Nat. Sci. Phila.

Fructifications erect, cespitose or fasciculate, and sometimes with stems grown together, coriaceous, branched, pallid, drying with stems warm buff and branches tawny; branches few, rather straight, filiform, angular-terete; branchlets many, dilated and fimbriate at the apex, then splitting into spreading branchlets; hymenium glabrous, amphigenous; basidia longitudinally septate, pyriform, $12-15 \times 8-9 \mu$; spores in preparations from herbarium specimens hyaline, even, simple, 8$10 \times 4 \frac{1}{2}-5 \mu$.

Cluster of fructifications $2-5 \mathrm{~cm}$. high, $2-3 \mathrm{~cm}$. broad. Individual from cluster has stem 5-10 mm. long, $\frac{1}{2}-1 \mathrm{~mm}$. thick; branches about $\frac{1}{4}-\frac{1}{3} \mathrm{~mm}$. thick.

On the ground in open woods. Massachusetts and New York to South Carolina and westward to Missouri. June to August.

This is a small species with the habit of a Pterula but with coriaceous structure and longitudinally septate basidia. The fructifications of a cluster may have their stems distant from one another by spaces equal to the diameter of the stems, but the branches interlock above; in other cases the fructifications are crowded closely together and united throughout their whole length. T. merismatoides may be distinguished from the preceding species by the smaller diameter of the stems and branches and from all the following species by its cespitose to fasciculate habit.

The collection from West Virginia, distributed as Thelephora pteruloides in Ell. \& Ev., 'N. Am. Fungi,' 3415 and 'Fungi Col.,' 1117, has the hymenium composed of basidia standing side by side in a distinct palisade layer and the basidia not longitudinally septate in my opinion.

Specimens examined:

Massachusetts : near Boston, Murray, comm. by Sprague, 250

(in Curtis Herb. under the name Thelephora pteruloides

B. \& C.) ; Woods Hole, G. T. Moore, 58.

New York: Ithaca, G. F. Atkinson, 37; Fishers Island, C. C. Hanmer, 1478 (in Hanmer Herb.).

New Jersey: Haddonfield, T. J. Collins comm. by C. G. Lloyd. Pennsylvania: Bethlehem, Schweinitz, type (in Herb. 
Schweinitz); York County, N. M. Glatfelter (in Mo. Bot. Gard. Herb., 44742); Kittanning, D. G. Sumstine.

South Carolina: M. A. Curtis, 1745 (the type and cotype of Thelephora pteruloides in Kew Herb. and Curtis Herb. respectively).

Ohio: Cincinnati, A. P. Morgan, Lloyd Herb., 2589 (determined by Morgan as Thelephora filamentosa).

Wisconsin: Lake Geneva, E. T.\& S. A. Harper, 842.

Missouri: Meramec Highlands, N. M. Glatfelter (in Mo. Bot. Gard. Herb., 44743).

6. T. aurantium Atkinson, Ann. Myc. 6: 59. 1908.

Type: in Cornell Univ. Herb. but cannot be found at present.

"Plants simple, slender, 1-3 cm. long, 2-3 mm. stout, dark orange, tough. Basidia subglobose, 10-12 $\mu$, longitudinally divided; sterigmata 4, long, slender, flexuous. Spores obovalsubelliptical, granular, then with an oil drop, 7-10 $\times 5-6 \mu$, white, hyaline.-C. U. herb., No. 10684, ground, woods, along small stream crossing Boone Road, Blowing Rock, Blue Ridge Mts., N. C. G. F. Atkinson, Aug. 19-Sept. 22, 1901.'”

-Original description.

T. aurantium differs from the preceding species of Tremellodendron by its simple fructifications. I have seen no specimens referable here. Professor Atkinson had intended to make a negative from his type so that I could include a figure of the species, but, upon going to the envelopes labelled $T$. aurantium, he found that they contained-by error of a helper-T. merismatoides instead. The specimens of $T$. aurantium have not been found.

7. T. simplex Burt, n. sp.

Plate 26, fig. 5 .

Type: in Mo. Bot. Gard. Herb. and in Farlow Herb.

Fructifications scattered, erect or suberect, drying hard, brittle, somewhat longitudinally wrinkled and sometimes compressed, black above, olive-ocher with the hymenium towards the base; hymenium amphigenous on the lower third of the fructification, olive-ocher, hyaline under the microscope, with surface consisting of colorless clavate paraphyses $5 \mu$ thick, 
and with basidia and spores at base of the paraphyses; basidia longitudinally septate; $11 \times 7 \mu$; spores colorless, even, $7 \frac{1}{2}-$ $9 \times 5-6 \mu$.

Fructifications about $2 \mathrm{~cm}$. long, about $2 \mathrm{~mm}$. thick.

In cane field. Porto Rico.

T. simplex is noteworthy by the column composed of longitudinally arranged, black hyphae, which extends the whole length of fructification and constitutes the whole, upper, sterile two-thirds of the fructification and is clothed by the ochraceous hymenium on the lower third. The specimens are broken off at the base, hence I cannot be sure that a stem was not originally present, but if present it would doubtless have been included in the packet. The general habit is that of a small Geoglossum or cylindric Xylaria.

Specimens examined:

Porto Rico: J.R. Johnston, comm. by W. G. Farlow, type (in Mo. Bot. Gard. Herb., 5119).

\section{EICHLERIELLA}

Eichleriella Bresadola, Ann. Myc. 1:115. 1903.-Hirneolina as a section of Sebacina Patouillard, Essai Taxon. 24. 1900.Hirneolina (Pat.) Saccardo, Syll. Fung. 17: 208. 1905.

Fructifications coriaceous, waxy or membranaceous, subgelatinous, cup-shaped or plano-concave, rarely pendulous, hymenium typically superior, discoid, inferior in pendulous forms, even or somewhat rugulose; basidia globose-ovoid, cruciately divided, with 2-4 sterigmata; spores hyaline, cylindric, somewhat curved. It is a Stereum or Cyphella with tremellaceous hymenium.

The type species of the genus is Eichleriella incarnata Bres.

The original definition of Eichleriella, which is translated above, should be broadened to accurately describe our North American species, which are as coriaceous as Stereum spadiceum. All have the hymenium inferior. Eichleriella gelatinosa is our only species with subgelatinous hymenium.

But few species of this genus are known. Five species of Eichleriella have been recognized up to the present time in North America, three in Europe, and two in South America; 
of our five, only one species, Eichleriella Leveilliana, ranges through the eastern United States; $E$. spinulosa occurs in both Europe and North America.

\section{Key to the Species}

Fructifications gray, small, $1 / 2-2 \mathrm{~mm}$. long, $1 / 2-1 \mathrm{~mm}$. broad, with habit of

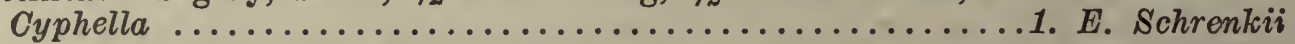

Fructifications the color of raspberries and cream, and peltate at first, 1-5 $\mathrm{cm}$. long, $1 / 2-1 \frac{1}{2} \mathrm{~cm}$. broad......................... Leveilliana

Fructifications ochraceous buff, $200-300 \mu$ thick; hymenium even; known from

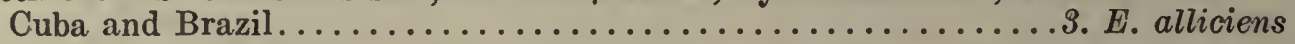

Fructifications wood-brown, with whitish margin; hymenium dry, with tubercules like Radulum............................ E. spinulosa Fructification white at first, then clay-color, tomentose, soft and spongy, $1 / 2 \mathrm{~cm}$. thick; hymenium gelatinous; known from Jamaica only ........

1. Eichleriella Schrenkii Burt, n. sp. $\quad$ Plate 27, fig. 8. Type: in Mo. Bot. Gard. Herb. and in Farlow Herb.

Fructifications gregarious, coriaceous, sessile, pezizoid, oblong or rotund, margin free and strongly inrolled, pubescent, smoke-gray; hymenium concave, pale smoke-gray to pallid neutral gray; basidia longitudinally septate, pyriform, $22 \times 11 \mu$; spores white in collection on slide, simple, curved, pointed at base, $12-19 \times 6-7 \frac{1}{2} \mu$.

Fructifications $\frac{1}{2}-2 \mathrm{~mm}$. long, $\frac{1}{2}-1 \mathrm{~mm}$. broad, $\frac{1}{2} \mathrm{~mm}$. thick.

On bark of dead limbs of Prosopis (mesquite). San Antonio, Texas. February.

The general habit of this fungus resembles that of very small specimens of Corticium Oakesii, of large species of Cenangium, or of a sessile Cyphella; from all of which Eichleriella Schrenkii is easily separated by its longitudinally septate basidia which show clearly in sectional preparations. The fructifications are much smaller than those of any other species of this genus heretofore described.

Specimens examined:

Texas: San Antonio, H. von Schrenk, type (in Mo. Bot. Gard. Herb., 42579), and also (in Mo. Bot. Gard. Herb., 42580).

2. E. Leveilliana (Berk. \& Curtis) Burt, n. comb.

Plate 27, fig. 9.

Corticium Leveillianum Berk. \& Curtis, Hooker's Jour. 
Bot. 1:238. 1849.-Stereum Leveillianum Berk. \& Curtis, Grevillea 1:163. 1873.

Type: type and cotype in Kew Herb. and in Curtis Herb., respectively.

Fructification coriaceous, soft, dry, rather thick, vinaceous fawn at first, whitening with age, resupinate-effused, with the margin free, sometimes narrowly reflexed, concolorous, minutely tomentose; hymenium composed of a surface layer about $30 \mu$ thick of paraphyses $1 \frac{1}{2}-2 \mu$ in diameter and of a layer of basidia under this; basidia longitudinally septate, 10-18 $\times 6-12 \mu$; spores in spore collection, white, simple, curved, pointed at base, $12-16 \times 5-6 \mu$.

Fructifications often $5 \mathrm{~mm}$. in diameter at first, finally up to $1-5 \mathrm{~cm}$. long, $\frac{1}{2}-1 \frac{1}{2} \mathrm{~cm}$. broad, about $\frac{1}{2} \mathrm{~mm}$. thick.

On dead limbs of several species. New York to Texas, Cuba, Jamaica, Central America, and Brazil. November to May.

This is a well-marked species upon which Berkeley made the following excellent graphic comment:

"At first forming little peltate orbicular spots, which, as they dilate, become closely attached to the matrix, with the exception of the margin, which is often free, soon confluent, soft, rather thick; of the colour of raspberries and cream. Hymenium often minutely pitted. Old specimens lose in great measure their ruddy hue, and are of a dead white."

I have seen no specimens having the hymenium minutely pitted.

Specimens examined.

Exsiccati: Ravenel, Fungi Car. II, 35.

New York: Hudson Falls, S. H. Burnham (in Mo. Bot. Gard.

Herb., 44009, 44170, 44194) ; Buffalo, G. W. Clinton.

South Carolina: M. A. Curtis, 1220, 92 (types and cotypes

in Kew Herb. and Curtis Herb., respectively); Ravenel,

Ravenel, Fungi Car. II, 35.

Georgia: Tallulah Falls, A. B. Seymour, Farlow Herb., C (in

Mo. Bot. Gard. Herb., 44608).

Texas: Austin, W. H. Long, 570, Cornell Univ. Herb.; San 
Antonio, A. B. Langlois, bd; same locality, H. von Schrenk (in Mo. Bot. Gard. Herb., 42576).

Cuba: San Diego de los Baños, Earle \& Murrill, 296, 356 in part, N. Y. Bot. Gard. Herb.

Jamaica: Cinchona, W. A. \& E. L. Murrill, N. Y. Bot. Gard., Fungi of Jamaica, 493.

Brazil : Blumenau, A. Möller, comm. by G. Bresadola; Matto Grosso Cuyaba, G. Malme, 599, comm. by L. Romell.

3. E. alliciens (Berk. \& Cooke) Burt, n. comb.

Plate 27, fig. 10.

Stereum alliciens Berk. \& Cooke, Linn. Soc. Bot. Jour. 15: 389. 1876; Massee, Linn. Soc. Bot. Jour. 17: 201. 1891.

Type: in Kew Herb.

Fructification coriaceous, resupinate, sometimes narrowly reflexed, separable, ochraceous buff, the margin slightly paler, the reflexed portion tomentose; structure in section, 200-300 $\mu$ thick, (1) with hyphae next to substratum ochraceous, loosely interwoven and protruded, $3 \mu$ in diameter, similar to those on outer surface of reflexed portion, (2) with intermediate layer 100-180 $\mu$ thick, composed of longitudinally arranged hyphae $2 \mu$ in diameter, (3) with hymenium composed of basidia $10 \mu$ below the surface, imbedded in jelly through which rise a few filiform paraphyses or hyphae to the surface; hymenium even, ochraceous buff; basidia longitudinally cruciately septate, pyriform, $12-15 \times 9-10 \mu$; spores colorless, simple, even, curved, $10-13 \times 3 \frac{1}{2}-5 \mu$.

Fructifications of type described as several inches long, originally orbicular; Cuban specimen $1 \mathrm{~cm}$. long, $1 \mathrm{~cm}$. broad, reflexed side 1-2 $\mathrm{mm}$. long, $1 \mathrm{~cm}$. broad.

On dead wood in virgin forest. Cuba and Brazil. March. The fructification resembles in habit and coloration that of a resupinate specimen of Stereum hirsutum with a very narrowly reflexed margin. The Cuban collection, of which but a single fructification was communicated to me, is much smaller than the Brazilian type and has the hyphae of the intermediate layer with gelatinously modified wall.

Specimens examined: 
Brazil: San Antonio da boa vista, Rio Javary, Traill, 1, type (in Kew Herb.).

Cuba: San Diego de los Baños, Pinar del Rio Province, Earle \& Murrill, 405, N. Y. Bot. Gard. Herb.

4. E. spinulosa (Berk. \& Curtis) Burt, n. comb.

Plate 27, fig. 11.

Radulum spinulosum Berk. \& Curtis, Grevillea 1:146. 1873. -Radulum deglubens Berk. \& Broome, Ann. and Mag. Nat. Hist. IV. 15: 32. 1875.-Eichleriella deglubens (Berk. \& Br.) Lloyd, Letter No. 45:7. 1893; Wakefield, Brit. Myc. Soc. Trans. 4:305. 1914.-Stereum rufum of English authors but not $S$. rufum Fries.-Radulum Kmetii Bresadola, I. R. Accad. degli Agiati Rovereto Atti III. 3 :102. 1897.-Eichleriella Kmetii Bresadola, Soc. Myc. France 25: 30. 1910.

Type: in Kew Herb.

Fructifications longitudinally and broadly effused, woodbrown, coriaceous-soft, separable, with the margin whitish, finally narrowly reflexed on the upper side and tomentose, or with margin everywhere free and curved outward; hymenium wood-brown, dry, usually bearing tubercules singly or in small clusters, with pale tips; basidia longitudinally septate, clavate, $25-36 \times 9 \mu$, arranged between paraphyses with brown tips; spores simple, colorless, cylindric, curved, 15-16 $\times 6 \mu$.

Fructifications range up to $6 \mathrm{~cm}$. long by 1-2 $\mathrm{cm}$. wide and may be larger by confluence, about $700 \mu$ thick; tubercules about $\frac{1}{2}-1 \mathrm{~mm}$. long.

Alabama. On bark of dead Populus trichocarpa, Idaho, and Oregon. July to September.

This species is distinguished by having a hymenium with configuration of a Radulum and cruciate basidia. The tubercules are often simple and cylindric, sometimes deformed and multifid. The wide distribution and yet the extremely local occurrence of this species together with the absence, until recently, of observations on its basidia have resulted in a very interesting synonymy. It is remarkable that this species, which occurs on Fraxinus, Populus, etc., in several countries of Europe, should have been collected in the United 
States in Alabama, Idaho, and Oregon only. I am greatly indebted to Mr. L. Romell for a preparation from the type of Radulum spinulosum which makes possible the reference to this species.

Specimens examined:

Sweden: Stockholm, L. Romell, 32\%, and three unnumbered collections.

Alabama: Peters, Curtis Herb., 4543, preparation from type (in Kew Herb.).

Idaho: Kaniksu National Forest, Priest River, J. R. Weir, 55 .

Oregon: Eugene, C.J.Humphrey, 1103.

5. E. gelatinosa Murrill, n. sp. Plate 27, fig. 12.

Type: in N. Y. Bot. Gard. Herb. and in Burt Herb.

Fructification coriaceous, effuso-reflexed, white when young, finally clay-colored, tomentose, soft to the touch, margin obtuse; context soft, spongy, zonate; hymenium tough, gelatinous, drying Hay's brown, even; basidia longitudinally septate, $13 \times 11 \mu$; spores simple, colorless, even, flattened on one side, $8-10 \times 6 \mu$.

Reflexed portion of fructification $1 \frac{1}{2}-2 \mathrm{~cm}$. long, $2 \frac{1}{2} \mathrm{~cm}$. wide, $\frac{1}{2} \mathrm{~cm}$. thick.

On rotting wood in wet, wooded regions. Jamaica. December and January.

Only two collections of one fructification each were made. That of December 17 is a white, young specimen, with no basidia developed, which shows the general habit and early characters of the species, but would not have been determinable except for the later collection of January 12-14, which shows the darker coloration assumed at maturity. The thick, spongy, soft pileus of the mature fructification distinguishes this species from others known at present.

Specimens examined:

Jamaica: Troy and Tyre, Cockpit country, W. A. Murrill \&

W. Harris, N. Y. Bot. Gard., Fungi of Jamaica, 1087, type (in N. Y. Bot. Gard. Herb.), a portion in Burt Herb.; Blue 
Hole, Priestman's River region, W A. Murrill, N. Y. Bot. Gard., Fungi of Jamaica, 180, immature specimen.

\section{SEBACINA}

Sebacina Tulasne, L. R. and C., Ann. Sci. Nat. V. 15: 223 226. pl. 10. f. 6-10. 1872; Linn. Soc. Bot. Jour. 13:35. 1873; Brefeld, Untersuch. Myk. 7:102-106. pl. 6. f. 22-26. 1888; Patouillard, Essai Taxon. Hym. 24, 25. 1900 (with the exclusion of section Hirneolina).-Exidiopsis Brefeld, Untersuch. Myk. 7:94. pl. 5. f. 20-22. 1888.-Stypella Möller, A., Bot. Mitth. a. d. Tropfen. 8, Protobasidiomyceten 166. pl. 4. f. 6, \%. 1895.

Fructification coriaceous, membranaceous or floccose, gelatinous, waxy or pulverulent, resupinate, with habit of Corticium; basidia longitudinally septate, close together or scattered, sometimes between bushy conidiophores; spores colorless, producing in germination a similar spore or a cluster of conidia.

The type species of the genus is Corticium incrustans Pers.

Sebacina incrustans occurs sometimes on the ground and incrusting herbaceous stems and various erect objects but is often on decaying wood; S. Helvelloides occurs on the ground and incrusting erect objects; $S$. chlorascens has been observed incrusting the mossy bases of living trees; the other species have been recorded only on dead wood and bark. A few members of this genus are thick and spongy and were originally included in Thelephora; usually the species are thin and Corticium-like in general habit and were in several instances published under Corticium. In the dried conditions some species of Sebacina may be tentatively recognized as such by having the hymenial surface glassy or resembling dried cartilage; but such a separation from Corticium is very uncertain, for some species of Sebacina dry with a dull, soft surface and some true Corticiums assume the appearance of dried cartilage in drying.

It seems probable that it will always be difficult to determine resupinate species of Hymenomycetes; it is not possible to do so from the descriptions alone of the earlier botanists. European authors have recently been enlarging such descrip- 
tions by giving spore characters, dimensions of basidia, cystidia, and hyphae, and the presence or absence of clamp connections. Such additional characters may often be obtained quickly by microscopic examination of a portion of the fructification which has been teased out and crushed down in dilute potassium hydrate solution; by these helpful additional characters, some species may be recognized with reasonable accuracy, but there are comparatively few such species. Structure in section of the fructification affords important characters for the identification of resupinate species. In practical work with these species, a microscopical mount of a sectional preparation of a type specimen is the next best thing for purposes of comparison to having the type itself.

My method of determining a resupinate specimen is to observe closely its general habit and characters, such as consistency, adnation, thickness, surface, margin, substratum, and color. Color is an important character when given in terms of an adequate color standard. The color which the specimens retain in drying is often the only color character available; it is more constant, fortunately, than is commonly appreciated, for it has to be the color factor in the comparison of herbarium specimens. The preliminary observation may suggest that the species is one of several of somewhat similar habit which may be of the same genus or of various genera. The sectional preparations, which are now made, may present ( $a$ ) a uniform, homogeneous arrangement of similar hyphae from substratum to hymenium, $(b)$ dissimilar hyphae or organs distributed uniformly throughout the whole fructification, $(c)$ a layered, heterogeneous arrangement of various types with the layers more or less sharply differentiated from one another, $(d)$ a stratose arrangement having the first stratum extend from the substratum to the upper surface of the first hymenium, the second stratum a repetition of the first and borne on the first, and so on. Under $a$ there are characteristic varieties of structure, constant for each species, such as all the hyphae in erect position extending from substratum to hymenial surface, or all interwoven, or all procumbent, and there are also constant 
differences in regard to whether the hyphae are crowded close together or are loosely arranged. Under $c$, a conspicuous example would be one in which the layer next to the substratum is composed of longitudinally arranged hyphae (that is, parallel with the substratum) crowded closely together; from this layer, a few branches might extend outward at right angles to the first layer and form a layer of loosely arranged, erect hyphae - the second layer; the hyphae of the second layer might branch abruptly at its outer surface and bear a compact hymenial layer. Some species invariably form a loosely interwoven layer next to the substratum, and on the surface of this layer form a dense hymenial layer, as, for example, Sebacina incrustans, S. chlorascens, and S. Helvelloides. Sterile fructifications may frequently be determined by their general characters and structure in section.

The preparations which reveal structure in section, give also spores, basidia, paraphyses, and other organs. From the combination of general characters, structure in section, and details of spores and noteworthy organs, the species becomes manifest. Our species of Sebacina are described in accordance with this method in the following pages.

\section{Key to The Specres}

Fructifications on the earth, running up and incrusting the bases of living

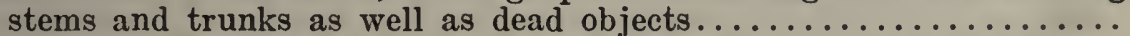
Fructifications confined to bark and wood of dead branches and trunks...

1. Sometimes passing into branches or ascending flaps; hymenial layer drying warm buff, 60-150 $\mu$ thick; paraphyses densely crowded and somewhat

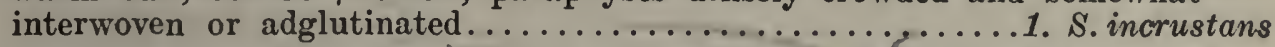

1. Pileate branches drying cream-color with a glaucous tint, imbricated, the apices spiculose or fimbriate; hymenial layer drying vinaceous brown,

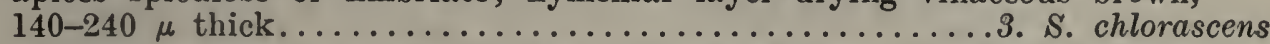

1. Not forming free branches or flaps; hymenial layer 200-300 $\mu$ thick; paraphyses straight and rod-like; basidia $20-25 \times 15 \mu \ldots \ldots 4$. S. Helvelloides 2. Fructifications white or whitish when $\operatorname{dry} \ldots \ldots \ldots \ldots \ldots \ldots \ldots \ldots$

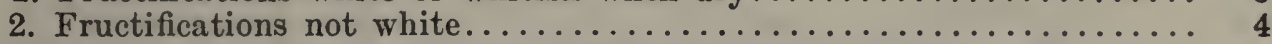

3. Hymenium composed of unbranched, flexuous, even-walled, deeply staining, clavate organs $40-45 \times 6 \mu$, in addition to few-branched paraphyses and

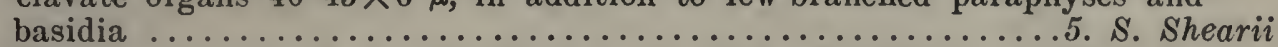

3. Hymenium composed of paraphyses and basidia; fructification $300-400 \mu$ thick; margin thick, not closely adnate to substratum......6. S. macrospora

3. Hymenium composed of basidia and paraphyses; fructification 50-150 $\mu$ thick, shining white at first; margin very thin and closely adnate. $\%$. S. calcea

3. Hymenium composed of basidia and paraphyses; fructification 200-300 $\mu$ thick, dirty whitish; hyphae incrusted in upper two-thirds of fructification; margin thin and closely adnate................. S. monticola 
4. Drying ochroleucous, basidia at or near the surface in tissue not sharply differentiated as a layer from tissue near substratum; much crystalline matter about $100 \mu$ below surface. On Alnus, South

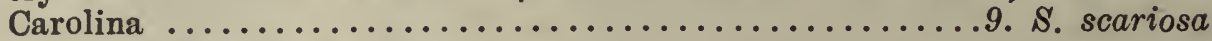

4. Drying some variety of brown .......................... 5

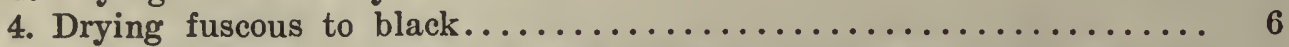

5. Drying cacao-brown (testaceous of Saccardo's 'Chromotaxia'); separable from substratum; resembling $S$. incrustans but with margin soon detached and spores $6-7 \times 4 \frac{1}{2}-5 \mu$. On juniper, Alabama....... S. deglubens

5. Blue-purple when fresh, drying tawny olive to Saccardo's umber where directly on the wood; adnate to substratum; $30-45 \mu$ thick; basidia $7-10 \times 6-8 \mu$; spores $6-7 \times 3-5 \mu \ldots \ldots \ldots \ldots \ldots \ldots \ldots . . \ldots \ldots$. S. podlachica

5. Drying cinnamon-brown; adnate to substratum; $100-140 \mu$ thick; scattered paraphyses with bushy-branched, brown tops rise $45-60 \mu$ above the basidia. On Magnolia, Delaware....................... S. cinnamomea 6. Hay's brown when moist, drying fuscous, the margin pale cartridgebuff; separable from substratum; 500-600 $\mu$ thick. On Populus,

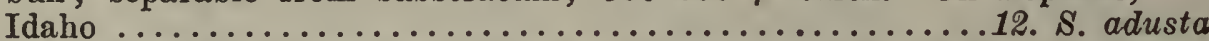

6. Drying blackish plumbeous; adnate to substratum; $150-200 \mu$ thick, the margin indeterminate. On Populus, Washington.....13. S. plumbea

6. Grayish when moist, drying dark mouse-gray and shining; adnate to substratum; 50-160 $\mu$ thick, the margin indeterminate. On very rotten wood, New England.......................... S. atrata

1. Sebacina incrustans Pers. ex Tulasne, Ann. Sci. Nat. Bot. V. 15: 225. pl. 10. f. 6-10. 1872; Linn. Soc. Bot. Jour. 13: 36. 1873.

Plate 27, fig. 13.

Corticium incrustans Persoon, Obs. Myc. 1:39. 1796.Thelephora incrustans Persoon, Syn. Fung. 573. 1801; Fries, Syst. Myc. 1:448. 1821.-Thelephora sebacea Persoon, Myc. Eur. 1:155. 1822; Fries, Elench. Fung. 1: 214. 1828; Hym. Eur. 637. 1874; Saccardo, Syll. Fung. 6: 540. 1888.-Corticium sebaceum Massee, Linn. Soc. Bot. Jour. 27:127. 1891.Merisma cristatum Persoon, Syn. Fung. 583. 1801.-Thelephora cristata Fries, Syst. Myc. 1:434. 1821; Hym. Eur. 637. 1874; Saccardo, Syll. Fung. 6: 539. 1888.-Sebacina incrustans Tul. ex Bresadola, in part (Hym. Hung. Kmet.), I. R. Acad. Sci. Agiati III. 3 : 117. 1897.

Mllustrations: Tulasne, loc. cit.-Persoon, Com. Fung. Clav. pl. 4. f. 4; Berkeley, Outlines Brit. Fung. pl. 17. f. 6; Brefeld, Untersuch. Myk. 7:pl. 6. f. 22-26. Hennings in Engl. \& Prantl, Nat. Pflanzenfam. (I. $1^{* *}$ ) : 91. f. 59 C, D; Nees, System pl. 34. f. 256 B; Patouillard, Tab. Anal. Fung. f. 155; and Essai Tax. Hym. 25. f. $17 a, b$; Soc. Myc. Fr. Bul. 5: pl. 7. f. 11.-See Saccardo, Syll. Fung. 20:945 for references to some additional illustrations which I have not seen. 
Type: authentic specimens of Thelephora incrustans and Merisma cristatum from Persoon in Kew Herb.

Fructifications coriaceous-fleshy, varied in form, creeping on the ground and ascending and incrusting small erect objects and forming little columns and free branches, the apices somewhat awl-shaped or fringed, or effused and resupinate on bark, whitish, drying warm buff; structure in section, $250-400 \mu$ thick, (1) with a broad layer of very loosely interwoven rather stiff hyphae, $2-2 \frac{1}{2} \mu$ in diameter, which divide above into fine branches and form (2) a densely interwoven layer about $60-150 \mu$ thick with the basidia in the upper 40-90 $\mu$ among the very fine ( $1 \frac{1}{2} \mu$ in diameter), densely crowded, somewhat interwoven filaments from the subhymenium; basidia longitudinally septate, ovoid or pyriform, 12-20 $\times 9$ $14 \mu$; spores colorless, simple, even, flattened on one side or curved, $12-14 \times 6-8 \mu$.

Fructifications 5-6 $\mathrm{cm}$. long, 2-5 cm. wide, ascending objects $2-5 \mathrm{~cm}$; ; pileate flaps, when present, $\frac{1}{2}-1 \mathrm{~cm}$. long.

On the ground in woods and incrusting objects, and resupinate on logs. Canada to Louisiana and westward to Missouri. June to October. Common.

$S$. incrustans is the common incrusting Sebacina of Eastern North America. It may usually be recognized at sight by coriaceous-fleshy consistency, occurrence on earth and running up and incrusting living objects, and pallid color. The thinner hymenial layer, paraphyses less rod-like in form, and finer and thinner-walled hyphae of layer next to the substratum afford structural characters separating specimens of this species from those of $S$. chlorascens and S. Helvelloides.

I exclude from the synonymy of $S$. cristata, Clavaria laciniata of Bulliard's 'Hist. Champ.' 1: 208. pl. 415. f. 1, because in the absence of authentic specimens and observations in regard to spores and basidia, it is not certain that $C$. laciniata Bull. is Merisma cristatum. Bulliard's figures represent quite as well an incrusting European fungus communicated to me by Bresadola under the name Thelephora fastidiosa (Pers.) Fr., which has simple basidia and colorless echinulate spores. This species is the Thelephora cristata 
of Patouillard's 'Tab. Anal. Fung.' No. 559, and Cristella cristata of his 'Essai Taxon. Hym.' $f$. 28. Patouillard notes that Clavaria laciniata is a synonym of the species which he figures. Because of the uncertainty as to whether figures of Thelephora cristata by European authors represent the true Merisma [Sebacina] cristatum Pers. or the echinulatespored $T$. fastidiosa (Pers.), I have refrained from citing any illustrations except that of Persoon, of whose species I have studied an authentic specimen.

Specimens examined:

Exsiccati: Ellis, N. Am. Fungi, 513.

The specimen in Thuemen, Myc. Univ. 2009, under the name Thelephora sebacea, collected in France, is Thelephora mollissima Pers.

Europe: authentic specimens of Thelephora incrustans and Merisma cristatum from Persoon in Kew Herb.

Sweden: sterile specimen determined as Thelephora cristata by E. Fries (in Fries Herb.) ; Stockholm, L. Romell, 54. Canada: J. Macoun, 5, 10. Quebec: Hull, J. Macoun, 203, 313.

Ontario: near Ottawa, J. Macoun, 40 (in Can. Geol. Surv. Herb.) ; London, J. Dearness.

Maine: Portage, L. W. Riddle.

New Hampshire: Shelburne, W. G. Farlow (in Farlow Herb.). Vermont: Middlebury, E. A. Burt, two collections.

Massachusetts: Williamstown, W. G. Farlow (in Farlow Herb.).

New York: Hudson Falls, S. H. Burnham, 2 (in Mo. Bot. Gard. Herb., 43995).

Pennsylvania: Michener, 5821 (in Curtis Herb.); Trexlertown, W. Herbst.

District of Columbia: Rock Creek, C. L. Shear, 793.

North Carolina: Asheville, H. C. Beardslee, 03126.

South Carolina: Ravenel, 1619 (in Curtis Herb.).

Louisiana: St. Martinville, A. B. Langlois, $F, 2015$; the same locality and collector, (3022 in Lloyd Herb.) ; Baton Rouge, Edgerton \& Humphrey, $66 \%$.

Ohio: A.P. Morgan (in Lloyd Herb., 2655, 2656) ; Cincinnati, 
C. G. Lloyd, 4198; Loveland, D. L. James (in U. S. Dept. Agr. Herb.).

Wisconsin: Blue Mounds, E. T. and S. A. Harper, 864, 879, 880; Madison, W. Trelease (in Mo. Bot. Gard. Herb., 5145, 44779); C. J. Humphrey, 2146 (in Mo. Bot. Gard. Herb., 44784).

Illinois: Riverside, E. T. and S. A. Harper, 698.

Missouri : Creve Coeur, E. A. Burt (in Mo. Bot. Gard. Herb., 44763).

2. S. deglubens (Berk. \& Curtis) Burt, n. comb.

Corticium deglubens Berk. \& Curtis, Grevillea 1: 166. 1873.

Type: type and cotype in Kew Herb. and Curtis Herb.

Fructification resupinate, effused, coriaceous, separable, white beneath, drying about cacao-brown, the margin very narrow, white, byssoid, soon detached; structure in section $250-300 \mu$ thick, (1) with a very loosely interwoven layer 180 $200 \mu$ thick, having hyphae $1 \frac{1}{2}-2 \mu$ in diameter which branch and form (2) a very densely interwoven layer $80 \mu$ thick with the basidia in the upper $30 \mu$, not quite reaching to the surface, among the very fine, densely interwoven filaments from the subhymenium; basidia longitudinally septate, $15 \times 10-12$ $\mu$; spores colorless, simple, even, flattened on one side, $6-7 \times 4 \frac{1}{2}-5 \mu$.

On juniper, Alabama.

This fungus has the same type of structure which is found in resupinate specimens of Sebacina incrustans. It differs from the latter in having the hymenium darker, all the spores found in a sectional preparation a little smaller, and the hyphae of the layer next to the substratum a little smaller and more flaccid than those of $S$. incrustans, and the margin was described as soon detached. These differences may be merely the variation from specific type of a single collection, or they may be those of a subspecies of $S$. incrustans which has taken on the saprophytic life on dead wood, prevalent for most species of Sebacina. Until other collections, referable to $S$. deglubens are made, the former view appears the more probable. 
Specimens examined:

Alabama: Peters, Curtis Herb., 4557, type (in Kew Herb.).

3. S. chlorascens Burt, n. sp.

Plate 27, fig. 15.

Type: in Mo. Bot. Gard. Herb. and in Farlow Herb.

Fructification coriaceous, drying cream-color with glaucous tint, effused, ascending and incrusting the mossy bases of

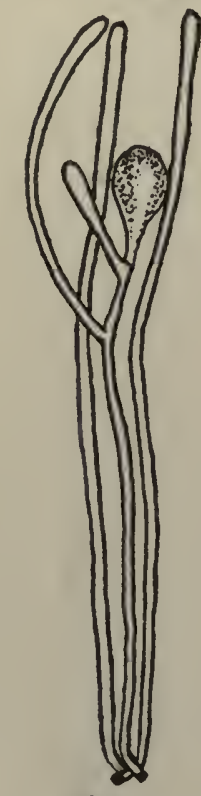

Fig. 1

S. chlorascens Paraphyses, basidium $\times 540$. trees and forming imbricated, free, pileate, sterile branches, the apices spiculose or fimbriate; hymenium gelatinous, drying vinaceous brown, occurring in somewhat scattered spots on the lower portions of the fructification; structure in section $800 \mu$ thick, with (1) a broad, spongy layer next to the substratum of loosely interwoven, rather rigid, even-walled hyphae $2 \frac{1}{2}-3 \mu$ in diameter, which bear (2) a sharply differentiated hymenial layer $140-240 \mu$ thick, composed of rod-like paraphyses $2 \mu$ in diameter, between which occur basidia throughout the outer $60 \mu$ of the layer; basidia longitudinally septate, pyriform, $15-18 \times 12 \mu$; spores simple, colorless, flattened on one side, $10-10 \frac{1}{2} \times$ 6-7 $\mu$.

Ascending objects 2-4 cm., 1-2 $\mathrm{cm}$. broad; free branches up to $5 \mathrm{~mm}$. long.

On mossy bases of living trees. Florida. Autumn.

As shown by the figures in pl. 27, the pileate branches of $S$. chlorascens do not resemble those of $S$. incrustans. The structure in section is different in every detail from that of specimens of the latter species and approaches more closely that of $S$. Helvelloides, but the fructification is thinner than that of the latter, has smaller basidia and spores, and the basidia distributed from the surface to about $60 \mu$ below the surface, and forms free pileate branches.

Specimens examined:

Florida: Cocoanut Grove, $R$. Thaxter, 98, type (in Mo. Bot. Gard. Herb., 43923, and in Farlow Herb.).

4. S. Helvelloides (Schw.) Burt, n. comb. Plate 27, fig. 14. 
Thelephora Helvelloides Schweinitz, Naturforsch. Ges. Leipzig Schrift. 1:108. 1822; Am. Phil. Soc. Trans. N. S. 4: 168. 1834; Fries, Elenchus Fung. 1:193. 1828; Epicr. 541. 1836-1838.-Corticium Helvelloides Massee, Linn. Soc. Bot. Jour. 27 : 153. 1891.-Corticium basale Peck, N. Y. State Mus. Rept. $43: 69$ (23). 1890.

Type: in Herb. Schw. and portions in Curtis Herb. and in Kew Herb.

Fructification coriaceous, spongy, effused, convex, closely adnate and incrusting, on ground in mosses and on bark at bases of living trees, at first whitish, drying honey-color to warm buff; structure in section, with (1) a very thick spongy layer next the substratum, of loosely interwoven, branched, rather rigid, even-walled, brownish hyphae, $3-3 \frac{1}{2} \mu$ in diameter, which bear (2) a fertile layer 200-300 $\mu$ thick made up of great numbers of erect, straight, cylindric paraphyses $2 \mu$ in diameter, between which occur the basidia at about 40-50 $\mu$ below the surface; basidia longitudinally septate, pyriform, 20-25 $\times 15 \mu$; spores colorless, simple, flattened or slightly curved on one side, $12-13 \times 6 \mu$.

Fructifications $3-15 \mathrm{~cm}$. long and wide, drying about $\frac{1}{2}-2$ $\mathrm{mm}$. thick to $9 \mathrm{~mm}$. thick in type which covers a cushion of moss plants.

On ground and bark at bases of living trees. New York to North Carolina. July and August.

Specimens of this species have somewhat the habit of thick specimens of Coniophora puteana but are of very different structure. The abundant, erect, unbranched, cylindric paraphyses often $200 \mu$ long which compose the greater part of the hymenium, and the large basidia are reliable characters for identifying Sebacina Helvelloides when sections are studied; the coarser and colored hyphae of the species give an additional character separating it from $S$. incrustans when the latter occurs strictly resupinate.

The type specimen is abnormal in thickness and ridged surface by running over and incrusting a bed of moss. The hanging rootlets referred to in the original description are 
moss stems. The specific name is rather fanciful and misleading.

Specimens examined:

New York: Whitehall, C. H. Peck, type of Corticium basale

(in Coll. N. Y. State); Alcove, C. L. Shear, 1221.

North Carolina: Salem, Schweinitz, type (in Herb. Schw., in

Curtis Herb., and in Kew Herb.).

5. S. Shearii Burt, n. sp.

Plate 27, fig. 16.

Type: in Burt. Herb., and in Shear Herb.

Fructification coriaceous, effused, dull white, drying pale olive-buff, cracked, the margin determinate, entire; structure in section, 140-200 $\mu$ thick, with (1) a broad and

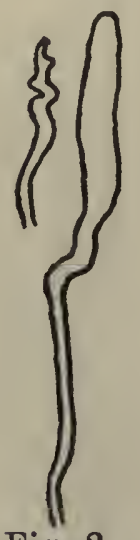

Fig. 2

S. Shearii.

Paraphysis

at left,

organ $\times 540$. dense layer next to the substratum of longitudinally arranged, slightly brownish, even-walled hyphae $1 \frac{1}{2}-2 \mu$ in diameter, which branch and curve outward at a right angle and form (2) a fertile, less compact layer $60-75 \mu$ thick of suberect, few-branched paraphyses $3 \mu$ in diameter, of basidia at about $15-20 \mu$ below the surface, and of scattered, even-walled, flexuous, cylindricclavate organs-perhaps gloeocystidia-40-45 $\times$ $6 \mu$, not emergent above the surface; basidia longitudinally septate, pyriform, $15 \times 9 \mu$, with sterigmata $18 \times 3 \mu$; spores colorless, simple, curved, $9-15 \times 4 \frac{1}{2}-6 \mu$.

Fructifications in crevices of bark at first, $2 \times 1 \mathrm{~mm}$, at length, by confluence, $7 \mathrm{~cm}$. long, $1 \mathrm{~cm}$. broad.

On dead Berberis vulgaris. District of Columbia. October. This species is well characterized by the presence in the hymenial layer of flexuous, even-walled organs, which are either latex or gloeocystidia, and by the broad layer of longitudinally arranged hyphae which shows relationship to Eichleriella, although the margin is not distinctly free. A few small granules are present on the hymenial surface but I do not know that they are a constant character.

Specimens examined:

District of Columbia: grounds U. S. Dept. Agr., Washington, C. L. Shear, 1238, type. 
6. S. macrospora (E. \& E.) Burt, n. comb.

Corticium macrosporum Ell. \& Ev., Torr. Bot. Club Bul. $27: 49.1900$.

Type: in N. Y. Bot. Gard. Herb.; specimens from type collection in Lloyd Herb., and in Burt Herb.

Fructification coriaceous, appressed, thin, dull white, cracked, the narrow, white, cottony margin sometimes narrowly involute; structure in section, $300-400 \mu$ thick, with (1) a very broad layer of longitudinally arranged and somewhat obliquely ascending crowded hyphae $1 \frac{1}{2} \mu$ in diameter, colorless next to substratum but brownish in upper part of layer, which pass into (2) the hymenial layer 60-100 $\mu$ thick, consisting of erect, bushy paraphyses and of basidia; basidia longitudinally septate, pyriform to subglobose, $15 \times 9-12 \mu$; spores colorless, simple, flattened on one side or curved, $10 \frac{1}{2} \times 4 \frac{1}{2}-6 \mu$.

Appearing at first in orbicular patches $3-5 \mathrm{~mm}$. in diameter, at length confluent and up to $4 \mathrm{~cm}$. long, $1 \frac{1}{2} \mathrm{~cm}$. broad.

On pine (Pinus Strobus) limbs. Ohio. September.

This species is near Sebacina calcea, but the single collection which has been studied seems distinct from the latter by the thick, determinate margin, sometimes free and slightly upturned, by the greater thickness of the fructifications, by the brown hyphae of the middle region, and by walls of hyphae not gelatinously modified as in S. calcea. A relationship to Eichleriella is manifest in the broad layer of longitudinally arranged hyphae and in the tendency of the margin to be slightly free. The original description gives this species as on "Fraxinus?", but the limbs are Pinus strobus. The spores are not exceptionally large; the specific name was probably based on immature basidia.

Specimens examined.

Ohio: Linwood, C. G. Lloyd, 3113, type collection.

7. S. calcea (Pers.) Bresadola, Fungi Tridentini 2:64. $p l$. 175. 1892.

Plate 27, fig. 17.

Thelephora calcea Persoon, Syn. Fung. 581. 1801; Myc. Eur. 1:153. 1822.-Thelephora calcea c. albido-fuscescens 
Fries, Elenchus Fung. 1:215. 1828.-Thelephora acerina forma Abietis Fries, Syst. Myc. 1:453. 1821.-Corticium Abietis (Fr.) Romell, Bot. Not. 1895 : 72. 1895.-Xerocarpus farinellus Karsten, Finska Vet.-Soc. Bidrag 37: 139. 1882.

Illustrations: Bresadola, loc. cit.; Patouillard, Essai Taxon. Hym. 25. f. $17 b$.

Fructification effused, closely adnate, crustaceous, slightly pulverulent, shining white at first, at length darkening in the central portion from cartridge-buff to pale drab-gray, cracked, the margin much thinner and farinaceous; structure

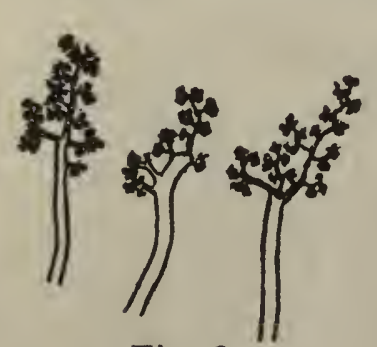

Fig. 3

S. calcea. Paraphyses $\times 540$. in section, 50-150 $\mu$ thick, (1) with hyphae next the substratum interwoven, $2 \mu$ thick, the wall gelatinously modified, (2) hymenial layer 40-60 $\mu$ thick, composed of basidia and of paraphyses branched at the apex into very fine branches loaded with minute granules; basidia more abundant in the lower portion of the hymenial layer, longitudinally septate, $14 \times 9 \mu$; spores colorless, simple, cylindric, curved, 8-12 $\times 4-5 \mu$.

Fructifications 3-9 cm. long, 1-3 cm. broad.

On bark and wood of dead branches of spruce, pine, hemlock, white cedar, oak, ash, elm, maple, and elder. Canada, northern New England, and New York to Georgia, and in Washington. March to January-perhaps throughout the year.

As good distinctive macroscopic characters this species has: chalky white color with central portions ashy; powdery surface under a lens; thinness on drying and margin still thinner, so that it appears mealy under a lens rather than membranous. The fine branches and granules at the tips of the paraphyses show best in lactic acid preparations; potassium hydrate solution has a solvent action here. I have not been able to study an authentic specimen of Thelephora calcea Pers. and accept Bresadola's conclusion on this point.

Specimens examined:

Exsiccati: Romell, Fungi Exs. Scand. 129.

Austria: G. Bresadola.

Sweden: L. Romell, 58, 59; Stockholm, L. Romell, Fungi Exs. 
Scand. These specimens are under the name Corticium Abietis.

Norway: Christiania, M.N. Blytt (in Herb. Fries and determined by Fries as Corticium calceum).

Finland: Mustiala, P. A. Karsten, under the name Xerocarpus farinellus.

Canada: J. Macoun, 30, 33.

New Hampshire: Chocorua, W. G. Farlow, two collections.

Vermont: Middlebury, E. A. Burt, two collections; Ripton, E. A. Burt; Little Notch, Bristol, E. A. Burt.

New York: Alcove, C. L. Shear, 1134, 1208; Hague, C. H. Peck, 10; Clear Water, G. F. Atkinson, Cornell Univ. Herb., 5049.

Georgia: Tipton, C. J. Humphrey, 17r; Savannah, C. J. Humphrey, 5106 (in Mo. Bot. Gard. Herb., 15081).

Washington: Bingen, W.N. Suksdorf, 695, 711, 763, 765, 864.

8. S. monticola Burt, n. sp.

Type: in Mo. Bot. Gard. Herb.

Fructification coriaceous, resupinate, cracked, dirty whitish approaching pale smoke-gray, the margin closely adnate; structure in section 200-300 $\mu$ thick, with hyphae colorless, $3-4 \mu$ in diameter, ascending obliquely from substratum to surface, densely crowded together, more interwoven and little incrusted in the lower third of the fructification, but more loosely arranged and heavily incrusted in the whole upper two-thirds, terminating in incrusted paraphyses which are either simple or 2-4-branched and with the hyphal body about $2 \frac{1}{2} \mu$ in diameter under the incrustation; basidia about $40 \mu$ below the surface of the hymenium, longitudinally septate, 15-20 $\times 9-12 \mu$; spores simple, colorless, even, cylindric, straight or curved, $9-10 \frac{1}{2} \times 5-5 \frac{1}{2} \mu$.

The portion of the fructification described is $5 \mathrm{~cm}$. long, about $1 \frac{1}{2} \mathrm{~cm}$. wide.

On bark of log of Picea Engelmanni, altitude 8,500 ft., Pike's Peak, Colorado. August.

This species belongs in the group with Sebacina calcea and S. macrospora; it is distinguished from both of these by the 
incrustation of its hyphae and by simpler paraphyses, which are either unbranched or with only about $2-4$ branches not branching repeatedly and becoming so attenuated as to be nearly invisible except for the granules which they bear.

Specimens examined:

Colorado: Pike's Peak, G. G. Hedgcock, comm. by C. J. Humphrey, 2571, type (in Mo. Bot. Gard. Herb., 15157).

9. S. scariosa (Berk. \& Curtis) Burt, n. comb.

Corticium scariosum Berk. \& Curtis, Grevillea 2:3. July, 1873.-Corticium secedens Saccardo, Syll. Fung. 6: 635. 1888.

Type: type and cotype in Kew Herb. and Curtis Herb., respectively.

"Forming a thin, oblong, membranous stratum, without any distinct border ; hymenium pulverulent ochroleucous."

-Original description.

Structure in section $300-600 \mu$ thick, with hyphae $2 \mu$ in diameter, branched, very loosely interwoven, extending from substratum to basidia, with walls gelatinously modified, imbedded in jelly, much crystalline matter about $90-120 \mu$ below the hymenial surface; basidia at or near the surface, longitudinally septate, pyriform to subglobose, $12-15 \times 9-12 \mu$; no spores found.

On alder, South Carolina.

The type specimens of this species have the general habit of Peniophora gigantea, which they also resemble in being separable and in cracking and peeling up from the substratum, but they are more lemon-yellow in color than specimens of the latter species. The structure in section is distinctive and suggestive of that of Eichleriella alliciens. Authors have sometimes confused Corticium scariosum B. \& C. with Corticium scariosum B. and Br., published from Ceylon a few months later in the same year. The types of these fungi are not of the same genus, the American specimens having longitudinally septate basidia.

Specimens examined:

South Carolina: Society Hill, M. A. Curtis, 4916 (type and cotype in Kew Herb. and Curtis Herb.). 
10. S. podlachica Bresadola, Ann. Myc. 1: 117. 1903.

Type: in Bresadola Herb. and a portion in Burt Herb.

Fructification effused, closely adnate, described as "e pallido-caerulea caesio-hyalina," drying tawny olive to Saccardo's umber where directly on the wood; structure in section $30-45 \mu$ thick, with hyphae $2 \mu$ in diameter closely crowded together and rising obliquely from substratum to the surface; basidia in upper $15 \mu$ of fructification among the hyphal filaments, longitudinally septate, pyriform, $7-10 \times 6-8 \mu$; spores colorless, simple, even, curved, $6-7 \times 3-5 \mu$.

Covering areas $5 \mathrm{~cm}$. long, $2 \mathrm{~cm}$. broad.

On decaying coniferous wood, Massachusetts; on decaying beech wood, Russian Poland.

The Massachusetts collection was noted as blue-purple when fresh; in some places algae coating the wood have been covered by the fructification and the modified color of this algal layer is seen through the dried fructification; where the fungus coats the wood directly, the color of specimens which have been several years in the herbarium is the tawny olive. The American collection agrees closely with that communicated by Bresadola.

Specimens examined:

Russian Poland: on beech wood, Eichler, comm. by Bresadola, part of type.

Massachusetts : on coniferous wood, W. G. Farlow.

11. S. cinnamomea Burt, n. sp. Plate 27, fig. 18.

Type: in Burt Herb.

Fructification effused, coriaceous, dry, closely adnate, drying cinnamon-brown, the margin determinate, thick, entire; structure in section $100-140 \mu$ thick, with (1) a layer 10-30 $\mu$ thick next to the substratum of longitudinally arranged, densely interwoven hyphae $2-2 \frac{1}{2} \mu$ in diameter, which bear (2) the hymenial layer composed of basidia at the lower side of

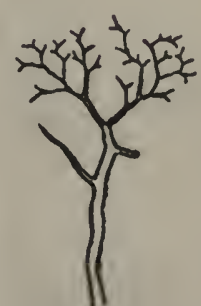

Fig. 4 S. cinnamomea. Paraphysis $\times 540$. the layer, and of loosely arranged, highly branched, bush- 
shaped paraphyses with brown branches of zigzag form, which rise $45-60 \mu$ above the basidia and give the characteristic color of the hymenium; basidia $15-20 \times 9-11 \mu$, longitudinal septation not positively made out; no spores found; paraphyses 75 $\mu$ long, trunk $1 \frac{1}{2}-2 \mu$ in diameter, sweep of branched top about $20 \mu$.

Fructification $4 \mathrm{~cm}$. long, $1 \mathrm{~cm}$. broad.

On limbs of dead Magnolia glauca. Maryland. December. It is not certain that this fungus is a Sebacina, for none of its basidium-like organs show longitudinal septa, although in a very few there is arrangement of the protoplasm suggestive of such septation. The specimen is a little too immature for generic reference but is probably a young Sebacina in my opinion. The species is distinct from others in possible genera by cinnamon-brown color, paraphyses scattered as to trunks but with such brown, bushy-branched tops as to form a compact surface of the color stated.

Specimens examined:

Maryland: Takoma Park, C. L. Shear, 1339, type.

12. S. adusta Burt, n. sp. Plate 27, fig. 19.

Type: in Burt Herb.

Fructification broadly effused, coriaceous, separable from the substratum, Hay's brown when moist, drying fuscous, the margin pale cartridgebuff, fibrillose-fimbriate; structure in section, $500-600 \mu$ thick, composed of densely interwoven and obliquely ascending hyphae $3 \mu$ in diameter, the walls not gelatinously modified, which bear the basidia at the surface of the hymenium; basidia longitudinally septate, pyriform, $12-16 \times 8-10 \mu$; spores colorless, simple, curved, 10-12 × 4-5 $\mu$.

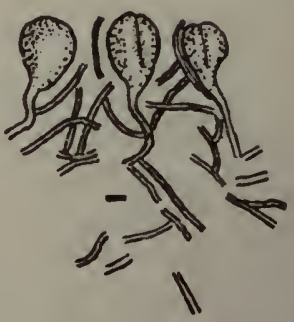

Fig. 5

S. adusta. Basidia and hyphae $\times 540$.

Fructification $12 \mathrm{~cm}$. long, $4 \mathrm{~cm}$. broad.

On decorticated trunk of Populus trichocarpa. Idaho. July to September.

In the single collection of this species which has been received the margin is everywhere closely applied to the substratum and shows no tendency towards becoming free or 
reflexed, hence the species must be included in Sebacina. The distinguishing specific characters are easy separation as an unbroken membrane of the moist fructification from the substratum, thickness of fructification, and position of the basidia at the surface of the hymenium.

Specimens examined:

Idaho: Kaniksu National Forest, Priest River, J. R. Weir, 12, type.

13. S. plumbea Burt, n. sp.

Plate 27, fig. 20.

Type: in Burt Herb.

Fructification effused, closely adnate, drying blackish plumbeous, pruinose, the margin indeterminate; structure in

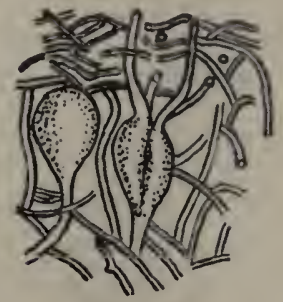

Fig. 6

S. plumbea.

Basidia and hyphae $\times 540$. section, $150-200 \mu$ thick, with (1) a broad layer next to the substratum containing much crystalline matter in the interspaces between the interwoven suberect hyphae $1 \frac{1}{2}-2 \mu$ in diameter, the wall gelatinously modified, and (2) a hymenial layer about $60 \mu$ thick consisting of basidia, and of hyphae which branch and form a densely interwoven hymenial surface; basidia about $30 \mu$ below the surface of hymenium, longitudinally septate, pyriform, 15-18 $\times 10-13 \mu$; spores colorless, simple, even, curved, $13-15 \times 4 \frac{1}{2}-6 \mu$.

Fructification $4-8 \mathrm{~cm}$. long, $\frac{1}{2}-1 \mathrm{~cm}$. broad.

On blackened wood of Populus trichocarpa. Washington. November.

The coloration and habit of specimens of this species agree closely with those of the European Corticium plumbeum Fr. which have been received from Karsten, but the internal structure is wholly different from that of the latter.

Specimens examined:

Washington: Bingen, W. N. Suksdorf, 862, type.

14. S. atrata Burt, n. sp.

Plate 27, fig. 21.

Type: in Burt Herb. and in Farlow Herb.

Fructification effused, somewhat gelatinous, closely adnate, grayish when moist, drying dark mouse-gray and shining, the margin thinning out and indeterminate; structure in section, 
50-160 $\mu$ thick, with even-walled hyphae $3 \mu$ in diameter, densely interwoven next to the substratum, then curving outward to form a hymenial layer 50-90 $\mu$ thick, consisting of

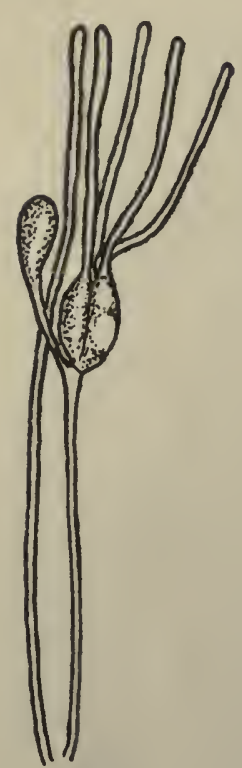

Fig. 7

S. atrata. Paraphysis, basidia $\times 540$. erect, parallel, rod-like paraphyses $2 \mu$ in diameter and of basidia about $30 \mu$ below the surface of the hymenium; basidia longitudinally septate, pyriform, about $18 \times 12 \mu$; spores colorless, simple, somewhat flattened on one side, $8-10 \times$ 6-7 $\mu$.

Fructifications $2 \frac{1}{2} \mathrm{~cm}$. long, $1 \frac{1}{2} \mathrm{~cm}$. broad.

On very rotten coniferous and frondose wood. New Hampshire and Massachusetts. May.

When bits of dried, specimens of this species are moistened, they become softer and more gelatinous than is usual with those of other species of the genus, but walls of the hyphae do not show gelatinous modification in sectional preparations. The paraphyses are as noteworthy as those of Sebacina Helvelloides, being arranged close together side by side in a palisade layer. They are sometimes simple rods, sometimes divided into equal branches which rise side by side to the surface of the hymenium.

Specimens examined:

New Hampshire: Chocorua, W. G. Farlow, two collections (of which No. $a$ is in Mo. Bot. Gard. Herb., 44782).

Massachusetts: Magnolia, W. G. Farlow, type.

(To be continued.) 



\section{Explanation of Plate}

\section{PLATE 26}

The figures of this plate have been reproduced natural size from photographs of dried herbarium specimens.

Fig. 1. Tremellodendron Cladonia. a, from specimen collected in Canada by J. Macoun, 78; $b$, collected at Hague, New York, by C. H. Peck, 7 ; c, collected at Cincinnati, Olio, by A. P. Morgan, Lloyd Herb., 32.

Fig. 2. T. Cladonia, from the type of Thelephora gracilis, collected in Alabama by F. S. Earle, 13.

Fig. 3. T. candidum. Collected at Newfane, Vermont, by C. D. Howe. $a$ agrees closely with the type and is my standard for comparison; $b$ could be separated without fracture into three portions, each having form of $a$.

Fig. 4. T. merismatoides. a, from specimen collected at York County, Pennsylvania, by N. M. Glatfelter; $b$, single fructification from the cluster $a ; c$, from a very fasciculate specimen having stems grown together and branches still fimbriate at apex, collected at Haddonfield, New Jersey, by T. J. Collins.

Fig. 5. T. simplex. From type collected in Porto Rico, by J. R. Johnston. The fructification on the right is inverted.

Fig. 6. T. pallidum. a, from specimen collected at Middlebury, Vermont, by E. A. Burt; $b$, from specimen in Mo. Bot. Gard. Herb., 712370, collected at St. Louis, Missouri, by N. M. Glatfelter. Botl show the growth together of the flattened pileate divisions.

Fig. 7. T. tenue. a, from type, collected at Chester Vale, Jamaica, by W. A. and E. L. Murrill, 400 ; $b$, from specimens collected at Cinchona, Jamaica, by the same collectors, 614 . 

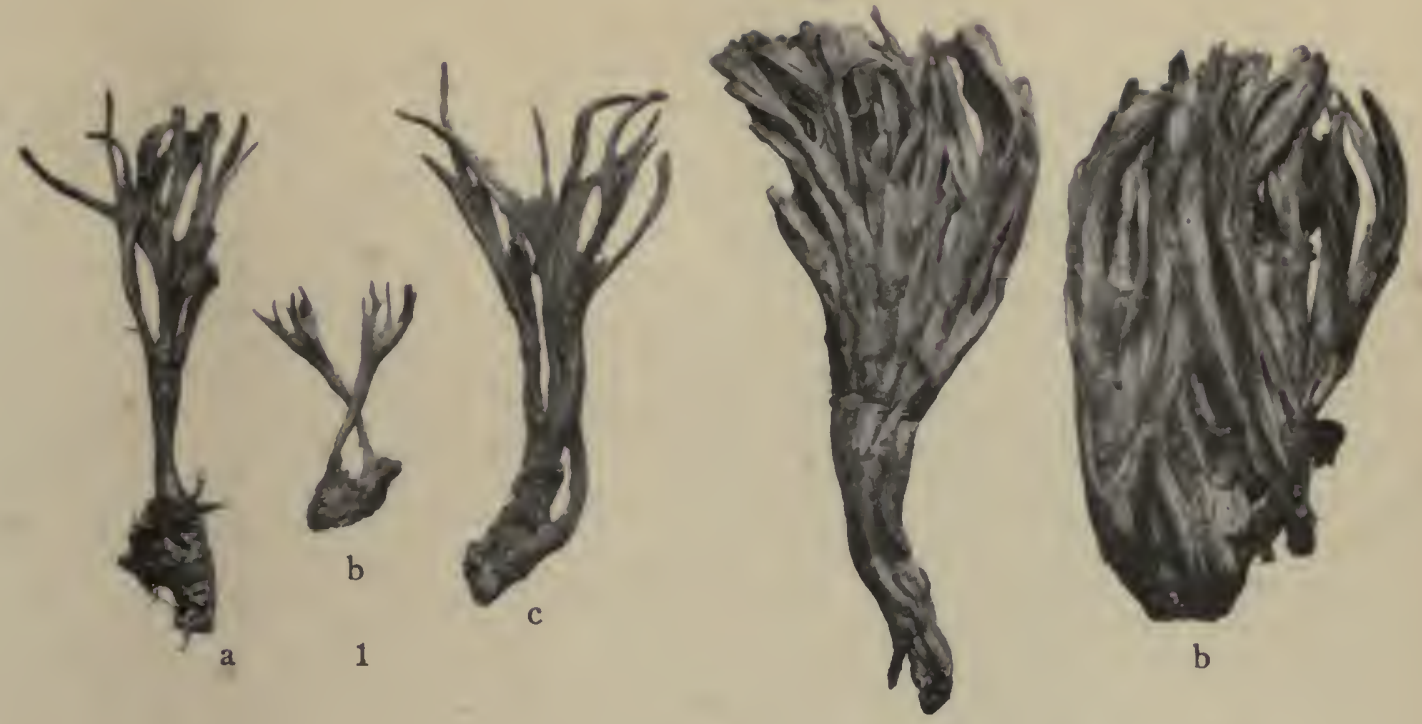

a 3

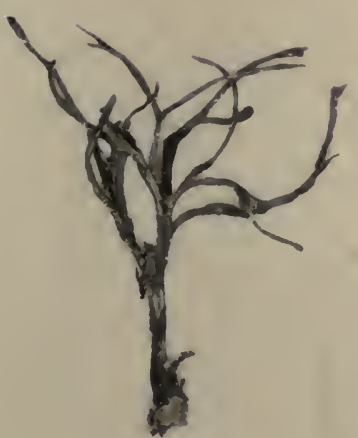

2
5
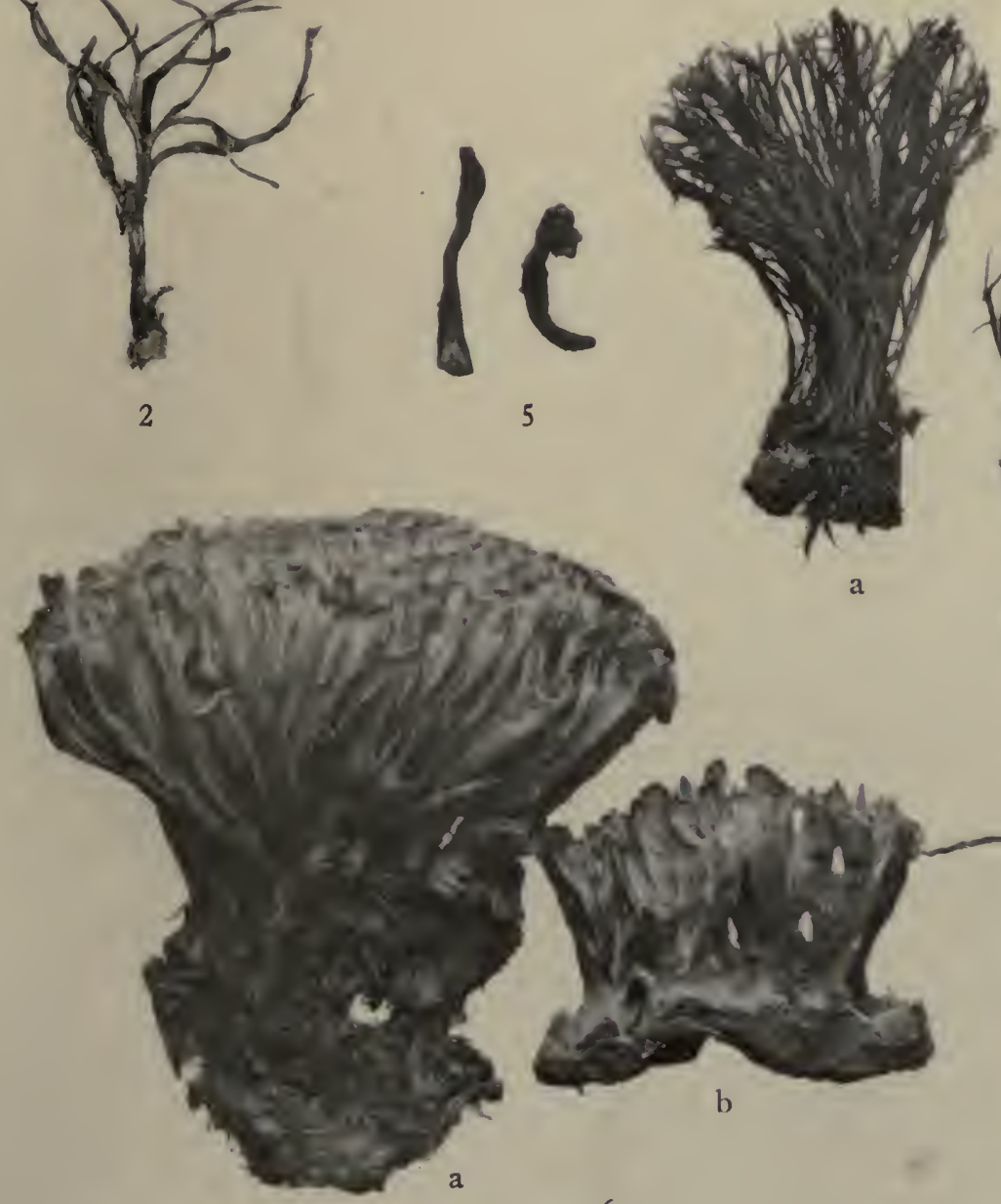

a
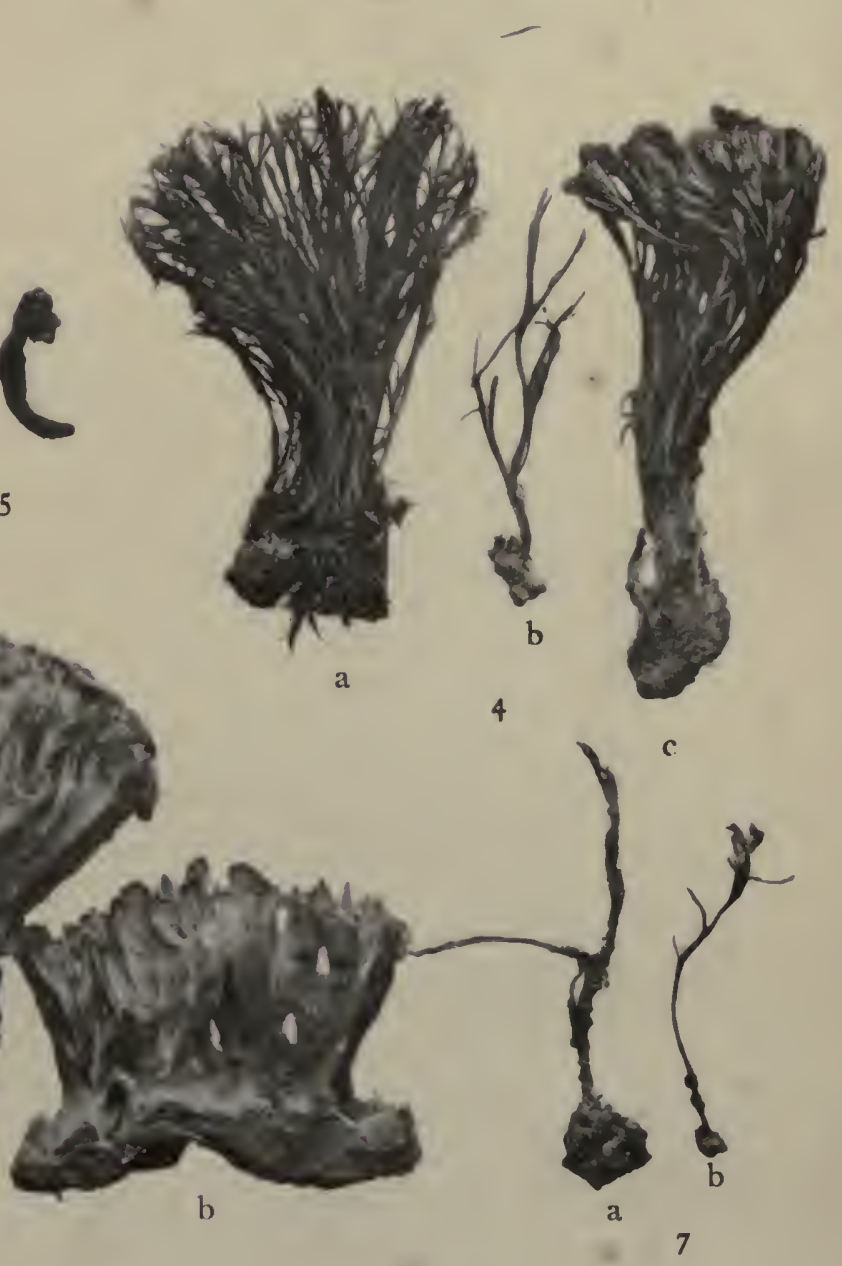

b
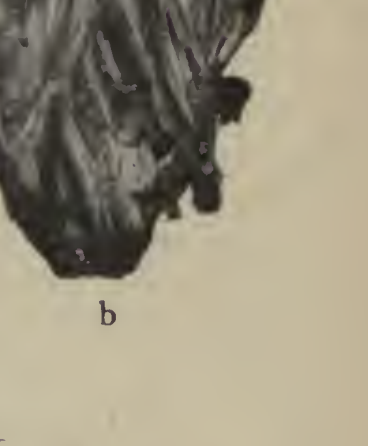




\section{Explanation of Plate}

PLATE 27

The figures of this plate have been reproduced natural size from photographs of dried herbarium specimens, except in the cases noted otherwise.

Fig. 8. Eichleriella Schrenkii. From the type collected at San Antonio, Texas, by $\mathrm{H}$. von Schrenk. $a$, photograph of a piece of limb bearing many fructifications, and $b$, drawing of median longitudinal section of single fructification, $\times 16$.

Fig. 9. E. Leveilliana. From specimens collected at San Antonio, Texas, by H. von Schrenk.

Fig. 10. E. alliciens. From specimen collected at San Diego de los Baños, Cuba, by Earle and Murrill, 405, in part.

Fig. 11. E. spinulosa. From specimen collected at Priest River, Idaho, by J. R. Weir, 55.

Fig. 12. E. gelatinosa. From specimens collected in Jamaica by W. A. Murrill and W. Harris. a, upper surface of No. $180 ; b$, type specimen, 1087, split longitudinally to show thickness of pileus and structure.

Fig. 13. Sebacina incrustans. $a$, from specimen collected at Middlebury, Vermont, by E. A. Burt; $b$, from specimen with pileate flaps, collected at Asheville, North Carolina, by H. C. Beardslee, 03126.

Fig. 14. S. Helvelloides. From specimen collected at Alcove, New York, by C. L. Shear, 1221. $a$ shows upper surface; $b$ is a vertical section from the same fructification to show thickness.

Fig. 15. S. chlorascens. From type specimen collected at Cocoanut Grove, Florida, by R. Thaxter, 98.

Fig. 16. S. Shearii. From type specimens collected at Washington, District of Columbia, by C. L. Shear, 1238.

Fig. 17. S. calcea. From specimen on white cedar bark, collected at Middlebury, Vermont, by E. A. Burt.

Fig. 18. S. cinnamomea. From type specimen collected at Takoma Park, Maryland, by C. L. Shear, 1339.

Fig. 19. S. adusta. From type specimen collected at Priest River, Idaho, by J. R. Weir, 12.

Fig. 20. S. plumbea. From type specimen collected at Bingen, Washington, by W. N. Suksdorf, 862 .

Fig. 21. S. atrata. From specimen collected at Chocorua, New Hampshire, by W. G. Farlow. 

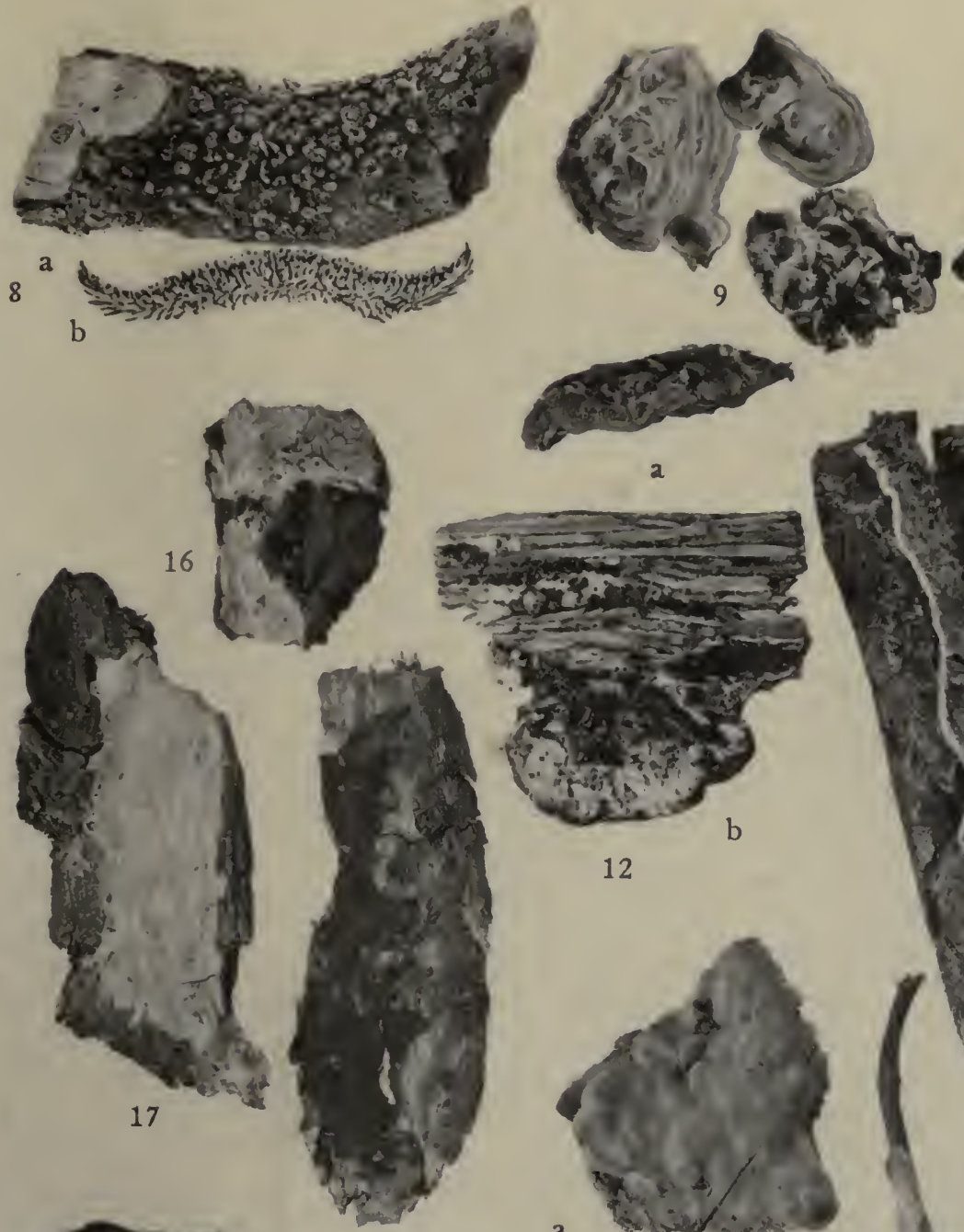

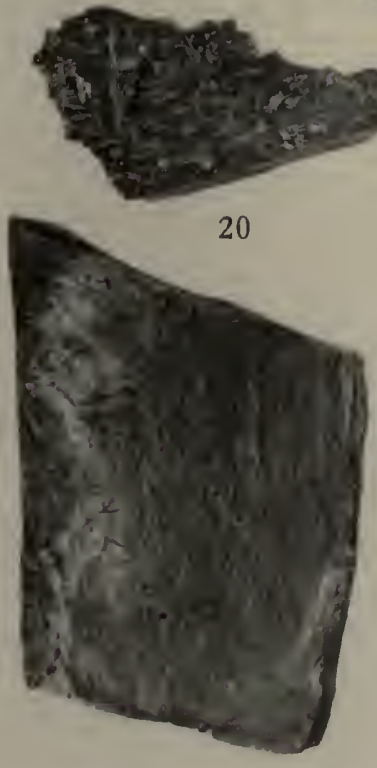

19
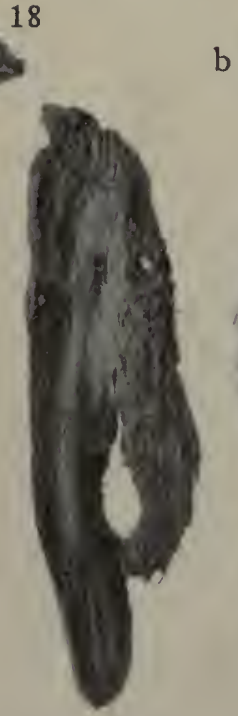

21

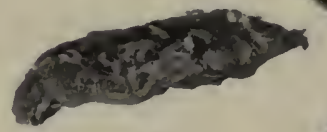

2

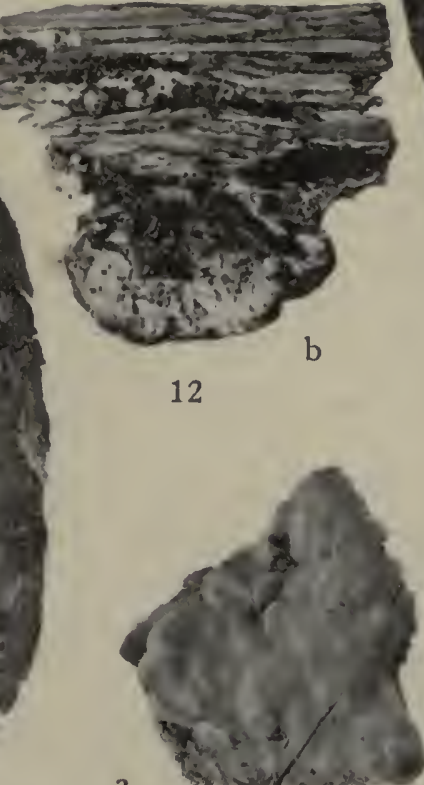

b

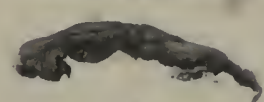

14

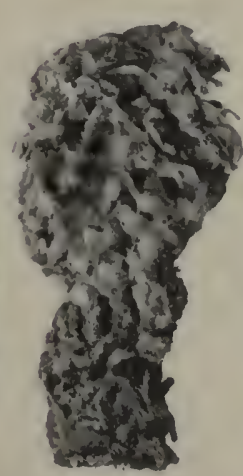

15

$77^{\circ}$ 



\section{The Thelephoraceae of North}

America. VI

\section{Hypochnus}

\section{DWAKD ANGUS BURT}

Reprinted frem ARS ALs of THE MISSOURI BOTANICAL

Gamin 3::0:3-241. April, 1916 


\title{
THE THELEPHORACEAE OF NORTH AMERICA VI ${ }^{1}$ Hypochnus
}

\author{
EDWARD ANGUS BURT
}

\begin{abstract}
Mycologist and Librarian to the Missouri Botanical Garden Associate Professor in the Henry Shaw School of Botany of Washington University
\end{abstract}

\section{HYPOCHNUS}

Hypochnus Fries emend. Karsten, Rev. Myc. $3^{\circ}: 23$. 1881; Finska Vetenskaps-Soc. Bidrag Natur och Folk 37:162. 1882 ; Finl. Basidsv. 438. 1889; Fries, Obs. Myc. 2 :278. 1818 and 1824, (in part); Syst. Myc. $3: 289.1829$, (in part); Gen. Hym. 16. 1836, (in part); Epicr. 569. 1838, (in part); Sacc. Syll. Fung. $6: 653.1888$, (in part); R. Fries, R. Sci. Soc. Gothoburgens Actis IV. 3:37. 1900.-Hypochnus as a subgenus of Corticium Fries, Hym. Eur. 659. 1874, (in part). - Tomentella Persoon ex Patouillard, ${ }^{2}$ Hym. Eur. 154. 1887; Schroeter, ${ }^{2}$ Krypt.-Fl. Schlesien 3:419. 1888; Engl. \& Prantl, Nat. Pflanzenfam. ( I:1**):117. 1898. - Tomentellina v. Höhnel \& Litschauer, K. Akad. Wiss. Wien Sitzungsber. 115: 1604. 1906.

Fructifications resupinate, effused, dry, coriaceous, feltlike or hypochnoid, usually composed of loosely interwoven hyphae which bear basidia sometimes in scattered clusters but more usually in a compact hymenium; hymenium even or papillose; basidia simple, bearing two or more spores, rough-walled to echinulate, distinctly colored in most species, pale-colored in a few, and hyaline in one or possibly more species.

${ }^{1}$ Issued September 30, 1916.

${ }^{2}$ Patouillard and Schroeter, in the works cited above, attributed Tomentella to Persoon, because ho used this word in parenthesis in the names of two species in his published note-book, Obs. Myc. 2:18 and 19, 1799, as follows:

"27. Corticium (Tomentella) ferrugineum.

"28. Corticium (Tomentella) chalibeum."

This is not generic publication of Tomentella. Why Persoon used the word is not evident; he did not adopt it as a genus in his following formal taxonomic works: 'Synopsis Fungorum' published in 1801, and 'Mycologia Europaea,' in 1822. Generic publication of Tomentella was not made until 1887 by Patouillard six years after Karsten's emendation of Hypochnus; hence Tomentella is a synonym of Hypochnus.

AN. MO. BOT. GARD. VOL. 3, 1916 
Hypochnus is separated from Thelephora, as I have limited the latter, by strictly resupinate habit; from Corticium and Peniophora by rough-walled to echinulate spores which are usually, but not always, distinctly colored; from Zygodesmus of the Hyphomycetes by true basidia which bear two or more spores; and from Grandinia and Odontia of the Hydnaceae by loosely interwoven, hypochnoid structure and more or less colored, rough-walled to echinulate spores.

As here treated, the species of Hypochnus form a natural, compact group at the foot of Hymenomycetes, with simple basidia, and closely resembling Zygodesmus in general habit and also in form and color of spores. Hypochnus is so closely related to Thelephora and Grandinia that many of its species have been published in those genera, as will be seen by the synonymy of species, or occur in those genera under manuscript names in the large herbaria.

The species of Hypochnus are apparently humus formers, for the fructifications are found under very rotten wood and other organic matter rather than on nearly sound wood. Hence they probably follow other fungi in wood destruction.

This is the first presentation of the North American species of Hypochnus. It shows the geographical distribution of the genus localized in the northeastern United States and along our Atlantic coast and ranging westward across the northern United States. Not an Hypochnus has been found in a series of 175 numbers of Thelephoraceae, mostly resupinate, collected by Dr. and Mrs. Murrill in Mexico.

The sketches of microscopic details of the species in this part were made by the aid of a camera lucida from preparations of such type or authentic specimens as are referred to in the accompanying text.

The development of the present conception of Hypochnus is of historical interest. When first published, Hypochnus comprised species which I refer to Hypochnus and Corticium; then tropical lichens predominated; in his last work Fries excluded the lichens, recognized the close relationship to Corticium and placed both Coniophora and Hypochnus as 
subgenera of Corticium. As several species of Corticium were still included in Hypochnus, Fries had good reason for regarding Hypochmus in his sense as closely related to Cor. ticium. Karsten's emendation of Hypochnus a few years later was logical, and in sympathy with the work of Fries, for it retained this name for the greatest number of cogeneric species both originally published in the genus and retained in the final work of Fries. These species are furthermore the only species for which the generic name $H y$ pochnus can be retained, for the other species of the subgenus in Fries' 'Hymenomycetes Europeae' revert to Corticium under modern study.

Hypochnus, as presented in Saccardo's 'Sylloge Fungorum,' is an aggregation of species of several genera and includes also the tropical lichens which Fries excluded from the genus in 1874. Hypochnus as given in Engler \& Prantl's 'Die Natürlichen Pflanzenfamilien,' is the presentation of a purely academic scheme of Schroeter's as to how the lower Hymenomycetes ought to be classified to have a family Hypochnacei, but the fungi do not fall in with the scheme. They cannot be separated from Corticium and Peniophora. Von Höhnel and P. Sydow have pointed out ${ }^{1}$ that Hypochnus in the sense of Schroeter must be abandoned as a genus and its species take their proper places in other genera. It is to be regretted that Saccardo's 'Sylloge Fungorum' and Engler \& Prantl's 'Die Natürlichen Pflanzenfamilien' give a false lead with regard to Hypochnus, for these works are the main reliance of plant pathologists in the matter of genera.

\section{Key to the Species}

Spores distinctly colored as seen with the microscope $\ldots . \ldots \ldots \ldots \ldots$...... 1 Spores so pale yellowish or hyaline as to appear hyaline or nearly

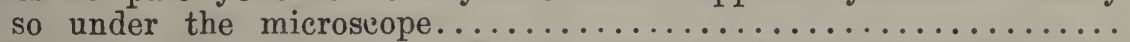

1. Fructification "ferruginous," i. e., Sudan-brown," Brussels-brown, and hazel of Ridgway; spores concolorous with the fructification, but wax-

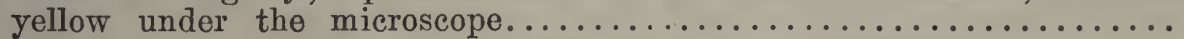

${ }^{1}$ Ann. Myc. 4:551. 1906. See also von Höhnel \& Litschauer, Ann. Myc. 4:288. 1906 .

*The technical color terms used in this work are those of Ridgway, Color Standards and Nomenclature. Washington, D. C., 1912. 
1. Fructification not "ferruginous"; spores not wax-yellow under the

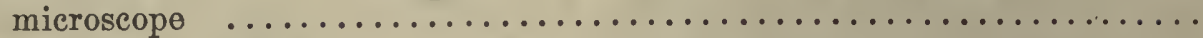

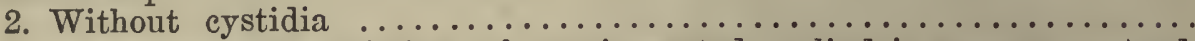

2. With cystidia consisting of non-incrusted, cylindric organs protrud-

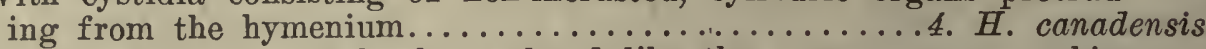

3. Fructification adnate; all hyphae colored like the spores; spores echin-

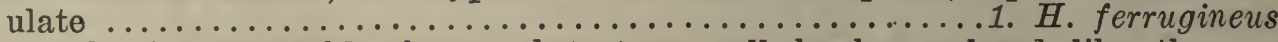

3. Fructification separable from substratum; all hyphae colored like the spores; spores aculeate ........................... rubiginosus

3. Fructification separable; hyphae dark-colored next to substratum; subłymenial hyphae colored like the spores; spores echinulate 3 . $H$. subferrugineus 4. Hyphae not nodose-septate, i. e., not having clamp connections ..... 5 4. Hyphae nodose-septate, i. e., with clamp connections .......... 6

5. Fructification ranging from drab to fuscous and Chaetura-drab, separable; spores and hyphae concolorous, dark olive-buff to buffy brown under the microscope; hyphae $4-5 \mu$ in diameter; spores aculeate or coarsely tuberculate ........................ H. umbrinus

5. Fructification vinaceous-brown becoming Rood's brown, adnate; hyphae colored next to substratum, hyaline in subhymenium, 4-5 $\mu$ in diameter; spores umber, aculeate, the body $5-6 \mu$ in diameter or $5-6 \times 4-5 \mu \ldots \ldots$. $\ldots \ldots \ldots \ldots \ldots \ldots \ldots \ldots \ldots \ldots \ldots \ldots \ldots \ldots \ldots \ldots . \ldots \ldots . \ldots \ldots$. subvinosus

5. Fructification deep olive-buff to dark olive-buff, adnate; spores and hyphae concolorous; hyphae near the substratum $8-10 \mu$, or more, in diameter; spores echinulate, the body $7-9 \mu$ in diameter............ H. isabellinus

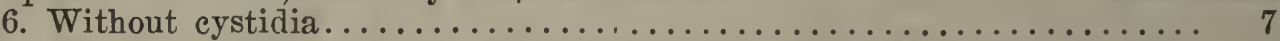

6. With cystidia consisting of non-incrusted cylindric organs protrud-

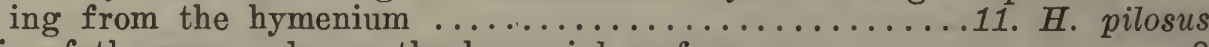

7. Margin of the same color as the hymenial surface............... 8

7. Margin of different color from the hymenial surface............. 12

8. Fructification dark-colored - cinnamon-drab, umber, sepia, fuscous -

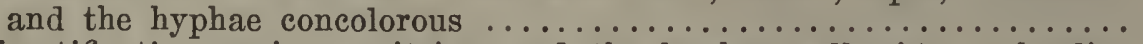

8. Fructification sepia or citrine, and the hypha yellowish or hyaline under the microscope after treatment with KHO solution..........

8. Fructification varying in brown from Saccardo's umber and snuffbrown to cinnamon-brown; hyphae and spores concolorous with the fructification; spores echinulate, the body $6-8 \times 5-7 \mu \ldots \ldots . .$. 
11. Fructification felty-membranaceous, light mineral-gray, $400 \mu$ thick, twolayered; hyphae $4 \mu$ in diameter; spores deep olive-buff to hyaline under the microscope, rough-walled or aculeate with very short points; on

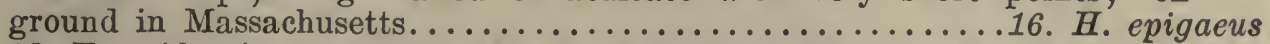

12. Fructification separable from substratum when moistened...... 13

12. Fructification aduate, fawn-color, under side and margin whitish; hyphae suberect, thin-walled, $21 / 2-3 \mu$ in diameter, hyaline under the microscope; known from Washington..............22. H. cervinus

13. KHO solution causes a color change when added to sections immersed in a

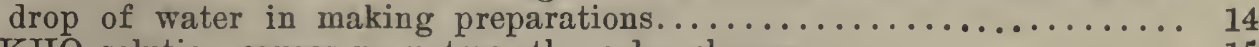

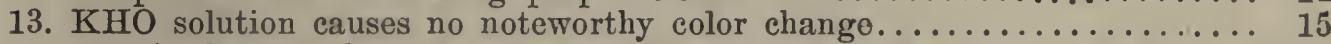

14. A change of color to between blue-green and sage-green is caused in the granules; fructification Chaetura-drab to fuscous, granular, the margin much paler, brownish and floccose; hyphae somewhat colored, $3-4 \mu$ in diameter...................... botryoides

14. A change of color to sage-green is caused in tho hymenium; fructification brownish olive, granular, the margin ochraceous-tawny; hyphae somewhat colored, only occasionally nodose-septate, $21 / 2-31 / 2 \mu$ in diameter, forming occasional rope-like strands next to substratum. $\ldots \ldots \ldots \ldots \ldots \ldots \ldots \ldots \ldots \ldots \ldots \ldots \ldots . \ldots \ldots \ldots . \ldots \ldots$. coriarius

14. Original colors are destroyed and the hyphae become sage-green; fructification olive-ocher at surface, with under side and margin brownish drab; hyphae $3 \mu$ in diameter, with some rope-like hyphal

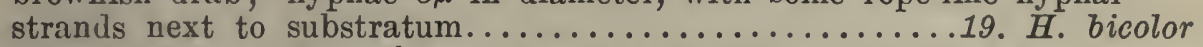

15. Fructification between walnut-brown and Vandyke-brown (a "dark red"') and the margin Isabella-color or melleus; hyphae colored, 5-6 $\mu$ in diameter, with rope-like strands next the substratum ........20. H. atroruber

15. Fructification with upper side pinkish buff to Isabella-color, the under side and margin bister; hyphae, $5-7 \mu$ in diameter, run along the substratum and give off suberect, interwoven, colored branches $31 / 2-41 / 2 \mu$ in diameter - no rope-like strands ..................... H. fuligineus

15. Fructification drab-gray, the margin whitish; hyphae hyaline under the

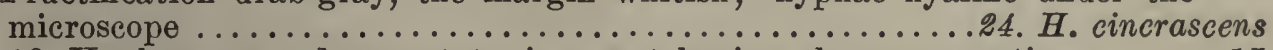
16. Hyphae not nodose-septate, i. e., not having clamp connections .... 17 16. Hyphae nodose-septate................................... 18

17. With cystidia; fructification pinkish buff, adnate ....25. $\dot{H}$. peniophoroides

17. Without cystidia; fructification becoming warm buff, thick, and firm, like Corticium portentosum; hyphae $2 \mu$ in diameter, terminating in the hymenium in dichotomously branched, antler-shaped organs; basidiospores hyaline or nearly so; even spores, colored like the hyphae, abundant between the hyphae...................... 6 . thelephoroides

17. Without cystidia; fructification pinkish buff to cinnamon-buff and avellaneous; hyphae $31 / 2-5 \mu$ in diameter, forming some rope-like strands next to substratum; spores with a slight tinge of buff in collection on

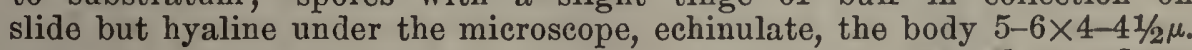

17. ..................................... H. zygodesmoides

17. Without cystidia; fructification Naples-yellow to deep colonial buff; hyphae $3-4 \mu$ in diameter, not forming rope-like strands; spores concolorous but sometimes hyaline under the microscope, echinulate, the body $4-5 \mu$ in diameter ....................... H. echinosporus 18. Fructification between olive-buff and deep olive-buff; spores concolorous, very pale under the microscope............29. H. fibrillosus

18. Fructification honey-yellow to drab and fuscous, the margin whitish or yellowish, flaxy-fibrillose, radiating; spores white in collection on slide, minutely echinulate with short, crowded spines, body

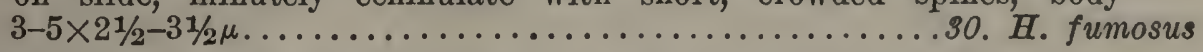

1. Hypochnus ferrugineus Pers. ex Fries, Obs. Myc. 2:280. 1818 and 1824; Karsten, Finska Vetenskaps-Soc. Bidrag Natur och Folk 37:162. 1882; Finl. Basidsv. 440. 1889; 
Sacc. Syll. Fung. 6:660. 1888; Bresadola, (Hym. Hung. Kmet.), I. R. Accad. Agiati Atti III. $3: 114.1897$.

Corticium (Tomentella) ferrugineum Persoon, Obs. Myc. 2:18. 1799. - Thelephora ferruginea Persoon, Syn. Fung. 2:578. 1801; Myc. Eur. 1:141. 1822; Fries, Elenchus Fung. 1:198. 1828; Epicr. 543. 1838. - Corticium ferrugineum subgenus Hypochnus Fries, Hym. Eur. 661. 1874. - Hypochnus ferruginosus (Fr.) Patouillard, Tab. Anal. Fung. 17. f. 26. 1883. - Tomentella ferruginea Pers. ex Schroeter, Krypt.-Fl. Schlesien 3:419. 1888 .

Illustrations: Patouillard, Tab. Anal. Fung. f. 26.

Fructification effused, adnate, often suborbicular, thin, dry,

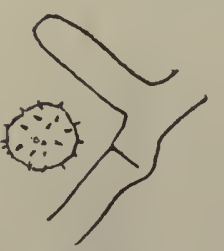

Fig. 1

H. ferrugineus.

Hypha, spore tomentose, hypochnoid, drying Sudan-brown; structure in section about $300 \mu$ thick, composed of loosely interwoven, even-walled hyphae $41 / 2-5 \mu$ in diameter, nodose-septate, concolorous through the whole fructification with the hymenium; no cystidia; basidia 4-spored; spores subglobose, concolorous with the fructification, echinulate, body of spore about $7-8 \mu$ in diameter.

Fructifications $2-4 \mathrm{~cm}$. in diameter or $3-6 \mathrm{~cm}$. long, about 2-3 cm. broad.

Under side decaying limbs and logs of various frondose species. Canada and New Brunswick to Georgia and westward to Michigan. July to October. Occasional.

This species is well marked by its very constant color, common to bóth hyphae and spores, and its occurrence in adnate, small, and very thin, hypochnoid areas of the form and dimensions given. American collections agree closely in above respects with the European specimens received from Bresadola which he has noted as surely $H$. ferrugineus.

Specimens examined:1

Sweden: Femsjö, L. Romell, 225, $22 \%$. Austria-Hungary: Trentino, G. Bresadola; Tatra Magna,

${ }^{1}$ With regard to the citation of specimens, all except those of "Exsiccati" are in Burt Herbarium, which are eited without explicit reference to place in other herbaria. For example, the specimens cited "Sweden: Femsjö, L. Romell, 225, 22\%," are in Burt Herbarium. The data given is that received with the 
Löcse, V. Greschik, comm. by G. Bresadola. New Brunswick: Campobello, W. G. Farlow. New Hampshire: Chocorua, W. G. Farlow.

Massachusetts: Belmont Spring, C. Bullard, comm. by W. G. Farlow; Sharon, A. P. D. Piguet, comm. by W. G. Farlow. New York: Alcove, C. L. Shear, 1316, in part; East Galway, E. A. Burt, two collections.

Georgia: Tallulah Falls, A. B. Seymour, comm. by W. G.

Farlow (in Mo. Bot. Gard. Herb., 43911).

Wisconsin: Blue Mounds, E.T.\& S. A. Harper, 876 .

2. H. rubiginosus Bresadola, (Hym. Hung. Kmet.), I. R. Accad. Agiati Atti III. 3 :114. 1897.

Zygodesmus rubiginosus Peck, N. Y. State Mus. Rept. 30 :58. 1879. - Tomentella rubiginosa (Bres.) R. Maire, Ann. Myc. $4: 335.1906$.

Type: in Bresadola Herb.; probably a portion in Burt Herb.

Fructifications effused, membranaceous, somewhat separable from the substratum, dry, tomentose, drying Brusselsbrown; hymenium even or granular; structure in section about $200-300 \mu$ thick, with all the hyphae bright-colored and giving their color to the fructification, about $3 \mu$ in diameter, nodoseseptate, thin-walled, lax, loosely interwoven towards the hymenium, longitudinally arranged next to the substratum, and occasionally consolidated there in rope-like, branching strands

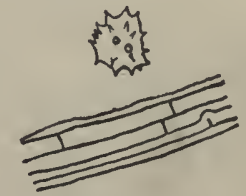

Fig. 2

H. rubiginosus. Hyphal strand, spore $\times 640$.

up to $15 \mu$ in diameter; no cystidia; spores concolorous with the fructification or more intensely colored, subglobose-angular, aculeate, body about $6-7 \mu$ in diameter, or $7-8 \times 6 \mu$.

Fructifications about $11 / 2-3 \mathrm{~cm}$. long, $1-2 \mathrm{~cm}$. broad.

On decaying leaves and decaying wood. Canada, New York, Louisiana, and British Columbia. October. Rare.

specimens and may identify duplicates in another herbarium. The location of all specimens in herbaria other than my own is designated by giving in parenthesis the name of the herbarium preceded by "in." For example, the specimen cited "Georgia: Tallulah Falls, A. B. Seymour, comm. by W. G. Farlow (in Mo. Bot. Gard. Herb., 43911)," is in Missouri Botanical Garden Herbarium, but not in Burt Herbarium. 
$H$. rubiginosus is very similar in color throughout to $H$. ferrugineus but differs in being membranaceous, in having spores aculeate rather than spinulose, and in having some hyphae parallel with substratum and occasionally forming rope-like strands. These strands are not mentioned by Bresadola in his description, but they are present in preparations from the specimen received from him and also in those from the few American collections referable to this species.

Specimens examined:

Hungary: on leaves of Juniperus and Quercus, Oct., 1888, Kmet, comm. by G. Bresadola, apparently part of type.

Canada: Lower St. Lawrence Valley, J. Macoun, ry.

New York: Greenbush, C. H. Peck, type of Zygodesmus rubiginosus (in Coll. N. Y. State); Alcove, C. L. Shear, 1329; Syracuse, L. M. Underwood, 36, 41 (both in Coll. N. Y. State).

Louisiana: St. Martinville, A. B. Langlois, ct.

British Columbia: Sidney, J. Macoun, 80, in part (in Mo. Bot. Gard. Herb., 8935).

3. H. subferrugineus Burt, n. sp.

Type: in Burt Herb.

Fructification effused, dry, membranaceous, separable from the substratum as a thin membrane, tomentose, drying Sudanbrown, with surface often granular in the center; structure in section $300-400 \mu$ thick,

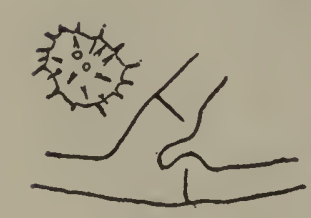

Fig. 3

H. subferrugineus. Hypha, spore $\times 640$. composed of (1) a few dark-colored, nodoseseptate hyphae 5-6 $\mu$ in diameter, running parallel with the substratum, loosely interwoven or sometimes in rope-like strands which give off (2) suberect, bright-colored, interwoven branches, concolorous with the hymenium, bearing the basidia; basidia 4spored; spores concolorous with the hymenium, subglobose, echinulate, with spore body $7-9 \times 6-8 \mu$; some color is dissolved from the sections when they are treated with KHO solution.

Fructifications $2-5 \mathrm{~cm}$. long, about $2-3 \mathrm{~cm}$. broad. 
Under side of decaying limbs and logs of both coniferous and frondose species. Canada and New England to Michigan, and in British Columbia; also in Sweden. August to October. Occasional.

This species has the same color externally as $H$. ferrugineus, from which it differs in being more compact, so that it is membranaceous and may be cautiously peeled up from the substratum. Dried specimens often have their central portion cracked and curled away from the substratum, while $H$. ferrugineus is adnate. Furthermore, $H$. subferrugineus has hyphae next to the substratum dark-colored and arranged longitudinally along the surface of the substratum, which is not the case in H. ferrugineus.

Specimens examined:

Exsiccati: Ellis, N. Am. Fungi, 421, under the name Zygodesmus rubiginosus.

Sweden: Femsjö, L. Romell, 233.

Canada: definite locality not stated, J. Macoun, 11; St. Lawrence Valley, J. Macoun, 20.

New Hampshire: Chocorua, W. G. Farlow, 1, 3, a collection dated Sept., 1903, and a collection dated 1915 - the last (in Mo. Bot. Gard. Herb.).

Vermont: Middlebury, E. A. Burt, two collections.

New York: Sylvan Beach, Oneida Co., H. D. House (in N.

Y. State Mus. Herb. and in Mo. Bot. Gard. Herb., 5893).

New Jersey: Newfield, J. B. Ellis, in Ellis, N. Am. Fungi, 421.

Michigan: Ann Arbor, A. H. W. Povah, 4 (in Mo. Bot. Gard. Herb., 11774).

British Columbia: Sidney, J. Macoun, 26, in part (in Mo. Bot. Gard. Herb., 8933).

4. H. canadensis Burt, n. sp.

Type: in Burt Herb.

Fructifications small, effused, membranaceous, easily separable from the substratum, dry, tomentose, drying between Brussels-brown and hazel, the margin very thin, fibrous; 
hymenium even or granular; in structure 400-500 $\mu$ thick, composed (1) next to the substratum of a few dark-colored, longitudinally arranged, nodose-septate hyphae $4-41 / 2 \mu$ in diameter, and (2) towards the hymenium of pale, thin and even-walled hyphae about $21 / 2-3 \mu$ in diameter, suberect, very loosely interwoven, which arise as lateral branches from the dark basal hyphae and bear basidia and cystidia; cystidia septate, cylindric, obtuse, even-walled, Saccardo's umber in color under the microscope, $4 \frac{1}{2}-5 \mu$ in diameter, emerging up to $80-100 \mu$; basidia 4-spored with the spores on slender sterigmata about $6 \mu$ long; spores Saccardo's umber under the microscope, globose, tuberculate, spore body $6-7 \mu$ in diameter.

Fructification usually $1-2 \mathrm{~cm}$. long, $1 / 2-1 \mathrm{~cm}$.

Fig. 4

H. canaden-

sis. Cystidium, spore $\times 640$. broad, one specimen $4 \mathrm{~cm}$. long.

On wood and bark of conifers decaying on the forest floor. Canada and New Hampshire to Idaho and British Columbia. August to November.

$H$. canadensis is a little darker in color than $H$. ferrugineus and is smaller and less conspicuous in the few collections which have been made. It differs from our other rustcolored species of Hypochnus in having cystidia. It is related to the European Hypochnus ferruginosus (v. Höhn. \& Litsch.) Burt, n. comb., = Tomentellina ferruginosa v. Höhn. \& Litsch, by the colored, cylindric cystidia, but the cystidia of our species are shorter and its hyphae finer, darker, and nodose-septate next to the substratum.

Specimens examined:

Canada: locality not stated, J. Macoun, 11.

Quebec: Ironsides, J. Macoun, 2ryb.

New Hampshire: Chocorua, W. G. Farlow, 2, and c4 (the latter in Mo. Bot. Gard. Herb., 44039).

Vermont: Middlebury, E. A. Burt, type.

Michigan: Ann Arbor, C. H. Kauffman, 36.

Idaho: Priest River, J. R. Weir, 1.

British Columbia: Kootenai Mountains, near Salmo, $J . R$. Weir, 504 (in Mo. Bot. Gard. Herb.). 
5. H. umbrinus (Fries) Burt, n. comb.

Thelephora umbrina Fries, Elenchus Fung. 1:199. 1828, but not T. umbrina Alb. \& Schw. Consp. Fung. 281. 1805. Corticium umbrinum Fries, Hym. Eur. 658. 1874. - Thelephora biennis Fries, Hym. Eur. 636. 1874, but not T. biennis Fries, Syst. Myc. 1:449. 1821. - T. arachnoidea Berk. \& Broome, Linn. Soc. Bot. Jour. 14:64. 1873, but not T. arachnoidea as understood by Bresadola, Ann. Myc. 1:108. 1903. Hypochnus tristis Karsten, Soc. pro Fauna et Flora Fennica Meddel. 9:71. 1883; Bresadola, Ann. Myc. 1:107. 1903. Hypochnopsis fuscata Karsten, Finl. Basidsv. 443. 1889. Hypochnus fuscatus Karsten in Sacc. Syll. Fung. 9:244. 1891. - Tomentella tristis (Karst.) v. Höhnel \& Litschauer, K. Akad. Wiss. Wien Sitzungsber. 115 :1572. 1906. - Hypochnus sitnensis Bresadola, I. R. Accad. Agiati Atti III. $3: 115$. 1897.

Type: in Herb. Fries, and an authentic specimen from Fries in Kew Herb.

Fructification effused, soft, separable, with the hymenial surface compact and membranaceous, varying from drab to fuscous and Chaetura-drab, underneath villose; structure in section $400-600 \mu$ thick, with some hyphae running along the substratum and ascending so as to form a loosely arranged layer near the substratum and then branching repeatedly to form a compact hymenium; hyphae concolorous with the fructification, thick-walled, not nodose-septate, not rough-walled, $4-5 \mu$ in diameter; basidia with 4 sterigmata; spores concolorous, globose or subglobose, aculeate or coarsely tuberculate,

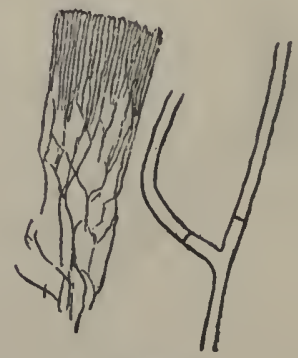

Fig. 5

H. umbrinus.

Section $\times 75$

Hypha×640. $6-7 \mu$ in diameter or $6-8 \times 41 / 2-7 \mu$; KHO solution dissolves some pigment from the sections and becomes dark-colored in their vicinity.

Fructifications 6-10 $\mathrm{cm}$. long, 3-5 cm. broad.

On rotting coniferous and frondose wood. New England to British Columbia. September to October. Common and cosmopolitan. 
Hypochnus umbrinus (Fr.) is noteworthy among the dark species by its hyphae not being nodose-septate, i. e., not having clamp connections. Its tuberculate or aculeate spores and compact hymenium afford additional distinctive characters.

Thelephora umbrina Alb. \& Schw. is regarded now by European botanists as a Coniophora, of which I have a specimen from Bresadola; what Fries understood by $T$. umbrina is exactly shown by an authentic specimen in Kew Herbarium. This specimen is a true Hypochnus in fine condition, dark-colored, with compact hymenium separated from the substratum by a thick layer of loosely arranged, suberect, thick-walled, colored hyphae, which do not have clamp connections. T. biennis, as used by Fries in 1821, is a description of the illustration in Bulliard's 'Herb. de la France' $2: 286$. pl. 436. f. 2. Fries stated that he had seen no specimens at that time. In 'Hymenomycetes Europaei,' published in 1874, he changed the description of $T$. biennis materially to adapt it to living specimens which he had seen. The resupinate specimen of this later period in Herb. Fries is not distinct from Hypochnus umbrinus. Authentic specimens of $H$. tristis and Hypochnopsis fuscata received from Karsten, and of Hypochnus sitnensis from Bresadola are the same species as already pointed out by Bresadola; ${ }^{1}$ still earlier, Romell stated in letters his belief that $H$. tristis is a synonym of $H$. umbrinus. My studies lead to the same conclusion. The type specimen of Thelephora arachnoidea Berk. \& Broome agrees closely with the Friesian specimen of $H$. umbrinus. Bresadola ${ }^{2}$ has described hyphae of $T$. arachnoidea as "punctato-scabrae vel tunica granoso-aculeolata primitus inductae, usque ad $9 \mu$ crassae," but in my preparation of the type of $T$. arachnoidea the walls of the hyphae are even and not more than $41 / 2 \mu$ in diameter. ${ }^{3}$

${ }^{1}$ Ann. Myc. 1:107. 1903.

${ }^{2} I b i d .$, p. 108.

${ }^{3}$ In the same connection Bresadola places Thelephora floridana Ell. \& Ev. as a synonym of $T$. arachnoidea, and he has been followed in this by von Höhnel. My preparations of the type of T. floridana in N. Y. Bot. Gard. Herb. show that this species is not a basidiomycete, and that its hyphae are nodose-septate. 
Specimens examined:

Sweden: Smolandia, from E. Fries (in Kew Herb.); Femsjö, L. Romell, 234, 235, and E. A. Burt; Stockholm, L. Romell, 229-232.

Finland: Mustiala, $P$. Karsten, authentic specimen of $H$. tristis; Messuby, P. Karsten, authentic specimen of $H y$ pochnopsis fuscata.

Hungary: A. Kmet, comm. by G. Bresadola, authentic specimen of Hypochnus sitnensis.

Ceylon: Habgalla, No. 539, Feb., 1868, the type of Thelephora arachnoidea Berk. \& Broome (in Kew Herb.).

Canada: J. Macoun, 64.

Ontario: Harraby, E. T.\& S. A. Harper, 593.

New Hampshire: Chocorua, W. G. Farlow, 9, 13, 14, 15, 22.

Vermont: Middlebury, E. A. Burt.

Massachusetts: Sharon, A. P. D. Piguet, comm. by W. G. Farlow.

New York: Lake Placid, C. H. Peck; Floodwood, E. A. Burt. Wisconsin: Blue Mounds, E. T. \& S. A. Harper, 860.

British Columbia: Kootenai Mountains, near Salmo, $J . R$. Weir, 441, 487 (in Mo. Bot. Gard. Herb., 8227, and 20225 respectively).

0 6. H. fuscus Pers. ex Fries, Obs. Myc. 2:280. 1818 and 1824; Karsten, Finska Vetenskaps-Soc. Bidrag Natur och Folk 37:163. 1882.

Corticium fuscum Persoon, Obs. Myc. 1:38. 1796; Fries, Hym. Eur. 651. 1874. - Thelephora fusca Fries, Syst. Myc. 1:451. 1821. - Thelephora vinosa Persoon, Syn. Fung. $2: 578$. 1801. - Tomentella fusca (Pers.) Schroeter, Krypt.-Fl. Schlesien $3: 419.1888$.

Type: existence of an authentic specimen unknown to me.

Fructification effused, membranaceous, separable, cinnamon-drab, darkening to Benzo-brown and Natal-brown; structure in section $200-350 \mu$ thick, with a few hyphae running along the substratum and ascending and branching or giving off suberect, loosely interwoven branches; hyphae concolorous

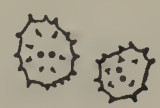

Fig. 6

H. fuscus. Spores $\times 640$. with the fructification but rather pale under the microscope, 
nodose-septate, 4-6 $\mu$ in diameter, sometimes collapsed; basidia with 4 sterigmata; spores darker than the hyphae, subglobose, sometimes flattened on one side, the spore body $6-7 \mu$ in diameter and short-aculeate in European and occasional American specimens, but more commonly $6-8 \times 6 \mu$ and echinulate in American specimens.

Fructifications 2-10 cm. long, 1-2 cm. broad.

On rotten coniferous and frondose wood of several species. Canada and New Brunswick to New Jersey and in Montana. July to October.

In the color of $H$. fuscus, there is a perceptible vinaceous component by which the species may be approximately recognized at sight. Confirmatory characters are the separable fructification and microscopical details of sections. The spores of most American specimens have slenderer and longer spines than those of European collections. H. fuscus is presented here as understood by Bresadola.

Specimens examined:

Sweden: Stockholm, L. Romell, 224 .

Hungary: $A$. Kmet, comm. by G. Bresadola.

Canada: locality not given, J. Macoun, 14; Ottawa, J. Macoun, 28.

New Brunswick: Campobello, W. G. Farlow, 4.

Massachusetts: Magnolia, W. G. Farlow, two collections.

New York: Albany, H. D. House \& Jos. Rubinger (in Mo. Bot. Gard. Herb., 8736); East Galway, E. A. Burt; Potsdam, $J . B$. Ellis (in Farlow Herb.).

New Jersey: Newfield, J. B. Ellis (in N. Y. Bot. Gard. Herb., under the name Thelephora floridana).

Montana: Missoula, J. R. Weir, 400 (in Mo. Bot. Gard. Herb., 22161).

7. H. spongiosus (Schw.) Burt, n. comb.

Thelephora spongiosa Schweinitz, Naturforsch. Ges. Leipzig Schrift. 1:109. 1822; Am. Phil. Soc. Trans. N. S. 4:168. 1834; Fries, Elenchus Fung. 1:193. 1828; Sacc. Syll. Fung. 6:545. 1888. - Hypochnus obscuratus Karsten, Hedwigia 35:46. 1896; Sacc. Syll. Fung. 14:226. 1900. 
Type: in Herb. Schweinitz.

Fructification effused, soft, felty-membranaceous, separable, in color varying from Saccardo's umber to bister, rarely fuscous, the margin thinning out and barely determinate; in structure $200-1200 \mu$ thick, with hyphae concolorous with the fructification, thick-walled, even, loosely interwoven, branching at a wide angle, abundantly nodose-septate, $41 / 2-5 \mu$ in diameter or rarely $6 \mu$; basidia with 4 sterigmata; spores concolorous, globose, or subglobose and flattened on one side, echinulate, about $6 \mu$ in diameter,

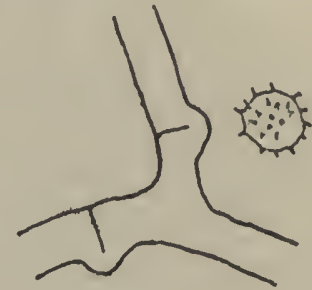

Fig. 7

H. spongiosus. Hypha, spore $\times 640$. or $6-9 \times 6-7 \mu$.

Fructifications 4-10 cm., and more, long, 2-5 cm. broad.

On rotten wood and bark of both frondose and coniferous species. Canada to North Carolina and westward to Montana, and in Bahama Islands. July to November. Probably common.

$H$. spongiosus belongs in the group with $H$. fuscus, $H$. umbrinus, and $H$. spiniferus. The absence of a vinaceous component in its color is a useful character for separation at a glance from $H$. fuscus. If the surface of $H$. spongiosus is viewed with a lens, the component fibers are seen running in all directions, as in felt or blotting paper. H. umbrinus has its hyphae lacking clamp connections, i. e., not nodoseseptate, and its basidia form a compact hymenium. H. spiniferus differs by having its hyphae spiny.

Specimens examined:

Finland: Mustiala, $P$. A. Karsten, authentic specimen of Hypochnus obscuratus.

Canada: Quebec, Ironsides, J. Macoun, 255.

New Hampshire: Chocorua, W. G. Farlow, 14.

Vermont: Middlebury, E. A. Burt, three collections; Lake Dunmore, E. A. Burt.

New York: Albany, H. D. House (in N. Y. State Mus. Herb. and in Mo. Bot. Gard. Herb., 15833).

North Carolina: Schweinitz, type (in Herb. Schweinitz). Indiana: Miller, E. T. \& S. A. Harper, 758. 
Wisconsin: Lake Geneva, E. T. \& S. A. Harper, 950.

Montana: Evaro, J. R. Weir, 436, 438 (in Mo. Bot. Gard. Herb., 19515 and 19597 respectively).

Bahama Islands: A. E. Wight (in Farlow Herb.).

8. H. spiniferus Burt, n. sp.

Type: in Farlow Herb. and in Burt Herb.

Fructification effused, membranaceous, separable, tomentose, varying from sepia to fuscous ; in structure about $1000 \mu$ thick, with the hyphae loosely interwoven,

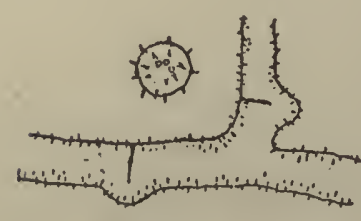

Fig. 8

H. spiniferus Hypha, spore $\times 640$. nodose-septate, thick-walled, concolorous with the fructification but darker near the substratum and spinulose, the paler hyphae rough-walled or even, body of largest hyphae $4-5 \mu$ in diameter, the spines about $1 \mu$ long, colored like the dark wall; basidia with 4 sterigmata; spores concolorous, globose, sometimes flattened on one side, echinulate, the body $6-8 \mu$ in diameter, or $6 \times 41 / 2-6 \mu$.

Fructifications about $5 \mathrm{~cm}$. long, $3 \mathrm{~cm}$. broad.

On rotten wood. New Hampshire and Massachusetts. August. Rare.

$H$. spiniferus is so similar to $H$. spongiosus in habit and coloration that it can be separated from the latter only by the distinctly spiny-walled and rough-walled hyphae of the former species. This character is as marked as in the capillitium of some Myxomycetes. The New Hampshire collections which I have included under $H$. spiniferus have roughwalled hyphae and no spines.

Specimens examined:

New Hampshire: Chocorua, W. G. Farlow, 11, and an unnumbered specimen collected in 1904. Massachusetts: Magnolia, W. G. Farlow, type.

9. H. granulosus (Peck) Burt, n. comb.

Grandinia tabacina Cooke \& Ellis, Grevillea 9:103. March, 1881, but not Hypochnus tabacinus Bresadola. - Zygodesmus granulosus Peck, Bot. Gaz. 6 :277. 1881. - Hypochnus elaeodes Bresadola, I. R. Accad. Agiati III. 3:115. 1897. 
Type: in Coll. N. Y. State.

Fructification effused, thin, membranaceous, separable from the substratum, granular, sepia, the margin somewhat radiate, concolorous or nearly so; in structure $200-400 \mu$ thick, composed of very loosely interwoven, thin-walled, occasionally nodoseseptate, hyphae $21 / 2-4 \mu$ in diameter, yellowish under the microscope, forming near the substratum some rope-like mycelial strands up to $15 \mu$ in diameter; spores concolorous with the hyphae, angular-subglobose, acule-

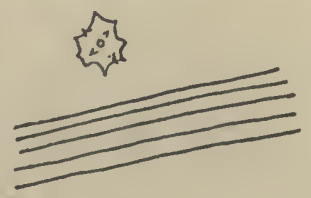

Fig. 9

H. granulosus. Spore, hyphal strand $\times 640$. ate, the body about $6 \mu$ in diameter; KHO solution produces no noteworthy color change in sections.

Fructifications $2-4 \mathrm{~cm}$. long, 1-2 $\mathrm{cm}$. broad.

On rotten bark and wood of frondose species. Massachusetts to New Jersey and Ohio. September to November. Rare.

$H$. granulosus is very closely related to $H$. coriarius and is distinguished from it by uniform color of the whole surface, while $H$. coriarius has the margin ochraceous-tawny. The lack of noteworthy color change by $\mathrm{KHO}$ solution is the only additional feature of difference for separating $H$. granulosus from $H$. coriarius. The specific name tabacina of Cooke and Ellis has priority, but is not now available because Bresadola has already used the name Hypochnus tabacinus for a valid species.

Specimens examined:

Exsiccati: Ellis, N. Am. Fungi, 421, under the name Zygodesmus chlorochaites.

Hungary: $A$. Kmet, authentic specimen of $H$. elaeodes from Bresadola, probably a portion of the type.

Massachusetts: Newton, W. G. Farlow; Mt. Tom, H. W. Harkness, type (in Coll. N. Y. State).

New York: Albany, H. D. House \& J. Rubinger (in Mo. Bot. Gard. Herb., 8733); Karner, H. D. House (in Mo. Bot. Gard. Herb., 44731); Alcove, C. L. Shear, 1316, in part. 
New Jersey: Newfield, J. B. Ellis, in Ellis, N. Am. Fungi, 421, and also the cotype of Grandinia tabacina (in N. Y. Bot. Gard. Herb.).

Ohio: A. P. Morgan, 525 (in N. Y. Bot. Gard. Herb., under the manuscript name Odontia olivacea).

10. H. olivascens (Berk. \& Curtis) Burt, n. comb.

Zygodesmus olivascens Berk. \& Curtis, Grevillea 3:145. 1875.

Type: type and cotype in Kew Herb. and in Curtis Herb. Fructification effused, thin, not separable, tomentose, citrine, yellowish citrine or buffy citrine, the margin thinning out; KHO solution dissolves some of the color upon coming in contact with the sections and becomes somewhat brownish in their vicinity; Fig. 10 in structure $150-200 \mu$ thick, with now and then H. olivascens. a hypha running along the substratum and
Spore 6040 . Spore $\times 640$. sending out suberect branches which branch repeatedly, become loosely interwoven, and are somewhat clustered; basal hyphae slightly colored, nodose-septate, thinwalled, $5-6 \mu$ in diameter; basidia with 4 sterigmata; spores subglobose, concolorous with the basal hyphae, aculeate-echinulate, the body about $6 \mu$ in diameter or $51 / 2-71 / 2 \times 51 / 2-7 \mu$.

Fructifications sometimes in little patches $1-2 \mathrm{~cm}$. long, $1 \frac{1}{2}-1 \mathrm{~cm}$. broad, sometimes growing more or less interruptedly over areas up to $15 \mathrm{~cm}$. long, $3 \mathrm{~cm}$. broad.

On very rotten wood and on bark of fallen branches of both coniferous and frondose species. New Brunswick to South Carolina. September to November. Probably common.

$H$. olivascens is readily distinguished from other species of Hypochmus by its conspicuous citrine color of some kind (flavovirens of Saccardo's 'Chromotaxia') which has been retained well by the original collection for more than sixty years. From the description, Tomentella flavovirens v. Hohn. \& Litsch. is but slightly, if at all, different from $H$. olivascens. 
Specimens examined:

Exsiccati: Ellis, N. Am. Fungi, 422, under the name Zygodesmus olivascens.

New Brunswick: Campobello, W. G. Farlow, 5.

New Hampshire: Chocorua, W. G. Farlow, 5, 6, 18.

Vermont: Weybridge, E. A. Burt.

Massachusetts: Magnolia, W. G. Farlow; Hyde Park, C. Bullard, comm. by W. G. Farlow; Sharon, A. P. D. Piguet (in Farlow Herb.); Stony Brook, G. R. Lyman, 167; Williamstown, W. G. Farlow, $\%$.

New York: North Greenbush, H. D. House, two collections (in N. Y. State Mus. Herb. and in Mo. Bot. Gard. Herb., 14852, 20191); Karner, H. D. House (in N. Y. State Mus. Herb. and in Mo. Bot. Gard. Herb., 44719); Ithaca, C. Thom, Cornell Univ. Herb., 13582.

New Jersey: Newfield, J. B. Ellis, in Ellis, N. Am. Fungi, 422.

Pennsylvania: Kittanning, D. R. Sumstine. Maryland: Takoma Park, C. L. Shear, 1064, 1082, 1092. South Carolina: Society Hill, M. A. Curtis, cotype (in Curtis Herb., 3204).

11. H. pilosus Burt, n. sp.

Type: in Burt Herb.

Fructification effused, byssoid, membranaceous, separable from substratum, dry, tomentose, drying Sayal-brown, the margin slightly paler, thin, narrow; hymenium even in places, somewhat granular and pitted elsewhere; structure in section $200-300 \mu$ thick, composed of hyphae about $4-41 / 2 \mu$ in diameter, branching at right angles, of the same color as the fructification, nodose-septate, rather rigid, very loosely interwoven, somewhat longitudinally interwoven next to the substratum; cystidia septate, sometimes granular incrusted, with the emergent portion colorless, thin-walled, cylindric,

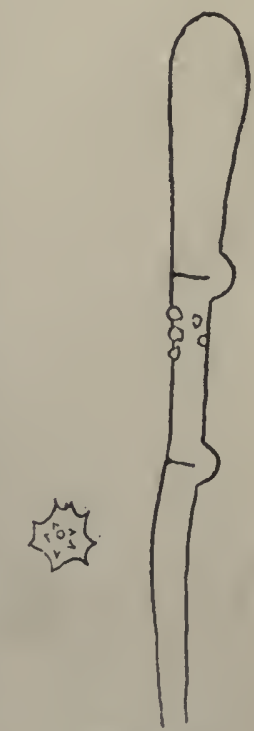

Fig. 11

H. pilosus. Spore, cystidium $\times 640$. $51 / 2-6 \mu$ in diameter, emerging $40-90 \mu$, tips obtuse or clavate; spores 4 to a basidium, slightly darker than 
the hyphae, subglobose-angular, aculeate, the spore body $7-9 \times 6 \mu$.

Fructification $8 \mathrm{~cm}$. long, 2-3 cm. broad - broken off at one end.

On bark of decaying Quercus alba, Lake Geneva, Wisconsin, July.

This fungus suggests Coniophora arida and $C$. puteana by its umber color and broadly effused fructifications, but it is a true Hypochnus, which is readily distinguished from other species of this genus by its color, hair-like cystidia, and the spores.

Specimens examined:

Wisconsin: Lake Geneva, E. T.\& S. A. Harper, 87\%.

12. H. isabellinus Fries, Obs. Myc. 2 :281. pl. 6. f. 3. 1818 and 1824; Sacc. Syll. Fung. 6:657. 1888; Bresadola, Ann. Myc. 1:106. 1903.

Corticium isabellinum (in section Hypochnus) Fries, Hym. Eur. 660. 1874. - H. argillaceus Karsten, Soc. pro Fauna et Flora Fennica Meddel. 6 :13. 1881; Sacc. Syll. Fung. 6: 661. 1888.

Type: there is a specimen from E. P. Fries in Curtis Herb.

Fructification effused, tomentose, thin, adnate, varying from deep olive-buff to dark olive-buff, the margin thinner, concolorous; in structure $60-200 \mu$,

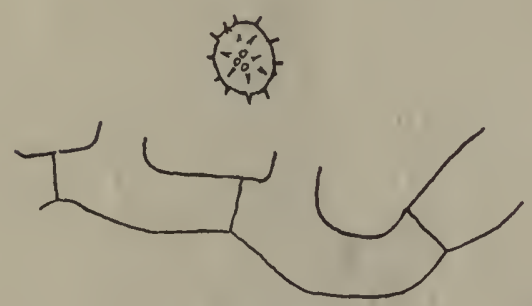

Fig. 12

H. isabellinus. Spore, hypha $\times 640$. rarely $300 \mu$, thick, with a few hyphae $8-10 \mu$, or more, in diameter, running along the substratum and sending out suberect, loosely interwoven branches; hyphae concolorous with the fructification, branching at right angles, thick-walled, not nodose-septate; basidia with 4 sterigmata; spores concolorous, globose, echinulate, the spore body $7-9 \mu$ in diameter.

Fructification 5-10 cm. long, $1 \frac{1}{2}-3 \mathrm{~cm}$. broad, and probably larger. 
On rotten wood and bark of both coniferous and frondose species. Canada to Florida, in Wisconsin and in Jamaica. May to January. Probably common.

$H$. isabellinus is a little thinner and a little paler than $H$. pannosus, and not separable from the substratum in the collections which I have studied. It is best distinguished from the latter species by the larger hyphae of $H$. isabellinus and lack of clamp connections.

Specimens examined:

Exsiccati: Ravenel, Fungi Am., 57b, under the name Zygodesmus pannosus; Thümen, Myc. Univ., 2275, under the name $Z$ ygodesmus pannosus.

Sweden: Upsala, Halmbyboda, from E. P. Fries (in Curtis Herb.) ; Stockholm, L. Romell, 219-222; Femsjö, L. Romell, 223, and E. Fries (in Herb. Fries under the manuscript name Hypochnus leprosus).

Canada: Rockcliffe Park, J. Macoun, 144; St. Lawrence Valley, J. Macoun, 2.

New Hampshire: Chocorua, W. G. Farlow, two collections. New Jersey: Newfield, J. B. Ellis, in Thümen, Myc. Univ., 2275.

Florida: Gainesville, H. W. Ravenel, in Ravenel, Fungi Am., $57 \mathrm{~b}$.

Wisconsin: New London, E. T.\& S. A. Harper, 949; Stevens Point, C. J. Humphrey, 1948 (in Mo. Bot. Gard. Herb., 4748).

Jamaica: Cinchona, W. A. \& Edna L. Murrill, N. Y. Bot. Gard., Fungi of Jamaica, 630.

13. H. pannosus (Berk. \& Curtis) Burt, n. comb.

Zygodesmus pannosus Berk. \& Curtis, Grevillea 3:112. 1875.

Type: cotype in Curtis Herb.

Fructification effused, byssoid-membranaceous, separable when well developed, tomentose, varying in brown from Saccardo's umber and snuff-brown to cinnamon-brown, the margin concolorous and thinning out; in structure 120-350 $\mu$ thick, with an occasional hypha running along the substratum 
but composed for the most part of suberect, branching, loosely interwoven, nodose-septate, thick-

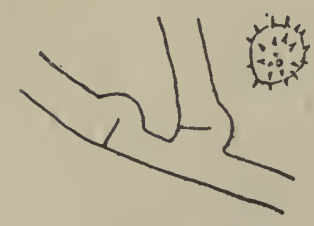

Fig. 13

H. pannosus. Spore, hypha $\times 640$. walled hyphae concolorous with the fructification, $4-6 \mu$ in diameter; basidia with 4 sterigmata; spores concolorous with the fructification, subglobose, sometimes flattened on one side, echinulate, the body $6-8 \times 5-7 \mu$.

Fructification $3-6 \mathrm{~cm}$. long, $1 \frac{1}{2}-3 \mathrm{~cm}$. broad.

On rotten wood and bark, usually of frondose species, and on the ground in woods. Canada to Louisiana; occurs in Europe also. September to December. Probably common.

$H$. pannosus and $H$. isabellinus are species of brown color approaching clay-color, and of cottony surface, which cannot be distinguished from each other with certainty except by microscopic characters. Well-developed fructifications of $H$. pannosus are thicker than those of $H$. isabellinus but thin fructifications of the former are frequently collected. $H$. pannosus has nodose-septate hyphae 4-6 $\mu$ in diameter, while the hyphae of $H$. isabellinus are not nodose-septate and next to the substratum are 8-10 $\mu$, or more, in diameter, and occasionally $15 \mu$ in diameter. KHO solution produces no noteworthy color change. The collection from Washington, referred with doubt to this species, has the spores with body $6 \times 41 / 2 \mu$, aculeate with scattered, very short points.

Specimens examined:

Sweden: Stockholm, L. Romell, 225; Femsjö, L. Romell, 228. Canada: Quebec, Ironsides, J. Macoun, 2rya.

New Hampshire: Chocorua, W. G. Farlow, 7,8 , and an unnumbered specimen; Shelburne, W. G. Farlow, 1.

Vermont: Middlebury, E. A. Burt.

Massachusetts: Magnolia, W. G. Farlow, c; Williamstown, W. G. Farlow, 5.

South Carolina: Santee Canal, Ravenel, 1117, cotype (in Curtis Herb., 3007).

Louisiana: St. Martinville, A. B. Langlois, cs. 
?Washington: Bingen, on Pinus ponderosa, W. N. Suksdorf, 860.

14. H. avellaneus Burt, $n$. sp.

Type: in Burt Herb.

Fructification effused, soft, membranaceous, separable, upper side between cartridge-buff and olive-buff and under side fuscous, the margin narrow, radiate, colored like the upper surface or whitish; in structure $300-400 \mu$ thick, with the hyphae snuff-brown under the microscope, thick-walled, nodose-septate, rather compactly interwoven; basidia 4-spored; spores concolorous with the hyphae, angular-subglo-

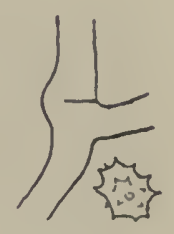

Fig. 14 H. avellaneus. Hypha, spore $X$ 640 . bose, aculeate, the body $6-71 / 2 \times 6 \mu$.

Fructification $5 \mathrm{~cm}$. long, $1 \mathrm{~cm}$. broad.

On wood of red fir in woods. Washington. October.

This species is marked by the pale color (nearly avellaneus of Saccardo's 'Chromotaxia') of the upper surface and margin and the fuscous subiculum.

Specimens examined:

Washington: Olympia, C. J. Humphrey, 6305, type.

15. H. sparsus Burt, n. sp.

Type: in Farlow Herb. and in Burt Herb.

Fructification effused, very thin, byssoid, not

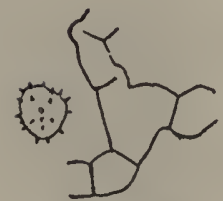

Fig. 15

H. sparsus. Spore, hypha $\times 640$. forming a membrane, adnate, drab, the margin of the same color, indeterminate; in structure 60 $75 \mu$ thick, with the hyphae hyaline under the microscope, short-celled, irregular in form and diameter, nodose-septate; basidia 4-spored; spores grayish olive under the microscope, echinulate, $6-7 \times 6 \mu$; no noteworthy color change by $\mathrm{KHO}$ solution.

Fructification 2-3 cm. long, 1-2 cm. broad.

On bark of fallen frondose limbs. New Hampshire. August.

When better known from other collections, $H$. sparsus may prove to be $H$. pannosus very sparsely developed. At pres- 
ent it appears distinct from the latter by its adnate, very thin fructification and short-celled, hyaline hyphae of irregular form and mode of branching.

Specimens examined:

New Hampshire: Madison, W. G. Farlow, 15, type; Chocorua, W. G. Farlow, 16.

16. H. epigaeus Burt, n. sp.

Type: in Farlow Herb. and in Burt Herb.

Fructification effused, soft, felty-membranaceous, tomentose, light mineral-gray, the margin thinning out and indeterminate; in structure $400 \mu$ thick, with hyphae hyaline, $4 \mu$ in diameter, thick-walled, no-

$\square \square$

Fig. 16

H. epigaeus. Spores $\times 640$. dose-septate, densely interwoven for $100 \mu$ next the substratum and then suberect and ascending side by side to the hymenium; basidia with 4 sterigmata; spores hyaline to deep olive-buff under the microscope, angular-globose, roughwalled or aculeate with very short points; spore body $6-7 \mu$ in diameter.

Fructification about $2 \mathrm{~cm}$. in diameter.

Running over ground among small mosses. Massachusetts. August.

This species is marked by its color, two-layered fructification, thick-walled and hyaline hyphae, and spores hardly more than rough-walled. H. cinerascens occurs on wood, is drab-gray, and has very thin-walled and delicate, loosely arranged hyphae $2-3 \mu$ in diameter, and smaller spores than $H$. epigaeus. $H$. chalybeus, as received from Bresadola, is pale at the surface only and has colored hyphae constituting the greater part of the fructification.

Specimens examined:

Massachusetts: Manchester, W. G. Farlow, 2, type.

17. H. botryoides (Schw.) Burt, n. comb.

Thelephora botryoides Schweinitz, Naturforsch. Ges. Leipzig Schrift. 1:109. 1822. - T. olivacea $\beta$ T. botryoides Fries, Elenchus Fung. 1:198. 1828; Schweinitz, Am. Phil. Soc. Trans. N. S. 4:168. 1834; Fries, Epicr. 543. 1838. - T. 
granosa Berk. \& Curtis, Grevillea 1:149. 1873; Sacc. Syll. Fung. 6:546. 1888. - Hypochnus granosus (Berk. \& Curtis) Bresadola, Ann. Myc. 1:108. 1903. - Zygodesmus bicolor Cooke \& Ellis, Grevillea 7:6. 1878.

Type: in Herb. Schweinitz.

Fructification effused, membranaceous, separable, drying Chaetura-drab to fuscous, the margin much paler, brownish and floccose; hymenium distinctly and closely granular; in section $300-400 \mu$ thick, with hyphae $3-4 \mu$ in diameter, nodose-septate, somewhat colored, thin-walled, a few running along the substratum, or forming rope-like strands, and sending out suberect, loosely interwoven branches which form the greater part of the fructification; KHO solution caus-

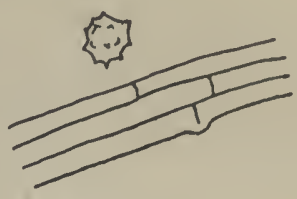

Fig. 17 H. botryoides. Spore, hyphal strand $\times 640$. es an immediate change of color in the tissue of the granules to between blue-green and sage-green when added to bits of the fructification in microscopic preparations; spores concolorous with the fructification, angularsubglobose, aculeate, the spore body $5-6 \times 4-5 \mu$.

Fructifications 1-5 cm. long, 1-4 cm. broad.

On rotten wood, both coniferous and frondose. New Hampshire to South Carolina and Alabama. August to January.

The fuscous color of the central portion of the fructification, paler margin, and occurrence of granules about 4 to the $\mathrm{mm}$. afford a good combination of characters for the recognition of $H$. botryoides by microscopic characters. Occasionally a fructification may vary towards Mars-brown. The blue-green color produced in the granules in microscopic preparations by adding $\mathrm{KHO}$ solution is a good positive character for this species, but is merely temporary.

Specimens examined:

Exsiccati: Ellis, N. Am. Fungi, 420, under the name Zygodesmus bicolor $\mathrm{C} . \& \mathrm{E}$.

New Hampshire: Chocorua, W. G. Farlow, 12, and also a collection of Sept., 1915 (in Farlow Herb. and in Mo. Bot. Gard. Herb., 8930).

Vermont: Middlebury, E. A. Burt, two collections. 
New York: Helderberg Mountains, C. H. Peck (in Coll. N. Y. State, under the name Zygodesmus bicolor C. \& E.).

New Jersey: Belleplain, C. L. Shear, 1253; Newfield, J. B. Ellis, in Ellis, N. Am. Fungi, 420.

Pennsylvania: Bethlehem, Schweinitz (in Herb. Schweinitz, as the Thelephora umbrina of Schweinitz, Syn. N. Am. Fungi, No. 578).

Maryland: Takoma Park, C. L: Shear, 1061, 1085.

North Carolina: Schweinitz, type (in Herb. Schweinitz).

South Carolina: M. A. Curtis, 2485, 3700, types of Thelephora granosa (in Kew Herb.). Alabama: Peters, type of T. granosa (in Kew Herb.).

18. $\mathbf{H}$. coriarius (Peck) Burt, n. comb.

Grandinia coriaria Peck, Buffalo Soc. Nat. Hist. Bul. 1:61. 1873; N. Y. State Mus. Rept. 26:71. 1874. - Hypochnus fulvo-cinctus Bresadola, I. R. Accad. Agiati Atti III. $3: 116$. 1897; Sacc. Syll. Fung. $14: 227.1900$.

Type: in Coll. N. Y. State.

Fructification effused, tomentose, membranaceous, separable from the substratum, under side and margin ochraceoustawny, upper side and minute crowded gran-

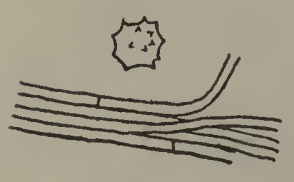

Fig. 18

H. coriarius. Spore, hyphal strand $\times 640$. ules brownish olive; in structure 200-350 $\mu$ thick, composed of closely arranged, somewhat interwoven, colored, thin-walled, occasionally nodose-septate, hyphae $21 / 2 \mu$ in diameter, forming occasional rope-like strands next to the substratum; basidia with 4 sterigmata; spores darker colored than the hyphae, subglobose-angular, aculeate, the body $5-6 \mu$ in diameter; KHO solution usually becomes dark colored next to the sections and changes the hymenial layer to sage-green.

Fructifications about $3-10 \mathrm{~cm}$. long, $11 / 2-4 \mathrm{~cm}$. broad.

On rotten wood, noted also on old leather and thallus of Peltigera aphthosa. Vermont to South Carolina and westward to Wisconsin. August to November.

This species is related to $H$. botryoides but may be distinguished from it by the more olivaceous color of the granu- 
lar region and brighter and more intensely colored margin and side next to substratum, and the rope-like hyphal strands next to substratum. The sage-green color given to hymenial tissue by $\mathrm{KHO}$ solution is a helpful determinative character in most cases; however, I have two collections which fail to give it. $H$. coriarius occurs in Herb. Schweinitz under the name Thelephora punicea Alb. \& Schw. The specimen is the No. 676 of Schweinitz, 'Syn. N. Am. Fungi'; it does not agree well with the original description of Albertini and Schweinitz and is not what European mycologists now understand as Thelephora (Hypochnus) punicea.

Specimens examined:

Hungary: A. Kmet, type of $H$. fulvo-cinctus (in Bresadola Herb.).

Vermont: Lake Dunmore, W. G. Farlow (in Farlow Herb.); Middlebury, E. A. Burt, three collections.

New York: Greenbush, C. H. Peck, type (in Coll. N. Y. State).

Pennsylvania: Kittanning, D.R. Sumstine; Bethlehem, Schweinitz (in Herb. Schweinitz, under the name Thelephora punicea).

South Carolina: Gourdin, C. J. Humphrey, 3281 (in Mo. Bot. Gard. Herb., 43118).

Ohio : C. G. Lloyd, 3882, 4199.

Wisconsin: Blue Mounds, E. T.\& S. A. Harper, 870.

19. H. bicolor Atkinson \& Burt, n. sp.

Type: in Burt Herb. and in Cornell Univ. Herb.

Fructification effused, membranaceous, separable, dry, central portion at the surface olive-ocher, underneath brownish drab and extended laterally as a brownish drab margin 1-5 mm. broad; structure in section about $400 \mu$ thick, (1) with the hyphae next the substratum slightly colored, thin-walled, lax,

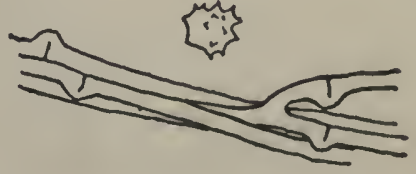

Fig. 19

H. bicolor. Spore, hypha $\times 640$. long-celled, nodose-septate, $3 \mu$ in diameter, either loosely interwoven or with some hyphae consolidated together into 
strands $6-15 \mu$ in diameter, and (2) with hyphae in the subhymenial region densely interwoven; no cystidia; basidia with spores on 4 slender sterigmata; spores olive-ocher, angular-subglobose, aculeate, the spore body $5-6 \times 41 / 2-6 \mu$; KHO solution changes the color of both the olive-ocher and the brownish drab hyphae to sage-green, later olive-gray.

Fructification $2 \mathrm{~cm}$. long, $11 / 4 \mathrm{~cm}$. broad, with the fertile, olive-ocher portion 5-10 mm. in diameter.

On dead wood in woods. New York. August.

The single collection of this species which has been found is conspicuous by its bright olive-ocher hymenial portion surrounded by a brownish drab margin. Both of these colors are destroyed when potassium hydrate solution is brought in contact with sections of the fructification in making microscopic preparations, and the hyphae become at once sagegreen, later olive-gray.

Specimens examined:

New York: Cascadilla Wood, Ithaca, C. J. Humphrey, comm.

by G. F. Atkinson, Cornell Univ. Herb., 22571.

o 20. H. atroruber (Peck) Burt, n. comb.

Zygodesmus atroruber Peck, Bot. Gaz. 6:277. 1881.

Type: in Coll. N. Y. State.

Fructification effused, membranaceous, separable, tomentose, with central portion granular and between walnut-

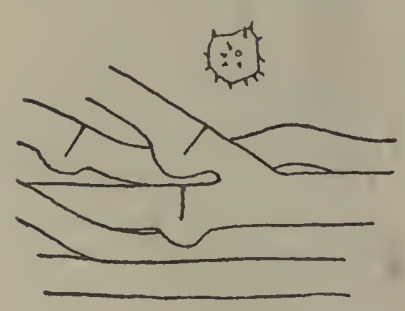

Fig. 20

H. atroruber. Spore, hyphal strand $\times 640$. brown and Vandyke-brown, the margin often conspicuously umber or Isabellacolor (melleus of Saccardo's 'Chromotaxia'); structure in section $300-500 \mu$ thick, composed of loosely interwoven

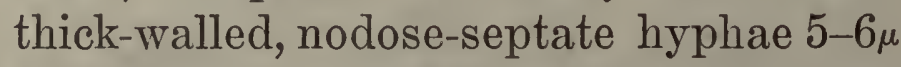
in diameter, concolorous with the fructification and connected with a few ropelike mycelial strands $12-20 \mu$ in diameter, which run along the substratum; basidia with 4 sterigmata; spores concolorous with the darker hyphae, subglobose, often flattened on one side, echinulate, the body $6-7 \times 5-6 \mu$.

Fructifications $3-6 \mathrm{~cm}$. long, 1-3 cm. broad. 
On decaying wood. New Hampshire to Maryland. September to January. Probably frequent.

H. atroruber is one of our finest species of the genus. It is conspicuous by the dark red central region bordered by a melleus (in the sense of 'Chromotaxia') margin. This margin was not noticed by Peck in the original description but is present on one side of his type. Specimens of $H$. atroruber lacking the characteristic melleus margin may be distinguished from $H$. rubiginosus by the coarser, darkercolored, thicker-walled hyphae of the former species.

Specimens examined:

Exsiccati: Ellis, N. Am. Fungi, 1390, under the name $Z y$ godesmus atroruber $\mathrm{Pk}$.

New Hampshire: Chocorua, W. G. Farlow, 10, and collection of Sept., 1915 (in Farlow Herb. and in Mo. Bot. Gard. Herb., 8931).

Massachusetts: Mt. Tom, H. W. Harkness, type of Zygodesmus atroruber Pk. (in Coll. N. Y. State); Magnolia, W. G. Farlow, b; Sharon, A. P. D. Piguet, comm. by W. G. Farlow, 21.

New Jersey: Newfield, J. B. Ellis, in Ellis, N. Am. Fungi, 1390.

Maryland: Takoma Park, C. L. Shear, 902, 1086.

21. H. subvinosus Burt, n. sp.

Type: in Burt Herb.

Fructification effused, thin, adnate, becoming granular, tomentose, vinaceous-brown, but becoming Rood's brown in the herbarium; in structure $250-300 \mu$ thick, composed of suberect, branching, loosely interwoven, thin-walled hyphae $4-5 \mu$ in diameter, not nodose-septate, colored near the substratum and hyaline near the basidia; basidia with 4

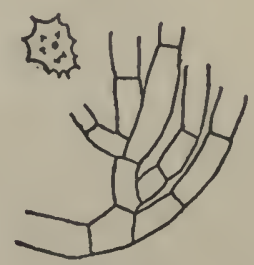

Fig. 21

H. subvinosus. Spore, hypha $\times 640$ sessile spores; spores umber, angular-subglobose, aculeate, the body $5-6 \mu$ in diameter, or 5-6 $\times 4-5 \mu$; no noteworthy color change by $\mathrm{KHO}$ solution.

Fructification $4 \mathrm{~cm}$. long, $21 / 2 \mathrm{~cm}$. broad. 
On bark of rotting frondose wood and on ground. New Hampshire to New Jersey. November. Rare.

The adnate habit, vinaceous-brown color of the fructifications, and the colored hyphae which are not nodose-septate, are the distinctive characters of $H$. subvinosus.

Specimens examined:

New Hampshire: Chocorua, W. G. Farlow, 3; Intervale, $R$.

Thaxter, 11 (in Farlow Herb. and in Mo. Bot. Gard. Herb., 43930).

Massachusetts: Sharon, A. P. D. Piguet, comm. by W. G. Farlow (in Mo. Bot. Gard. Herb., 43914).

New Jersey : Belleplain, C. L. Shear, 1251, type.

22. H. cervinus Burt, n. sp.

Type: in Burt Herb.

Fructifications in very small, interrupted, cir-

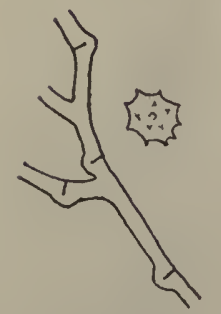

Fig. 22

H. cervinus. Hypha, spore $\times 640$. cular patches, becoming sometimes confluent and effused, byssoid, thin, not separable, fawn-color, with the under side and margin whitish; in structure $75-100 \mu$ thick, consisting of loosely interwoven, rather suberect, thin-walled hyphae $21 / 2-$ $3 \mu$ in diameter, nodose-septate, hyaline under the microscope; basidia with 4 sterigmata; spores slightly colored, subglobose, short aculeate, the body $5-6 \mu$ in diameter, or $6 \times 5 \mu$.

Fructifications 2-5 mm. in diameter, more or less confluent over an area $2 \mathrm{~cm}$. long, $1 \mathrm{~cm}$. broad.

On bark of dead Acer macrophyllum lying on the ground. Washington. November 1.

In the only collection which has been made, $H$. cervinus is characterized by its occurrence in very small, thin fructifications, not separable from substratum, fawn-color at the center with a whitish margin, and by having hyaline, nodoseseptate hyphae. $H$. cinerascens is of different color, thicker, and separable from the substratum.

Specimens examined:

Washington: W. Klickitat County, W. N. Suksdorf, 847, type.

23. $\mathrm{H}$. fuligineus Burt, $\mathrm{n}$. sp.

Type: in Burt Herb. and in Farlow Herb. 
Fructification effused, soft, felty-membranaceous, separable, upper surface pinkish buff to Isabella-color, under side and margin bister; in structure 200-1200 $\mu$ thick, with hyphae bister under the microscope, thick-walled, nodose-septate, $5-7 \mu$ in diameter, a few running next to and parallel with the substratum and giving off suberect, loosely interwoven branches of the same color, $31 / 2-41 / 2 \mu$ in diameter; basidia with 4 sterigmata; spores bister under the microscope, globose or subglobose, echinulate, the

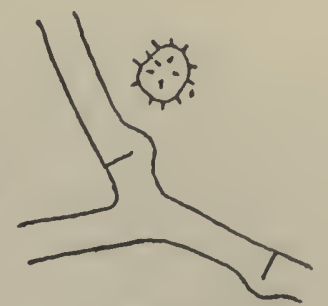

Fig. 23

$H$. fuligineus. Hypha, spore $\times 640$. body $6-7 \mu$ in diameter, or $6-9 \times 6-7 \mu$; no color change by KHO solution.

Fructification $4-10 \mathrm{~cm}$. long, 2-4 cm. broad.

On rotten frondose wood. New England and Wisconsin. August and September.

H. fuligineus is much thicker, firmer, and more spongy than $H$. atroruber and $H$. cinerascens, and differs from them further in coloration and in hyphal characters. In its thick spongy structure and microscopic details it suggests $H$. spongiosus to such a degree that I have been disposed to regard $H$. fuligineus as a subspecies of $H$. spongiosus but this seems precluded by the importance of color characters in Hypochnus.

Specimens examined:

New Hampshire: Chocorua, W. G. Farlow, 4, type.

Vermont: Middlebury, E. A. Burt.

Massachusetts: Magnolia, W. G. Farlow, $d$, and an unnumbered collection of 1903.

Wisconsin: Blue Mounds, E. T.\& S. A. Harper, 878.

24. H. cinerascens Karsten, Soc. pro Fauna et Flora Fennica Meddel. 16 :2. 1888; Finl. Basidsv. 441. 1889; Sacc. Syll. Fung. 9 :244. 1891; Bresadola, Ann. Myc. 1:108. 1903.

Tomentella cinerascens (Karst.) v. Höhnel \& Litschauer, K. Akad. Wiss. Wien Sitzungsber. 115 :1570. 1906.

Type: authentic specimen in Burt Herb. 
Fructification effused, byssoid, membranaceous, separable, drab-gray, the margin the same color or whitish; in structure

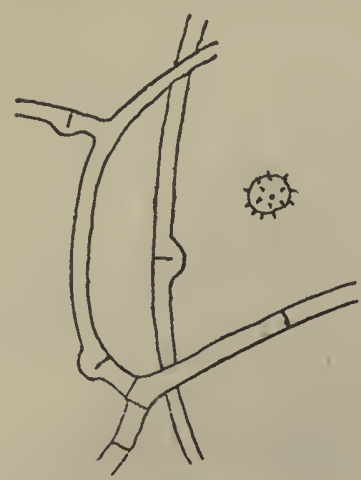

Fig. 24

H. cinerascens. Hyphae, spore $\times 640$. 200-350 $\mu$ thick, with the hyphae hyaline under the microscope, thin-walled, nodoseseptate, loosely interwoven; basidia with 4 sterigmata; spores drab-gray in a spore collection, globose, echinulate, the body $41 / 2-51 / 2 \mu$ in diameter.

Fructification 2-3 cm. long, 1-11/2 cm. broad.

On bark of Alnus. New Hampshire and Montana. September.

This species is distinguished from $H$. epigaeus by drab-gray color, fructification easily separable from substratum, occurrence on wood, smaller and echinulate spores, and hyphae of smaller diameter and more uniformly interwoven.

Specimens examined:

Finland: Mustiala, P. A. Karsten.

New Hampshire: Chocorua, W. G. Farlow, $1 \%$.

Montana: Missoula, J. R. Weir, 440 (in

Mo. Bot. Gard. Herb., 22144).

25. H. peniophoroides Burt, n. sp.

Type: in Burt Herb. and in N. Y. Bot. Gard. Herb.

Fructification long and widely effused, coriaceous, compact, adnate, glabrous, pinkish buff, the margin entire, determinate; in structure $300-400 \mu$ thick, stratose, composed of fine interwoven hyphae and numerous cystidia; hyphae concolorous with the fructification, $11 / 2 \mu$ in diameter, not nodose-septate, densely interwoven, dichotomously branched, and with antler-shaped hyphal branches especially noticeable at the surface of the hymenium; cystidia very

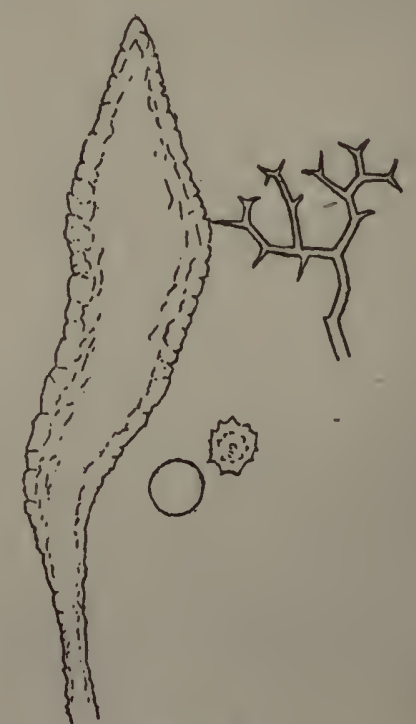

Fig. 25

H. peniophoroides. Cystidium, antler-shaped organ, spores $\times 640$. numerous in all regions of fructification, cylindric, acute, 36- 
$60 \times 12 \mu$, emerging up to $25 \mu$; basidia with 4 sterigmata; spores globose, becoming pinkish buff and tuberculate, the body $6 \mu$ in diameter.

Fructification more than $7 \mathrm{~cm}$. long, more than $4 \mathrm{~cm}$. broad.

On bark of rotten frondose wood in woods. Louisiana and Jamaica. September to November.

This species is included in Hypochnus on account of its mature spores, whose tubercules are short and small. The immature spores are hyaline and even; hence immature specimens of this species are likely to be referred to Peniophora. The presence in the hymenium of dichotomously branched, antler-shaped, hyphal branches such as are present in Corticium investiens and Grandinia granulosa is a unique character which I have not observed in any species of Peniophora and which should make possible identification of immature specimens. In habit, $H$. peniophoroides resembles Corticium portentosum and Thelephora pallescens Schw.

Specimens examined:

Louisiana: St. Martinville, A. B. Langlois, v.

Jamaica: Mooretown, F. S. Earle, type, N. Y. Bot. Gard., Plants of Jamaica, 540.

26. H. thelephoroides (Ell. \& Ev.) Burt, n. comb.

Corticium thelephoroides Ellis \& Everhart, Jour. Myc. 1:88. 1885; Sacc. Syll. Fung. 6:630. 1888.

Type: in N. Y. Bot. Gard. Herb., and portions in Kew Herb., Farlow Herb., and Mo. Bot. Gard. Herb.

Fructification effused, adnate, thick, compact, at first pale olive-buff, becoming warm buff in the herbarium, the under side and very narrow margin Saccardo's umber; in structure 150-1200 $\mu$ thick, with (1) a densely interwoven layer about $60 \mu$ thick next to substratum and (2) with a hymenial layer composed of hyphae, antler-shaped hyphal branches, and numerous imbedded, concolor-

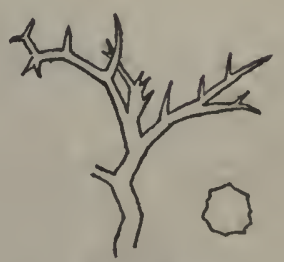

Fig. 26

H. thelephoroides. Antler-shaped organ, spore $\times 640$. ous spores; hyphae thick-walled, not nodose-septate, $11 / 2-2 \mu$ 
in diameter, honey-yellow under the microscope, forming in the interior of the layer and at the surface of the hymenium numerous dichotomously branched branches with subulate tips which resemble the antlers of a stag; basidia bearing 4 spores on sterigmata; basidiospores hyaline, or very nearly so, under the microscope, rough-walled or aculeate with very short points, globose, body $5-51 / 2 \mu$ in diameter; imbedded spores honey-yellow under the microscope, even or rarely rough, $5-6 \mu$ in diameter.

Fructification 1-4 cm. long, $1 / 2-2 \mathrm{~cm}$. broad, often in lobate, connected masses.

On fir logs. Washington and British Columbia. July.

The basidia of this species show best in the recent collection $120 \mu$ thick, from which the illustration has been made. The stage of the type is much thicker apparently by growth of great numbers of the antler-like hyphal branches which conceal the basidia. This species resembles closely in habit, structure, and spore characters Thelephora pallescens Schw. of eastern North America, except that the spores of $T$. pallescens show by magnification with a $11 / 2$-inch objective only rarely a minutely rough wall. $H$. peniophoroides differs by having cystidia.

Specimens examined:

Washington: Carpenter, 90, type (in N. Y. Bot. Gard. Herb.,

Kew Herb., and in Mo. Bot. Gard. Herb.).

British Columbia: Vancouver, J. Macoun, v. 178, comm. by

J. Dearness, (in Mo. Bot. Gard. Herb., 8938).

27. H. zygodesmoides (Ellis) Burt, n. comb.

Thelephora zygodesmoides Ellis, N. Am. Fungi (Exsic.), 715. 1882; Cooke, Grevillea $20: 34$. 1891; Sacc. Syll. Fung. $11: 117.1895$.

Type: Ellis, N. Am. Fungi, 715.

Fructification effused, thin, arachnoid-membranaceous, separable from the substratum, pinkish buff to cinnamonbuff and avellaneous, the margin of the same color, narrow, byssoid; in structure $200-400 \mu$ thick, with some rope-like strands up to $15 \mu$ in diameter next to the substratum; 
hyphae pinkish buff under the microscope, thinwalled, collapsing, not nodose-septate, very loosely interwoven, $31 / 2-5 \mu$ in diameter; basidia clavate, $28 \times 5 \mu$, with 4 short sterigmata; spores with a slight tinge of buff in collection on slide but hyaline under the microscope, ovoid, uneven to echinulate, the body $5-6 \times$ Spore, hypha 6640. $4-41 / 2 \mu$.

Fructifications 2-3 cm. long, 1-2 cm. broad.

Under side of decaying pine logs. Quebec to New Jersey. August to January. Rare.

In this species a loose subiculum is present next to the wood and bears on its surface a delicate hymenium, suggesting in habit Corticium arachnoideum but colored. Hypochnus zygodesmoides is not as bright yellow as $H$. echinosporus and has paler spores than the latter and not globose.

Specimens examined:

Exsiccati: Ellis, N. Am. Fungi, 715, under the name Thelephora zygodesmoides.

Quebec: Ironsides, J. Macoun, 266.

Vermont: Middlebury, E. A. Burt.

New Jersey: Newfield, J. B. Ellis, type, in Ellis, N. Am. Fungi, 715.

28. H. echinosporus (Ellis) Burt, n. comb.

Corticium echinosporum Ellis, Torr. Bot. Club Bul. 8:64.

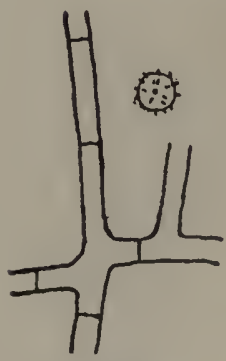

Fig. 28.

H. echinosporus. Hy. pha, spore $\times 640$. 1881; Sacc. Syll. Fung. 6:633. 1888; Wakefield, Brit. Myc. Soc. Trans. $5: 129.1915$.

Type: in N. Y. Bot. Gard. Herb.

Fructification effused, membranaceous, separable, Naples-yellow to deep colonial buff, the margin concolorous, scanty, indeterminate; in structure $200 \mu$ thick, consisting of a thin, soft, hymenial membrane upon the loosely interwoven threads of the subiculum; hyphae concolorous (sometimes hyaline under the microscope), thinwalled, not nodose-septate, $3-4 \mu$ in diameter, lax, very loosely interwoven, suberect, branching towards the 
outer end to form a membranous hymenium; no cystidia; basidia with 4 sterigmata; spores concolorous (sometimes hyaline under the microscope), globose, echinulate, the body $4-5 \mu$ in diameter.

Fructification 2-4 cm. long, 1-2 cm. broad.

On rotting pine wood and bark. Canada to Louisiana and in Oregon; occurs in Sweden also. August to December.

The distinguishing characters of $H$. echinosporus are its bright yellow fructifications of somewhat a straw-colored yellow, with hyphae and globose echinulate spores of the same color. Under the microscope this tint of yellow is not very intense and may be unnoticed, and regarded as hyaline. Bresadola ${ }^{1}$ regards Corticium echinosporum as a synonym of $H$. pellicula Fr. (=Corticium mollis var pellicula Fr.). The specimen which Karsten has communicated to me as Corticium pellicula Fr. has even spores and incrusted hyphae and is a true Corticium. It seems best to regard $H$. echinosporus as valid until there is found an earlier name supported by an authentic specimen. It is only rarely possible to recognize resupinate species of the higher fungi from the descriptions alone of the earlier mycologists.

Specimens examined:

Exsiccati: Ellis, N. Am. Fungi, 608, under the name Corticium echinosporum.

Sweden: Stockholm, L. Romell, 154.

Quebec: Hull, J. Macoun, 385.

Ontario: Ottawa, J. Macoun, 668.

New York: Freeville, G. F. Atkinson, Bot. Dept. Cornell Univ., 3277 ; Ithaca, G. F. Atkinson, 22762.

New Jersey: Newfield, J. B. Ellis, in Ellis, N. Am. Fungi, 608.

Louisiana: Abita Springs, A. B. Langlois, 2638.

Oregon: Corvallis, W. A. Murrill, N. Y. Bot. Gard., Fungi of Oregon, 921, 922 (in N. Y. Bot. Gard. Herb. and in Mo. Bot. Gard. Herb., 5690 and 8937).

\section{H. fibrillosus, Burt, n. sp.}

Type: in Burt Herb.

${ }^{1}$ Ann. Myc. 1:107. 1903. 
Fructification widely effused, thin, with surface a reticulate, felty web, perforate, not separable, between olive-buff and deep olive-buff; in structure 100-150 $\mu$ thick, with hyphae thick-walled, nodose-septate, giving their color to the fructification but nearly hyaline under the microscope, $3-31 / 2 \mu$ in diameter, minutely rough-walled near the substratum and sending out loosely interwoven branches which bear clusters of basidia; basidia $18 \times 5 \mu$, bearing 4 spores on short sterig-

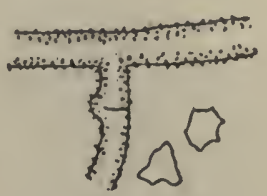

Fig. 29

H. fibrillosus. Spores, hypha $\times 640$. mata; spores concolorous with the hyphae, angular, the body $3-31 / 2 \mu$ in diameter.

The specimen, $6 \mathrm{~cm}$. in diameter, is a portion of a large specimen and does not show the natural margin.

On very rotten coniferous wood. Canada. September.

This species has the general habit and color of Corticium vagum and is well characterized by its general habit, pale color, and small angular spores.

Specimens examined:

Canada: locality not stated, J. Macoun, 25, Sept. 29, 1892.

0 30. H. fumosus Fries, Obs. Myc. 2:279. 1818 and 1824.

Corticium fumosum Fries, Epicr. 562. 1838; Hym. Eur. 651. 1874; Sacc. Syll. Fung. 6:613. 1888. - Phlebia vaga Fries, Syst. Myc. 1:428. 1821; Elenchus Fung. 1:155. 1828; Epicr. 527. 1838; Hym. Eur. 625. 1874; Sacc. Syll. Fung. 6:498. 1888; Bresadola, I. R. Accad. Agiati Atti III. 3 :105. 1897.Corticium sulphureum Pers. Obs. Myc. 1:38. 1796, but not Corticium sulphureum Fries. - Odontia fusca Cooke \& Ellis, Grevillea $9: 103.1881$; Sacc. Syll. Fung. 6:509. 1888.

Fructification effused, membranaceous, separa-

용 ble, with the outer surface more or less overrun with intricate, branching, anastomosing threads,

Fig. 30 then granular, honey-yellow to drab and fuscous, $\mathrm{H}$. fumosus. the margin whitish or yellowish, flaxy-fibrillose, Spore $\times 640$.

radiating; in structure about $200 \mu$, rarely up to $500 \mu$, thick, with hyphae longitudinally interwoven, occasionally nodose-septate, $21 / 2-31 / 2 \mu$ in diameter, thin-walled, hyaline, or slightly smoky if the fructification is dark colored; no 
cystidia; basidia with 4 sterigmata; spores white in collection on slide, ovoid, minutely echinulate with short crowded spines, spore body $3-5 \times 21 / 2-31 / 2 \mu$.

Fructifications 3-10 cm. long, 11/2-4 cm. broad.

On rotten wood and bark of both coniferous and frondose species. Canada to North Carolina and westward to Washington, and in Jamaica. April to January. Common.

Collections of this species have been placed by recent authors in the genera Corticium, Phlebia, and Odontia, as an anomalous species which has no relationship to the species proper of these genera. The affinities of this fungus are with the species of Hypochnus by habit, dry hypochnoid structure, form of hymenial surface, and form of spore. The species is best regarded as a hyaline-spored Hypochnus, which is naturally connected with the dark-spored members of this genus by the pale-spored $H$. echinosporus, $H$. zygodesmoides, etc. The existence of an authentic specimen of $\mathrm{Hy}$ pochnus fumosus is unknown to the writer, but this fungus is so distinguished among the species of Thelephoraceae that the lack of such a specimen is not serious in this case. Romell and Bresadola regard this fungus as the $H$. fumosus of Fries. My own study of the large series of Scandinavian Thelephoraceae received from Romell and Karsten leads me to the same conclusion.

Specimens examined:

Exsiccati : Ellis, N. Am. Fungi, 509; Ell. \& Ev., Fungi Col., 1018, in both under the name Odontia fusca.

Sweden: Stockholm, L. Romell, 96 .

Austria-Hungary: Tatra Magna, V. Greschik, two collections, comm. by G. Bresadola.

Canada: locality not stated, J. Macoun, 27; Lower St. Lawrence Valley, J. Macoun, 23.

New Brunswick: Campobello, W. G. Farlow, 6 .

Ontario: Ottawa, J. Macoun, 24; Harraby, Lake Rosseau, E. T. \& S. A. Harper, 744 .

British Columbia: near Salmo, J. R. Weir, 460, 528 (in Mo. Bot. Gard. Herb., 9207 and 22647 respectively). 
New Hampshire: Chocorua, W. G. Farlow, 3.

Vermont: Middlebury, E. A. Burt, three collections. Massachusetts: W. G. Farlow (in Farlow Herb.).

New York: Albany, H. D. House \& J. Rubinger (in Mo. Bot. Gard. Herb., 6327); Alcove, C. L. Shear, 1330; Floodwood, E. A. Burt, four collections; Sylvan Beach, Oneida Co., H. D. House (in Mo. Bot. Gard. Herb., 7664); Karner, H. D. House, 166, 168, 204 (in Mo. Bot. Gard. Herb., 44716, 44717 , and 44725 respectively).

New Jersey: Belleplain, C. L. Shear, 1252; Newfield, J. B. Ellis, and also two specimens distributed in his exsiccati.

Maryland: Takoma Park, C. L. Shear, 966.

North Carolina: Blowing Rock, G. F. Atkinson, Bot. Dept. Cornell Univ., 4197.

Wisconsin: Lake Geneva, E. T. \& S. A. Harper, 898.

Colorado: Portland Mine, Cripple Creek, C. J. Humphrey, ryz29.

Montana: Evaro, J. R. Weir, 423 (in Mo. Bot. Gard. Herb., 13273).

Idaho: Priest River, J. R. Weir, 16, 22, 43.

Washington: Bingen, W. N. Suksdorf, 853.

Jamaica: Monkey Hill, W. A. Murrill, N. Y. Bot. Gard., Fungi of Jamaica, 806.

31. H. aurantiacus (Pat.) Burt, n. comb.

Tomentella aurantiaca Patouillard, Soc. Myc. Fr. Bul. $24: 3$. 1908.

Fructification obscure, aurantiacus; hyphae fuscous under the microscope, nodose-septate, $2-3 \mu$ in diameter; spores angular-globose, fuscous, $5-8 \mu$ in diameter.

On bark of trees. Guadeloupe.-Description overlooked until too late for insertion near $H$. bicolor, with which specimens should be compared.

\section{Change of Name}

Sebacina plumbea Burt, Mo. Bot. Gard. Ann. 2.765. 1915, should be changed to Sebacina plumbescens Burt, for the former name is preoccupied by Sebacina plumbea Bres., which is not the same species.

(To be continued.) 
$v^{u}$

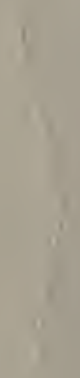




\section{The Thelephoraceae of North}

America. VII

\section{Septobasidium}

\section{- TiWAM ANGUS BURT}

Reprinted from Axvals oh trm Mibsourl Botanical. Garint 3:319-343. September. 1916 
ax. $=-1$

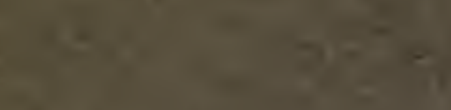

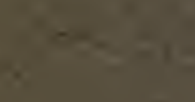

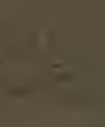

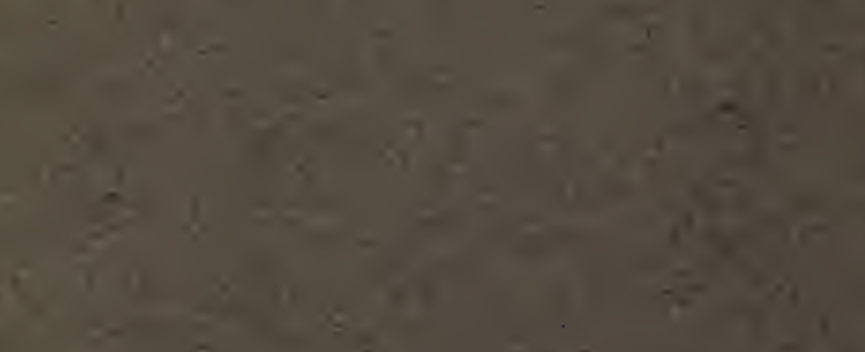

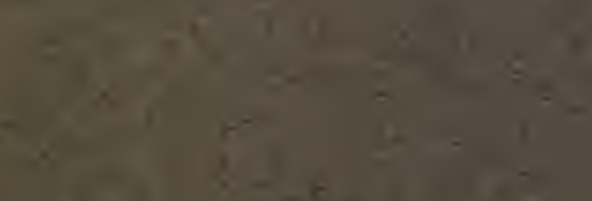

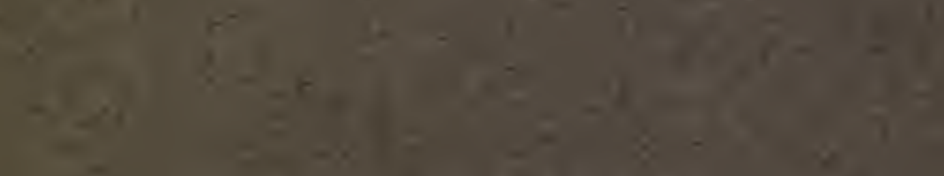

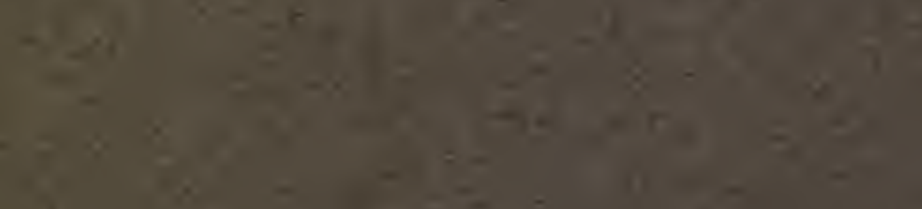

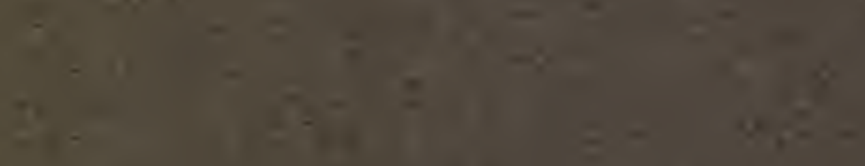

$+2$

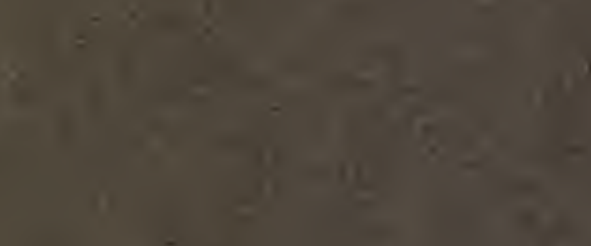

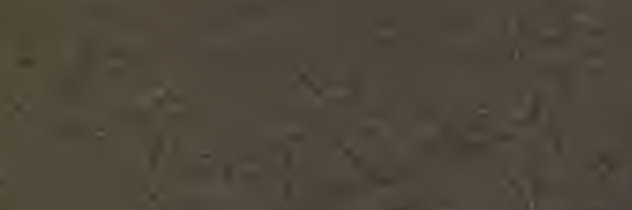

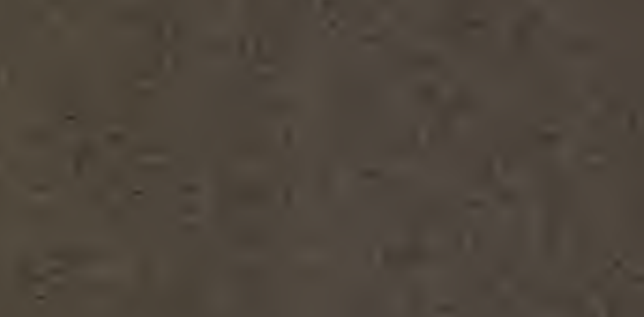

$3+2=-2$

$\$$ 


\title{
THE THELEPHORACEAE OF NORTH AMERICA. VII ${ }^{1}$
}

\author{
Septobasidium \\ EDWARD ANGUS BURT \\ Mycologist and Librarian to the Missouri Botanical Garden \\ Associate Professor in the Henry Shaw School of Botany of \\ Washington University
}

\section{SEPTOBASIDIUM}

Septobasidium Patouillard, Jour. de Bot. 6:61. textf. 1892; Essai Taxon. Hym. 7. 1900; Sacc. Syll. Fung. 11:118. 1895; ibid. $14: 215.1900$; ibid. $16: 184.1902$; ibid. $17: 203.1905$; ibid. 21 :445. 1913. - Jola Möller, A., Bot. Mitth. a. d. Tropfen 8, Protobasidiomyceten 22-29. pl. 4. f. 4. 1895; Engl. \& Prantl, Nat. Pflanzenfam. I.1**:84. 1897; Sacc. Syll. Fung. 14:245. 1900.

The genus was founded upon Septobasidium pedicellatum Pat. and Septobasidium velutinum Pat.

Fructifications resupinate, effused, coriaceous, producing probasidia upon the hyphae at or near the hymenial surface; the probasidia remain attached to the hyphae and either produce at the apex a few-celled, hyaline, spore-bearing filament, or elongate, become septate, and differentiate into such a filament, usually termed a transversely septate basidium; spores simple, hyaline, even, borne one to each cell by the terminal cell and next lower cells.

The spores are apparently produced in succession upon the spore-bearing organ rather than simultaneously, for in only two instances have I observed two spores present at the same time upon the same organ; in these the two spores were very unequal in size. One sees a spore attached to the terminal cell more frequently than to lower cells but perhaps

NoтE.-Explanation in regard to the citation of specimens studied is given in Part VI, Ann. Mo. Bot. Gard. 3:208, footnote. The technical color terms used in this work are those of Ridgway, Color Standards and Nomenclature. Washington, D. C., 1912.

1Issued November 4, 1916.

ANN. Mo. Bot. Gard., Vol. 3, 1916 
because of the more favorable position of the terminal cell. I have frequently observed a spore attached to some one or other of the upper three cells of the spore-bearing organ but have seen such attachment to the fourth cell only in $S$. castaneum, although often noting on the fourth cell in some species a lateral protuberance similar to those to which spores were attached in the upper cells. The spore-bearing stage is apparently of very brief duration, judging by the few collections which show this stage well. Specimens are usually collected sterile or with probasidia. It is hoped that the record given as to the month when each of our species has been collected in spore-bearing condition may aid in securing more valuable specimens for study in the future.

Septobasidium is not one of the genera of the Thelephoraceae, for its spore-producing organs are not simple basidia. The genus is treated here merely for the convenience of students of the Thelephoraceae, as in the case of Tremellodendron, Eichleriella, and Sebacina. The coriaceous structure and resupinate habit of the species of Septobasidium are so similar to those of Corticium and other resupinate genera of the Thelephoraceae that examination by the microscope of sections of the fructification is necessary to distinguish an unfamiliar species of Septobasidium from Corticium, etc. Many of the known species of Septobasidium were originally published as Corticiums and Thelephoras, and it is probable that careful study of authentic specimens of the earlier species of these genera will lead to the transfer of additional species to Septobasidium. It is possible that some authors may have mistaken the pyriform to globose probasidia of species of Septobasidium for conidia and have published such species as Hyphomycetes. The probasidia may be distinguished from hyphomycetous spores by the former bodies remaining attached to the hyphae; the probasidia do not float about loose in preparations.

I am indebted to Dr. R. P. Burke for transmitting to me in fresh condition spore-bearing material of three species of Septobasidium. Spore falls were obtained from this material for germination experiments and some material was 
fixed and preserved for a cytological study of Septobasidium during spore production. Discussion of the systematic relationships of Septobasidium may well await the completion of such study.

The species of Septobasidium are tropical or subtropical. Extreme northern stations, based on specimens examined by the writer, are London, Ontario, Canada, and Madison, Wisconsin-both are stations for $S$. pseudopedicellatum, which is the most frequent species of the United States.

With regard to the biology of Septobasidium, several specimens of this genus-usually of $S$. pseudopedicellatum-have been noted by their respective collectors as occurring especially on plants badly affected by scale insects. Other specimens show scale insects numerous about the fructification and overrun by it. Petch ${ }^{1}$ in a note on the biology of $\mathrm{Sep}$ tobasidium states that from examination of a long series of specimens, it has been determined that these fungi are parasitic on colonies of scale insects which they overgrow and destroy completely, and that these fungi live, not on secretions of the insects, but upon the insects themselves.

In addition to independent observations on the association of Septobasidium with scale insects, other facts tending to show an entomogenous adaptation of Septobasidium are the following:

(1) All species of Septobasidium known to the writer occur only on living branches or leaves, and in no instance has there been penetration by the fungus through the epidermis or bark into the living tissues of the substratum, or any injury or deformation or gall response by the branch or leaf.

(2) Spores are produced by S. pseudopedicellatum, in the region from North Carolina and Alabama to Porto Rico, in May when young colonies of the scale insects are forming. Mr. Seagle wrote to me that the old fructifications of $S$. pseudopedicellatum disappear from his apple trees in North Carolina in late spring and in early summer, and new fruc-

${ }^{1}$ Ann. Bot. 25:843. 1911. 
tifications grow which become large by early winter. The collections which I have studied, made during fall and early winter, have been in vegetative rather than in fruiting stage.

On the other hand, some specimens of Septobasidium in herbaria have no scale insects on the portions of twigs bearing the fructifications of Septobasidium, but I can not say as to whether these fructifications made their start on clean twigs or on scattered scale insects which they have completely overgrown and destroyed.

\section{Key to the Species}

Fructification having the hymenial layer or membrane raised above the substratum and supported on scattered pillars composed of parallel

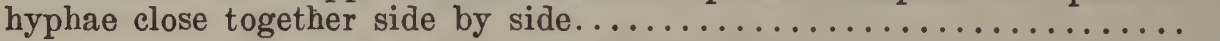

Fructification having the hymenial layer supported on pillars but with the pillars less regular in form than in the above and composed of loosely interwoven and curving hyphae. Known from Cuba......10. S. cirratum

Fructification lacking supporting hyphal pillars, with hyphae extending from substratum to the hymenial region without noteworthy consoli-

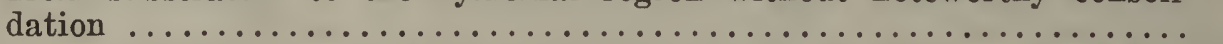

1. With erect or suberect paraphyses or hyphal branches at the surface of the

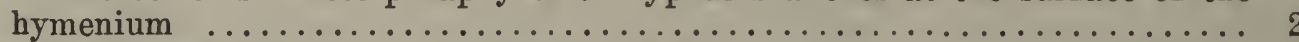

1. With surface of hymenium composed of longitudinally arranged and inter-

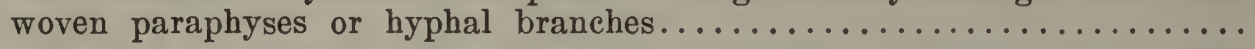

1. Structure of surface of hymenium not published; probasidia $20 \times 15-20 \mu$, persistent at the base of the spore-bearing organs; spore-bearing organs horseshoe-shaped, $35 \times 10 \mu$. In Cuba ................. S. pedicellatum

1. Structure of surface of hymenium not published; fructification black, shining, very thin. In Guadeloupe. ..................... S. atratum

2. Fructification $1 / 3-1 / 2 \mathrm{~mm}$. thick; probasidia $12 \times 7-9 \mu$; spore-bearing

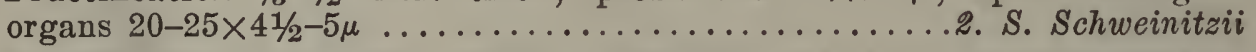

2. Fructification 1-11/2 mm. thick; probasidia $26 \times 11 \mu$; spore-bearing organs hook-shaped, up to $50 \times 8 \mu$. In Mexico ............ S. tropicale

2. Fructification 1-11/2 mm. thick; probasidia $13-25 \times 10-13 \mu$; spore-bearing organs straight, up to $60 \times 11 \mu$; spores $13 \times 51 / 2 \mu$. In Jamaica...

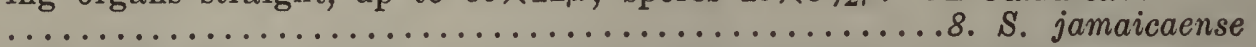

2. Fructification not-shining, velutinous, aniline-black, becoming fuscous in the herbarium; probasidia $15-20 \mu$ in diameter ....... S. Patouillardii

3. Fructification glabrous, shining......................... 4

4. Varying from avellaneous and wood-brown to cinnamon-brown; probasidia $12-20 \times 8-15 \mu$; spores $17-22 \times 4-5 \mu \quad \ldots$. ..4. S. pseudopedicellatum

4. Vandyke brown when in vegetative condition, olive-brown when fertile; probasidia $11-15 \times 9-10 \mu$; spores $12 \times 3-31 / 2 \mu \ldots \ldots \ldots .5$. S. castaneum

4. Olive-brown darkening to dark neutral gray; probasidia and spores unknown. In Nicaragua. ........................ S. sublilacinum

5. Fructification divided into many narrow, sinuous divisions, better shown

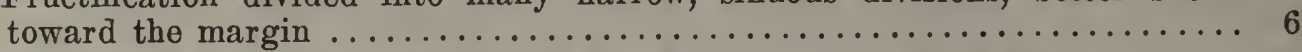

5. Fructification not divided but with surface reticulated with obtuse veins; at first drab or Prout's brown then Chaetura-drab..........13. S. retiforme

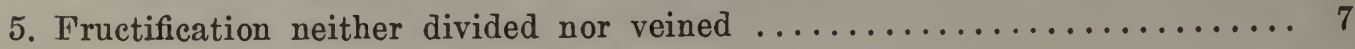


6. Plumbeous when bright colored, often smoke-gray or pallid mouse-gray,

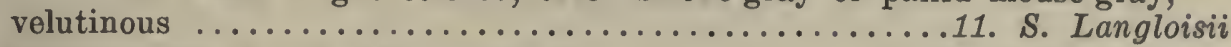

6. Honey-yellow to old gold, velutinous ................ S. frustulosum

7. Hymenial crust glabrous, between mouse-gray and hair-brown; middle region spongy, lacunose; fructification $11 / 2-2 \mathrm{~mm}$. thick. In Cuba.....

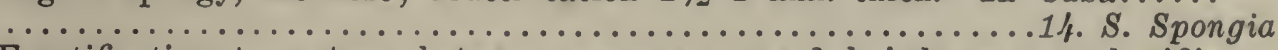

7. Fructification tomentose, between mouse-gray and hair-brown; probasidia $12-15 \mu$ in diameter; spores $12-15 \times 5-6 \mu \ldots \ldots \ldots \ldots \ldots . . . . .15$. S. fumigatum

7. Fructification pubescent, white at first, pale olive-buff in the herbarium; probasidia $15-17 \mu$ in diameter; spores $15-20 \times 51 / 2-6 \mu$. In California....

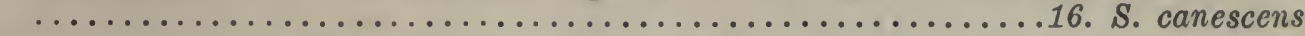

7. Fructification velutinous, between lilac-gray and pallid smoke-gray; probasidia up to $9 \mu$ in diameter; spores $11-13 \times 31 / 2-41 / 2 \mu$. In Trinidad......

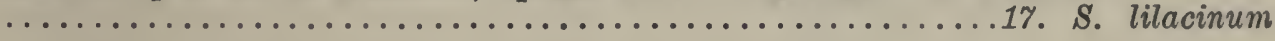

1. Septobasidium pedicellatum Patouillard, Jour. de Bot. $6: 61$. textf. 1892.

Thelephora pedicellata of C. Wright's Cuban Exsiccati, but not of Schweinitz.

Type: in Museum of Paris.

Fructification with pillars or pedicels composed of hyphae which branch towards the upper end and pass into and support the hymenial crust; probasidia subglobose, $20 \times 15-20 \mu$, arising as lateral outgrowths near the ends of the final branches of the hyphae, producing from the apex a hyaline, cylindric, spore-bearing organ, $35 \times 10 \mu, 2-3$-septate, which becomes horseshoe-shaped, slightly constricted at the septa, and has a small protruberance on the convex side of each cell; no spores seen.

The above is a summary of the account by Patouillard, ${ }^{1}$ of the structure of the specimen in the Museum of Paris, collected in Cuba by C. Wright and distributed by him in his Cuban exsiccati under the name Thelephora pedicellata. Wright made two collections in Cuba which were determined by Berkeley and Curtis ${ }^{2}$ as Thelephora pedicellata. Since Patouillard omitted the data on the label of the specimen which he studied, I do not know now which of Wright's numbers is the type collection and have to defer a fuller consideration of this species to the supplement to my monograph.

${ }^{1}$ Loc. cit.

'Linn. Soc. Bot. Jour. 10:329. 1868. 
2. S. Schweinitzii Burt, n. sp.

Thelephora pedicellata Schweinitz, Naturforsch. Ges. Leipzig Schrift. 1:108. pl. 2. f. 3. 1822; Fries, Elenchus Fung. 1:200. 1828; Epicr. 544. 1838; Sacc. Syll. Fung. 6:544. 1888. Not Septobasidium pedicellatum Pat.

Illustrations: Schweinitz, loc. cit.

Type: in Herb. Schweinitz.

Fructification resupinate, coriaceous, dry, not separable from the substratum, varying from drab and cinnamon-drab to wood-brown, the margin undulate, whitish; in structure 3-layered, with

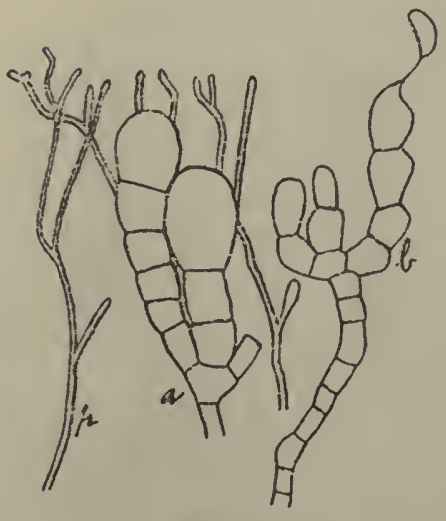

Fig. 1

S. Schweinitzii.

$a$, portion of hymenium showing paraphyses and two probasidia; $b$, spore-bearing organ and spore; $p$, paraphysis. $\times$ 640 .

(1) a layer next to the substratum of densely interwoven, colored hyphae $3-31 / 2 \mu$ in diameter, which form (2) a layer of erect hyphal pillars or pedi-

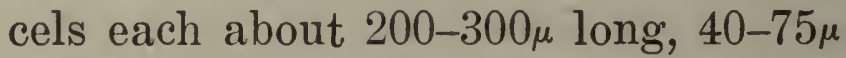
in diameter, about 2 to a millimeter, and pass into and support at the outer end (3) the hymenial layer $120-200 \mu$ thick, composed of densely interwoven, colored hyphae $3-31 / 2 \mu$ in diameter, of erect, flexuous, filiform, sparingly branched, hyaline paraphyses or hyphal branches about $11 / 2 \mu$ in diameter, and, when in fertile stage, of hyaline, thin-walled, erect probasidia, pyriform to subglobose, $12 \times$ $7-9 \mu$ in the type, borne on the colored hyphae; spores simple, hyaline, even, curved, $5 \times 21 / 2 \mu$ (as seen attached in the type but perhaps immature), borne singly at the apex of the terminal cell of a short filament $20-25 \times 41 / 2-5 \mu$, about 4 cells long, curved to fish-hook-shaped in form, which develops from the probasidium.

Fructifications 2 - several $\mathrm{cm}$. long, 1 - several $\mathrm{cm}$. broad, $1 / 3^{-1 / 2} \mathrm{~mm}$. thick.

On living branches. North Carolina to Louisiana. Frequent in winter. 
The above description is based on the Schweinitzian type and presents the characters of a rare species which has not been distinguished heretofore from the following $S$. pseudopedicellatum, a thicker, larger, common, and widely distributed species. S. Schweinitzii is characterized by its erect filiform paraphyses, curved to hook-shaped, spore-bearing organs, and small spores, although it is not certain that fullsized mature spores have yet been seen.

I refer to S. Schweinitzii a collection made by P. L. Ricker on Persea, in Georgia, during August, because this specimen has small probasidia, hook-shaped, few-celled, hyaline, sporebearing organs, and spores $7 \times 3 \frac{1}{2} \mu$; but in this specimen only a few paraphyses are present, the probasidia and hookshaped organs are at the very surface of the hymenium, and small, globose organs $5 \mu$ in diameter are occasionally present, borne laterally on the hyphae in the lower part of the hymenial layer. I have not studied with the microscope the Cuban specimen of S. pedicellatum, collected by C. Wright, one of the species upon the structure of which Patouillard founded the genus Septobasidium. He found this specimen to have probasidia and hook-shaped organs. Both probasidia and the hyaline organs are described as larger than they measure in the Schweinitzian type. In the Cuban specimen the probasidia are stated to be $20 \mu$ in diameter or 20 $\times 15 \mu$, and the hook-shaped organs as $35 \times 10 \mu$, and the former persist full size, with the septate hook-shaped organs connected with them like a promycelium with its teleutospore. These differences indicate that the Cuban specimen belongs to a species distinct from Thelephora pedicellata Schw. It is necessary to substitute a new specific name for "pedicellata" in making the transfer of Thelephora pedicellata Schw. to Septobasidium, because there is already a valid Septobasidium pedicellatum.

Specimens examined:

North Carolina: Schweinitz, type (in Herb. Schw.). Georgia: Bugaboo Island, Okeefenokee Swamp, P. L. Ricker, 921. 
Louisiana: Gibson, F. T. McLean, comm. by P. Spaulding.

3. S. tropicale Burt, n. sp.

Type: in Mo. Bot. Gard. Herb. and in Farlow Herb.

Fructification resupinate, effused, coriaceous, dry, not separable from substratum, glabrous, not shining, avellaneous, the margin concolorous, squamulose-fimbriate, not closely ad-

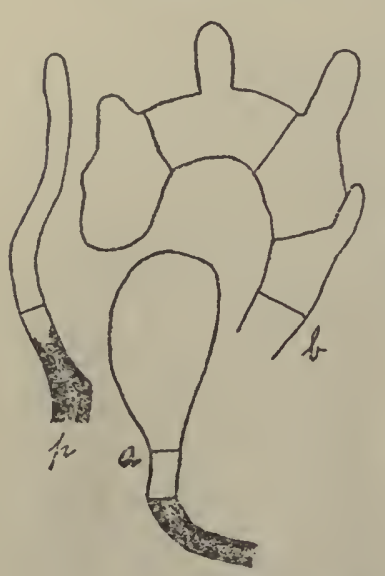

Fig. 2

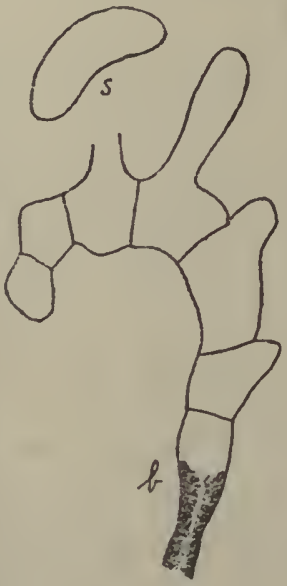

S. tropicale.

$a$, probasidium; $b$, two spore-bearing organs; $s$, spore; $p$, paraphysis. $\times$ 640 . nate; in structure 3-layered, with (1) a layer next to the substratum of densely interwoven, concolorous, thick-walled hyphae $3-31 / 2 \mu$ in diameter, which pass into and form (2) a layer of numerous erect, slender pillar's about $40 \mu$ in diameter, 5 or 6 to the millimeter, whose hyphae spread apart at the outer end, branch, and form and support (3) the hymenial crust about $200 \mu$ thick, densely interwoven throughout, with the even, thick-walled, colored hyphae up to $6 \mu$ in diameter on the under side, more erect, paler, and about $2 \mu$ in diameter at the surface; probasidia terminal on the hyphae, hyaline or but slightly colored, pyriform, $26 \times 11 \mu$, at the surface of the hymenium; a spore partially imbedded in the hymenium is hyaline, simple, even, curved, $19 \times 6 \mu$, no others seen; fish-hook-shaped organs, such as probably bear the spores, are present in the surface of the hymenium, several-celled, up to $50 \times 8 \mu$, with prominent protuberances from cells on the convex side of the organ.

Fructification $4 \mathrm{~cm}$. long, about $2 \mathrm{~cm}$. broad, 1-11/2 $\mathrm{mm}$. thick.

On bark of living branches of Quercus. Mexico.

The distinctive characters of this species are avellaneous color, surface not shining, margin squamulose-fimbriate, not closely adnate as in the preceding species, and thicker hy- 
menial crust not loosely interwoven on its under sides, probasidia terminal on the hyphae, and the large hook-shaped, presumably spore-bearing, organs of the upper surface. If these organs grow out from the probasidia, the probasidium must differentiate into the organ, for I have traced the curved organ back to the colored hyphal cells.

Specimens examined:

Mexico: locality not stated, C. G. Pringle, comm. by W. G. Farlow, 5 (in Mo. Bot. Gard. Herb., 44590).

\section{S. pseudopedicellatum Burt, n. sp.}

Thelephora pedicellata of most American authors but not of Schweinitz.

Type: in Mo. Bot. Gard. Herb.

Fructification resupinate, effused, coriaceous, dry, not separable from the substratum, varying from avellaneous and
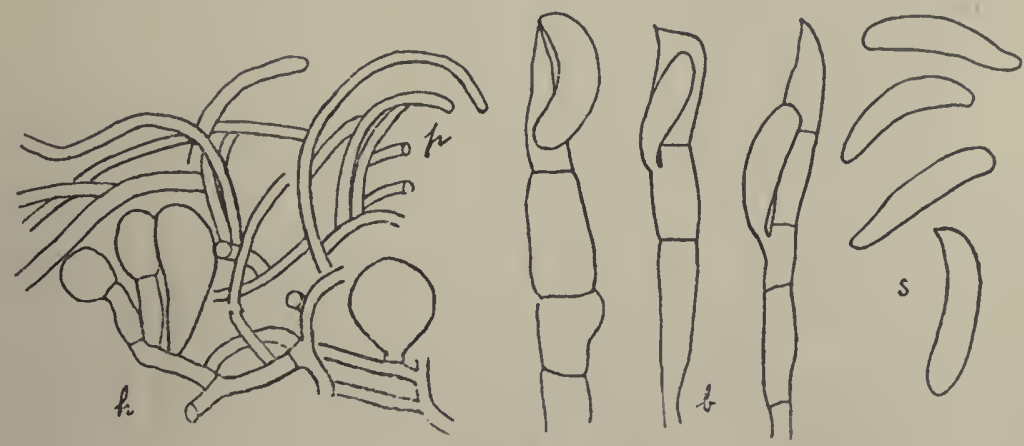

Fig. 3

S. pseudopedicellatum.

$h$, portion of hymenium showing the longitudinally interwoven hyphal ends or paraphyses and some probasidia; $b$, three spore-bearing organs; $s$, spores. $\times 640$.

wood-brown to cinnamon-brown, the margin undulate, whitish; in structure three-layered, with (1) a layer next to the substratum of densely interwoven, thick-walled, slightly colored hyphae $3 \mu$ in diameter, which form (2) a layer of erect, hyphal pillar's, or pedicels, each about $500 \mu$ long, 20 $40 \mu$ in diameter, about $3-5$ to a millimeter, whose hyphae spread apart at the upper end of the pillars, branch, and form and support (3) the hymenial crust about $300 \mu$ thick, with hyphae loosely interwoven near the pillars, $3-31 / 2 \mu$ in 
diameter, very dense at the outer surface with the hyphal branches or paraphyses $2 \mu$ in diameter, curved longitudinally along the surface and densely interwoven; erect probasidia nearly hyaline, rich in protoplasm, deeply staining, pyriform, $12-20 \times 8-15 \mu$, are borne laterally on the hyphae about $15 \mu$ below the surface of the hymenium; spores white in a spore

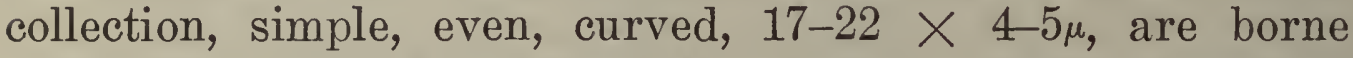
singly from each of the upper three cells (so far as observed) of a straight or flexuous, few-celled, hyaline organ up to $60 \times 5-51 / 2 \mu$, which grows from the probasidium and protrudes above the surface of the hymenium.

Fructifications 2-15 cm. long, 1-8 cm. broad, 1-11/2 mm. thick.

On small, living branches of apple, orange, oak, Nyssa, Cornus, Liquidambar, and also on orange leaves in one collection; sometimes, perhaps always, associated with scale insects. Canada to Florida and Louisiana and westward to Wisconsin; also in Cuba and Porto Rico. December to August; spores produced in the last of May.

S. pseudopedicellatum is the common Septobasidium of southeastern United States. It may be recognized by its brown, glabrous, shining, foliaceous crust which is raised and supported about a millimeter above the substratum on perpendicular, hyphal pillars which are as conspicuous as the rhizoids of a lichen. Old specimens may crack, break the hyphal pillars, and the hymenial crust curl outward so as to show the broken pillars attached to the under side. Sterile specimens of this species have been heretofore referred to $S$. pedicellatum, but a collection of fertile specimens received from Dr. R. P. Burke in May of the present year shows that our common species differs from $S$. pedicellatum by having large spores produced on a straight or but slightly curved, much larger, spore-bearing organ, paraphyses or hyphal branches at the surface of the hymenium curved and densely longitudinally interwoven, larger probasidia, and larger and thicker fructifications. Even in sterile condition the longitudinally interwoven paraphyses are sufficiently distinctive. 
Specimens examined:

Exsiccati: Ellis, N. Am. Fungi, 12, under the name Thelephora pedicellata.

Canada: Ontario, London, J. Dearness, 3396 (in Mo. Bot. Gard. Herb., 43802).

New Jersey: Newfield, J. B. Ellis; also from same locality in Ellis, N. Am. Fungi, 12.

Pennsylvania: Trexlertown, W. Herbst, comm. by Lloyd Herb., 2232.

North Carolina: Reepsville, J. P. Seagle, two collections, one of which was communicated by F. L. Stevens.

Florida: W.W. Calkins; Daytona, R. Thaxter, $75 a$ (in Farlow Herb. and in Mo. Bot. Gard. Herb., 43894); Kissimmee, comm. by F. C. Wolf (in Mo. Bot. Gard. Herb., 44205); same locality, B. E. Evans (in Mo. Bot. Gard. Herb., 44403); Ft. Myers, H. S. Fawcett (in Fawcett Herb.) ; Gainesville, H. E. Stevens, comm. by E. Bartholomew, 40b (in Mo. Bot. Gard. Herb., 44212).

Alabama: Peters, 75 (in Curtis Herb.) ; F. S. Earle \& C. F. Baker (in Lloyd Herb., 3454); Auburn, Alabama Biological Survey; Montgomery, R. P. Burke, 49, and the type collection (in Mo. Bot. Gard. Herb., 10979, and 20659, type).

Louisiana: Gibson, F. T. McLean, comm. by P. Spaulding; St. Martinville, A. B. Langlois, three collections, two of which are (in Lloyd Herb., 2411, 3533).

Kentucky: comm. by A. H. Gilbert (in Mo. Bot. Gard. Herb., 44323); "in mountains," P. Garman (in Mo. Bot. Gard. Herb., 44302).

Wisconsin: Madison, W. Trelease (in Mo. Bot. Gard. Herb., 5164).

Cuba: Ceballos, H. S. Fawcett, 10, 39 (in Mo. Bot. Gard. Herb., 15005, 15018); Isle of Pines, H. S. Fawcett, 15 (in Mo. Bot. Gard. Herb., 15094).

Porto Rico: Mayaguez, F. S. Earle, 79, N. Y. Bot. Gard. Herb. 
5. S. castaneum Burt, n. sp.

Type: in Mo. Bot. Gard. Herb.

Fructification resupinate, effused, coriaceous, dry, not separable from the substratum, glabrous, cracking in drying into pieces about $10 \times 5 \mathrm{~mm}$, olive-brown when fertile, Vandyke brown when in vegetative condition, the margin concolorous; in structure 3-layered, with (1) a layer next to substratum of opaque, concolorous hyphae $4 \mu$ in diameter, which form (2) a layer of pillared or spongy structure, in some places with pillars up to $150 \mu$ in diameter, about $1 \mathrm{~mm}$. apart, and in other places with a spongy mass of obliquely ascending, interwoven hyphae similar to those of the pillars. This layer supports (3) the

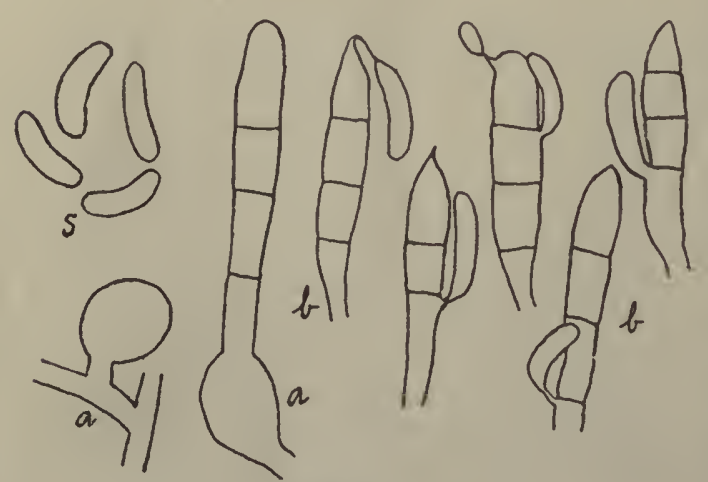

Fig. 4

S. castaneum.

a, two probasidia, one persistent at base of the spore-bearing organ which grows from it; $b$, six spore-bearing organs; $s$, spores. $\times 640$.

hymenial crust, sometimes stratose, with hyphae loosely interwoven on the under side, $3-4 \mu$ in diameter, very dense at the outer surface, with the hyphal branches or paraphyses $2 \mu$ in diameter, curved longitudinally along the surface and densely interwoven; erect probasidia slightly colored, rich in protoplasm, deeply staining, pyriform, $11-15 \times 9-10 \mu$, are borne laterally on the hyphae about $15 \mu$ below the surface of the hymenium; spores hyaline, simple, even, curved, $12 \times$ $3-31 / 2 \mu$, borne singly from each of the upper four cells of a straight, few-celled, even-walled, clavate, hyaline organ 30-40 $\times 6 \mu$, which grows from the probasidium and protrudes above the surface of the hymenium.

Fructification 8-15 cm. long, wholly surrounding limbs $21 / 2 \mathrm{~cm}$. in diameter, $1-11 / 2 \mathrm{~mm}$. thick.

On living bark in swamp, Montgomery, Alabama. May and August-fertile in May. 
This species is closely related to $S$. pseudopedicellatum but is more deeply colored, has more opaque hyphae, and smaller spores and spore-bearing organs. No lateral protuberances or papillae have been observed on the latter.

Specimens examined:

Alabama: Montgomery, R. P. Burke, two collections (in Mo. Bot. Gard. Herb., 20421, type, and 20693).

6. S. sublilacinum (Ellis \& Ev.) Burt, n. comb.

Thelephora sublilacina Ellis \& Ev. State Univ. Iowa, Lab. Nat. Sci. Bul. 13 :67. 1896; Sacc. Syll. Fung. 14:214. 1900.

Type: in N. Y. Bot. Gard. Herb.

Fructification resupinate, effused, coriaceous, dry, not separable from the substratum, glabrous, shining, olive-brown, darkening to dark neutral gray; in structure 3-layered, with (1) a layer next to the substratum, $40-60 \mu$ thick, of closely crowded, longitudinally arranged hyphae concolorous with the fructification, $4-41 / 2 \mu$ in diameter, which form (2) a layer of pillars $40-60 \mu$ in diameter, about $2-4$ to a millimeter, whose hyphae spread apart at the outer end and form and support (3) the hymenial crust about $60 \mu$ thick, densely interwoven throughout, with even, thick-walled, concolorous hyphae 3$31 / 2 \mu$ in diameter on the under side, $2 \mu$ in diameter, nearly hyaline, and densely, longitudinally interwoven at the surface; probasidia, spores or other organs not present in the type.

Fructification about $1 / 2 \mathrm{~cm}$. in diameter, $3 / 4 \mathrm{~mm}$. thick.

On living branches. Nicaragua.

The type specimen of this species, when viewed from above, agrees so closely with the cotype of S. Spongia in color and habit that one is strongly disposed to regard the two specimens as of the same species. S. sublilacinum has, however, the coarser hyphae, a three-layered structure, and distinct pillars. It seems best to regard it as a distinct species, at least until fertile specimens define the species more definitely.

Specimens examined:

Nicaragua: C. L. Smith, 108, type (in N. Y. Bot. Gard. Herb.). 
7. S. Patouillardii Burt, n. sp.

S. (very near) Leprieurii (Mont.) Patouillard, Soc. Myc. Fr. Bul. 16:55. 1900.

Type: in Burt Herb.

Fructification resupinate, effused, coriaceous, dry, velutinous, aniline-black at first, becoming fuscous in the herbarium, the margin rather thick and determinate; in structure $200-400 \mu$ thick, with (1) next to the

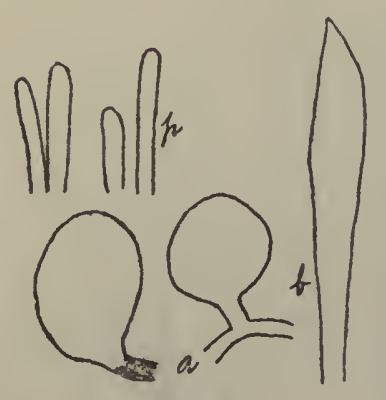

Fig. 5

S. Patouillardii.

$a$, two probasidia; $b$, spore-bearing organ; $p$, four paraphyses or hyphal ends. $\times 640$. substratum a thin layer of loosely interwoven hyphae $3 \mu$ in diameter, buffy brown under the microscope, which form (2) a layer of hyphal pillars each about $30-50 \mu$ in diameter, $100-200 \mu$ long, about 3-4 to a millimeter, whose hyphae spread apart above and form (3) the interwoven hymenial layer containing some probasidia and with the surface composed of numerous erect, nearly straight, fuscous hyphal branches or paraphyses $2 \mu$ in diameter; probasidia hyaline, subglobose, $15-20 \mu$ in diameter, erect on short branches of the colored hyphae; no spores found; the only possible spore-bearing organ seen is $46 \times 71 / 2 \mu$, acuminate at the apex.

Fructifications 2-31/2 cm. long, 1-2 cm. broad, 200-400 mm. thick.

On living branches of ash, Liquidambar, and Nyssa. Florida to Louisiana. November to March; a January collection has a few probasidia.

This species may be recognized by its thin fructification resembling a piece of black velvet, slightly raised from the substratum on such short and slender pillars as to be barely visible without the aid of a lens. Patouillard determined this species for Mr. Langlois as very near to S. Leprieurii. Since Corticium Leprieurii was originally described as glabrous, shining, and chocolate-colored, and since no specimens like ours have yet been collected in the region between Guiana and the United States, our specimens are probably a distinct species which should have a definite name. 
Specimens examined:

Florida: Daytona, R. Thaxter, $75 b$ (in Farlow Herb. and

No. Bot. Gard. Herb., 43895).

Alabama: Auburn, F. S. Earle \& C. F. Baker, also (in Mo.

Bot. Gard. Herb., 5165).

Louisiana: St. Martinville, A. B. Langlois, 3005, determined

by Patouillard as $S$. (very near) Leprieurii; Gibson, $F . T$.

McLean, comm. by P. Spaulding, type-some fragments near a specimen of another species, but having probasidia, etc., as drawn, taken as the type because more mature than other collections cited.

8. S. jamaicaense Burt, n. sp.

Type: in Burt Herb. and N. Y. Bot. Gard. Herb.

Fructification resupinate, effused, coriaceous, spongy, dry, thick, bister, with the subiculum bone-brown; in structure with (1) next to the substratum a thin layer of interwoven hyphae which form (2) a layer of probably oblique, weak, very slender, crowded, hyphal pillars $12-20 \mu$ in diameter, up to $2000 \mu$ long, with hyphae even, $4-5 \mu$ in diameter, buffy brown under the microscope, diverging above to form (3) a spongy hymenial layer $300-400 \mu$ thick, with hyphae which rise obliquely, are loosely interwoven, and bear probasidia laterally at the outer surface of the layer and terminate in hyaline or subhyaline, curved branches

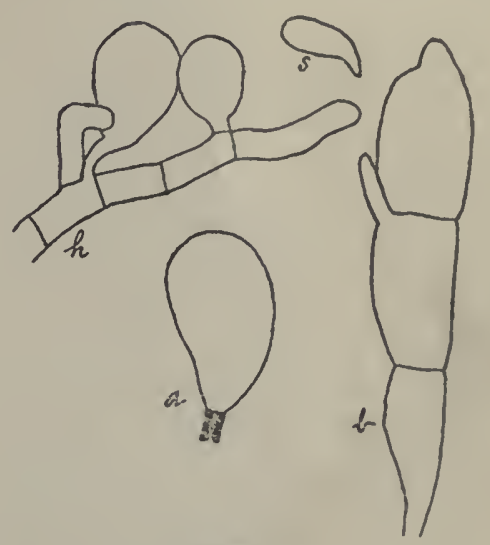

Fig. 6

S. jamaicaense.

$h$, hyphal end bearing two probasidia in the surface of the hymenium; $a$, probasidium; $b$, spore-bearing organ; $s$, spore. $\times 640$. or tips; probasidia hyaline, subglobose or pyriform, $13-25 \times$ $10-13 \mu$, quickly developing into hyaline, straight, few-celled, spore-bearing organs up to $60 \times 11 \mu$; spores simple, hyaline, slightly curved, $13 \times 51 / 2 \mu$.

Fructification larger than $6 \mathrm{~cm}$. long, $2 \mathrm{~cm}$. broad, 1-11/2 $\mathrm{mm}$. thick-fractured on all sides and not showing natural margin. 
On bark. Base of John Crow Peak, altitude 5500 feet. Jamaica. April.

The type of this species has so thick and spongy a hymenial layer that I have tried to regard this specimen as the fertile stage of $S$. Spongia, but the well-developed layer of pillars is in the way of such reference and the hyphae are rather coarser than in S. Spongia.

Specimens examined:

Jamaica: John Crow Peak, L. M. Underwood, 2439.

9. S. atratum Patouillard, Soc. Myc. Fr. Bul. 16:181. 1900.

Type: location unknown.

Fructification resupinate, greatly extended, glabrous, shining, thin, with the margin fimbriate and incrusting; subiculum black, formed of rigid, erect, short bundles composed of hyphae but little branched, $4-5 \mu$ in diameter, with the wall thick and brown under the microscope; hymenial crust thin, fragile, continuous, glabrous, ombre noir, paler at the periphery; probasidia at first globose, $10-12 \mu$ in diameter, growing on the sides of erect hyphae of the hymenial crust a little below their ends; spores and spore-bearing organs not present.

On living trunk of Eugenia Jambos. Morne Gommier, near Galion, Guadeloupe. P. Duss.

In connection with the original description, Patouillard stated that S. Spongia is "epais, roux, spongieux, lacuneux," and that $S$. atratum is "tres mince, et noir." I have seen no specimens of $S$. atratum and base the above account of this species wholly on the original description.

10. S. cirratum Burt, n. sp.

Type: in Mo. Bot. Gard. Herb. and Humphrey Herb.

Fructification resupinate, effused, coriaceous, spongy, dry, cracked, velutinous, between Benzo-brown and brownish drab, with fuscous subiculum, the margin divided into narrow, sinuous divisions; in structure up to $700 \mu$ thick, with (1) next to the substratum a layer of interwoven hyphae, which form (2) a layer of pillars not uniform in diameter, composed of hyphae loosely interwoven, curled together, 
suggestive of ringlets in sectional preparations, which support (3) the hymenial layer $200-300 \mu$ thick, with hyphae $2-21 / 2 \mu$ in diameter, notably curved, branched, and loosely interwoven, olive-brown under the microscope, bearing in the lower part of the layer numerous concolorous, globose bodies $11 \mu$ in diameter, and toward the outer surface hyaline probasidia $11 \mu$ in diameter also, and terminating at the surface in fine, hyaline branches $1 \mu$ in diameter, with recurved or coiled tips; spores simple, hyaline, even, curved, 18 $\times 6 \mu$; spore-bearing organs few-

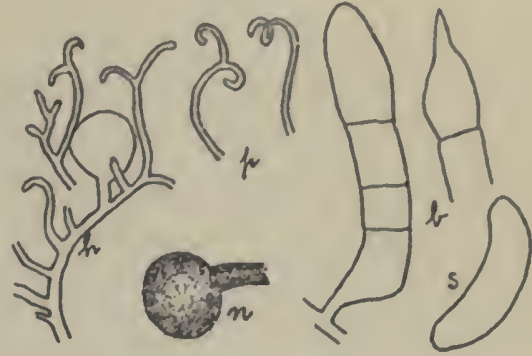

Fig. 7

S. cirratum.

$h$, portion of hymenium show. ing hypha bearing paraphyses and a probasidium; $b$, sporebearing organs; $n$, colored body from deeper portion of hymenial layer; $p$, two paraphyses; $s$, spore. $\times 640$. celled, straight, cylindric, about $35-40 \times 71 / 2 \mu$, differentiating from the probasidia.

Fructifications $5 \mathrm{~cm}$. long, $11 / 2 \mathrm{~cm}$. broad.

On trunk of living hardwood tree near the base. Cuba. December. Seen but once by the collector.

$S$. cirratum has so nearly the color and habit of Hypochnus fuscus that it was a surprise to find the specimen a Septobasidium. The color and sinuously divided margin suggest S. Langloisii. The pillars composed of loosely interwoven and curving hyphae are unique and separate this species sharply from all our species of the $S$. pedicellatum group. The hyphae are too fine and too curving for S. Spongia.

Specimens examined:

Cuba: Omaja, C. J. Humphrey, $27 \% 3$ (in Mo. Bot. Gard. Herb., 15836).

11. S. Langloisii Patouillard, Soc. Myc. Fr. Bul. 16:54. 1900.

Type: a portion in Burt Herb.

Fructification resupinate, effused, dry, velutinous, plumbeous when bright colored, but often smoke-gray or pallid mouse-gray, repeatedly divided into many narrow, sinuous 
divisions which are more distinct towards the margin; in structure 200-250 $\mu$ thick, with hyphae fuscous under the micro-

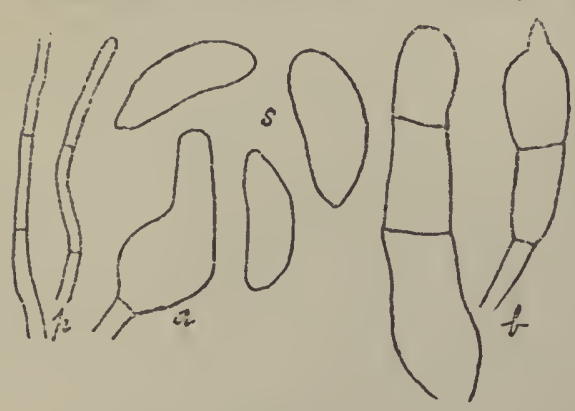

Fig. 8

S. Langloisii. $a$, probasidium forming a spore-bearing organ; $b$, two spore-bearing organs; $p$, paraphyses; $s$, spores. $\times 640$. scope, thick-walled, even, loosely interwoven from substratum to hymenium, densely interwoven in the hymenium and bearing hyaline, flexuous, suberect terminal branches or paraphyses and hyaline probasidia which are exceeded by the paraphyses; spores hyaline, simple, even, slightly curved, $15-21 \times 5-71 / 2 \mu$, apparently produced singly at the apex of a nearly straight, 2-3-celled, spore-bearing organ into which the probasidium develops.

Fructification up to $5 \mathrm{~cm}$. long, $21 / 2 \mathrm{~cm}$. broad, $1 / 4 \mathrm{~mm}$. thick.

On bark of living branches of Crataegus, Carpinus, and water oak. Florida to Louisiana and in Grenada. November to May.

This species resembles $S$. frustulosum in having the fructification divided into narrow sinuous divisions and differs from that species in being blue colored, verging into smokegray or paler in some specimens, instead of honey-yellow. The specimen from Grenada is thinner than those from other localities.

Specimens examined:

Exsiccati: Ravenel, Fungi Am., 450, under the name Stereum pruinatum.

Florida: Gainesville, H. E. Stevens, comm. by E. Bartholomew, 40a (in Mo. Bot. Gard. Herb., 44211); same locality, Ravenel, in Ravenel, Fungi Am., 450.

Alabama: Montgomery, R. P. Burke, 52 (in Mo. Bot. Gard. Herb., 9558).

Louisiana: St. Martinville, A. B. Langlois, 2995, type. 
Grenada: Grand Etang, R. Thaxter, comm. by W. G. Farlow, a (in Mo. Bot. Gard. Herb., 43912).

12. S. frustulosum (Berk. \& Curtis) Patouillard, Soc. Myc. Fr. Bul. $10: 79$. pl. 3. f. 4. 1894.

Hymenochaete frustulosa Berk. \& Curtis, Linn. Soc. Bot. Jour. 10 :334. 1868; Sacc. Syll. Fung. 6 :601. 1888.

Illustrations: Patouillard, loc. cit.

Type: type and cotype in Kew Herb. and Curtis Herb.

Fructification resupinate, effused, coriaceous, dry, velutinous, honey-yellow to old gold, repeatedly divided into many. narrow, sinuous, reticulate divisions which are more distinct towards the margin; in structure about $600-700 \mu$ thick, 3-layered, with next to the substratum a broad layer, up to $200 \mu$ thick, with hyphae densely longitudinally arranged, $2 \mu$ in diameter, concolorous with the fructification, which ascend, without forming pillars, as (2) the loosely arranged middle layer, whose hy-

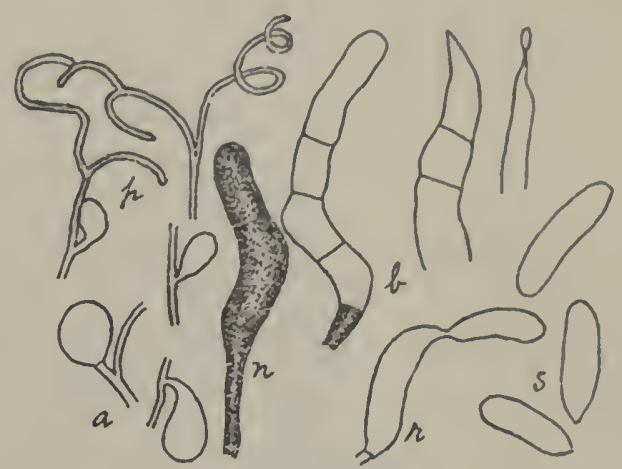

Fig. 9

S. frustulosum.

$a$, probasidia; $b$, three spore-bearing organs; $n$, septate colored organ; $p$, paraphyses; $r$, probasidium bearing a spore; $s$, spores. $\times 640$. phae pass into and form (3) the hymenial crust which is finally very dense and compact in fully developed specimens, about $200 \mu$ thick, with hyphae concolorous, even, $11 / 2-2 \mu$ in diameter, branching towards the surface into flexuous branches, or paraphyses, about $1 \mu$ in diameter, once or twice dichotomously branched and with tips curved or spirally coiled; probasidia borne laterally on the hyphae, hyaline, pyriform, $9 \times 51 / 2 \mu$, becoming elongated and septate as a few-celled, spore-bearing organ, or producing directly a sterigma bearing one spore; spores hyaline, even, cylindric, nearly straight, $13-17 \times 4-5 \mu$.

Fructifications up to $10 \mathrm{~cm}$. long, 1-2 $\mathrm{cm}$. broad, less than $1 \mathrm{~mm}$. thick. 
On bark of living limbs of frondose species. Mexico, West Indies, and Venezuela. February, March, November; sporebearing in November.

This species is highly distinguished by honey-yellow color and the division of its fructification into narrow, sinuous, branched divisions, resembling those of the thallus of the lichens, Physcia stellaris and $P$. obscura. Spore-bearing organs are not abundant in the only fertile specimen which I have seen. They appear to become somewhat corkscrew-shaped, with no indication of bearing spores except on the terminal cell, but I was not certain on this point because the occasional attached spores were along the edge of thick sections where only the apex of the organ extended beyond the paraphyses. In two cases probasidia were bearing at the apex, each a body of the form and dimensions of a spore of this species. In the deeper portions of the fructifications brown, pyriform bodies of the same size and form as the probasidia are borne by the hyphae in the same location as the probasidia. These brown organs are often of the same dimensions as the spore-bearing organs, septate, and gorged with brown contents.

Specimens examined:

Exsiccati: Smith, Cent. Am. Fungi, 100, under the name Thelephora retiformis.

Mexico: Sanborn, Oaxaca, C. R. Orcutt, 3334 (in Mo. Bot. Gard. Herb.).

Nicaragua: Castillo Viejo, C. L. Smith, in Smith, Cent. Am. Fungi, 100.

Cuba: C. Wright, 244, cotype (in Curtis Herb.).

Grenada: Grand Etang, R. Thaxter, comm. by W. G. Farlow, 11.

Venezuela: Fendler, 279 (in Farlow Herb. and in Mo. Bot. Gard. Herb., 20411).

13. S. retiforme (Berk. \& Curtis) Patouillard, Soc. Myc. Fr. Bul. 16: 55. 1900.

Thelephora retiformis Berk. \& Curtis, Linn. Soc. Bot. Jour. $10: 330.1868$; Sacc. Syll. Fung. 6:544. 1888. 
Type: type and cotype in Kew Herb. and Curtis Herb.

Fructification resupinate, effused, coriaceous, at first drab or Prout's brown, then Chaetura-drab, the hymenial surface reticulated with obtuse veins, pulverulent; in structure $700 \mu$ thick, with the hyphae colored, $3-4 \mu$ in diameter, short-celled, loosely interwoven or rising obliquely from substratum to hymenial surface and there densely interwoven longitudinally and bearing laterally brown, globose or pyriform bodies $13-15 \times 10-13 \mu$, and slightly colored probasidia of the same size and form; a single spore in the hymenial surface is hyaline, even, curved, 15 $\times 4 \mu$; no spore-bearing organs found.

Fructification 1-4 cm. long, about $700 \mu$ thick.

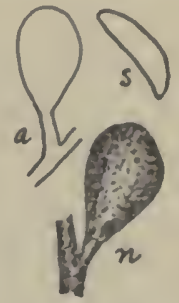

Fig. 10

S. retiforme. $a$, probasidium; $n$, col. ored organ; $s$, spore. $\times$ 640.

On living branches of apple, pear, peach, Carya. District of Columbia to Louisiana and Cuba. November to February, producing probasidia in February.

$S$. retiforme resembles a small foliaceous lichen in habit. It may be distinguished from our other species by its drab to brown color and reticulately veined hymenial surface. The spore characters stated are uncertain for only one spore was seen.

Specimens examined:

Exsiccati: Ellis \& Ev., N. Am. Fungi, 2604.

District of Columbia: Washington, comm. by Mrs. F. W. Patterson.

Georgia: Fort Valley, comm. by Mrs. F. W. Patterson.

Alabama: Forestdale, C. C. Woodward, comm. by J. B. Rorer; Abbeville, S. T. Slaton (also in Lloyd Herb., 3460, and in Mo. Bot. Gard. Herb., 5166).

Louisiana: St. Martinville, A. B. Langlois, 2233.

Cuba: C. Wright, 288, cotype (in Curtis Herb.).

14. S. Spongia (Berk. \& Curtis) Patouillard, Soc. Myc. Fr. Bul. 16:181. 1900.

Thelephora Spongia Berk. \& Curtis, Linn. Soc. Bot. Jour. $10: 330$. 1868; Sace. Syll. Fung. 6:542. 1888.

Type: type and cotype in Kew Herb. and Curtis Herb. 
Fructification resupinate, effused, not separable from the substratum, dry, glabrous, shining, between mouse-gray and hair-brown, the margin strigose; in structure lacunose, spongy, about $1 \mathrm{~mm}$. thick when dry, distending

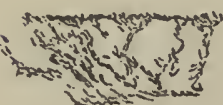

Fig. 11

S. Spongia.

Vertical section of fructification showing s p on $\mathrm{g} y$ structure. $\times 9$. to $11 / 2-2 \mathrm{~mm}$. when moistened, with hyphae $3-31 / 2 \mu$ in diameter, fuscous to clove-brown under the microscope, densely longitudinally arranged in masses along the substratum and rising obliquely so as to form a spongy structure with vacant spaces up to $800 \times 500 \mu$, united above into a continuous hymenial crust $40-80 \mu$ thick; probasidia, spores, and spore-bearing organs not present.

Fructification "spreading for many inches," $11 / 2-2 \mathrm{~mm}$. thick.

On bark of cacao trees. Cuba.

S. Spongia is distinguished from our other species in the group having a glabrous hymenial crust by the spongy, rather than pillared, structure of the middle region of the fructification. The surface of the cotype is infested with a colorless hyphomycete whose hyphae are densely crowded together and agglutinated; hence fertile specimens of this species will probably be browner than the original sterile, infested specimen.

Specimens examined:

Cuba: C. Wright, 566, cotype (in Curtis Herb., and a portion in Mo. Bot. Gard. Herb., 44592, by kindness of Dr. Farlow).

? Mexico: Monterey, Sierra Madre, C. G. Pringle, comm. by W. G. Farlow, 6 (in Mo. Bot. Gard. Herb., 44591).

15. S. fumigatum Burt, n. sp.

Type: in Mo. Bot. Gard. Herb. and Humphrey Herb.

Fructification resupinate, long and broadly effused, not separable from substratum, coriaceous, tomentose, between mouse-gray and hair-brown, rarely with surface pale, the margin thinning out and concolorous; in structure $800-1500 \mu$ thick, with hyphae buffy brown under the microscope, even, thick-walled, $4 \mu$ in diameter, loosely interwoven and ascend- 
ing from substratum to hymenial region; in the hymenial region the hyphae become more densely interwoven and bear laterally numerous hyaline, subglobose probasidia $12-15 \mu$ in diameter, and terminate in small, curved or loosely coiled, colored branches-hardly paraphyses- $2 \mu$ in diameter, which form the surface of the hymenium; spores simple, hyaline, even, slightly curved, 12-15 $\times 5-6 \mu$, borne on the upper three cells of a fewcelled, nearly straight, hyaline, spore-bearing organ 40 $50 \times 6-71 / 2 \mu$, into which the probasidium develops.

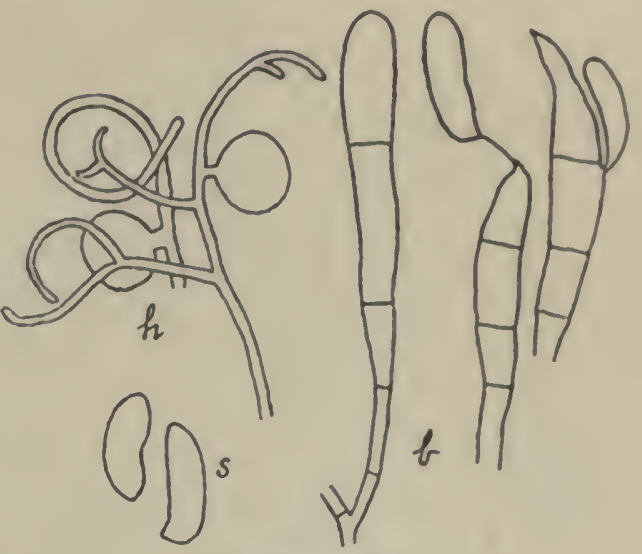

Fig. 12

S. fumigatum

$h$, portion of hymenium showing hyphae bearing probasidia and terminating in curved and coiled ends; $b$, three spore-bearing organs; $s$, spores. $\times 640$.

Up to $5 \mathrm{~m}$. long, several $\mathrm{cm}$. broad, $4 / 5-11 / 2 \mathrm{~mm}$. thick.

On trunks of living sapling of Acer rubrum and probably other species. South Carolina, Alabama, and Cuba. November to May; spores most numerous in May.

$S$. fumigatum has the general habit and color of Hypochnus spongiosus and is readily distinguishable among the North American species of Septobasidium by its mousegray color, tomentose surface, and felty structure of loosely interwoven hyphae which do not form pillars. It is only rarely that I have seen spores or evidences of spore production upon other than the terminal cell in this species.

Specimens examined:

South Carolina: Gourdin, C. J. Humphrey, 2588, type (in Mo. Bot. Gard. Herb., 43822).

Alabama: Montgomery, R. P. Burke, 50, and an unnumbered collection (in Mo. Bot. Gard. Herb., 11382, 20068).

Cuba: C. Wright, Fungi Cubenses Wrightiani, 838, comm. by W. G. Farlow (in Farlow Herb. and Mo. Bot. Gard. Herb., 43907). 
16. S. canescens Burt, n. sp.

Type: in Mo. Bot. Gard. Herb.

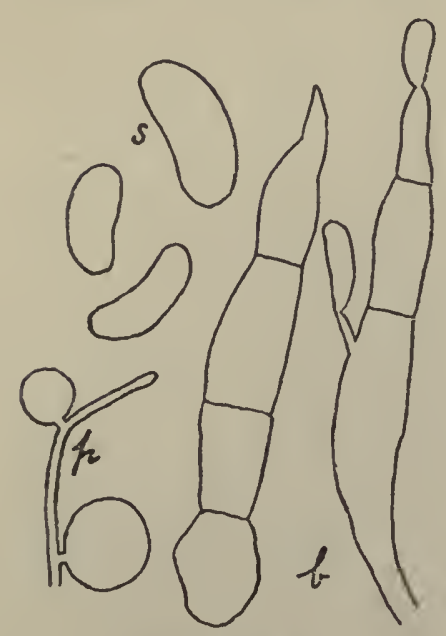

Fig. 13

S. canescens.

$p$, hypha in hymenial surface bearing probasidia; $b$, two spore-bearing organs; $s$, spores. $\times$ 640 .

Fructification resupinate, effused, coriaceous, cottony, pubescent, white at first, pale olive-buff in the herbarium, the margin thinning out; in structure 500-900 $\mu$ thick, with the hyphae hyaline, even, $41 / 2 \mu$ in diameter, densely interwoven next to the substratum, suberect, or ascending: obliquely and loosely interwoven to the hymenial surface and there bearing probasidia laterally among slightly curved hyphal branches about $2 \mu$ in diameter; probasidia hyaline, subglobose, $15-17 \mu$ in diameter, producing a few-celled organ $71 / 2 \mu$ in diameter, up to $60 \mu$ long, which bears spores on its upper three cells; spores simple, hyaline, even, curved, 15-20 $\times 51 / 2-6 \mu$.

Fructifications about $2-4 \mathrm{~cm}$. long, $1-11 / 2 \mathrm{~cm}$. broad, sometimes arranged more or less interruptedly for up to $25 \mathrm{~cm}$. along the under side of limbs.

Associated fairly constantly with scale insects on small living branches of Quercus on a residence street, Pasadena, California. November to March.

$S$. canescens is characterized by its white to whitish color, cottony structure, and pubescent surface. Spores were observed attached to one or more of the upper three cells of the spore-bearing organ but with the terminal cell giving the most indication of spore production. I am indebted to Prof. H. S. Fawcett for the collection made in March to show this species in best fruiting condition.

Specimens examined:

California: Pasadena, H. S. Fancett, comm. by W. A. Setchell (in Mo. Bot. Gard. Herb., 44037); same locality, A. G. Smith, comm. by H. S. Fawcett (in Mo. Bot. Gard. Herb., 44246). 
17. S. lilacinum Burt, n. sp.

Type: in Farlow Herb. and Burt Herb.

Fructification resupinate, effused, coriaceous, dry, adnate, velutinous, between lilac-gray and pallid smoke-gray, the margin adnate, fimbriate; in structure $80-200 \mu$ thick, with hypliae thin-walled, $2-21 / 2 \mu$ in diameter, somewhat colored near the substratum, ascending and interwoven and becoming hyaline towards the hymenium, finer, $11 / 2 \mu$ in diameter, and bearing laterally probasidia, and extending beyond the probasidia and branching, with tips curved to form the velvety surface of the hymenium; probasidia hyaline, even, globose, up to $9 \mu$ in diameter; spores simple, hyaline, even, slightly curved, $11-13 \times 31 / 2-41 / 2 \mu$, borne on a few-celled, spore-bearing organ

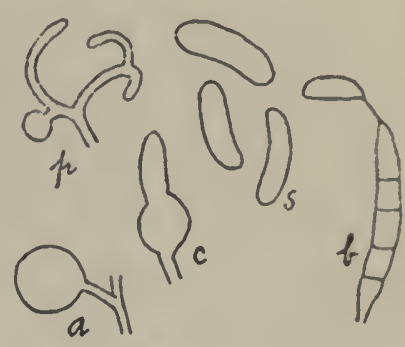

Fig. 14

S. lilacinum. $p$, hyaline portion of hypha in hymenial surface bearing a probasidium; $a$, mature probasidium; $c$, probasidium with young spore-bearing organ; $b$, spore-hearing organ; $s$, spores. $\times 640$. about $20-30 \times 4-5 \mu$, slightly curved at first.

Fructifications more than $6 \mathrm{~cm}$. long, more than $11 / 2 \mathrm{~cm}$. wide.

On bark, Maravals, Trinidad, West Indies.

This species is characterized by its very thin, velvety fructification, pallid smoke-gray with a slight lilac tint, fine hyphae, and small probasidia, spore-bearing organs, and spores. The spore-bearing organs were slightly curved in all cases where spores were attached to them; in the sections some of these organs appeared strongly curved or hookshaped but my preparations did not demonstrate this point positively, for the numerous curved hyphal branches were confusing.

Specimens examined:

Trinidad: Maravals, R. Thaxter, comm. by W. G. Farlow, 28 , type.

(To be continued.) 
$3^{4}$

$+$

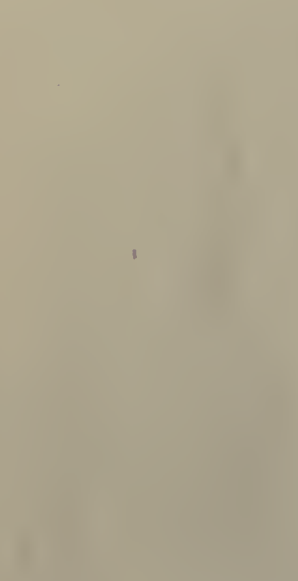

y 


\section{The Thelephoraceae of North}

America. VIII

\section{Coniophora}

FITI ARI) AVGTS BIR'

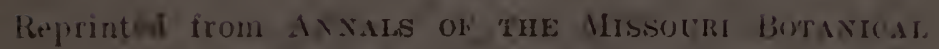

CARDET 4:237-269. Septrinher, 1917 

THE THELEPHORACEAE OF NORTH AMERICA. VII ${ }^{1}$

Coniophora

EDWARD ANGUS BURT

Mycologist and Librarian to the Missouri Botanical Garden Associate Professor in the Henry Shaw School of Botany of

Washington University

\section{CONIOPHORA}

Coniophora De Candolle, Fl. Fr. 6 : 34. 1815; Persoon, Myc. Eur. 1 : 153. 1822; Karsten, Rev. Myc. $3^{9}$ : 23. 1881; Finska Vet.-Soc. Bidrag Natur och Folk 37 : 159. 1882; Sacc. Syll. Fung. 6 : 647. 1888; Massee, Linn. Soc. Bot. Jour. 25 : 128. 1889; Schroeter, Krypt.-Fl. Schlesien 3 :430. 1888; Engl. \& Prantl, Nat. Pflanzenfam. I.1** :120. 1898.-Coniophora as a subgenus of Corticium Fries, Hym. Eur. 657. 1874; Cooke, Grevillea 8 : 88. 1880.-Coniophorella Karsten, Finl. Basidsv. 438. 1889; Bresadola, Ann. Myc. 1 :110. 1903.

Fructifications resupinate, effused, fleshy, subcoriaceous or membranaceous; hymenium somewhat undulate-tubercular, granular, or even, usually pulverulent with the spores; cystidia present in some species; basidia simple; spores even, ochraceous, sometimes nearly colorless.

Coniophora is closely connected on one side with Corticium and Peniophora by such pale-spored species as Coniophora polyporoidea, on another side with the colored-spored section of Merulius, and on still another with Grandinia by several species with granular or minute papillae in the hymenium, although the spores of Coniophora are colored, while those of Grandinia are white.

Fully developed, mature fructifications of Merulius have the hymenial surface more or less reticulate with obtuse folds, imperfectly porose, or obsoletely toothed, while the departure from the even hymenial surface in Coniophora is at the most only undulate-tubercular or granular. Since some species

NoTE.-Explanation in regard to the citation of specimens studied is given in Part VI, Ann. Mo. Bot. Gard. 3: 208, footnote. The technical color terms used in this work are those of Ridgway, Color Standards and Nomenclature. Washington, D. C., 1912.

${ }^{1}$ Issued September 20, 1917.

ANn. Mo. Bot. GARD., Vol. 4, 1917 
of Merulius have the hymenium even in some small, immature fructifications and with a broad, marginal, even region in larger ones, it is necessary to see fully mature and well-developed fructifications to be certain that a collection of one of these connecting species is a Coniophora rather than a Merulius. The absence of a definite statement by De Candolle on this point led Fries to question the generic position of Coniophora membranacea DC.

The dark color of spores in the mass in spore collections is a decisive character for distinguishing some species of Coniophora from Corticium and Peniophora. In working with dried herbarium specimens which lack spore collections, if the natural color pigment of sections is destroyed and bleached by KHO solution, some sections should be treated with lactic acid to determine whether the spores are hyaline or pigmented like the hyphae. In my experience lactic acid does not change a common, ochraceous, fungous pigment which is dissolved and bleached by $\mathrm{KHO}$ solution.

All our species of Coniophora are saprophytic on wood and cause dry rot of the wood. The most of these species are rare or have been collected infrequently, and record is lacking of the extent of rot which they cause. Coniophora cerebella, more commonly called $C$. puteana, is common and widely distributed throughout the northern United States and Canada. It is very destructive to structural timber of coniferous species if poorly seasoned or if used in moist places where there is a poor circulation of air or if used in contact with the ground without previous treatment with a wood preservative. In the United States this species seems to be as important an agent of timber decay as the Merulius lacrymans group of species is in Europe. While Coniophora cerebella attacks chiefly coniferous timber of buildings, bridges, docks, etc., in forests it is often found on logs of deciduous species. $C$. arida is another species of this genus so common as to be of economic importance. This species has been collected but rarely on other than a coniferous substratum; it ranges rather farther south than the general range of $C$. cerebella but has not been received from farther south than Louisiana. 
The collections which have been available seem to indicate that Coniophora is more abundant in temperate than in tropical regions.

Our few species which have cystidia are not segregated as Coniophorella, because such segregation would place two common species, C. suffocata and $C$. olivascens, in the position of troublesome intermediates with some of their specimens seeming to belong in Coniophora in the restricted sense and others in Coniophorella. The per cent of connecting species is obviously too large for cleavage into natural genera.

\section{Key to the Species}

Neither incrusted nor hair-like cystidia present in the hymenium, with the exception of $C$. suffocata which sometimes has short cystidia barely distinguishable from the basidia, and of $C$. olivascens, some sections of

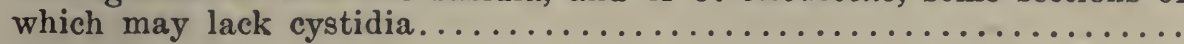

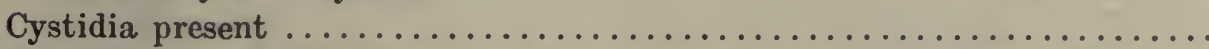

1. Fructification fleshy when growing, often $1 \mathrm{~mm}$. thick, separable from substratum; hyphae densely interwoven, 4-7 $\mu$ in diameter, not in-

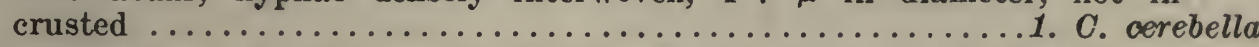

1. Fructification drying tawny olive to snuff-brown, 200-250 $\mu$ thick, not fleshy, separable from the substratum; spores fusiform, tapering at both ends, $18-21 \times 5-6 \mu \ldots \ldots \ldots \ldots \ldots \ldots \ldots \ldots \ldots \ldots . \ldots \ldots$. fusispora

1. Fructification not fleshy, dry; spores less than $15 \mu$ long........... 2

2. Spores $8 \times 3-4 \mu$; fructification described originally as sulphur-

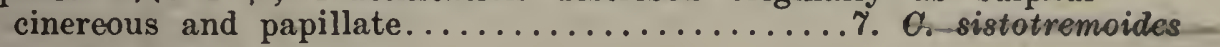

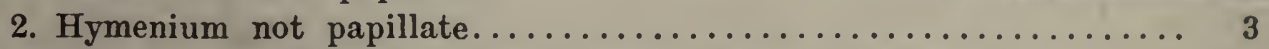

3. Fructification not stratose; spores between 10 and $13 \mu$ long........ 4

3. Fructification not stratose; spores less than $10 \mu$ long................ 6

3. Fructification stratose, snuff-brown throughout, velvety, $\frac{1}{2}-1 \mathrm{~mm}$. thick

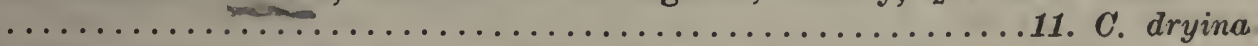

4. Fructification neither stratose nor with incrusted hyphae....... 5

4. Fructification not stratose but with incrusted hyphae, avellaneous to tawny olive and Saccardo's umber................ 12. . suffocata

5. Fructification adnate, 100-500 $\mu$ thick, drying from warm buff to tawny olive or darker, with paler margin; hyphae loosely interwoven, $2-3 \mu$ in diameter, without inflations....................... C. arida

5. Closely resembling $C$. arida but with hyphal portions occasionally swollen to $4-7 \mu$ in diameter............................. C. Kalmiae 6. Spores ellipsoidal, $7-8 \times 3-4 \mu$; hyphae with inflations 9-12 $\mu$ in diameter, and with pyriform, vesicular hyphal ends.....5. C. inflata

6. Spores broadly ovoid........................... 7

6. Spores subglobose, $4-5 \times 4 \mu$; fructification pinkish tan; hyphae not incrusted, not nodose-septate. (C. olivascens has nodose-scptate hyphae $) \ldots \ldots \ldots \ldots \ldots \ldots \ldots \ldots \ldots \ldots \ldots \ldots \ldots \ldots \ldots \ldots \ldots \ldots$. Harperi

7. Fructification membranaceous, separable, pinkish buff, the margin white, cottony, and usually with prominent radiating mycelial strands......

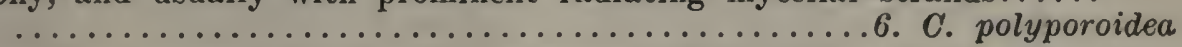

7. Fructification spongy, hypochnoid, between pinkish buff and cinnamonbuff throughout and at the margin; hyphae $6-7 \mu$ in diameter...8. C. vaga 
7. Fructification light pinkish cinnamon, adnate; hyphae $2-2 \frac{1}{2} \mu$ in diameter,

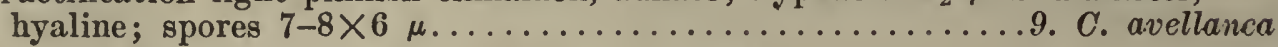

8. Cystidia large, more than $5 \mu$ in diameter............... 9

8. Cystidia small, only $3-5 \mu$ in diameter................. 11

9. Spores more than $7 \mu$ long; fructification dark-colored, sepia, and buffy

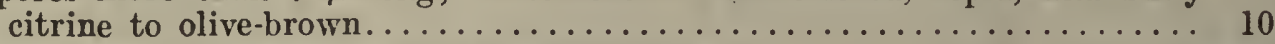

9. Spores $3 \times 2 \mu$; fructification primuline-yellow..............16. C. flava

10. Fructification very dark, drying Saccardo's umber to olive-brown throughout; hyphae rigid; cystidia protruding up to $120 \mu \ldots$...

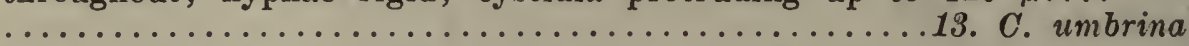

10. Fructification paler, buffy citrine and Saccardo's olive to brownish olive; hyphae paler and thinner-walled, often collapsed; cystidia protruding up to $100 \mu \ldots \ldots \ldots \ldots \ldots \ldots \ldots \ldots \ldots \ldots$. $C$. olivacea

10. Fructification drying sepia; hyphae nearly black, rigid; cystidia protruding up to $60 \mu$; spores $9-10 \times 4 \frac{1}{2}-6 \mu \ldots \ldots .15$. C. atrocinerea

11. Spores $6-7 \times 2 \frac{1}{2}-3 \mu$; fructification very thin, adnate, drying raw sienna, suggestive of the conidial stroma of an Hypoxylon.........1\%. C. laeticolor

11. Spores $4-4 \frac{1}{2} \times 2 \frac{1}{2}-3 \mu$, pale and concolorous with the hyphae; fructification cream-color to Naples yellow throughout; hyphae loosely interwoven, rigid, abundantly nodose-septate................ C. byssoidea

11. Spores about $5 \times 3 \frac{1}{2} \mu$, dark-colored; fructification olive-lake to olivecitrine; hyphae lax, hyaline..................... olivascens

1. Coniophora cerebella Pers. Myc. Eur. 1:155. 1822; Schroeter, Krypt.-Fl. Schlesien 3 : 430. 1888; Bresadola, Ann. Myc. $1: 110.1903$.

Thelephora cerebella Pers. Syn. Fung. 580. 1801; Alb. \& Schw. Consp. Fung. 282. 1805.-Thelephora puteana Schumacher, Pl. Saell. 2 : 397. 1803; Fries, Syst. Myc. 1 : 448. 1821; Elenchus Fung. 1 : 194. 1828; Pers. Myc. Eur. 1 : 144. 1822.Corticium (subg. Coniophora) puteanum (Schum.) Fries, Hym. Eur. 657. 1874; Cooke, Grevillea 8:88. 1880.-Coniophora puteana (Schum.) Karsten, Finska Vet.-Soc. Bidrag Natur och Folk $37: 159$. 1882; Finl. Basidsv. 435. 1889; Patouillard, Tab. Anal. Fung. 113. f. 253. 1884; Sacc. Syll. Fung. 6 : 647. 1888; Massee, Linn. Soc. Bot. Jour. $25: 129$. 1889.

Illustrations: Fl. Dan. pl. 2035; Patouillard, Tab. Anal. Fung. f. 253, 579; Möller, Hausschwamm-forsch. 1 : pl. 3. f. r; pl. 4. f. 8, 9, 11; pl. 5. f. 15; Hennings in Engl. \& Prantl, Nat. Pflanzenfam. I. $1^{* *}: f .67 F, G$.

Fructification broadly effused, suborbicular, fleshy, separable from the substratum, drying Isabella-color and tawny olive to Brussels brown, the margin whitish and mucedinous; hymenium even, undulate or gyrose, with low and broad, 
dome-shaped tubercules; in structure $300-1000 \mu$ thick, composed of densely interwoven, hyaline, even-walled hyphae 4-7 $\mu$ in diameter; no cystidia; basidia with 4 sterigmata; spores giving their color to the hymenium, even, 10-14×6-7 $\mu$.

Fructifications usually about $4-6 \mathrm{~cm}$. in diameter or elongated up to $15 \mathrm{~cm}$. long, $5 \mathrm{~cm}$. broad, sometimes larger, $\frac{1}{3}-1 \mathrm{~mm}$. thick.

On logs and wood of both coniferous and frondose species, but more common on coniferous kinds. Quebec to District of Columbia and westward to British Columbia and California. Apparently rare in tropical America. July to February.

Well-developed specimens of $C$. cerebella are fleshy and thick and frequently

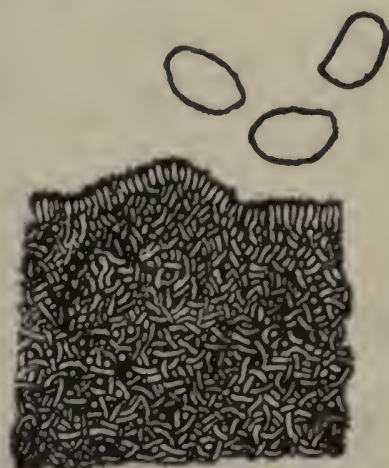

Fig. 1

C. cerebella.

Section of fructification $\times 45 ;$ s pores $\times 665$. have the hymenial surface protrude in broad, dome-shaped tubercules; young and thin fructifications are likely to be confused with $C$. arida, which has the same color but in section has its hyphae much less compactly interwoven and not as coarse as in $C$. cerebella.

Specimens examined:

Exsiccati: Cavara, Fungi Longobardiae, 14; Ell. \& Ev., N. Am. Fungi, 1588 (in copy of Mo. Bot. Gard. Herb. but not in copies of Farlow Herb. and of U. S. Dept. Agr. Herb.); Karsten, Fungi Fenn., 135; Krieger, Fungi Sax., 1201.

Sweden: Femsjö, E. Fries (in Herb. Fries, determined by Fries).

Finland: P. A. Karsten, in Karsten, Fungi Fenn., 135. Austria-Hungary : definite locality not given, Strasser, comm. by J. Bresadola.

Germany: Saxony, W. Krieger, in Krieger, Fungi Sax., 1201. Italy: Pavia, F. Cavara, in Cavara, Fungi Longobardiae, 14. Canada: definite locality not given, J. Macoun, 11, 23, 44, 58, 79; Lower St. Lawrence Valley, J. Macoun, 13.

Quebec: Hull, J. Macoun, 37r; Montreal, H. von Schrenk (in Mo. Bot. Gard. Herb., 44053). 
Ontario: Ottawa, J. Macoun, 36, ro0; Harraby, Lake Rosseau, E. T.\& S. A. Harper, 591, 594.

Vermont: Middlebury, $E$. A. Burt, two collections; Little Notch, E. A. Burt.

Massachusetts: Belmont Spring, W. G. Farlow, 4; Weston, C. Bullard, comm. by W. G. Farlow; Cambridge (in Mo. Bot. Gard. Herb., 43890).

New York: Albany, H. D. House (in Mo. Bot. Gard. Herb., 14831) ; Floodwood, C. H. Peck; Ithaca, G. F. Atkinson, 2603, and Cornell Univ. Herb., 14190, and L. A. Zinn, 88 (the last in Mo. Bot. Gard. Herb., 9062).

New Jersey: Newfield, J. B. Ellis, in Ell. \& Ev., N. Am. Fungi, 1588 in some copies.

Pennsylvania: Spruce Creek, J. H. Faull, 324 (in Mo. Bot. Gard. Herb., 44928); State College, L. O. Overholts, 2660 (in Mo. Bot. Gard. Herb., 13160).

District of Columbia: Washington, C. L. Shear, 1268.

Ohio: Cincinnati, A. P. Morgan, Lloyd Herb., 2603.

Michigan: Ann Arbor, C. H. Kauffman, 33, 46 (the latter in Mo. Bot. Gard Herb., 6823); Escanaba, C. J. Humphrey, 1449 (in Mo. Bot. Gard. Herb., 4825) ; New Richmond, $R$. W. Kellet, comm. by A. H. W. Povah, 8 (in Mo. Bot. Gard. Herb., 13263).

Illinois: River Forest, E. T. \& S. A. Harper, 829.

Iowa: Webster Co., O. M. Oleson, 447 (in Mo. Bot. Gard. Herb., 44054).

Missouri: St. Louis, B. M. Duggar (in Mo. Bot. Gard. Herb., $5687)$.

Montana: Missoula, J. R. Weir, 399 (in Mo. Bot. Gard. Herb., 9535) ; Bonner, J. R. Weir, 407 (in Mo. Bot. Gard. Herb., 21604).

Idaho: Priest River, J. R. Weir, 67, 139 (the latter in Mo. Bot. Gard. Herb., 8344).

British Columbia: Sidney, J. Macoun, 2 (in Mo. Bot. Gard. Herb., 5756) ; locality not given, J. Macoun, 855, comm. by J. Dearness (in Mo. Bot. Gard. Herb., 12410).

Washington: Bingen, W. N. Suksdorf, 667, 880; Olympia, C. J. Humphrey, 6294 . 
California: Berkeley, H. A. Lee, two collections, comm. by W. A. Setchell, 1017, 1018 (in Mo. Bot. Gard. Herb., 44243, 44244); San Francisco, W. A. Setchell, 1034 (in Mo. Bot. Gard. Herb., 44242).

Mexico: Guernavaca, W. A. \& Edna L. Murrill, 534, N. Y. Bot. Gard., Fungi of Mexico (in Mo. Bot. Gard. Herb., 54511).

2. C. fusispora (Cooke \& Ell.) Cooke in Sacc. Syll. Fung. 6 : 650. 1888; Massee, Linn. Soc. Bot. Jour. 25 : 133.1889.

Corticium fusisporum Cooke \& Ell. Grevillea 8 : 11. 1879.Corticium fusisporum (subg. Coniophora) Cooke, Grevillea $8: 89.1880$.

Type: type and cotype in Kew Herb. and in N. Y. Bot. Gard. Herb. respectively.

Fructification effused, thin, soft, readily separable, drying from tawny olive to snuff-brown, the margin mucedinous, pallid; hymenium even, pulverulent; structure in section 200-250 $\mu$ thick with (1) a layer next to the substratum of loosely and longitudinally arranged hyphae, hyaline, thin-walled, collapsing, 4-5 $\mu$ in diameter, sometimes granuleincrusted, sometimes forming rope-like mycelial strands 20-25 $\mu$ in diameter, and with (2) a compact hymenial layer; no cystidia; spores giving the color to the fructification, fusiform, tapering at both ends, curved at the base, $18-21 \times 5-6 \mu$.

On pine wood in wood pile and on pine logs. Newfield, New Jersey. September.

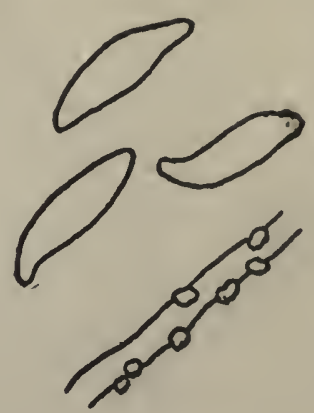

Fig. 2

C. fusispora.

Spores, incrusted hypha. $\times 665$.

This species is so similar to $C$. cerebella in color and probably in diameter of fructification that when Ellis collected it again, seven years after his type collection, he confused these later specimens with $C$. puteana and distributed some specimens under the latter name in some copies of his exsiccati. $C$. fusispora is distinct from $C$. cerebella by being thinner, dry rather than fleshy, having longer and more pointed spores, and by being two-layered and with the layer next to the substratum composed of very loosely arranged hyphae having 
some granular incrustation rather than of a uniformly compact, fleshy, non-incrusted hyphal structure from substratum to basidia as in C. cerebella.

Specimens examined:

Exsiccati: Ell. \& Ev., N. Am. Fungi, 1588 (in the copies of U. S. Dept. Agr. Herb. and of Farlow Herb., but not in copy of Mo. Bot. Gard. Herb.).

New Jersey: Newfield, J. B. Ellis, 3092 to Cooke, type (in

Kew Herb.); same locality and collector, Ell. \& Ev., N. Am. Fungi, 1588 (in copies of U. S. Dept. Agr. Herb. and of Farlow Herb.).

3. C. arida (Fr.) Karsten, Finska Vet.-Soc. Bidrag Natur och Folk $37: 161$. 1882; Sacc. Syll. Fung. 6 : 648. 1888; Massee, Linn. Soc. Bot. Jour. 25 : 132. 1889.

Thelephora arida Fries, Elenchus Fung. 1:197. 1828.Corticium aridum (subg. Coniophora) Fries, Hym. Eur. 659. 1874; Cooke, Grevillea 8:89. 1880.-Coniophora Cookei Massee, Linn. Soc. Bot. Jour. 25 : 136. 1889; Sacc. Syll. Fung. 9 : 242.1891.

Illustrations: Fries, Icones Hym. pl. 199. f. 1.

Type: in Herb. Fries, authentic specimen in Kew Herb.

Fructification effused, membranaceous, adnate, drying from warm buff to tawny olive or rarely darker, the margin paler and sometimes whitish; hymenium even,
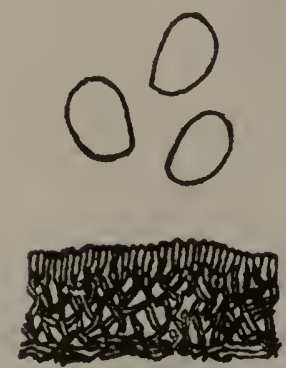

Fig. 3

C. arida.

Section of fructification $\times 45$; spores $\times 665$. pulverulent; structure in section 100-500 $\mu$ thick, composed of loosely interwoven, thinwalled, often collapsing, usually hyaline hyphae $2-3 \mu$ in diameter, not incrusted; no cystidia; basidia with 4 sterigmata, protruding; spores tawny olive in a spore collection, even, $10-12 \times 6-7 \mu$.

Fructifications $4-20 \mathrm{~cm}$. long, $1-8 \mathrm{~cm}$. broad, $1 / 10^{-1 / 2} \mathrm{~mm}$. thick.

Common on prostrate limbs and logs and on under side of boards and timbers of coniferous species, rarely on frondose species. Canada to Louisiana and westward to Idaho. 
Coniophora arida, although frequently confused with $C$. cerebella, is very distinct from it by brighter color and adnate habit, and dry and thin, rather than fleshy and thick, structure; in sections the hyphae of $C$. arida are only $2-4 \mu$ in diameter, finer, thinner-walled and often collapsed, and more loosely interwoven than those of $C$. cerebella. C. arida and C. cerebella are both important timber destroyers.

Specimens examined:

Exsiccati: Cooke, Fungi Brit., ed. 2, 11, under the name Thelephora puteana; Ell. \& Ev., Fungi Col., 1306, under the name Coniophora Ellisii; Romell, Fungi Exs. Scand., $37 \mathrm{a}$ and $\mathrm{b}$.

Sweden: Femsjö, E. Fries, type (in Herb. Fries) ; L. Romell, 207; Stockholm, L. Romell, 205, and two collections in Romell, Fungi Exs. Scand., 37a and b.

England: Hampstead, in Cooke, Fungi Brit., ed. 2, 11.

Ontario: Ottawa, J. Macoun, 19; Port Credit, J. H. Faull, Univ. Toronto Herb., 308 (in Mo. Bot. Gard. Herb., 44891); Toronto, G. H. Graham, Univ. Toronto Herb., 683 (in Mo. Bot. Gard. Herb., 44942); Wilcox Lake, J. H. Faull, Univ. Toronto Herb., 647 (in Mo. Bot. Gard. Herb., 44927).

Vermont: Little Notch, near Bristol, E. A. Burt.

Massachusetts: Magnolia, W. G. Farlow.

Rhode Island: East Providence, W. G. Farlow.

New York: Albany, H. D. House, 1384, N. Y. State Mus. Herb., T2, and two unnumbered collections (in Mo. Bot. Gard. Herb., 54579, 14832, and 54383 respectively) ; Karner, H. D. House, N. Y. State Mus. Herb., 14.189, 14.203, 14.204, and an unnumbered collection (in Mo. Bot. Gard. Herb., $44723,44724,44726,54381$ respectively); Ithaca, G. F. Atkinson, 29, 9238 (in Cornell Univ. Herb.).

New Jersey: Newfield, J. B. Ellis, 3425, cotype of Coniophora Cookei (in N. Y. Bot. Gard. Herb.) and the specimen in Ell. \& Ev., Fungi Col., 1306.

Pennsylvania: Carbondale, E. A. Burt.

North Carolina: Biltmore, E. Bartholomew, 5659 (in Mo. Bot. Gard. Herb., 44269).

Louisiana: St. Martinville, A. B. Langlois, $c z$. 
Illinois: Riverside, E.T.\& S. A. Harper, 851.

Missouri: St. Louis, E. A. Burt (in Mo. Bot. Gard. Herb., 54696).

Idaho: Priest River, J. R. Weir, 83, 548 (the latter in Mo. Bot. Gard. Herb., 17806) ; Avery, J. R. Weir, 393 (in Mo. Bot. Gard. Herb., 11982).

4. C. Kalmiae (Peck) Burt, n. comb.

Corticium Kalmiae Peck, N. Y. State Mus. Rept. 46 : 109. 1893; Sacc. Syll. Fung. 11 : 125. 1895.

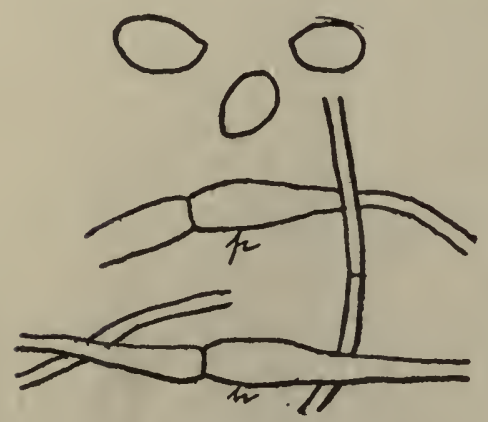

Fig. 4

C. Kalmiae.

Spores; hyphae with swollen portions, p. $\times 665$.

Type: in Coll. N. Y. State.

Fructification effused, thin, tender, adnate, drying straw-yellow to tawny olive, the subiculum and margin composed of slender, whitish filaments; hymenium glabrous, continuous; structure in section 150-300 $\mu$ thick, composed of loosely interwoven, hyaline, non-incrusted hyphae mostly $2-3 \mu$ in diameter but with occasionally a portion of a hypha swollen and 4-7 $\mu$ in diameter; no cystidia; spores tawny olive in a spore collection, even, 9-12×6-7 $\mu$.

Fructification 3-4 cm. long, 2-3 cm. broad.

On prostrate limbs and logs of frondose species, a single collection on hemlock spruce. Vermont and New York. September and October. Rare.

The type of this species is bright straw-yellow; the other collections which I have referred here have similar structure but are rather darker, approaching $C$. arida, from which, perhaps, $C$. Kalmiae is not specifically distinct. The occasional swollen portions of hyphae afford the best character for separation from $C$. arida.

Specimens examined:

Vermont: Little Notch, near Bristol, E. A. Burt.

New York: Shokan, C. H. Peck, type (in Coll. N. Y. State);

Ithaca, C. H. Kauffman, Cornell Univ. Herb., 14191; C. Thom, Cornell Univ. Herb., 14192-both of the Ithaca specimens comm. by G. F. Atkinson. 
5. C. inflata Burt, n. sp.

Type: in Mo. Bot. Gard. Herb.

Fructification effused, dry, membranaceous, separable, drying avellaneous, the margin mucedinous, concolorous in some places, deep olive-buff in others; hymenium even, pulverulent; in structure $300 \mu$ thick, with hyphae next to the substratum very loosely arranged, colored, forming some rope-like strands up to $15 \mu$ in diameter; hyphae $3-6 \mu$ in diameter, here and there globosely inflated up to $9-12 \mu$ in diameter, and sometimes with pyriform or subglobose, vesicular branches or hyphal ends up to $12 \times 9 \mu$; no cystidia; spores colored, even, $7-8 \times$ $3-4 \mu$.

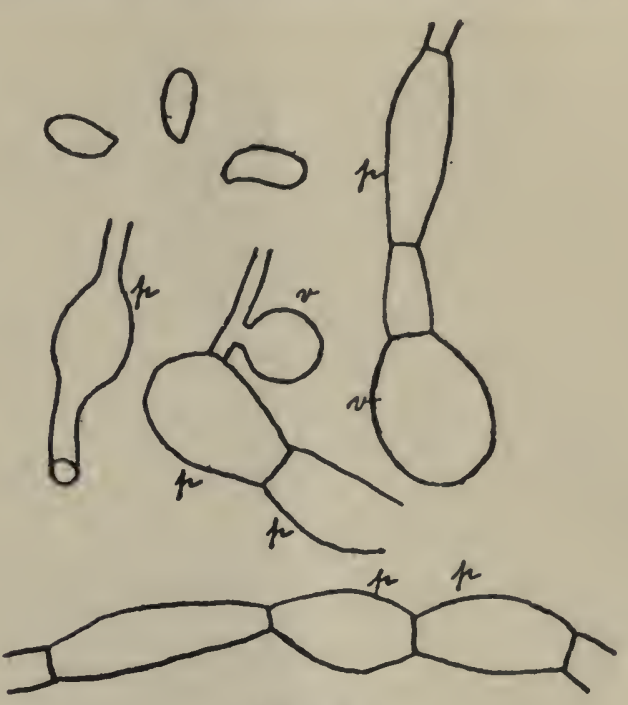

Fig. 5

C. inflata.

Spores; hyphae with inflated portions, $p$, and vesicular ends, $v$. $\times 665$.

Fructifications 5-10 cm. long, 3-5 cm. broad.

On a pine box in contact with the soil in a garden. Parral, Mexico. August.

This species is characterized by fructification becoming separable from substratum, by dry and loosely interwoven structure, by inflated or vesicular hyphal organs, and by smaller spores than any of the preceding species. The dry rot caused in the pine wood is of the brown, brittle type. The vesicular organs do not appear to be chlamydospores.

Specimens examined:

Mexico: Parral, Chihuahua, E. O. Matthews, 22, type (in Mo. Bot. Gard. Herb., 4511).

6. C. polyporoidea (Berk. \& Curtis) Burt, n. comb.

Corticium polyporoideum Berk. \& Curtis, Grevillea 1: 177. 1873; Sace. Syll. Fung. 6 : 618. 1888; Massee, Linn. Soc. Bot. Jour. $27: 130$. 1890. - Corticium alboflavescens Ell. \& Ev. Acad. Nat. Sci. Phila. Proc. 1894 : 324.1894 ; Sacc. Syll. Fung. 
11 : 124. 1895. - Coniophora alboflavescens (Ell. \& Ev.) v. Höhn. \& Litsch. K. Akad. Wiss. Wien Sitzungsber. 116 : 791. 1907.-Coniophora Petersii v. Höhn. \& Litsch. K. Akad. Wiss. Wien Sitzungsber. 117 : 1086. 1908, but not Corticium Petersii Berk. \& Curtis.

Type: type and cotype in Kew Herb. and Curtis Herb.

Fructification effused, membranaceous,
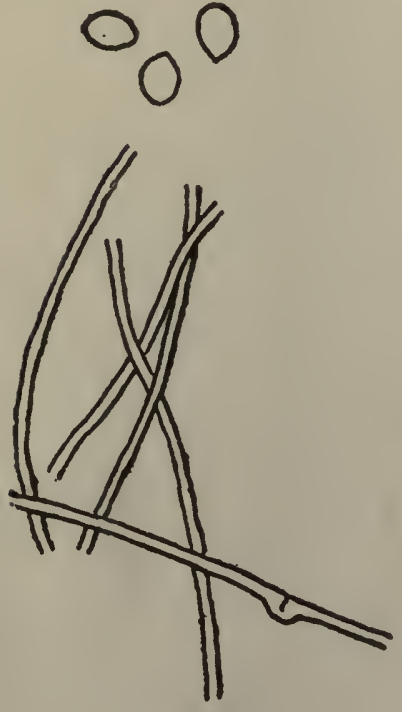

Fig. 6

C. polyporoidea. Spores, hyphae. $\times 665$. separable, drying pinkish buff, the margin white, cottony, often with radiating mycelial strands; hymenium even, pulverulent; in structure 400-1000 $\mu$ thick, composed (1) of a supporting layer of very loosely interwoven, hyaline hyphae $2 \frac{1}{2}-3$ $\mu$ in diameter, incrusted with scattered granules, and (2) of a compact hymenium; no cystidia; spores slightly colored under the microscope, even or slightly rough, $6-8 \times 4 \frac{1}{2}-6 \mu$.

Fructifications 1-15 cm. long, 1-5 cm. broad.

On prostrate fallen limbs and wood of various frondose and, more rarely, coniferous species, and on bark at bases of trees. New Hampshire to Florida and westward to Michigan and Arkansas. June to March.

This fine species has the color and surface texture of buckskin leather and a distinctly white margin. The spores differ from those of other species of the genus in having so little color and in absorbing eosin stain so intensely that their original color is masked by the dye and the species likely to be mistaken for a Corticium. The roughish spores show relationship to Hypochnus.

Specimens examined:

Exsiccati: Ell. \& Ev., N. Am. Fungi, 1716, under the name Corticium Petersii, and 3005, under the name Corticium alboflavescens; Ell. \& Ev., Fungi Col., 608, under the name Corticium Petersii, and 403, under the name Corticium alboflavescens; Ravenel, Fungi Am., 125, under the name Cor- 
ticium ochroleucum, and 723, under the name Corticium Petersii.

New Hampshire: Chocorua, W. G. Farlow, 19.

Vermont: Middlebury, E. A. Burt.

New York: Alcove, C. L. Shear, 1213; Copake, C. H. Peck, N. Y. State Mus. Herb., T8 (in Mo. Bot. Gard. Herb., 54580 ); East Galway, E. A. Burt, two collections ; Fort Ann, S. H. Burnham, 46 (in Mo. Bot. Gard. Herb., 54424) ; Gansevoort, C. H. Peck, N. Y. State Mus. Herb., T29 (in Mo. Bot. Gard. Herb., 54786); Karner, H. D. House (in Mo. Bot. Gard. Herb., 54382).

North Carolina: Asheville, H.C. Beardslee, 02125; Blowing Rock, G. F. Atkinson, 4196, 4319, 4329 (the last in Cornell Univ. Herb.).

South Carolina: Seaboard, in Ravenel, Fungi Am., 723.

Georgia: Tallulah Falls, A. B. Seymour, comm. by W. G. Farlow, FF.

Florida: W. W. Calkins (in U. S. Dept. Agr. Herb.), and in Ell. \& Ev., N. Am. Fungi, 1716; Gainesville, Ravenel, in Ravenel, Fungi Am., 125.

Alabama: Peters, type and cotype (in Kew Herb. and in Curtis Herb., 4559).

West Virginia: Nuttallburg, L. W. Nuttall, type distributions of Corticium alboflavescens, in Ell. \& Ev., N. Am. Fungi, 3005, and Fungi Col., 403.

Michigan: Ann Arbor, C. H.Kauffman, 35.

Ohio: Cincinnati, C. G. Lloyd, 4525.

Kentucky: Harlan, C. H. Kauffman, 67 (in Mo. Bot. Gard. Herb., 16419) ; Mammoth Cave, C. G. Lloyd, 2561.

Arkansas: Fordyce, C. J. Humphrey, 5828; Arkansas National Forest, W. H. Long, 19861 (in Mo. Bot. Gard. Herb., 8959); Womble, W. H. Long, 19791 (in Mo. Bot. Gard. Herb., 6388).

7. C. sistotremoides (Schw.) Massee, Linn. Soc. Bot. Jour. 25 : 133. 1889; Sacc. Syll. Fung. 9 : 241. 1891.

Thelephora sistotremoides Schweinitz, Naturforsch. Ges. Leipzig Schrift. 1:109. 1822; Am. Phil. Soc. Trans. N. S. 
$4: 168$. 1832; Fries, Elenchus Fung. $1: 198$. 1828. _Odontia sistotremoides (Schw.) Fries, Epicr. 529. 1838.

Type: a fragment in Herb. Schweinitz and portions in Herb. Fries and in Kew Herb. probably.

Effused, papery, papillate, sulphur-cinereous,

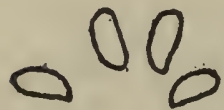

Fig. 7

C. sistotremoides.

Spores $\times 665$. the margin byssoid and white; papillae minute, pilose.

Broadly effused here and there on wood. Papillae abnormal, minute, occurring in the hymenium in scattered distant clusters, with the form in all respects of the teeth of Sistotrema and clothed with hairs as in T. botryoides.

- Translation of original description.

The portion of the type in Herb. Schweinitz is very small and not well preserved. I found its spores Saccardo's melleus, even, $8 \times 3-4 \mu$, and hyphae of the same color, but did not detect scattered, clustered granules in the hymenial surface. The portion preserved may, however, have been from the even region between the clustered granules. Fries received a specimen of $C$. sistotremoides from Schweinitz and in 'Epicrisis' transferred this species to Odontia, placing it next to Odontia fimbriata and describing the granules as wartlike, minute, dentiform, with apex concolorous and fimbriate.

I have been on the lookout for a Coniophora which combines in one specimen both the granular surface described by Schweinitz and Fries and the spore characters of the authentic specimen but have not yet found it. Coniophora olivascens has a granular surface to its fructification, but its spores are smaller than those of $C$. sistotremoides, more subglobose in form, and its hyphae are hyaline. Schweinitz's statement that the papillae are clothed with hairs as in his Hypochnus botryoides is important in showing that he refers to a surface composed of matted hyphae as seen with a lens in the case of Hypochnus botryoides and not necessarily to the presence of hair-like cystidia protruding from the granules in sections, although Fries must have had the latter type of structure in mind to lead him to place this species in Odontia between $O$. Barba Jovis and O. fimbriata. 
The northern specimens cited below have the approximate spore characters of $C$. sistotremoides but an even hymenium, hence they are all referred with doubt to this species for the present. Possibly the granular condition of this species may be confined to the vicinity of North Carolina.

Specimens examined:

Vermont: Grand View Mt., E. A. Burt.

Massachusetts: Magnolia, W. G. Farlow; Manchester, W. G. Farlow, 3.

New York: Alcove, C. L. Shear, 1130.

North Carolina: Schweinitz, type (in Herb. Schweinitz).

8. C. vaga Burt, n. sp.

Type: in Mo. Bot. Gard. Herb.

Fructification effused, spongy, hypochnoid, tomentose, drying between pinkish buff and cinnamon-buff, the margin thinning out and concolorous; in structure $300 \mu$ thick, composed of loosely interwoven, short-celled, suberect hyphae 6-7 $\mu$ in diameter, not incrusted, not nodose-septate, slightly colored and giving their color to the fructification; no cystidia; spores slightly colored, concolorous with the hyphae, even, apiculate, $71 / 2-9 \times 4 \frac{1}{2}-6 \mu$.

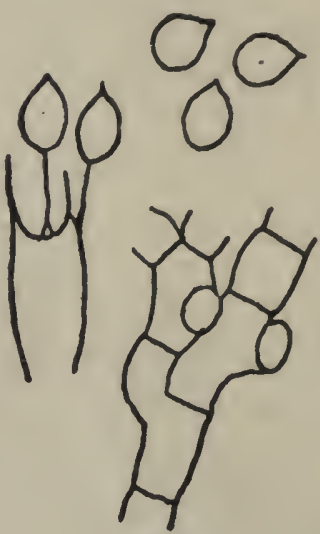

Fig. 8

C. vaga.

B a s id i u m with sterigmata, sporcs, hypha. $\times 665$.

Fructifications $8 \mathrm{~cm}$. or more long, $3 \mathrm{~cm}$. broad.

On bark of old log of Ulmus americana. Hudson Falls, New York. September.

In its general appearance $C$. vaga somewhat resembles $C o r$ ticium vagum but the former is more compact and darker colored, and its spores are colored, shorter, broader, and almost mucronate-pointed.

Specimens examined:

New York: Hudson Falls, S. H. Burnham, 20, type (in Mo.

Bot. Gard. Herb., 54498).

9. C. avellanea Burt, n. sp.

Type: in Burt Herb. 
Fructification effused, dry, adnate, drying light pinkish cinnamon (exactly avellaneous of Saccardo's 'Chromotaxia'), the margin concolorous, determinate; hymenium even, pulverulent; in structure 120-200 $\mu$ thick, with the hyphae $2-2 \frac{1}{2} \mu$ in diameter, hyaline, not incrusted, not nodose-

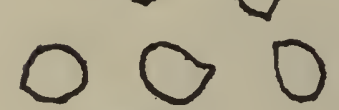

Fig. 9

C. avellanea.

Spores $\times 665$.

septate, running longitudinally and crowded together along the substratum, densely interwoven in the subhymenium; no cystidia; spores olive-buff in spore collection, only slightly colored under the microscope, even, $7-8 \times 6 \mu$.

Fructification $3-5 \mathrm{~cm}$. long, 1-3 cm. broad.

On decorticated coniferous wood. New York and Ohio. April and August.

$C$. avellanea differs from all the preceding species by its avellaneous color, closely adnate habit, thin and dense structure, fine hyphae, and nearly subglobose, slightly colored spores. C. Harperi is of nearly the same color, but has a loosely interwoven subiculum next to the substratum, coarser hyphae, and smaller spores.

Specimens examined:

New York: Altamont, E. A. Burt; East Galway, E. A. Burt, type.

Ohio: Madisonville, C. G. Lloyd, 0191.

10. C. Harperi Burt, n. sp.

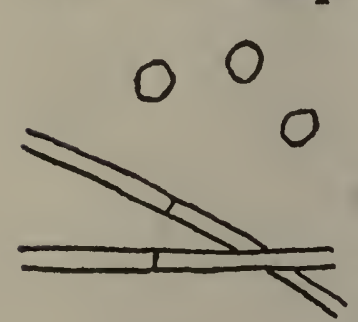

Type: in Burt Herb.

Fructification effused, dry, membranaceous, drying pinkish tan, brittle, not strongly attached to the substratum, the subiculum and margin whitish, floccose; hymenium even,

Fig. 10 pulverulent; in structure 150-200 $\mu$ thick,

C. Harperi. composed of loosely interwoven, suberect, Spores, hyphae. hyaline hyphae not incrusted, not nodose-
$\times 665$. septate, $3 \frac{1}{2}-5 \mu$ in diameter; no cystidia; spores slightly colored, even, sometimes slightly subangular, subglobose, $4-5 \times 4 \mu$.

Fructification 3-7 cm. long, 2-3 cm. broad. 
On white oak bark. Lake Geneva, Wisconsin. July.

This collection was at first referred to C. olivascens, but it differs from it in having no olivaceous component in its color, and its spores are subglobose and slightly subangular and its hyphae not nodose-septate. The fructifications are suggestive of Corticium arachnoideum in forming a delicate hymenial pellicle which is supported on a very thin and loose subiculum, but the hymenium and the spores are colored.

Specimens examined:

Wisconsin: Lake Geneva, E. T.\& S. A. Harper, 958, type.

11. C. dryina (Berk. \& Curtis) Massee, Linn. Soc. Bot. Jour. 25 : 135. 1889.

Corticium dryinum Berk. \& Curtis, Grevillea 1: 179. 1873; Sacc. Syll. Fung. 6 : 634. 1888.

Type: type and cotype in Kew Herb. and Curtis Herb. respectively.

Fructification effused, thick, dry, adnate, velvety, drying snuff-brown both externally and within; hymenium even, velvety; in structure 500-1000 $\mu$ thick with (1) next to the substratum a thin layer composed of closely interwoven, thick-walled, rigid hyphae $4-41 / 2 \mu$ in diameter, nodose-septate, not incrusted, concolorous with the fructification, and with (2) a broad stratose hymenial layer made up of about 4 or 5 sets of hymenia and supporting subhymenial layers whose hyphae are erect, branching, concolorous, $4-41 / 2 \mu$ in diameter; no cys-
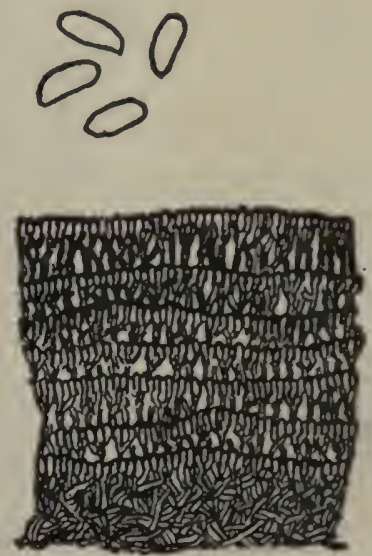

Fig. 11

C. dryina.

Section of fructification showing stratose structure $\times 45$ spores $\times 665$. tidia; basidia colored like the fructification, with 4 sterigmata; spores concolorous with the fructification, even, curved, pointed at the place of attachment, $8-9 \times 3 \frac{1}{2}-4 \mu$.

Fructification probably large, in the specimens known being about $4 \mathrm{~cm}$. long, $3 \mathrm{~cm}$. broad, and not having the original margin.

On rough surface of decaying oak wood. Alabama. November. 
It is surprising that only the original collection of $C$. dryina has been made, for the two portions which are the type and cotype were apparently from a large conspicuous fructification. C. dryina has as distinguishing characters its thickness, snuff-brown color throughout, velvety surface, absence of cystidia, and stratose structure.

Specimens examined:

Alabama: Peters, 709, type and cotype (in Kew Herb. and Curtis Herb., 5204, respectively).

12. C. suffocata (Peck) Massee, Linn. Soc. Bot. Jour. $25: 138.1889$.

Corticium suffocatum Peck, N. Y. State Mus. Rept. 30 : 48.

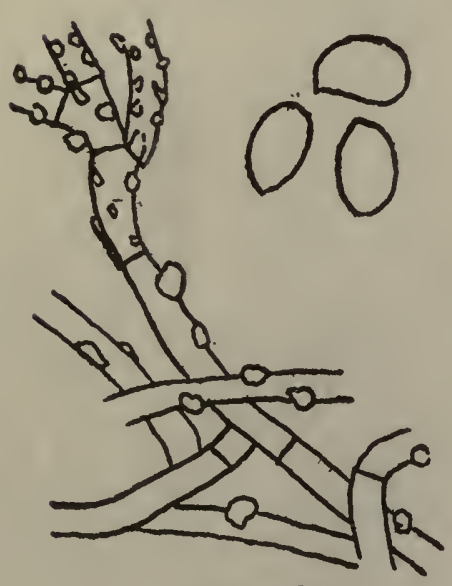

Fig. 12

C. suffocata.

Incrusted hyphae, spores. $\times 665$.
1879; Sacc. Syll. Fung. $6: 621.1888$.

Type: in Coll. N. Y. State.

Fructification effused, indeterminate, membranaceous, not fleshy, somewhat separable when thick, drying from avellaneous to tawny olive and Saccardo's umber, the under side and margin usually whitish and mucedinous; hymenium even; in structure $60-500 \mu$ thick, composed of loosely interwoven, usually hyaline, sometimes brownish, more or less incrusted hyphae $3 \frac{1}{2}-6 \mu$ in diameter under the incrustation, not nodose-septate; no cystidia or with cystidia barely distinguishable from immature basidia; spores snuff-brown in a spore collection, even, 10-12×6-7 $\mu$.

Fructification 2-9 $\mathrm{cm}$. long, 1-5 cm. broad.

Common on under side of coniferous boards and limbs lying on the ground, rare on frondose species. Canada to Louisiana and westward to Vancouver Island and Washington. May to January.

This species bears some resemblance to $C$. cerebella and C. arida, approaching the former in its separable tendency when thick and the latter in general habit, coloration, dry structure, and loose arrangement of its hyphae. It is distin- 
guished from both species by having incrusted hyphae which are coarser than those of $C$. arida. The European $C$. Betulae Karst., of which I have an authentic specimen, does not form a compact hymenial membrane, is very thin, not at all separable from substratum, has the margin similar to the central portion of the fructification, hyphae frequently nodose-septate, and cystidia always present, $6 \mu$ in diameter, emerging 20-30 $\mu$ above the basidia-differing in all the above respects from our C. suffocata. C. subcinnamomea Karst. differs by having in its hymenium noteworthy branching paraphyses and small, flexuous cystidia. C. suffocata is probably very destructive as a timber rot. The cystidia when occasionally distinguishable are about $6 \mu$ in diameter and emerge up to 20 or even $40 \mu$ above the basidia.

Specimens examined:

Exsiccati: Ellis, N. Am. Fungi, 328, under the name Hymenochaete Ellisii; Ell. \& Ev., Fungi Col., 219, under the name Coniophora puteana.

Canada: Lower St. Lawrence Valley, J. Macoun, 7, 48, 55. Ontario: Ottawa, J. Macoun, 416; Toronto, G. H. Graham, Univ. Toronto Herb., 681 (in Mo. Bot. Gard. Herb., 44939). Vermont: Middlebury, E. A. Burt.

Massachusetts: Belmont Spring, C. Bullard, comm. by W. G. Farlow, 3, and an unnumbered specimen; Hammond's Pond, Brookline, G. R. Lyman, 176.

New York: Alcove, C. L. Shear, 1303; East Galway, E. A. Burt; Ithaca, G. F. Atkinson, 997; Karner, H. D. House, N. Y. State Mus. Herb., 14.165 (in Mo. Bot. Gard. Herb., 44714); Sandlake, C. H. Peck, type (in Coll. N. Y. State). New Jersey: Newfield, J. B. Ellis, in Ellis, N. Am. Fungi, 328, and in Ell. \& Ev., Fungi Col., 219, and on white oak, Feb. 3, 1877 (in Farlow Herb.).

Pennsylvania: State College, C. R. Orton, comm. by L. O. Overholts, 2897 (in Mo. Bot. Gard. Herb., 5719).

District of Columbia: Rock Creek, C. L. Shear, 1350.

Florida: W. W. Calkins (in U. S. Dept. Agr. Herb., under the name Corticium epichlorum).

Louisiana: St. Martinville, A. B. Langlois, cg. 
Indiana: Millers, E.T.\&S. A. Harper, 648.

Illinois: Glenellyn, E. T. \& S. A. Harper, 956.

Missouri : Creve Coeur, E. A. Burt (in Mo. Bot. Gard. Herb., 54782).

Montana: Evaro, J. R. Weir, 432 (in Mo. Bot. Gard. Herb., 1807).

Idaho: Priest River, J. R. Weir, 8.

British Columbia: Vancouver Island, J. Macoun, comm. by J. Dearness, V 134 (in Mo. Bot. Gard. Herb., 23093).

Washington: Bingen, W. N. Suksdorf, 868, 895, 956; Kalama, C. J. Humphrey, 6226; Olympia, C. J. Humphrey, 6335.

13. C. umbrina Alb. \& Schw. ex Fries in Sacc. Syll. Fung. 6 : 652. 1888; Massee, Linn. Soc. Bot. Jour. 25 : 131. 1889.

Thelephora umbrina var. $\beta$. Alb. \&

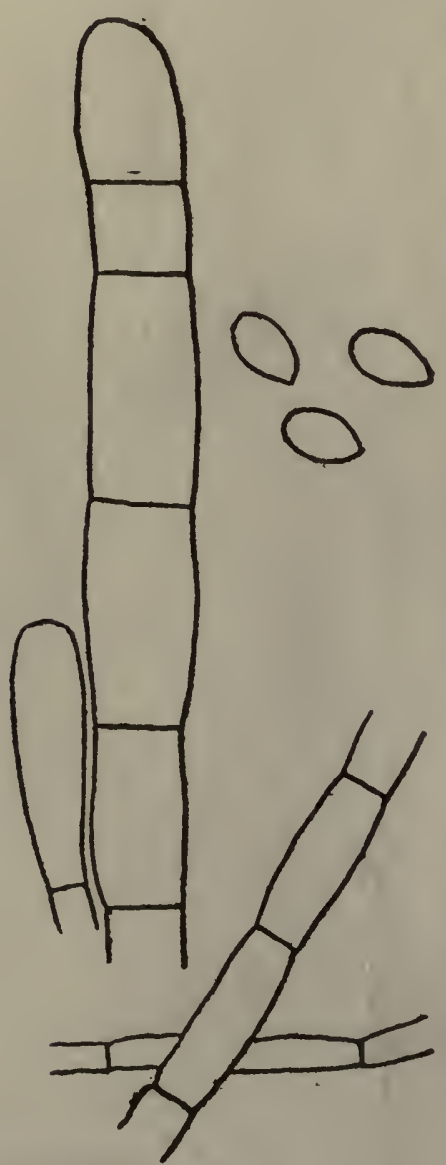

Fig. 13

C. umbrina.

Young basidium, upper portion of cystidium, spores, hyphae. $\times 665$. Schw. Consp. Fung. 281. 1805.-Thelephora umbrina (Alb. \& Schw.) Fries, Elenchus Fung. 1 : 199. 1828; Epicr. 543. 1838. - Corticium (subg. Coniophora) umbrinum (Alb. \& Schw.) Fries, Hym. Eur. 658. 1874.-Coniophorella umbrina (Alb. \& Schw.) Bresadola, Ann. Myc. 1: 111. 1903.

Type : location of type unknown to me.

Fructification effused, soft, not readily separable, villose beneath, drying Saccardo's umber to olive-brown, the margin usually of the same color, narrow, radiating; hymenium even, sometimes granular, tomentose, setulose; in structure $180-400 \mu$ thick, with the hyphae colored, 3-6 $\mu$ or rarely more in diameter, rather rigid, not nodose-septate, loosely interwoven; cystidia concolorous, septate, obtuse, 100-200×9-12 $\mu$, emerging up to $120 \mu$, even or granuleincrusted; spores concolorous under the microscope, even, $9-12 \times 5-6 \mu$, flattened on one side. 
Fructifications up to $3-8 \mathrm{~cm}$. long, $2-4 \mathrm{~cm}$. broad.

Under rotting pine boards and limbs on the ground. New York, Maryland, and Washington. October to December. Probably rare.

This species is characterized by its dark color-usually olive-brown-dark-colored hyphae, and very large, septate, colored, incrusted cystidia. Our American specimens agree well with that from Europe received from Bresadola, whose view of this species I follow.

Specimens examined: Russian Poland: Eichler, comm. by G. Bresadola. New York: Alcove, C. L. Shear, 1326. Maryland: Takoma Park, C. L. Shear, 997. Washington: Bingen, W. N. Suksdorf, 869, 870 .

14. C. olivacea (Fr.) Karsten, Finska Vet.-Soc. Bidrag Natur och Folk $37: 162$. 1882; Sacc. Syll. Fung. 6 : 649. 1888; Massee, Linn. Soc. Bot. Jour. 25 : 129. 1889; Bresadola, I. R. Accad. Agiati Atti III. 3 : 116. 1897.

Hypochnus olivaceus Fries, Obs. Myc. 2:282. 1818 (in part).-Thelephora olivacea Fries, Elenchus Fung. 1:197. 1828 (in part).-Corticium (subg. Hypochnus) olivaceum Fries, Hym. Eur. 660. 1874 (in part).-Corticium (subg.Coniophora) olivaceum (Fr.) Cooke, Grevillea 8 : 89. 1880.-Coniophorella olivacea (Fr.) Karsten, Finl. Basidsv. 438. 1889; Bresadola, Ann. Myc. 1 : 110. 1903.-Corticium leucothrix Berk. \& Curtis, Grevillea 2:4. 1873.-Corticium (subg. Coniophora) leucothrix (Berk. \& Curtis) Cooke, Grevillea $8: 89$. 1880.-Coniophora leucothrix (Berk. \& Curtis) Cooke in Sacc. Syll. Fung. 6 : 648. 1888; Massee, Linn. Soc. Bot. Jour. 25 : 133. 1889.Corticium brunneolum Berk. \& Curtis, Grevillea $2: 4.1873$. -Corticium (subg. Coniophora) brunneolum (Berk. \& Curtis) Cooke, Grevillea 8:88. 1880. - Coniophora brunneola (Berk. \& Curtis) Cooke in Sacc. Syll. Fung. 6 : 648. 1888; Massee, Linn. Soc. Bot. Jour. 25 : 134. 1889.-Hymenochaete Ellisii Berk. \& Cooke, Grevillea 4:162. 1876. - Corticium (subg. Coniophora) Ellisii (Berk. \& Cooke) Cooke, Grevillea 8:89. 1880.-Coniophora Ellisii (Berk. \& Cooke) Cooke in 
Sacc. Syll. Fung. 6 : 648. 1888; Massee, Linn. Soc. Bot. Jour. 25 : 129. 1889.-Coniophora fulvo-olivacea Massee, Linn. Soc. Bot. Jour. 25 : 134. 1889; Sacc. Syll. Fung. 9 : 241. 1891.

Type: in Herb. Fries; the specimen in Kew Herb. from Fries and named by him Thelephora olivacea is Coniophora Betulae.

Fructification effused, adnate, somewhat felt-like, and sep-

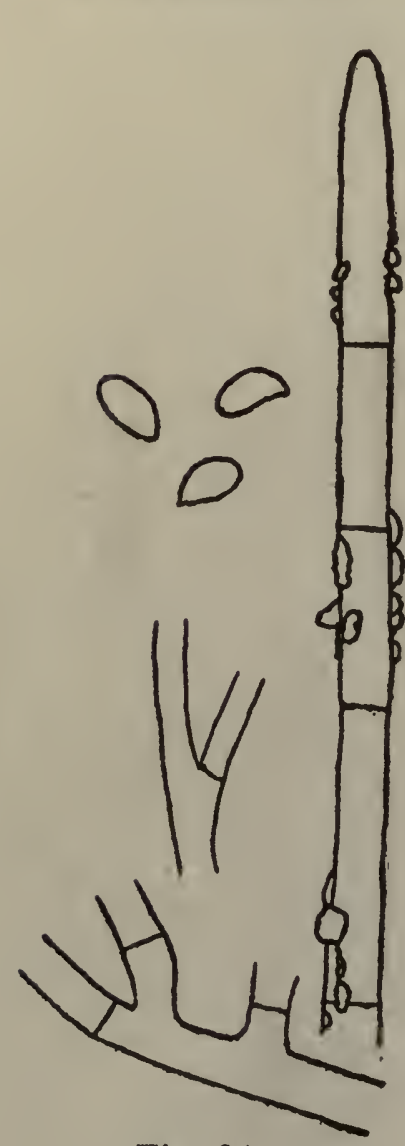

Fig. 14

C. olivacea.

Spores, protruded por. tion of cystidium, hyphae. $\times 665$. arable from the substratum with a scalpel, drying buffy citrine and Saccardo's olive to brownish olive, the margin thinning out and sometimes whitish; hymenium even, tomentose, setulose; in structure $200-700 \mu$ thick, composed of more or less colored hyphae 3-6 $\mu$ in diameter, not nodoseseptate, not usually incrusted, which are loosely interwoven next to the substratum and form a very dense hymenial layer; cystidia septate, granule-incrusted, tapering upward, concolorous with the hyphae at the base, paler above, 8-12 $\mu$ in diameter, protruding 50-100 $\mu$; spores colored, even, $7-12 \times 4 \frac{1}{2}-5 \frac{1}{2} \quad \mu$, often flattened on one side.

Fructification $4-10 \mathrm{~cm}$. long, 2-5 cm. broad.

On coniferous wood and bark, rarely on frondose species. Canada to Louisiana and westward to Idaho.

C. olivacea is paler externally and internally than $C$. umbrina, has fewer cystidia, and hyphae with usually thinner walls and often collapsed. I have been able to detect no morphological characters which sharply separate these species. I was not able to study in Herb. Fries the original collection from Femsjö of Coniophora olivacea, for the specimen was loaned to Bresadola when I was at Upsala. I have presented C. olivacea as understood by Bresadola in the specimen conmunicated to me by him and cited below. The specimen of 
Thelephora olivacea from Fries in Kew Herb., determined by Fries, has small, non-septate cystidia and incrusted hyphae, and is quite different from $C$. olivacea as understood by Bresadola. The specimen in Kew Herb. is not distinct from Coniophora Betulae Karst.

Specimens examined:

Exsiccati: Ell. \& Ev., N. Am. Fungi, 3211; Krieger, Fungi Sax., 2011; Rabenhorst-Winter, Fungi Eur., 2721.

Finland: Karsten, in Rabenhorst-Winter, Fungi Eur., 2721 (in Kew Herb., the type of Coniophora fulvo-olivacea).

Sweden: L. Romell, 209; Stockholm, L. Romell, 208.

Germany: Schandau, W. Krieger, in Krieger, Fungi Sax., 2011.

Austria-Hungary: G. Bresadola.

Canada: J. Macoun, 252; St. Lawrence Valley, J. Macoun, 67. Ontario: Ottawa, J. Macoun, 382.

New Hampshire: Chocorua, W. G. Farlow.

Vermont: Middlebury, E. A. Burt.

New York: Floodwood, C. H. Peck; Ithaca, G. F. Atkinson, 2516; A. J. Pieters, Cornell Univ. Herb., 5261; G. F. Atkin son, Cornell Univ. Herb., 14352; Karner, H. D. House (in Mo. Bot. Gard. Herb., 54395).

New Jersey: Newfield, J. B. Ellis, in Ell. \& Ev., N. Am. Fungi, 3211.

Pennsylvania: Trexlertown, W. Herbst.

Maryland: Takoma Park, C. L. Shear, 969.

South Carolina: Society Hill, M. A. Curtis, 4775, the cotype of Corticium leucothrix (in Curtis Herb.).

Georgia: Tallulah Falls, A. B. Seymour \& W. L. Moss, comm. by W. G. Farlow, a (in Mo. Bot. Gard. Herb., 44596).

Alabama: Bessie Junction, C. J. Humphrey, 5355.

Louisiana: Dr. Hale, the cotype of Corticium brunneolum (in Curtis Herb., 3664); Abita Springs, A. B. Langlois, 2695, 2696.

Ohio: Linwood, C. G. Lloyd, 02834.

Missouri: Creve Coeur, E. A. Burt (in Mo. Bot. Gard. Herb., 54770 ); St. Louis, E. A. Burt (in Mo. Bot. Gard. Herb., $54781)$. 
Montana: Banner, J. R. Weir, 405 (in Mo. Bot. Gard. Herb., 10582).

Idaho: Kaniksu National Forest, Priest River, J. R. Weir, 68.

15. C. atrocinerea Karsten in de Thümen, Myc. Univ. 1806. 1881; Soc. pro Fauna et Flora Fennica Meddel. $6: 12.1881$; Finska Vet.-Soc. Bidrag Natur och Folk 37 : 162. 1882; Sacc. Syll. Fung. 6 : 650. 1888; Massee, Linn. Soc. Bot. Jour. 25 : 132. 1889.

Coniophorella atrocinerea Karsten, Finl. Basidsv. 438. 1889. Type: type distribution in de Thümen, Myc. Univ., 1806.

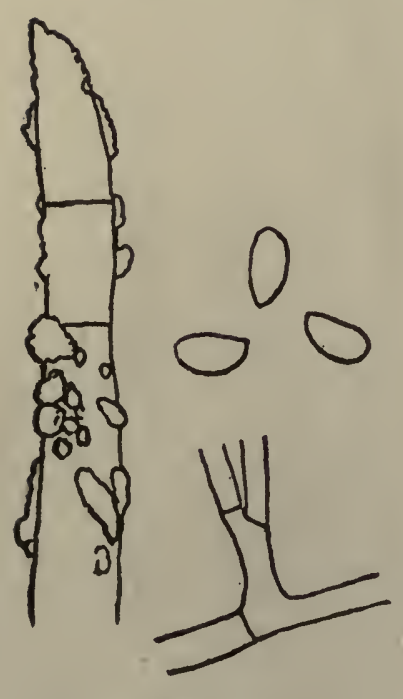

Fig. 15

C. atrocinerea.

Protruded part of cystidium, s p o res, hypha. $\times 665$.

Fructification effused, byssoid-membranaceous, adnate, drying sepia, the margin somewhat mucedinous and paler, sometimes whitish; hymenium even; in structure 250-500 $\mu$ thick, composed of loosely interwoven, nearly black, rigid, even hyphae $3 \frac{1}{2}-5 \mu$ in diameter, not nodoseseptate, not incrusted; cystidia incrusted, septate, $9-15 \mu$ in diameter, emerging up to $60 \mu$; spores colored, even, $9-10 \times 41 / 2-6 \mu$.

Fructifications 1-2 cm. long, $1 \mathrm{~cm}$. broad, becoming confluent in crevices of the bark so as to form patches up to $8 \mathrm{~cm}$. long.

In crevices of bark of pine logs. Louisiana. January.

The Louisiana collection agrees closely with the type distribution from Finland in all respects except in having slightly broader spores, which are $6 \mu$ in diameter in the American specimen and usually about $4 \frac{1}{2} \mu$ in the type, although published by Karsten as $5-6 \mu$. This species is very distinct by its firm, rigid, and nearly black hyphae. It is strange that two specimens of so similar and marked structure occur at such widely distant localities without intermediate stations.

Specimens examined:

Exsiccati : de Thümen, Myc. Univ., 1806.

Finland: Mustiala, P. A. Karsten, type distribution, in de Thümen, Myc. Univ., 1806. 
Louisiana: St. Martinville, A. B. Langlois, 2639 in part.

16. C. flava Burt, n. sp.

Type: in Burt Herb. and N. Y. Bot. Gard. Herb.

Fructification effused, soft, membranaceous, separable from the substratum, drying primuline-yellow throughout, with the margin a little paler; hymenium even, cracked, somewhat pulverulent; in structure $400 \mu$ thick (1) with the hyphae loosely interwoven next to the substratum, $3-4 \frac{1}{2} \mu$ in diameter, occasionally nodose-septate, frequently more or less incrusted, and (2) with the hyphae more densely arranged in the subhymenium, more regularly incrusted, and containing many heavily incrusted, cylindric cystidia 8-9 $\mu$ in diameter, which do not protrude beyond the surface of the hymenium; hymenial cystidia usually not incrusted, 5-7 $\mu$ in diameter, emerging up to $30 \mu$, occasionally with a few incrusting granules near the base; spores concolorous with the hyphae and the fructification, borne 4 to a basidium, even, flattened or slightly curved on one side, $4 \times 2 \mu$.

The portion of a fructification which $I$ have seen is $11 / 2 \times 1 \mathrm{~cm}$.

Substratum not noted. Jamaica. January.
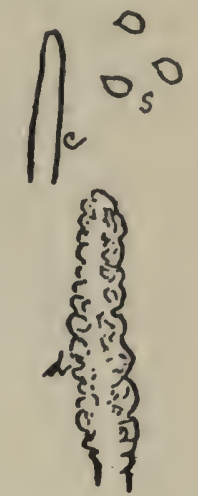

Fig. 16

C. flava.

Protrud. ed $p$ art of cystidium, $c$; i n c r u sted cystidium from interior of fructificat i o n, d; spores,s. $\times 665$.

Although I have seen but a small portion of a fructification, which does not afford data as to margin or substratum, this portion shows a species which should be readily recognized by its bright yellow color throughout, peeling away from the substratum in a compact sheet, small spores flattened on one side, and by heavily incrusted, wholly buried cystidia.

Specimens examined:

Jamaica: Troy and Tyre, Cockpit Country, $2000 \mathrm{ft}$. altitude, W. A. Murrill \& W. Harris, N. Y. Bot. Gard., Fungi of Jamaica, 1089.

17. C. laeticolor Karsten, Finl. Basidsv. 436. 1889; Massee, Linn. Soc. Bot. Jour. 25 : 137. 1889. 
Xerocarpus laeticolor Karsten, Finska Vet.-Soc. Bidrag Natur och Folk 37 : 137. 1882; Soc. pro Fauna et Flora Fennica Meddel. 9 : 52. 1883.-Corticium laeticolor (Karst.) Sacc. Syll. Fung. 6 : 636. 1888.-Coniophora crocea Karsten, Rev. Myc. 9:10. 1887; (this synonym published by Karsten); Soo. pro Fauna et Flora Fennica Meddel. 14 : 83. 1888; Sacc. Syll. Fung. 6 : 651. 1888; Massee, Linn. Soc. Bot. Jour. 25 : 137. 1889.

Type: authentic specimen of $C$. crocea in Burt Herb.

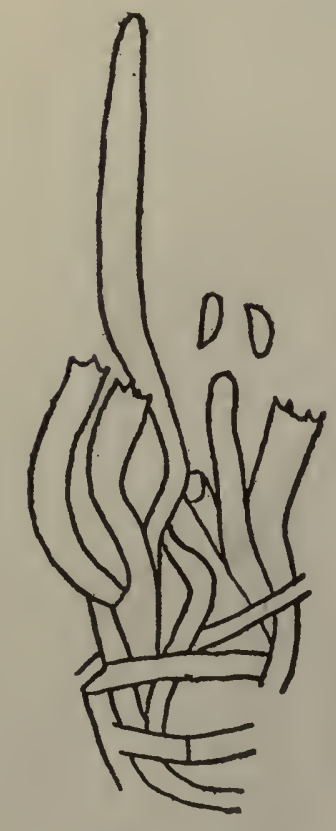

Fig. 17

C. laeticolor.

Section showing hyphae, cystidium, basidia, s p ores. $\times 665$.

Fructification effused, adnate, indeterminate, drying raw sienna, the margin of the same color, thinning out; hymenium even, compact, somewhat pulverulent; in structure 60-120 $\mu$ thick, with the hyphae giving their bright color to the fructification, not incrusted, occasionally nodose-septate, $3-4 \mu$ in diameter, ascending more or less densely from the substratum to the hymenial surface; cystidia cylindric, not incrusted, simple, or few-septate, $4-4 \frac{1}{2} \mu$ in diameter, emerging 20-60 $\mu$; spores concolorous with the hyphae, even, flattened on one side or slightly curved, $6-7 \times 21 / 2-3 \mu$.

Fructifications $4 \mathrm{~cm}$. long, 2-21/2 $\mathrm{cm}$. broad. On badly decayed, coniferous wood. Elkmont, Tennessee. September. Probably rare.

This species suggests by its bright color and thin, adnate habit the conidial stroma of some species of Hypoxylon, and it may have been overlooked heretofore on account of this resemblance. It is well marked by its bright color, thin and compact habit of growth, small, slender spores, and cystidia.

Specimens examined:

Finland: Mustiala, P.A. Karsten, under the name Coniophora crocea.

Tennessee: Elkmont, C. H. Kauffman, 70 (in Mo. Bot. Gard. Herb., 16397). 
18. C. byssoidea (Pers.) Fries, Hym. Eur. 659. 1874 (in subg. Coniophora); Karsten, Finska Vet.-Soc. Bidrag Natur och Folk 37 : 160. 1882; Sacc. Syll. Fung. 6 : 652. 1888.

Thelephora byssoides Persoon, Syn. Fung. 577. 1801; Fries, Syst. Myc. 1 : 452. 1821.-Corticium (subg. Coniophora) byssoideum (Pers.) Fries, Hym. Eur. 659. 1874.-Coniophorella byssoidea (Pers.) Bresadola, Ann. Myc. 1:111. 1903; Sacc. Syll. Fung. 17 : 183. 1905.-Peniophora byssoidea (Pers.) v. Höhn. \& Litsch. K. Akad. Wiss. Wien Sitzungsber. 117 : 1084. 1908.-Diplonema sordescens Karsten, Finl. Basidsv. 430. 1889.-Peniophora sordescens (Karst.) Sacc. Syll. Fung. 9 : 240. 1891.

Fructification effused, dry, at first flaxy and hypochnoid, at length compact at the disk, drying cream-color to Naples yellow, the margin flaxy; hymenium even, tomentose; in structure 150-350 $\mu$ thick, composed of very loosely interwoven, rigid, nodose-septate hyphae 3-4 $\mu$ in diameter, which give the color to the fructification; cystidia slender, tapering, sharp-pointed, non-incrusted hairs, frequently nodoseseptate, concolorous with the hyphae, $3-4 \frac{1}{2} \mu$ in diameter, emerging up to $20-60$ $\mu$; spores concolorous with the hyphae but sometimes nearly hyaline under the microscope ,even, $4-4 \frac{1}{2} \times 21 / 2-3 \mu$, perhaps larger in spore collections.

Fructifications ranging from 1 to $6 \mathrm{~cm}$. in diameter, or perhaps larger.

On wood and objects on the ground and

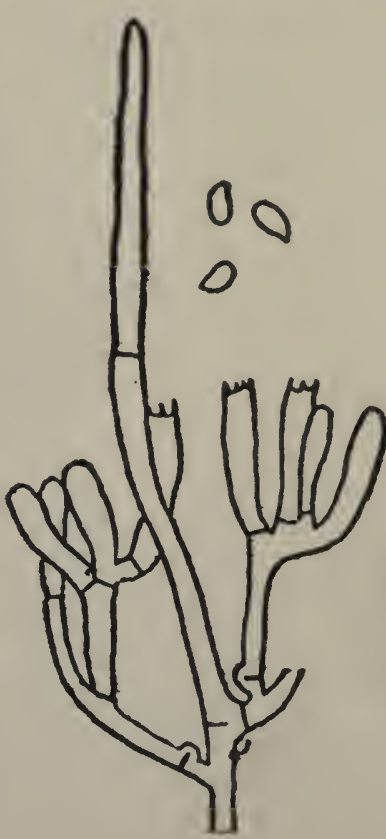

Fig. 18

C. byssoidea.

Hypha bearing cystidium and $b$ a s id i a ; spores. $\times 665$. running over the humus in pine woods. Canada to Louisiana and westward to British Columbia and Oregon, also in Jamaica; apparently very common in the northwest. June to December.

If one does not overlook the pale color of the small spores, this species is easily recognized, for in Coniophora it is noteworthy among all species of the genus by its bright color- 
cream-color to Naples yellow throughout-hypochnoid structure, rather stiff, loosely arranged, nodose-septate hyphae, and slender septate cystidia frequently nodose-septate.

Specimens examined:

Exsiccati: Cooke, Fungi Brit., ed. 2, 607, under the name Corticium sulphureum; Krieger, Fungi Sax., 363.

Finland: Mustiala, P.A. Karsten, authentic specimen of Diplonema sordescens.

Sweden: L. Romell, 78, 79; Stockholm, L. Romell, 110, 111, 236.

Germany: Saxony, Königstein, W. Krieger, in Krieger, Fungi Sax., 363.

Austria-Hungary: G. Bresadola.

England: in Cooke, Fungi Brit., ed. 2, 607, under the name Corticium sulphureum.

Canada: locality not given, J. Macoun, 10 in part, 15, 22; Lower St. Lawrence Valley, J. Macoun, 39, 59, 61.

Ontario: Ottawa, J. Macoun, 142, 143.

Vermont: Middlebury, E. A. Burt, two collections.

Connecticut: New Haven, G. P. Clinton.

New York: Fall Creek, G. F. Atkinson, 7994; Freeville, G. F. Atkinson, 2589.

Florida: locality not given, $W$. W. Calkins; Jacksonville, R. A. Harper, 1, 2, 3, 11 (in Mo. Bot. Gard. Herb., 5452754530 respectively).

Louisiana: De Ridder, C. J. Humphrey, 2527 (in Mo. Bot. Gard. Herb., 12532); St. Martinville, A. B. Langlois, di, j. Michigan: Michigamme, C. J. Humphrey, 1455 (in Mo. Bot. Gard. Herb., 22972).

Montana: Birch Creek, Beaverhead National Forest, C. J. Humphrey, 2553 (in Mo. Bot. Gard. Herb., 9524).

Idaho: Coeur d'Alene, J. R. Weir, 623 (in Mo. Bot. Gard. Herb., 13853) ; Priest River, J. R. Weir, 132, 343 (in Mo. Bot. Gard. Herb., 15761, 21363).

British Columbia: Kootenai Mountains, near Salmo, $J$. $R$. Weir, 518, 537, 623, 448, 475, 483, 492, 505, 504 in part, 486 (in Mo. Bot. Gard. Herb., 19420, 1737, 13853, 8836, 20977, 21979, 21982, 2096, 14169, 20226 respectively); Sidney, 
J. Macoun, 26 in part, 27 (in Mo. Bot. Gard. Herb., 5681, 8934 ) ; Vancouver Island, J. Macoun, comm. by J. Dearness, V 186 (in Mo. Bot. Gard. Herb., 20183).

Oregon: Joseph, C. L. Shear, $103 \%$.

Jamaica: Cinchona, W. A. \& Edna L. Murrill, N. Y. Bot. Gard., Fungi of Jamaica, 459.

19. C. olivascens (Berk. \& Curtis) Massee, Linn. Soc. Bot. Jour. 25 : 138. 1889.

Corticium olivascens Berk. \& Curtis, Grevillea 1: 179. 1873; Sacc. Syll. Fung. 6 : 619. 1888.-Corticium prasinum Berk. \& Curtis, Grevillea 1 : 179. 1873; Sacc. Syll. Fung. 6 : 619. 1888; Massee, Linn. Soc. Bot. Jour. 27 : 153. 1890.-Coniophora prasina (Berk. \& Curtis) v. Höhn. \& Litsch. K. Akad. Wiss. Wien Sitzungsber. $116: 781$. 1907. - Corticium chlorinum Berk. \& Curtis, Grevillea 1:179. 1873; Sacc. Syll. Fung. 6 : 636. 1888; Massee, Linn. Soc. Bot. Jour. 27 : 154. 1890.Coniophora subochracea Peck, N. Y. State Mus. Rept. $50: 114.1897$; Sacc. Syll. Fung. $14: 225.1899$.

Type: type and cotype in Kew Herb. and Curtis Herb. respectively.

Fructification effused, dry, adnate, drying olive-lake to olive-citrine, the subiculum and margin whitish, floccose; hymenium even or minutely granular, more or less cracked; in structure 200$400 \mu$ thick, with the granules rising up to $200 \mu$ more, composed of hyaline, thinwalled, often collapsed, nodose-septate hyphae 3-5 $\mu$ in diameter, loosely interwoven, sometimes with rope-like hyphal strands near the substratum; granules

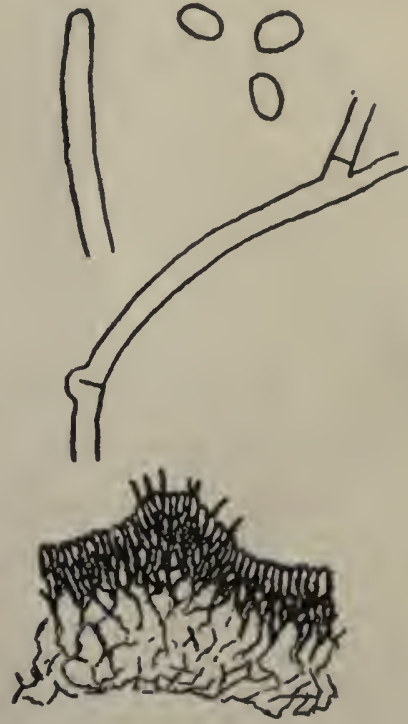

Fig. 19

C. olivascens.

Protruded part of cys. tidium, spores, and hypha, $\times 665$; section showing cystidia on a granule $\times 45$. dome-shaped, bearing hair-like cystidia scattered or in small clusters, not incrusted, often nodose-septate, $4-5 \mu$ in diameter, emerging up to $60 \mu$; spores Isabella-color in a spore collection, even, $4-6 \times 3-4 \mu$, mostly $5 \times 3 \frac{1}{2} \mu$. 
Fructifications 11/2 $-3 \mathrm{~cm}$. long, 1-2 cm. broad.

On coniferous bark and wood on the ground and on palmetto. Ontario to Louisiana, and in Cuba and the Bahama Islands. July to April.

C. olivascens is distinguished by its olivaceous color varying by intermediate shades to almost bottle-green, by its small spores, and by having hair-like cystidia protrude from its granules, frequently in clusters, as in the genus Odontia. The granular hymenial surface appears to be more frequent in northern collections than in those from the south, and the hyphae are more abundantly nodose-septate in northern specimens. Occasionally a collection will fail to show cystidia in a set of sections, especially if the fructification is rather young, but examination of other sets of sections from the oldest and most granular portions of the fructification will eventually demonstrate cystidia. Grandinia virescens. Pk. is colored exactly like $C$. olivascens and has the same general habit, but the spores of G.virescens are darker and minutely aculeate when the fructification is fully mature.

Specimens examined:

Exsiccati: Ravenel, Fungi Car. 5 : 29.

Canada: Ottawa, J. Macoun, 25.

Ontario: Port Credit, J. H. Faull, 321 (in Mo. Bot. Gard. Herb., 44945).

Massachusetts: Boston, Murray, cotype (in Curtis Herb., 6392).

New York: Albany, H. D. House (in Mo. Bot. Gard. Herb., 15946); East Galway, E. A. Burt; Ithaca, G. F. Atkinson, 22977; C. J. Humphrey, Cornell Univ. Herb., 22562; Karner, H. D. House, 14.190, 14.169, and two unnumbered collections (in Mo. Bot. Gard. Herb., 44718, 44720, 54363, 54364) ; Menands, C. H. Peck, type of Coniophora subochracea (in Coll. N. Y. State); Westport, C. H. Peck (in N. Y. State Mus. Herb. and in Mo. Bot. Gard. Herb.).

New Jersey: Newfield, J. B. Ellis, comm. by W. G. Farlow (in Mo. Bot. Gard. Herb., 44641).

Pennsylvania: Whitehaven, G. F. Atkinson, 8653.

Alabama: Peters, type distribution of Corticium prasinum in 
Ravenel, Fungi Car. 5:29, and cotype (in Curtis Herb., $6080)$.

Louisiana: Abita Springs, A. B. Langlois, 2639 in part; St. Martinville, A. B. Langlois, $u$.

Michigan: Ann Arbor, C. H. Kauffman, 21.

Bahama Islands: Nassau, A.E. Wight, comm. by W. G. Farlow.

Cuba: San Diego de los Banos, Earle \& Murrill, 334, N. Y. Bot. Gard., Fungi of Cuba.

\section{EXCLUDED SPECIES}

C. capnoides Ell. \& Ev. Phila. Acad. Nat. Sci. Proc. 1894 : 324. 1894; Sacc. Syll. Fung. 11 : 129. 1895.

Type: type distribution in Ell. \& Ev., N. Am. Fungi, 2808.

This fungus bears its spores singly on conidiophores, as stated in the original description, and is not a basidiomycete.

C. sordulenta Cooke \& Massee in Sacc. Syll. Fung. $6: 650$. 1888; Massee, Linn. Soc. Bot. Jour. 25 : 132. 1889.

Type: type in Kew Herb.

This species is not distinct from Thelephora pallescens Schw., whose relationship to Hypochnus thelephoroides (Ell. \& Ev.) Burt was pointed out in my comment on the latter in Ann. Mo. Bot. Gard. 3 : 236. 1916. I have recently prepared a new set of sections from the authentic specimen of Thelephora pallescens Schw. in Curtis Herb. This specimen is in fine condition and shows the spores fully as rough-walled or aculeate in aqueous mounts as those of Hypochnus thelephoroides, which, therefore, becomes a synonym of $T$. pallescens and should be displaced in my account of our species of Hypochnus by the name Hypochnus pallescens (Schw.) Burt, with synonymy and distribution as follows:

26. Hypochnus pallescens (Schw.) Burt, n. comb.

Thelephora pallescens Schweinitz, Am. Phil. Soc. Trans. N. S. 4:167. 1832.-Stereum pallescens Schweinitz in Sacc. Syll. Fung. 6 : 586. 1888.-Corticium pallescens (Schw.) Massee, Linn. Soc. Bot. Jour. 27 : 129. 1890._Thelephora insinuans Schweinitz, Am. Phil. Soc. Trans. N. S. 4 : 167. 1832.- 
Stereum insinuans Schweinitz in Sacc. Syll. Fung. 6:586. 1888.-Coniophora insinuans (Schw.) Massee, Linn. Soc. Bot. Jour. 25 : 138. 1889.-Corticium (subg. Coniophora) sordulentum Cooke \& Massee, Grevillea 16 : 69. 1888.-Coniophora sordulenta Cooke \& Massee in Sacc. Syll. Fung. 6 : 650. 1888; Massee, Linn. Soc. Bot. Jour. $25: 132$. 1889.-Corticium thelephoroides Ell. \& Ev. Jour. Myc. 1 : 88. 1885; Sacc. Syll. Fung. 6 : 630. 1888.-Hypochnus thelephoroides (Ell. \& Ev.) Burt, Ann. Mo. Bot. Gard. 3 : 235. 1916.

Specimens examined:

Exsiccati: Ell. \& Ev., N. Am. Fungi, 2020, under the name Corticium dryinum; Ell. \& Ev., Fungi Col., 706, under the name Corticium vagum; Ravenel, Fungi Am., 719, under the name Peniophora flavido-alba (in copy of U. S. Dept. Agr. Herb.).

Canada: Cedar Hill, Van Island, J. Macoun, 62.

New Hampshire: Chocorua, W. G. Farlow.

Massachusetts: Sharon, A.P.D.Piguet, comm. by W. G. Farlow (in Farlow Herb. and in Mo. Bot. Gard. Herb., 54787). New Jersey: Newfield, J. B. Ellis, in Ell. \& Ev., Fungi Col., 706.

Pennsylvania: Bethlehem, Schweinitz, types of Thelephora pallescens and Thelephora insinuans (in Herb. Schw. and in Curtis Herb.).

Georgia: Darien, H.W. Ravenel, in Ravenel, Fungi Am., 719 (in copy of U. S. Dept. Agr. Herb.).

Florida: W. W. Calkins, U. S. Dept. Agr. Herb.; Jacksonville, W. W. Calkins, in Ell. \& Ev., N. Am. Fungi, 2020; New Smyrna, C. G. Lloyd, 2138.

Louisiana: Lake Charles, C. J. Humphrey, 2538 (in Mo. Bot. Gard. Herb., 12959); St. Martinville, A. B. Langlois, az, c, $u, y, 2633,2673$, and a specimen comm. by C. G. Lloyd, 3017. Texas: Houston, H. W. Ravenel, 239, U. S. Dept. Agr. Herb. Illinois: Cerro Gordo, L. O. Overholts, 3284 (in Mo. Bot. Gard. Herb., 10640).

Missouri : comm. by J. B. Ellis, 5055, type of Corticium sordulentum (in Kew Herb.). 
Washington: Carpenter, 90, type of Corticium thelephoroides (in N. Y. Bot. Gard. Herb., Kew Herb., Farlow Herb., and Mo. Bot. Gard. Herb.).

British Columbia: Kootenai Mountains, near Salmo, J. $R$. Weir, 497 (in Mo. Bot. Gard. Herb., 21978); Vancouver, J. Macoun, V 178, comm. by J. Dearness (in Mo. Bot. Gard. Herb., 8938).

Mexico: Colima, W. A. \& E. L. Murrill, N. Y. Bot. Gard., Fungi of Mexico, 591 (in Mo. Bot. Gard. Herb.).

Jamaica: Morce's Gap, W. A. \& E. L. Murrill, N. Y. Bot. Gard., Fungi of Jamaica, 658.

Cuba: Alto Cedro, L. M. Underwood \& F. S. Earle, N. Y. Bot. Gard., Plants of Cuba, 1530; San Diego de los Banos, Pinar del Rio Province, F. S. Earle \& W. A. Murrill, 572, N. Y. Bot. Gard.

Porto Rico: Rio Piedras, J. A. Stevenson, 5794 (in Mo. Bot. Gard. Herb., 54691).

Trinidad: Arepo Lavanna, R. Thaxter, comm. by W. G. Farlow, 20.

(To be continued.) 
27 
The Thelephoraceae of North America. IX

\section{Mleuridiscus}

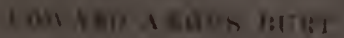

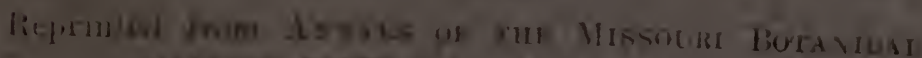

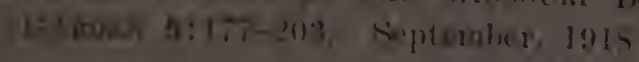


$= \pm$

sit $=10+1$

$-1=\frac{1}{y}=0$

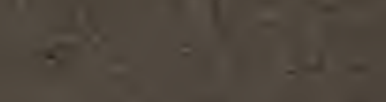

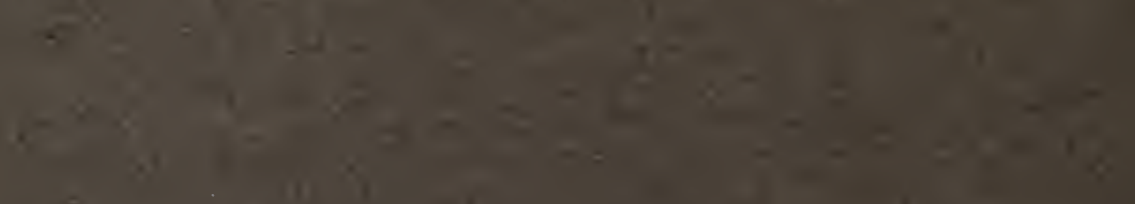

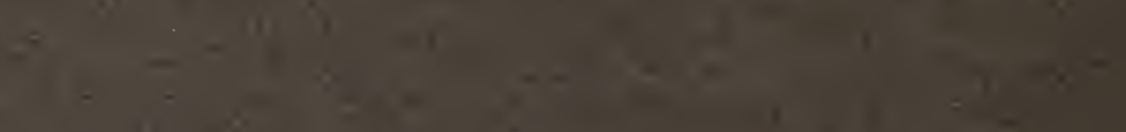

8

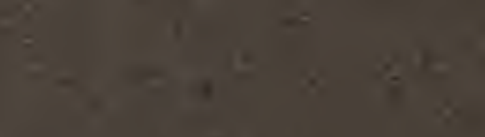

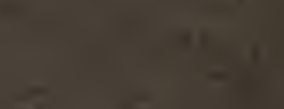

$=1-x+2=8-8=$

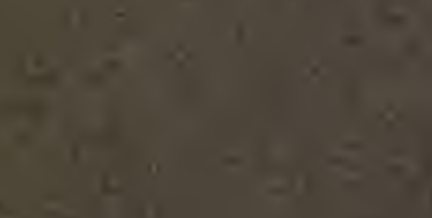

$-2=$

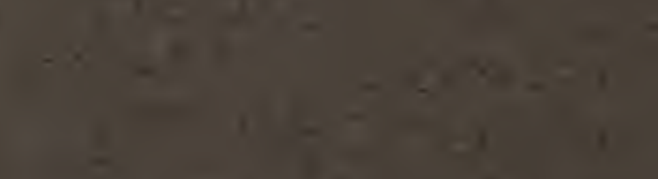


THE THELEPHORACEAE OF NORTH AMERICA. IX ${ }^{1}$

Aleurodiscus

\author{
EDWARD ANGUS BURT \\ Mycologist and Librarian to the Missouri Botanical Garden \\ Professor in the Henry Shaw School of Botany of \\ Washington University
}

\title{
ALEURODISCUS
}

Aleurodiscus Rabenhorst, Fungi Eur. Exs., 1824 (without diagnosis). 1874; Hedwigia 13 : 184 (without diagnosis). 1874; Schroeter, Krypt.-Fl. Schlesien 3 : 429. 1888; Engl. \& Prantl, Nat. Pflanzenfam. $\left(1.1^{* *}\right): 120$. 1898; Patouillard, Essai Taxon. Hym. 52. 1900; v. Höhn. \& Litsch. K. Akad. Wiss. Wien Sitzungsber. 116 : 793. pl. 1-4. 1907; Bourd. \& Galz. Soc. Myc. Fr. Bul. 28 : 349. 1913.

Fructifications resupinate, sometimes with margin free all around and somewhat saucer-shaped, rarely dimidiate and attached by the base, drying coriaceous; hymenium pulverulent; paraphyses noteworthy, modified into forms such as moniliform, or racemose by presence of short lateral branches - these paraphyses are sometimes called dendrophyses; granular or crystalline matter often in great quantity between the basidia, paraphyses, and hyphae of the fructification; basidia simple, usually large and with four large sterigmata; spores simple, usually large, with colorless cell wall.

The type species is Aleurodiscus amorphus (Pers.) Rabenh. originally published as Peziza amorpha by Persoon, then transferred to Thelephora by Fries when known to be a basid-

${ }^{1}$ Issued September 20, 1918.

ANN. MO. BOT. GARD., VOL. 5, 1918 
iomycete, and finally referred by Fries with doubt to Corticium and regarded by Quelet as a Cyphella.

Into Aleurodiscus have been assembled species of related structure which were originally published in Corticium and Stereum on the basis of form of fructification, but which are noteworthy by basidia and spores often enormous in dimensions for the genera to which these species were originally referred, and which sometimes have paraphyses of remarkable form, and the fructification greatly thickened in some species by so large an amount of incrusted or granular matter as to render it very difficult to make out the detailed structure of basidia and paraphyses in good sectional preparations. The granular and crystalline matter may be dissolved from the sections by warming them on the slide in a few drops of dilute hydrochloric acid, but with the disadvantage of leaving the paraphyses and other organs with rather vague outlines, as though somewhat collapsed or disorganized.

Some species now referred to Aleurodiscus are intermediate between this genus and other genera by the absence of any notable development of some one or other of the foregoing characters, and it is too largely a matter of personal opinion as to just which species should be transferred. On the whole, Aleurodiscus is probably useful, although bound to be a source of confusion by introducing into a scheme of classification based upon form and general structure of fructification a conflicting scheme of classification based upon rather trivial, and often poorly shown, features of microscopic detail, with disregard of diversity in form and general structure of fructification involved. Innovations of this kind should certainly be exceptional.

Of the 25 species of Aleurodiscus which have been recognized up to the present time, 14 occur in North America, 8 in Europe, 5 in Asia and Australia, 2 in Africa, and 2 in South America. A. acerinus is the only one of these which is of world-wide distribution; $A$. amorphus is the only other species common to both Europe and North America, and in North America it is restricted to northern United States and Canada. Only 3 species, $A$. acerinus, $A$. candidus, 
and $A$. nivosus, have wide range in the United States. Our other species are local: 7 comprise the total for New England, 7 are subtropical or tropical, and 5 are present in the Rocky Mountain states or westward.

\section{Key to the Species}

Fructifications discoid, cup-shaped, pezizaeform, as in A. amorphus...... Fructifications normally effuso-reflexed, sometimes with margin free all around, as in A. Oakcsii, sometimes barely showing color of under side, as in $A$. candidus, which is often strictly resupinate.............

Fructifications resupinate, effused, the margin never reflexed..........

1. Spores minutely echinulate; paraphyses moniliform; free margin of fructification light-colored on under side; on balsam fir and spruce......

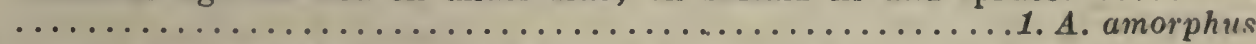

1. Spores even; paraphyses of bottle-brush form; free margin of under side of fructification deep mouse-gray; on hemlock in New England and

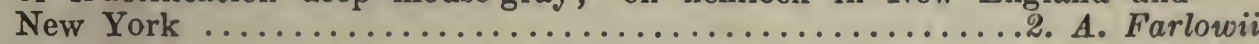

1. Spores even; some paraphyses of bottle-brush form, others with moniliform tips; margin of under side of fructification light-colored; on Ostrya and other frondose species........................ A. Oakesiix

2. Spores even; some paraphyses of bottle-brush form, others with mo-

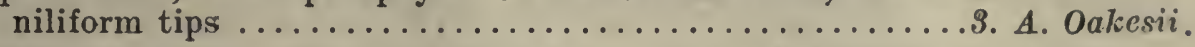

2. Spores minutely echinulate, apiculate; many paraphyses of bottlebrush form, none moniliform; sometimes resupinate; Jamaica to

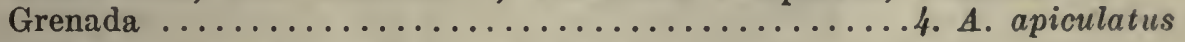

2. Spores even; paraphyses with somewhat corymbosely branched, filiform tips, made out with great difficulty because of the large amount of incrusting and crystalline matter present; fructification chalk-white, orbicular; sometimes resupinate........5. A. candidus

3. Fructifications drying between antimony-yellow and yellow-ocher at the surface, white within, staining herbarium sheets and envelopes yellow

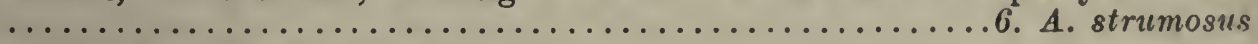

3. Fructifications not egg-yellow ........................ 4

4. Paraphyses heavily loaded with incrusting matter, so that their branching is not easily made out, not of bottle-brush form.......

4. Paraphyses with short lateral prongs, i. e., of bottle-brush form, and not organs for carrying heavy incrustation.

5. Paraphyses filiform, spirally twisted or flexuous; spores even, $11-18 \times$ $9 \frac{1}{2}-13 \mu$; globose organs staining brown with iodine, $6-15 \mu$ in diameter, scattered throughout the fructification; in Cuba and Jamaica..\%. A. seriatus

5. Paraphyses with corymbosely branched tips; spores even, $15-20 \times 12-16 \mu$; gloeocystidia clavate, $18-30 \times 9 \mu$; fructifications white; on bark of living cedar trees.............................. A. nivosius

5. Paraphyses with racemosely branched tips; spores even, 10-12 $\times 6-7 \mu$; gloeocystidia not present........................... acerinus

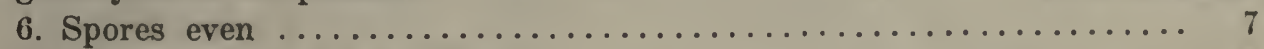

6. Spores minutely echinulate..................... 8

7. Bottle-brush portions of paraphyses $10-15 \times 3-4 \frac{1}{2} \mu$ over lateral prongs; spores 13-15 $\times 9-11 \mu$; on Rubus and Vitis in Massachusetts, Maryland,

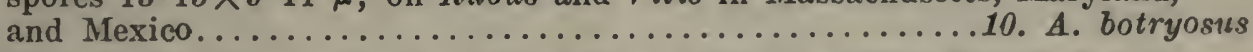

7. Bottle-brush portions $15 \times 6 \mu$ over lateral prongs; spores globose, $9 \mu$ in diameter; fructifications cream-buff, 600-800 $\mu$ thick, zonato with crystalline matter; on Quercus in New Mexico............... A. cremeus 
8. Bottle-brush structure disorganized by $\mathrm{KHO}$ solution; spores $12-15 \times$ 9-12 $\mu$; fructifications white, $60-90 \mu$ thick; on frondose wood in Cuba ................................. A. tenuis

8. Paraphyses flexuous, $6 \mu$ in diameter, some of them with a cluster of prongs at the tips; spores subglobose, 15-20 $\mu$ in diameter; on Tsuga and Pseudotsuga in Idaho and westward......13. A. penicillatus

8. Bottle-brush organs about $23 \times 12 \mu$, cockroach-shaped; spores subglobose, 6-12 $\mu$ in diameter; on Abies, Thuja, and Larix in Idaho and British Columbia......................... Weirii

1. A. amorphus (Pers.) Rabenhorst, Fungi Eur. Exs., 1824. 1874; Hedwigia 13 : 184. 1874; Cooke, Grevillea $3: 136$. 1875; Schroeter, Krypt.-Fl. Schlesien $3: 429$. 1888; v. Höhn. \& Litsch. K. Akad. Wiss. Wien Sitzungsber. 116 : 799. pl. 1. f. 2. 1907 ; Bourd. \& Galz. Soc. Myc. Fr. Bul. 28 : 350. 1913.

Peziza amorpha Persoon, Syn. Fung. 657. 1801; Myc. Eur. 1 : 269. 1822.-Thelephora amorpha (Pers.) Fries, Elenchus Fung. 1:183. 1828.-Corticium amorphum (Pers.) Fries, Epicr. 559. 1838; Hym. Eur. 648. 1874; Sacc. Syll. Fung. 6 : 606. 1888.-Cyphella amorpha (Pers.) Quelet, Ench. Fung. 215. 1886. - Nodularia balsamicola Peck, N. Y. State Mus. Rept. 24 : 96. pl. 4. f. 23-26. 1872.

Illustrations: De Bary, Comp. Morph. and Phys. Fungi, f. 30; Hennings in Engl. \& Prantl, Nat. Pflanzenfam. (1.1**) : f. $67, C-D$; v. Höhn. \& Litsch. K. Akad. Wiss. Wien Sitzungsber. 116 : pl. 1. f. 2; Patouillard, Tab. Anal. Fung. f. 581; Peck, N. Y. State Mus. Rept. 24 : pl. 4. f. 23-26.

Fructifications disk-shaped, scattered or sometimes confluent, somewhat fleshy, drying coriaceous, attached by a point, the margin free, elevated, incurved; hymenium convex, pulverulent, buff-pink at first, becoming deep olive-buff in the herbarium, the margin paler; in structure 500-1000 $\mu$ thick, composed of densely interwoven, hyaline hyphae $3 \mu$ in diameter, granule-incrusted and with the granules crystalline and sometimes up to $12 \mu$ in diameter but not so numerous as to conceal the structure of the fructification; paraphyses hyaline, filiform, flexuous, often moniliform, $4-4 \frac{1}{2} \mu$ in diameter; basidia clavate, large, $120 \times 18 \mu$, with four large sterigmata; spores subglobose with hyaline wall, minutely echinulate, 20-27×16-21 $\mu$.

Fructifications 1-3 and $4 \mathrm{~mm}$. in diameter, $\frac{1}{2}-1 \mathrm{~mm}$. thick where not attached, $2 \mathrm{~mm}$. thick where attached. 
On balsam fir, spruce, and Thuja plicata. Newfoundland to New York and westward to Oregon. Infrequent.

The aspect of $A$. amorphus is that of a small Peziza, which may account for the infrequency of this species in the collections which have been sent to me for determination. The large, minutely spinulose spores and moniliform paraphyses a $\mathrm{r}$ e distinguishing microscopic char acters. The echinulate marking of the spores is very faint in the collections from I d a ho westward.

Specimens examined :

Exsiccati: Ell. \& Ev., N. Am. Fungi, 2733 ; Krieger, Fungi Sax., 619, 1908; Oudemans,

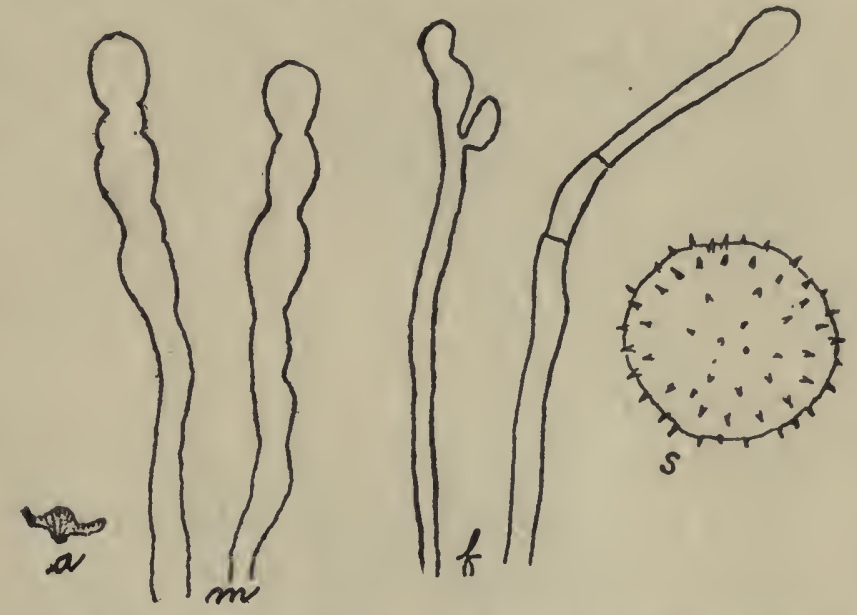

Fig. 1. A. amorphus. Section of fructification showing tubercular base of attachment, $a, \times 2$; moniliform paraphyses, $m$; flexuous paraphyses, $f$; and spore, s. $\times 870$.

Fungi Neerlandici Exs., 285; Romell, Fungi Scand. Exs., 130; de Thümen, Myc. Univ., 1508 (in Burt copy but not in Mo. Bot. Gard. Herb. copy), under the name Dasyscypha calycina.

Sweden: Omberg, G. Schotte, in Romell, Fungi Scand. Exs., 130.

Germany: Saxony, Königstein, W. Krieger, in Krieger, Fungi Sax., 619; Schandau, W. Krieger, in Krieger, Fungi Sax., 1908.

Switzerland: Neuchatel, $P$. Morthier, in de Thümen, Myc. Univ., 1508.

Holland: in Oudemans, Fungi Neerlandici Exs., 285.

France: Fautrey (in Lloyd Herb., 4353).

Newfoundland: Frenchman's Cove, A. C. Waghorne, 319 (in Mo. Bot. Gard. Herb.).

Prince Edward's Island: Rustico Bay, J. Macoun, 342.

Ontario: Lake Nipigon, J. Macoun. 
New Hampshire: Camp, Ellis R., U. \& C., from Underwood Coll. (in N. Y. Bot. Gard. Herb. and in Mo. Bot. Gard. Herb., 4773); Chocorua, W. G. Farlow; Shelburne, W. G. Farlow (in Mo. Bot. Gard. Herb., 4772).

New York: Adirondack Mts., S. L. Clarke (in N. Y. Bot. Gard. Herb.); Lake Placid, W. A. \& Edna L. Murrill, 209, 1127 (in N. Y. Bot. Gard. Herb.); East Galway, E. A. Burt; Indian Lake, C. H. Peck, type of Nodularia balsamicola (in Coll. N. Y. State and N. Y. Bot. Gard. Herb.) ; Willsboro, Essex Co., C. O. Smith.

Michigan: Vermilion, A. H. W. Povah, 198 (in Mo. Bot. Gard. Herb., 13634).

Wisconsin: Madison, Miss A. O. Stucki, 55, Univ. of Wisconsin Herb.

Idaho: Pend d'Oreil, J. B. Leibig, in Ell. \& Ev., N. Am. Fungi, 2733; Priest River, J.R. Weir, 311, 358 (in Mo. Bot. Gard. Herb., 7065 and 10229 respectively).

British Columbia: Sidney, J. Macoun, 29, 31 (in Mo. Bot. Gard. Herb., 6773 and 6774 respectively).

Washington: Chehalis, C. J. Humphrey, 5276; Olympic Mts., T. C. Frye, 18 (in Farlow Herb., N. Y. Bot. Gard. Herb., and Mo. Bot. Gard. Herb., 44301).

Oregon: Mt. Hood, T. C. Frye, 15 (in N. Y. Bot. Gard. Herb., and in Mo. Bot. Gard. Herb., 55444); Forest Grove, A. $R$. Sweetser.

2. A. Farlowii Burt, n. sp.

Type: in Farlow Herb. and Burt Herb.

Fructifications disk-shaped, scattered or sometimes confluent, coriaceous, attached by a point or tubercle, the margin free, incurved, under side deep mouse-gray; hymenium convex, pulverulent, avellaneous at first, becoming drab in the herbarium; in structure, with the hyphae arising from the substratum, hyaline, even, thick-walled, densely interwoven, $3 \mu$ in diameter, not incrusted, then radiating outward in all directions to form the hymenium, made up of basidia and paraphyses, with the latter extending about $30 \mu$ beyond the basidia; paraphyses of the racemose kind, resembling hya- 
line bottle brushes, 6-7 $\mu$ in diameter over branches, with central axis bearing along its whole length short lateral branches of equal length, densely crowded together; basidia clavate, 36-54×9-12 $\mu$; spores hyaline, even, flattened on one side, $13-18 \times 9-12 \mu$.

Fructifications $1-1 \frac{1}{2} \mathrm{~mm}$. in diameter, unless elongated by confluence of two or three, about $\frac{1}{2} \mathrm{~mm}$. thick.

On dead twigs of hemlock, perhaps on balsam fir also. New Hampshire and New York. Rare.

A. Farlowii has the general aspect of $A$. amorphus but may be separated from this species when examined superficially, by its smaller fructifications, which are nearly black on the unattached part of the under side, while those of the larger species are light-colored; the small basidia, small spores, bottlebrush paraphyses, and absence of incrusting matter afford additional decisive characters. $A$. Oakesii has

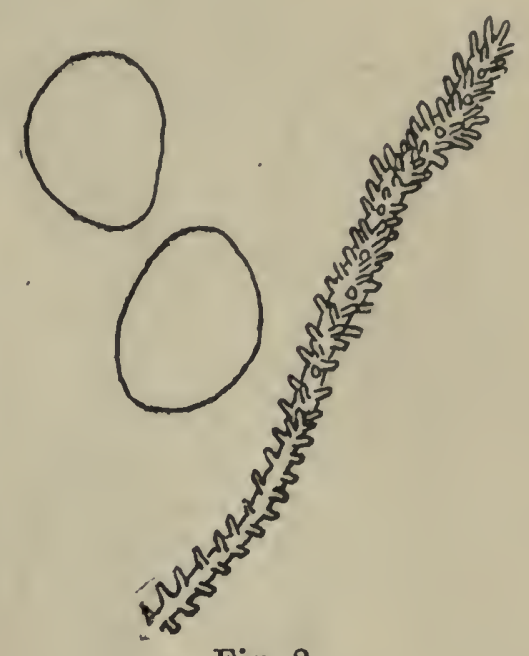

Fig. 2

A. Farlowii.

Two spores and bottle-brush paraphysis. $\times 870$.

bottle-brush paraphyses which are of greater diameter than those of $A$. Farlowii and with fewer branches and its fructifications are much larger and of a different form.

Specimens examined:

New Hampshire: Chocorua, W. G. Farlow; King's Ravine, or Hhaca

W. G. Farlow, type.

New York: Vaughns, Hudson Falls, S. H. Burnham, 21, and an unnumbered collection (in Mo. Bot. Gard. Herb., 44014 and 44121 respectively).

3. A. Oakesii (Berk. \& Curtis) Cooke, Grevillea $3: 172$. 1875; v. Höhn. \& Litsch. K. Akad. Wiss. Wien Sitzungsber. 116 : 802. pl. 3. f. 1. 1907.

Corticium Oakesii Berk. \& Curtis, Grevillea 1:166. 1873; Sacc. Syll. Fung. 6 : 606. 1888; Pierce, Torr. Bot. Club Bul. $17: 301 . p l .110$. f. $a-i .1890$. 
Illustrations: Patouillard, Rev. Myc. 12. pl. 107 bis. f. $5 a$, d; Pierce, Torr. Bot. Club Bul. 17 : pl. 110. f. $a-i$; v. Höhn. \& Litsch. K. Akad. Wiss. Wien Sitzungsber. $116: p l$. 3. f. 1.

Type: type distribution in Ravenel, Fungi Car. $3: 32$.

Fructifications disk-shaped, pezizaeform, scattered or confluent, somewhat fleshy, drying coriaceous, attached by the

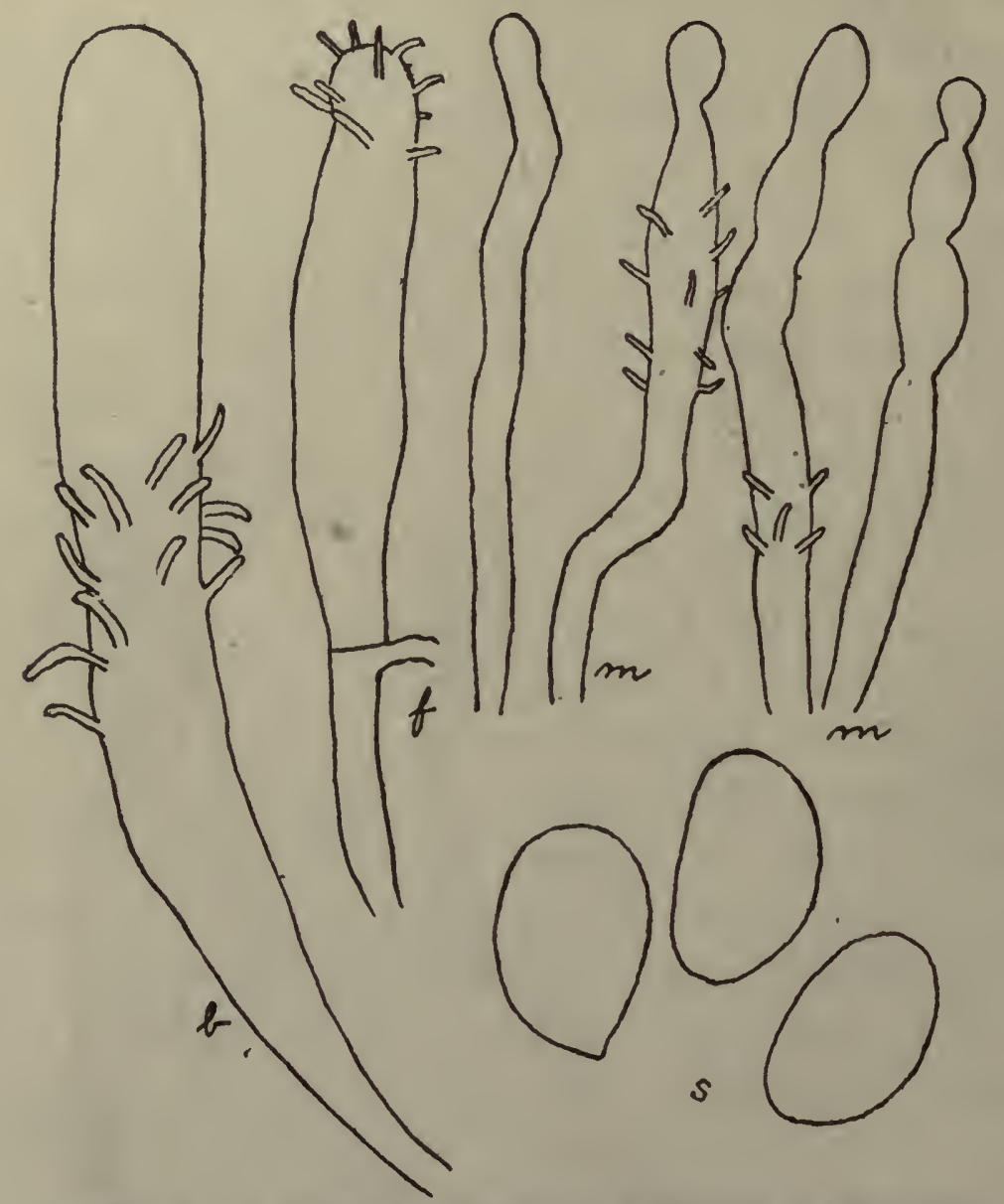

Fig. 3. A. Oakesii. Immature basidium, $b$; flexuous paraphyses, $f$; moniliform paraphyses, $m$, some with whorl-like clusters of lateral, bottle-brush prongs; spores, s. $\times 870$.

center, the margin free, elevated, incurved, whitish and tomentose on the under side; hymenium concave, pulverulent, drying avellaneous; in structure about $600 \mu$ thick, composed of hyaline hyphae $3-3 \frac{1}{2} \mu$ in diameter, rather thick-walled, sometimes granule-incrusted, longitudinally arranged and interwoven next to the substratum, curving outward to bear the hymenium, consisting of basidia and filiform paraphyses with 
tips of two kinds; most tips are racemose with about 12 lateral branches $3 \mu$ long standing out from an axis $6 \mu$ in diameter, other tips consist of 2 or 3 moniliform bodies - either kind of paraphysis may bear a cluster of lateral branches at some region more or less distant from the end; basidia 80$100 \times 12 \mu$; spores hyaline, even, $18-21 \times 12-13 \mu$.

Fructifications 1-2 mm. in diameter, becoming confluent into masses $2 \times 1 \mathrm{~cm}$.

On bark of dead Ostrya virginica, Quercus alba, Q. macrocarpa, Salix, hickory, etc. Canada to Alabama, westward to Missouri.

A. Oakesii resembles $A$. amorphus so closely in aspect that it was regarded by Fries in his 'Hymenomycetes Europaei' as a synonym of the latter species, from which Cooke demonstrated that it was clearly distinct by the paraphyses. It may be separated at sight by the hymenium of A. Oakesii not being convex, by the fructifications becoming very large by confluence, and by its occurrence on bark of frondose species.

Specimens examined:

Exsiccati : Ellis, N. Am. Fungi, 935a and b; Ell. \& Ev., Fungi Col., 310; Kellerman, Ohio Fungi, 125; Rabenhorst, Fungi Eur., 3232; Ravenel, Fungi Car. 3 : 32, type distribution; Shear, N. Y. Fungi, 116.

Canada: Ontario, Carleton Place, J. Macoun, 422; London, J. Dearness, 2647 (in Mo. Bot. Gard. Herb., 19516).

New England: Oakes (in Curtis Herb., 3102).

Vermont: Middlebury, E. A. Burt.

Rhode Island: Olney (in Curtis Herb., 1827).

New York: Alcove, C. L. Shear, in Shear, N. Y. Fungi, 116; Altamont, E. A. Burt; definite locality not given, Sartwell (in Curtis Herb., and in Mo. Bot. Gard. Herb., 4830); Buffalo, G. W. Clinton (in U. S. Dept. Agr. Herb.).

New Jersey: Laning (in Curtis Herb., and in Mo. Bot. Gard. Herb., 44128, 44129).

Pennsylvania: Bethlehem, E.A. Rau, in Ellis, N. Am. Fungi, 935a; Spruce Creek, J. H. Faull, Univ. of Toronto Herb., 366 (in Mo. Bot. Gard. Herb., 44915); State College, C. $R$. Orton, 3 (in.Mo. Bot. Gard. Herb., 44080) ; Trexlertown, $W$. 
Herbst, 85; West Chester, Everhart, Haines, Jefferis \& Gray, in Ellis, N. Am. Fungi, 935b.

West Virginia: Nuttallburg, L. W. Nuttall, in Ell. \& Ev., Fungi Col., 310.

Alabama: Peters, in Ravenel, Fungi Car. 3:32, and (in Curtis Herb., 3868).

Ohio: Cincinnati, A. P. Morgan (in Lloyd Herb.) ; Columbus, $F$. J. Tyler, in Kellerman, Ohio Fungi, 125; Oberlin, $F$. D. Kelsey (in Lloyd Herb., and in Mo. Bot. Gard. Herb., 4831). Michigan: Ann Arbor, A. J. Pieters (in U. S. Dept. Agr. Herb.).

Indiana: Crawfordsville, D. Reddick, 11.

Illinois: River Forest, Miss A. O. Stucki, 11, Univ. of Wisconsin Herb.

Wisconsin: Madison, four collections, as follows: collector not given (in Mo. Bot. Gard. Herb., 4832); M. C. Jensen, comm. by C. J. Humphrey (in Mo. Bot. Gard. Herb., 42942); W. Trelease, 67 (in Mo. Bot. Gard. Herb., 4799); Miss A. O. Stucki, 54, Univ. of Wisconsin Herb.

Iowa: Decorah, E. W. D. Holway (in U. S. Dept. Agr. Herb.) ; Webster County, O. M. Oleson, 1.

Missouri: Columbia, B. M. Duggar, 401; Perryville, C. H. Demetrio, in Rabenhorst, Fungi Eur., 3232.

4. A. apiculatus Burt, n. sp.

Type : in Burt Herb.

Fructifications resupinate, effused, sometimes narrowly reflexed, coriaceous, pulverulent, drying pinkish buff, the reflexed margin tomentose, white, inrolled; in structure 600 $800 \mu$ thick, with the hyphae hyaline, even, thick-walled, $3 \frac{1}{2}-4 \mu$ in diameter, not incrusted, not nodose-septate, loosely interwoven in the outer surface of the reflexed part, densely interwoven and longitudinally arranged in the middle region of that part and near the substratum, then curving outward and ascending to form the subhymenium and hymenium; all organs in subhymenium clothed with lateral prongs; paraphyses hyaline, some with outer end racemosely branched, 6-7 $\mu$ in diameter over branches, with the branches clothing the sides of the paraphyses for about $40-45 \mu$, and others with 
outer end even and lateral prongs present at lower level of hymenium; basidia clavate, up to $100 \times 12-15 \mu$, with 4 prominent sterigmata about $15 \mu$ long; spores hyaline, unequilateral, apiculate, minutely echinulate, $20-25 \times 12-15 \mu$.

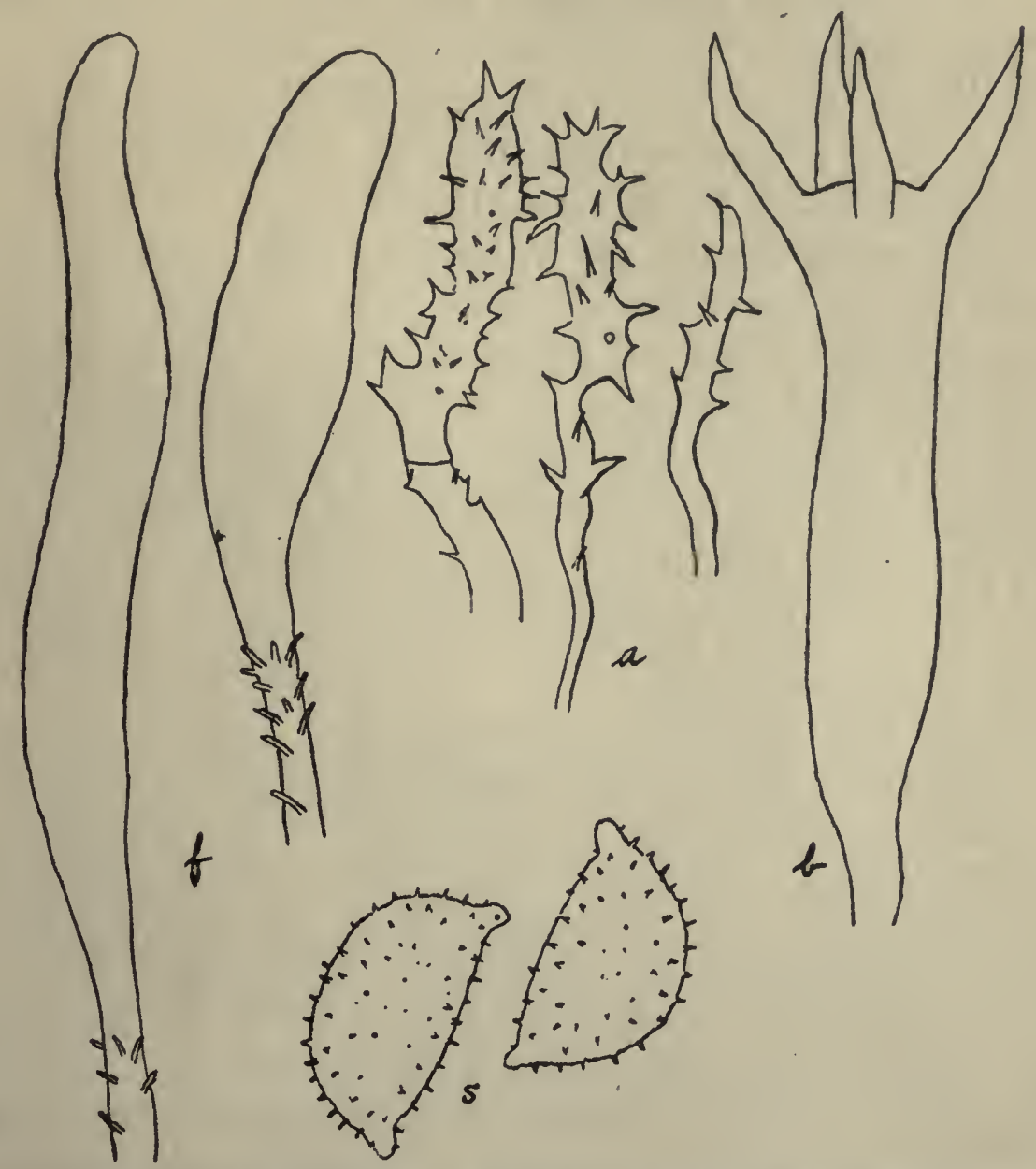

Fig. 4. A. apiculatus. Flexuous paraphyses, $f$; paraphyses with aculeate prongs, $a$; basidium, $b$; and spores, $s . \times 870$.

Fructifications $2 \frac{1}{2}-10 \mathrm{~cm}$. long, 6-15 mm. broad, with reflexed margin 1-1 $\frac{1}{2} \mathrm{~mm}$. broad.

On bark of pole of frondose wood on ground at 5,000 ft. altitude, and on dead limbs. Jamaica, Porto Rico, and Grenada. November.

Until microscopic examination of the sections was made, the collections were regarded as consisting of large specimens of $A$. Oakesii, which this species resembles in aspect but from which it differs in spore characters and in the absence of mo- 
niliform paraphyses. The collections from Porto Rico and Grenada are probably rather immature, for many of their spores are even.

Specimens examined:

Jamaica: Cinchona, F. S. Earle, 401, N. Y. Bot. Gard., Plants of Jamaica, type.

Porto Rico: Vieques Island, Campo Cieto to Ensenada Hondo, J. A. Shafer, 3048 (in N. Y. Bot. Gard. Herb., and in Mo. Bot. Gard. Herb., 55453).

Grenada: Grand Etang, R. Thaxter, comm. by W. G. Farlow, 6 .

5. A. candidus (Schw.) Burt, n. comb.

Thelephora candida Schweinitz, Naturforsch. Ges. Leipzig Schrift. 1 : 110. 1822; Fries, Elenchus Fung. 1:189. 1828.Thelephora candidissima Schweinitz, Am. Phil. Soc. Trans. N. S. $4: 167$. 1832.-Stereum candidum (Schw.) Fries, Epicr. 552. 1838; Sacc. Syll. Fung. 6 : 585. 1888; Massee, Linn. Soc. Bot. Jour. 27 : 200. 1890.

Type: in Herb. Schweinitz, Herb. Fries, and Curtis Herb.

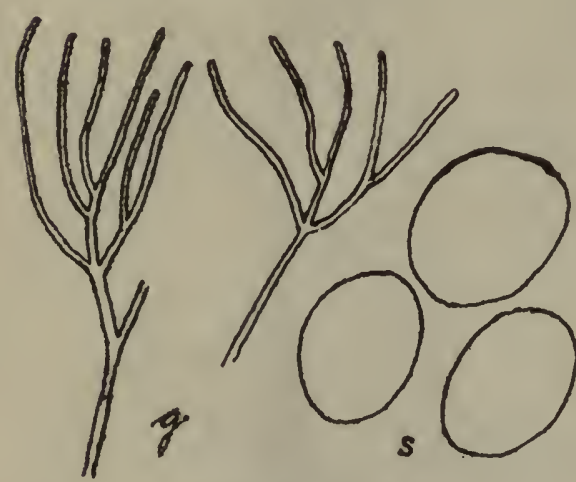

Fig. 5

A. candidus.

Granule-bearing paraphyses, $g$, after removal of the granular matter by $\mathrm{HCl}$; spores of type, $s$. $\times 870$. hymenium composed of clavate basidia $45-60 \times 10-15 \mu$, and of thin-walled, hyaline, flexuous, incrusted, hyphal paraphyses with tips bushy, somewhat corymbosely branched, branches 2-3 $\mu$ in diameter under their incrustation, not moniliform and noteworthy, as are the hyphae, by the large amount of 
crystalline matter attached to them-often by only a corner or small end of the crystal; spores hyaline, even, subglobose, $15-17 \times 11-14 \mu$.

Fructifications usually $3-6 \mathrm{~mm}$. in diameter, sometimes $1-2 \mathrm{~cm}$.

On bark of trunks of living oaks, rarely on ash and maple. New York to Florida, westward to Missouri, in California, Mexico, and Jamaica. August to January.

This species resembles $A$. disciformis of Europe very closely in aspect but differs from it in being chalk-white, in having the margin blackening on the under side, in being thicker, somewhat zonate within, containing much more crystalline matter, and in having thinner-walled, slenderer, more hyphal-like, and more heavily incrusted paraphyses which are not at all moniliform at the tips. The spores may prove minutely rough-walled; winter collections of this species are desirable.

Specimens examined:

Exsiccati: Ellis, N. Am. Fungi, 1206; Ell. \& Ev., N. Am. Fungi, 3208, under the name Stereum acerinum; Ell. \& Ev., Fungi Col., 605; Ravenel, Fungi Am., 120; Ravenel, Fungi Car. 1:32.

New York: Buffalo, G. W. Clinton.

Pennsylvania: Bethlehem, E. A. Rau, in Ellis, N. Am. Fungi, 1206.

Maryland: Takoma Park, C. L. Shear, 1104.

West Virginia: Nuttallburg, L. W. Nuttall, two collections, in Ell. \& Ev., N. Am. Fungi, 3208, and in Ell. \& Ev., Fungi Col., 605.

North Carolina: Salem, Schweinitz (in Herb. Fries and in Curtis Herb.); Blowing Rock, G. F. Atkinson, 4193, 4320; Chapel Hill, H. R. Totten, comm. by W. C. Coker, Univ. of N. Car. Herb., 1377a (in Mo. Bot. Gard. Herb., 9057).

South Carolina: Aiken, H. W. Ravenel, in Ravenel, Fungi Am., 120; locality not stated, H.W. Ravenel, Fungi Car. $1: 32$.

Florida: Sands Key, R. A. Harper, 8 (in Mo. Bot. Gard. Herb., 54526). 
Alabama: Montgomery, R. P. Burke, 121 (in Mo. Bot. Gard. Herb., 21223).

Ohio: Lancaster, W. A. Kellerman, 284.

Missouri: Creve Coeur, L. O. Overholts, 669 (in Mo. Bot. Gard. Herb., 4801); St. Louis, E. A. Burt (in Mo. Bot. Gard. Herb., 44044).

California: Muir Woods, W. A. Murrill, 1155, N. Y. Bot. Gard. (in Mo. Bot. Gard. Herb., 55453).

Mexico: Oaxaca, E. W. D. Holway.

Jamaica: Cinchona, W. A. \& Edna L. Murrill, 565, N. Y. Bot. Gard., Fungi of Jamaica.

6. A. strumosus (Fries) Burt, n. comb.

Stereum strumosum Fries (Nov. Symb. Myc. 95), R. Soc. Sci. Upsal. Actis III. 1 : 111. 1851; Berk. \& Curtis, Linn. Soc. Bot. Jour. 10 : 333. 1868; Sacc. Syll. Fung. 6 : 586. 1888; Massee, Linn. Soc. Bot. Jour. 27 : 203. 1890.-Stereum (?) vitellinum Leveille in Triana \& Planchon, Prod. Fl. NovoGranat. Crypt. 157. 1863-1867.-Stereum Mancianum Sacc. \&

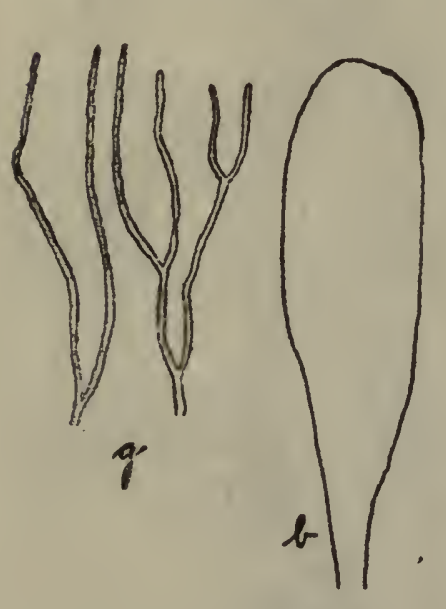

Fig. 6

A. strumosus.

Granule-bearing paraphyses, $g$, after removal of the granular matter by $\mathrm{HCl}$; immature basidium, $b$; proteid bodies, pr. $\times 870$. Cub. in Sacc. Syll. Fung. 6 : 583. 1888.-Aleurodiscus Mancianus (Sacc. \& Cub.) Patouillard, Soc. Myc. Fr. Bul. 16 : 180. 1901.

Type: specimen from Fries in Kew Herb.

Fructifications resupinate, adnate, orbicular, scattered, sometimes confluent and effused, drying between antimony-yellow and yellow-ocher at the surface and white within, the margin rather thick, sometimes free, entire; in structure 300-500 $\mu$ thick, rarely stratose, composed of granule-incrusted, thin-walled, hyaline hyphae, some of which are suberect, $2 \mu$ in diameter under incrustation, barely visible except by their load of incrusting grains, interwoven, and apparently branches from the 
coarser hyphae; globose organs of proteid reaction, 6-15 $\mu$ in diameter, with shriveled or wrinkled surface, are scattered throughout the fructification; hymenium composed of granule-incrusted hyphal systems and of presumable basidia buried among the incrusted hyphae; such basidia-like bodies clavate, $60-100 \times 15-20 \mu$, yellow in KHO preparations, simple, none seen bearing sterigmata; detached spores hyaline, even, $18-27 \times 12-21 \mu$.

Fructifications 2-5 mm. in diameter, becoming up to $3 \mathrm{~cm}$. long by confluence.

On bark of frondose trees. South Carolina to Louisiana, West Indies, and Mexico to Colombia.

This species may be recognized by its pulverulent, eggyellow, orbicular fructifications which are white within and contain so much granular matter as to render other details of internal structure obscure and difficult of determination. This granular matter holds together so as to show that it is incrusting matter upon very tenuous, nonstaining hyphal filaments. While I do not doubt that the large, yellow, clavate organs near the hymenial surface but buried in the granular matter are immature basidia, still I have not demonstrated their sterigmata in the preparations of any of the collections which have been examined up to the present. The globose organs show distinctly in stained preparations which have been heated in dilute $\mathrm{HCl}$ to free them of the crystalline matter.

Specimens examined:

Exsiccati: Ravenel, Fungi Car. 3:28, under the herbarium name Corticium citrinum Berk. \& Rav. but not of Fries.

South Carolina: in Ravenel, Fungi Car. 3:28; Black Oak, H. W. Ravenel, 139\%, under the name Corticium citrinum (in Curtis Herb.).

Florida: Daytona, R. Thaxter, 52, 62 (in Farlow Herb. and in Mo. Bot. Gard. Herb., 43942 and 43944); Ocala, $R$. Thaxter, 58 (in Farlow Herb., and in Mo. Bot. Gard. Herb., 43943).

Louisiana: St. Martinville, A. B. Langlois, 1953. Jamaica: Morce's Gap,W. A. \& Edna L. Murrill, 714, N. Y. Bot. Gard., Fungi of Samaica. 
Cuba: C. Wright (in Curtis Herb.) ; Alto Cedro, Earle \& Murrill, 495; Herradura, Earle \& Murrill, 156.

Porto Rico: Bayamon, J. A. Stevenson, 6758 (in Mo. Bot. Gard. Herb., 55058).

Trinidad: Verdant Vale, $R$. Thaxter, comm. by W. G. Farlow, 23.

Mexico: probably portion of type (from E. Fries in Kew Herb.) ; Orizaba, W. A. \& Edna L. Murrill, ry8 (in N. Y. Bot. Gard. Herb., and Mo. Bot. Gard. Herb., 54608).

Nicaragua: C. Wright, U. S. Northern Pacific Expl. Exp., under the name Corticium sulphureum (in Curtis Herb.).

7. A. seriatus (Berk. \& Curtis) Burt, n. comb.

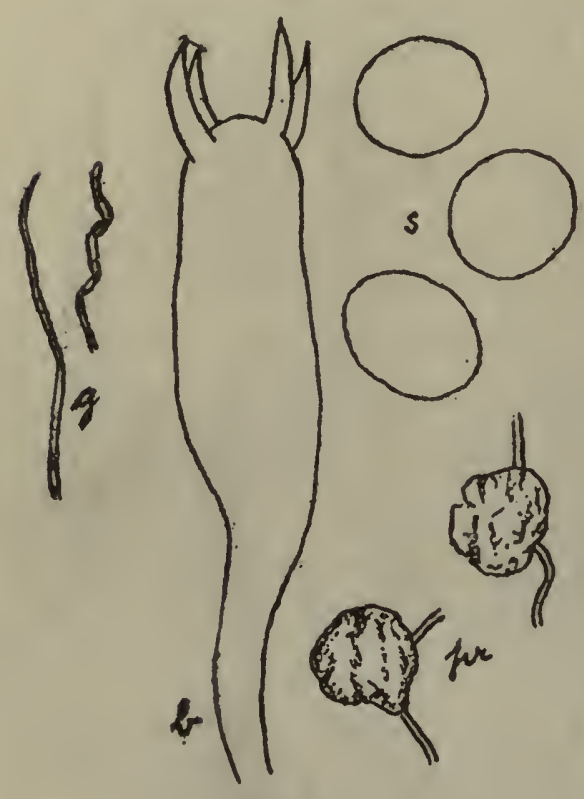

Fig. 7

A. seriatus.

Flexuous and spirally twisted paraphyses, $g$, after removal of the granular matter by $\mathrm{HCl}$; basidium, $b$; spores, $s$; proteid bodies, $p r$. $\times 870$. hyphal filaments, or paraphyses, which are filiform, thinwalled, flexuous or spirally twisted, $2 \mu$ in diameter under the incrustation; basidia $40-50 \times 12 \mu$, with 4 sterigmata, each about $9 \times 3 \mu$; spores hyaline, even, $11-18 \times 9 \frac{1}{2}-13 \mu$; globose organs of proteid reaction, $6-15 \mu$ in diameter, with shriveled 
or wrinkled surface, are scattered throughout the fructification.

Fructifications of type $2-6 \times 2-4 \mathrm{~mm}$. -15 fructifications on an area $4 \frac{1}{2} \times 2 \mathrm{~cm}$.

On bark of frondose trees. Jamaica and Cuba. October to January.

In the original description $A$. seriatus was regarded as allied to $A$. candidus, but it is much closer to $A$. nivosus, differing with the latter from $A$. candidus by convex surface of fructification, by margin not at all free nor reflexed, and by incrusting matter of hyphae not occurring in large crystalline grains. All the collections which I have referred to $A$. seriatus have been scanty and bearing few spores; this species seems distinct from $A$. nivosus by the absence of clavate or cylindric gloeocystidia and by having the paraphyses spirally twisted and usually distinct from their tips to about the base of the basidia, and by having characteristic globose organs scattered throughout the sections, such as occur in Corticium pallidum Bres. and have been regarded and figured by $\nabla$. Höhnel \& Litschauer as gloeocystidia. ${ }^{1}$

Specimens examined:

Jamaica: Cinchona, W. A.\& Edna L. Murrill, 565, N. Y. Bot.

Gard., Fungi of Jamaica; near Hope Gardens, W. A. Murrill, 20, -N. Y. Bot. Gard., Fungi of Jamaica; Troy and Tyre, W. A. Murrill \& W. Harris, 1106, N. Y. Bot. Gard., Fungi of Jamaica.

Cuba: C. Wright, 283, type (in Curtis Herb.) ; Ceballos, C. J. Humphrey, 2847 (in Mo. Bot. Gard. Herb., 20202).

8. A. nivoșus (Berk. \& Curtis) v. Höhn. \& Litsch. K. Akad. Wiss. Wien Sitzungsber. $116: 808$. pl. 4. f. 2. 1907.

Stereum acerinum var. nivosum Berk. \& Curtis, Grevillea 1:165. 1873 (lacks description but refers to specimen in Ravenel, Fungi Car. 2 : 37); Sacc. Syll. Fung. 6 : 588. 1888.

Type: type distribution in Ravenel, Fungi Car. $2: 37$, under the name Stereum acerinum.

Fructifications small, resupinate, adnate, circular or oblong, convex at first, becoming plane, white, the margin thick, de-

${ }^{2}$ K. Akad. Wiss. Wien Sitzungsber. $116: 838$. text f. 20. 1907. 
terminate, adnate; in structure $200-250 \mu$ thick, not stratose, composed of erect, interwoven, thin-walled, hyaline hyphae about $2 \mu$ in diameter, bearing a large amount of incrusting granular matter; hymenium consisting of basidia, gloeocystidia, paraphyses, and many incrusted hyphae; gloeo-

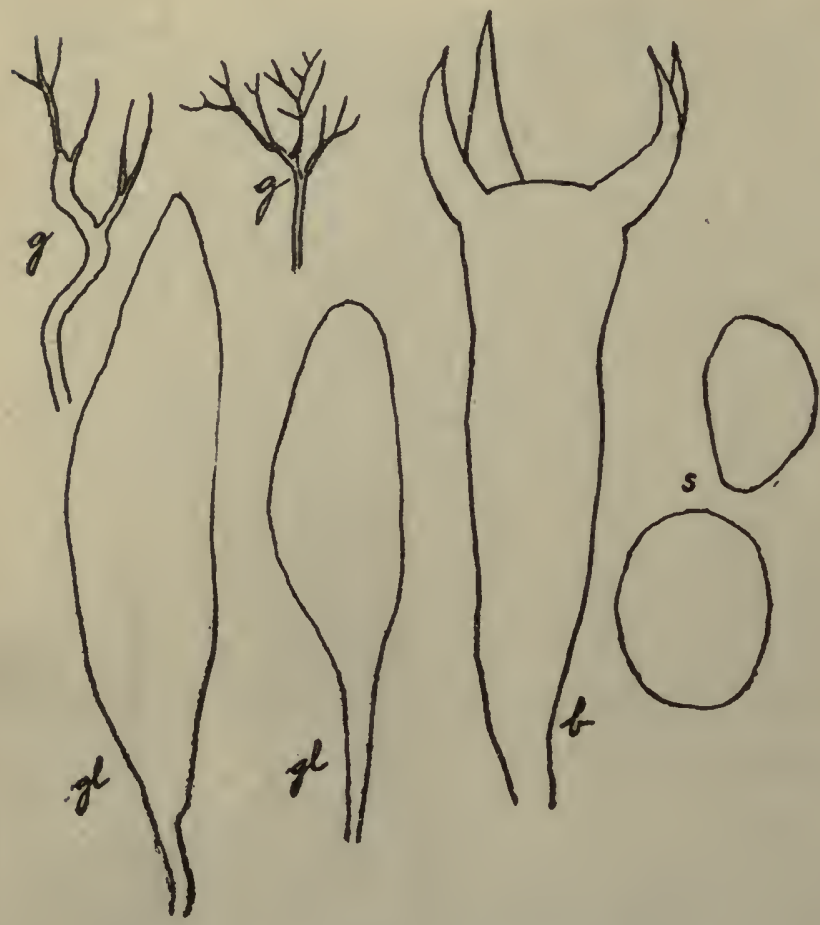

Fig. 8. A. nivosus. Granule-bearing paraphyses, $g$, after removal of the granular matter by $\mathrm{HCl}$; gloeocystidia, $g l$; basidium, $b$; spores, s. $\times 870$. cystidia clavate, hyaline, even, $18-30 \times 9 \mu$; paraphyses about $2-3 \mu$ in diameter under the incrustation, cylindric, flexuous, more or less irregular in form, somewhat cor y m b o s ly branched at surface of hymenium and with branches loaded with crystalline matter; basidia clavate, $40-60 \times$ 12-16 $\mu$, only rarely found, with 4 divergent sterigmata; spores hyaline, even, $15-20 \times 12$ $16 \mu$.

Fructifications $\quad 3-30$ mm. long, about 2-6 mm. broad.

On bark of living trees, common on Juniperus virginiana, occurs also on Juniperus occidentalis and Chamaecyparis. Vermont to Texas, westward to Oregon, and in Jamaica. Throughout the year.

A. nivosus is intermediate between $A$. candidus and $A$. acerinus, differing from the former by thinner and more elongated fructifications which are not at all stratose within, by incrusting matter not in the form of large, angular, crystalline grains, by margin with no tendency to be free nor blackening on under side, and by the common occurrence of the fructification on bark of living red cedar. It differs from $A$. acerinus by presence of gloeocystidia, which show best near 
the substratum, by the corymbosely branched paraphyses, and by the larger spores. Von Höhnel's figures and description of A. nivosus are incorrect in regard to spores and paraphyses.

Specimens examined:

Exsiccati: Bartholomew, Fungi Col., 2880; Ellis, N. Am. Fungi, 326; Ell. \& Ev., Fungi Col., 1207 ; Rabenhorst, Fungi Eur., 3647a and b; Ravenel, Fungi Am., 119; Ravenel, Fungi Car. 2:37, type distribution; Shear, N. Y. Fungi, 52 ; de Thümen, Myc. Univ., 711.

Vermont: Middlebury, E. A. Burt.

Massachusetts: Cambridge, E. A. Burt; Medford, W. Trelease, 80 (in Mo. Bot. Gard. Herb., 5059); Waltham, E. A. Burt; Waverly, W.A. Setchell.

Connecticut: Norwich, W. A. Setchell.

New York: Alcove, C. L. Shear, in Shear, N. Y. Fungi, 52; Orient, R. Latham, 189 (in Mo. Bot. Gard. Herb., 44228).

New Jersey: Newfield, J. B. Ellis, 1518, comm. by W. G. Farlow (in Mo. Bot. Gard. Herb.), in Ellis, N. Am. Fungi, 326, and in Ell. \& Ev., Fungi Col., 1207.

Virginia: Woodstock, C. L. Shear, 1194.

South Carolina: H.W. Ravenel, in Ravenel, Fungi Car. 2 : 37 ; Aiken, H. W. Ravenel, in Ravenel, Fungi Am., 119, and in de Thümen, Myc. Univ., 711; Clemson College, P. $H$. Rolfs, 1618.

Florida: Gainesville, N. L. T. Nelson, 95 (in Lloyd Herb.).

Alabama: Spring Hill, C. Mohr, comm. by H. von Schrenk (in Mo. Bot. Gard. Herb., 43020).

Texas: Austin, W. H. Long, 534.

Ohio: Oxford, L. O. Overholts, 662 (in Mo. Bot. Gard. Herb., $55445)$.

Kentucky: Mammoth Cave, C. G. Lloyd, 2560.

Missouri: Perryville, C. H. Demetrio, in Rabenhorst, Fungi Eur., 3647b.

Arkansas: Batesville, E. Bartholomew, in Bartholomew, Fungi Col., 2880.

Kansas: Manhattan, W. A. Kellerman, in Rabenhorst, Fungi Eur., 3647a, and' (in U. S. Dept. Agr. Herb.). 
Oregon: White Pine, J. R. Weir, 398 (in Mo. Bot. Gard. Herb., 16266).

Jamaica: Cinchona, F. S. Earle, 417, N. Y. Bot. Gard., Plants of Jamaica.

9. A. acerinus (Pers.) v. Höhn. \& Litsch. K. Akad. Wiss. Wien Sitzungsber. 116 : 804. pl. 2. f. 6. 1907; Bourd. \& Galz. Soc. Myc. Fr. Bul. 28 : 352. 1913.

Corticium acerinum Persoon, Obs. Myc. 1:37. 1796; Romell, Bot. Not. 1895 : 71. 1895. - Thelephora acerina Persoon, Syn. Fung. 581. 1801; Myc. Eur. 1:152. 1822; Fries, Syst. Myc. $1: 453$. 1821; Hym. Eur. 648. 1874.-Stereum

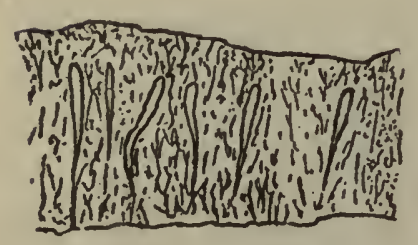

Fig. 9

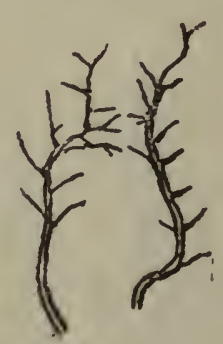

A. acerinus.

Vertical section of fructification showing scattered immature basidia and absence of gloeocystidia, $\times 92$; granule-bearing paraphyses after removal of the granular matter by HCl. $\times 870$. acerinum (Pers.) Fries, Epicr. 554. 1838; Sacc. Syll. Fung. 6 : 587. 1888.

Fructifications scattered, resupinate, crustaceous, adnate, thin, even, white, the margin abrupt; in structure $45-80 \mu$ thick, consisting of densely arranged, hyaline, thin-walled, suberect hyphae about $2-3 \mu$ in diameter, heavily incrusted, rising between the basidia to the surface and terminating in a racemose manner with short, slender branches, loaded with crystalline matter; basidia clavate, $30-45 \times 6 \mu$; spores hyaline, even, $10-12 \times 6-7 \mu$.

Fructifications about $3 \mathrm{~mm}$. in diameter, rarely elongated up to $10 \mathrm{~mm}$. long, $3 \mathrm{~mm}$. broad.

On bark of trunks of living maple, oak, etc. Vermont to Texas, westward to Missouri, and in Cuba and Mexico. Throughout the year.

This species may be recognized by its occurrence in scattered, small, white, circular or oblong fructifications on the bark of trunks of living white oak, maple, elm, ash, etc. The smaller spores, racemose paraphyses, and absence of gloeocystidia are structural characters separating the species from $A$. seriatus and A. nivosus. Our American collections are 
frequently merely a thin mycelium containing a great deal of incrusting matter and not showing basidia and spores.

Specimens examined:

Exsiccati: Berkeley, Brit. Fungi, 65; Fl. Exs. AustroHungarica, 3152, under the name Corticium calceum; Romell, Fungi Scand. Exs., 125, 127.

Sweden: Stockholm, L. Romell, in Romell, Fungi Scand. Exs., 125, 127.

Austria-Hungary: Peggau, Wettstein, in Fl. Exs. AustroHungarica, 3152 ; Trento, G. Bresadola.

England: M. J. Berkeley, in Berkeley, Brit. Fungi, 65.

New Hampshire: Chocorua, W. G. Farlow; Jaffrey, W. G. Farlow.

Vermont: Grand View Mt., E. A. Burt; Middlebury, E. A. Burt.

New York: G. F. Atkinson, 7987; Alcove, C. L. Shear, 1302, 1305; Buffalo, G. W. Clinton, comm. by U. S. Dept. Agr. Herb.; East Galway, E. A. Burt; Ithaca, L. A. Zimm, 90 (in Mo. Bot. Gard. Herb., 9061), G. F. Atkinson, 22964; Orient, R. Latham, 59 (in Mo. Bot. Gard. Herb., 44234); Vaughns, S. H. Burnham, 11 (in Mo. Bot. Gard. Herb., 44106).

Pennsylvania: State College, L. O. Overholts \& A.S. Rhoads, comm. by L. O. Overholts, 3143 (in Mo. Bot. Gard. Herb., $5720)$.

Maryland: Plummers Island, C. L. Shear, 1183; Takoma Park, C. L. Shear, 1070.

North Carolina: Chapel Hill, H. R. Totten, comm. by W. C. Coker, Univ. of N. Car. Herb., 2020 (in Mo. Bot. Gard. Herb., 8871). = 2. sciccrosposue

South Carolina: Clemson College, P. H. Rolfs, 1824.

Florida: Cocoanut Grove, $R$. Thaxter, 89 (in Farlow Herb., and in Mo. Bot. Gard. Herb., 43913); Palm Beach, $R$. Thaxter, 9 (in Farlow Herb., and in Mo. Bot. Gard. Herb., 43925).

Alabama: Montgomery County, R. P. Burke, 64 (in Mo. Bot. Gard. Herb., 15119).

Mississippi: Hattiesburg, C. J. Humphrey, 5442. 
Louisiana: Baton Rouge, Edgerton \& Humphrey, comm. by C. J. Humphrey, 5600.

Texas: Houston, H. W. Ravenel, 269, comm. by U. S. Dept. Agr. Herb.

Missouri: Creve Coeur Lake, L. O. Overholts, 3168 (in Mo. Bot. Gard. Herb., 5707).

Mexico: Jalapa, W.A. \& Edna L. Murrill, 331 (in N. Y. Bot. Gard. Herb., and in Mo. Bot. Gard. Herb., 54502) ; Orizaba, W. A. \& Edna L. Murrill, ry6 (in N. Y. Bot. Gard. Herb., and in Mo. Bot. Gard. Herb., 54613).

10. A. botryosus Burt, n. sp.

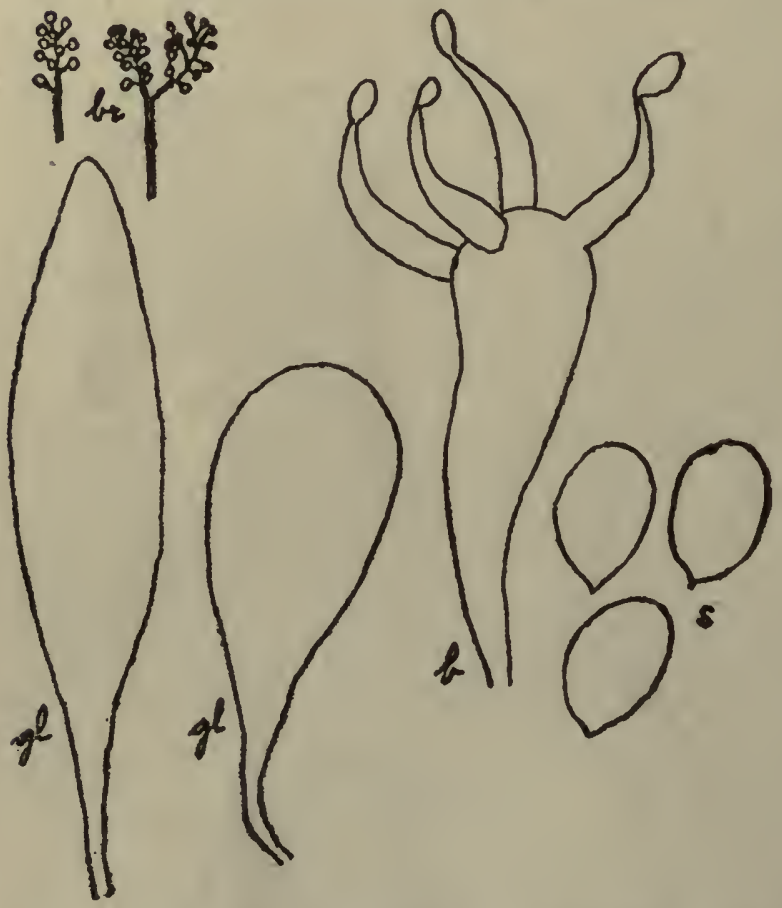

Fig. 10. A. botryosus. Racemose paraphyses, $b r$; gloeocystidia, $g l$; basidium, $b$; and spores, $s . \times 870$.
Type: in Burt Herb. Fructifications resupinate, effused, adnate, scattered, becoming confluent, at first white and very thin, finally thicker, cracking in drying and sometimes pale olive-buff, the margin thinning out, pruinose; in structure $150-200 \mu$ thick, composed of erect, crowded hyphae, gloeocystidia, basidia, and short, erect, bottlebrush branches similar to $\mathrm{th}$ e paraphyses; hyphae hyaline, even, thin-walled, with irregular outlines, $2 \mu$ in diameter; gloeocystidia usually near the substratum, cylindric, flexuous, $80 \times 6-7 \mu$, or sometimes clavate, $45 \times 12-16$ $\mu$; basidia clavate, about $40 \times 12 \mu$, with 4 divergent sterigmata $15 \mu$ long, $3-4 \mu$ in diameter at base; spores hyaline, even, $13-15 \times 9-11 \mu$; paraphyses with tips racemose and the short lateral prongs minutely globose at the end; racemose portions $10-15 \times 3-4 \frac{1}{2} \mu$ over branches; similar racemose 
branches are more or less abundant through the whole of the fructification.

Fructifications at first $2-3 \times 1-1 \frac{1}{2} \mathrm{~mm}$., becoming confluent over areas $3-8 \mathrm{~cm} . \times 5-10 \mathrm{~mm}$.

On dead stems of Rubus and Vitis. Massachusetts, Maryland, and Mexico. November to April. Rare.

This species closely resembles in aspect and general details of structure an authentic specimen of $A$. cerussatus in my herbarium, but differs from the latter species chiefly in having bottle-brush organs not confined to the hymenial surface but distributed through the whole thickness of the fructification; other less important differences are slightly larger spores and basidia and much larger sterigmata, and less widely effused fructifications. $A$. botryosus resembles $A$. nivosus somewhat in aspect but differs from it by having bottle-brush paraphyses. Thelephora albidocarnea Schw., originally collected on Vitis and to which I have referred in my herbarium two scanty collections on Vitis, has aspect very similar to $A$. botryosus, but sectional preparations of $T$. albidocarnea do not show gloeocystidia and apparently have much smaller basidia and spores. T. albidocarnea should receive consideration when collections resembling $A$. botryosus are made on Vitis.

Specimens examined:

Massachusetts: Sharon, A. P. D. Piguet, two collections (in Farlow Herb., and in Mo. Bot. Gard. Herb., 54774, 55277). Maryland: Takoma Park, C. L. Shear, 1025, type, 112\%, and $135 \%$.

Mexico: Jalapa, W. A. \& Edna L. Murrill, 320 (in N. Y. Bot. Gard. Herb., and in Mo. Bot. Gard. Herb., 54497).

11. A. cremeus Burt, n. sp.

Type: in Mo. Bot. Gard. Herb.

Fructifications resupinate, effused, adnate, convex at first, then confluent and plane, drying cracked and cream-buff, the margin thick and entire; in structure $600-800 \mu$ thick, containing much crystalline matter arranged in layers, with hyphae suberect, interwoven; hymenium composed of clavate basidia, bottle-brush paraphyses 6-7 $\mu$ in diameter, and of 
clavate, even-walled paraphyses $6 \mu$ in diameter with the tip more or less constricted to form a single moniliform body; gloeocystidia few, inconspicuous, clavate or cylindric, flex-

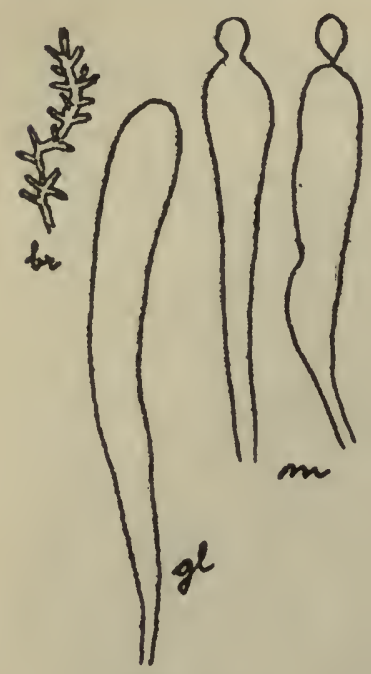

Fig. 11

A. cremeus.

Bottle-brush paraphysis, br; other paraphyses, $m$; gloeocystidium, $g l . \times 870$. uous, $30-45 \times 5-6 \mu$; no basidia with sterigmata observed; probable spores imbedded in hymenial surface, spherical, even, hyaline, $9 \mu$ in diameter.

Fructifications at first $2-5 \mathrm{~mm}$. long, about $1-2 \frac{1}{2} \mathrm{~mm}$. broad, becoming confluent into masses $5 \mathrm{~cm}$. long, $1-1 \frac{1}{2} \mathrm{~cm}$. broad.

On decorticated dead wood of Quercus Gambelii. New Mexico. September.

$A$. cremeus belongs in the group with A. botryosus, 'A. cerussatus, and A. penicillatus but is much thicker than these and differs in its other characters as enumerated. A. croceus Pat., of Ecuador, differs by reflexed margin, larger and ovoid spores, and absence of paraphyses with moniliform tips.

Specimens examined:

New Mexico: Cienega Canyon, W. H. Long, 21528, type (in Mo. Bot. Gard. Herb., 55128).

12. A. tenuis Burt, n. sp.

Type: in Mo. Bot. Gard. Herb. and in Lloyd Herb.

Fructifications resupinate, effused, very thin, white, pruinose, the margin entire; in structure 60-90 $\mu$ thick, composed of two kinds of densely arranged, e r e ct organs which start from the substratum and extend to surface of hymenium - (1)

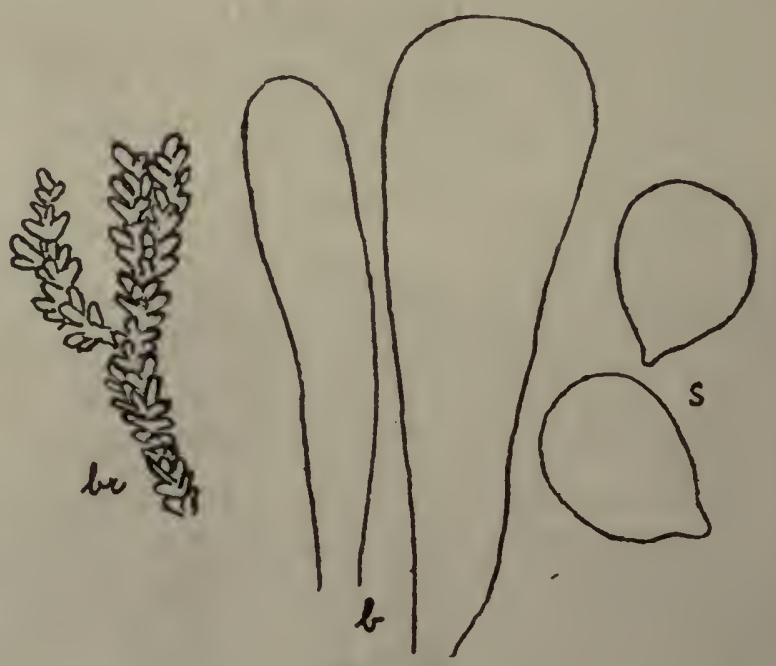

Fig. 12

A. tenuis.

Paraphyses before treatment with $\mathrm{KHO}$, $b r$; immature basidia, $b$; and spores, $s$. $\times 870$. 
bushy, branched, cylindric, bottle-brush paraphyses about $4 \frac{1}{2} \mu$ in diameter over prongs, uniformly clothed for their length with such lateral outgrowths which are disorganized and dissolved by KHO solution but not affected by dilute hydrochloric acid nor lactic acid, and (2) deeply staining, cylindric organs usually $4 \frac{1}{2}-5 \mu$ in diameter, sometimes clavate and then up to $9 \mu$ in diameter; spores hyaline, even, $12-15 \times$ 9-12 $\mu$.

Fructifications $1-1 \frac{1}{2} \mathrm{~cm}$. broad, $7 \mathrm{~cm}$. long, and broken at both ends.

On small dead twigs of frondose wood. Cuba. March.

This species may be recognized at the time of collection by its snow-white color, very thin fructification which resembles a thin Corticium, and occurrence along one side of small dead twigs of frondose species; the small, even spores and bushy paraphyses whose bottle-brush outer surface is disorganized by treatment of preparation with KHO solution afford good distinctive microscopical characters. Mature basidia, when found, may show that this species belongs in Sebacina rather than in Aleurodiscus-a view which seems the more probable because of the peculiar effect of KHO solution upon the paraphyses.

Specimens examined:

Cuba: C. G. Lloyd, 421, 422, type (in Mo. Bot. Gard. Herb., 55178,55179 respectively).

\section{A. penicillatus Burt, n. sp.}

Type: in Burt Herb.

Fructification resupinate, effused, adnate, cracking in drying, pale ochraceous-buff at first, becoming between light buff and pinkish buff in the herbarium, the margin determinate; in structure about $200 \mu$ thick, composed of loosely interwoven, suberect, hyaline hyphae $3 \mu$ in diameter, occasionally nodoseseptate, not incrusted; hymenium composed of large, clavate basidia about $75 \times 18 \mu$, with large sterigmata, and of flexuous paraphyses about $6 \mu$ in diameter, of several forms, of which the most noteworthy have about the obtuse apex a cluster of about 12 acicular branches, each about $4 \mu$ long; spores hya- 
line, minutely echinulate, subglobose, $15-18 \mu$, or rarely $20 \mu$, in diameter.

Fructifications at first about $2-3 \mathrm{~mm}$. in diameter, then laterally confluent into patches up to $10 \mathrm{~cm}$. long and $2 \mathrm{~cm}$. broad.

On stem and twigs of dead standing seedling of Pseudotsuga

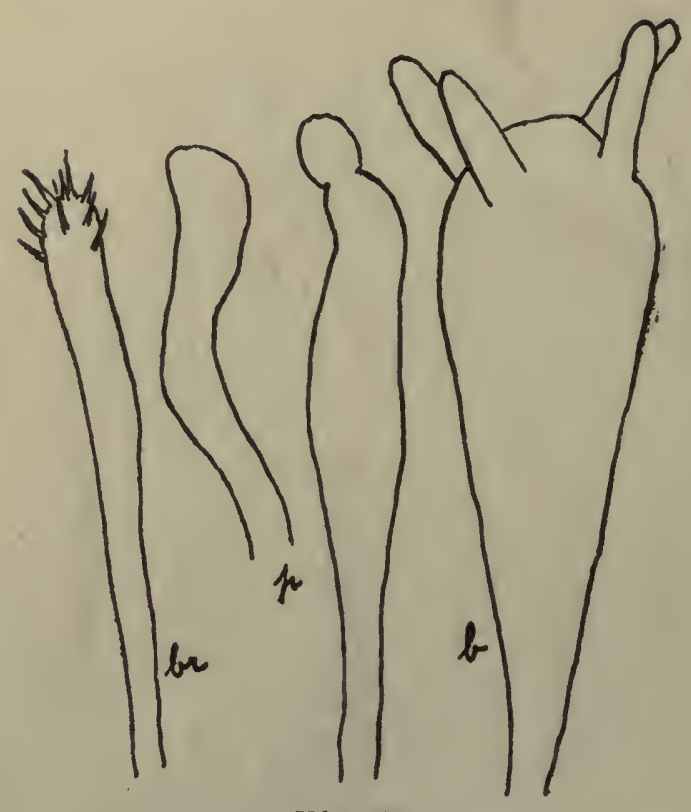

Fig. 13

A. penicillatus.

taxifolia and on limbs of Tsuga heterophylla on the ground. Idaho, Washington, and Oregon. September and October. Rare.

This species is so thin and widely effused that it is likely to be regarded as a Corticium until examined with a microscope. If sought for especially it could probably be recognized when collected by its Brush paraphyses, $b r$; other paraphyses, $p$; buff color and occurbasidium $b . \times 870$.

rence upon western Tsuga and Pseudotsuga. The minutely echinulate, globose spores, brush-shaped paraphyses occurring between ordinary flexuous paraphyses, and the thin fructification wholly destitute of crystalline and granular matter are a good combination of characters separating $A$. penicillatus from other resupinate species.

Specimens examined:

Idaho: Priest River, J. R. Weir, 109, 129 (in Mo. Bot. Gard. Herb., 10811 and 12721).

Washington: Hoquiam, C. J. Humphrey, 6384; Sequim, J. M. Grant, comm. by Mrs. F. W. Patterson (in Mo. Bot. Gard. Herb., 8936).

Oregon: Eugene, C. J. Humphrey, 6084, type. 
14. A. Weirii Burt, n. sp.

Type: in Burt Herb.

Fructification resupinate, broadly effused, adnate, glabrous, becoming cracked into small polygonal masses, drying cartridge-buff, the margin thinning out; in structure 200-900 $\mu$

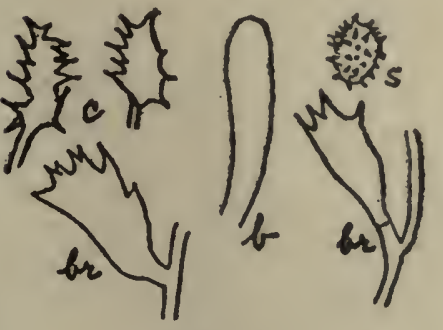

Fig. 14

A. Weirii.

Cockroach-shaped paraphyses, $c$; somewhat similar hyphal branches from interior of section, br; immature basidium, $b$; spore, s. $\times 870$.

thick, composed of thin-walled, irregular, hyaline hyphae $2 \mu$ in diameter, which bear laterally here and there short, erect branches with ovoid body $15 \times 4-4 \frac{1}{2} \mu$, from which radiate 6-12 prongs, each $4-4 \frac{1}{2} \mu$ long, and constitute the paraphyses at surface of the hymenium; basidia with sterigmata not found; spores hyaline, minutely echinulate, subglobose, $6 \times 5-6 \mu$ in one specimen, $10-12 \times 9-10 \frac{1}{2} \mu$ in another.

Fructification 1-3 cm. long, 1-2 cm. broad on bark; 8-10 $\mathrm{cm}$. long, 2-3 $\mathrm{cm}$. broad on decorticated wood-broken off at one end and along one side in the latter specimens.

On rotting wood of Abies grandis and Thuja plicata and on bark of Larix occidentalis. Idaho and British Columbia. August and September.

$A$. Weirii has the aspect of a widely effused Corticium, but it is distinguished from any Corticium of similar aspect by the minutely echinulate spores; the cockroach-shaped paraphyses distinguish this species from other species of Aleurodiscus.

Specimens examined:

Idaho: Priest River, J. R. Weir, 70, type, and 389 (the latter in Mo. Bot. Gard. Herb., 12249).

British Columbia: Kootenai Mts., near Salmo, J. R. Weir, 459, 490 (in Mo. Bot. Gard. Herb., 8768 and 21980 respectively).

(To be continued.) 

The Thelephoraceae of North America. X

\section{Hymenochaete}

\section{EDWARD ANGL'S BUK']}

Reprinted trum arinas of the Missuurt Botanicat,

GAfDEt $5: 301-372$. November, 1918 



\title{
THE THELEPHORACEAE OF NORTH AMERICA. $\mathrm{X}^{1}$
}

\author{
Hymenochaete \\ EDWARD ANGUS BURT \\ Mycologist and Librarian to the Missouri Botanical Garden \\ Professor in the Henry Shaw School of Botany of \\ Washington University
}

\section{HYMENOCHAETE}

Hymenochaete Léveillé, Ann. Sci. Nat. Bot. III. 5 : 150. 1846; Berk. \& Curtis, Linn. Soc. Bot. Jour. 10 : 333. 1868; Cooke, Grevillea 8 : 145. 1880; Sacc. Syll. Fung. 6 : 588. 1888; Massee, Linn. Soc. Bot. Jour. 27 : 95. 1890; Engl. \& Prantl, Nat. Pflanzenfam. $\left(1: 1^{* *}\right): 121.1898$.

Fructifications coriaceous to hard, of varied form from stipitate to resupinate; hymenium even or rarely granular, containing slender, somewhat conical, colored setae between the basidia; basidia simple; spores hyaline, even.

There is no type species, for this genus is a fine example of basing the generic conception upon a group of thelephoraceous species, some stipitate, some dimidiate, some reflexed, and some resupinate, which agree in having setae in the hymenium.

In addition to the distinctive morphological character of elongated, conical setae in the hymenium, there is also a chemical substance in the tissue of all the species of Hymenochaete which I have studied, that causes an immediate darkening of sections when dilute potassium hydrate is brought in contact with them. This darkening is so great as to make the sections too opaque for study if more than a mere trace of this usually useful reagent is employed to swell the sections. One has to use instead lactic acid to have the sections remain clear enough to show their fine structural details. The greatly elongated, colored cystidia and conducting organs which are present in the deeper tissue and curve into, or even protrude above, the hymenial surface in some species of Stereum, as, for example, S. umbrinum, S. abietinum, S. glaucescens, etc.,

${ }^{1}$ Issued December 23, 1918. 
have been confused by some authors with setae and have led to the publication of several such species under Hymenochaete. Istvanffi ${ }^{1}$ has shown that there is a fundamental difference between such organs and the conical, pointed setae which are characteristic of Hymenochaete. In any doubtful case which the student may meet it would be well to aid conclusion by the color reaction with solution of potassium hydrate already mentioned. In my experience the dimensions of setae are not sufficiently constant to hardly more than grade these organs as large, medium, and small.

According to our present knowledge, Hymenochaete attains its greatest development both in form and in number of species in the western continent where it culminates in a small group of indigenous stipitate species. Temperature conditions are important in the geographical distribution of the species of this genus; this is shown by the long east and west range across North America of common species, in comparison with the much shorter north and south range. Furthermore, Hymenochaete is a genus of tropical species rather than of the cooler portion of the north temperate zone, for in contrast with the 29 species occurring from the Gulf States to Brazil only 13 species are known north of the latitude of Virginia, and from Europe perhaps 9 species, of which 6 are well known.

Original descriptions of the species of Hymenochaete have required considerable modification with regard to characters referring to form, because they were based upon too limited an amount of material. In the case of species of Thelephoraceae growing on prostrate logs, the inclination of the substratum at the point of attachment and the position of the substratum as to whether over or under the fructification are important in determining the habit and form of the fructification. For example, a species present in quantity on a log slightly raised above the ground will often show fine resupinate specimens on the under side of the log; about an eighth of a circumference up the side of the log the upper margin is reflexed, becoming longer reflexed and with a shorter resu-

${ }^{1}$ Physiologische Anatomie der Pilze. Jahrb. f. wiss. Bot. 29 : 410. 1896. 
pinate base as the fungus occurs higher on the side of the log; beyond one-fourth of a circumference upward from the bottom of the log, umbonate-sessile, dimidiate, and flabelliform specimens are frequently collected. I have a fine campanulate specimen of Stereum fasciatum which I found on the top of a log surrounded by this species. For these reasons the form of fungi growing on prostrate logs is not as reliable a character as it is in case of species growing on the ground or in the case of a flowering plant, and a student having in hand only a resupinate or only a flabelliform fructification from some herbarium must not be too confident that the respective species are always resupinate or always flabelliform.

The degree of differentiation in structure of the fructification of Hymenochaete has not been used in systematic work heretofore, so far as I am aware. Such structure affords, however, constant, positive, fundamental characters of easy determination. In the simplest condition of the fructification in this genus, only a setigerous layer is present, in the next degree higher of development, a hyphal layer connects the setigerous layer with the substratum or may be extended from the substratum as the upper surface of the pileus; in a still more highly developed condition, the hyphal layer is differentiated into an intermediate layer and a denser and dark zone, and usually into a second hyphal layer adnate to the substratum or forming the surface of the pileus.

\section{Key to the Species}

Fructifications in preparations of sections show at least both a setigerous layer and a hyphal layer destitute of setae.................

Fructifications lack a hyphal layer, i. e., have the setigerous layer seated

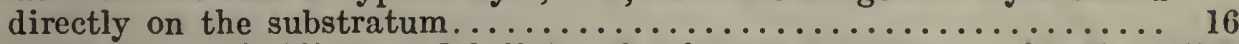

Fructifications dimidiate or flabellate, of unknown structure....s\%. $H$. pallida

1. Not stratose, i. e., consisting of but one setigerous layer of more or less

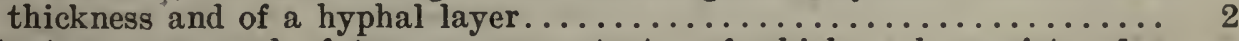

1. Stratose, composed of two or more strata, of which each consists of a

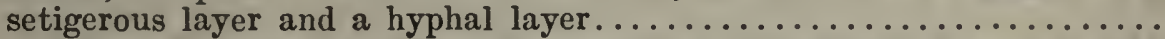

2. Hyphal layer simple and homogeneous throughout, i. e., not with a portion differentiated as an internal or bordering, conspicuously

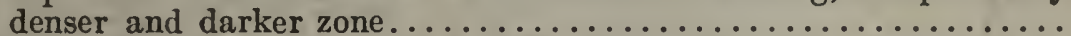

2. Hyphal layer not simple but differentiated into an intermediato layer and at least a bordering, denser and darker zone on the side towards the substratum or upper surface of the reflexed

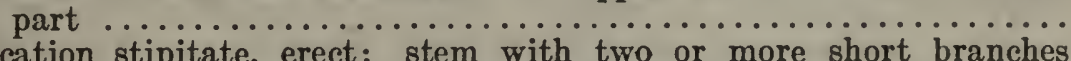

3. Fructification stipitate, erect; stem with two or more short branches 1 16 2 at or near its apex and each bearing an expanded pileus..1. H. damaecornis 
3. Old, dark, zonate specimens of above.............. ${ }^{*}$ Stage $H$. formosa

3. Fructification stipitate, erect; stem bearing a single reniform pileus.... $\ldots \ldots \ldots \ldots \ldots \ldots \ldots \ldots \ldots \ldots \ldots \ldots \ldots \ldots \ldots \ldots \ldots \ldots \ldots \ldots \ldots$. $H$. reniformis

3. Not stipitate, but resupinate, or with pileus reflexed or sessile....... 4

4. Always resupinate so far as known yet. Guard against locating here the first-stratum stage of the stratose species and resupinate

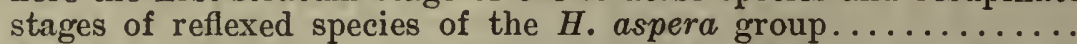

4. Reflexed or dimidiate; resupinate specimens of $H$. Cacao and $H$. aspera have been found and perhaps may yet be found for the

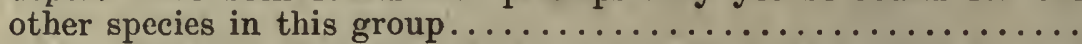

5. Fructification clay-color to antique brown, 100-140 $\mu$ thick, with hyphae loosely interwoven, suberect, 3-4 $\mu$ in diameter; setae $30-75 \times 6-8 \mu$, scattered in the outer half of fructification; on Corylus, Ostrya, and

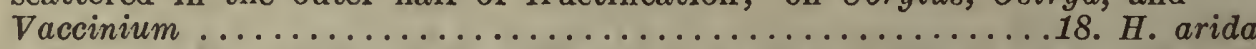

5. Hyphal layer very thin usually and may be overlooked unless substratum is included in the sections; setigerous layer up to $500 \mu$ or more thick, zonate; causes a pocketed rot of wood; in Cuba, Venezuela, and

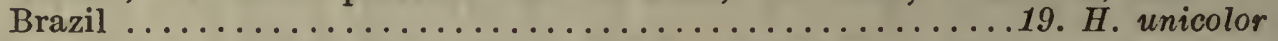

5. Hyphal layer $1-2 \mathrm{~mm}$. thick, very compact; setae few, $70-90 \times 8 \mu$, starting from the dark subhymenium; parasitic on living limbs of Alnus, Benzoin, etc., where they rub together............20. H. agglutinans

6. Not cracked, antique brown to Brussels-brown, finally 2-6 strata thick, with the setigerous layers $30-45 \mu$ thick and equalled or exceeded by the alternating hyphal layers......21. H. cinnamomea

6. Not cracked, antique brown to Brussels-brown, finally up to 15 strata thick; strata with layers thinner than in the preceding species; paraphyses colored, with branched tips; in Panama

6. Cracking in drying, Argus-brown, very compact, finally several strata thick, with setigerous layers $45-200 \mu$ thick, and exceeding the hyphal layers........................... H. spreta

7. Setigerous layer $90 \mu$ thick, with setae crowded together in all its parts;

in Cuba, Jamaica, and Venezuela....................... H. Cacao

7. Setigerous layer not more than $60 \mu$ thick............................ 8

8. Pileus rough on the upper side with strigose, matted fibers; hymenium granular like that of Thelephora terrestris; margin with bright-colored mycelial strands; in Cuba, Jamaica, and Venezuela

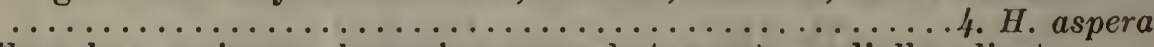

8. Pileus bay, sericeous, becoming somewhat zonate, radially plicate; margin lobed, often proliferous, yellow ocher; setae very large, $90-120 \times 12-15 \mu$; in Jamaica and Guiana.......5. H. Berkeleyana

8. Pileus Argus-brown above and beneath, concentrically sulcate and somewhat zonate and shining above, very thin and papery; setae $65-90 \times 9-10 \frac{1}{2} \mu$; in South Carolina and the West Indies to Chile

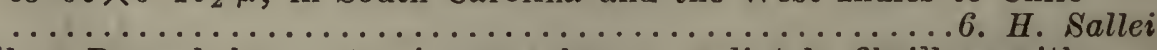

8. Pileus Brussels-brown to cinnamon-brown, radiately fibrillose with adnate fibrils, concentrically ridged; hymenium snuff-brown; setae $60-90 \times 7 \frac{1}{2}-10 \mu$; from Ontario to New Jersey....7. H. borealis

9. Setigerous layer not more than $50 \mu$ thick................... 10

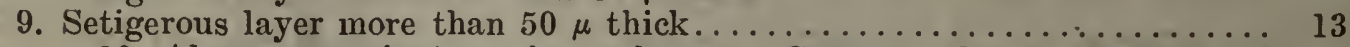
10. Always resupinate so far as known. Compare also $H_{\text {. }}$ Curtisii and

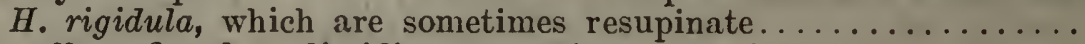
10. Usually reflexed or dimidiate, sometimes resupinate . . . . . . . . . 12

11. Hymenium Isabella-color to tawny olive, cracked, margin somewhat sulphur-yellow; the adnate, bordering, dark zone next to substratum absent in some places; from Alabama to Mexico.........24. H. epichlora

11. Hymenium between wood-brown and Saccardo's umber; intermediate layer, connecting dark zone, and hyphal layer adnate to substratum are

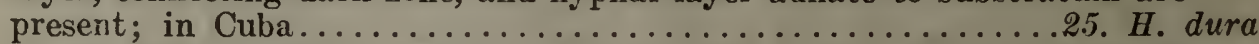
12. Becoming narrowly reflexed, Benzo-brown, rather rigid; hymenium Benzo-brown; setae crowded together in all parts of the setigerous layer; in Cuba and Venezuela................. H. rigidula 
12. Resupinate or reflexed, drying pliant, antique brown; hymenium velvety, antique brown; setae few and usually far apart, $60-70 \times 6-8 \mu$; Massachusetts to Texas and westward to Oregon ..................................... Curtisii

12. Dimidiate and imbricated, or effuso-reflexed, concentrically sulcate, Argus-brown, pliant; hymenium buckthorn-brown; setae few and far apart, $30 \times 5-6 \mu$; Porto Rico to Venezuela and Guiana......

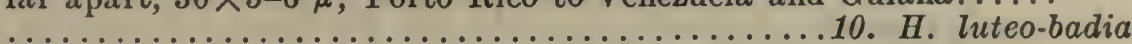

13. Always resupinate so far as known yet. Compare $H$. tabacina and $H$. rubiginosa which are frequently resupinate................. 14

13. Usually reflexed or dimidiate, sometimes resupinate............. 15

14. 200-700 $\mu$ thick, tawny olive to Brussels-brown, separable from the substratum; a narrow, dark zone divides the hyphal layer into an intermediate layer and a broad layer attached to the substratum; Arkansas to Mexico and in Cuba................... H. leonina

14. 120-260 $\mu$ thick, fulvous; lower dark zone is adnate to substratum; cystidia present; in Louisiana and Jamaica...........2\%. H. fulva

14. $120-240 \mu$ thick, between Verona-brown and cinnamon-drab, slightly glaucous, adnate; lower dark zone bordering the intermediate layer is adnate to substratum; paraphyses colored, with pinnatifid tips; Georgia to Mexico, and in Cuba and Jamaica..28. H. pinnatifida

15. Usually reflexed, sometimes resupinate, thin, sericeous, and antique brown at first, finally glabrous and deep brownish drab, the margin and intermediate layer orange-yellow; hymenium snuff-brown to sepia, deeply cracked in resupinate portions into radiating systems, about one system for each centimeter of area; common throughout Canada

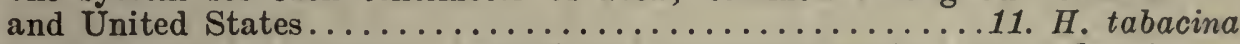

15. Fructifications imbricated, conchiform, umbonate-sessile, or reflexed, sericeous, lineate-radiate, becoming variegated with concentric brown zones; closely related to $H$. tabacina but not cracking into radiating systems; found on vertical surfaces; Canada to Carolina............ $\ldots \ldots \ldots \ldots \ldots \ldots \ldots \ldots \ldots \ldots \ldots \ldots \ldots \ldots \ldots \ldots \ldots \ldots \ldots . \ldots \ldots$. H. badio-ferruginea

15. Reflexed, sometimes resupinate, coriaceous $\ldots \ldots \ldots$ rigid, thick, concentrically sulcate, Brussels-brown, becoming fuscous-black, the margin ochraceoustawny; hymenium colliculose, bister, with conspicuous setae; Canada to Mexico and westward to the Pacific, and in Porto Rico.13. H. rubiginosa

15. Broadly reflexed, coriaceous-rigid, shallowly concentrically sulcate, zonate, Prout's brown; hymenium even, Sudan-brown; setigerous layer zonate, $300-400 \mu$ thick, having scattered setae $35-40 \times 4 \frac{1}{2}-5 \mu$; in

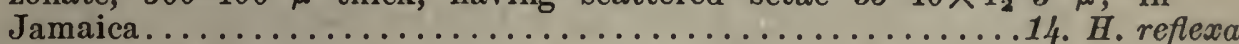

15. Imbricated, flabelliform, dimidiate, umbonate-sessile, or reflexed, thin, pliant when dry, concentrically sulcate, becoming snuff-brown to Rood's brown; hymenium even, antique brown; setigerous layer 80-100 $\mu$ thick, having setae $35-45 \times 4 \frac{1}{2}-6 \mu$; in Cuba and Porto Rico......15. H. cubensis 16. Fructifications somewhat hoof-shaped, sessile, with a black, hard crust on the upper side; hymenium whitish, $3 \mathrm{~mm}$. thick, zonate

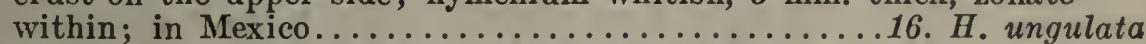

16. Fructification with upper edge sometimes barely reflexed, and black; hymenium drab, 400-1000 $\mu$ thick; growing on bark of living trunks of oak, elm, etc.; New Jersey to Florida and in

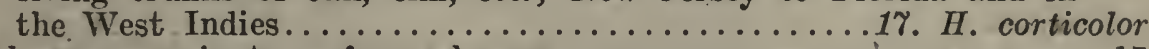

16. Always resupinate so far as known.................. 17

17. Setae crowded, $27-45 \times 4 \frac{1}{2}-5 \mu$; hymenium cinnamon-brown to Prout's brown; in Cuba and Jamaica........................ multisetae

17. Colorless, incrusted cystidia and colored setae present, the setae about $30 \times 4 \frac{1}{2} \mu$, only rarely emergent; hymenium vinaceous-buff; in Cuba..

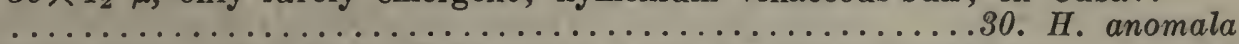

17. Having setae larger than $27-45 \times 4 \frac{1}{2}-5 \mu$ and not having cystidia....... 18

18. Cinnamon-brown to bister and Rood's brown, cracked into small 4-6-sided areas, $150-500 \mu$ thick; setae $60-70 \times 8-12 \mu$, starting in all parts of the fructification; Canada to Texas, westward to Kentucky, and in Jamaica............................. corrugata 
18. Tawny olive, not cracked, up to $90 \mu$ thick; setae $60-90 \times 9-12 \mu$, all starting from the dark zone next to the substratum; Vermont to Pennsylvania and Illinois............32. H. episphaeria

18. Dresden-brown, differs in structure from $H$. episphaeria by having spores $7-9 \times 3 \frac{1}{2} \mu$ and by containing crystalline masses $12-15 \mu$ in diameter; in Louisiana and Cuba................. H. cervina

18. Between bister and Vandyke-brown, slightly velvety when young, becoming glabrous, cracked, 200-300 $\mu$ thick, dark and opaque; setae $50-90 \times 8-10 \mu$, starting in all parts of the fructification;

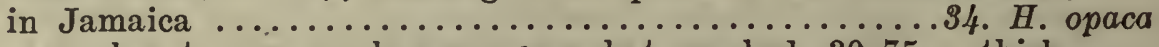

18. Raw umber to mummy-brown, somewhat cracked, $30-75 \mu$ thick; setae $36-45 \times 5-7 \mu$; on Thuja and Tsuga; Vermont to Florida and in British Columbia.......................... tenuis

18. Bister to warm sepia, somewhat colliculose, not cracked; $150-200 \mu$ thick; setae abundant, $60-75 \times 8-9 \mu$, starting in all parts of the fructification; with general aspect of resupinate $H$. rubiginosa but thin and adnate; in Vermont, Maryland, Ohio, and Kentucky .................................. H. fuliginosa

\section{Arrangement of the Species}

I. Stipitate species $\ldots \ldots \ldots \ldots \ldots \ldots \ldots \ldots \ldots \ldots \ldots \ldots \ldots \ldots, 1-2$

II. Dimidiate, umbonate-sessile and reflexed species, many of which occur resupinate.

a. Hyphal layer not differentiated into an intermediate layer proper and a bordering, denser, dark zone on its upper side.........

b. Hyphal layer differentiated into an intermediate layer and at least a bordering, denser, dark zone on its upper side.

* Setigerous layer not more than $50 \mu$ thick.............

* Setigerous layer more than $50 \mu$ thick.............. 11-15

c. No hyphal layer.......................................... 16

III. Resupinate species, none of which occur reflexed.

a. Hyphal layer not differentiated into an intermediate layer proper and a bordering, denser, dark zone on the side towards the substratum.

* Not stratose ............................. 18-20

* Stratose ............................ 21-23

b. Hyphal layer differentiated into an intermediate layer and at least a bordering, denser, dark zone on the side towards the substratum.

* Setigerous layer not more than $50 \mu$ thick........... 24-25

** Setigerous layer more than $50 \mu$ thick............... 26-28

c. No hyphal layer-setigerous layer seated directly on the substratum. No. 17 is nearly always resupinate.

* Setae small, $27-45 \times 4 \frac{1}{2}-5 \mu \ldots \ldots \ldots \ldots \ldots \ldots \ldots \ldots . . . \ldots . . .29$

* Both setae and colorless, incrusted cystidia present...... 30

** Setae larger than $27-45 \times 4 \frac{1}{2}-5 \mu$ and not having cystidia. 31-36

IV. Dimidiate, somewhat flabellate species whose structure is not known...

1. Hymenochaete damaecornis Link ex Léveillé, Ann. Sci. Nat. Bot. III. 5 : 151. 1846 ; Sacc. Syll. Fung. 6 : 589. 1888; Massee, Linn. Soc. Bot. Jour. $27: 96.1890 . \quad$ Plate 16, fig. 1. Stereum damicorne Link, Ges. Naturforsch. Freunde Berlin Mag. 3 : 40. 1809; Fries, Epicr. 546. 1838; R. Soc. Sci. Upsal. Actis III. 1 : 109. 1851; Lloyd, Letter 46 : 6. 1913.-Thelephora damaecornis Link ex Fries, Linnaea 5 : 524. 1830.-Hymeno- 
chaete formosa Léveillé, Ann. Sci. Nat. Bot. III. 5 : 151. 1846. -An Thelephora speciosa Fries, Linnaea 5 : 525. 1830?

Fructifications with several to many pilei borne on very short branches of a common central stem at or near its apex; stem cylindric, velutinous with setae, hazel to Brussels-brown; pilei coriaceous, thin, expanded, drying strongly inrolled, even or sometimes rugose, silky and antique brown when young, finally glabrous except for setae which are scattered over the upper surface and more abundant towards the stem, bister, and sometimes concentrically zonate with narrow dark zones near the margin; hymenium a little darker than the upper surface, Prout's brown to Mars brown, abundantly and conspicuously setulose; in structure $200-500 \mu$ thick, composed of a setigerous layer up to $150 \mu$ thick and of a hyphal layer constituting the remainder and not bordered on either side by a dense, dark zone; setae 90-150×9-15 $\mu$, emerging up to $60 \mu$, tapering upward from the base, starting from all

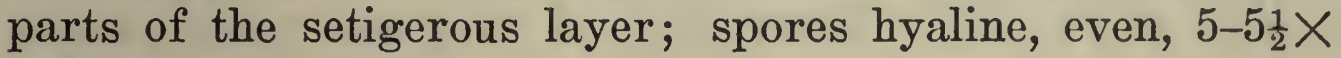
$4-4 \frac{1}{2} \mu$.

Fructifications $3-15 \mathrm{~cm}$. high, $1 \frac{1}{2}-3 \mathrm{~cm}$. broad; individual pilei 1-1 $\frac{1}{2} \mathrm{~cm}$. long, 1-3 cm. broad; stem 2-14 cm. long, 2-3 $\mathrm{mm}$. in diameter in dried specimens not cited under $H$. formosa on a following page.

On roots of trees and among leaves in thick woods. West Indies and Mexico to Brazil. Qctober to March.

$H$. damaecornis exhibits wide variation in the dimensions of its fructifications and in the number of pilei which are borne on the central stem; the short branches of the latter are somewhat flattened in radial planes with respect to the central stem if so many pilei are present that some are borne along the sides of the stem below the terminal cluster. Where only four pilei are present in a symmetrical terminal cluster, there is bifurcation of the main stem into two flattened branches, and of these again into the more broadly flattened bases of the individual pilei. There is often a curious twisting of the end of the branch and base of the pileus through an angle of 90 degrees to bring the plane of the pileus dorsiventral, if we may compare it with a leaf. In this connection, 
the lateral pilei of $H$. Schomburgkii in Hennings' figure in Engler \& Prantl's 'Nat. Pflanzenfam.' are perhaps conventional. In the collection made in Jamaica by Murrill and Harris, 1057, as cited below, there is one old fructification with pileus dark-colored and obscurely zonate which could be referred to $H$. formosa; this fructification is in a cluster of younger, azonate fructifications. The specimen upon which Fries based his Thelephora speciosa was evidently a fructification of $H$. damaecornis with upper surface of the pilei bearing more setae than the normal, for he gives its distinctive character as "undique velutino" and on the preceding page has described the stem of $H$. damaecornis as "velutinus," which we know to be by setae. The specimen collected by Peck in Providence, New York, which is cited in Sacc. 'Syll. Fung.' as the northern station of Hymenochaete speciosa, has no setae and should not have been referred to this species. I have omitted reference to Plumier, Filic. Am. pl. 168. figs. H, K, as illustrations of $H$. damaecornis, for it is incredible that the draftsman who executed pls. 1-167 of that work could have had before him a specimen of $H$. damaecornis when he made figs. $H$ and $K$ of pl. 168 .

Specimens examined, additional to those cited under $H$. formosa:

Cuba: C. Wright, 272 (Curtis Herb.); Sierra Nipe, Oriente, J. A. Shafer, 3326 (in N. Y. Bot. Gard. Herb., and in Mo. Bot. Gard. Herb., 55553).

Jamaica: Mabiss River, L. M. Underwood, 1399, comm. by N. Y. Bot. Gard. Herb.; Troy and Tyre, W. A. Murrill \& W. Harris, 1057 (in N. Y. Bot. Gard. Herb., Mo. Bot. Gard. Herb., 55552, and in Burt Herb.).

Honduras: M. E. Peck (in N. Y. Bot. Gard. Herb.).

* Stage H. formosa Léveillé, Ann. Sci. Nat. Bot. III. 5 : 151. 1846; Sacc. Syll. Fung. 6 : 589. 1888; Massee, Linn. Soc. Bot. Jour. 27 : 96. 1890._Compare Bresadola, Hedwigia 35 : 289. 1896.

Plate 16, fig. 2.

An Hymenochaete Schomburgkii Hennings in Sacc. Syll. Fung. 9 : 227. 1891; Engl. \& Prantl, Nat. Pflanzenfam. (I. $\left.1^{* *}\right): 121 . f .68$ F. 1898 ? 
Illustrations: Broteria $5: p l$. 2. f. 3 .

Fructifications with several to many pilei borne on very short branches of a common central stem at or near its apex; stem cylindric, velutinous with setae, hazel to Brussels-brown; pilei coriaceous, thin, expanded, drying strongly inrolled, even or sometimes rugose, silky and antique brown when young, finally glabrous except for setae which are scattered over the upper surface and more abundant towards the stem, bister, concentrically zonate, with narrow, dark zones near the margin; hymenium a little darker than the upper surface, Prout's brown to Mars brown, abundantly and conspicuously setulose; in structure $250-400 \mu$ thick, composed of a setigerous layer up to $150 \mu$ thick and of a hyphal layer constituting the remainder, and not bordered on either side by a denser dark zone; setae $90-150 \times 9-15 \mu$, emerging up to $40 \mu$, tapering upward from the base, starting from all parts of the setigerous layer; spores not found.

Fructifications $5-8 \mathrm{~cm}$. high, $2-3 \mathrm{~cm}$. broad; individual pilei up to $2 \mathrm{~cm}$. broad and $2 \mathrm{~cm}$. long in specimens seen; stem $3-5 \mathrm{~cm}$. long, $2-4 \mathrm{~mm}$. in diameter in dried specimens.

On the ground and buried wood. Guadaloupe and Honduras to Brazil. October.

I have seen only two collections which seem referable to $H$. formosa and the one of these from Honduras contains a young, bright-colored fructification which affords the details concerning the young stage given in the body of the above description and does away with the distinction as to zonation of pileus upon which Léveille founded $H$. formosa, the original description of which appears to have been based upon an old form of $H$. damaecornis at a period in mycological work when mere form differences were over-emphasized. I give $H$. formosa with full description in the hope that more ample collections may be accumulated which are not confined to a single stage of development.

Specimens examined:

Exsiccati: Rick, Fungi Austro-Am., 10.

British Honduras: M. E. Peck (in N. Y. Bot. Gard. Herb., and in Mo. Bot. Gard. Herb., 55551). 
Brazil: Sao Leopoldo, Rio Grande do Sul, J. Rick, in Rick, Fungi Austro-Am., 10.

2. H. reniformis (Fries) Léveillé, Ann. Sci. Nat. Bot. III. 5 : 151. 1846; Cooke, Grevillea 8 : 145. 1880; Sacc. Syll. Fung. 6 : 588. 1888; Massee, Linn. Soc. Bot. Jour. $27: 96 . p l$. 5. f. 1. 1890; Romell, K. Svenska Vet.-Akad. Bihang till Handl. Afd. III. 26 ${ }^{16}$ : 42. 1901.

Stereum reniforme Fries, Epicr. 546. 1838; R. Soc. Sci. Upsal. Actis III. 1 : 109. 1851; Léveillé, Ann. Sci. Nat. Bot. III. 2 : 210. 1844; Berkeley, Ann. \& Mag. Nat. Hist. 10 : 382. pl. 11. f. 11. 1842.

"S. reniforme, coriaceum, cinnamomeum, pileo dimidiato reniformi integerrimo zonato, stipite e basi torulosa decumbente adscendente, hymenio laevi velutino. In American calidiori. Eumorphum, subvelutinum. Pileus uncialis."

-Original description of Fries.

In typical specimens of this species a single reniform pileus is borne at the apex of the stem. Berkeley, loc. cit., referred to this species a specimen whose pileus is slightly bilobed, which he figured, and he noted that the whole fructification was sprinkled with short, bright, brown setae. Romell describes the spores as hyaline, obliquely ellipsoidal, $5-6 \times 4 \mu$.

$H$. reniformis has been collected several times in Brazil but not yet in the West Indies or Central America, so far as I know.

3. H. Cacao Berkeley, Linn. Soc. Bot. Jour. 10 : 333. 1868; Linn. Soc. Trans. II. 1 : 403. pl. 46. f. 1-3. 1879; Sacc. Syll. Fung. 6 : 592. 1888; Massee, Linn. Soc. Bot. Jour. 27 : 100. 1890.

Stereum Cacao Berkeley, Hooker's London Jour. Bot. 6 : 169. 1854.

Illustrations: Linn. Soc. Trans. II. $1: p l$. 46. f. 1-3; Engl. \& Prantl, Nat. Pflanzenfam. (I. $1^{* *}$ ) : 122. text f. 68 D, E.

Type: in Kew Herb. and a portion in Mo. Bot. Gard. Herb.

Fructifications sessile, flabelliform, connate, deeply lobed and plicate, upper surface velvety, concentrically sulcate, Brussels-brown; hymenium between fuscous and blackish 
brown (3); in structure $600 \mu$ thick, composed of a setigerous layer $90 \mu$ broad and of a hyphal layer $500 \mu$ broad, having densely arranged, colored hyphae $4 \frac{1}{2}$ $\mu$ in diameter, running longitudinally, curving on the one side into the hymenium and on the other into the surface of the pileus; setae ventricose at base, $18 \times 4 \frac{1}{2} 5 \mu$, densely crowded together in all parts of the broad setigerous layer; spores hyaline, even, $4 \times 3 \mu$.

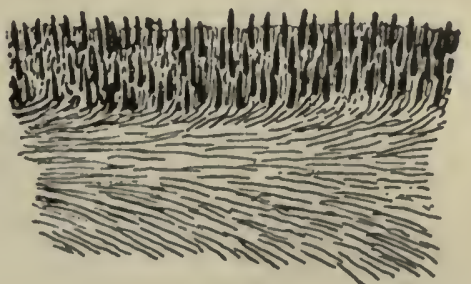

Fig. 1

H. Cacao.

Section $\times 68$. From type.

Fructifications $3 \frac{1}{2} \mathrm{~cm}$. broad, $3 \mathrm{~cm}$. long.

On dead wood. Jamaica, Cuba, and Venezuela. July. Rare.

By the kindness of Sir David Prain, I have been able to study a portion of the type of $H$. Cacao collected in the Khasia Mountains, India; it has the hymenium olive-drab now but is of the same form and structure as American specimens. The American specimens are a rich tobacco-brown with darker hymenium. This species is noteworthy by having the setae densely crowded together through a zone $90 \mu$ broad. The collection by Earle, 406, cited below, seems referable to $H$. Cacao on account of the color of the hymenium and structure in section but it is wholly resupinate.

Specimens examined:

India: Khasia Mts., Dr. Hooker, portion of type comm. by Sir David Prain (in Mo. Bot. Gard. Herb., 55559).

Jamaica: Cinchona, F. S. Earle, 406, comm. by N. Y. Bot. Gard. Herb., and W. J. Robinson (in N. Y. Bot. Gard. Herb., and in Mo. Bot. Gard. Herb., 55481).

Cuba: C. Wright, 526 (in Curtis Herb.).

Venezuela: Fendler (in Curtis Herb.).

4. H. aspera Berk. \& Curtis, Linn. Soc. Bot. Jour. 10 : 334. 1868; Sacc. Syll. Fung. 6 : 592. 1888; Massee, Linn. Soc. Bot. Jour. $27: 100.1890$.

An Hydnum resupinatum Swartz, Prodr. 149. 1788; Fl. Ind. Occ. $3: 1921$. 1806?-An Thelephora setosa Swartz in Berkeley, Ann. \& Mag. Nat. Hist. 10 : 381. pl. 11. f. 10. 1842? Not Hymenochaete setosa Berk. \& Curtis, Grevillea 1:165. 
1873; Sacc. Syll. Fung. 6:538. 1888.-Hydnochaete setosa (Swartz) Lloyd, Myc. Notes 41:559. text f. 766. 1916.

Illustrations: Berkeley, Ann. \& Mag. Nat. Hist. 10 : pl. 11. f. 10; Lloyd, Myc. Notes 41:559. text f. 766 .

Type: in Kew Herb. and Curtis Herb., and of Thelephora setosa in Brit. Mus. Herb.

Fructifications broadly reflexed and with a narrow, resupinate base, or dimidiate, sessile, imbricated, laterally confluent, very thin, drying pliable, with upper surface rough with coarse, strigose, matted

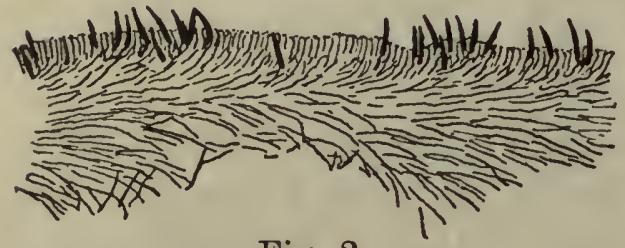

Fig. 2

H. aspera.

Section $\times 68$. See $p l .16, f . s$. fibers, very shallowly concentrically sulcate; hymenium granular, snuff-brown; in structure $150-400 \mu$ thick, with a narrow setigerous layer consisting of the hymenium, and with the hyphal layer composed of longitudinally arranged, colored hyphae $2 \mu$ in diameter which curve outward and become interwoven to form the upper surface of the pileus-no dense, dark zones present; setae scattered, $60-75 \times 6 \mu$, tapering from the base, emerging up to 30 $\mu$, some starting from the subhymenium but mostly from the hymenium; spores hyaline, even, $3 \times 2 \mu$ as seen on basidia.

Pilei of fructifications $1-2 \frac{1}{2} \mathrm{~cm}$. long, 1-5 cm. broad, sometimes resupinate on areas up to $5 \times 3 \mathrm{~cm}$.

On dead frondose wood on the ground in forests. Cuba, Jamaica, and Venezuela. October to March.

H. aspera may be recognized by its thin, pliant pileus, which is rough on the upper surface with strigose matted fibers, by granular hymenium which is as granular as in Thelephora terrestris, and by the short, brighter-colored mycelial strands which form the resupinate margin.

Specimens examined:

Cuba: C. Wright, 211, type (in Curtis Herb.); Alto Cedro, F. S. Earle, 340, Earle \& Murrill, 488, and Underwood \& Earle, 1513, all from N. Y. Bot. Gard. Herb.; Ciego de Avila, Puerto Principe, Earle \& Murrill, 605, comm. by N. Y. Bot. Gard. Herb. 
5. H. Berkeleyana (Montagne) Cooke, Grevillea $8: 147$. 1880; Sacc. Syll. Fung. 6 : 596. 1888.

Stereum Berkeleyanum Montagne, Ann. Sci. Nat. Bot. IV. 1:140. 1854; Syll. Crypt. 178. 1856.

Type: authentic specimen in Kew Herb.-probably portion of type.

Fructifications effuso-reflexed, cespitose-imbricated, often dimidiate, radiately rugose, sericeous, with the hairs radially decumbent, bay, becoming somewhat zonate with interrupted blackish zones, radially plicate, the margin lobed, sometimes proliferous, yellow ocher; hymenium not rimose, antique brown; in structure 500-600 $\mu$ thick, with the hyphal layer not bordered on either side by a dark, dense zone, and composed of closely and longitudinally arranged, colored, very

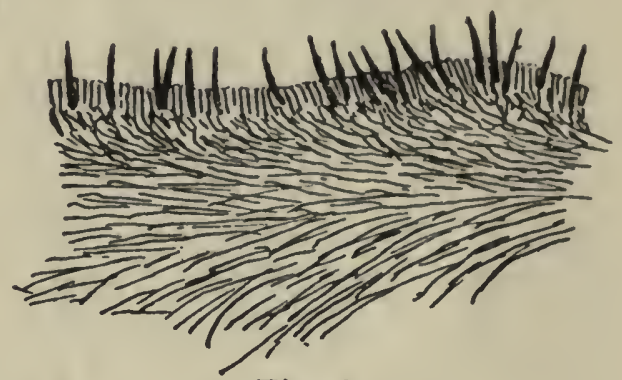

Fig. 3

H. Berkeleyana.

Section $\times 44$. See $p l .16, f .5$. thick-walled hyphae $3 \frac{1}{2}-4 \mu$ in diameter and up to $5 \mu$ on the upper surface of the pileus; setae scattered, not crowded, 90-120 $\times 12-15 \mu$, emerging 60-75 $\mu$, tapering from the base upward to a slender point; spores hyaline, even, $6 \times 3 \frac{1}{2} \mu$.

Fructifications with reflexed part $1 \mathrm{~cm}$. broad, $1 \mathrm{~cm}$. long, laterally confluent into clusters up to $3 \mathrm{~cm}$. broad.

On bark and rotten wood. Jamaica and Guiana. December and January. Rare.

The general aspect of $H$. Berkeleyana is suggestive of that of $H$. badio-ferruginea but the former has its pilei more crowded together than the latter and radially plicate. The absence of any dark zones bordering the intermediate layer of $H$. Berkeleyana sharply separates this species from the $H$. tabacina group when sections are examined, and places the species in the group with $H$. attenuata and $H$. Sallei, from both of which it is distinct by its plicate, more crowded pilei, covering of the pilei, and larger setae. I had not received the collections from Jamaica, cited below, when I studied the authentic specimen from Montagne at Kew, but these later 
collections agree so well with the original description and my preparation of $H$. Berkeleyana that I regard them as certainly the same species.

Specimens examined:

Jamaica: Chester Vale, W. A. \& Edna L. Murrill, 371, comm. by N. Y. Bot. Gard. Herb.; Cinchona, W. A. \& Edna L. Murrill, 445, comm. by N. Y. Bot. Gard. Herb.

Guiana: Cayenne, from Montagne (in Kew Herb.).

6. H. Sallei Berk. \& Curtis, Linn. Soc. Bot. Jour. 10 : 333. 1868; Cooke, Grevillea 8 :146. 1880; Sacc. Syll. Fung. 6 : 593. 1888; Massee, Linn. Soc. Bot. Jour. 27 : 101. 1890.

Stereum elegantissimum Speggazini, Soc. Cientif. Argentina Anal. 16 : 38. 1883. - Hymenochaete elegantissima (Speg.) Sacc. Syll. Fung. 6 : 594. 1888; Massee, Linn. Soc. Bot. Jour. 27 : 99. 1890.-Stereum tenuissimum Fries, R. Soc. Sci. Upsal. Actis III. 1:111. 1851, but not of Berkeley, Hooker's London Jour. Bot. 6 : 510. 1847.-Hymenochaete tenuissima Berkeley, Linn. Soc. Bot. Jour. 10 : 333. 1868, but not Stereum tenuissimum Berkeley, Hooker's London Jour. Bot. 6 : 510. 1847.

Illustrations: Broteria 5 : pl.2.f. 4. 1906.

Type: in Kew Herb. and Curtis Herb.

Fructifications very thin, papery, flexible when dry, umbonate-sessile and laterally confluent, or reflexed and imbricated,

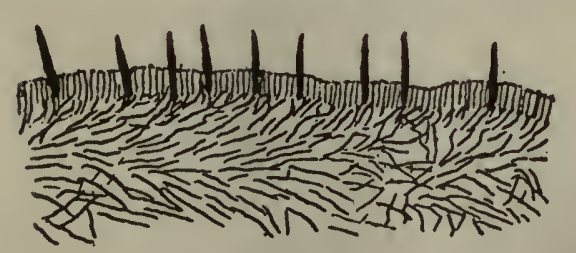

Fig. 4

H. Sallei.

Section $\times 68$. From type. See $p l .17, f .15$.

at first fibrous on the upper surface, antique brown, soon silkyfibrous, with the fibers radially arranged, Argus-brown to auburn, concentrically sulcate, and at length somewhat zonate and shining, the margin lobed; hymenium Argus-brown; in structure 200$400 \mu$ thick, with the hyphal layer simple, not bordered by a dark zone, composed of somewhat loosely interwoven and longitudinally arranged, thick-walled, colored hyphae $3 \frac{1}{2}-4 \frac{1}{2} \mu$ in diameter; setae $65-90 \times 9-10 \frac{1}{2} \mu$, emerging up to $60 \mu$, starting from the subhymenium which is not ap- 
preciably darker than adjacent tissue; spores hyaline, even, $3-4 \times 1 \frac{1}{2}-2 \frac{1}{2} \mu$.

Fructifications $1 \frac{1}{2}-3 \mathrm{~cm}$. in diameter and laterally confluent, or with reflexed part $1-2 \frac{1}{2} \mathrm{~cm}$. long, up to $4 \mathrm{~cm}$.., and more, broad by lateral confluence.

On dead twigs, prostrate limbs, and at base of trees of frondose species. South Carolina, West Indies, Mexico, and South America to Paraguay and Chile. September to May. Common.

Fully developed specimens of $H$. Sallei may be recognized by their thin, papery pileus which may be folded without breaking, which is a rich Argus-brown both on the upper side and hymenium, and concentrically sulcate, somewhat zonate, and shining on the upper side also. Collections of young specimens of this species when first found were referred by early authors to $H$. tenuissima, a Ceylon species, of which good material is now available for comparison in the collection from Ceylon distributed in Sydow, Fungi Exotici Exs., 318, and in Elmer, Philippine Island Plants, 9850, both of which I have compared with a portion of the type communicated by Sir David Prain through the kindness of Miss Wakefield. The true $H$. tenuissima has its upper surface clothed with coarse pubescence, as stated in the original description, and the fibers of this pubescence do not finally become decumbent, radiately arranged, and the surface shining; the hymenium of $H$. tenuissima is somewhat radiately rugose and between Isabella-color and Dresden-brown - not antique brown.

Specimens examined:

Exsiccati: Balansa, Pl. du Paraguay, 3916, under the name Hymenochaete elegantissima; Ravenel, Fungi Am., 718, under the name Hymenochaete badio-ferruginea; Rick, Fungi Austro-Am., 31, under the name Hymenochaete tenuissima; Smith, Central Am. Fungi, 149, under the name Hymenochaete tabacina.

South Carolina: Seaboard, H. W. Ravenel, in Ravenel, Fungi Am., 718.

Florida: C. G. Lloyd, 2071. 
Cuba: C. Wright, 278, type (in Kew Herb. and in Curtis Herb.), and 531, under the name H. tenuissima (in Kew Herb.), and 275, under the name $H$. tenuissima (in Curtis Herb.); Alto Cedro, F. S. Earle, 339, and Earle \& Murrill, 514, Underwood \& Earle, 1512, 1569, 5182, all comm. by N. Y. Bot. Gard. Herb. ; Artemisa, O. Ames \& R. G. Leavitt, comm. by W. G. Farlow; El Yunque, Mt. Baracoa, Underwood \& Earle, 765, 1235, comm. by N. Y. Bot. Gard. Herb.; La Gloria, Camagüey, J. A. Shafer, 741 (in N. Y. Bot. Gard. Herb., and in Mo. Bot. Gard. Herb., 55509); Omaja, C. J. Humphrey, 2750 (in Mo. Bot. Gard. Herb., 8639); Sierra Nipe, J. A. Shafer, 3375 (in N. Y. Bot. Gard. Herb., and in Mo. Bot. Gard. Herb., 55510); Tacajo, Nipe Bay, F. S. Earle, $B$.

Porto Rico: Espinosa, J. A. Stevenson, 6373 (in Mo. Bot. Gard. Herb., 55081).

Jamaica: Castleton Gardens, F. S. Earle, 246, comm. by N. Y. Bot. Gard. Herb.; Cinchona, W. A. \& Edna L. Murrill, 445, comm. by N. Y. Bot. Gard. Herb.; Mandeville, A. E. Wight, comm. by W. G. Farlow; Mansfield, near Bath, Wm. $R$. Maxon, comm. by W. G. Farlow, and L. M. Underwood, 2780, comm. by N. Y. Bot. Gard. Herb.; Moore Town, W. A. \& Edna L. Murrill, 162, 1113, comm. by N. Y. Bot. Gard. Herb.; Troy and Tyre, L. M. Underwood, 2970, comm. by N. Y. Bot. Gard. Herb., and W. A. Murrill \& W. Harris, 858, 924, 1010, comm. by N. Y. Bot. Gard. Herb.

St. Kitts: Molyneaux Estate, N.L. Britton \& J. F. Cowell, 338, comm. by N. Y. Bot. Gard. Herb.

Grenada: Grand Etang, R. Thaxter, comm. by W. G. Farlow, 1.

Mexico: Cordoba, Salle (in Kew Herb.); Xuchiles, Cordoba, W. A. \& Edna L. Murrill, 1215 (in N. Y. Bot. Gard. Herb., and in Mo. Bot. Gard. Herb., 54606); Jalapa, W. A.\& Edna L. Murrill, 190 (in N. Y. Bot. Gard. Herb., and in Mo. Bot. Gard. Herb., 54447), and C. L. Smith, in Smith, Central Am. Fungi, 149; Orizaba, W. A. \& Edna L. Murrill, 751, 794 (in N. Y. Bot. Gard. Herb., and in Mo. Bot. Gard. Herb., 54630, 54642). 
Brazil: Rio Grande do Sul, J. Rick, in Rick, Fungi AustroAm., 31.

Paraguay: in Balansa, $\mathrm{Pl}$. du Paraguay, 3916 (in Kew Herb.). Chile: Central Chile, R. P. Nataniel Costes (in N. Y. Bot. Gard. Herb., and in Mo. Bot. Gard. Herb., 44782).

7. H. borealis Burt, n. sp.

Type: in Burt Herb.

Fructifications thin, pliant, imbricated, reflexed, attenuated towards the base, or umbonate-sessile and attached along one side, radiately fibrillose, concentrically ridged, Brusselsbrown to cinnamon-brown; hymenium even, not cracked, snuff-brown; in structure 240-340 $\mu$ thick, with the setigerous layer $60 \mu$ thick, and with the hyphal layer not bordered on either side by a dense, dark zone, and having its hyphae rather loosely interwoven and longitudinally arranged, colored, $2 \frac{1}{2} \mu$ in diameter; setae scat-

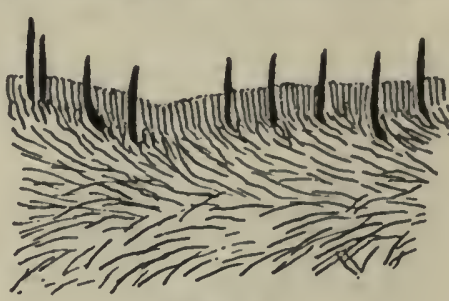

Fig. 5

H. borealis.

Section $\times 68$. From type. See $p l .16, f .6$. tered, $60-90 \times 7 \frac{1}{2}-10 \mu$, emerging up to $60 \mu$, starting from all parts of the setigerous layer; spores hyaline, even, $4-6 \times 2-3 \mu$.

Fructifications 8-12 mm. in diameter, reflexed portion up to $4 \mathrm{~mm}$. long.

On decorticated frondose wood. Ontario to New Jersey. October to April. Rare.

$H$. borealis is distinguished by having a simpler structure in section than any other of the pileate species which occur in the north. The absence of dark, dense zones bordering on an intermediate layer separates it at once from $H$. badioferruginea. $H$. attenuata of the East Indies is a closely related species but the latter has its pileus strigose-hirsute.

Specimens examined:

Ontario: London, J. Dearness, 1017 (in N. Y. Bot. Gard. Herb., and in Mo. Bot. Gard. Herb., 55513).

Vermont: Abby Pond, Ripton, E. A. Burt, type.

New Jersey: Newfield, J. B. Ellis (in N. Y. Bot. Gard. Herb., and in Mo. Bot. Gard. Herb., 55503). 
8. H. rigidula Berk. \& Curtis, Linn. Soc. Bot. Jour. 10 : 334. 1868; Cooke, Grevillea $8: 146$. 1880; Sacc. Syll. Fung. 6 : 593. 1888; Massee, Linn. Soc. Bot. Jour. 27 : 99. 1890.

An $H$. fulvella Berk. \& Curtis in Cooke, Grevillea $8: 148$. 1880; Sacc. Syll. Fung. 6 : 598. 1888; Massee, Linn. Soc. Bot. Jour. 27 : 104. 1890?-An H. pulcherrima Massee, Linn. Soc. Bot. Jour. 27 : 104. pl. 5. f. 4. 1890 ; Sacc. Syll. Fung. 9 : 229. 1891? - An H. scruposa Massee in Cooke, Grevillea $20: 11$. 1891; Sacc. Syll. Fung. 11 : 123. 1895?

Type: in Kew Herb. and Curtis Herb.

Fructifications resupinate, effused, becoming narrowly reflexed, lobed, coriaceous, rather rigid, with the upper surface of the reflexed part velvety, snuff-brown at first, later Benzo-

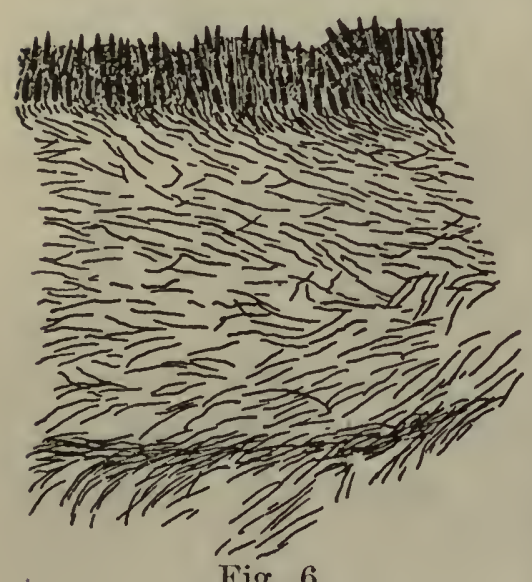

Fig. 6

H. rigidula. brown; hymenium Benzo-brown, ochraceous-tawny near the margin; in structure $300-500 \mu$ thick, with the setigerous layer $30-45 \mu$ broad and with the intermediate layer comprising most of the thickness of the fructification and bordered on each side by a narrow, dense, dark zone, of which that on the setigerous side is the less distinct; hyphae of intermediate layer $3-4 \mu$ in diameter, colored, somewhat interwoven and longitudinally arranged; setae conical, $30-45 \times 6-8 \mu$, larger ones sometimes found, emerging up to $30 \mu$, very numerous, starting from all portions of the setigerous layer; spores probably hyaline, even, $4 \times 1 \frac{1}{2}-2 \mu$.

Fructifications with reflexed portion $\frac{1}{2}-1 \mathrm{~cm}$. long, resupinate over areas $4 \times 1-1 \frac{1}{2} \mathrm{~cm}$.

On dead wood and bark of frondose species. Cuba and Venezuela. March. Rare.

On account of the dark zones bordering its intermediate layer, $H$. rigidula belongs in the small group, of which $H$. tabacina and $H$. rubiginosa are more common examples; it is distinguishable from all these species by the great number and crowded arrangement of its setae in the setigerous layer, 
a feature which it shares with $H$. Cacao. $H$. rigidula differs from $H$. Cacao by having its intermediate layer bordered by a prominent dark zone on its outer side, by being effusoreflexed, and with less black in the color of its hymenium. In dried condition it is more rigid than $H$. tabacina and the other species of its group with the exception of $H$. rubiginosa, from all forms of which it may be distinguished at sight by less conspicuous setae when viewed with a hand lens and by the much thinner, setigerous layer when sections are examined. So few spores of $H$. rigidula have been seen in the preparations that the spore dimensions given are very doubtful. My belief in the specific identity of $H$. fulvella is based upon the similarity of sectional preparations; since noting this similarity of structure, I have not had an opportunity to confirm my opinion by placing the original specimens side by side and comparing them with regard to general aspect. I did not find $H$. pulcherrima when I was at Kew, and in reply to my letter to Miss Wakefield concerning the original Fendler number for this type, Sir David Prain has written, "With regard to $H$. pulcherrima Mass., the specimen indicated by Massee as No. 3721a was removed by him from a gathering of $H$. fulvella B., the label of which, in Berkeley's handwriting, is 'Stereum fulvellum B. \& C. 173, Venezuela.' Massee named it on the sheet ' $H$. scruposa,' but evidently he changed the name before publishing it."-It seems probable that in the year following the publication of $H$. pulcherrima, Cooke saw the specimen upon which it was based, still labelled with only the herbarium name $H$. scruposa Massee and published the latter. I have studied the specimen in Curtis Herbarium labelled "Stereum fulvellum B. \& C., Fendler, 173. Venezuela" and found it to have the characteristic structure of $H$. rigidula and $H$. fulvella and to agree well with the published descriptions of $H$. fulvella, H. pulcherrima, and H. scruposa.

Specimens examined:

Cuba: C. Wright, 529, type (in Kew Herb. and in Curtis Herb.) ; Herradura, Earle \& Murrill, 170, comm. by N. Y. Bot. Gard. Herb. ; San Diego de los Baños, Earle \& Murrill, 219, comm. by N. Y. Bot. Gard. Herb. 
Grenada: Grand Etang, $R$. Thaxter, comm. by W. G. Farlow. Venezuela: Fendler, 175, type of Hymenochaete fulvella (in Kew Herb.), and 173 (in Curtis Herb., under the name Stereum fulvellum).

9. H. Curtisii (Berk.) Morgan, Cincinnati Soc. Nat. Hist. Jour. $10: 197.1888$.

Stereum Curtisii Berkeley, Grevillea 1:164. 1873; Sacc. Syll. Fung. 6 : 581. 1888; Massee, Linn. Soc. Bot. Jour. 27 : 195. 1890.

Type: type distribution in Ravenel, Fungi Car. $3: 26$.

Fructifications at first orbicular, then effused, confluent, becoming reflexed, coriaceous, thin, separable, drying pliant, the upper surface at first silky, fibrillose, somewhat concentrically

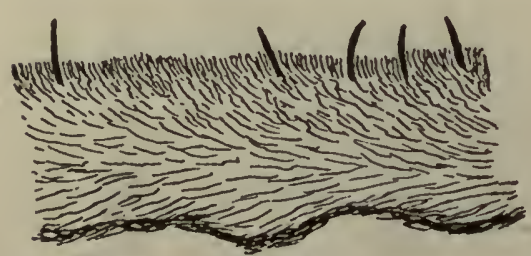

Fig. 7 ridged, antique brown, becoming glabrous and hair-brown when old; hymenium not cracking, velvety, antique brown; in structure 140 $240 \mu$ thick, with intermediate layer bordered by a narrow, dense, dark H. Curtisii.

Section $\times 68$. From type. See $p l .17, f .9$. zone towards the upper surface of the pileus or the substratum, the hyphae densely and longitudinally arranged, colored, thin-walled, $2 \frac{1}{2} \mu$ in diameter; setae few and far apart usually, 60-70×6-8 $\mu$, emerging up to $45 \mu$, tapering upward to a sharp point; spores hyaline, allantoid, $6-7 \times 1 \frac{1}{2}-2 \mu$.

Fructifications confluent along under side of limbs for 2-20 cm. or more, $1 \frac{1}{2}-2 \frac{1}{2} \mathrm{~cm}$. broad; reflexed lobes $5 \mathrm{~mm}$. long, 10-15 mm. broad.

On rotting limbs of Quercus and other frondose species. Massachusetts to Texas and westward to Oregon-in low altitudes. April to December. Common.

H. Curtisii may be recognized by its rich antique brown color, thin, pliant, reflexed portions, velvety hymenium which is not at all cracked, and by the notable scarcity of setae which cannot be found in the hymenium with a pocket lens and are sometimes lacking in thin sections in microscopic prepara- 
tions. The geographical range of $H$. Curtisii overlaps on the north the southern range of $H$. tabacina, and it is itself displaced in the West Indies, Mexico, and further south by H. Sallei.

Specimens examined:

Exsiccati: Bartholomew, Fungi Col., 2381, 2882, 4290, 4635; Ellis, N. Am. Fungi, 16; Ell. \& Ev., Fungi Col., 103; Rabenhorst-Winter, Fungi Eur., 3525, under the name Stereum tabacinum, with note; Ravenel, Fungi Am., 222, 446; Fungi Car. 3 : 26; de Thümen, Myc. Univ., 113.

Massachusetts: Cambridge, L. M. Underwood, 1080 (in N. Y. Bot. Gard. Herb., and in Mo. Bot. Gard. Herb., 55542); East Sudbury, A. B. Seymour, $T 18$ (in Seymour Herb., and in Mo. Bot. Gard. Herb., 18349).

Connecticut: Central Valley, J. L. Sheldon, 5, comm. by N. Y. Bot. Gard. Herb.

New York: Grand View, H. von Schrenk (in Mo. Bot. Gard. Herb., 43024); New York Botanical Garden, Bronx Park, Class in Mycology (in N. Y. Bot. Gard. Herb., and in Mo. Bot. Gard. Herb., 55533) ; Staten Island, S. C. Edwards, in Lloyd Herb., 06902; White Plains, W. H. Ballou (in Mo. Bot. Gard. Herb., 55032).

New Jersey: from Laning Herb. (in Mo. Bot. Gard. Herb., 5182); Forked River, W. H. Ballou, 2; Lakefield, E. A. Daniels, comm. by H. Webster; Newfield, J. B. Ellis, comm. by Lloyd Herb., also (in Mo. Bot. Gard. Herb., 55534), and in Ellis, N. Am. Fungi, 16, in Ell. \& Ev., Fungi Col., 103, and in de Thümen, Myc. Univ., 113.

Pennsylvania: from Michener Herb., two specimens (in Mo. Bot. Gard. Herb., 55528, 55529) ; Bethlehem, Schweinitz (in Herb. Schweinitz, under the name Thelephora leprosa of Syn. N. Am. Fungi, No. 636); Ohio Pyle, W. A. Murrill, 1067 (in N. Y. Bot. Gard. Herb.).

Maryland: Hyattsville, F. L. Scribner, 83, comm. by U. S. Dept. Agr. Herb.; Takoma Park, C. L. Shear, 1074. District of Columbia: W. A. Murrill, 1464 (in N. Y. Bot. Gard. Herb., and in Mo. Bot. Gard. Herb., 55535); Takoma Park, P. L. Ricker, 819 . 
Virginia: W. A. Murrill (in N. Y. Bot. Gard. Herb.) ; Arlington, W. H. Long, 12690 (in Mo. Bot. Gard. Herb., 44164); Mt. Vernon, P. L. Ricker, 1122; Woodstock, C. L. Shear, 1190.

North Carolina: H.W. Ravenel (in Curtis Herb., 1646).

South Carolina: H. W. Ravenel, type distribution, in Ravenel, Fungi Car. 3 : 26; Aiken, H. W. Ravenel, in Ravenel, Fungi Am., 446; Clemson College, P. H. Rolfs, 1822, 1823, and $H$. D. House, in Bartholomew, Fungi Col., 2381.

Georgia: Darien, H. W. Ravenel, in Ravenel, Fungi Am., 222. Florida: C. G. Lloyd, 2116 (in Lloyd Herb.); West Palm Beach, $R$. Thaxter, 83 (in Mo. Bot. Gard. Herb., 43900).

Alabama: Auburn, F.S. Earle, 123, and an unnumbered specimen (in Mo. Bot. Gard. Herb., 55537, 55538); New Albany, A. B. Seymour, 2930 (in N. Y. Bot. Gard. Herb.).

Mississippi: Jackson, E. Bartholomew, 5791 (in Mo. Bot. Gard. Herb., 44123), and in Bartholomew, Fungi Col., 4635; Ocean Springs, F. S. Earle, 182 (in Mo. Bot. Gard. Herb., 5176), and an unnumbered specimen, comm. by U. S. Dept. Agr. Herb.

Louisiana: Acadia Parish, A. B. Langlois; Alden Bridge, W. Trelease (in Mo. Bot. Gard. Herb., 5169); St. Martinville, A. B. Langlois, comm. by Lloyd Herb., 2423.

Texas: Gonzales, C. L. Shear, 1230; Houston, H.W. Ravenel, $36,38,134,160$, comm. by U. S. Dept. Agr. Herb.

Ohio: Oberlin, F. D. Kelsey, 821 (in N. Y. Bot. Gard. Herb.). Kentucky: Crittenden, C. G. Lloyd, 3126; Mammoth Cave, C. G. Lloyd, 1189.

Tennessee: Elkmont, C. H. Kauffman, 76 (in Mo. Bot. Gard. Herb., 44997).

Wisconsin: Blue Mounds, Miss A. O. Stucki, 29, Univ. of Wisconsin Herb. ; Madison, W. Trelease, r7, 79 (in Mo. Bot. Gard. Herb., 5169, 5170, and in Seymour Herb.), and Miss A. O. Stucki, 63, Univ. of Wisconsin Herb.

Minnesota: Princeton, C. J. Humphrey, 990 (in Mo. Bot. Gard. Herb., 10274).

Missouri: Bismarck, L. O. Overholts (in Mo. Bot. Gard. Herb., 55539); Columbia, B. M. Duggar, 88; Perryville, C. 
H. Demetrio, in Rabenhorst-Winter, Fungi Eur., 3525; Jefferson Barracks, St. Louis, E. A. Burt, and L. O. Overholts (in Mo. Bot. Gard. Herb., 43774 and 44049 respectively).

Arkansas: Batesville, E. Bartholomew, in Bartholomew, Fungi Col., 2882; Cass, W. H. Long, 19804 (in N. Y. Bot. Gard. Herb., and in Mo. Bot. Gard. Herb., 9141).

Oklahoma: Spiro, E. Bartholomew, in Bartholomew, Fungi Col., 4290.

Nebraska: Long Pine, V. B. Walker, 9 (in Mo. Bot. Gard. Herb., 13932).

Oregon: Portland, J.R. Weir, 544 (in Lloyd Herb., 0311, and in Mo. Bot. Gard. Herb., 19624).

10. H. luteo-badia (Fries) v. Höhn. \& Litsch. K. Akad. Wiss. Wien Sitzungsber. 116 : 754. 1907.

Thelephora luteo-badia Fries, Linnaea $5: 526.1830$-Stereum luteo-badium Fries, Epicr. 547. 1838; Sacc. Syll. Fung. 6 : 571. 1888; Lloyd, Letter $46: 6$. 1913.-Thelephora Kunzei Hooker, Bot. Misc. 2 : 163. pl. 85. 1831.-Hymenochaete Kunzei (Hooker) Massee, Linn. Soc. Bot. Jour. 27 : 100. 1890 ; Sacc. Syll. Fung. 11 : 122. 1895.-Stereum laetum Berkeley, Acad. Nat. Sci. Phila. Jour. $2: 279$. 1853.-Hymenochaete laeta Berkeley in Cooke, Grevillea $8: 146.1880$; Sacc. Syll. Fung. 6 : 591. 1888; Massee, Linn. Soc. Bot. Jour. 27 : 99. 1890.Stereum pulchrum (Schweinitz) Cooke in Sacc. Syll. Fung. $6: 561.1888$.

Illustrations: Hooker, Bot. Misc. $2: p l .85$.

Type: type distribution in Weigelt Exs., under the name Thelephora badia Hook.? - a specimen in Mo. Bot. Gard. Herb., 5205.

Fructifications dimidiate and imbricated or effuso-reflexed, lobed,

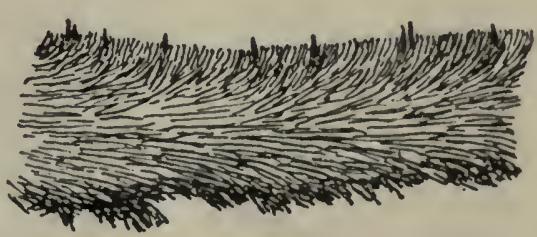

Fig. 8

H. luteo-badia. Section $\times 68$. From type. See $p l .1 \%, f .11$. very thin, coriaceous, pliant when dry, velvety when young, becoming somewhat glabrous and minutely fibrillose when older, concentrically sulcate, and sometimes zonate or radiately rugose, drying Argus-brown; hymenium even, dry- 
ing buckthorn-brown; in structure 200-300 $\mu$ thick, with a broad, compact intermediate layer of longitudinally arranged, colored hyphae $2-2 \frac{1}{2} \mu$ in diameter, which is connected with the velvety covering of the upper surface of the pileus by a narrow, dark zone; setae very few, tapering from the base, 30×5-6 $\mu$, emerging 10-20 $\mu$ above the hymenium; spores hyaline, even, $4-4 \frac{1}{2} \times 2 \frac{1}{2} \mu$.

Fructifications $1 \frac{1}{2}-2 \frac{1}{2} \mathrm{~cm}$. long, $2-4 \mathrm{~cm}$. broad; resupinate portion of reflexed specimens may be up to $3 \times 2 \mathrm{~cm}$. in specimens seen so far.

On rotting trunks of frondose species. Porto Rico to Venezuela and Guiana. May. Probably common.

H. luteo-badia is a beautiful tropical species which is well characterized by its name, for the contrast in color between the buckthorn-brown or tawny olive hymenium and the Argusbrown (chestnut color) upper surface of the pileus is a constant and distinguishing character; setae are as few and far apart in the hymenium as they are in $H$. Curtisii; the absence of a dark subhymenial zone bordering the hyphal layer is an additional character which separates $H$. luteo-badia from many other species of Hymenochaete.

Specimens examined:

Porto Rico: Ponce, F. S. Earle, 114, 159, comm. by N. Y. Bot. Gard. Herb.

Trinidad: Sangre Grande, R. Thaxter, comm. by W. G. Farlow, 29.

Venezuela: Fendler 174 (in Curtis Herb.); Margarita, A. F. Blakeslee, two collections, comm. by W. G. Farlow.

British Guiana: Sir R. Schomburgh, comm. by G. Bresadola; also specimen under name Thelephora laeta, ex. Hooker Herb. (in Herb. Berkeley in Kew Herb.).

Dutch Guiana: Surinam, Weigelt, distributed under the name Thelephora badia Hook. ?, the type distribution of both Thelephora luteo-badia and Thelephora Kunzei (in Mo. Bot. Gard. Herb., 5250); specimen from Herb. Schweinitz under the herbarium name Thelephora pulchra, type of both Stereum laetum and Stereum pulchrum (in Curtis Herb.). 
11. H. tabacina Sowerby ex Léveillé, Ann. Sci. Nat. Bot. III. 5 : 152. 1846; Cooke, Grevillea 8 : 145. 1880; Sacc. Syll. Fung. 6 : 590. 1888; Massee, Linn. Soc. Bot. Jour. 27 : 112. 1890.

Helvella nicotiana Bolton, Hist. Funguses, 174. pl. 174. 1789. - Auricularia tabacina Sowerby, British Fungi, pl. 25. 1797.Thelephora tabacina (Sow.) Fries, Syst. Myc. 1:437. 1821; Elenchus Fung. 1:173. 1828.-Stereum tabacinum (Sow.) Fries, Epicr. 550. 1838; Hym. Eur. 641. 1874.-Thelephora avellana Fries, Syst. Myc. 1:442. 1821 (in part); Elenchus Fung. 1:188. 1828 (in part).-Stereum avellanum Fries, Epicr. 551. 1838 (in part); Hym. Eur. 642.1874 (in part). -Hymenochaete avellana (Fr.) Cooke, Grevillea 8 : 146. 1880; Sacc. Syll. Fung. 6 : 592. 1888; Massee, Linn. Soc. Bot. Jour. 27 : 103. 1890.-Thelephora imbricatula Schweinitz, Am. Phil. Soc. Trans. N. S. 4:166. 1832.-Hymenochaete imbricatula (Schw.) Léveillé, Ann. Sci. Nat. Bot. III. 5 : 152. 1846; Cooke, Grevillea 8 : 146. 1880; Massee, Linn. Soc. Bot. Jour. 27 : 103. 1890.-H. imbricata Sacc. Syll. Fung. 6 : 593. 1888.

Illustrations: Bolton, Hist. Funguses, pl. 174; Sowerby, British Fungi, $p l$. 25-type illustration.

Fructifications coriaceous, effuso-reflexed, often imbricated, sometimes wholly resupinate, thin, sericeous, antique brown, at length becoming glabrous and deep brownish drab, the margin and intermediate layer orange-yellow; hym eniu m snuffbrown to sepia, often deeply cracked where resupinate, with a series of radial anastomosing cracks for each centimeter of area; in structure $340-600$ $\mu$ thick, with the setigerous

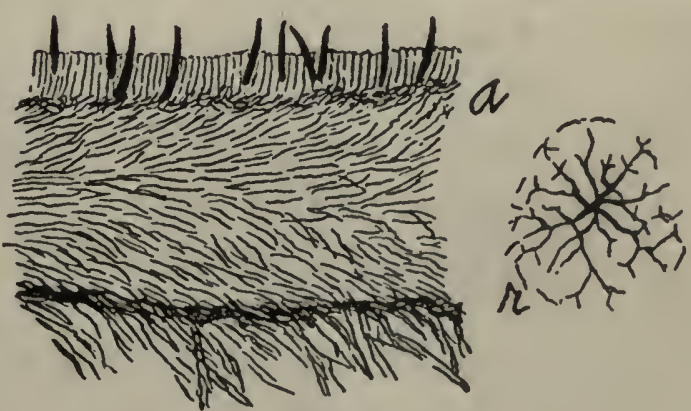

Fig. 9

H. tabacina.

Section, $a, \times 68$; system of radiating cracks in hymenium, $r, \times 4 \frac{1}{2}$. See $p l$. $1 \%$, f. 16 .

layer $100 \mu$ thick, and with the intermediate layer bordered on each side by a narrow, dark, dense zone; hyphae $2 \frac{1}{2}-3 \mu$ in diameter, orange-yellow, longitudinally arranged in the intermediate layer; setae 60-90×6-12 $\mu$, emerging up 
to $50 \mu$, originating from all parts of the setigerous layer although chiefly from the dark, subhymenial zone; spores hyaline, even, curved, 5-6 $\times 1 \frac{1}{2}-2 \mu$, as seen in preparation of sections.

Reflexed portion 3-7 mm. long, 10-15 mm. broad, often laterally confluent; resupinate portions up to $3 \times 30 \mathrm{~cm}$. and more.

On dead limbs, usually of frondose species. Canada to Mexico, Maine to the Pacific coast, Alaska to California. Common in the north, rare further south. Throughout the year.

H. tabacina is the commonest species of its genus in the northern United States and may be recognized by its reflexed fructifications tobacco-colored with bright golden yellow margin and intermediate layer, and by having the hymenium deeply cracked in resupinate portions into radiating systems, one system for about each centimeter of area. The specimen under the name Stereum avellanum from Fries in Kew Herb. is the old glabrous, somewhat reddish stage of $H$. tabacina; this specimen has led to the transfer of Stereum avellanum to Hymenochaete by British authors and Saccardo. An older specimen of Thelephora avellana in Herb. Fries collected by E. Fries at Femsjö is not distinct from Stereum glaucescens but is unfortunately on coniferous wood, while $T$. avellana was published as occurring on Corylus, a frequent substratum in Europe for H. tabacina. The type of Thelephora imbricatula in Herb. Schweinitz is a mixture of Hymenochaete tabacina, mounted on the right of the card, and of $H$. corrugata, mounted at the left. Both these species are present in the sample of T. imbricatula in Curtis Herb. but their order has been reversed in mounting. The portion of the original description pertaining to characters of reflexed portions of the fructifications is obviously based upon the $H$. tabacina portion of the type. Since Léveille's transfer of $T$. imbricatula to Hymenochaete was probably based upon an authentic specimen from Schweinitz in Museum of Paris Herb., in 1846, this specimen will probably show whether any of $H$. corrugata 
was mixed in the type of $H$. imbricatula as distributed by Schweinitz.

Specimens examined:

Exsiccati: Bartholomew, Fungi Col., 3134; Berkeley, Brit. Fungi, 248; Ellis, N. Am. Fungi, 13; Ell. \& Ev., Fungi Col., 102; Krieger, Fungi Sax., 270; Libert, Pl. Crypt. Arduennae, 121; Oudemans, Fungi Neerlandici Exs., 240; Shear, N. Y. Fungi, 314; de Thümen, Myc. Univ., 211, 211 b. Finland: Mustiala, P.A. Karsten, in de Thümen, Myc. Univ., 211.

Sweden: L. Romell, 37, 38; Stockholm, L. Romell, 342.

Germany: Saxony, in Krieger, Fungi Sax., 270.

Austria-Hungary: Trient Alps, J. Bresadola.

Holland: in Oudemans, Fungi Neerlandici Exs., 240.

England: in Berkeley, Brit. Fungi, 248.

France: F. Fautrey (in Lloyd Herb., 3316).

Belgium: in Libert, Pl. Crypt. Arduennae, 121.

Newfoundland: A. C. Waghorne (in Mo. Bot. Gard. Herb., 5179, 5180); Chappel, A. C. Waghorne, 12 (in N. Y. Bot. Gard. Herb., and in Mo. Bot. Gard. Herb., 5178).

Quebec: Gaspé, J. Macoun, 244; Montreal, R. J. Blair, comm. by L. O. Overholts, 3814 (in Mo. Bot. Gard. Herb., 54993). Ontario: Bond Lake, J. H. Faull, Univ. of Toronto Herb., 351 (in Mo. Bot. Gard. Herb., 44881); London, J. Dearness; Ottawa, J. Macoun, 22, 229; Port Credit, J. H. Faull, Univ. of Toronto Herb., 350, 351 (in Mo. Bot. Gard. Herb., 44876, 44866); Toronto, Thos. Langton, Univ. of Toronto Herb., 502 (in Mo. Bot. Gard. Herb., 44843); Wilcox Lake, G. H. Graham, Univ. of Toronto Herb., 686 (in Mo. Bot. Gard. Herb., 44940).

Maine: Orono, P. L. Ricker (in Seymour Herb.); Piscataquis County, W. A. Murrill, 1943, 2007, 2075, 2110, 2175 (in N. Y. Bot. Gard. Herb., and in Mo. Bot. Gard. Herb., 55522-6); Penobscot County, W. A. Murrill, 1802 (in N. Y. Bot. Gard. Herb., and in Mo. Bot. Gard. Herb., 55527) ; Pittston Farm, E. R. Hodson, comm. by P. L. Ricker, 202 ; Portage, L. W. Riddle, 5 . 
New Hampshire: Chocorua, W. G. Farlow, two collections; Gilmanton, J. Blake, comm. by P. L. Ricker; Mt. Wonalancet, H. von Schrenk (in Mo. Bot. Gard. Herb., 42846); North Woodstock, comm. by Univ. of Wisconsin Herb., 11; Shelburne, W. G. Farlow (in Mo. Bot. Gard. Herb., 4782), and H. von Schrenk (in Mo. Bot. Gard. Herb., 5172).

Vermont: Abby Pond, Ripton, E. A. Burt; Little Notch, E. A. Burt; Lost Pleiad Pond, E. A. Burt; North Ferrisburg, E. A. Burt; Ripton, E. A. Burt.

Massachusetts: Cambridge, G. R. Lyman; Fresh Pond, G. R. Lyman; Magnolia, W. G. Farlow; Sharon, A. P. D. Piguet, comm. by W. G. Farlow, 1 (in Mo. Bot. Gard. Herb., 55006).

Connecticut: Central Village, J. L. Sheldon, comm. by N. Y. Bot. Gard. Herb.; Norwich, W. A. Setchell.

New York: Torrey, part of type of Thelephora imbricatula Schw. (on right of card in Herb. Schweinitz and on left of card in Curtis Herb.); Adirondacks, G. F. Atkinson, b; Alcove, C. L. Shear, 1101, 1308, and in Shear, N. Y. Fungi, 314 ; Altamont, E. A. Burt; Brookton, H. Fitzpatrick, 1054 (in Mo. Bot. Gard. Herb., 54773) ; East Galway, E. A. Burt, two collections; Fort Ann, S. H. Burnham, 18 (in Mo. Bot. Gard. Herb., 54422) ; Freeville, G. F. Atkinson, 2584; Riverside Park, New York City, H. J. Whittemore, 18 (in N. Y. Bot. Gard. Herb., and in Mo. Bot. Gard. Herb., 55511); Vaughns, S. H. Burnham, 10 (in Mo. Bot. Gard. Herb., 44001).

New Jersey: Forked River, W. H. Ballou, 3; Newfield, J. B. Ellis, in Ellis, N. Am. Fungi, 13, in Ell. \& Ev., Fungi Col., 102, and in de Thümen, Myc. Univ., 211b.

Pennsylvania: State College, A. S. Rhoads \& C. R. Orton, 12 (in Mo. Bot. Gard. Herb., 44092) ; Trexlertown, W. Herbst, comm. by Lloyd Herb., 3593; Wright's Gap, A. S. Rhoads, comm. by L. O. Overholts, 3409 (in Mo. Bot. Gard. Herb., $7152)$.

Delaware: Wilmington, A. Commons, 1427 (in N. Y. Bot. Gard. Herb.).

North Carolina: Blowing Rock, G. F. Atkinson, 4031, 4331. 
Michigan: Ann Arbor, L. N. Johnson, 1654 (in N. Y. Bot. Gard. Herb.); Glen Lake, C. G. Lloyd, 02554, 02555; Isle Royal, Allen \& Stuntz, 41, 43, both comm. by Univ. of Wisconsin Herb.; Vermillion, A. H. W. Povah, 141, 138, 311, $193,147,358,351,188,213,149,192,197,770,328$ (in Mo. Bot. Gard. Herb., 15588, 17200, 16526, 20697, 21065, 21552, $22080,20470,20615,20650,20674,22122,22322$, and 22350 respectively).

Wisconsin: Madison, V. B. Walker, 8 (in Mo. Bot. Gard. Herb., 11963).

Minnesota: Lake Itaska, comm. by E. L. Jensen, 7 (in Mo. Bot. Gard. Herb., 10372).

Missouri: Cox's Switch, H. von Schrenk (in Mo. Bot. Gard. Herb., 42864).

Colorado: Tolland, 8000-10000 ft. altitude, F. J. Seaver \& E. Bethel (in N. Y. Bot. Gard. Herb., and in Mo. Bot. Gard. Herb., 42761).

Montana: comm. by E. L. Jensen, 6 (in Mo. Bot. Gard. Herb., 10362) ; Evaro, J. R. Weir, 430, 417, 418 (in Mo. Bot. Gard. Herb., 3469, 14771, 14769); Missoula, J. R. Weir, 433, 429 (in Mo. Bot. Gard. Herb., 3917, 13019).

Idaho: Priest River, J. R. Weir, 94, 89, 100, 101 (in Mo. Bot. Gard. Herb., 8153, 12554, 15945, 15835), and 18.

Alaska: Sitka, W. Trelease, 583a (in Mo. Bot. Gard. Herb., 5168).

British Columbia: Hastings, J. Macoun, 63; Kootenai Mts., near Salmo, J. R. Weir, 514 (in Mo. Bot. Gard. Herb., 1740) ; Sidney, J. Macoun, 38, 68, 76 (in Mo. Bot. Gard. Herb., 6688, 55366, 55367).

Washington: Bingen, W.N. Suksdorf, 686, 691, 718, 743, 746, 873; Bainbridge Island, E. Bartholomew, in Bartholomew, Fungi Col., 3134; Kalama, C. J. Humphrey, 6163, 6201; Seattle, W. A. Murrill, 123, and an unnumbered specimen (in N. Y. Bot. Gard. Herb., and in Mo. Bot. Gard. Herb., 55530,55531 ).

Oregon: Blue Mts., C. L. Shear, 789, 796; Corvallis, C. E. Owens, 2082, 2138 (in Mo. Bot. Gard. Herb., 44248, 44698); Philomath, G. B. Posey, comm. by C. E. Owens, 2058 (in 
Mo. Bot. Gard. Herb., 43879); Wallowa Lake, C. L. Shear, 790, 792, 794 .

California: R. A. Harper, 129 (in N. Y. Bot. Gard. Herb., and in Mo. Bot. Gard. Herb., 55532); Ferndale, S. C. Edwards (in N. Y. Bot. Gard. Herb., and in Mo. Bot. Gard. Herb., 55533); Mt. Tamalpais, Marion Co., W. 'A. Setchell \& C. C. Dobie, 1026 (in Mo. Bot. Gard. Herb., 44240); Muir Woods, R. A. Harper (in N. Y. Bot. Gard. Herb., and in Mo. Bot. Gard. Herb., 55534); Palo Alto, W. A. Murrill \& L. S. Abrams, 1290 (in N. Y. Bot. Gard. Herb.) ; San Mateo Mts., E. B. Copeland, comm. by C. F. Baker, 1800, and (in Mo. Bot. Gard. Herb., 5173).

Mexico: Jalapa, $5000 \mathrm{ft}$. altitude, W. A. \& Edna L. Murrill, 118, 119 (in N. Y. Bot. Gard. Herb., and in Mo. Bot. Gard. Herb., 10925, 10747).

12. H. badio-ferruginea (Mont.) Léveillé, Ann. Sci. Nat. Bot. III. 5 : 152. 1846; Cooke, Grevillea 8 : 146. 1880; Sacc. Syll. Fung. 6 : 591. 1888; Massee, Linn. Soc. Bot. Jour. 27 : 101. 1890.

Stereum badio-ferrugineum Montagne, Ann. Sci. Nat. Bot. II. 20 : 367. 1843; Syll. Crypt. 178. 1856.

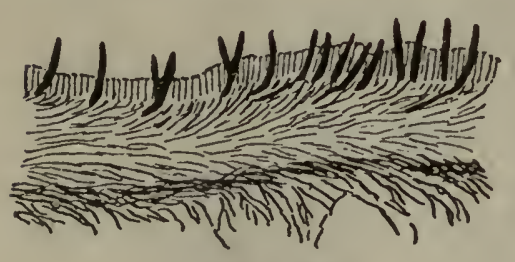

Fig. 10

$\mathrm{H}$. badio-ferruginea.

Section $\times 68$. From authentic specimen.

see $p l .16, f .4$.

Type: in Museum of Paris Herb., according to Léveillé, loc. cit.; authentic specimen of later collection from Montagne to Berkeley, in Kew Herb.

Fructifications imbricated, conchiform, umbonate-sessile or reflexed, thin, drying pliant, with the upper surface sericeous, lineateradiate, Sayal-brown when young, becoming variegated with concentric, glabrous, bay or chestnut-brown zones; hymenium snuff-brown, sometimes minutely cracked; in structure 200-300 $\mu$ thick, with a dark, dense, subhymenial zone and with the hyphal layer composed of a broad intermediate layer of longitudinally arranged, golden-yellow hyphae $3 \frac{1}{2} \boldsymbol{\mu}$ in diameter, connected with the loosely arranged 
hyphae of the upper surface of the pileus by a narrow, dark, dense zone; setae cylindric below, acute, 50-75×8-10 $\mu$, emerging up to $50 \mu$, starting from various parts of the dark subhymenial zone, abundant but not crowded; spores hyaline, even, somewhat curved, $4-6 \times 1-2 \mu$, as seen in preparations of sections.

Fructifications with pilei 4-7 $\mathrm{mm}$. long, 4-10 $\mathrm{mm}$. broad, sometimes laterally confluent; resupinate portions, when present, $\frac{1}{2}-2 \times 2 \frac{1}{2}-7 \frac{1}{2} \mathrm{~cm}$.

On erect rotting stumps of frondose species-rarely on prostrate logs. Canada to Carolina. June to January. Occasional.

This species is so closely related to $H$. tabacina that I have been doubtful whether it is not a form of the latter somewhat modified in form of fructifications through growing on a vertical surface. $H$. badio-ferruginea may be separated from $H$. tabacina by growing upon a vertical surface and by the small imbricated, conchiform pilei which are thinner than those of H. tabacina, and by the hymenium either not at all cracked or with narrow cracks which do not form systems radiating from several centers in the resupinate portioneach system of cracks from its own center. The type of $H$. badio-ferruginea was collected in New York by Menand. All European specimens of $H$. tabacina which $I$ have seen are distinct also from $H$.badio-ferruginea in the characters enumerated above.

Specimens examined:

Canada: Bushwood, J. Macoun, 115.

New Brunswick: Tobique River, G. N. Hay.

Maine: Piscataquis County, W. A. Murrill, 1941, 2232, 2246, 2248 (in N. Y. Bot. Gard. Herb., and in Mo. Bot. Gard. Herb., 55515-55518); Penobscot County, W. A. Murrill, 1807 (in N. Y. Bot. Gard. Herb., and in Mo. Bot. Gard. Herb., 55506).

New Hampshire: P. Wilson (in N. Y. Bot. Gard. Herb., and in Mo. Bot. Gard. Herb., 55519); Camp, Ellis R., U. \& C., from Underwood Coll., 8 (in N. Y. Bot. Gard. Herb., and in Mo. Bot. Gard. Herb., 55502); White Mts., U. \& C., 19, 
32, from Underwood Coll. (in N. Y. Bot. Gard. Herb., and in Mo. Bot. Gard. Herb., 55520, 55521).

Vermont: Middlebury, E. A. Burt.

New York: Adirondacks, G. F. Atkinson, a; East Galway, E. A. Burt, two collections; Floodwood, E. A. Burt.

New Jersey: Lakewood, $E$. A. Daniels, comm. by H. Webster. Carolina: specimen determined by Montagne (in Kew Herb.).

13. H. rubiginosa Dickson ex Léveillé, Ann. Sci. Nat. Bot. III. 5 : 151. 1846; Cooke, Grevillea $8: 145$. 1880; Sacc. Syll. Fung. 6 :589. 1888; Massee, Linn. Soc. Bot. Jour. $27: 97$. 1890; Brown, Mycologia 7 : 1. pl. 149-151. 1915.

Helvella rubiginosa Dickson, Fasc. Pl. Crypt. Brit. 1 : 20. 1785; Sowerby, Brit. Fungi, pl. 26. 1796.-Thelephora rubiginosa Schrader, Spic. Fl. Germ. 185. 1794; Persoon, Syn. Fung. 567. 1801; Myc. Eur. 1 : 120. 1822; Fries, Syst. Myc. 1 : 436. 1821.-Stereum rubiginosum Fries, Epicr. 550. 1838; Hym. Eur. 641. 1874.-A Aricularia ferruginea Bulliard, Herb. de la France 2 : 281. pl. 378. 1787; Sowerby, Brit. Fungi, pl. 26. 1796.-Stereum ferrugineum Bulliard ex Fries, Epicr. 550. 1838; Hym. Eur. 640. 1874; Sacc. Syll. Fung. 6 : 565. 1888. - Hymenochaete ferruginea (Bulliard) Massee, Linn. Soc. Bot. Jour. 27 : 103. 1890; Bresadola, I. R. Accad. Agiati Atti III. $3: 109.1897$.

Illustrations: Bulliard, Herb. de la France, pl. 378; Fl.

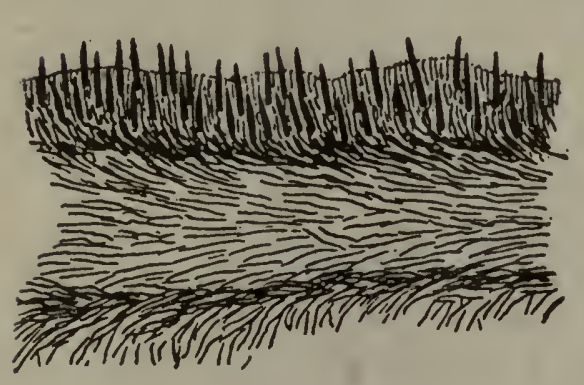

Fig. 11

H. rubiginosa.

Section $\times 68$. See $p l .1 \%, f .14$. Danica, pl. 1619. f. 2; Sowerby, Brit. Fungi, $p l$. 26; Rabenhorst, Krypt.-Fl. $1: 320$. f. 1; Brown, Mycologia $7: p l$. 149-151.

Fructifications coriaceous-rigid, effused, reflexed, or sometimes wholly resupinate, separable, somewhat fasciate above, concentrically sulcate, velvety, Brusselsbrown, finally glabrous, fuscousblack, the margin ochraceous-tawny; hymenium conspicuously setulose under a lens, somewhat colliculose, bister; in structure $500-700 \mu$ thick, with the broad, dense, dark, setigerous layer $160 \mu$ thick and with the intermediate layer 
composed of longitudinally arranged, colored hyphae $2 \frac{1}{2} \mu$ in diameter and bordered above by a narrow, dense, dark zone; setae very numerous, slightly curved, tapering upward to a very sharp point, 50-60×5-6 $\mu$, emerging up to $45 \mu$, starting from all parts of the setigerous layer; spores hyaline, even, $4-6 \times 2-3 \mu$.

Fructifications with reflexed portion 1-2 $\frac{1}{2} \mathrm{~cm}$. long, 1-3 cm. broad and sometimes larger by lateral confluence; resupinate portion $7-8 \times 1-3 \mathrm{~cm}$.

On decaying logs and stumps of oak and other frondose species. Canada to Mexico, westward to Oregon and California, and in Porto Rico. July to February, persisting to June. Common.

H. rubiginosa may be recognized by its rigid pileus, velvety, concentrically sulcate, and Brussels-brown (rubiginous) in color, by the colliculose, bister hymenium whose dark red component color and setae show to advantage in reflected light, and by the brighter ochraceous margin. Even resupinate specimens may be recognized at sight by being separable from the substratum, and by the form and color of the hymenium and the contrasting bright margin. The structure in section is equally constant and distinctive. This species produces a pocketed heart rot in oak wood.

Specimens examined:

Exsiccati: Bartholomew, Fungi Col., 3133; Berkeley, Brit. Fungi, 247; Ellis, N. Am. Fungi, 327; Kunze, Fungi Sel., 203 ; Rabenhorst, Herb. Myc., 212.

England: in Berkeley, Brit. Fungi, 247; Kenilworth, W. A. Murrill (in N. Y. Bot. Gard. Herb., and in Mo. Bot. Gard. Herb., 55542).

Sweden: Upsala, E. Fries, det. by Fries as Stereum ferrugineum, comm. by L. Romell, 27; Femsjö, L. Romell, 35; Halland, L. Romell, 36; Lapland, L. Romell, 396, 397.

Germany: J. Kunze, in Kunze, Fungi Sel., 203 (in Mo. Bot. Gard. Herb., 44098); from Persoon, under the name Thelephora rubiginosa (in Kew Herb.); Dresden, in Rabenhorst, Herb. Myc., 212. 
Austria-Hungary: Löcse, V. Greschick, comm. by Bresadola, under the name Hymenochaete ferruginea.

Canada: J. Macoun, 92; Lower St. Lawrence Valley, J. Macoun, 63; London, Ontario, J. Dearness, 981 (in N. Y. Bot. Gard. Herb.).

Maine: Orono (in N. Y. Bot. Gard. Herb.).

Vermont: Lake Dunmore, E. A. Burt, two collections; Middlebury, $E$. A. Burt, two collections.

Massachusetts: Webster, R. G. Leavitt.

Connecticut: V.S. White (in N. Y. Bot. Gard. Herb.) ; Central Village, J. L. Sheldon, 25, comm. by N. Y. Bot. Gard. Herb.; Redding, F. S. Earle, 455, and Underwood \& Earle, 498 (both in N. Y. Bot. Gard. Herb., and in Mo. Bot. Gard. Herb., 55540, 55541).

New York: Alcove, C. L. Shear, 241; East Galway, E. A. Burt, five collections; Ithaca, G. F. Atkinson, 22942, 22942a, and Van Hook, comm. by G. F. Atkinson, A, and H. P. Brown (in Mo. Bot. Gard. Herb., 44099); Karner, H. D. House (in N. Y. State Mus. Herb., and in Mo. Bot. Gard. Herb., 54355); New Berlin, W. H. Long, 19070 (in Mo. Bot. Gard. Herb., 44163); New York Botanic Garden, Class in Mycology (in N. Y. Bot. Gard. Herb., and in Mo. Bot. Gard. Herb., 55543).

New Jersey: Fort Lee, W. A. Murrill (in N. Y. Bot. Gard. Herb., and in Mo. Bot. Gard. Herb., 55545); Hackensack Swamp, W. H. Ballou, 1.

Pennsylvania: Bear Meadows, A. S. Rhoads, 10 (in Mo. Bot. Gard. Herb., 44087); Kittanning, D. R. Sumstine; Ohio Pyle, W. A. Murrill, 1087 (in N. Y. Bot. Gard. Herb., and in Mo. Bot. Gard. Herb., 55546); Sayre, W. C. Barbour, 1386 (in N. Y. Bot. Gard. Herb., and in Mo. Bot. Gard. Herb., 55547) ; Spruce Creek, J. H. Faull, Univ. of Toronto Herb., 348 (in Mo. Bot. Gard. Herb., 44880) ; Trexlertown, C. G. Lloyd, 0019, 0256; West Chester, Haines, Everhart \& Jefferis, in Ellis, N. Am. Fungi, 327.

Maryland: Takoma Park, C. L. Shear, 1274.

Virginia: Blacksburg, Miss V. W. Murrill, 19 (in N. Y. Bot. 
Gard. Herb., and in Mo. Bot. Gard. Herb., 55548); Woodstock, C. L. Shear, 1192.

North Carolina: comm. by W. H. Long, 12930, 19123 (in Mo. Bot. Gard. Herb., 44162, 44165) ; Blowing Rock, G. F. Atkinson, 4030, 4188, 4309, 4310, 4312, 4321; Pink Bed Valley, Transylvania Co., W. A. Murrill \& H. D. House, 422 (in N. Y. Bot. Gard. Herb.).

Florida: C. G. Lloyd, 4858.

Alabama: Montgomery, R. P. Burke, 149 (in Mo. Bot. Gard. Herb., 44905).

Louisiana: Bogalusa, C. J. Humphrey, 5499 (in Mo. Bot. Gard. Herb., 13613); St. Martinville, A. B. Langlois.

Ohio: C. G. Lloyd, 3910; Cincinnati, A. P. Morgan, comm. by Lloyd Herb., 2636, and C. G. Lloyd, 4527; Linwood, C. G. Lloyd (in Lloyd Herb., 07374, and in Mo. Bot. Gard. Herb., 55554); Miami Valley, A. P. Morgan (in Mo. Bot. Gard. Herb., 5177).

West Virginia: Eglon, C. G. Lloyd, 02714; Morgantown, J. L. Sheldon, 3537, comm. by N. Y. Bot. Gard. Herb.

Tennessee: Elkmont, C. H. Kauffman, 75 (in Mo. Bot. Gard. Herb., 21462).

Indiana: Crawfordsville, D. Reddick, 1, 16; Lafayette, C. R. Orton, 6 (in Mo. Bot. Gard. Herb., 44083).

Illinois: River Forest, E. T. \& S. A. Harper, 630.

Wisconsin: Blue Mounds, Univ. of Wisconsin Herb., 24; Madison (in Mo. Bot. Gard. Herb., 4996).

Missouri: Creve Coeur, E. A. Burt (in Mo. Bot. Gard. Herb., 10405), and P. Spaulding (in Mo. Bot. Gard. Herb., 44097); Upper Creve Coeur, E. A. Burt (in Mo. Bot. Gard. Herb., 44048).

Arkansas: Cass, W. H. Long, 19806 (in Mo. Bot. Gard. Herb., 8966).

Nebraska: Saltillo, C. L. Shear, 1093.

Kansas: Emporia, E. Bartholomew, in Bartholomew, Fungi Col., 3133.

Arizona: Santa Catalina Mts., G. G. Hedgcock \& W. H. Long, comm. by C. J. Humphrey, 2507 (in Mo. Bot. Gard. Herb., 42934). 
Oregon: Corvallis, C. E. Owens, 2137, 2148 (in Mo. Bot. Gard. Herb., 44696, 9187).

California: Palo Alto, W. A. Murrill \& L. S. Abrams, 1161 (in N. Y. Bot. Gard. Herb.).

Mexico: Guernavaca, W. A. \& Edna L. Murrill, 406 (in N. Y. Bot. Gard. Herb., and in Mo. Bot. Gard. Herb., 54533).

Porto Rico: El Duque, J. A. Stevenson \& J. R. Johnston, 1487 (in Mo. Bot. Gard. Herb., 6597) ; Rio Piedras, J. A. Stevenson \& R. C. Rose, comm. by J. A. Stevenson, 6514 (in Mo. Bot. Gard. Herb., 55088).

14. H. reflexa Burt, n. sp.

Type: in Burt Herb. and N. Y. Bot. Gard. Herb.

Fructifications effused, broadly reflexed, thin, rigid, fibrillose, Prout's brown, finally glabrous, shallowly concentrically

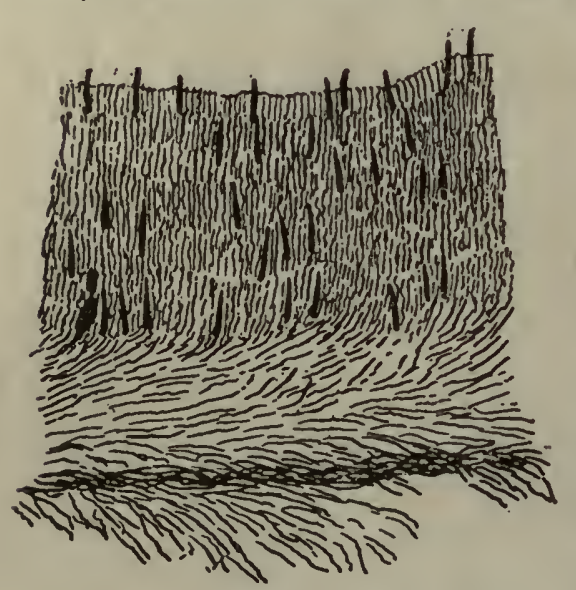

Fig. 12

H. reflexa.

Section $\times 68$. From type. See $p l .17, f .13$.

sulcate and zonate, with obscure blackish zones in the furrows; hymenium even, not cracked, Sudan-brown; in structure 500$600 \mu$ thick, composed of a zonate setigerous layer $300-400 \mu$ thick and of an intermediate layer bordered on the upper side by a dense, but not dark, zone which connects with the more loosely arranged hyphae of the upper surface of the pileus; setigerous layer very compact, composed of crowded, erect hyphae, between which are scattered, slender setae, slightly curved, sharp-pointed, 35-40X $4 \frac{1}{2}-5 \mu$, emerging up to $30 \mu$, present in all parts of the layer; hyphae of intermediate layer densely, longitudinally arranged, colored, $2 \frac{1}{2} \mu$ in diameter; no spores found.

Fructification with reflexed portion $2 \mathrm{~cm}$. long, about $8 \mathrm{~cm}$. broad; resupinate strip $3 \mathrm{~mm}$. across at base of reflexed portion is all of resupinate portion which was collected.

Under side of decaying wood. Jamaica. January. Rare. $H$. reflexa bears some resemblance to $H$. rubiginosa in its rigid and dark-colored pileus; a similar resemblance to $H$. 
rubiginosa was stated by Fries, Elenchus Fung. $1: 174$, in the comment of the original description of Thelephora leprosa collected in Brazil. If the specimen of Thelephora leprosa upon which Léveillé based his transfer of this species of Hymenochaete is still in the Museum of Paris Herbarium and is from the original collection, comparison with this specimen may show that $H$. reflexa should be regarded as a synonym of $T$. leprosa. The structure in section of $H$. reflexa is very like that of $H$. unicolor, but the hymenium is of different color and all the collections of $H$. unicolor have the margin closely adnate.

Specimens examined:

Jamaica: Troy and Tyre, W. A. Murrill \& W. Harris, 989, type, comm. by N. Y. Bot. Gard. Herb.

15. H. cubensis Burt, n. sp.

Type: in Burt Herb. and N. Y. Bot. Gard. Herb.

Fructifications imbricated, flabelliform, dimidiate, umbonatesessile and attached along one side, or effused and reflexed, thin, coriaceous, pliant when dry, minutely tomentose, concentrically sulcate, antique brown when young, becoming snuff-brown to Rood's brown; hymenium even, antique brown; in structure 300 $400 \mu$ thick, with a setigerous layer $80-100 \mu$ broad and a narrow intermediate layer which

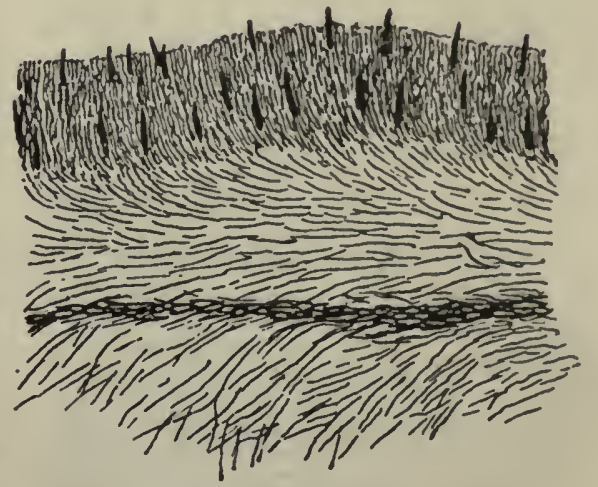

Fig. 13

$H$. cubensis.

Section $\times 68$. From type. See $p l .17, f .8$.

is connected by a narrow, dark, dense zone with the loosely arranged hyphae of the upper surface of the pileus; setae not abundant, $35-45 \times 4 \frac{1}{2}-6 \mu$, emerging up to $30 \mu$, slender, somewhat falcate, sharp-pointed, occurring in all parts of the setigerous layer which contains many colored, amorphous grains also; hyphae of intermediate layer $2 \frac{1}{2}-3 \mu$ in diameter, colored; spores hyaline, even, $4-4 \frac{1}{2} \times 2 \mu$.

Fructifications $1 \mathrm{~cm}$. from umbo to margin, or when dimidiate 1-2 $\mathrm{cm}$. broad, 1-2 cm. long, and sometimes larger by 
lateral confluence; resupinate portions about $2 \mathrm{~cm}$. in diameter present in one collection.

On rotting frondose wood and logs in dense forests, causing a pocketed rot. Cuba and Porto Rico. February and March. Frequent.

$H$. cubensis is related to $H$. reflexa in structure, but its fructifications are smaller and thinner than those of the latter, and are nearly always umbonate-sessile or dimidiate-only very rarely reflexed-and do not become glabrous and darkcolored, with resemblance to $H$. rubiginosa. Such ample collections of $H$. cubensis have been made that it seems as though this species should have been described heretofore, but I have failed to find anything in earlier work to which these specimens may be referred.

Specimens examined:

Cuba: Alto Cedro, L. M. Underwood \& F. S. Earle, 1491, type, and 1565, and Earle \& Murrill, 456, all comm. by N. Y. Bot. Gard. Herb.; La Gloria, Camagüey, J. A. Shafer, 739 (in N. Y. Bot. Gard. Herb., and in Mo. Bot. Gard. Herb., 55549); Managua, Havana Province, Earle \& Murrill, 21, comm. by N. Y. Bot. Gard. Herb.

Porto Rico: Monte Cerrote, near Adjuntas, N. L. Britton \& S. Brown, 5479 (in N. Y. Bot. Gard. Herb., and in Mo. Bot. Gard. Herb., 55550).

16. H. ungulata Burt, n. sp.

Plate 17, fig. 17.

Type: in Mo. Bot. Gard. Herb. and N. Y. Bot. Gard. Herb. Pileus very hard, tuberculate-ungulate, sessile, decurrent, triangular in section, with the upper surface black, crust-like, glabrous, the margin obtuse; hymenium oblique, pruinose, between white and pearl-gray; in structure $3 \mathrm{~mm}$. thick, no intermediate layer found, composed of a setigerous layer $1 \mathrm{~mm}$. or more thick, of layered structure, and of the stony pseudoparenchymatous crust; setae $75 \times 9 \mu$, tapering from the base, very abundant, starting from all parts of the setigerous layer; no spores found.

Pileus $3 \mathrm{~mm}$. long, 5-12 mm. wide, $2-3 \mathrm{~mm}$. thick.

On bark of dead standing trunk or stump in virgin forest, $5000 \mathrm{ft}$. altitude. Mexico. December. 
H. ungulata is unique in our species of this genus by its small, hoof-shaped fructifications with ashy white hymenium and crust-like, dull black upper surface. The fructifications are so hard that they turn the edge of the razor immediately in sectioning and have not afforded good preparations for showing the structure above the setigerous layer. $H$. ungulata probably belongs in the group with $H$. corticolor.

Specimens examined:

Mexico: Jalapa, W. A. \& Edna L. Murrill, 176, type (in N. Y.

Bot. Gard. Herb., and in Mo. Bot. Gard. Herb., 44970).

17. H. corticolor Berk. \& Ravenel, Grevillea 1 : 165. 1873; Cooke, Grevillea 8 : 147. 1880; Sacc. Syll. Fung. 6 : 595. 1888; Massee, Linn. Soc. Bot. Jour. 27 : 111. 1890.

Type: type distribution in Ravenel, Fungi Car. $3: 30$.

Fructifications hard, woody, either wholly resupinate, adnate, and following the inequalities of the substratum, or with the upper edge thickened, barely reflexed, black, glabrous ; hymenium drab, even; in structure 400 $1000 \mu$ thick, lacking an intermediate layer, with the setigerous layer constituting the whole thickness of the fructification and composed of densely arranged, suberect, interwoven, pale hyphae, much crystalline matter, and scattered setae; setae $60-75 \times 9 \mu$, emerging up to $45 \mu$, sharp-pointed, distributed in all parts of the fructification;

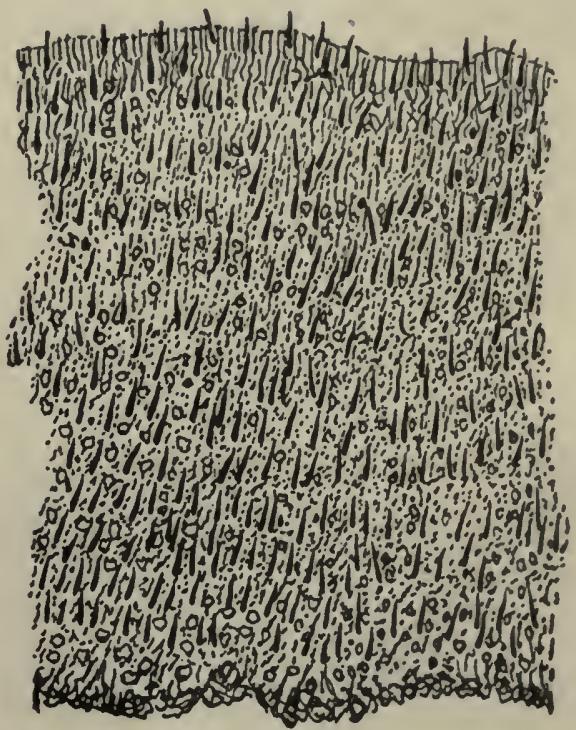

Fig. 14 H. corticolor.

Section $\times 44$. From type. See $p l .16, f . \%$. spores hyaline, even, flattened on one side, $4 \frac{1}{2} \times 3 \frac{1}{2} \mu$.

Resupinate over areas $1-3 \times 1 \frac{1}{2}-5 \mathrm{~cm}$., with reflexed margin $1-1 \frac{1}{2} \mathrm{~mm}$. broad.

On bark, often in its crevices, of living trunks of oak, elm, Magnolia, and other frondose species. New Jersey to Florida, and in Cuba, Jamaica, and Grenada. Autumn to February. 
The absence of an intermediate layer is likely to place the usual collections of resupinate $H$. corticolor in the group of species with $H$. corrugata, H. cervina, $H$. Pellicula, H. tenuis, etc., from all of which $H$. corticolor is distinguishable at sight by its great thickness, drab hymenium, black upper surface of reflexed edge, and occurrence on the bark of living tree trunks. This species attains its best development in South Carolina and Florida. The black upper surface of the reflexed edge is a good character for separation from $H$. unicolor.

Specimens examined:

Exsiccati: Ellis, N. Am. Fungi, 408; Ravenel, Fungi Car. 3 : 30; Fungi Am., 121.

New Jersey: Newfield, J. B. Ellis, in Ellis, N. Am. Fungi, 408.

Maryland: Takoma Park, C. L. Shear, 1003, 1096.

South Carolina: H. W. Ravenel, Curtis Herb., 1553 (in Kew Herb.), and in Ravenel, Fungi Car. 3 : 30, type distribution. Florida: Cocoanut Grove, $R$. Thaxter, 79 (in Farlow Herb., and in Mo. Bot. Gard. Herb., 43984) ; Daytona, R. Thaxter, 13 (in Farlow Herb., and in Mo. Bot. Gard. Herb., 43933); Gainesville, N. L. T. Nelson (in Lloyd Herb., and in Mo. Bot. Gard. Herb., 55455), and H. W. Ravenel, in Ravenel, Fungi Am., 121.

Cuba: San Diego de los Baños, Earle $\&$ Murrill, 198, comm. by N. Y. Bot. Gard. Herb.

Jamaica: Cinchona, W. A. Edna L. Murrill, 419, comm. by N. Y. Bot. Gard. Herb.

Grenada: Grand Etang, R. Thaxter, comm. by W. G. Farlow, 13.

18. H. arida Karsten in Sacc. Syll. Fung. 9 : 228. 1891; Bresadola, Ann. Myc. 1: 93. 1903.

Hymenochaetella arida Karsten, Finska Vet.-Soc. Bidrag Natur och Folk 48 : 428. 1889.-H. laxa Karsten, Finska Vet.Soc. Bidrag Natur och Folk 48 : 429. 1889.-Hymenochaete laxa Karsten in Sacc. Syll. Fung. 9 : 228. 1891.-Corticium simulans Berk. \& Rav. in Cooke, Grevillea 6 : 132.1878 (without description but with reference to Ravenel, Fungi Am., 10); Ravenel, Fungi Car. 5:25 (without description); de 
Thümen, Myc. Univ., 512 (without description).-Probably not Corticium simulans Berk. \& Broome, Linn. Soc. Bot. Jour. 14 : 72. 1873.-Hymenochaete simulans (Berk. \& Rav.) Peck, N. Y. State Mus. Rept. 49 : 34. 1897 (without description); v. Höhn. \& Litsch. K. Akad. Wiss. Wien Sitzungsber. 116 : 775. 1907.

Type: authentic specimen from Karsten in Burt Herb.

Fructifications resupinate, effused, scattered, orbicular at first, then laterally confluent, thin, dry, adnate, not cracked, drying clay-color to antique brown, the margin thinning out; in structure 100-140 $\mu$ thick, composed of loosely interwoven, suberect hyphae 3-4 $\mu$ in diameter, colored like the fructification, stiff, not nodose-septate, forming a homogeneous layer, without a dense zone from substratum to hymenium, and bearing scattered setae in the upper portion of the layer; setae $30-75 \times 6-8 \mu$, emerg-

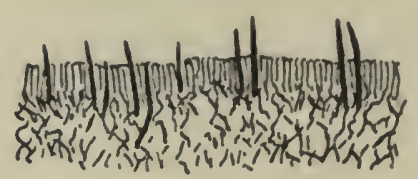

Fig. 15

H. arida.

Section $\times 68$. From authentic specimen. ing up to $35 \mu$, not numerous, tapering upward; spores in spore collection from Swedish specimen white, even, allantoid, $6-7 \times 2 \mu$ as seen in side view, $2 \frac{1}{2}-3 \mu$ broad in front view, and $6-7 \times 3 \frac{1}{2}-4 \mu$, flattened on one side in American specimens.

Fructifications at first $2-3 \times 2 \mathrm{~mm}$., later laterally confluent over areas $9 \times 1-1 \frac{1}{2} \mathrm{~cm}$.

On bark of dead branches of Corylus, Ostrya virginica, and Vaccinium arboreum. Finland, Sweden, Vermont to South Carolina, and in Michigan. October to April.

The fructifications of $H$. arida are at first small, scattered, and suborbicular and later become confluent and elongated so as to resemble closely in aspect and color Coniophora arida. The spores of American collections are about twice the breadth of those of European specimens cited, but the agreement between the European and American specimens is so close in general aspect and in the very simple structure of the fructification in section that I believe the American and European specimens are of the same species. The distinguishing characters of $H$. arida are its resemblance in aspect to Coniophora arida, structure consisting of a single, homo- 
geneous layer of loosely interwoven, suberect hyphae, with setae distributed in outer half of the layer, rather large spores, and the occurrence in the United States upon bark of Ostrya and Vaccinium arboreum. Von Höhnel and Litschauer in their notes on types in Karsten's herbarium ${ }^{1}$ referred Hymenochaete arida and $H$. laxa to $H$. unicolor and $H$. cinnamomea respectively - species with which they have nothing in common except color.

Specimens examined:

Exsiccati: Ravenel, Fungi Car. 5 : 25; Fungi Am., 10; de Thümen, Myc. Univ., 512.--in each under the name Corticium simulans B. \& Rav.

Finland: Mustiala, $P$. A. Karsten, authentic specimen and another specimen communicated by Bresadola; Runsala, $P$. A. Karsten, authentic specimen of Hymenochaetella laxa.

Sweden: Upsala, C. G. Lloyd, 08425 (in Lloyd Herb., and in Mo. Bot. Gard. Herb., 55472).

Vermont: Middlebury, E. A. Burt.

New York: Fort Ann, S. H. Burnham, 41 (in Mo. Bot. Gard. Herb., 54456).

South Carolina: Aiken, H. W. Ravenel, in Ravenel, Fungi Car. 5 : 25, Fungi Am., 10, and in de Thümen, Myc. Univ., 512.

Michigan: Ann Arbor, C. H. Kauffman, 32.

19. H. unicolor Berk. \& Curtis, Linn. Soc. Bot. Jour. 10 : 335. 1868; Cooke, Grevillea 8 : 148. 1880; Sacc. Syll. Fung. 6 : 597. 1888; Massee, Linn. Soc. Bot. Jour. 27 : 108. 1890; Lloyd, Myc. Notes 41 : 572. text f. 780, 781. 1916.

H. fuliginosa Berk. \& Curtis, Linn. Soc. Bot. Jour. 10 : 335. 1868; not $H$. fuliginosa (Pers.) Lév.

Type: in Kew Herb.

Fructification resupinate, long and broadly effused, adnate, dense, cracked, brittle, scaling off from the wood, drying antique brown; in structure 500-700 $\mu$ thick, composed of a very thick, somewhat zonate, setigerous layer and of a thin hyphal layer which is often not sharply distinguishable from the setigerous layer; hyphae $2 \frac{1}{2}-3 \mu$ in diameter; setae scat-

${ }^{1} \mathrm{~K}$. Akad. Wiss. Wien Sitzungsber. 115 : 1577, 1578. 1906. 
tered in all parts of the setigerous layer, sometimes slightly falcate, 50-60 $\times 5-6 \mu$, emerging up to $40 \mu$, tapering from the base to a slender and sharp apex; basidia with 4 sterigmata; spores in spore collection white, even, $5-5 \frac{1}{2} \times 3 \frac{1}{2}-4 \mu$; causing pocketed rot in decorticated hard wood.

Covering decorticated poles 20 feet long.

On dead frondose wood. Cuba, Venezuela, and Brazil. December to April.

$H$. unicolor has the coloration and general aspect of $H$. cinnamomea and $H$. spreta but is usually rimose in contrast with the former and with a more velvety hymenium than the latter and is of a very dense structure with its hyphae arranged parallel with the rather uniformly distributed setae, while $H$. cinnamomea and $H$. spreta are stratose, with alternating layers of loosely

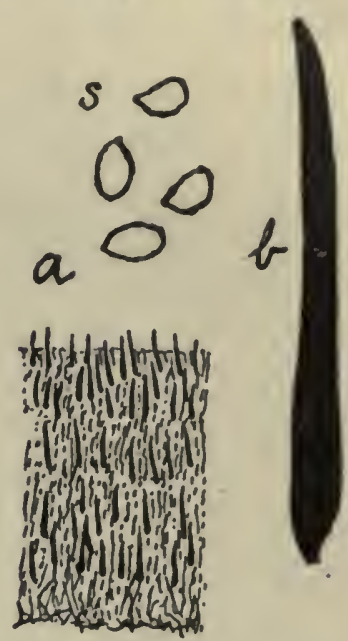

Fig. 16

H. unicolor.

Section, $a, \times 44$; seta, $b$, and spores, $s, \times 850$. interwoven hyphae separating the two or more hymenial layers. The dry rot produced in the wood by $H$. unicolor is a pocketed rot, as shown by the fine collection by Lloyd and well shown in his fig. 781, cited above, while the rot produced by $H$. spreta is a soft, fibrous sap rot which attacks the sap-wood uniformly from the outer surface. The specimen referred by Berkeley and Curtis to $H$. fuliginosa, collected in Cuba, C. Wright, 188, differs so slightly from the type of $H$. unicolor that it will probably be included in $H$. unicolor when better known by other collections.

Specimens examined:

Cuba: C. Wright, 541, type (in Kew Herb.) and an unnumbered collection of $185 \%$, under the name of $H$. cinnamomea (in Curtis Herb.), and 188, under the name Hymenochaete fuliginosa (in Kew Herb.) ; C. G. Lloyd, 142, 171 (in Lloyd Herb., and in Mo. Bot. Gard. Herb., 55458, 55473) ; Ceballos, C. J. Humphrey, 2585, 2590, 2696, 2829, 2964 (in Mo. Bot. Gard. Herb., 16043, 16052, 1778, 14838, 1766).

Jamaica: Troy and Tyre, W. A. Murrill \& W. Harris, 991, comm. by N. Y. Bot. Gard. Herb. 
Venezuela: Margarita, A. F. Blakeslee, comm. by W. G. Farlow.

Brazil: Blumenau, A. Möller, comm. by J. Bresadola, under the name Hymenochaete fuliginosa, as listed in Hedwigia $35: 289.1896$.

20. H. agglutinans Ellis, Torr. Bot. Club Bul. 5 : 46. 1874; Sacc. Syll. Fung. 6 : 602. 1888; Massee, Linn. Soc. Bot. Jour. 27 : 106. 1890; Graves, Mycologia 6 : 279. pl. 145. 1914.

Hymenochaete ambiens Berk. \& Curtis in Cooke, Grevillea 8 : 147. 1880; Sacc. Syll. Fung. 6 : 596. 1888; Massee, Linn. Soc. Bot. Jour. 27 : 106. 1890.

Type: probably in N. Y. Bot. Gard. Herb.

Fructifications resupinate, effused, adnate, orbicular, at first of loose texture and cream-buff, then thick, very compact, concentrically sulcate, and antique brown, with the margin thick, determinate, and cream-buff, finally becoming black during the winter, infecting living limbs where they rub together and finally uniting them firmly; in structure 1-2 $\mathrm{mm}$. thick, composed of a single homogeneous hyphal layer of densely interwoven, thick-walled hyphae concolorous with the fructification and bearing at the outer surface of this layer an opaque subhymenium upon which the setae stand; setae $70-90 \times 9 \mu$, protruding $60 \mu$, few, scattered, starting from the subhymenium; basidia and spores not found.

Fructifications 3-7 cm. in diameter, 1-2 mm. thick.

Infecting living branches of Alnus, Benzoin, Acer, etc., where they rub together. August to April. New Hampshire to Florida, westward to Idaho, and in Cuba. Frequent.

This species is easily recognized by its remarkable habit of joining together branches which have rubbed together and formed areas for infection. From these areas the fructification spreads so as to often encircle one or both limbs, at the same time killing the portions of the limbs beyond the fructification, as described by Graves in his article cited above.

Specimens examined:

Exsiccati: Ellis, N. Am. Fungi, 939; Ell. \& Ev., Fungi Col., 807; de Thümen, Myc. Univ., 309. 
New Hampshire: Chocorua, W. G. Farlow.

Vermont: Lost Pleiad Pond, Ripton, E. A. Burt; Middlebury, E. A. Burt.

Massachusetts: Cherry Brook, Weston, A. B. Seymour, T 4 (in Mo. Bot. Gard. Herb., 43888); Magnolia, W. G. Farlow; Sharon, A. P. D. Piguet, comm. by W. G. Farlow (in Mo. Bot. Gard. Herb., 55475) ; Waltham, A. B. Seymour, T 5 (in Mo. Bot. Gard. Herb., 43889).

Connecticut: Storrs, A. E. Moss, comm. by P. W. Graff, 39 (in Mo. Bot. Gard. Herb., 44791).

New York: Albany, C. G. Lloyd, 07112 (in Lloyd Herb.); Alcove, C. L. Shear, 999; Brooklyn, F. H. Ames (in Lloyd Herb., 438); Chappaqua, Mrs. C. E. Ryder \& Mrs. W. A. Murrill (in N. Y. Bot. Gard. Herb.); Ithaca, G. F. Atkinson, 2022; Scarsdale, Mrs. Livingston \& Miss Crane, comm. by N. Y. Bot. Gard. Herb.

New Jersey: C. F. Austin, 57 (in Curtis Herb. as an undetermined Corticium and in Kew Herb. as the type of Hymenochaete ambiens Berk. \& Curtis); Newfield, J. B. Ellis, in Ellis, N. Am. Fungi, 939, in Ell. \& Ev., Fungi Col., 807, and in de Thümen, Myc. Univ., 309.

Pennsylvania: Trexlertown, W. Herbst, 1.

North Carolina: Biltmore Estate, W. A. Murrill (in N. Y. Bot. Gard. Herb., and in Mo. Bot. Gard. Herb., 55477).

Florida: Sorrento, R. Thaxter, 74 (in Farlow Herb., and in Mo. Bot. Gard. Herb., 43896).

Ohio: Linwood, C. G. Lloyd, 1879.

Wisconsin: Madeline Island, near Bayfield, V. B. Walker, 4 (in Mo. Bot. Gard. Herb., 6631).

Idaho: Priest River, J. R. Weir, 345 (in Mo. Bot. Gard. Herb., 6853).

Cuba: Alto Cedro, Santiago, F. S. Earle, 346, from Herb. de Cuba Estacion Central Agronomica.

21. H. cinnamomea (Pers.) Bresadola, I. R. Accad. Agiati Atti III. 3 : 110. 1897.

Thelephora cinnamomea Persoon, Myc. Eur. 1: 141. 1822; Fries, Elenchus Fung. 1 : 201. 1828.-Corticium cinnamomeum 
(Pers.) Fries, Epicr. 561. 1838; Hym. Eur. 650. 1874.Hymenochaetella rudis Karsten, Hedwigia $35: 173$. 1896.Hymenochaete rudis Karsten in Sacc. Syll. Fung. 14: 218. 1899.

Type: specimen determined by Fries in Herb. Fries.

Fructification resupinate, widely effused, adnate, velvety, not cracked, drying antique brown to Brussels-brown, the margin tomentose-fibrillose; in structure

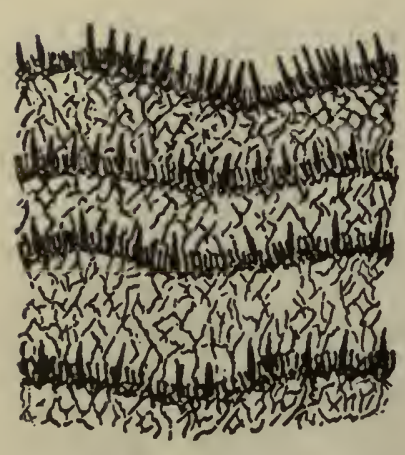

Fig. 17

H. cinnamomea.

Section $\times 44$. From specimen in Herb. Fries. becoming 500-1000 $\mu$ thick, stratose, ranging up to 6 strata, each composed of a setigerous layer $30-45 \mu$ broad and of a hyphal layer of equal or greater breadth, with hyphae colored like the fructification, loosely interwoven, $3 \mu$ in diameter; setae $60-90 \times 5-6 \mu$, protruding up to $60 \mu$, tapering upward from the base, originating in all parts of the setigerous layers; spores hyaline, even, $4 \frac{1}{2}-6 \times 2-2 \frac{1}{2} \mu$ as seen in sectional preparations, stated by Bresadola to be $6-9 \times 2 \frac{1}{2} \mu$ as obtained from spore collections.

Fructifications $3-7 \times 1 \frac{1}{2}-2 \frac{1}{2} \mathrm{~cm}$.

On bark and decaying wood of both frondose and coniferous species but usually on the former. New York to California and British Columbia. June to April. Rare.

$H$. cinnamomea closely resembles in color and general aspect Hypochnus ferrugineus but is thicker and with a more compact hymenium. I base my idea of $H$. cinnamomea on the specimen from Norway determined by Fries and the fine specimens of identical structure collected in Lapland by Romell, in Finland by Karsten, and in Ardennes by Libert. The specimen from Hungary, received from Bresadola, has the same aspect, velvety, not cracked, and a thin surface setigerous layer but varies toward $H$. spreta by having its deeper setigerous layers more than $45 \mu$ broad and exceeding the adjoining hyphal layers. This specimen from Bresadola formerly led me to regard $H$. spreta as a synonym of $H$. cinnamomea and to refer to $H$. cinnamomea for my correspond- 
ents many specimens which will be found cited under $H$. spreta. $H$. cinnamomea appears clearly distinct from $H$. spreta by its velvety surface, not contracting greatly in thick specimens nor cracking to the substratum so as to form small, isolated, rectangular masses, by setigerous layers $30-45 \mu$ broad and usually narrower than the adjoining hyphal layers, and spores up to $4 \frac{1}{2}-9 \mu$ long. Several of the American specimens cited below are first-stratum stages.

Specimens examined:

Exsiccati: Libert, Pl. Crypt. Arduennae, 122.

Norway: Christiania, M. N. Blytt (in Herb. Fries, det. by E. Fries).

Sweden: L. Romell, 85, first-stratum stage; Lapland, $L$. Romell, 398, 399.

Finland: Mustiala, P. A. Karsten, authentic specimen of $H y$ menochaetella rudis.

Hungary: Kmet, det. and comm. by J. Bresadola.

Belgium: in Libert, Pl. Crypt. Arduennae, 122.

New York: Staten Island, W. H. Ballou (in N. Y. Bot. Gard.

Herb., and in Mo. Bot. Gard. Herb., 55544).

Ohio: Cincinnati, C. G. Lloyd, $450 \%$.

Illinois: Riverside, E.T.\& S. A. Harper, $65 \%$.

Nebraska: Woodlawn, C. L. Shear, 1026, first-stratum stage.

Kansas: Rooks Co., E. Bartholomew, first-stratum stage.

California: Santa Barbara, O. M. Oleson, 17, first-stratum stage.

British Columbia: Sidney, J. Macoun, 37, 99, 111 (in Mo. Bot. Gard. Herb., 6687, 55364, 55365). Nos. 37 and 111 are in the first-stratum stage.

22. H. digitata Burt, n. sp.

Type: in N. Y. Bot. Gard. Herb. and Mo. Bot. Gard. Herb.

Fructification resupinate, long and broadly effused, adnate, drying between Brussels-brown and antique brown, with hymenium somewhat granular, the margin determinate, very thin; in structure stratose, $800 \mu$ thick, composed of about 15 narrow, loosely interwoven, hyphal layers alternating with the same number of very dense, dark and opaque setigerous layers 
of about equal breadth and equal to the loosely interwoven layers; hyphae about $2 \mu$ in diameter, concolorous with the fructification; setae $50-60 \times 6 \mu$, emerging up to $50 \mu$, tapering

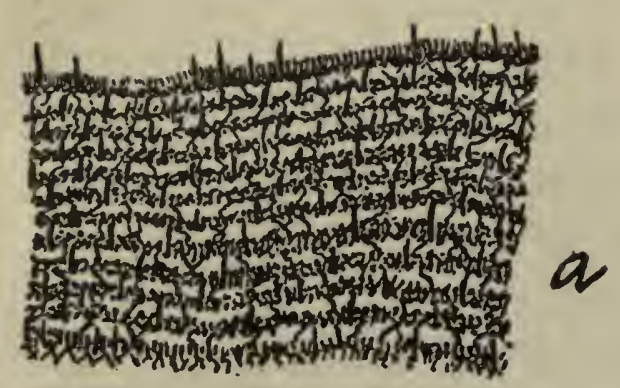

Fig. 18

H. digitata.

from base to a sharp \% point, colored like $\mathrm{t} \mathrm{h}$ e fructification; paraphyses colored like other organs, filiform, divided at the apex into about three short, fingerlike branches or prongs; basidia and spores not found.

Fructification $13 \times 5 \mathrm{~cm}$., broken off along three sidesprobably large.

On bark of rotten logs in forests. Panama. March.

$H$. digitata belongs in the group of species with stratose fructifications, of which $H$. spreta is the best known. H. digitata should be easily recognized by its bright ferruginous brown color, fructification composed of very many and very narrow strata, and paraphyses with digitately, or sometimes pinnately, branched tips. Setae occur not only in the hymenial surface but also rather sparingly in the other setigerous layers throughout the fructification.

Specimens examined:

Panama: El Boquete, Chiriqui, W. R. Maxon, 5559, type, Smithsonian Survey of Panama Canal Zone (in N. Y. Bot. Gard. Herb., and in Mo. Bot. Gard. Herb., 55469).

23. H. spreta Peck, N. Y. State Mus. Rept. $30: 47$. 1879; Sacc. Syll. Fung. $6: 595.1888$.

Hymenochaete laevigata Massee, Linn. Soc. Bot. Jour. 27 : 107. 1890.

Type: in N. Y. State Mus. Herb.

Fructifications resupinate, long and widely effused, adnate, rimose, drying Argus-brown to snuff-brown, the margin thinning out, velvety when young; in structure $300-500 \mu$ thick, 
stratose, composed of $1-3$, or rarely up to 5 , pairs of setigerous and hyphal layers, with the setigerous layers very dense, about $45-200 \mu$ thick, exceeding the alternating hyphal layers which are composed of loosely interwoven, thick-walled, colored, even hyphae $3 \mu$ in diameter; setae numerous, slender, subfalcate, $60-75 \times 6 \mu$, originating at all levels in each setigerous layer, protruding up to $50 \mu$; spores hyaline, even, $4 \frac{1}{2} \times 2 \frac{1}{2} \mu$.

Fructifications $4-25 \times 2-10 \mathrm{~cm}$.

Usually on decaying wood of frondose species, rarely on coniferous wood. Canada to Alabama and westward to Washington, California, and

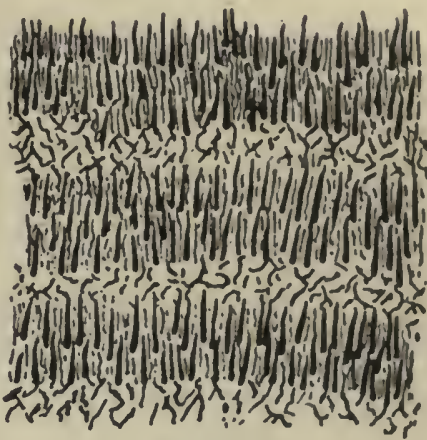

Fig. 19

H. spreta.

Section $\times 44$. From type. British Columbia. April to January. Common.

The stratose structure of well-developed fructifications of $H$. spreta locates this species in a small group of three species, of which the others are $H$. digitata and $H$. cinnamomea, from both of which thick fructifications of $H$. spreta may be separated readily by being deeply cracked and having setigerous layers from $45-150 \mu$, or rarely more, in thickness, very compact, and exceeding in thickness the adjoining, loosely interwoven hyphal layers. Fructifications of $H$. spreta in its firststratum stage, consisting of but one hyphal layer and one setigerous layer, are frequently not cracked but have the setigerous layer $45 \mu$ or more thick and thicker than the hyphal layer.

Specimens examined:

Exsiccati: Ell. \& Ev., N. Am. 'Fungi, 1936, 3304-the latter under the name Hymenochaete unicolor; Ell. \& Ev., Fungi Col., 806, under the name $H$. unicolor.

Canada: Comox, Van Island, J. Macoun, 18.

Prince Edward's Island: J. Macoun, 344.

Ontario: London, J. Dearness; Ottawa, J. Macoun, 6.

New Hampshire: Chocorua, W. G. Farlow, two collections, one of which (in Mo. Bot. Gard. Herb., 55258).

Vermont: Middlebury, C. G. Lloyd, 10671 (in Lloyd Herb., 
and in Mo. Bot. Gard. Herb., 55483), and E. A. Burt, four collections.

New York: Alcove, C. L. Shear, 1310; East Galway, E. A. Burt; Hudson Falls, S. H. Burnham, 45 (in Mo. Bot. Gard. Herb., 54458); Ithaca, G. F. Atkinson, 8656; Karner, H. D. House (in N. Y. State Mus. Herb., 14.159, and in Mo. Bot. Gard. Herb., 44710); New York, W. H. Ballou (in Lloyd Herb., 12121, and in Mo. Bot. Gard. Herb., 55457).

New Jersey: Newfield, J. B. Ellis (in N. Y. Bot. Gard. Herb. and in Mo. Bot. Gard. Herb.).

Pennsylvania: Bethlehem, Schweinitz (in Herb. Schweinitz, under the name Thelephora laevigata and the type of Hymenochaete laevigata Massee).

District of Columbia: Takoma Park, C. L. Shear, 1346.

Georgia: Ribbon Brook, Tallulah Falls, A. B. Seymour, comm. by W. G. Farlow, EE (in Mo. Bot. Gard. Herb., 44603).

Florida: Cocoanut Grove, R. Thaxter, 55 (in Farlow Herb., and in Mo. Bot. Gard. Herb., 43491); Nixon-Lewis Hammock, Dade Co., J. K. Small \& C. A. Mosier, 5396 (in N. Y. Bot. Gard. Herb., and in Mo. Bot. Gard. Herb., 55485).

Alabama: Auburn, F. S. Earle (in N. Y. Bot. Gard. Herb., and in Mo. Bot. Gard. Herb., 55486).

West Virginia: Eglon, C. G. Lloyd, 1450, 1565 (in Lloyd Herb., and in Mo. Bot. Gard. Herb., 55484 and 55488) ; Nuttallburg, L. W. Nuttall, in Ell. \& Ev., N. Am. Fungi, 3304, and in Fungi Col., 806.

Ohio: Cincinnati, A. P. Morgan, comm. by C. G. Lloyd, 2610, and C. G. Lloyd, 3578 .

Indiana: Crawfordsville, D. Reddick, 15; Millers, E. T. \& S. A. Harper, 934.

Kentucky: Crittenden, C. G. Lloyd, 07159, 10836 (in Lloyd Herb., and in Mo. Bot. Gard. Herb., 55468 and 55487).

Montana: Evaro, J. R. Weir, 422 (in Mo. Bot. Gard. Herb., 14766).

Idaho: Priest River, J. R. Weir, 2.

Washington: Bingen, W. N. Suksdorf, 849; Sedro-Woolley, C. J. Humphrey, 7487 (in Mo. Bot. Gard. Herb., 10968); 
Stanwood, C. J. Humphrey, 6395, 7395 (in Mo. Bot. Gard. Herb., 42935 and 11042).

California: Palo Alto, W. A. Murrill \& L. S. Abrams, 1240 (in N. Y. Bot. Gard. Herb.).

British Columbia: J. Macoun, in Ell. \& Ev., N. Am. Fungi, 1936; Kootenai Mts., near Salmo, J. R. Weir, 494 (in Mo. Bot. Gard. Herb., 21796) ; Sidney, J. Macoun, 79, and an unnumbered collection (in Mo. Bot. Gard. Herb., 9967, $6687)$.

24. H. epichlora (Berk. \& Curtis) Cooke, Grevillea $8: 147$. 1880; Sacc. Syll. Fung. 6 : 596. 1888.

Corticium epichlorum Berk. \& Curtis, Grevillea 1:178. 1873; Massee, Linn. Soc. Bot. Jour. 27 : 119. 1890.-Hymenochaete asperata Ell. \& Ev. Torr. Bot. Club Bul. 27 : 50. 1890; Sacc. Syll. Fung. 16 : 188. 1902.

Type: type distribution in Ravenel, Fungi Car. 5 : 24.

Fructification resupinate, broadly effused, thin, adnate, cracked, drying Isabella-color to tawny olive, with a thin oliveocher subiculum forming a slight margin; in structure 75-120 $\mu$ thick, with the hyphal layer composed of loosely arranged, ascending, thinwalled hyphae $2 \frac{1}{2} \mu$ in diameter, colored like the fructification, in some places forming a narrow,

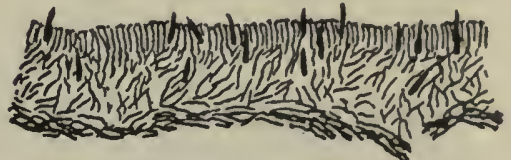

Fig. 20

H. epichlora. dense zone next to the substratum; setae scattered, $36-45 \times$ $4 \frac{1}{2}-5 \mu$, protruding up to $30 \mu$, starting from different levels of the hymenium and subhymenium, tapering upward to a slender point; spores in spore collection white, even, $3-4 \frac{1}{2} X$ $2-2 \frac{1}{2} \mu$, flattened on one side.

Fructifications $5-10 \times 1-3 \mathrm{~cm}$. and broken off at both ends -probably large.

On bark of dead Symplocos, Vitis, and other frondose woods. Alabama to Louisiana and in Mexico. August to November.

$H$. epichlora has some resemblance in aspect to $H$. corrugata on account of its cracked hymenial surface but it is dis- 
tinguished from the latter species by the somewhat sulphuryellow margin and subiculum which forms a broad hyphal layer destitute of setae between the subhymenium and the substratum; the spores of $H$. epichlora are shorter than those of $H$. corrugata and the setae are fewer and smaller.

Specimens examined:

Exsiccati: Ravenel, Fungi Car. 5 : 24, type distribution.

Alabama: Peters, 6118 (in Kew Herb.), and in Ravenel, Fungi Car. 5 : 24.

Louisiana: Abita Springs, 'A. B. Langlois, 2647 to Ellis, type of Hymenochaete asperata (in N. Y. Bot. Gard. Herb., and in Mo. Bot. Gard. Herb., 55491) ; Baton Rouge, Edgerton \& Humphrey, comm. by C. J. Humphrey, 5727; St. Martinville, A. B. Langlois, al, am.

Mexico: Jalapa, W. A. \& Edna L. Murrill, 338, 344, 345 (in N. Y. Bot. Gard. Herb., and in Mo. Bot. Gard. Herb., 54480, 54460, and 54461).

25. H. dura Berk. \& Curtis, Linn. Soc. Bot. Jour. 10 : 334. 1868; Cooke, Grevillea 8 : 147. 1880; Sacc. Syll. Fung. 6 : 596. 1888; Massee, Linn. Soc. Bot. Jour. 27 :

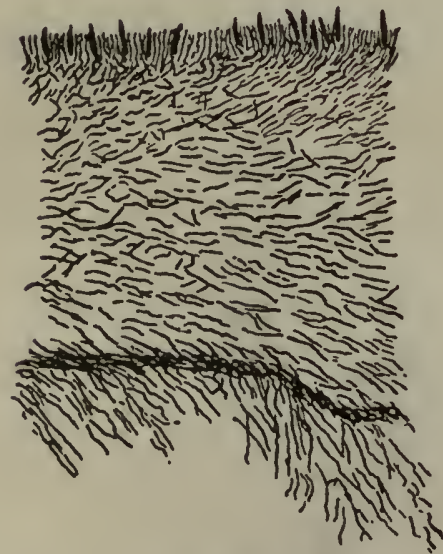

Fig. 21

H. dura.

Section $\times 68$. From type. 105. 1890.

Type: in Kew Herb. and Curtis Herb.

Fructifications resupinate, orbicular, rigid when dry, spongy when moistened, drying between wood-brown and Saccardo's umber, the margin thick, obtuse, paler than the hymenium; in structure 600-700 $\mu$ thick, with the intermediate layer bordered on each side by a narrow, dense, dark zone, that on the under side connecting the intermediate layer with a dense hyphal layer $100 \mu$ broad, situated on the substratum; hyphae of intermediate layer baryta-yellow, $2 \mu$ in diameter, longitudinally arranged, somewhat loosely interwoven; setae 30-36 $\times 5-6 \mu$, scattered between the hair-like paraphyses which they exceed but slightly, terminating in slender, curved, very 
sharp-pointed tips, confined to the hymenium; spores hyaline, even, $5 \times 3 \mu$.

Fructifications $1-3 \mathrm{~cm}$. in diameter.

On dead, erect trees. Cuba. February. Rare.

In the original description, $H$. dura was said to be allied to $H$. unicolor, but if so, it is in aspect only, for when seen in section it is wholly different in structure from the latter, having a narrow setigerous layer and a broad, intermediate layer which is connected by a conspicuous dark zone with a welldeveloped hyphal layer next to the substratum. This structure in section places $H$. dura in the group with $H$. tabacina, from which, and from the other species of this group, it is distinct by its hairy hymenium and small, scattered setae.

Specimens examined:

Cuba: C. Wright, 241, type (in Kew Herb. and in Curtis Herb.).

26. H. leonina Berk. \& Curtis, Linn. Soc. Bot. Jour. 10 : 334. 1868; Cooke, Grevillea $8: 148$. 1880; Sacc. Syll. Fung. 6 : 597. 1888; Massee, Linn. Soc. Bot. Jour. 27 : 107. 1890.

Type: in Kew Herb. and Curtis Herb.

Fructifications resupinate, widely effused, thick, coriaceous, separable from substratum when moist, not cracked, drying tawny olive to Brussels-brown, the margin tomentose; in structure 200-700 $\mu$ thick, composed of (1) a compact setigerous layer 50-75

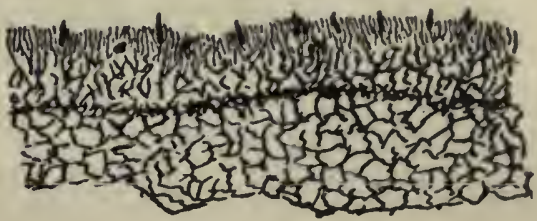

Fig. 22

H. leonina. Section $\times 44$. From type. $\mu$ thick, with the setae starting at different levels within it, and of (2) a broad, supporting hyphal layer 100-600 $\mu$ thick, composed of loosely interwoven, rather longitudinally arranged hyphae $3 \mu$ in diameter, stiff, colored like the fructification; in fully developed, thick fructifications the hyphal layer is divided parallel with the substratum by a nar-

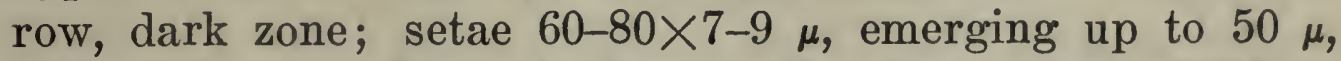
conical, tapering from the base to the apex; spores hyaline, even, $5-6 \times 3-3 \frac{1}{2} \mu$. 
Probably large; small fructifications laterally confluent for $10 \mathrm{~cm}$., 1-2 cm. broad; large fructifications $7 \mathrm{~cm}$. in diameter and broken off on three sides.

On frondose limbs. Arkansas to Mexico, and in Cuba. August to March.

H. leonina has been resupinate in all collections which seem referable here by structure. The species is well marked by its usual tawny olive color, coriaceous structure which enables it to be dissected away from the substratum when moist, by the distribution of the setae in the hymenium and the dark, dense subhymenium, and by the broad, bright-colored hyphal layer which is finally divided in the middle by a narrow, dark zone.

Specimens examined:

Arkansas: Fordyce, C.J.Humphrey, 5837.

Louisiana: Baton Rouge, C. J. Humphrey, 5691 (in Mo. Bot.

Gard. Herb., 20707); St. Martinville, A. B. Langlois, 2091, ai. Mexico: Vera Cruz, Sanborn, C.R. Orcutt, 2920 (in N. Y. Bot.

Gard. Herb., and in Mo. Bot. Gard. Herb., 37362).

Cuba: C. Wright, 532, type (in Kew Herb. and in Curtis Herb.) ; C. G. Lloyd, 143 (in Lloyd Herb., and in Mo. Bot. Gard. Herb., 55474); Alto Cedro, Earle \& Murrill, 505, comm. by N. Y. Bot. Gard. Herb.; Baracoa, Underwood \& Earle, 780, comm. by N. Y. Bot. Gard. Herb.; Pinar del Rio Province, Earle \& Murrill, 197, comm. by N. Y. Bot. Gard. Herb.

\section{H. fulva Burt, n. sp.}

Type: in Burt Herb. and N. Y. Bot. Gard. Herb.

Fructifications resupinate, effused, thin, adnate, not cracking in drying, between Saccardo's umber and cinnamon-brown, the margin entire, determinate; in structure 120-260 $\mu$ thick, with the intermediate layer bordered on each side by a dark, dense zone-that on the under side directly adnate to the substratum and that on the other being subhymenial in position, 40-105 $\mu$ thick, bearing at first few setae but thickening with age and at length having many setae starting in all its parts; hyphae of intermediate layer colored, loosely interwoven, $2 \frac{1}{2}-3 \mu$ in diameter; setae $75-90 \times 7 \frac{1}{2}-9 \mu$, emerg- 
ing up to $60 \mu$, not crowded, starting in the dark subhymenial zone and rising through the hymenium, tapering upward from the base; cystidia $12-30 \times 6-18 \mu$, largest when
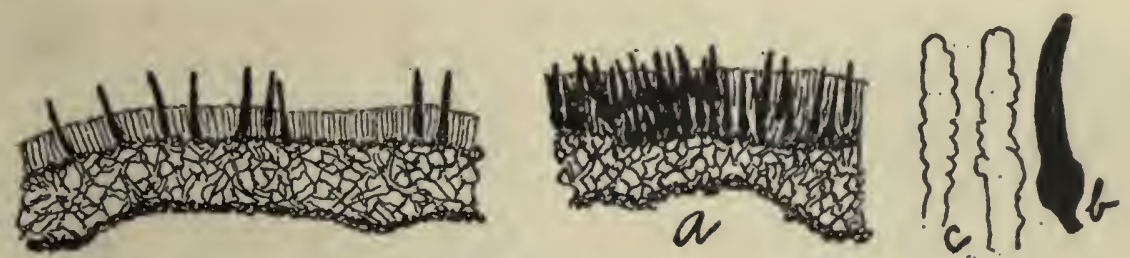

Fig. 23

H. fulva.

Section on left, $\times 68$, from type; section $a, \times 68$, seta, $b$, and cystidia, $c, \times 375$, from Langlois, aj.

seated on the dark, subhymenial zone; spores borne 4 to a basidium, hyaline, even, $4 \frac{1}{2}-5 \times 2 \frac{1}{2}-3 \mu$.

Fructifications $1 \times 1-1 \frac{1}{2} \mathrm{~cm}$., becoming laterally confluent for $7 \mathrm{~cm}$. or more.

On rotting fallen limbs of frondose species. In Louisiana and Jamaica-at 4500-5200 ft. altitude in the latter. December.

H. fulva may be recognized among resupinate species by its fulvous color, not cracking, presence of an intermediate layer bordered on each side by a dark zone, with that on the under side seated directly on the substratum, and by the cystidia.

Specimens examined:

Louisiana: St. Martinville, A. B. Langlois, $a j$, and a specimen comm. by Lloyd Herb., 2422 in part.

Jamaica: Cinchona, W. A. \& Edna L. Murrill, 645, type, comm. by N. Y. Bot. Gard. Herb.; Blue Hole, W. A. Murrill, $182 \frac{1}{2}$, comm. by N. Y. Bot. Gard. Herb.

28. H. pinnatifida Burt, n. sp.

Type: in Lloyd Herb. and Burt Herb.

Fructifications resupinate, effused, adnate, scattered, sometimes confluent, somewhat orbicular, drying between Veronabrown and cinnamon-drab, slightly glaucous, the margin antique brown, narrow, rather thick, somewhat velvety; in structure 120-240 $\mu$ thick, composed of a setigerous layer $40-80 \mu$ broad and of a loosely interwoven intermediate layer which is 
bordered on each side by a narrow, dense, dark zone; hyphae

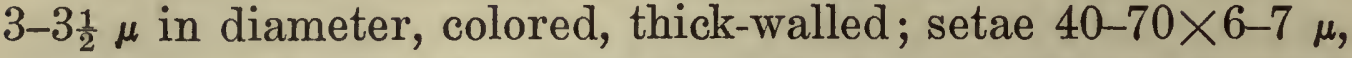
emerging up to $30 \mu$, tapering from the base, abundant but not crowded; c o lo red para-

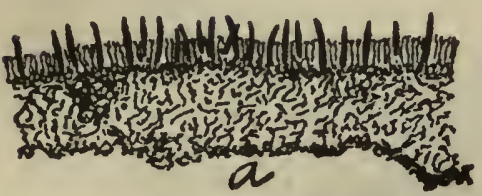

Fig. 24

H. pinnatifida.

Section, $a, \times 68$; paraphyses, $p, \times 640$. See $p l .17, f .12$.

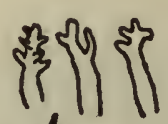

p

physes 1-2 $\mu$ in diameter, with pinnatifid tips, are conspicuous in the hymenium; spores hyaline, even, flattened on one side, $4-5 \times 1 \frac{1}{2} \mu$, borne 4 to a basidium as seen in preparations of sections.

Fructifications about $1-3 \mathrm{~cm}$. in diameter.

On bark of fallen frondose limbs. Georgia to Louisiana, in Mexico, Cuba, and Jamaica. August to April. Apparently common.

$H$. pinnatifida has some resemblance to resupinate $H$. rubiginosa, but the setae of the former are less conspicuous with the aid of a lens; the presence of colored paraphyses with pinnatifid tips distinguishes $H$. pinnatifida from all other nonstratose species.

Specimens examined:

Exsiccati: Ell. \& Ev., N. Am. Fungi, 1713, under the name Hymenochaete insularis; Ravenel, Fungi Am., 122, under the name Hymenochaete rubiginosa.

Georgia: Atlanta, E. Bartholomew, 5675 (in Mo. Bot. Gard. Herb., 44260).

Florida: G. C. Fisher (in Lloyd Herb., 08238); W. W. Calkins, 82, 93 (in N. Y. Bot. Gard. Herb., and in Mo. Bot. Gard. Herb., 55489, 55490), and in Ell. \& Ev., N. Am. Fungi, 1713; Gainesville, H. W. Ravenel, in Ravenel, Fungi Am., 122; Jacksonville, W.W. Calkins (in N. Y. Bot. Gard. Herb., and in Mo. Bot. Gard. Herb.) ; New Smyrna, C. G. Lloyd, 2139, type, and 2140.

Alabama: Auburn, F. S. Earle, 114 (in N. Y. Bot. Gard. Herb., and in Mo. Bot. Gard. Herb., 55492).

Mississippi: Jackson, E. Bartholomew, 5798 (in Mo. Bot. Gard. Herb., 44268). 
Louisiana: Abita Springs, A. B. Langlois, 2647 to Burt; Bogalusa, C.J. Humphrey, 5491; St. Martinville, A. B. Langlois, 1621, $c b, c d, D$, and a specimen from Lloyd Herb., 2422 in part; definite locality not stated, A. B. Langlois, 136 (in U. 'S. Dept. Agr. Herb., in Farlow Herb., and in Mo. Bot. Gard. Herb., 44047).

Mexico: Botteri, 31 (in Curtis Herb., under the name Hymenochaete rubiginosa).

Cuba: Managua, Earle \& Murrill, 6, 31, comm. by N. Y. Bot. Gard. Herb.

Jamaica: Mandeville, A.E. Wight, comm. by W. G. Farlow.

29. H. multisetae Burt, n. sp.

Type: in Mo. Bot. Gard. Herb. and Humphrey Herb.

Fructifications resupinate, effused, adnate, thin, cinnamonbrown to Prout's brown, finally somewhat cracked, the margin determinate; in structure $35-100 \mu$ thick, lacking an intermediate layer, with the setigerous layer dense and opaque; setae very abundant and crowded, small, 27$45 \times 4 \frac{1}{2}-5 \mu$, emerging up to $30 \mu$, starting from all parts of the setigerous layer,

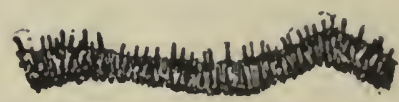

Fig. 25

H. multisetae. Section $\times 68$. From type. tapering upward; spores hyaline, even, $3-4 \times 1-2 \mu$, but few found.

Fructifications $2-10 \times 1-2 \mathrm{~cm}$, sometimes encircling small limbs.

On fallen hardwood limbs in wet wooded region. Cuba and Jamaica. December and January.

$H$. multisetae belongs in the same group of species as $H$. opaca, which it resembles in aspect. It may be distinguished from the latter by its thinner fructifications and smaller setae.

Specimens examined:

Cuba: Ceballos, C. J. Humphrey, 2808, type (in Mo. Bot. Gard. Herb., 1786).

Jamaica: Chester Vale, W. A. \& Edna L. Murrill, 325, 346, comm. by N. Y. Bot. Gard. Herb.; Moneague, W. A. Murrill, 1186, comm. by N. Y. Bot. Gard. Herb.; Troy and Tyre, 
W. A. Murrill \& W. Harris, 926, comm. by N. Y. Bot. Gard. Herb.

30. H. anomala Burt, n. sp.

Type: in Burt Herb. and N. Y. Bot. Gard. Herb.

Fructification resupinate, adnate, thin, vinaceous-buff, cracked, the margin determinate; in structure 75-125 $\mu$ thick,
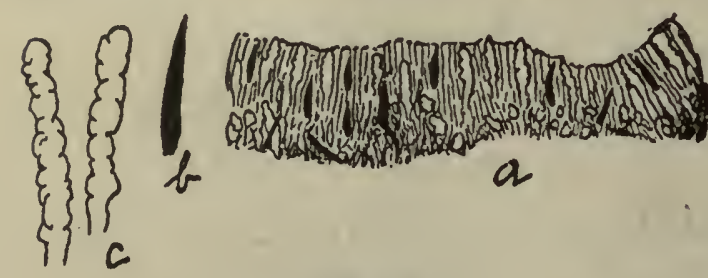

Fig. 26

H. anomala.

Section, $a, \times 120$; seta, $b$, and cystidia, c, $\times 375$. From type. lacking a hyphal layer, composed of scattered setae, cystidia, suberect, colorless, incrusted hyphae, and crystalline matter; setae $20-50 \times 4 \frac{1}{2} \mu$, emerging up to $20 \mu$ but usually not emerging, flexuous, tapering upward, starting from all parts of the setigerous layer; cystidia colorless, incrusted, $16-20 \times 6 \mu$, not emergent; spores hyaline, even, $4 \times 2 \frac{1}{2} \mu$.

Fructification $2 \frac{1}{2} \mathrm{~cm} . \times 5 \mathrm{~mm}$., broken off at one end.

On prostrate decorticated limbs in dry thickets. Cuba. March. Rare.

$H$. anomala is noteworthy by its pale color, small fructification, setae only rarely protruding, and incrusted hyphae and cystidia. It differs from $H$. cervina in paler color outside and within, and in having cystidia.

Specimens examined:

Cuba: Managua, Earle \& Murrill, 36, type, comm. by N. Y.

Bot. Gard. Herb.

31. H. corrugata (Fr.) Léveillé, Ann. Sci. Nat. Bot. III. 5 : 152. 1846; Cooke, Grevillea 8 : 147. 1880; Sacc. Syll. Fung. 6 : 595. 1888; Massee, Linn. Soc. Bot. Jour. 27 : 110. 1890.

Thelephora corrugata Fries, Obs. Myc. 1 : 154. 1815; Elenchus Fung. 1 : 224. 1828; Persoon, Myc. Eur. 1 : 134. 1822.Corticium corrugatum Fries, Epicr. 565. 1838; Hym. Eur. 656. 1874. - Hymenochaete insularis Berkeley, Grevillea 1:165. 1873; Cooke, Grevillea 8 : 148. 1880; Sacc. Syll. Fung. 6 : 598. 1888; Massee, Linn. Soc. Bot. Jour. 27 : 107. 1890. 
Type: authentic specimen from Fries reported in Kew Herb. by Massee, loc. cit.

Fructifications resupinate, widely effused, closely adnate, cracked into small 4-6-sided areas, sometimes grumous, drying from cinnamon-brown to bister and Rood's brown and sometimes weathered to mouse-gray, the margin thinning out and sometimes paler; in structure $150-500 \mu$ thick, composed of densely interwoven hyphae $3 \mu$ in diameter, colored like the fructification, and of very numerous setae 60 $70 \times 8-12 \mu$, emerging up to $50 \mu$, somewhat cylindric below, taper-

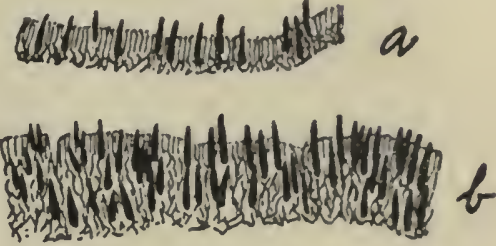

Fig. 27

H. corrugata.

Section of young fructification, $a$, and of older fructification, $b, \times 68$. ing above, distributed throughout the fructification; spores white in collection on slide, even, allantoid, $4 \frac{1}{2}-7 \times 1 \frac{1}{2}-2 \mu$.

Very variable in size, ranging from $2 \frac{1}{2} \times 1 \mathrm{~cm}$. to $20 \times 7 \mathrm{~cm}$., sometimes much larger.

Very common on dead fallen limbs and trunks of frondose species, such as beech, maple, birch, and alder, rarely on coniferous wood. Canada to Texas and westward to Ohio and Kentucky, and in Jamaica. July to April.

The distinguishing characters of $H$. corrugata are its closely adnate fructification, which cracks into small, polygonal areas about 1-3 to a $\mathrm{mm}$. and sometimes scales off, distribution of the rather stout setae throughout the whole very dense fructification from substratum to hymenium, and white, allantoid spores about $4 \frac{1}{2}-7 \times 1 \frac{1}{2}-2 \mu$. American collections of $H$. corrugata have a broader range in color than the European collections cited below. H. insularis Berk. is based upon a specimen Rood's brown in color, with whitish margin, orbicular form, and thickness of $160 \mu$. I have tried to regard $H$. insularis as a distinct species but it intergrades too completely in all its characters with typical $H$. corrugata. H. episphaeria (Schw.) is very near $H$. corrugata but is less cracked, extremely thin, and has most of its setae starting conspicuously on a dark delimiting zone next to the substratum. 
Specimens examined:

Exsiccati: Bartholomew, Fungi Col., 4425, 4931; Berkeley, Brit. Fungi, 249, 298; Ellis, N. Am. Fungi, 14; Ell. \& Ev., Fungi Col., 8; Krieger, Fungi Sax., 717, 1422, the latter under the name Hymenochaete cinnamomea; Krypt. Exs. Vind., 714; Ravenel, Fungi Am., 123, under the name Hymenochaete crocata, 124; Fungi Car. 5:26; Shear, N. Y. Fungi, 53; de Thümen, Myc. Univ., 9.

England: Berkeley, Brit. Fungi, 249, 298.

France: (in Lloyd Herb., 3346).

Germany: Saxony, W. Krieger, in Krieger, Fungi Sax., 717, 1422.

Austria-Hungary: Rosenau, P. Strasser, Krypt. Exs. Vind., 714.

Canada: J. Macoun, 17, 19, 25; Lower St. Lawrence Valley, J. Macoun, 63 .

Ontario: Casselman, J. Macoun, 362, 365; London, J. Dearness, in Bartholomew, Fungi Col., 4425, and (in Lloyd Herb., 12001) ; Temagami, C. G. Lloyd, 07564 (in Lloyd Herb.).

Quebec: Hull, J.Macoun, 242.

Maine: Costigan, W. A. Murrill, 1761 (in N. Y. Bot. Gard. Herb., and in Mo. Bot. Gard. Herb., 55459); Orono, $F . L$. Harvey, comm. by P. L. Ricker, 1, 2.

New Hampshire: P. Wilson (in N. Y. Bot. Gard. Herb., and in Mo. Bot. Gard. Herb., 55471); Chocorua, W. G. Farlow.

Vermont: Middlebury, E. A. Burt, two collections; Smugglers' Notch, E. A. Burt; Ripton, E. A. Burt.

Massachusetts: Magnolia, W. G. Farlow, two collections; Sharon, W. G. Farlow (in Mo. Bot. Gard. Herb., 6960), A. P. D. Piguet, two collections, comm. by W. G. Farlow (in Mo. Bot. Gard. Herb., 44046, 55228) ; Wellesley, L. W. Riddle, 15. New York: Adirondack Mts., C. H. Peck, T 27 (in N. Y. State Mus. Herb., and in Mo. Bot. Gard. Herb., 54650); Albany, C. G. Lloyd, or179 (in Lloyd Herb., and in Mo. Bot. Gard. Herb., 55482); Alcove, C. L. Shear, 1003, and in Shear, N. Y. Fungi, 53; Catskill Mts., C. H. Peck, T 11 (in N. Y. State Mus. Herb., and in Mo. Bot. Gard. Herb., 54578); East Galway, E. A. Burt; Freeville, G. F. Atkinson, 3279; 
Fort Ann, S. H. Burnham, 39 (in Mo. Bot. Gard. Herb., 54423); Hudson Falls, S. H. Burnham, 30 (in Mo. Bot. Gard. Herb., 54482); Ithaca, G. F. Atkinson, 2815; Karner, H. D. House (in N. Y. State Mus. Herb., and in Mo. Bot. Gard. Herb., 55196); Lake Placid, W. A. \& Edna L. Murrill, 152 (in N. Y. Bot. Gard. Herb., and in Mo. Bot. Gard. Herb., 55001); North Greenbush, H. D. House, two collections (in N. Y. State Mus. Herb., and in Mo. Bot. Gard. Herb., 54385/6) ; Orient, R. Latham, 154 (in Mo. Bot. Gard. Herb., 44229).

New Jersey: Newfield, J. B. Ellis, in Ellis, N. Am. Fungi, 14, in Ell. \& Ev., Fungi Col., 8, and in de Thümen, Myc. Univ., 9. Pennsylvania: Charter Oak, L. O. Overholts, 3773 (in Mo. Bot. Gard. Herb., 54991); Trexlertown, W. Herbst, 79.

Maryland: Takoma Park, C. L. Shear, 1161.

North Carolina: $M$. A. Curtis, 4456, type of $H$. insularis (in Kew Herb. and in Curtis Herb.).

South Carolina: Aiken, H.W. Ravenel, in Ravenel, Fungi Am., 123, 124.

Florida: New Smyrna, C. G. Lloyd, 2120.

Alabama: Peters, in Ravenel, Fungi Car. 5 : 26; Montgomery, R. P. Burke, 53, 63 (in Mo. Bot. Gard. Herb., 16746, 18222). Mississippi: Jackson, E. Bartholomew, 5780 (in Mo. Bot. Gard. Herb., 9188), and in Bartholomew, Fungi Col., 4931.

Louisiana: St. Martinville, A. B. Langlois, cc, and an unnumbered collection.

Texas: Houston, H. W. Ravenel, 261.

West Virginia: Eglon, C. G. Lloyd, 1411 (in Lloyd Herb., and in Mo. Bot. Gard. Herb., 55470); Paw Paw, C. L. Shear, 1178.

Michigan: Isle Royal, Allen \& Shuntz, 16, comm. by Univ. of Wisconsin Herb.

Ohio: Cincinnati, A. P. Morgan, comm. by Lloyd Herb., 2593; College Hill, Aiken, comm. by Lloyd Herb., 2328.

Kentucky: Crittenden, C. G. Lloyd, N; Harlan, C. H. Kauffman, 74 (in Mo. Bot. Gard. Herb., 21533).

Jamaica: Morce's Gap, W. A. \& Edna L. Murrill, 732, comm. by N. Y. Bot. Gard. Herb. 
32. H. episphaeria (Schw.) Massee, Linn. Soc. Bot. Jour. 27 : 111. 1890; Cooke, Grevillea 20 : 11. 1891; Sacc. Syll. Fung. $11: 123.1895$.

Thelephora episphaeria Schweinitz in Fries, Elenchus Fung. 1 : 225, 1828; Am. Phil. Soc. Trans. N. S. 4 : 169. 1832.

Type: in Herb. Schweinitz, Kew Herb., and Curtis Herb.

Fructification resupinate, effused, closely adnate, conforming to the irregularities of the substratum, drying buckthornbrown to tawny olive; in structure up to $90 \mu$ thick, with hyphae

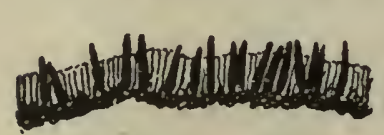

Fig. 28

H. episphaeria.

Section $\times 68$. From type. rigid, interwoven, $2-2 \frac{1}{2} \mu$ in diameter, giving their color to the fructification; setae 60-90×9-12 $\mu$, emerging up to $15 \mu$, cylindric, obtuse, starting directly from the dark, opaque, delimiting zone next to the substratum, as differentiated in permanent preparations which were treated with $\mathrm{KHO}$ solution and stained with eosin; no spores found in type, but hyaline, even, allantoid, $4-5 \times 1 \frac{1}{2}-2 \mu$ in collections referred here.

Fructifications 1-2 cm. broad, $2-5 \mathrm{~cm}$. long.

Under side of dead frondose limbs-type on Alnus and Diatrype stigma. Vermont to Pennsylvania and Illinois.

$H$. episphaeria resembles $H$. arida and $H$. cinnamomea in aspect, but is thinner, lacks a hyphal layer, and has its setae starting from the substratum, or very near it, and extending up through the hymenium.

Specimens examined:

Vermont: Middlebury, C. G. Lloyd, 07221 (in Lloyd Herb., and in Mo. Bot. Gard. Herb., 55558).

Massachusetts: Weston, A. B. Seymour, T 19 (in Mo. Bot. Gard. Herb., 18358).

New York: Albany, C. G. Lloyd, 07120 (in Lloy.d Herb., and in Mo. Bot. Gard. Herb., 55481).

Pennsylvania: Bethlehem, Schweinitz, type (in Herb. Schweinitz, in Kew Herb., and in Curtis Herb.) ; Trexlertown, $W$. Herbst, comm. by Lloyd Herb., 3612.

Ohio: Cincinnati, A.P.\&L.V. Morgan, under the name $H$. insularis, comm. by U. S. Dept. Agr. Herb.

Illinois: River Forest, E.T.\& S. A. Harper, 742. 
33. H. cervina Berk. \& Curtis, Linn. Soc. Bot. Jour. 10 : 334. 1868; Cooke, Grevillea 8:147. 1880; Sacc. Syll. Fung. 6 : 596. 1888; Massee, Linn. Soc. Bot. Jour. 27 : 114. 1890.

Type: in Kew Herb. and Curtis Herb.

Fructification resupinate, effused, adnate, very thin, usually cracked, drying Dresden-brown, the margin thinning out; in structure 80-200 $\mu$ thick, composed of densely interwoven, suberect hyphae, of crystalline masses, and of setae; hyphae $2 \frac{1}{2}-3 \mu$ in diameter, giving their color to the fructification; crystalline masses $12-15 \mu$ in diameter; setae distributed in all parts of the section and some starting from the substratum, $60-90 \times$ 10-12 $\mu$, emerging up to $40 \mu$,

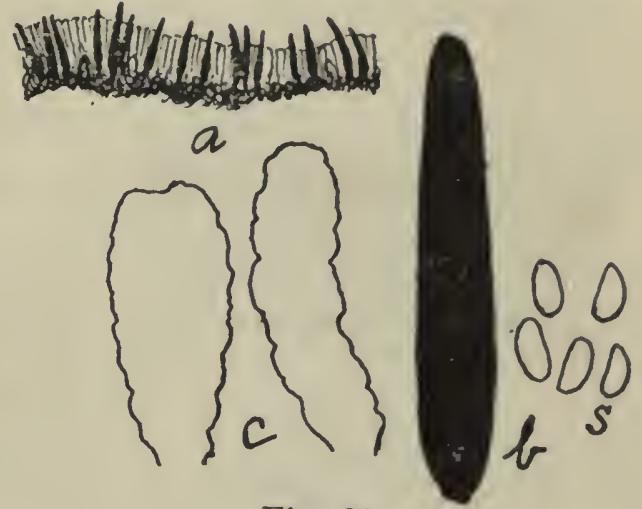

Fig. 29

H. cervina.

Section, $a, \times 68$; seta, $b$, cystidia, $c$, and spores, $s, \times 640$. From type. tapering from the base to a sharp apex; spores hyaline, even, $7-9 \times 3 \frac{1}{2} \mu$.

Fructifications $5 \mathrm{~cm}$. or more long, about 1-2 cm. broad.

On dead limbs and decorticated wood. Illinois, Louisiana, and Cuba.

By reason of its thin fructification, few hyphae, and abundant setae starting from substratum, $H$. cervina is near $H$. episphaeria in structure and general aspect, but may be distinguished from this species by larger spores and by the presence of cystidia which finally become crystalline masses. Berkeley's comment that specimens of $H$. cervina resemble Hymenochaete Curtisii is misleading and probably due to his having referred to $H$. cervina a collection of Stereum umbrinum, the Curtis Herb., 2308.

Specimens examined:

Louisiana: 'A. B. Langlois, 267, comm. by U. S. Dept. Agr. Herb.

Cuba: C. Wright, 213, type (in Kew Herb. and in Curtis 
Herb.) ; Alto Cedro, Underwood \& Earle, 1527, comm. by N. Y. Bot. Gard. Herb.

34. H. opaca Burt, n. sp.

Type: in Burt Herb. and N. Y. Bot. Gard. Herb.

Fructifications resupinate, effused, adnate, when slightly velvety, very thin, and between bister and Van brown, finally becoming glabrous, somewhat thicker, Vandyke-

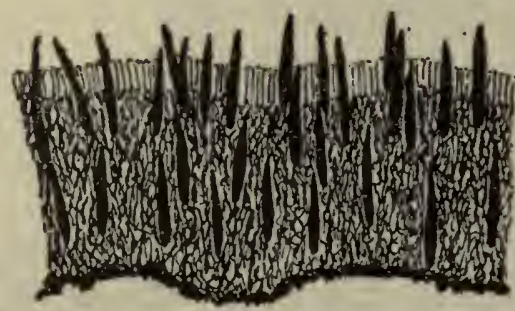

Fig. 30

H. opaca.

Section $\times 68$. From type. brown and cracked, the margin thinning out; in structure 200-300 $\mu$ thick, lacking an intermediate layer, with the setigerous layer very dense and opaque and composed of suberect, interwoven, dark hyphae, and of setae; setae $50-90 \times 8-10 \mu$, emerging up to $60 \mu$, starting from all parts of the setigerous layer; spores hyaline, even, $3 \frac{1}{2}-5 \times 1 \frac{1}{2}-2 \mu$.

Fructifications $3-5 \times 1-2 \mathrm{~cm}$.

On bark of dead frondose limbs. Wet, wooded region, 2000-4000 ft. altitude. Jamaica. December and January.

$H$. opaca belongs in the group with $H$. corrugata and $H$. tenuis, from both of which it differs by its velvety surface when young, different color, darker hyphae, and denser and more opaque structure in sectional preparations.

Specimens examined:

Jamaica: Chester Vale, W. A. \& Edna L. Murrill, 297, comm. by N. Y. Bot. Gard. Herb.; Cinchona, W. A. \& Edna L. Murrill, 538, type, comm. by N. Y. Bot. Gard. Herb.; Troy and Tyre, W. A. Murrill \& W. Harris, 923, 93\%, comm. by N. Y. Bot. Gard. Herb.

35. H. tenuis Peck, N. Y. State Mus. Rept. 40 : 57. 1887 ; Sacc. Syll. Fung. 6 : 599. 1888; Massee, Linn. Soc. Bot. Jour. $27: 109.1890$.

Type: in N. Y. State Mus. Herb.

Fructifications resupinate, effused, becoming confluent, very thin, adnate, somewhat cracked, velvety, drying from raw umber to mummy-brown, the margin thinning out, indeter- 
minate; in structure $30-75 \mu$ thick, composed of a setigerous layer of densely interwoven hyphae $1 \frac{1}{2} \mu$ in diameter and of very numerous setae uniformly distributed from substratum to hymenium, $36-45 \times 5-7 \mu$, protruding up

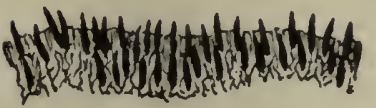

Fig. 31

H. tenuis. Section $\times 68$. From type. to $30 \mu$, tapering upward, and terminating in slender, somewhat curved, very sharp tips; spores in spore collection white, even, flattened on one side, $4 \frac{1}{2}-5 \frac{1}{2} \times 2-2 \frac{1}{2} \mu$.

Fructifications $\frac{1}{2}-1 \frac{1}{2} \times \frac{1}{2} \mathrm{~cm}$, finally confluent over areas up to $7 \times 2-2 \frac{1}{2} \mathrm{~cm}$.

On bark and decorticated wood of fallen limbs of Thuja, Tsuga, and Sabal. Vermont to Florida and in British Columbia. August to June. Rare.

$H$. tenuis belongs in the group of species with $H$. corrugata and $H$. episphaeria, from which it differs by occurrence on coniferous substratum, raw umber color, and smaller setae and the spores. The cracking of the fructification tends toward rectangular areas, as in $H$. spreta, rather than to 5or 6 -sided polygons, characteristic of $H$. corrugata.

Specimens examined:

Vermont: Ripton, E. A. Burt.

New York: Altamont, E. A. Burt; Adirondack Mts., C. $H$. Peck, type (in N. Y. State Mus. Herb.).

Pennsylvania: Bellefonte, L. O. Overholts, 3730 (in Mo. Bot. Gard. Herb., 55095).

Florida: Green Cove Springs, Dr. Martin (in Ellis Coll. of N. Y. Bot. Gard. Herb., and in Mo. Bot. Gard. Herb., 55004). British Columbia: Kootenai Mts., near Salmo, J. R. Weir, 499 (in Mo. Bot. Gard. Herb., 3916).

36. H. fuliginosa (Pers.) Bresadola, ${ }^{1}$ Ann. Myc. 1:93. 1903.

Thelephora fuliginosa Persoon, Myc. Eur. 1 :145. 1822.Stereum fuliginosum (Pers.) Fries, Epicr. 554. 1838; Нym.

1 Bresadola states, loc. cit., that $H$. fuliginosa as understood by him is not $H$. fuliginosa (Pers.) Lev., although both give the same synonymy with the name. Leveille's combination has priority if both authors refer to the same species and it precludes Bresadola's later use of this name for a different species: hence, if, as Bresadola states, $H$. fuliginosa sensu Léveille is distinct from $H$. fuliginosa sensu Bresadola, then Hymenochaete fusca Karsten is the name which should stand instead of the combination by Bresadola. 
Eur. 645. 1874.-Hymenochaetella fusca Karsten, Hedwigia 35 : 174. 1896. - Hymenochaete fusca Karsten in Sacc. Syll. Fung. $14: 218.1900$.

Fructifications resupinate, broadly effused, adnate, thin, not cracked, somewhat colliculose, bister to warm sepia, conspicuously setulose under a lens, the margin determinate; in

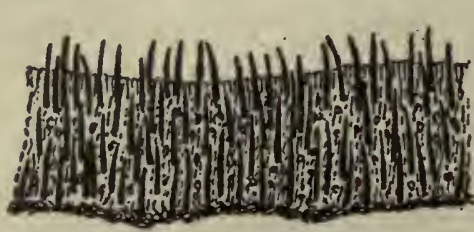

Fig. 32

$\mathrm{H}$. fuliginosa.

Section $\times 68$. From Bresadola. See $p l .17, f .10$. structure with setigerous layer 150 $200 \mu$ thick, sessile upon the substratum; setae abundant, $60-75 \times 8-9$ $\mu$, emerging up to $45 \mu$, starting from all parts of the setigerous layer; spores of spore collection white, even, $4 \times 2 \mu$.

Covering areas up to $15 \times 5 \mathrm{~cm}$.

On decorticated, rotting wood of frondose species. Vermont, Maryland, Ohio, Kentucky, and in Cuba. June to October. Local.

$H$. fuliginosa has the aspect of a resupinate $H$. rubiginosa, but is not separable and lacks the conspicuous ochraceoustawny margin of the latter; when sections are viewed with the microscope they show a setigerous layer like that of $H$. rubiginosa but differing by having this setigerous layer seated directly upon the substratum instead of upon an intermediate layer. The structure in section places $H$. fuliginosa in the group of species with $H$. corrugata; it is distinguished from the latter by not cracking, by colliculose surface, and by color. American specimens agree well with that received from Bresadola, whom I have followed as to name for the present.

Specimens examined:

Sweden: authentic specimen from Karsten of Hymenochaete fusca, comm. by J. Bresadola.

Austria-Hungary: Hungary, Kmet, det. and comm. by J. Bresadola.

Vermont: Middlebury, E. A. Burt, three collections, and C. G. Lloyd, 10693 (in Lloyd Herb., and in Mo. Bot. Gard. Herb., 55555 ).

Maryland: Takoma Park, C. L. Shear, $115 \%$. 
Ohio: Cincinnati, A. P. Morgan, comm. by Lloyd Herb., 2642; locality not stated, C. G. Lloyd, 3579.

Kentucky: Crittenden, C. G. Lloyd, 1414 (in Lloyd Herb., and in Mo. Bot. Gard. Herb., 55556).

Cuba: C. G. Lloyd, 435 (in Lloyd Herb., and in Mo. Bot. Gard. Herb., 55156).

\section{SPECIES IMPERFECTLY KNOWN}

37. Hymenochaete pallida Cooke \& Massee, Linn. Soc. Bot. Jour. 27 : 97. 1890; Sacc. Syll. Fung. 9 : 227. 1891.

Type: in Kew Herb.

"Cartilagineo-coriacea; pileo reniformi v. subflabellato, applanato, spongioso-velutino, pallido, concentrice sulcatozonato, margine sublobato, acuto; hymenio lineato-rugoso, velutino, umbrino, subrutilante; setis prominulis, subclavatis, $40-50 \times 5 \mu$; sporae ellipsoideae, $6 \times 3-4 \mu$. (Type in Herb. Kew.)

"Mexico.

"Pilei thin, 1-2 in. across, densely velvety, the pile arranged in a porous, sponge-like manner, pallid, when old almost white."

-Original description.

I did not find the type of $H$. pallida in Kew Herbarium and can make no addition to the above description.

\section{EXCLUDED SPECIES}

Hymenochaete abnormis Peck, H. fimbriata Ell. \& Ev., and $H$. rugispora Ell. \& Ev. have colored paraphyses rather than cystidia and will receive consideration in Stereum.

Hymenochaete crassa (Lév.) Berk. is Stereum umbrinum or very near it.

Hymenochaete frustulosa Berk. \& Curtis is Septobasidium frustulosum.

Hymenochaete multispinulosa Peck is Stereum umbrinum. Hymenochaete musicola Berk. \& Curtis is an Asterostroma. Hymenochaete paupercula Berk. \& Curtis is a Peniophora. 
Hymenochaete purpurea Cooke \& Morgan is Stereum umbrinum.

Hymenochaete setosa Berk. \& Curtis is a Hyphomycete.

Hymenochaete siparia Berk. \& Curtis is a Septobasidium in poor condition.

Hymenochaete tomentosa Berk. \& Curtis is a Hyphomycete.

(To be continued.) 


\section{Explanation of Plate}

\section{PLATE 16}

The figures of this plate have been reproduced natural size from dried herbarium specimens.

Fig. 1. Hymenochaete damaecomis. Figure on right, from specimen collected in Jamaica by L. M. Underwood, 1399; two on left, from collection in Cuba by J. A. Shafer, 3326.

Fig. 2. H. formosa stage. From collection in British Honduras by M. E. Peck.

Fig. 3. H. aspera. Upper figure, upper surface of reflexed portion of specimen collected in Cuba by F. S. Earle, 340; lower figure, hymenium of resupinate specimen collected in Cuba by Underwood and Earle, 1513.

Fig. 4. H. badio-ferruginea. Collected at East Galway, New York, by E. A. Burt.

Fig. 5. H. Berkeleyana. Upper figure, a rosette-like cluster viewed from above, collected in Jamaica by W. A. and E. L. Murrill, 371 ; lower figure, hymenium of a single pileus.

Fig. 6. H. borealis. Upper figure, a cluster of imbricated fructifications from the type collected at Abby Pond, Ripton, Vermont, by E. A. Burt; lower figure, hymenium of a single pileus.

Fig. 7. $H$. corticolor. Reflexed specimens collected at Gainesville, Florida, by N. L. T. Nelson. 


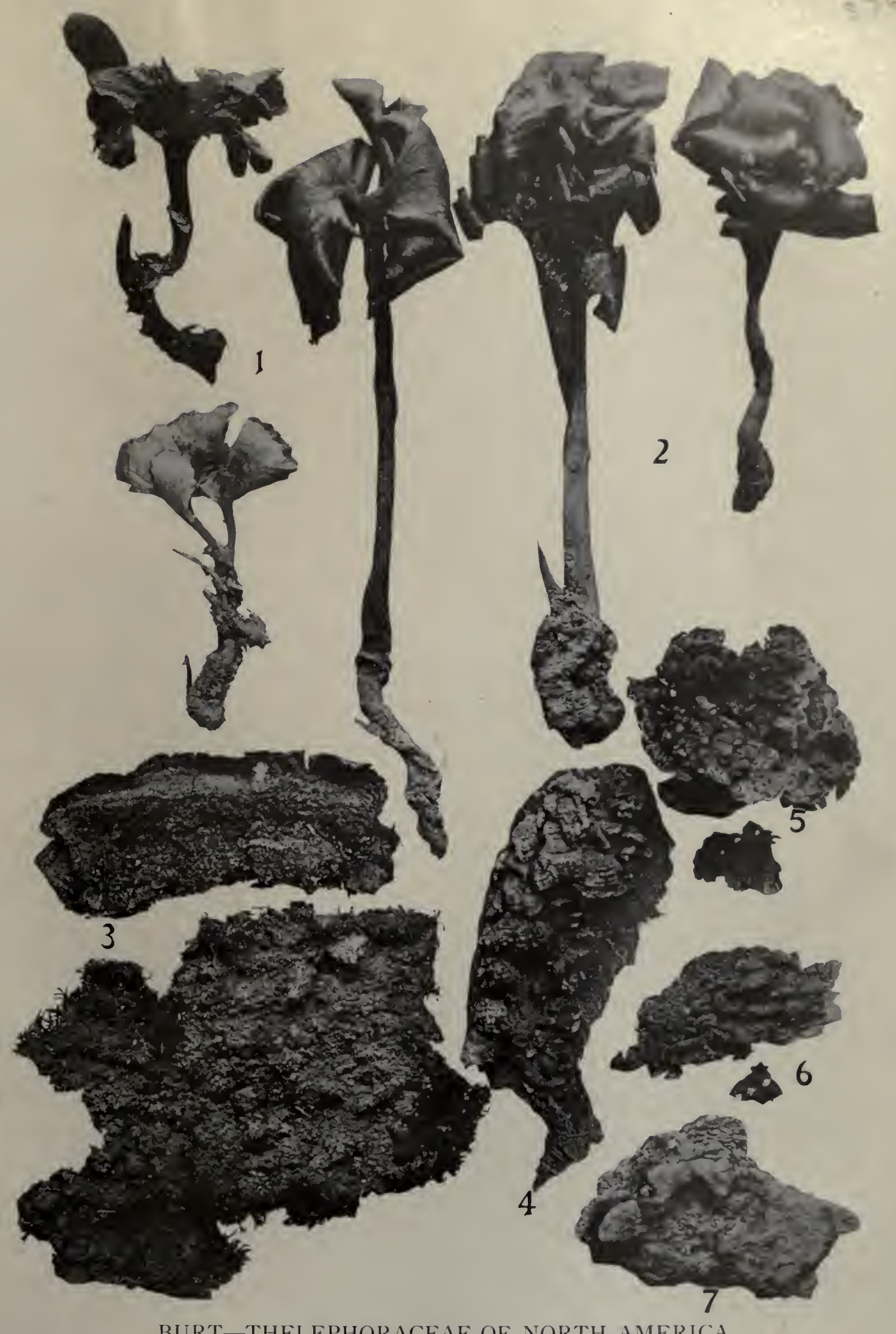

BURT-THELEPHORACEAE OF NORTH AMERICA

1. HYMENOCHAETE DAMAECORNIS.-2. H. FORMOSA STAGE.-3. H. ASPERA.-4. II. BADIOFERRUGINEA. -5. H. BERKELEYANA.-6. H. BOREALIS.-7. H. CORTICOLOR. 



\section{Explanation of Plate}

\section{PLATE 17}

The figures of this plate have been reproduced natural size from dried herbarium specimens.

Fig. 8. Hymenochaete cubensis. Figure on left, upper side of pileus, and figure on right, hymenium of two small pilei, from collection in Cuba by Underwood and Earle, 1565.

Fig. 9. H. Curtisii. Reflexed specimens on bark collected near St. Louis, Missouri, by L. O. Overholts; the lower figure shows upper surface of the narrowly reflexed part.

Fig. 10. H. fuliginosa. Collected at Middlebury, Vermont, by E. A. Burt.

Fig. 11. H. luteo-badia. Upper figure, upper surface, and lower figure, hymenium of specimen from, type distribution in Weigelt Exs., 1827, collected in Dutch Guiana.

Fig. 12. H. pinnatifida. From collection at New Smyrna, Florida, by C. G. Lloyd, 2140.

Fig. 13. H. reflexa. Upper figure, upper surface, and lower figure, hymenium of type collected in Jamaica by W. A. Murrill and W. Harris, 989.

Fig. 14. H. rubiginosa. Collected at Lake Dunmore, Vermont, by E. A. Burt.

Fig. 15. H. Sallei. Upper figure, upper surface, and lower figure, hymenium of specimen collected in Florida by C. G. Lloyd, 2071.

Fig. 16. H. tabacina. Collected at North Ferrisburg, Vermont, by $\mathrm{E}$. A. Burt. The cross lines of half-tone reproduction render somewhat indistinct the systems of cracks of the hymenium which were hoped to be shown.

Fig. 17. H. ungulata. From the type, collected at Jalapa, Mexico, by W. A. and E. L. Murrill, 176. 


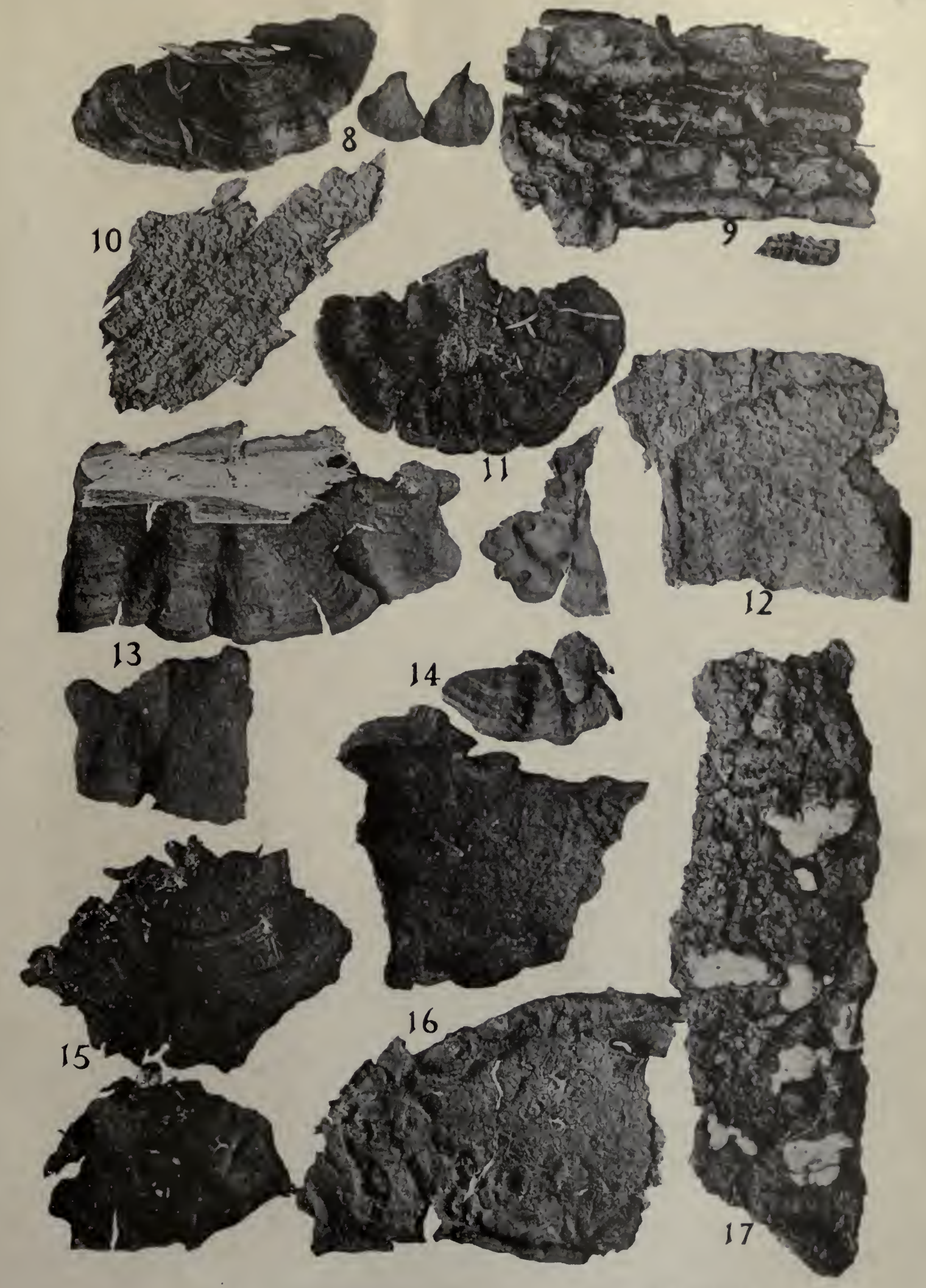

BURT-THELEPHORACEAE OF NORTH AMERICA

8. HYMENOCHAETE CUBENSIS.-9. H. CURTISII-10. H. FULIGINOSA.-11. H. LUTEO-IBADIA.12. H. PINNATIFIDA.-13. H. REFLEXA.-14. H. RUBIGINOSA.-15. H. SALLEI.16. H. TABACINA.-17. H. UNGULATA. 


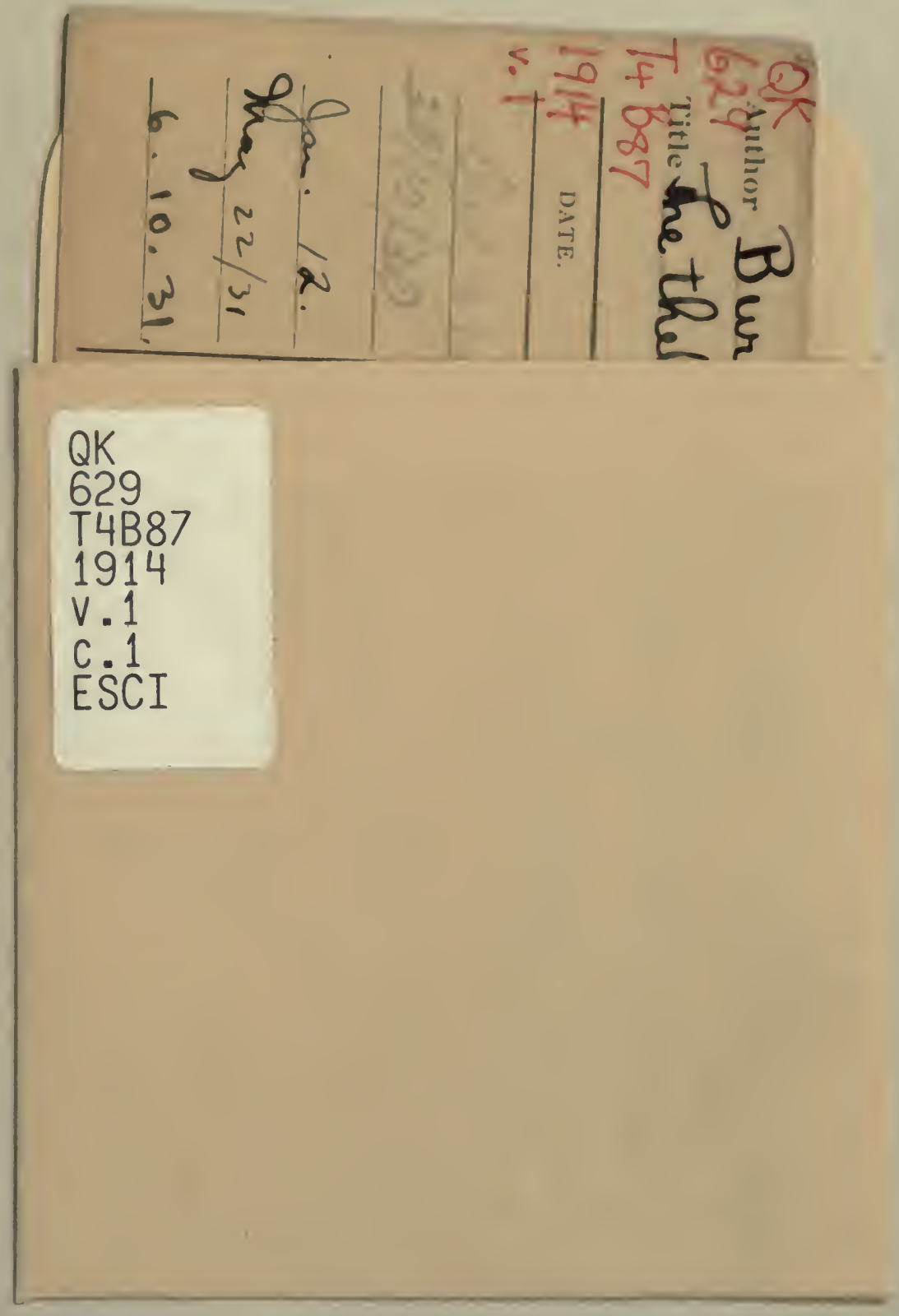


